\title{
Razvoj i mijene poimanja Gotame Buddhe i njegova životopisa u starijem buddhizmu
}

Grabovac, Višnja

Doctoral thesis / Disertacija

2021

Degree Grantor / Ustanova koja je dodijelila akademski / stručni stupanj: University of Zagreb, Faculty of Humanities and Social Sciences / Sveučilište u Zagrebu, Filozofski fakultet

https://doi.org/10.17234/diss.2021.7470

Permanent link / Trajna poveznica: https://urn.nsk.hr/urn:nbn:hr:131:809997

Rights / Prava: In copyright/Zaštićeno autorskim pravom.

Download date / Datum preuzimanja: 2023-04-26

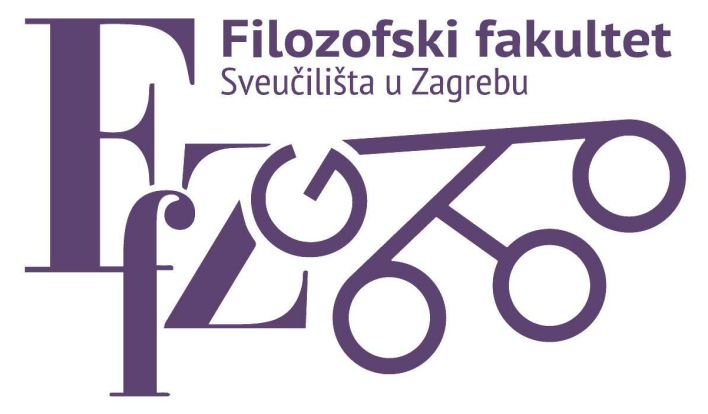

Repository / Repozitorij:

ODRAZ - open repository of the University of Zagreb Faculty of Humanities and Social Sciences
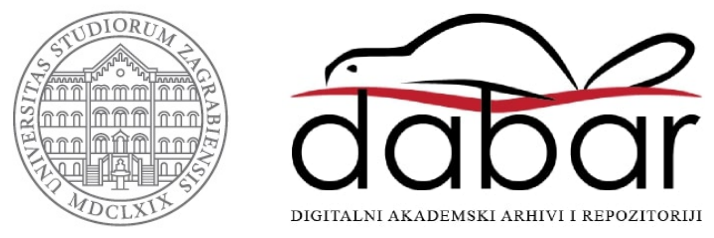


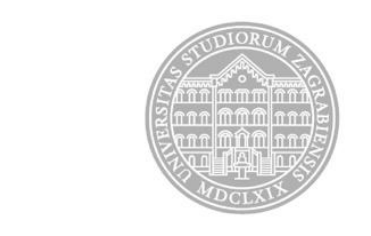

Sveučilište u Zagrebu

Filozofski fakultet

Višnja Grabovac

\title{
RAZVOJ I MIJENE POIMANJA GOTAME BUDDHE I NJEGOVA ŽIVOTOPISA U STARIJEM BUDDHIZMU
}

\author{
DOKTORSKI RAD
}

Zagreb, 2021. 



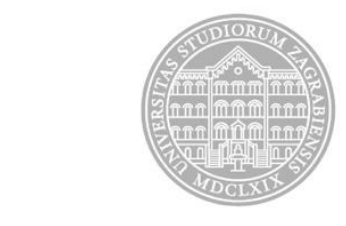

Sveučilište u Zagrebu

Filozofski fakultet

Višnja Grabovac

\title{
RAZVOJ I MIJENE POIMANJA GOTAME BUDDHE I NJEGOVA ŽIVOTOPISA U STARIJEM BUDDHIZMU
}

DOKTORSKI RAD

\author{
Mentor: \\ Dr. sc. Mislav Ježić
}

Zagreb, 2021. 


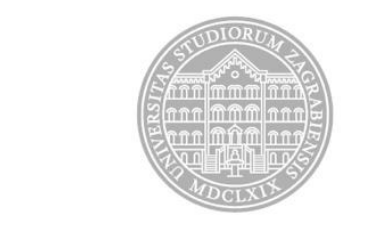

University of Zagreb

Faculty of Humanities and Social Sciences

Višnja Grabovac

\section{THE DEVELOPMENT AND CHANGES OF THE CONCEPT OF GOTAMA BUDDHA AND HIS BIOGRAPHY IN THE SCHOOLS OF LESSER VEHICLE}

DOCTORAL THESIS

Supervisor:

Dr. sc. Mislav Ježić

Zagreb, 2021. 



\section{Sažetak}

Razvoj i mijene poimanja Gotame Buddhe i njegova životopisa u starijem buddhizmu

U ovome će se radu dati prikaz Buddhina životopisa u školama tzv. starijega budhizma. Temelj za istraživanje ključnih biografskih epizoda bit će pālijski kanon Tipițaka, Nidānakathā (komentar uz pālijsku kanonsku zbirku Đātaka) i Mahāvastu (sjevernoindijsko djelo sačuvano na tzv. buddhističkome hibridnom sanskrtu). Nakon kratkoga uvoda (poglavlje 1) u kojem će se dati kratak pregled glavnih smjerova u dosadašnjim istraživanjima Buddhina životopisa, dat će se ključni podatci o korištenim izvorima ali i buddhističkim školama kojima ti izvori pripadaju (theravāda i mahāsanghika-lokottaravāda). U narednih pet poglavlja (poglavlja 3 do 7) bit će izdvojene sljedeće epizode životopisa Gotame Buddhe: rođenje i začeće, odlazak u beskućništvo, probuđenje, pokretanje kotača nauka i ulazak u konačnu nibbānu. Odabrani biografski fragmenti bit će najprije prevedeni na hrvatski jezik čime će se domaćem čitatelju ponuditi dijelovi Buddhina životopisa koji su do sada bili dostupni samo kroz prijevode na engleski ili neki drugi svjetski jezik. U tome središnjem dijelu rada pokušat će se ukazati na zajedničku jezgru predaje o životu Gotame Buddhe ali i na razlike prisutne među korištenim izvorima. U osmome poglavlju izdvojit će se svim izvorima zajedničke sastavnice životopisa (Buddhini epiteti, uloga čudesnih i zadivljujućih pojava koje prate ključne trenutke njegova života, veličanje Buddhinih savršenstava i postignuća, isticanje njegove nadmoći nad nebesnicima, povećanje broja Buddhinih prijašnjih rođenja kao i povećanje broja prethodnih buddha) i ukazati na stupanj njihova prisustva u pojedinome izvoru. U zaključnome dijelu rada (poglavlje 9) sažet će se rezultati istraživanja ali i ukazati na važnost i ulogu životopisa Gotame Buddhe u razvoju i širenju buddhizma.

\section{Ključne riječi}

Gotama Buddha, životopis, stariji buddhizam, Tipițaka, Nidānakathā, Mahāvastu, biografski fragmenti, theravāda, lokottaravāda, poimanje Gotame Buddhe 


\section{Summary}

The Development and Changes of the Concept of Gotama Buddha and his Biography in the Schools of Lesser Vehicle

The talent, enthusiasm, and effort of prominent scholars such as Burnouf, Lassen, Westergaard, Childers, and others, laid a solid foundation for the period of intensive editing, translation, interpretation, and publishing of Buddhist texts which started in the last quarter of the nineteenth century. By that time, Rasmus K. Rask, while staying in Ceylon, collected numerous Pāli and Sinhala manuscripts (1821); Burnouf and Lassen published their Essai sur le Pali (1826); in 1837 Georg Turnouf published the text and translation of Mahāvamsa; in 1869 I. P. Minaev published the text and translation of the Pātimokkha (1869); Viggo Fausbol translated Dhammapada into Latin in 1855, and in 1875 Childers edited and published Mahāparinibbānasutta. In 1837 a parcel containing Sanskrit Buddhist manuscripts sent by Brian H. Hodgson from Nepal reached Société Asiatique in Paris and was received by Burnouf who dedicated much of his time and passion to examine them. Not only manuscripts in Pāli and Sanskrit were studied - Tibetan, Chinese and Mongolian sources also became available to Western scholars, all of which prepared a way for the next generation of great scholars dedicated to the study of Buddhism. From the last quarter of the 19th century until approximately the middle of the 20th century, the field of Buddhist studies saw an increase in published texts and their translations. In that period, eminent scholars such as Émile Senart, T.W. Rhys Davids and his wife C. A.F. Rhys Davids, Hermann Oldenberg, Hendrik Kern, Étienne Lamotte, Sylvain Lévi, Louis de La Vallée Poussin, Wilhelm Geiger - to name just a few, strongly contributed to our knowledge of Indian Buddhism. The Pali Text Society, established by T.W. Rhys Davids in 1881 gathered many experts and incited the publishing of numerous and various Buddhist texts. T.W. Rhys Davids, his wife Caroline A.F. Rhys Davids, and Hermann Oldenberg are perhaps the best-known members of the so-called Anglo-German school. This group of authors considered texts preserved in Pāli to be the oldest and most valuable documents for our knowledge and understanding of the oldest (original) Buddhism. On the other side was the so-called Franco-Belgian school with Louis de La Vallée Poussin, Émile Senart, and Hendrik Kern as its most prominent members. They did not insist on Pāli texts as primary sources and they differed in their interpretation of the Buddhist texts. The two schools held different views about the founder of Buddhism as well. Scholars belonging to the Anglo-German school were convinced that Buddhist texts did preserve the earliest memories of Gotama Buddha and they considered him primarily a man whose life, over time, was 
hindered by numerous myths and legends. They firmly believed in philological methods and tried to reconstruct the life of Gotama by differing the earlier (more realistic) and later (more mythological and legendary) layers of Buddhist texts. Scholars of the opposing school considered Buddha's biography mostly as a "meeting point" of much earlier mythological elements, believing however that Buddha's life story contains some traces of realistic and historical facts. Among Franco-Belgians, the most radical view was held by Hendrik Kern who considered Gotama to be nothing more than a solar god. The two lines of thought became paradigmatical and most of the subsequent researches about the life of Gotama came to be inclined either to the Anglo-German or Franco-Belgian position. In more recent times, starting from the middle of the 20th century, new lines of the investigation appeared and scholars started to rely more confidently not only on the textual but also epigraphical, archeological, and other non-textual sources for a better understanding of the history and development of Indian Buddhism and the biography of its founder.

The present thesis aims to present the major biographical episodes of the life of Gotama Buddha, namely, his conception and birth, going forth into homelessness, awakening, first sermon, and parinibbāna. It also offers their translation into the Croatian language since the majority of them, until now, were known to the Croatian audience only by the medium of English or some other major language. The main sources for the study of the development and changes of the conception of Gotama Buddha in the schools of Lesser Vehicle are Pāli canon Tipițaka (except for Abhidhammapiṭaka), Nidānakathā and Mahāvastu. The first two sources belong to the theravāda, while Mahāvastu belongs to the mahāsanghika-lokottaravāda school of thought. By extracting and comparing major biographical episodes one cannot expect to reach a definite conclusion about the diachronic development of Gotama Buddha's biography since chosen textual sources belong to different schools, have a different purpose, and were shaped, over more than eight centuries, in culturally, politically and geographically distant areas. Still, by comparing biographical episodes one can try to point not only to the elements common to all sources but also to the more or less subtle changes in the perception of Gotama Buddha and the development of his biography among different Buddhist schools. The thesis is an attempt to justify the following assumption: the difference between Pāli texts, even those considered to represent an older layer of tradition, and the Mahāvastu, which due to some of its features is considered a transition to the so-called Mahāyāna Buddhism in which the Buddha becomes a supernatural or otherworldly being, cannot be interpreted as the result of a linear process of divination in which Gotama gradually lost his human characteristics and eventually became a supernatural being having an astonishing biography. The development of Buddha's 
biography can be perhaps more properly interpreted as a process of its concentric spread around biographical details common to all sources. In that process, the biographical tradition was enriched with new details and even whole new episodes. The degree of "innovation" depended on the purpose of the text but also on the need to emphasize those biographical details that corroborated the views of a particular school.

The Introduction (in which the aim of the present thesis is outlined ) is followed by the second chapter (Textual Sources) which brings the crucial information about the first two baskets of the Pāli canon Tipițaka, Nidānakathā, and Mahāvastu. Buddhist schools, namely theravāda and mahāsanghika-lokottaravāda to which these sources belong, are also briefly presented. The third chapter (The Conception and Birth of Gotama Buddha) is based on the following primary texts: Acchariyabbhutadhammasutta (MN iii. 119-124), Añguttaranikāya (AN ii. 130-132), Mahāpadānasutta (DN ii. 1-54), Suttanipāta (Sn. 686-693), Nidānakathā (JātA. I. 50-53), and Mahāvastu (Mv. i. 98-100, 142-153, 197-227, Mv. ii. 1-30). The fourth chapter (Going Forth into Homelessness) is based on Ariyapariyesanāsutta (MN i. 161-167), Dvedhāvitakkasutta (MN i. 116), Mahāsaccakasutta (MN i. 240), Suttanipāta (Sn. 405-424), Soṇadaṇụasutta (DN i. 115), Sukhumālasutta (AN i. 145-148), Mahāpadānasutta (DN ii. 2130), Nidānakathā (JātA. I. 59-65) and Mahāvastu (Mv. i. 154-158, 227-228, Mv. ii. 115-134, 140-167, 189-210, 299-300). The fifth chapter (Awakening) brings forth selected passages from Bhayabheravasutta (MN i. 21-24), Ariyapariyesanāsutta (MN i. 167), Dvedhāvittakasutta (MN i. 117), Mahāsaccakasutta (MN i. 247-248), Vinayapiṭaka (Vin. i. 1-6), Mahāpadānasutta (DN ii. 30-36); Nidānakathā (JātA. I. 75-76), and Mahāvastu (Mv. i. 228-231, Mv. ii. 131133, Mv. ii. 263-271, followed by Mv. ii. 276-288, Mv. ii. 300-349, 397-420). The sixth chapter (First Sermon) is based on Vinayapitaka (Vin. i. 10-12), Dhammacakkappavattanasutta (SN v. 420-424), Ariyapariyesanāsutta (MN i. 173), Mahāpadānasutta (DN ii. 35-42), Nidānakathā (JātA. I. 81-82), and Mahāvastu (Mv. iii. 330-334, Mv. iii. 340-341). The seventh chapter (Buddha's Parinibbāna) contains Croatian translations of the most prominent and wellknown passages from Pāli Mahāparinibbānasutta, contained in Dīghanikāya (sutta number 16). It also contains a short passage from Mahāvastu which describes events after Buddha's death as well as a concise discussion about the importance of Buddha's relics in the history of Buddhism. These five chapters contain major biographical episodes and follow the same methodology. The selected passages are translated into Croatian language and then compared in the attempt to establish what elements of the biographical tradition are common to all sources as well as to point out those elements which differ, considering that the chosen primary sources belong to schools that are opposed to each other when it comes to their view of Buddha's nature. 
The eighth chapter (Changes in the Biography) highlights several ways which were employed by Buddhist authors/ compilers not only to broaden Buddha's biography but also to give it a stamp of grandness and extraordinariness. By analyzing Buddha's epithets, his physical, intellectual, and spiritual perfections, the purpose of miracles in his biography, the role of gods and heavenly beings in the crucial moments of his life, the ever-increasing number of Buddha's past births and number of previous buddhas, the attempt is made to demonstrate in which degree are these elements present in selected primary sources. The last, ninth chapter (Conclusion) gives a summary of the research and outlines the most important features of Buddha's biography which developed parallelly with the growth and spread of Buddhism.

\section{Keywords}

Gotama Buddha, biography, older Buddhism, Tipițaka, Nidānakathā, Mahāvastu, biographical fragments, theravāda, lokottaravāda, the concept of Gotama Buddha 


\section{Sadržaj}

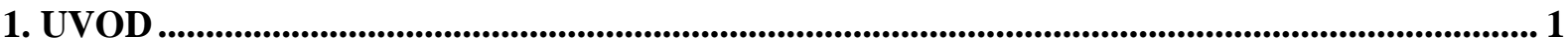

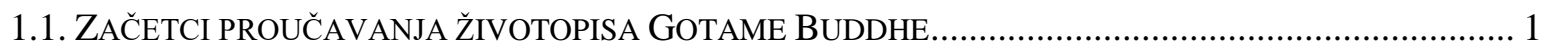

1.2. PROPITIVANJA NOVIJEGA DATUMA I KRITIKA TZV. TWO-TIERED - MODELA ................................... 4

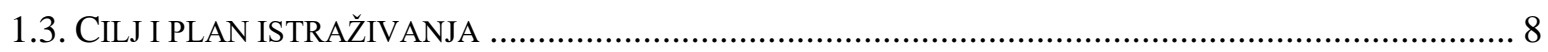

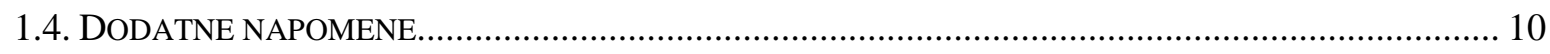

2. TEKSTOVNI IZVORI: TIPIṬAKA, NIDĀNAKATHĀ, MAHĀVASTU................................... 11

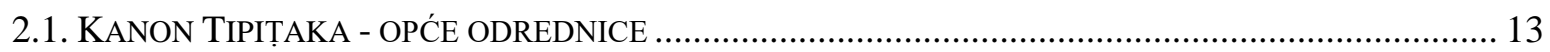

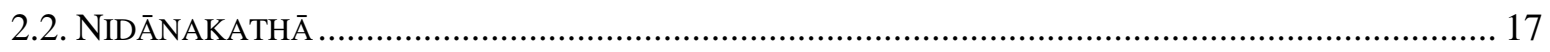

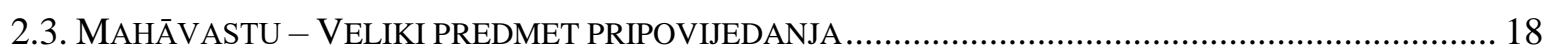

2.4. ŠKOLE THERAVĀDA I MAHĀSĀṄGHIKA-LOKOTTARAVĀDA ..................................................... 23

3. ZAČEĆE I ROĐENJE GOTAME BUDDHE ................................................................... 28

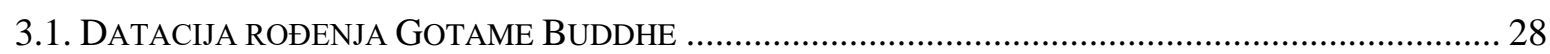



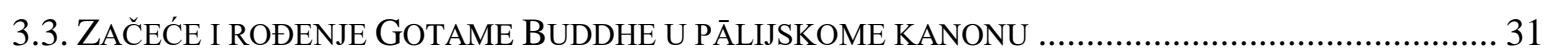

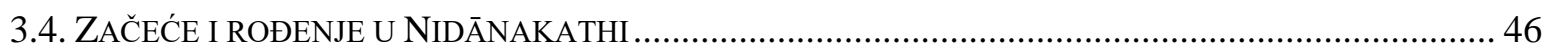

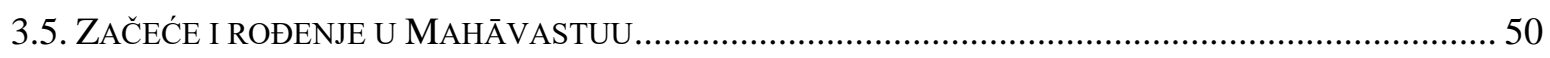

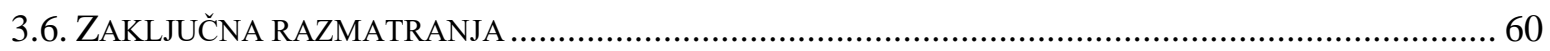

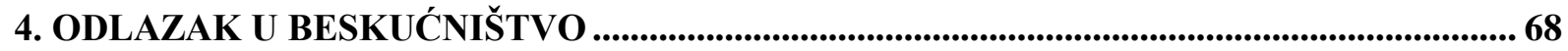

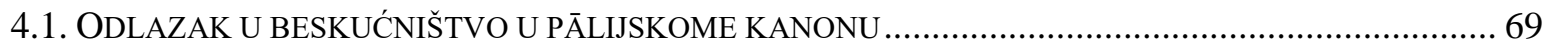

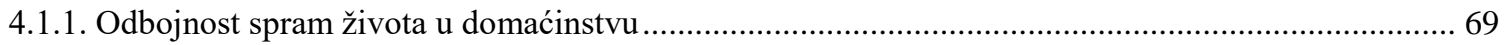

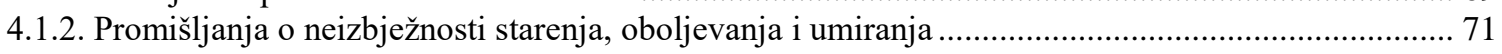

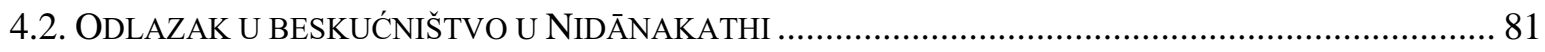

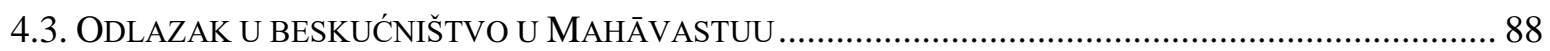

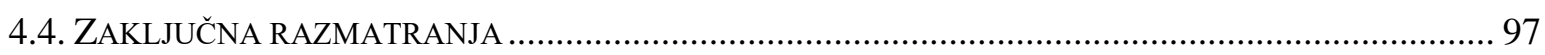

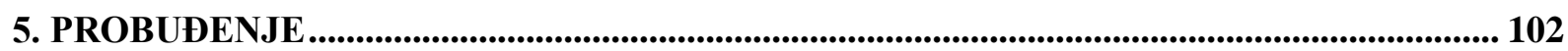

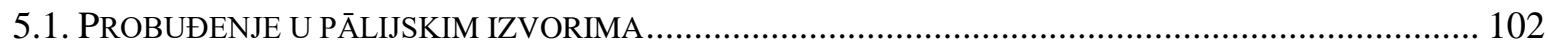

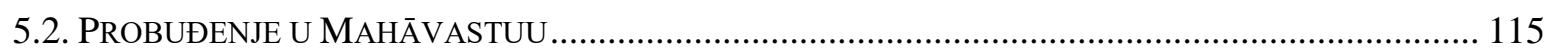

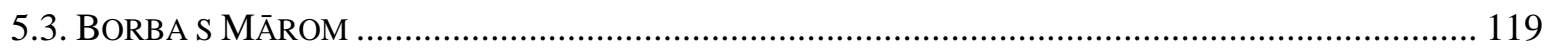

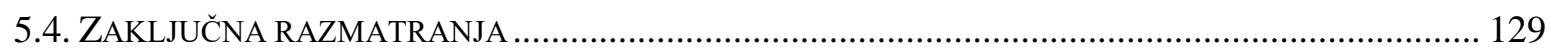

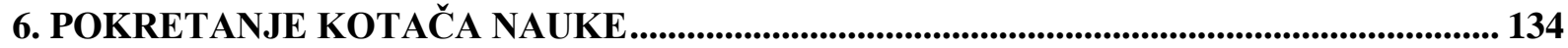

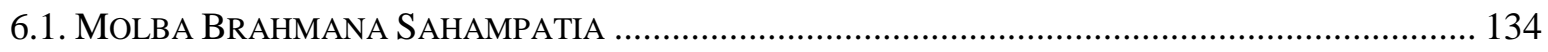



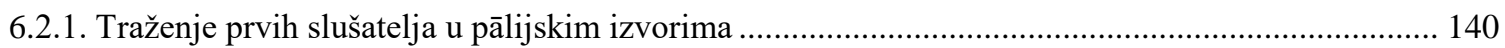

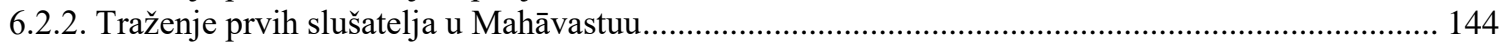

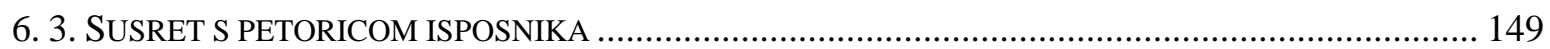

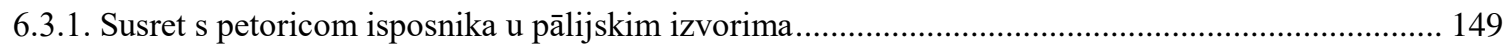

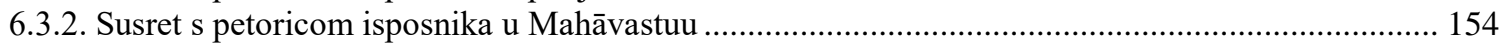

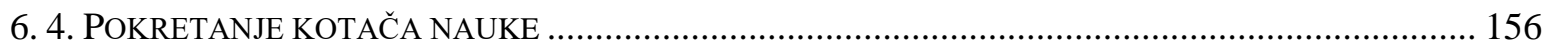

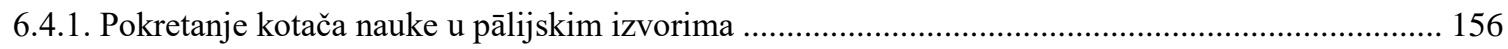

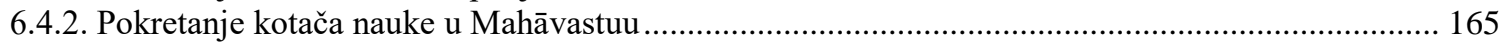

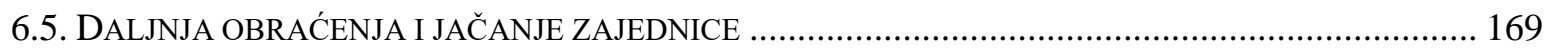

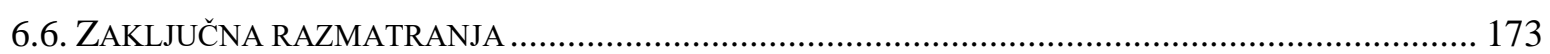

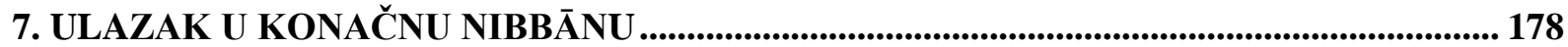




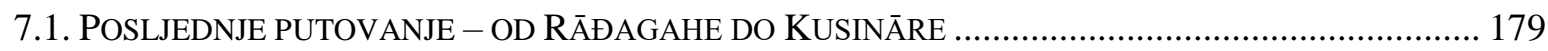

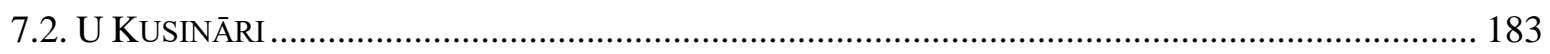

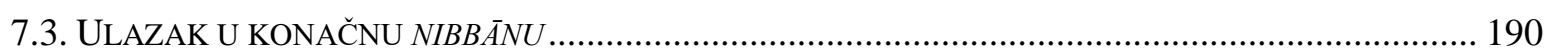

7.4. O DOGAĐAJIMA NAKON GOTAMINA ULASKA U KONAČNU NIBBĀNU ......................................... 194

7.5. O DOGAĐAJIMA NAKON GAUTAMINA ULASKA U KONAČNU NIRVĀNUU U MAHĀVASTUU........... 198

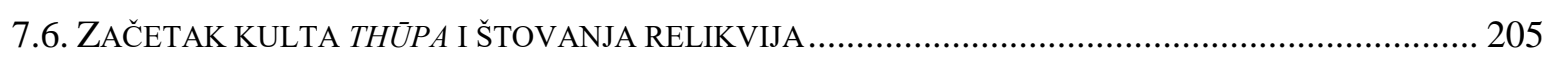

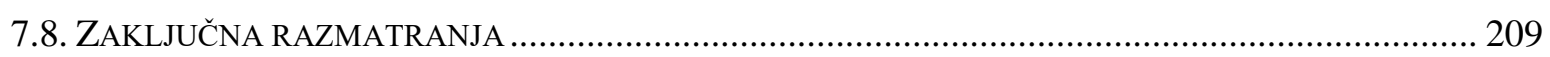

8. MIJENE U ŽIVOTOPISU GOTAME BUDDHE .......................................................... 213

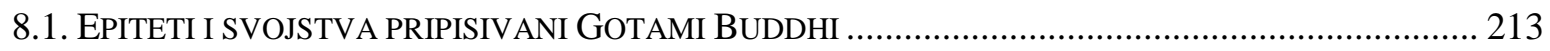

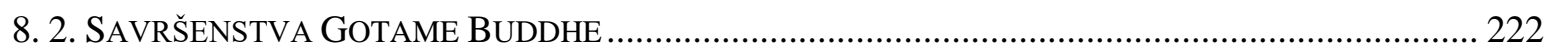

8. 2. 1. Duhovno-intelektualno savršenstvo Gotame Buddhe ………………….................................... 222

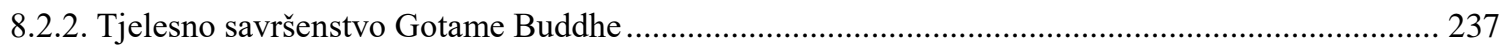

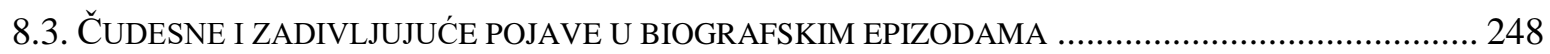

8.4. PRISUSTVO NEBESNIKA U KLJUČNIM TRENUTCIMA BUDDHINA ŽIVOTA ..................................... 262

8.5. POVEĆANJE BROJA PRETHODNIH BUDDHA I PRETHODNIH BUDDHINIH ROĐENJA ...................... 267

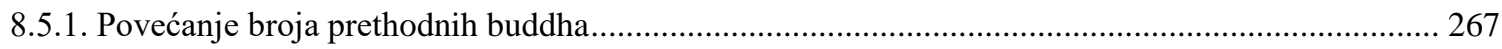

8.5.2. Povećanje broja prethodnih Buddhinih života i bujanje đātaka....................................................... 272

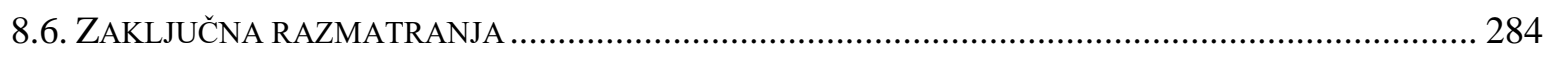

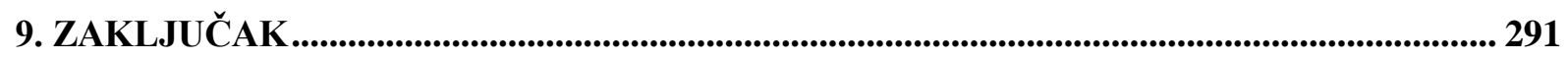

9. 1. UKRATKO O ŽIVOTOPISU GOTAME BUDDHE U KORIŠTENIM IZVORIMA ................................... 291

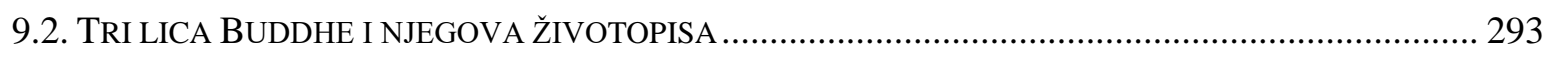

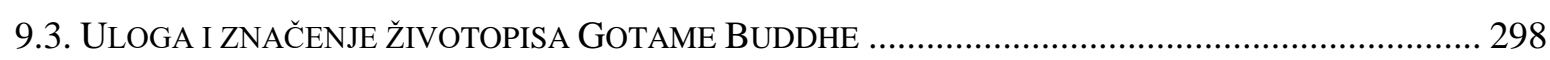

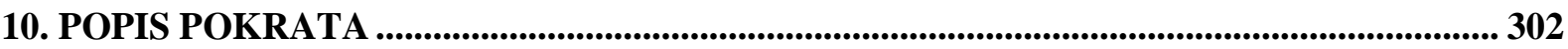

11. POPIS PRIMARNE I SEKUNDARNE LITERATURE ....................................................303

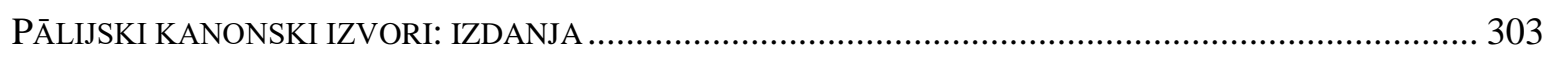

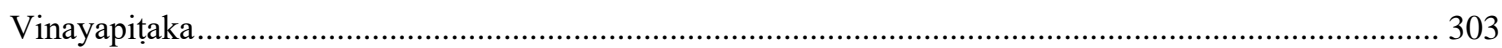

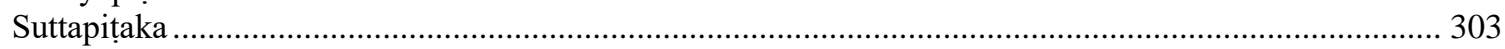

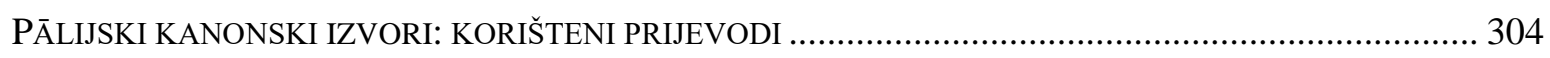

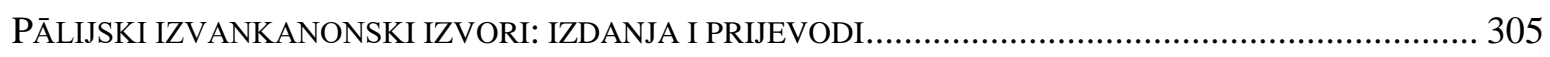

TEKSTOVI NA BUDDHISTIČKOM HIBRIDNOM SANSKRTU I SANSKRTU: IZDANJA I PRIJEVODI ........... 305

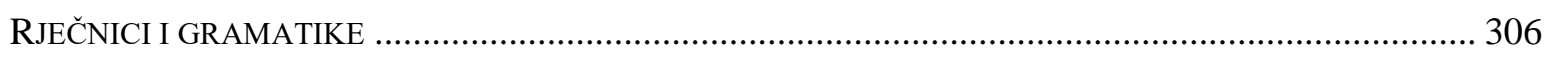






\section{UVOD}

\subsection{Začetci proučavanja životopisa Gotame Buddhe}

Intenzivno proučavanje životopisa Gotame Buddhe započelo je na Zapadu na prijelazu iz devetnaestoga $\mathrm{u}$ dvadeseto stoljeće i podudara se sa začetkom kritičkoga proučavanja buddhizma. ${ }^{1}$ Godine 1881. T.W. Rhys Davids osnovao je Pali Text Society, izdavačko društvo pod čijim je okriljem sakupljen, uređen i preveden velik dio pālijskoga korpusa buddhističkih tekstova, a u razdoblju od 1921. do 1925. godine T. W. Rhys Davids i William Stede u zajedničkom su poduhvatu objavili i pālijsko-engleski rječnik. T.W. Rhys Davids, njegova supruga Caroline A. F. Rhys Davids i Hermann Oldenberg ubrajaju se u najistaknutije pripadnike tzv. anglo-germanske škole koja je theravādski kanon sačuvan na jeziku pāliju smatrala najvažnijim izvorom za proučavanje ranoga ili izvornoga buddhizma pa tako i za proučavanje životopisa njegova osnivača. Prema shvaćanju je tih pionira buddhističkih studija Gotama Buddha povijesna ličnost čiji se život, u većoj ili manjoj mjeri, može rekonstruirati odstranjivanjem iracionalnih i mitoloških elemenata iz njegova životopisa, a koji su se tijekom razvojnoga puta buddhizma nataložili oko njegove povijesne jezgre. ${ }^{2}$ Spomenuti predstavnici anglo-germanske škole bili su složni u mišljenju da se proučavanje ranoga buddhizma treba temeljiti na pālijskim izvorima $\mathrm{i}$ da se pritom "ne smijemo oslanjati na vrlo zanimljive sanskrtske ili tibetske izvore". ${ }^{3}$ Čvrsto uvjerenje T. W. Rhys Davidsa u mogućnost rekonstrukcije izvornoga buddhizma pa tako i činjenica vezanih uz život njegova osnivača opisuje sljedeći izvadak:

There was certainly a historical basis for the Buddhist legend; and if it be asked whether it is at all possible to separate the true from the false, I would reply, that the difficulty, though great, is apt to be exaggerated. The retailers of these legends are not cunning forgers, but simple-minded men, with whose modes of thought we can put ourselves more or less en rapport; we are getting to know what kind of things to expect from their hero-worship, and religious reverence, and

\footnotetext{
${ }^{1}$ Za pregled literature koja je prethodila sustavnim istraživanjima započetima u 19. stoljeću vidi primjerice Thomas (1927/2000: xiii-xviii), Reynolds (1976: 37), De Jong (1976: 4-23), Almond (1988: 7-12).

${ }^{2}$ Kada je riječ o ranom ili izvornom buddhizmu Schmithausen (1992: 110-112) sažima stavove istaknutih autora: Some scholars, like Frauwallner and Gombrich, consider the bulk of the canonical Suttas to be essentially authentic i.e. to go back to the Buddha himself [...] Other scholars like G. Schopen seem to advocate a position of extreme distrust in the reliability of the transmitted Sütrapitaka, tending to regard most of the materials contained in them to represent later developments and not original Buddhism. [...] A third position mantains that the Sutta materials compromise both early and later elements, and that they should and can be stratified mainly by internal criteria.

${ }^{3}$ Oldenberg (1881/2007: 77). Usp. i Rhys Davids (1896/1907: 89).
} 
delight in the physically marvelous; and we are not without information as to what was, and what was not, historically possible in the fifth century B.C. in the eastern valley of the Ganges. ${ }^{4}$

Hermann Oldenberg objavio je 1881. godine knjigu Buddha: Sein Leben, seine Lehre, seine Gemeinde, a koja je i danas, kao i u vrijeme svoga objavljivanja, nezaobilazan izvor u proučavanju buddhizma i Gotamina životopisa. U tome je djelu Oldenberg jasno izrazio svoju uvjerenost u mogućnost da se filološkim metodama dođe do povijesne jezgre predaje o životu Gotame Buddhe:

[...] ipak zadržavamo kao čvrstu jezgru pripovijesti o Buddhi čitav niz pozitivnih činjenica na koje smijemo polagati pravo kao možda skroman, ali posve osiguran posjed povijesne spoznaje. [...] Čak bi i na indijskom tlu bilo nezamislivo da zajednica koja se nazivala imenom sina plemena Sakya, samo jedno stoljeće nakon njegove smrti, više nije čuvala ispravno sjećanje na najvažnija imena osoba oko Buddhe i na određene izvanjske temeljne činjenice njegova života, koliko god da je obavijen tisućama legenda. (Oldenberg, 1881/2007: 95-96).

Navedeni ulomak svojevrsni je zaključak Oldenbergove kritike Émilea Senarta i njegova djela Essai sur la légende du Bouddha objavljenoga 1875. godine. U tome je djelu Senart iznio stav o gotovo posvemašnjoj nemogućnosti da se o životu osnivača buddhizma sazna išto što bi se moglo smatrati povijesno utemeljenim. Prema Senartovu je mišljenju učitelj poznat kao Gotama Buddha zaista postojao i začeo ono što danas nazivamo buddhizmom. Međutim, njegov je život gotovo u cijelosti zakrila legenda koja ga je s vremenom preobličila u onosvjetsko i nadnaravno biće koje nije ništa drugo do odraz arhetipskoga solarnog mita. Iscrpno i vješto potkrjepljujući svoju tezu, Senart je dao upečatljiv doprinos proučavanju poredbene mitologije. Međutim, važno je istaknuti, a to je i Oldenberg naglasio, da je Senart glavninu svojih istraživanja temeljio na sjevernoindijskim sanskrtskim tekstovima kasnijega datuma. ${ }^{5}$ Oldenberg je, naprotiv, čvrsto vjerovao u autoritet pālijskoga korpusa kanonskih tekstova te je nastojao razlučiti slojeve teksta na temelju njihovih stilističkih obilježja kako bi došao do najranije predaje.

Među učenjake koji su proučavali Buddhin životopis kao odraz arhetipskoga solarnog mita, i koji su se u svojim istraživanjima uglavnom oslanjali na mlađe sanskrtske izvore, uz Émilea Senarta, ubraja se i Hendrik Kern koji je u razdoblju od 1881. do 1883. godine objavio

\footnotetext{
${ }^{4}$ Rhys Davids (1877/1912: 16).

5 Rhys Davids je (1877/1912: 190-193) sažeo Senartove zaključke i naglasio da Senart nikako ne poriče povijesnost Gotame Buddhe.
} 
Geschiedenis van het Buddhisme in Indië. Pod snažnim je Senartovim utjecajem otišao korak dalje i zaključio da Buddha nikada nije bio više od utjelovljenja solarnoga mita i odbacio svaku mogućnost otkrivanja povijesnoga Gotame. O Kernovu ekstremnom stavu De Jong (1974/1976: 26) piše:

Like Senart, he considered the Buddha to be a solar god. However, Kern was much more astronomical in his exegesis than Senart. The twelve nidāna are the twelve months of the year. The six heretical teachers are the planets. The Buddha's first preaching takes place in midsummer, and this is why the Middle Way is its theme. Kern never hesitates in his identifications with stars, planets, and constellations. ${ }^{6}$

Émile Senart, Hendrik Kern, Étienne Lamotte, Louis de la Vallée-Poussin, Jean Przyluski i Sylvain Lévi najistaknutiji su predstavnici tzv. franko-belgijske škole koja je po mnogim svojim stavovima stajala $\mathrm{u}$ opreci s anglo-germanskom školom kako po pitanju izbora primarnih tekstova i jasno izraženoj sumnji u mogućnost opisa izvornoga buddhizma tako i po svome odnosu spram njegova osnivača. ${ }^{7}$ Kada je riječ o odnosu spram Gotame Buddhe, opreku između anglo-germanske i franko-belgijske škole sažeo je Foucher (1949/2003: 5):

We should like to venture the statement that both Oldenberg and Senart are right and also wrong, right in what they admit and wrong in what they omit. In Senart's image of the Buddha, it is the man that is missing; in Oldenberg's it is the God.

Pojedini stavovi franko-belgijske škole imaju potporu velikoga dijela istraživača buddhizma i životopisa Gotame Buddhe i to možda ponajviše zahvaljujući Étienneu Lamotteu koji je u svome opsežnome i cijenjenom djelu Histoire du bouddhisme indien, objavljenome 1958. godine, sažeo polaznu pretpostavku ali i problem istraživanja na sljedeći način:

Buddhism could not be explained unless we accept that it has its origin in the strong personality of its founder. [...] What was the doctrine of the Buddha and the first holy ones, his disciples? This is impossible to say with certainty. It was an oral doctrine of which we have no satisfactory evidence. The codification of the writings did not take place until many centuries after

\footnotetext{
${ }^{6}$ O Kernovu stavu v. i Bronkhorst (2009: 9-27) i Thomas (1927/2000: 216-217).

${ }^{7}$ Sličnoga je stava i E. J. Thomas (1927/2000: xvii-xviii): It is undeniable that in the story of Buddha there has been a growth, and even in the oldest documents we can trace records of varying antiquity. [...] Is there a historical basis at all? [...] We have many records, many related facts, dates, and archeological remains, as well as the actually existing Buddhistic peoples with their systems. Do these data point to an origin in the growth and spread of a myth, in which the religious belief in a god has been gradually converted into an apparently historical event, or is the basis a historical person who lived in the sixth century B.C.?
} 
Śākyamuni's decease when the religion had already been profoundly changed and generations of scholars had already added considerably to the holy words. ${ }^{8}$

Do nedavno su Oldenberg i Senart bili predstavnici dvaju glavnih smjerova u proučavanju životopisa Gotame Buddhe i, kako ističe de Jong (1974/1976: 29), moguće je gotovo sva kasnija istraživanja vezana uz proučavanje životopisa Gotame podijeliti u dvije skupine ovisno o njihovom priklanjanju Senartovom ili Oldenbergovom stavu. Ipak, pokušaj se izmirenja ovih po mnogo čemu oprečnih struja kao i začetak novoga pristupa nazire već u djelu E. J. Thomasa koji u predgovoru svoje knjige The Life of Buddha as Legend and History, izvorno objavljene 1927. godine, piše sljedeće:

There has been a tendency in Germany and England to depend almost entirely on the Pāli sources, neglecting the works of schools preserved in Sanskrit, and in Tibetan and Chinese translations from the Sanskrit, which although often later than the Pāli, yet are parallel and more or less independent traditions, and cannot safely be ignored. The Pāli itself is no primitive record, but the growth of a long tradition in one school. The Sanskrit needs to be equally closely analyzed [...]. ${ }^{9}$

Od otprilike sredine 20. stoljeća javljaju se istraživanja u kojima se pažnja u podjednakoj mjeri posvećuje pālijskim, sanskrtskim i ne-indijskim tekstovima ali i epigrafskim, arheološkim i ostalim ne-tekstualnim izvorima. Tako je, primjerice, Alfred Foucher 1949. godine objavio knjigu La vie du Bouddha, d'après les textes et les monuments de l'Inde u kojoj je usporedio epizode Gotamina života u pālijskim, sanskrtskim, tibetskim i kineskim izvorima, a posebnu je pažnju posvetio sadržajima buddhističkih skulptura i reljefa koji se susreću u Sānćhī, Āmarāvatī i Gandhāri.

\subsection{Propitivanja novijega datuma i kritika tzv. two-tiered - modela}

Godine 1988. Phillip C. Almond objavio je knjigu pod naslovom British Discovery of Buddhism u kojoj je, oslanjajući se djelomično na Edwarda Saida i njegov Orijentalizam, pokušao potaknuti ponovno propitivanje nekih od temeljnih i općeprihvaćenih pretpostavki u polju buddhističkih studija formuliranih tijekom druge polovice 19. stoljeća. ${ }^{10}$ Almondova je teza sljedeća:

\footnotetext{
${ }^{8}$ Lamotte (1958/1988: 63).

${ }^{9}$ Thomas (1927/2000: v). Usp. Katičić (1973: 186).

${ }^{10}$ V. i Hallisey (1995: 31 i d.) u: Lopez, ur. (1995). Timm (1997: 588) piše: Contemporary Buddhology involves the effort to develop strategies for understanding, and moving beyond, the limits of Orientalism. This effort arises in response to a realization that much past scholarship arrogates interpretative authority to serve colonial political agendas and Western elitism. U kontekstu proučavanja i vrednovanja buddhističe umjetnosti, posebno
} 
It was the Victorians who developed the discourse within which Buddhism was circumscribed, who deemed it a worthy focus of Western attention; it was they who brought forth the network of texts within which Buddhism was located. And it was they who determined the framework in which Buddhism was imaginatively constructed, not only for themselves but also in the final analysis for the East itself. ${ }^{11}$

Kada je riječ o odnosu spram Gotame Buddhe u viktorijanskome razdoblju, Almond (1988: 56) piše:

The Buddha of mid and late Victorian times is locatable in history through his contemporary textual presence. He is an object conceptually related to a developing naturalistic view of the universe, to an emergent critical view of the Bible, to an India under British hegemony, to a world view increasingly determined by a geologically and biologically based chronology and progressively less by a Biblical chronology and cosmology. The Buddha is very much a human figure, one not to be compared with gods, but with other historical personalities - with Jesus, Mohammed, or Luther.

Sličnoga je stava i Franklin (2005: 946):

Victorian Buddhologists like Müller and the Rhys Davidses spent their professional lives translating and comparatively analyzing ancient texts from disparate locations - Tibet, China, Ceylon, and Burma, for instance. Driven by a Protestant belief in the truth-telling authority of the most ancient textual sources, they unavoidably participated in the appropriation of Buddhism from its indigenous contexts by attempting to strip it of local mythologies and turn it into a purified textual object of Western knowledge, a project that was inseparable from the British national project of imperialism.

Proces ili pokušaj "demitologizacije" buddhizma, posebno kada je riječ o proučavanju životopisa Gotame Buddhe, prisutan u zapadnim istraživanjima od 19. stoljeća nadalje, svoje uporište ima u nerijetko primjenjivanome tzv. two-tiered - modelu buddhizma. Taj je model u kontekstu kasnoantičkoga kršćanstva detaljno razradio Peter Brown koji u svojoj knjizi The Cult of the Saints - Its Rise and Function in Latin Christianity (1981) piše:

skulpturalne, DeCaroli (2004: 7) piše: We had inherited notions about what is appropriate to a Buddhist context, and too often we are willing to dismiss or make excuses for evidence that does not conform to these notions. Za vrednovanje arheoloških otkrića u kolonijalnom i post-kolonijalnom razdoblju v. Fogelin (2003). Za povijest razvoja buddhističkih studija v. npr. Welbon (1968) i De Jong (1974/1976).

${ }^{11}$ Almond (1988: 140). Usp. i Schopen (1991). 
When applied to the nature of religious change in late antiquity, the "two-tiered" model encourages the historian to assume that a change in the piety of the late-antique men, of the kind associated with the rise of the cult of saints, must have been the result of the capitulation by the enlighted elites of the Christian church to modes of thought previously current only among the "vulgar". The result has been a tendency to explain much of the cultural and religious history in late antiquity in terms of drastic "landslide" in the relation between the elites and the masses. ${ }^{12}$

Primjenu toga modela, a koji pretpostavlja oštru opreku između elitnoga i popularnoga, na pokušaj opisivanja uzroka divinizacije Gotame Buddhe možda je ponajbolje izrazio Lamotte (1958/1988: 645):

If monks, devoted to a life of study and meditation, are able to resign themselves to regarding their founder only as a sage who had entered Nirvāna, lay followers who are exposed to the difficulties of their times, require something other than a "dead god" of whom only "remains" (śarīra) could be revered. They want a living god, a "god superior to the gods" (devātideva) who will continue his beneficial activity among them, who can predict the future, perform wonders, and whose worship (püja) will be something more than mere recollection (anusmrti). ${ }^{13}$

Slijedeći temeljnu pretpostavku toga modela, moguće je mitološke nadogradnje kao i čudesne, zadivljujuće i onosvjetske elemente u predaji o životu Gotame Buddhe pripisati utjecaju svjetovnih/ laičkih/ popularnih elemenata ili ih objasniti kao posljedicu podlijeganja ukusu masa. Međutim, posljednjih je desetljeća Brownova teza pronašla svoj put i do buddhističkih studija i pojedinih autora koji su istaknuli ulogu koju je two-tiered - model imao u oblikovanju nekih temeljnih pretpostavaka vezanih uz razvoj buddhizma. Tako Strong (2004: 2), u kontekstu kulta relikvija u buddhizmu, piše:

During the nineteenth and early twentieth century, at least in certain circles, the second, or Protestant perspective came to be predominant. [...] The existence of relics in the Buddhist

\footnotetext{
${ }^{12}$ Brown (1981: 17). Brown smatra da je na takvo tumačenje razvoja religije ponajviše utjecao David Hume koji je u svome eseju The Natural History of Religion mijene u razvoju religije objasnio kao posljedicu intelektualne ili duhovne ograničenosti prosječnoga čovjeka. Hume (1757: 54) tako piše: It is remarkable, that the principles of religion have a kind of flux and reflux in the human mind, and that men have a natural tendency to rise from idolatry to theism, and to sink again from theism into idolatry. The vulgar, that is, indeed, all mankind, a few excepted, being ignorant and uninstructed, never elevate their contemplation to the heavens [...].

${ }^{13}$ Usp. i Oldenberg (1881/ 2007: 347, 350 i d.), Rhys Davids (1903/1911: 220), Pande (1957: 394), Duttt, S. (1957: 144): We are thus put on track of a "popular Buddhism", exiting side by side with the "monkish", not based on the monk-made scripture, not enceased perhaps in cult, doctrines and dogmas nor cast into formularies and categories, but a Buddhism, more or less fluid and formless and mingled with folk-lore and folk forms of piety. Hirakawa (1990: 3) također objašnjava nadnaravne elemente prisutne u životopisu Gotame Buddhe kao odgovor na religiozne potrebe laika.
} 
tradition, when it was recognized at all, was thus seen as a concession to the superstition and devotional needs of the lay populace. Expounded by prominent scholars such as Hermann Oldenberg, this two-tiered view lingered well into the twentieth century and may, indeed, still be found. ${ }^{14}$

Privlačnost primjene toga modela pojašnjava Ray (1994/1999: 21-22):

Scholars have embraced the two-tiered model of Buddhism not only because it is found in the normative textual tradition. Equally important, this model also provides a coherent and thorough explanation of the basic structures of Indian Buddhism and is particularly useful in placing a number of phenomena that do not seem to conform to the notion of a pure, elite, monastic Buddhism.

Kada je riječ o proučavanju razvoja životopisa Gotame Buddhe taj se model pokazao kao vrlo praktičan i nerijetko je primjenjivan. Tomomichi Nitta (2008) također podvrgava kritici tzv. historical reductionist approach devetnaestoga stoljeća prema kojem je, u proučavanju životopisa Gotame Buddhe, naglasak stavljen na pokušaj rekonstrukcije najvjerojatnije, najracionalnije verzije njegova života, a na uštrb svih mitoloških i čudesnih elemenata koji se ili zanemaruju ili smatraju posljedicom "kvarenja" buddhizma. Autor se poziva i na zaključke pojedinih japanskih znanstvenika:

[...] Kōichi Hokazono (1994), criticizing the "historical reductionist approach" of both Oldenberg (1881) and Nakamura (1958), states that "the life story [of the Buddha] which is obtained by such [an approach] is nothing but meager traces" and "what is possible [for such an approach] is only to choose seemingly historical facts [from the life of the Buddha] from a relative point of view and to bring his image as close as possible to that of a human being." Further, Hokazono states that "the most significant aspect of the mythical legend in the Buddha's life story is to express the concept of Buddha." Masahiro Shimoda, a noted Japanese scholar, also questions the history centrism in modern Buddhist philology. Relying on the research carried out by Roger-Pol Droit and Philip Almond, he points out that the image of the Buddha as "a noble philosopher and moralist," which was created in the Buddhist Studies of nineteenth-century Europe, is not, in fact, based on either philological or historical evidence, but produced by the European scholars at that time attaching their ideal image of a human being to the Buddha. ${ }^{15}$

\footnotetext{
${ }^{14}$ Usp. Schopen (1997: 1-55), DeCaroli (2004: 8), Sharf (1999: 76).

${ }^{15}$ Nitta (2008: 48).
} 
U potrazi za novim pristupima i propitivanju naslijeđenih polaznih pretpostavki, u sve se većem broju istraživanja novijega datuma napuštaju neki od zaključaka koji proizlaze iz ideje o dvorazinskome buddhizmu kao i ideja o postupnom kvarenju buddhizma. Za zapadni se ukus čudesni, iracionalni i mitološki elementi prisutni u životopisu Gotame Buddhe ne zanemaruju ili odbacuju kao posljedica podlijeganja ukusu masa, već se uzimaju kao punovrijedni izvori za razumijevanje razvojnoga puta buddhizma pa tako i životopisa njegova osnivača.

Novi smjer u proučavanju životopisa u buddhizmu jasno je izražen i u zborniku radova Sacred Biography in Buddhist Tradition of South and South East Asia (1997):

More recent scholarship departs from the confines of rationalistic, positivist reconstruction of chronological history, recognizing the interpretive value of mythic, artistic, and cultural themes as expressions of principal tenets underlying the tradition. ${ }^{16}$

\subsection{Cilj i plan istraživanja}

Izvori za proučavanje životopisa Gotame Buddhe u ovome će radu biti prve dvije zbirke (košare) pālijskoga kanona Tipiṭake koji pripada školi theravāda, Nidānakathā (uvod u komentar uz kanonsku knjigu Đātaka), također theravādsko djelo i Mahāvastu, sjevernoindijsko djelo mlađega postanka koje pripada školi lokottaravāda. Ta su tri izvora odabrana iz nekoliko razloga. Prvo, svi ti izvori pripadaju tzv. hīnayānskomu buddhizmu, čime je prikaz razvoja i mijena u Buddhinu životopisu ograničen na jedan vid buddhizma. Drugo, pālijski kanon i Mahāvastu potječu sa sjevernoga dijela indijskoga potkontinenta, ali je pālijski kanon relativno rano prenesen na Śri Lañku u kojoj buddhizam, od svoga dolaska na otok pa do danas, nije imao većih zapreka niti je bio pod utjecajem značajnijih vjerskih sljedaba. Tu je kanon, početkom nove ere, u konačnici i zapisan i tako je, za razliku od Mahāvastua, ostao u većoj mjeri "konzerviran". Nidānakathā je theravādsko djelo uobličeno u otprilike isto vrijeme kad i Mahāvastu ali, budući da je sastavljeno na Śri Laṅki, može poslužiti kao primjer tendencija u razvoju životopisa unutar theravādskoga buddhizma. Usporedbom se tih triju izvora, a koji se razlikuju ne samo po vremenu i mjestu nastanka već i po svojoj svrsi, ne može pretendirati na razrađen dijakronijski prikaz razvoja Buddhina životopisa ali se može ukazati na svim izvorima zajedničke elemente kao i na razlike u prikazu ključnih epizoda Buddhina života. Treće, navedenim su izvorima obuhvaćena djela dvaju škola (theravāda i mahāsañghikalokkotaravāda) koje su oprečne po svome temeljnom odnosu spram Gotame Buddhe pa se

\footnotetext{
${ }^{16}$ Schober (1997a: 3) u: Schober (ur.) (1997).
} 
usporedbom može pokazati kako je poimanje Gotame Buddhe u određenoj školi utjecalo na razvoj njegova životopisa u pojedinom izvoru.

U narednome će poglavlju (drugo poglavlje) biti izneseni najvažniji podatci o korpusima tekstova na koje se ovaj rad oslanja u proučavanju ključnih epizoda života Gotame Buddhe. To su, kako je rečeno, prve dvije zbirke theravādskoga kanona Tipiṭake, Nidānakathā i Mahāvastu. Dat će se, dakle, nužni podatci o vremenu njihova nastanka, jeziku na kojem su sastavljeni, njihovu sadržaju, a dat će se i kratak prikaz razvoja buddhističkih škola kako bi se pokazale osobitosti dvaju škola (theravāda i lokottaravāda) kojima navedeni korpusi tekstova pripadaju.

Pet narednih poglavlja bit će posvećeno ključnim epizodama Buddhina životopisa. To su: začeće i rođenje (treće poglavlje), odlazak u beskućništvo (četvrto poglavlje), probuđenje (peto poglavlje), pokretanje kotača nauke (šesto poglavlje) i ulazak u konačnu nibbānu/ nirvāṇu (sedmo poglavlje). Odabrani biografski fragmenti bit će s izvornika, pālija i buddhističkoga hibridnog sanskrta, prevedeni na hrvatski jezik čime će se, između ostaloga, domaćemu čitatelju pružiti uvid u mnoge dijelove Buddhina životopisa koji do sada nisu bili dostupni na hrvatskome jeziku. Ključni dijelovi nabrojanih epizoda bit će potom uspoređeni kako bi se istaknule sličnosti i razlike u njihovu prikazu u pojedinom izvoru. Ta poglavlja predstavljaju prvi korak u pokušaju opravdanja polazne pretpostavke ovoga rada. Ta je, ukratko, sljedeća: razlika između pālijskih tekstova, čak i onih njihovih dijelova koji se uvriježeno ubrajaju u stariji sloj predaje, i Mahāvastua koji se zbog nekih svojih obilježja smatra prijelazom prema tzv. mahāyanskom buddhizmu u kojem Buddha postaje nadnaravno ili ono-svjetsko biće, gotovo je u cijelosti "kvantitativne" naravi. Drugim riječima, razvoj životopisa Gotame Buddhe neprikladno je, barem u okvirima korištenih izvora, tumačiti kao linearan proces divinizacije u kojem je čovjek Gotama postepeno gubio svoja ljudska obilježja i s vremenom postao nadnaravno biće zapanjujućega životnoga puta. Prikladnije je govoriti o mijenama unutar razvojnoga puta toga životopisa budući da se čak i u pālijskim tekstovima koji se ubrajuju u ranije slojeve predaje nazire kult Buddhine ličnosti te da se paralelno s ulomcima u kojima se Buddha pojavljuje kao čovjek javljaju i ulomci u kojima je naglasak stavljen na čudesne i nadljudske Buddhine osobine. U Mahāvastuu je pak, u odnosu na pālijske izvore, vidljiva promjena u odnosu spram Gotame Buddhe, a koja svoje ishodište ima u lokottaravādskome poimanju Buddhine naravi. Ono se, između ostaloga, s jedne strane, očituje kroz zanemarivanje onoga što bi Gotamu moglo dovesti u vezu s njegovom ljudskom prirodom i, s druge strane, kroz naglašavanje nad-ljudskih Buddhinih obilježja stečenih u mnogobrojnim prethodnim rođenjima, kao i kroz težnju da se ključni trenutci njegova života što je više moguće iskite i 
zasite čudesnim i zadivljujućim elementima. Ipak, pokušat će se pokazati da elementi ključnih biografskih epizoda u Mahāvastuu u velikoj mjeri slijede skicu koja se susreće i u pālijskim izvorima. Drugim riječima, Mahāvastu ne odbacuje Buddhu koji se susreće u pālijskome kanonu već, nadograđujući svim izvorima zajednički predložak, pomiče težište u smjeru shvaćanja nadnaravnoga značaja Buddhe prisutnoga među pripadnicima škole kojoj to djelo pripada.

Kao ilustracija i potkrjepa te pretpostavke poslužit će sedmo poglavlje. U njem će se pažnja posvetiti istaknutim elementima životopisa Gotame Buddhe To su: Buddhini epiteti, uloga čudesnih i zadivljujućih pojava koje prate ključne trenutke njegova života, veličanje Buddhinih savršenstava i postignuća, isticanje njegove nadmoći nad nebesnicima i povećanje broja Buddhinih prijašnjih rođenja kao i povećanje broja prethodnih buddha.

U zaključnome će se poglavlju rada sažeti rezultati istraživanja, a dat će se i kratak osvrt na značenje i važnost životopisa Gotame Buddhe unutar razvojnoga puta buddhizma i buddhističke književne tradicije.

\subsection{Dodatne napomene}

Rad se oslanja na korpuse tekstova koji su sačuvani na dva jezika (pāli i buddhistički hibridni sanskrt). U glavnini teksta i kada je riječ o pālijskim izvorima (Tipițaka i Nidānakathā) koriste se pālijske inačice imena i pojmova kao što su, primjerice, Gotama, dhamma, nibbāna. Kada je riječ o Mahāvastuu i ostalim sanskrtskim izvorima koriste se sanskrtske inačice - Gautama, dharma, nirvāṇa. Kada se to bude smatralo potrebnim, dat će se obje inačice. Također, Buddha i Bodhisatta pisani velikim početnim slovom odnose se na povijesnoga Gotamu Buddhu, dok se pisani malim slovom odnose na ostale buddhe i bodhisatte, odnosno na klasu bića. Numeracija primarnih izvora slijedi izdanja pālijskoga kanona Pali Text Society-a i Senartovo izdanje Mahāvastua. Primarni su tekstovi preuzeti sa mrežnih stranica GRETIL-a (Göttingen Register of Electronic Texts in Indian Languages and related Indological Materials from Central and Southeast Asia). Popis se pokrata nalazi u završnome dijelu rada. 


\section{TEKSTOVNI IZVORI: TIPIṬAKA, NIDĀNAKATHĀ, MAHĀVASTU}

U svojoj je knjizi The Earliest Vinaya and the Beginnings of Buddhist Literature (1956) Erich Frauwallner pokušao dokazati da je u svojoj izvornoj verziji Vinayapitaka, na početku Odsječaka (pāli Khandhaka, skt. Skandhaka), sadržavala cjelovit životopis Gotame Buddhe. ${ }^{17}$ Taj je proto-životopis, prema njegovoj pretpostavci, sadržavao prikaz Buddhina rodoslovlja, rođenja, mladosti, probuđenja i javnoga djelovanja zaključno s obraćenjem Śăriputre i Maudgalyāyane. Slijedio je potom opis pravila vezanih uz život zajednice, a životopis je završavao prikazom posljednjih Buddhinih dana i njegove smrti. Na samome je njegovu kraju donesen i prikaz prvoga i drugoga buddhističkoga sabora. Životopis, u kojem su svoje mjesto našli raznovrsni materijali iz različitih izvora, poslužio je kao izvor za sve buduće Buddhine životopise koji završavaju obraćenjem Śāriputre i Maudgalyāyane. S vremenom je taj, u svom izvornom obliku cjelovit životopis izgubljen dok su se pojedini njegovi ulomci, kao što je primjerice prikaz Buddhinih posljednjih dana i smrti koji je svoje mjesto našao unutar Sūtrapițake, našli razasuti u različitim kanonskim knjigama. Opovrgnuvši Frauwallnerovu teoriju, Lamotte je (1958/1988: 178-179; 652-653) predložio sljedeće razvojne stupnjeve Buddhina životopisa (1958/1988: 648): ${ }^{18}$

1. biografski fragmenti uvršteni u Sūtrapițake,

2. cjeloviti ili fragmentarni životopisi u Vinayama,

3. zasebni i nepotpuni Buddhini “Životi” (od početka nove ere),

4. cjelovit životopis u Vinayi škole mūlasarvāstivādina (4. st.),

5. Nidānakathā i sinhaleške kronike (5. st.).

Biografski fragmenti u prve četiri āgame (pāli nikāya) Sūtrapițake različitih škola nisu kronološki posloženi i ne nude cjelovit životopis. Naglasak je stavljen na biografske fragmente u razdoblju nakon Buddhina probuđenja i prve propovijedi, odnosno na događaje koji su uslijedili nakon početka javnoga djelovanja.

Cjelovit se Buddhin životopis ne nalazi ni u različitim Vinayama koje, s izuzetkom Vinayapiṭake škole mūlasarvāstivāde, uglavnom sadrže fragmente koji su umetnuti s ciljem pojašnjavanja okolnosti u kojima je Buddha izrekao pojedino pravilo. Ipak, pālijska Vinaya kao i vinaye škola mahīśasaka i dharmaguptaka sadrže na početku Odsječaka (Mahāvagga) nešto

\footnotetext{
${ }^{17}$ Frauwallner se nadovezao i detaljno razradio Finotovu pretpostavku da su u izvornoj verziji prikaz Buddhinih posljednjih dana i smrti i prikaz prvih dvaju sabora tvorili jedinstvenu cjelinu. V. Finot (1932).

${ }^{18} \mathrm{~S}$ teorijom postupnoga razvoja slažu se i Bareau (Recherches sur la biographie du Bouddha dans les Sutrapițaka et les Vinayapițaka anciens, 2 vols., Paris, 1963-1971) i Foucher (La vie du Bouddha d'après les textes et les monuments de l'Inde, Paris: Payot, 1949).
} 
dulji prikaz Buddhina života koji se proteže od trenutka probuđenja pa do obraćenja Śāriputre (pāli Sāriputta). ${ }^{19}$

Zasebni su se i nepotpuni Buddhini “Životi” pojavili tek početkom nove ere, a prvi njihovi prijevodi na kineski jezik otprilike u drugom stoljeću. Na sanskrtu su, ili točnije na buddhističkom hibridnom sanskrtu, sačuvana dva djela; Lalitavistara koja završava s preobraćenjem Śāriputre i Maudgalyāyane i Mahāvastu koji završava preobraćenjem trojice braće Kāśyapa. Oba djela imaju svoje paralele u kanonskoj književnosti, a pojedine se strofe ponekad čine arhaičnije negoli odgovarajući kanonski ulomci. Međutim, u cijelosti gledano, na ovome su stupnju razvoja Buddhina životopisa epizode njegova života razrađenije i obilježene brojnim novim detaljima. Đātake, priče o prijašnjim Buddhinim egzistencijama, imaju na ovome stupnju izrazito veliku ulogu, što posebno dolazi do izražaja u Mahāvastuu koji je njima u cijelosti prožet.

Cjeloviti se životopisi, koji obuhvaćaju vrijeme od silaska Gotame s nebesa Tușita do njegove smrti i razdiobe relikvija, javljaju od 2. stoljeća. Neki su od tih životopisa, kao što je primjerice Buddhaćarita autora Saṅgharakșe, sačuvani isključivo u kineskim prijevodima. Buddhaćarita cijenjenoga pjesnika Aśvaghoṣe u cijelosti je sačuvana u prijevodima na kineski i tibetski jezik, dok su na izvornome sanskrtu sačuvana pjevanja od I do XIV. Cjelovit se životopis nalazi i u Vinayi škole mūlasarvāstivāde ${ }^{20}$ koja je sačuvana u kineskom i tibetskom prijevodu $^{21}$ dok su na sanskrtskome izvorniku sačuvani samo fragmenti. Djela ove skupine obilježena su posvemašnjim prepuštanjem želji da život Gotame Buddhe oslika sa što čudesnijim, nevjerojatnijim i dramatičnijim detaljima, a pojedine su epizode, u prijašnjem razdoblju dobro poznate i utvrđene, ovdje poprimile sasvim nova obilježja dok su neke od njih i sasvim izmijenjene. ${ }^{22}$

Sinhaleška su djela nastala vjerojatno pod utjecajem sjevernoindijskih zasebnih i nepotpunih životopisa, međutim, sklonost čudesnomu i zadivljujućemu izražena je u nešto manjoj mjeri. Reprezentativno djelo te skupine predstavlja Nidānakathā, komentar uz pālijsku knjigu Đātaka.

\footnotetext{
${ }^{19}$ Vinaye škola mahīśasaka i dharmaguptaka sadrže još i kraći prikaz Buddhina rodoslovlja, rođenja kao i života do trenutka probuđenja. V. Lamotte (1958/1988: 653).

${ }^{20}$ Dutt, N. (1942-1950). Gilgit Manuscripts III/IV, Srinagar. U ovome je izdanju Vinaye izostavljen životopis koji se nalazi u knjigama Sanghabhedavastu i Vinayakṣudraka.

${ }^{21}$ Prijevod s tibetskog na engleski jezik u: Rockhill, W.W. (1884/2012).

${ }^{22}$ V. Lamotte (1958/1988: 659).
} 
Odabirom biografskih predaja iz prve dvije košare pālijskoga kanona te Nidānakathe i Mahāvastua u ovome su radu dani primjeri za četiri od ukupno pet stupnjeva Lamotteova shvaćanja razvojnoga puta životopisa Gotame Buddhe. Za dopunu životopisa iz Vinaye škole mūlasarvāstivādina (4. st.) trebalo bi se osloniti i na kineske i tibetske prijevode, a što nadilazi opseg ovoga rada.

\subsection{Kanon Tipitaka - opće odrednice}

Kanon škole theravāde (skt. sthaviravāda) - Tipițaka (Tripiṭaka), podijeljen je u tri (pāli. ti-, skt. tri-) skupine tekstova ili tri košare (pițaka). ${ }^{23}$ Prva košara, Vinayapiṭaka (Košara redovničke discipline $)^{24}$ sadrži uglavnom propise vezane uz život u redovničkoj zajednici i dijelom se temelji na ispovjednom formularu Pātimokkhi (Pratimokșa). Suttapițaka (Sūtrapițaka) ili Košara poučnih razgovara zbirka je tekstova u kojoj su uglavnom sadržane Buddhine propovijedi. Abhidhammapițaka (Abhidharmapițaka), Košara razmatranja o nauci, iz kasnijega je doba i u cijelosti je posjeduju samo škole theravāda i sarvāstivāda. ${ }^{25}$ U kanonskim se tekstovima redovito spominje podjela na dhammu i vinayu, a prikaz se nastanka toga prvoga kanona koji se je sastojao od samo dvije skupine tekstova (dvipițaka) nalazi u završnome poglavlju Ćullavagge u kojem se pripovijeda povijest prvoga buddhističkoga sabora. ${ }^{26}$ Izraz tipitaka spominje se u kasnijem kanonskome tekstu. ${ }^{27}$

Proučavanje se ključnih epizoda života Gotame Buddhe u ovome radu oslanja na prve dvije košare kanona, a te se sastoje od sljedećih dijelova:

Vinayapitaka:

I. Suttavibhanga (Tumačenje sutta): Pārāđika, Pāćittiya

\footnotetext{
${ }^{23}$ Podjeli na tri košare prethodi podjela na sljedećih devet udova ili članova (añga): sutta, geyya, veyyākarana, gāthā, udāna, itivuttaka, đātaka, abbhutadhama i vedalla. Iako među zapadnim istraživačima postoje razilaženja u mišljenju što točno znači pojedini izraz, tradicionalno se tumačenje oslanja na komentatora Buddhaghosu (5. st). Prema njegovu se tumačenju (Smp. I. 16) Buddhina riječ (buddhavaćana) mogla razvrstati u sedam kategorija među kojima je i podjela na devet udova: Evam etam sabbam pi Buddhavaanam rasavasenam ekavidham, dhammavinayavasena duvidham, pathamamajjhimapacchimavasena tividham, tathä pitakavasena, nikäyavasena pancavidham, añgavasena navavidham, dhammakkhandavasena caturäsītisahassavidhan ti veditabbam. V. i Geiger (1943/1996: 13-14), Winternitz (1933/1999:10). Sjevernoindijska tradicija slijedi podjelu na dvanaest udova, međutim, u Mahāvastuu se također spominje podjela na devet udova (Mv. i. 300-301).

${ }^{24}$ Nazivi košara preuzeti od Katičića (1973: 153).

${ }^{25}$ Izraz Abhidhamma, u značenju zasebne košare učenja, javlja se tek u kasnijim kronikama i komentarima. Kanonski tekstovi izraz abhidhamma rabe isključivo u značenju nauka ili doktrine iznešene u ne-književnome stilu (v. npr. DN iii. 267, MN i. 472). Tekstovi sakupljeni u Abhidhammapițaki izrasli su vjerojatno iz tabličnih sažetaka ili obrazaca (mātikāa, skt. $m \bar{a} t r k \bar{a})$ i uglavnom se sastoje od nabrajanja, sistematizacija i tumačenja nauka. Podjela na devet ili dvanaest udova ne navodi mātike.

${ }^{26}$ Vin. ii. $284-308$ (Ćullavagga XI).

${ }^{27}$ Vin. v. 3, 14.
} 

II. Khandhaka (Odsječci): Mahāvagga, Ćullavagga
III. Parivāra

Suttapitaka:

I. Dīghanikāya (Zbirka dugih izlaganja)

II. Mađđhimanikāya (Zbirka srednje dugih izlaganja)

III. Saṃyuttanikāya (Zbirka izlaganja razvrstanih u skupine)

IV. Añguttaranikāya (Zbirka izlaganja s jednim članom više):

V. Khuddakanikāya (Zbirka manjih komada ). U tu su zbirku uvrštena sljedeća djela:

Khuddakapāṭha, Dhammapada, Udāna, Itivuttaka, Suttanipāta, Vimānavatthu, Petavatthu, Theragāthā, Therīgāthā, Đātaka, Niddesa, Paṭisambhidāmagga, Apadāna, Buddhavaṃsa, Ćariyāpițaka.

Prema buddhističkoj je predaji kanon na Śri Lañku donio Mahinda (brat ili sin kralja Aśoke) u 3. st. pr. n. e. nakon trećega sabora u Pāțaliputti, ${ }^{28}$ a kanon je sa svojim komentarima (atțhakathā) zapisan prema sinhaleškim kronikama nešto prije početka nove ere, u vrijeme vladavine kralja Vattagamāṇia (29-17. g. pr. n. e.). ${ }^{29}$ Do toga je vremena kanon prenošen usmenim putem i nema sumnje da je do svoga zapisivanja pretrpio mnoge izmjene i da su mlađi tekstovi pronašli svoj put do kanonizacije. Činjenica da je kanon zapisan ne znači da je bio u cijelosti zatvoren. Naime, još su u petome stoljeću trajale rasprave o pojedinim tekstovima sakupljenima unutar Khuddakanikāye. Kanon je, po svemu sudeći, nastajao postepenim uvođenjem novih tekstova koji su se recitirali na okupljanjima redovnika, a koji su započinjali uvodnim riječima evam me sutạ̣ (tako sam čuo). Ti su tekstovi potom prolazili kroz svojevrsnu provjeru i, u slučaju “povoljne ocjene”, bili dodjeljivani odgovarajućoj zbirci i tako zadobivali kanonski status. ${ }^{30} \mathrm{Na}$ reljefima i natpisima datiranima u 3. st. pr. n. e. susreću se prizori iz đātaka ili njihovi naslovi te izrazi dhammakathika (koji propovijeda doktrinu), suttantika (koji recitira sutte), vinayadhara (stručnjak za pitanja redovničke discipline), pețakin (koji poznaje pițake) i pañcanekāyika (koji poznaje pet nikāya). ${ }^{31}$ Također, natpis iz Bairata daje popis

\footnotetext{
${ }^{28}$ Dpv. VIII. 13, Smp. I. 64, 3-4, Mhv. XII. 7-8. Oldenberg (1879/1964: li) predaju o Mahindi ne smatra povijesno utemeljenom: In fact, it cannot by any means, with the requisite strictness, be considered as sufficiently attested, that Mahinda brought the sacred texts to Ceylon. S druge strane Wynne (2005: 65), oslanjujući se na sadržaj 13. Aśokina edikta, sinhaleške kronike i zaključke Frauwallnera i Gombricha, zaključuje: [...] that the tradition of the Buddhist missions in Aśoka's time is relatively accurate [...].

${ }^{29}$ Dpv. XX. 20-21, Mhv. XXXIII. 100-101.

${ }^{30} \mathrm{DN}$ ii. $123, \mathrm{AN}$ ii. 167.

${ }^{31}$ Rhys Davids (1903/1911: 167-168), Winternitz (1933/1999: 17), Oldenberg (1964: xl, bilj. 1).
} 
tekstova koje kralj Aśoka smatra posebno prikladnima za učenje, a tekstovi se pod istim ili sličnim naslovima mogu pronaći unutar Suttapițake. ${ }^{32}$ Može se tako zaključiti da je do otprilike polovice 3. st. pr. n. e. već postojala zbirka tekstova podijeljena u sutte, piṭake i nikāye. ${ }^{33}$

Kanon je sačuvan na srednjoindijskom jeziku pāliju. Potrebno je, međutim, napomenuti da se pāli u značenju jezika kanonskih tekstova ne spominje u theravādskome kanonu. Izraz pāli javlja se u sinhaleškim kronikama kao i u komentarima na kanonske tekstove, međutim, tu ima značenje tekst i to prvenstveno kanonski tekst suprotstavljen komentaru (ațthakatha $).{ }^{34} \mathrm{U}$ komentarima se izraz pāli koristi i kao sinonim za Buddhinu riječ (buddhavaćana). Jezik kanonskih tekstova komentari poistovjećuju s māgadhskim narječjem ili jezikom (māgadhinirutti, māgadhikabhāsā). ${ }^{35}$ Štoviše, buddhistička tradicija tvrdi da je sam Buddha propovijedao na māgadhskom pa se iz toga razloga māgadhski ponekad naziva i mūlabhāsā, odnosno korijenski ili izvorni jezik kanona. Čini se da je shvaćanje izraza pāli u značenju određenoga jezika kanonskih tekstova posljedica krivoga tumačenja složenice pālibhāsa (jezik tekstova) a koja je, čini se pod snažnim utjecajem Buddhaghosinim, podrazumijevala māgadhski. ${ }^{36}$

\footnotetext{
${ }^{32}$ Npr. Ariyavāsā = DN iii. 269 i d., Anāgatabhayāni = AN iii. 105-108, Munigāthā = Sn. 207-221, Moneyyasutta $=$ AN i. 273, Lāghulovāda = MN i. 414 i d. Schopen (1985: 12): We also know that at least seven texts (dhammapaliyāya) were known to Aśoka since he refers to them by name in his Bhäbrā Edict, but unfortunately only three of these have been identified with anything approaching unanimity (Muni-Gāthā = Suttanipāta vss. 207-221, Moneyya sūte = Nālaka-sutta. Suttanipāta vss. 699-723, Upatisa-pasine = Sāriputta-sutta. Suttanipāta vss. 955975) and even these are not certain.

${ }^{33}$ Kada je riječ o vremenskim okvirima nastanka kanona, u novije su vrijeme pojedini istraživači doveli u pitanje stavove koje su zastupali učenjaci poput primjerice Oldenberga ili Rhys Davidsa. Schopen (1997: 24) tako piše: We also know that there is no evidence to indicate that a canon existed prior to the Alu-vihära redaction. Although Aśoka in his Bhäbrä Edict specifically enjoined both monks and laymen to recite certain texts, which he named, he nowhere in his records gives any indication that he knew of a canon, or the classification of texts into nikayyas. We do know, however, that the epithet pañcanekāyika occurss in the Bhärhut and Sāñ $\bar{c}$ inscriptions, but we also know that Lamotte has shown that it is unlikely that this refers to the five collections of the Süttapitaka. And even if it could be shown to refer to the nikayas as codified collections, this would still not push the data for the collection of at least some texts into nikayas much beyond the first century B.C.E., the approximate date of the inscriptions from Bhärhut and Sāñcī. Kao odgovor na Schopenov skepticizam Wynne (2005: 65) zaključuje da je najveći dio tekstova sadržanih unutar prve dvije pițake na Śri Lan̉ku stigao oko 250 g. pr. n. e. Tvrdi dalje da podudarnosti u pojedinim kanonskim tekstovima različitih buddhističkih škola navode na zaključak da su vjerojatno nastali prije raskola unutar buddhističke zajednice, odnosno u razdoblju između prvoga i drugoga općeg sabora.

${ }^{34}$ Npr. Pālimattam idh' ānītam, $n^{\prime}$ atthi ațthakathā idha (Mhv. XXXVII. 227).

${ }^{35}$ Npr. Vsm. 441-442: Sabhāvaniruttiyā Māgadhikāya sabbasattānaim mūlabhāsāya, Mhv. XXXVII. 244: sabbesam mūlabhāsāya Māgadhāya niruttiyā.

${ }^{36}$ Tradicija se oslanja na Buddhaghosin komentar uz ulomak u pālijskoj Vinayi (Ćullavagga 5.33= Vin. ii. 139,1) u kojem tvrdi da pod Buddhinim vlastitim jezikom podrazumijeva māgadhski (sammāsambuddhena vuttappakāro Māgadhikavohāro), Smp. VI. 1214. U tome ga tumačenju slijedi i Geiger (1943/1996: 7). Winternitz je (1933/1999: 14) također mišljenja da tradicija koja izjednačuje pāli s māgadhskim sadrži neku povijesnu vrijednost i smatra da je u osnovi pālija stari māgadhski.
} 
Buddhistička tradicija koja poistovjećuje pāli s māgadhskim ili māgadhski smatra dijalektalnom njegovom osnovom opovrgnuta je. ${ }^{37}$ Pāli, kako ga danas poznajemo, nije jedinstven jezik i u povijesti se njegova razvoja može razlučiti nekoliko slojeva. ${ }^{38}$ Danas je uglavnom prihvaćen stav da pāli predstavlja mješavinu dijalekata, odnosno da je svojevrsna "Kunstsprache”, međutim na pitanje dijalekata u osnovi pālija još nije do kraja odgovoreno. ${ }^{39}$

Pri pokušaju ispisivanja životopisa osnivača buddhizma na umu treba imati da je pālijski kanon zapisan tek krajem stare ere do kada je buddhizam kao vjerski pokret prošao kroz niz razvojnih stupnjeva. U kanonski su korpus s vremenom ušla djela koja su nedvojbeno mlađega postanka i koja u bitnome odražuju promjene koje su zadesile redovničku zajednicu kao i društvo u kojem je ona djelovala. Kanon kakav ga danas poznajemo predstavlja tako kompilaciju tekstova različitih po vremenu nastanka kao i po svome odnosu spram Gotame Buddhe.

Ključne se epizode života Gotame Buddhe nalaze u kanonu iznesene na sljedećim mjestima:

Začeće: MN iii. 118-122 (Aććhariyabbhutadhammasutta, MN sutta br. 123), DN ii. 1213 (Mahāpadānasutta, DN br. 14), AN ii. 130-131 (Paṭhamatathāgatāććhariyasutta, AN 4. 127)

Rođenje: MN iii. 122-124 (Aććhariyabbhutadhammasutta, MN br. 123), DN ii. 14-20 (Mahāpadānasutta, DN br. 14), Sn. 679-693 (Nālakasutta, Sn. 3.11), AN ii. 131-132 (Paṭhamatathāgatāććhariyasutta, AN 4. 127)

Odlazak u beskućništvo: $M N$ i. 161-167 (Ariyapariyesanāsutta, MN br. 26), MN i. 116 (Dvedhavitakkasutta, MN br. 19), MN i. 240 (Mahāsaććakasutta, MN br. 36), Sn. 405-424 (Pabbađđāsutta, Sn. 3.1), DN i. 115 (Soṇadaṇḍasutta, DN br. 4), AN i. 145-148 (Sukhumālasutta, SN 3. 39), DN ii. 21-30 (Mahāpadānasutta, DN br. 14)

Probuđenje: $M N$ i. 21-24 (Bhayabheravasutta, $M N$ br. 4), $M N$ i. 167 i d. (Ariyapariyesanāsutta, MN br. 26), MN i. 117 (Dvedhavittakasutta, MN br. 19), MN i. 247-

\footnotetext{
${ }^{37}$ Burnouf, Lassen (1826).

${ }^{38}$ Geiger (1943/1996:1-2).

${ }^{39}$ Oldenberg (1879/1964: XLVIII) odbacuje mogućnost da je pāli istovjetan s māgadhskim. Nešto dalje izražava i svoje neslaganje s Westerggardom i Kuhnom koji su, temeljeći svoje mišljenje na odlomku Mahāvaṃse, zaključili da je pāli bio dijalekt grada Uđđaina. Oldenberg je stava da se podrijetlo pālija treba tražiti južno od planinskoga lanca Vindhya, odnosno na području nekadašnjih kraljevstva Andhre i Kalinge. Rhys Davds (1903/1911:153-154) podrijetlo pālija traži na području Kosale. No, primjerice, Hinüber (1996: 5) smatra da pāli svoj temelj ima u jeziku koji je bio prisutan u zapadnome a ne istočnome dijelu Indije ali da neke značajke istočnoga govora svjedoče o ranijoj verziji kanonskih tekstova. Taj proto-kanonski jezik Lüders (1940: 280) naziva Alt-Ardhamāgadhī. Da je pāli u svome temelju jezik zapadne Indije smatra i Oberlies (2001: 1) koji ističe jezične paralele s jezikom Aśokinih natpisa, posebno onih u Girnāru. Nakamura (1980/1987: 23-24) smatra da podrijetlo pālija treba tražiti na području sjeverozapadne Indije ali da tragovi māgadhizama svjedoče o ranijoj verziji kanona koji je bio sastavljen na jeziku različitom od pālija.
} 
248 (Mahāsaććakasutta, MN br. 36), Vin. i. 1-6 (Mahāvagga, I. 1. 1-I. 5. 13), DN ii. 30-36 (Mahāpadānasutta, DN br. 14)

Pokretanje kotača nauka: Vin. i. 10-12 (Mahāvagga, I. 6, 17-32), SN v. 420-424 (Dhammaćakkappavattanasutta, SN 56. 11), MN i. 173 (Ariyapariyesanāsutta, MN br. 26), DN ii. 35-42 (Mahāpadānasutta, DN br. 14)

Posljednji mjeseci života i parinibbāna: DN ii. 72-168 (Mahāparinibbānasutta, DN br. 16), SN i. 157-159 (Parinibbāna, SN 1. 6, 2.5.)

\subsection{Nidānakathā}

Nidānakathā je uvod u pālijski komentar uz pālijsku knjigu Đātaka, uvrštenu u Khuddakanikāyu. Đātake, odnosno pripovijesti o Buddhinim prethodnim egzistencijama, pojavljuju se relativno rano u pregledu kanonskih književnih vrsta, međutim rijetko se pojavljuju unutar tekstova prve četiri zbirke Suttapițake. ${ }^{40}$ Đātake su, čini se, bile popularne još u 3. ili 2. stoljeću pr. n. e budući da se na stūpama u Bhārhutu i Sāñćhī nalaze reljefi sa scenama iz đātaka, a ponegdje su uklesani čak i njihovi naslovi. ${ }^{41}$ Procvat te književne vrste zbio se najvjerojatnije za vrijeme ili nakon razdoblja vladavine kralja Aśoke kada se njihov broj naglo povećava i kada mnoge od njih nastaju pod utjecajem lokalnih književnih tradicija i vjerovanja. Dvije velike zbirke đātaka, koje su svoje mjesto pronašle unutar Khuddakanikāye, kanonizirane su do početka nove ere, odnosno do vremena zapisivanja tekstova. To su Ćariyāpiṭaka, zbirka od trideset i pet đātaka i Đātaka, zbirka od njih 547. Kanonska knjiga Đātaka sadrži metričke dijelove $(g \bar{a} t h \bar{a})$, dok prozni dijelovi nisu bili čvrsto utvrđeni. Kada je kanonska knjiga uobličena, utvrđen je prozni okvir đātaka u opširnom komentaru, a taj se naziva Đātakațțhakathā. Iako je komentar preveden na sinhaleški jezik, metrički su dijelovi ostali na pāliju. Komentar u obliku u kojem ga danas posjedujemo preveden je sa sinhaleškoga na pāli najvjerojatnije u 5. stoljeću. On sadrži preko pet stotina đātaka, naziva se Đātakaț̣havanṇṇana (ĐātA.), a Nidānakathā mu je uvod. Uglavnom su to prozne pripovijetke sa stihovima, a prema svome se sadržaju mogu podijeliti na basne, legende, bajke i moralne pouke. Izvori đātaka su raznoliki, a bitno je napomenuti da se mnoge od njih mogu pronaći i u drugim djelima indijske pripovjedačke tradicije. $^{42}$

\footnotetext{
${ }^{40}$ Usprkos nezastupljenosti đātaka u tome dijelu kanona Reynolds (1976: 21) ističe: [...] the presence of jātaka stories in the early strata of remebered word of the Buddha proves that the genre cannot be easily lightly passed off as a development associated with a late "popularization" of the Buddha's original message.

${ }^{41}$ Rhys Davids (1903/1911: 209).

${ }^{42}$ Npr. u Pañćatantri, Tatrākhyāyiki i Hitopadeśi.
} 
Nidānakathā je podijeljena u tri dijela. Prvi dio o dalekoj prošlosti (dūrenidāna) započinje Bodhisattinim zavjetom izrečenim pred buddhom Dīpañkarom i proteže se preko vremena dvadest i četiriju Gotaminih prethodnika sve do trenutka rođenja u nebesima Tusita. Dio o ne tako dalekoj prošlosti (avidūrenidāna) donosi najprije opis Bodhisattina boravka u nebesima Tusita, a potom se opisuju njegovo začeće i rođenje i događaji do njegova probuđenja. Treći dio o bližem vremenu (santikenidāna) proteže se od Buddhina probuđenja do Anāthapiṇụikinoga darivanja parka kraljevića Đete redovničkoj zajednici. Nidānakathā se uvelike oslanja i poziva na Buddhavaṃsu, tekst Khuddakanikāye o prethodnim buddhama, i na već spomenutu Ćariyāpițaku. Valja napomenuti da se Nidānakathā u pojedinim slučajevima poziva na pripovijesti u Ćariyāpiṭaki koje se ne nalaze u Ćariyāpițaki kakvu danas poznajemo. Hinüber (1996: 64-65) pretpostavlja da je sačuvana Ćariyāpițaka južnoindijska verzija dok se Nidānakathā poziva na verziju Ćariyāpițake prisutne na Śri Lañki. ${ }^{43}$ Također, Nidānakathā svojom strukturom nalikuje na životopise kao što su Mahāvastu i Lalitavistara, a koji se ponekad nazivaju "nepotpunim životopisima". ${ }^{44}$

Ključne se epizode života Gotame Buddhe nalaze u sljedećim dijelovima Nidānakathe:

Začeće: ĐātA. I. 50-52

Rođenje: ĐātA. I. 52-53

Odlazak u beskućništvo: ĐātA. I. 59-65

Probuđenje: ĐātA. I. 75-76:

Prva propovijed: ĐātA. I. $81-82$

\subsection{Mahāvastu - Veliki predmet pripovijedanja ${ }^{45}$}

Godine 1837. pariška je Société Asiatique zaprimila pošiljku rukupisa koju je iz Nepala poslao Brian H. Hodgson. ${ }^{46}$ Među njima su se nalazile i kopije rukopisa Mahāvastua koje je Eugène Burnouf predstavio kao voluminous collection of legends related to the founder of Buddhism. ${ }^{47}$ Burnouf je prvi zamijetio da se u kolofonu drugoga prologa (nidāna) spominje i ime škole kojoj djelo pripada, a koja se do tada bila poznata samo preko kineskih i tibetskih izvora:

\footnotetext{
${ }^{43}$ To bi objasnilo činjenicu da Nidānakathā donosi pripovijest za svako od deset savršenstava dok sačuvana verzija Ćariyāpițake ilustrira samo njih sedam. Cousins pretpostavlja da lista od sedam savršenstava prisutna u sačuvanoj verziji Ćariyāpițake predstavlja raniji sloj u razvoju nauke o deset savršenstava, u: Appleton (2010: 100).

${ }^{44}$ Lamotte (1958/1988: 648).

${ }^{45}$ Windisch se (1909: 474) oslanja na Oldenberga kada Mahā-vastu prevodi kao "der Grosse Gegenstand". Tvrdi također da se vastu (pāli vatthu) može uzeti i u značenju "Geschichte", ime bi dakle moglo značiti "Velepripovijest".

${ }^{46}$ Katalog se rukopisa nalazi u: Cowell i Eggeling (1875).

${ }^{47}$ Burnouf (1844/2010: 66).
} 
I regard this book no less to be one of the most ancient compilations that the collection of Nepal has preserved for us, and the indication alone contained in this title, the "Lesson of the Mahāsāṃghikas", brought together with the Tibetan tradition related to the name of the disciples of Kāśyapa, in my eyes ensures to it a great value and incontestable antiquity. ${ }^{48}$

Međutim, predvidjevši da u istom kolofonu stoji da Mahāvastu pripada Vinayapiṭaki, Burnouf je zaključio da djelo nije kanonsko i da nepalska zbirka ne sadrži knjige koje pripadaju vinayi. ${ }^{49}$ Burnoufov propust komentirao je i Senart (1882: iv) u uvodu svojega izdanja Mahāvastua koje je priredio u razdoblju od 1882. do 1897. godine. Senart je na raspolaganju imao šest rukopisa ${ }^{50}$ na temelju kojih je rekonstruirao kolofon:

āryamahāsāmghikānām lokottaravādinām madhyadeśikānāṃ pāṭ̂nena vinayapițakasya mahāvastuye ādi / ${ }^{11}$

J. J. Jones koji je u razdoblju od 1949. do 1956. godine napravio prvi prijevod Senartova izdanja preveo ga je na sljedeći način:

Here begins the Mahāvastu, which is based on the redaction of the Vinaya Pitaka made by the noble Mahāsānghikās, the Lokkotaravādins of the Middle Country. ${ }^{52}$

Usprkos naslovu koji Mahāvastu povezuje s Vinayapițakom, Oldenberg, Windisch i RhysDavids bili su složni u mišljenju da Mahāvastu nije kanonsko djelo već da se temelji na pālijskim Odsječcima (Khandhakā) pa tako primjerice Windisch (1909: 476) tvrdi:

Der Hauptbeweis aber dafür, dass Mahāvastu aus dem Mahāvagga erwachsen ist, beruht darauf, dass die ersten vierundzwanzig Kapitel des Mahāvagga zu einem grossen Teile wörtlich im Mahāvastu enthalten sind. ${ }^{53}$

\footnotetext{
${ }^{48}$ Burnouf (1844/2010: 423).

${ }^{49}$ Burnouf (1844/2010: 87). Tournier (2012: 89, bilj. 11) naglašava: This is not due to the lacuna in the copy he consulted since the phrase vinayapițakasya mahāvastuye ādi is contained in it.

${ }^{50}$ Senart (1882: v-ix).

${ }^{51}$ Mv. i. 2. 13-14.

52 Jones (1949/2007, sv. 1: 3).

${ }^{53}$ Usp. Rhys-Davids (1910/2007: 257), Oldenberg (1912: 133), Dessein (2009: 40-41).
} 
Takvu je stavu uvelike pripomogla i činjenica da je u rukopisima kojima se je služio Senart Mahāvastu okarakteriziran kao Mahāvastu-avadāna ${ }^{54}$ što je dodatno učvrstilo stajalište da djelo nije u strogom smislu dio Vinayapitake i da pripada korpusu avadāna. ${ }^{55}$

Otkriće novih rukopisa u Nepalu ${ }^{56}$ navelo je pojedine autore kao što su Kōgen Mizuno, Akira Hirakawa i Akira Yuyama da utvrde da je Mahāvastu izvorni naslov djela, a da je epitet avadāna dodan naknadno, u procesu kompilacije tekstova. Prema njihovu je shvaćanju Mahāvastu izvorno bio dio Vinayapițake ali je u procesu uvrštavanja novih tekstova došlo do promjene književnoga roda. ${ }^{57} \mathrm{U}$ novije je vrijeme veliku pažnju novim rukopisima posvetio Vincent Tournier koji se je posebno usredotočio na tzv. rukopis $S a$ koji za sada predstavlja najraniju cjelovitu kopiju Mahāvastua (12/13 st.). ${ }^{58}$ Niže sažeti Tournierovi zaključci temelje se na njegovim radovima objavljenima 2012. i 2017. godine.

1. Tournier (2012: 92) ne odobrava Jonesov prijevod tvrdeći da se pāthena odnosi na ime škole i da se vinayapițakasya treba uzeti u značenju partitivnoga genitiva pa predlaže sljedeći prijevod:

[...] it is to be translated as "beginning of the Mahāvastu (literally: the "Great Chapter") of the Vinayapitaka, according to the recension of the Mahāsāṃghika - Lokottaravādins" etc.

2. Na mjestu izraza madhyadeśika koji se nalazi u kolofonu Senartova izdanja, u rukopisu Sa stoji madhyuddeśika. Tournier (2012: 95-96) piše:

As remarked already by Roth (1985), manuscript Sa preserves the genuine reading Madhyuddeśika also shared with other texts of the school. It means according to him "those who recite [the Pratimokșasūtra] through the medium of an intermediate type of language" [...] What is certain is that this epithet, pertaining to Vinaya terminology, was later on corrupted into Madhyadeśika, "residents of Madhyadeśa", in the process of manuscript transmission.

\footnotetext{
${ }^{54}$ Npr. Mv. iii. 461. 13-14: iti āryamahāsāṃghikānām lokottaravādinām pāthena iti śrīmahāvastu-avadānam samāptam //.

${ }^{55}$ Tako primjerice Prebish (1994: 64) uvrštava Mahāvastu u poglavlje "Non-Canonical Vinaya Literature" tvrdeći da je djelo avadāna.

${ }^{56}$ Prijepis rukopisa objavljen je u Yuyama (2001).

${ }^{57}$ U: Tornier (2012: 93). Slična se tvrdnja nalazi i kod Hinübera (1996: 19, §36) koji, govoreći o uvrštavanju novih tekstova u mūlasarvāstivādinsku Vinayu, piše: Thus the law texts are slowly overgrown with stories, to such extent that there is almost a change of genre, from law books to Avadāna.

${ }^{58}$ Tournier prihvaća Yuyaminu dataciju u: Yuyama (2001: xlvii-xlviii).
} 
3. Tournier (2012: 93-94; 2017: 610) smatra da je epitet avadāna rezultat interpretacije teksta u 17. stoljeću, kada je taj književni rod u Nepalu bio iznimno popularan.

4. Pripadnost Vinayi lokottaravādina je neupitna, međutim Tournier (2012: 94; 2017 : 611) smatra da unutarnja struktura Mahāvastua ne odgovara pālijskim Odsječcima već da djelo treba shvatiti kao a companion to the Mahāsānghika Bhikṣu-Prakīrnaka, with the initial raison d'être to offer a narrative background to the latter text's categories [...]".

5. Rukopis $T a$ datairan u 1657. godinu, drugi je najstariji rukopis i apograf je rukopisa Sa. Rukopis je prepisao Đayamuni koji je nerijetko ujednačavao sintaksu i sankrtizirao prākrtizme. Ipak, u cijelosti gledano, rukopis $T a$ vjerno slijedi rukopis $S a$. Tournier (2012: 98; 2017: 610) ističe kako se epitet avadāna po prvi puta spominje u rukopisu Ta u završnome kolofonu koji je nadodao Đayamuni: This innovation had important concequences for the way Mahāvastu was concieved afterwards, since it was transmitted to the later manuscript tradition.

6. Svi kasniji rukopisi, uključujući i šest rukopisa kojima se služio Senart, temelje se na rukopisu $T a$.

Mahāvastu je sačuvan na buddhističkom hibridnom sanskrtu koji se ponekad naziva buddhistički sanskrt ili miješani sanskrt. Edgerton (1953/1998, sv. 1: 1) hibridnim sanskrtom označuje jezik velikoga dijela buddhističkih tekstova s područja sjeverne Indije. Hibridni se sanskrt temelji na srednjoindijskome dijalektu čiji identitet nije jasno utvrđen. Pojedine svoje značajke dijeli s pālijem, ardhamagadhī i apabhramśom. Bitna je odlika toga jezika da je vrlo rano potpao pod snažan utjecaj sanskrta. Stupanj sanskrtizacije ovisi o razdoblju u kojem je pojedino djelo nastalo, ali može varirati i unutar samoga teksta. Ugrubo rečeno, što je djelo mlađe, utjecaj je sanskrta veći. Prema stupnju sanskrtizacije Edgerton (1953/1998, sv. 1: xxv) buddhističke tekstove dijeli u tri skupine, a Mahāvastu ubraja u prvu skupinu, odnosno u skupinu tekstova u kojima su obilježja srednjoindijskoga tipa očuvana u najvećoj mjeri. Valja napomenuti da su dijelovi u stihovima redovito manje podložni promjenama, a pretpostavlja se da su tomu razlog metrički zahtjevi koji otežavaju sanskrtizaciju kao i veća važnost ili "svetost" koja se pripisivala stihovima. Prozni su dijelovi u većoj mjeri sanskrtizirani tako da uvelike nalikuju standardnomu sanskrtu. Edgerton je pokušao pokazati da je hibridni sanskrt samostalan jezik s vlastitim leksikom i gramatikom i da se ne može svesti na modifikaciju nekoga drugog dijalekta. ${ }^{59}$

\footnotetext{
${ }^{59}$ Edgerton (1953/1998, sv. 1: 1-14).
} 
Mahāvastu je, kao i Nidānakathā, podijeljen u tri dijela. U prvome se opisuju događaji iz prijašnjih Buddhinih života, drugi dio započinje opisom Buddhina začeća i rođenja i završava opisom njegova probuđenja, dok treći dio, koji je djelomično podudaran s dijelom Vinayapiṭake zvanim Mahāvagga, sadrži, između ostalog, opis obraćenja nekih istaknutih Buddhinih učenika i opis pokretanja kotača nauka.

Buddhin je životopis središnja tema ovoga opsežnoga djela, međutim, on se ne iznosi kronološkim slijedom. Naprotiv, isprekidan je izlaganjem brojnih đātaka i sūtra, što nerijetko otežava čitanje. Mnoge se životopisne epizode susreću nekoliko puta, a katkad su iste epizode ili đātake iznesene s modifikacijama. Đātake su u tome djelu zastupljene u mnogo većoj mjeri negoli je to slučaj u pālijskome kanonu i služe kao mjesto za umnožavanje i isticanje Buddhinih vrlina. Gomilanjem pripovijesti o Buddhinim prethodnim egzistencijama, njegov je životpis prerastao i zasjenio njegovu posljednju egzistenciju i proširio se na nemjerljivo vrijeme koje joj je prethodilo. U Mahāvastu su svoj izraz pronašle i mnoge ideje karakteristične za tzv. mahāyānski buddhizam, kao što su primjerice nauka o četiri puta (ispravnoga) djelovanja (ćaryā), nauka o deset razvojnih stupnjeva bodhisattve (daśabhūmi) kao i ideja o beskonačnom broju buddha i bodhisattva.

Mahāvastu odražuje razvijeni tip životopisa koji se je oblikovao otprilike od 1. st. pr. n. e. da bi svoj konačan oblik zadobio u 5. ili 6. stoljeću. ${ }^{60}$ Mjesta na kojima se iznose ključne epizode Gautamina života jesu sljedeća:

Začeće: Mv. i. 98, 142-147, 197-214, Mv. ii. 1-18

Rođenje: Mv. i. 99-100, 148-153, 215-227, Mv. ii. 18-30

Odlazak u beskućništvo: Mv. i. 154-158, 227-228, Mv. ii. 115-134; 140-167; 189$210 ; 299-300$

Probuđenje: Mv. i. 228-231; Mv. ii. 131-133; Mv. ii. 263-271, nastavak u ii. 276288; Mv. ii. 300-349; 397-420

Pokretanje kotača nauke: Mv. iii. 330-334, Mv. iii. 340-341

O događajima nakon Gautamina ulaska u konačnu nirvāṇu: Mv. i. 63-74

\footnotetext{
${ }^{60}$ Tournier (2017: 609).
} 


\section{4. Škole theravāda i mahāsānghhika-lokottaravāda}

Tradicionalno se stariji buddhizam dijeli u dvije grane (mahāsānghika i theravāda, skt. sthaviravāda) ${ }^{61}$ i njihove ogranke ili škole (nikāya, vāda, āćariyavāda) ${ }^{62}$

Vasumitra u raspravi Samayabhedoparaćanaćakra (3/4. st.) donosi sljedeću podjelu glavnih grana i njihovih ogranaka: ${ }^{63}$

I. Mahāsānnghika: ekavyavahārika, ${ }^{64}$ lokottaravāda, kaukkutika, bahuśrutīya, prađñāptivāda, ćaityaśaila, aparaśaila, uttaraśaila

II. Sthaviravāda: sarvāstivāda, vātsīputrīya, dharmottarīya, bhadrāyanīya, saṃmitīya, ćhannagirika, dharmaguptaka, mahīśāsaka, kāśyapīya, sautrāntika, mūlasarvāstivāda ili haimavata

Sinhaleški izvori donose sljedeću podjelu: ${ }^{65}$

I. Mahāsānghika: gokulika, ekabyohārika, paṇn̄âtti, bahusuttaka, ćetiya

II. Theravāda: mahiṃsāsaka, vađđiputtaka, dhamuttarika, bhaddayānika, ćhannagarika, saṃmiti, sabbatthivāda, dhammagutta, kassapika, sañkatika, suttavāda

Kada je riječ o vremenu raskola na te dvije grane Vasumitra u Samayabhedoparaćanaćakri tvrdi da se dogodio 100 ili 116 godina nakon Buddhine parinirvāṇe. ${ }^{66}$ Stotinu se godina spominje i u Dīpavaṃsi (V. 30-39). Prema tradiciji škole saṃmitīye koju bilježe Bhavya i Tāranātha raskol se dogodio 137 godina nakon parinirvāne. ${ }^{67}$ Prema tradiciji sthaviravādina koju bilježi Bhavya raskol se dogodio 160 godina nakon Buddhine parinirvāṇe. ${ }^{68}$ Sanggharāđā Dharmakīrti u svome djelu Nikāyasaṃraha (14. st.) tvrdi da se raskol dogodio tijekom sabora kojim je predsjedao Tissa Moggaliputtatissa u 236. godini nakon Buddhine parinirvāṇe.

Kao razlog za raskol zajednice na dvije grane theravādski izvor Dīpavaṃsa navodi deset točaka (dasavatthūni) ili deset krivovjenih praksa zajednice Vađđiputtaka koje su dovele do

\footnotetext{
${ }^{61}$ Za izvore koji donose podjelu starijega buddhizma u dvije grane v. Lamotte (1958/1988: 529-535). Za grafički prikaz raspodjele škola v. Hirakawa (1990: 112-116).

${ }^{62}$ Cousins (1988/1990: 27) smatra da su izrazi nikāya, vāda, āćariyavāda u kasnijem razdoblju postali sinonimi.

${ }^{63}$ Masuda (1925: 14-17).

${ }^{64}$ Cousins (1988/1990: 48) : [...] it seems likely that the Lokottaravādins and the Ekavyavahärikas are two names for the same school.

${ }^{65}$ Dpv. V. 39-54. Ista se podjela susreće u Mhv. V. 1-13.

${ }^{66}$ Masuda (1925: 14).

${ }^{67}$ Lamotte (1958/1988: 535).

${ }^{68}$ Prebish i Nattier (1977: 271) ističu da je zapravo riječ o sarvāstivādskoj tradiciji.
} 
drugoga sabora u Vesālī i raskola. ${ }^{69}$ Vasumitra (sarvāstivādski izvor) kao razlog navodi pet teza redovnika Mahādeve. ${ }^{70}$ Pet se teza kao razlog navodi i u sarvāstivādskome djelu Abhidharmamahāvibhāṣāśāstra, međutim tu se navodi kako su teze izazvale raskol među mahāsañghikama i sarvāstivādinima. Bhavya u djelu Nikāyabhedavibhañgavyākhyāna prenosi tri tradicije: prema sthavirama su raskol izazvala različita neslaganja ali se ti razlozi ne navode izričito; tradicija mahāsānghika nabraja osamnaest škola ne navodeći razlog za inicijalni raskol; prema tradiciji škole saṃmitīya raskol je izazvao redovnik Bhadra koji je zastupao pet teza. U Śāriputraparipréćchāsūtri, djelu koje pripada mahāsāṅghikama, tvrdi se da je raskol izazvalo uvođenje novih pravila u Vinayapiṭaku među budućim sthavirama.

Izvore koji donose vrijeme i objašnjenja za raskol u buddhističkoj zajednici kao i detaljan pregled zapadnih istraživanja donijeli su Prebish i Nattier (1977). Odbacujući pet Mahādevinih teza i deset točaka neslaganja po pitanju redovničke discipline kao razlog raskola, autori zaključuju:

First, that Mahadeva has nothing to do with the primary schism between the Mahāsaṃghikas and Sthaviras [...]. Second, that the sole cause of the initial schism in Buddhist history pertained to matters of Vinaya, but rather than representing a reaction of orthodox Buddhists to Mahāsaṃghika laxity, as maintained by both Bareau and Demieville, represents a reaction on the part of the future Mahāsamphikas to an unwarranted expansion of the root Vinaya text on the part of the future Sthaviras [...]. Finally, that the date proposed by Bareau for the schism (137 A.N.) is arrived at in less than certain terms, and that 116 A.N. is a significantly more reasonable date to maintain. (Prebish i Nattier, 1977: 238-239)

Cousins (1988/1990: 48) također smatra da su najraniju podjelu izazvala neslaganja u pitanjima redovničke discipline, a da su Mahādevine teze izazvale kasniji, unutarnji raskol među mahāsāṅghikama. ${ }^{71}$

Theravāda se iz Pāțaliputre gdje je imala svoje središte proširila zapadnom (Kauśāmbi), središnjom (Uđđain) i južnom Indijom (Kāñóīi), bila je prisutna i u Sārnāthu, ${ }^{72}$ a na Śri Lañku je stigla u 3. st. pr. n. e. Prikaz dolaska buddhizma na Śri Laṅku opisan je u Mahāvaṃsi, Dīpavamsi i uvodu Buddhaghosinoga komentara uz Vinayu. Sva tri izvora spominju i osnivanje

\footnotetext{
${ }^{69}$ Hofinger je (1964) prvi dokazao da se raskol na dvije grane, theravādu i mahāsañghiku, nije dogodio tijekom drugoga sabora u Vaiśālī.

${ }^{70}$ Masuda (1925: 14).

${ }^{71}$ Usp. Nattier i Prebish (ibid. 261 i d.).

${ }^{72}$ Dutt, N. (1970/1998: 135).
} 
prvoga samostana (Mahāvihāra) u Anuradhapuri. Prvi se raskol unutar sinhaleške theravādske zajednice dogodio otprilike u vrijeme zapisivanja kanona, u vrijeme kralja Vaț̣agāmaṇia, kada je osnovan samostan Abhayagiri. Drugi se raskol dogodio u 4. stoljeću, za vrijeme vladavine kralja Mahāsene, kada je osnovan samostan Đetavana. Pālijski kanon pripada tradiciji samostana Mahāvihāra. ${ }^{73}$

U svome uvodu u izdanje pālijske Vinayapițake Oldenberg (1879/1964: xli-xlii), uspoređujući nazive škola u sjevernoindijskim izvorima s nazivima škola $u$ sinhaleškim izvorima, zaključuje da je sinhaleška theravāda bila poznata i pod imenom vibhađđavāda (skt. vibhađyavāda). Spomen se vibhađđavāde nalazi u Ćullavaggi (Vin. ii. 72) te u Dīpavamsi i u komentaru uz Kathāvatthu. ${ }^{74}$ Vasumitra ne spominje vibhađđavādu, a N. Dutt (1970/1998: 211) napominje:

[...] that Vibhajyavāda was sometimes affixed to the name of a school on account of certain adherents differing in minor points from the principal doctrines of a particular school and preferring to distinguish themselves as Vibhajyavādins of that particular school. In this way, we may explain that Vibhajyavāda of the Ceylonese tradition, that is, Ceylonese did not accept in toto the doctrines of the Sthavira school.

Epigrafske nalaze u kojima se spominje vibhađđavāda iznio je Cousins (2001: 140 i d.) koji navodi kako se najraniji spomen sinhaleške theravāde (taṃbapaṇaka) odnosno vibhađđavāde nalazi na natpisu u hramu u Nāgārđunikoṇḍi (3. st.). ${ }^{75}$

Prema Vasumitri svi ogranci škole mahāsānghika tvrde da su bodhisattve i buddhe nadsvjetovna bića što je prepoznatljiv nauk te škole. N. Dutt (1970/1998: 64-65) ogranke škole mahāsānghika dijeli na sjeverne i južne. Sjeverne mahāsāṅghike (ekavyavahārika, kaukkuṭika, bahuśrutīya, prađñāptivāda, lokottaravāda) svoje su uporište do sedmoga stoljeća imale na području Magadhe (Pāțaliputra). Središte su imale i u Mathuri gdje se, na natpisu na kapitelu datiranome u 1. st. pr. n. e., nalazi i najstariji njihov spomen. ${ }^{76}$ Sjeverne su mahāsānghike bile prisutne i u Wardaku i Andarabu (današnji Afganistan) te Kašmiru. Južna skupina mahāsāṅghika (pūrvaśaila ili uttaraśaila, aparaśaila, siddhārthika, rāđagirīya, ćetīya) bila je

\footnotetext{
${ }^{73}$ Detaljnije u Gombrich (1988/2006: 139 i d.).

${ }^{74}$ V. Cousins (2001: 134-137).

${ }^{75}$ V. i Sastri (1983: 22-23). Popis natpisa donio je Lamotte (1958/1988: 523-526).

${ }^{76}$ Lamotte (1958/1988: 527), Dutt N. (1930: 132-134).
} 
prisutna na području Andhre, a natpisi u Amarāvatī, Đagayyapeți i Nāgārđunakoṇ̣i donose imena pojedinih škola. ${ }^{77}$

Kada je riječ o lokottaravādi, Śāriputraparipréchhā i Samayabhedoparipanaćakra navode kako je ta škola nastala otprilike dva stoljeća nakon Buddhine parinirvāne. Po pitanjima temeljnoga nauka Vasumitra i Vinītideva ne razlikuju lokottaravādu od mahāsānghike ili ekavyavahārike. Tradicija škole saṃmitīye (koju bilježi Bhavya) ne razlikuje lokottaravādu i ekavyavahāriku u doktrinama dok Taranātha izjednačuje lokottaravādu s kaukkutikom. Bareau izjednačuje lokottaravādu i ekavyavahāriku, a Dutt lokottarvādu i ćaitīyu. Iako se u pojedinim theravādskim izvorima navode neke od nauka prema kojima se Buddha poima kao nadnaravno, onosvjetsko biće te nabrajaju neki ogranci mahāsānghika, lokottarvāda se ne spominje. ${ }^{78}$ Škola je bila prisutna na sjeverozapadu Indije i području današnjega Afganistana. ${ }^{79}$

Kada je riječ o poimanju buddha i bodhisattva N. Dutt je (1970/1998: 215-217) sažeo theravādske doktrine:

1) Buddha je ovosvjetsko biće,

2) Buddha posjeduje fizičko tijelo podložno propadanju i umiranju,

3) Biće postaje buddhom iskustvom probuđenja (bodhi),

4) Buddha je nadišao suosjećanje (karuṇa) i dobronamjernost (mettā), ali ih iskazuje drugim bićima,

5) Buddha ne može izložiti sav nauk odjednom,

6) bodhisattve su obična bića podložna kvarljivosti i nisu samopostajući (upapāduka).

Prema Vasumitri su sljedeći stavovi svojstveni svim ograncima mahāsāmighika: ${ }^{80}$

1) Buddhino je tijelo u cijelosti nadnaravno (lokottara), oslobođeno je svih nesavršenstava i onečišćenja (āsrava-visaṃyukta), nije ovosvjetsko, neuništivo je, ${ }^{81}$

2) svaka tathāgatina riječ posvećena je dharmi,

3) Buddha može izreći sav nauk odjednom (dosl. jednim zvukom),

4) sve što buddha izrekne je istinito.

5) Tathāgatino je pojavno tijelo (rūpakāya) bezgranično,

\footnotetext{
${ }^{77}$ Dutt N. (1930: 63), Dessein (2009: 34-35).

${ }^{78}$ Baruah (2000: 47-48).

${ }^{79}$ Watters (1904: 116-120).

${ }^{80}$ Za ostale točke v. Masuda (1925: 18). V. i Dutt N. (1970/1998: 73-74).

${ }^{81}$ U Katthāvatthuu XVIII. 1, 2 tvrdi se da je osnova za ovu herezu pogrešno tumačenje kanonskoga ulomka (SN iii. 140) u kojem stoji: Bhagavā loke jāto loke sambuddho lokam abhibhuyya viharati anupalitto lokenā ti (Buddha je rođen u svijetu, probuđen u svijetu, nadišao je svijet i živi neuprljan svijetom).
} 
6) Tathāgatina je moć (teđas) bezgranična,

7) duljina života buddhe je neograničena,

8) Buddha se ne može zasititi buđenja drugih bića,

9) Buddha je neprestano u stanju zadubljenja, on niti ikada spava niti sanja,

10) u svome pojavnome tijelu (nirmāṇakāya) može se pojaviti bilo gdje na svijetu,

11) Buddha može sve razumjeti u jednom trenutku i odgovoriti na sva pitanja bez trenutka oklijevanja. Buddhin je um kao ogledalo,

12) Buddha je u svakome trenutku svjestan da se ne može ponovno roditi,

13) bodhisattve za vrijeme boravka u majčinoj utrobi ne prolaze kroz četiri stadija u razvoju ploda,

14) u trenutku začeća bodhisattve poprimaju obličje bijeloga slona,

15) svaki se bodhisattva rađa iz desne majčine strane,

16) u bodhisattvama nema mržnje ni pohlepe,

17) bodhisattve se ponekad rađaju u lošim stanjima (durgati) kako bi pomogli osjećajućim bićima.

Takve su se razlike u stavovima dviju predaja odrazile i u tekstovima o Buddhinu životu i životima bodhisattva (đātakama), kakve nam prikazuju prve dvije košare theravādskoga kanona, Nidānakathā i Mahāvastu. 


\section{ZAČEĆE I ROĐENJE GOTAME BUDDHE}

\subsection{Datacija rođenja Gotame Buddhe}

Određenje godine rođenja Gotame Buddhe vezano je uz dataciju njegove smrti. Naime, prema općenitoj je buddhističkoj predaji Gotama preminuo u dobi od osamdeset godina, ${ }^{82} \mathrm{a} \mathrm{u}$ određivanju godine Buddhine smrti ističu se dvije glavne struje.

Prva slijedi tzv. dugu kronologiju koja se susreće u sinhaleškim kronikama Dīpavaṃsi (4. st.) i Mahāvaṃsi (5. st.) ${ }^{83}$ Prema toj je sinhaleškoj (theravādskoj) tradiciji, između Buddhine smrti i posvećenja Aśoke za kralja (269. ili 268. pr. n. e.) proteklo 218 godina, ${ }^{84}$ čime se godina smrti smješta u otprilike 486. ili 485. pr. n. e, a godina rođenja u 566. ili 565. godinu pr. n. e. Dugu kronologiju slijede primjerice Charpentier (1922: 156) koji kao godinu rođenja predlaže 560., Fleet (1909: 6) koji je prihvatio 562. te E. J. Thomas (1927/2000: 27) i Geiger (1943/1996: 9) koji predlažu 563. godinu pr. n. e. Lamotte (1958/1988: 14) i Wayman (1997/1998: 295) također slijede dugu kronologiju i uzimaju 566. godinu pr. n. e. kao godinu rođenja.

Kratka kronologija, posvjedočena u sjevernoindijskim sanskrtskim i pojedinim kineskim tekstovima, navodi kako je između Buddhine smrti i posvećenja kralja Aśoke proteklo oko stotinu godina. ${ }^{85}$ Bechert je (1982), istaknuvši nedostatke i slabe točke u prihvaćanju duge kronologije, prihvatio kratku kronologiju pa je kao mogući vremenski okvir Buddhine smrti predložio razdoblje između 368 i 370. pr. n. e. S kratkom se kronologijom slažu i Ui Hakuju koji predlaže 466. godinu pr. n. e. kao godinu rođenja, ${ }^{86}$ Norman (1997: 39) koji predlaže 480. i 400. godinu pr. n. e. kao godine Buddhina rođenja i smrti, Nakamura (2000/2002: 71) koji Buddhin život omeđuje razdobljem između 463. i 383. godine pr. n. e. i Gombrich (1992: 246) koji za godinu rođenja uzima 484. godinu pr. n. e. ${ }^{87}$ Ovdje su navedeni rezultati istraživanja zapadnih autora budući da su indijski autori uglavnom (uz poneku iznimku) dolazili do rezultata

\footnotetext{
${ }^{82}$ Npr. MN ii. 124, DN ii. 151.

${ }^{83}$ Dugu kronologiju potvrđuje i tzv. dotted record, v. Pachow (1965: 342-349). Bechert (1982: 30-31) naglašava da je tradicija potekla sa Śri Lañke i smatra da se ne može uzeti u obzir kao neovisan izvor.

${ }^{84}$ Dpv. VI. 1, Mhv. V. 21. Bechert (1982: 30) upozorava na krivi izračun godine Aśokine krunidbe u sinhaleškim izvorima i napominje da se 480. pr. n. e. kao približna godina Buddhine smrti dobiva oslanjanjem na "corrected Ceylonese chronology". Za literaturu vezanu uz ključne datume Aśokine vladavine v. npr. Lamotte (1958/1988: 216).

${ }^{85}$ Trag kratke kronologije susreće se, međutim, i u Dpv. I. 24-25 gdje se nalazi Buddhino "proročanstvo" da će se prvi buddhistički sabor održati četiri mjeseca nakon njegove smrti, a treći 118 godina kasnije. Treći se sabor spominje isključivo u theravādskim izvorima koji se slažu da je održan pod pokroviteljstvom kralja Aśoke u osamnaestoj godini njegove vladavine.

${ }^{86} \mathrm{U}$ : Hirakawa (1990: 22).

${ }^{87}$ S Gombrichov zaključak prihvaća i Wynne (2005: 47). S kratkom se kronologijom slažu i Westergaard koji kao godinu smrti uzima 368. ili 370. i Kern koji razdoblje smrti smješta između 380. i 388. pr. n. e. U: Nakamura (2000/2002: 71).
} 
koji nisu imali većega utjecaja na zapadna istraživanja. ${ }^{88}$ Pojednostavljeno bi se moglo reći da su većinom bili skloniji dužoj kronologiji.

Pitanje vremenskoga okvira Buddhina života iznimno je zanimljivo, izazovno i važno, a budući da bi opširniji prikaz te problematike nadilazio okvire ovoga rada, na ovome je mjestu moguće prihvatiti Lamotteov prijedlog (1958/1988: 14):

The modern historian can opt for either the long chronology or the short but should take the dual calculation into account according to whether he is using a Sinhalese or a Sanskrit source. ${ }^{89}$

\subsection{Podrijetlo Gotame Buddhe}

Buddhistički tektovi sadrže razbacane ulomke iz kojih je moguće sastaviti predaju o Gotaminu podrijetlu. Gotama je smatran potomkom legendarnoga kralja i junaka Okkāke (skt. Ikṣvāku) ${ }^{90}$ koji se spominje već i u Ṛksaṃhiti (X, 60,4). Mahāvastu donosi sljedeće rodoslovlje (od starijega prema mlađem pokoljenju): Mahāsammata, Kalyāṇa, Rava, Upoṣadha, Mandhātṛ, Suđāta, Ikṣvaku. ${ }^{91}$ Kasnije sinhaleške kronike Mahāvaṃsa (poglavlje II) i Dīpavaṃsa (poglavlje III) donose iznimno duga rodoslavlja. Ikșvāku se, pak, smatra sinom Manua, sina Vivasvantova i oca ljudske vrste u našem "Manuovu razdoblju”, i začetnikom "Sunčeve dinastije" kojoj se pribrajaju kraljevi istočnoga kraljevstva Kosale.

Pleme Sākya (Sākiya, Sakka, skt. Śākya), kojemu je Buddha pripadao, imalo je svoje središte u gradu Kapilavatthuu (Kapilavastu). ${ }^{92}$ Imena Gotaminih roditelja predaja navodi kao

\footnotetext{
${ }^{88}$ Zanimljiv pregled rezultata indijskih autora nalazi se u Hartmann (1991: 27-45).

${ }^{89} \mathrm{U}$ novije vrijeme pojedini autori dovode u sumnju obje kronologije pa tako primjerice Gombrich (1989: 350) zaključuje:[I]f we wish to date the Buddha we must ignore the ancient chronologies and start afresh.

${ }^{90}$ DN i. 92. V. i Mv. i. 98, 100, Mv. iii. 246.

${ }^{91}$ Mv. i. 348.

${ }^{92}$ DN i. 91. Za ključne podatke o Kapilavatthuu v. Nakamura (2000/2002: 48), Trainor (2013: 436-437).
} 
Māyā ${ }^{-93}$ i Suddhodana (Śuddhodana) ${ }^{94}$, a Gotama ${ }^{95}$ mu je bilo obiteljsko ili ime njegove gotre ${ }^{96}$. U Suttanipāti se navodi kako je ime gotre Ādićća, a isto se tvrdi i u Mahāvastuu gdje je ime gotre Āditya. ${ }^{97}$ Osobno ime Sidhattha (skt. Siddhārtha) ne nalazi se u ranijim tekstovima. ${ }^{98} \mathrm{U}$ Mahāvastuu postoje dvije inačice imena, Siddhārtha ${ }^{99}$ i Sarvārthasiddha ${ }^{100}$. Navodi se također da je pleme Sakya bilo pod vlašću kralja Kosale, ${ }^{101}$ a u Aggaññasutti se (DN ii. 8) navodi kako je u vrijeme Gotamina života vladar Kosale bio kralj Pasenadi. Gotama je također khattiyo đātiyā khattiyakule uppanno odnosno "rođen u kasti kšatriya, u obitelji kšatriya". ${ }^{102}$

Kao mjesto Gotamina rođenja navodi se gaj Lumbin̄̄ nedaleko od grada Kapilavatthua, u današnjem Nepalu. ${ }^{103}$

\footnotetext{
${ }^{93}$ Thīg. 162: Bahūnam vata atthāya, māyā janayi gotamam, v. i Bhv. I. 66. Senart je (1882: 267) ime Gotamine majke smatrao kasnijim dodatkom, svodeći smrt Māye na alegorijski prikaz jutarnje magle koja kao i noć iščezava pred sunčevim zrakama. Oldenberg (1881/2007: 97) odriješito odbacuje Senartovo mitsko tumačenje imena.
}

${ }^{94}$ Nakamura (2000/2002: 47) na temelju starosti sutta u kojima se spominju zaključuje da su imena vjerojatno istinita. Da je Suddhodāna bio kralj, kasniji je dodatak (npr. u DN ii. 7, Bhv. I. 66, XXVI. 13). U Soṇadaṇ̣asutti (DN i. 115) navodi se samo da je potekao iz plemenite obitelji i s majčine i s očeve strane (usp. Mv. ii. 2). Bhv. XXVI. 14 sadrži sljedeći ulomak: Nagaram kapilavatthu me, rājā suddhodano pitā, Mayham janettikā mātāa, māyādevīti vuccati. U Mhv. 21-24 Suddhodana je mahārāđāa, Siddhārtha kumāra. V. i Mv. iii. 109. 11-12.

${ }^{95}$ Thag. 534, Thīg. 192, DN ii. 3. Gotama je složenica sačinjena od imenice go (krava, govedo) i sufiksa -tama kojim se tvori superlativ (najodličniji, najbolji). Nakamura (2000/2002: 42) naglašava da nema potvrde da je složenica gotama ikad označavala "najodličniju kravu". Ježić (usmena napomena) nudi sljedeće objašnjenje: srednjoindoarijski Gotama u sanskrtu se prenosi kao Gautama. Vjerojatno je to ime po gotri (rodoslovlju po brahmanskome učitelju) i značilo bi da je rod budućega Buddhe imao, po predaji, za svećenika u svojem domu nekoga tko je podrijetlo izvodio od Vāmadeve Gautame, rgvedskoga pjesnika s kojim se povezuje autorstvo 4. kruga (maṇdale) Rkssamhite. Ime njegova oca ili pretka Gotama moglo ga je označivati kao najbogatijega govedima (go), koja je mogao steći kao nagrade za svećeničku/ pjesničku službu.

${ }^{96}$ Norman (1997:23): Siddhattha's gotra name was Gotama, but Gotama is not a kșatriya name, so it probably represents a borrowing of the family purohita's gotra name.

${ }^{97}$ Sn. 423: Ādiccā nāma gottena, Sākiyā nāma jātīyā. Za ostala mjesta v. Nakamura (2000/2002:. 40, bilj. 45). Mv. ii. 199. 16: [...] ädityo nāma gotreṇa śákiyo nāma jātiye. Ježić (usmena napomena) smatra da tu gotra nema pravo značenje nego da znači općenito podrijetlo: bili su iz Sunčeve loze.

${ }^{98}$ Thomas (1927/2000: 44) smatra da je siddhattha epitet koji je s vremenom postao osobno ime.

${ }^{99}$ Mv. ii. 47. 11,75.19, 145. 9.

${ }^{100}$ Mv. iii. 176. 2, 263. 2, Lv. 96.

${ }^{101} \mathrm{Sn} .422, \mathrm{MN}$ ii. 124.

102 DN ii. 3: Aham bhikkhave etarahi araham sammā sambuddho khattiyo jātiyā ahosiṃ, khattiyakule uppanno. Zanimljivo je da u Vāsețthasutti Suttanipāte Gotama, tvrdeći da se brahmanom ne postaje rođenjem u brahmanskoj obitelji već ispravnim djelovanjem, implicira da je i sam brahman. S druge strane, u Sundarikabhāradvāđasutti Suttanipāte (Sn. 455-456) Gotama se odriče pripadnosti bilo kojoj kasti: Na brāhmano nomhi na räjaputto, Na vessāyano uda koci nomhi, Gottam pariññāya puthujjanānam. Akiñcano manta carāmi loke.

${ }^{103}$ Sn. 683: Sakyāna gāme janapade lumbineyye. Hodočašća u Lumbinī bila su nerijetko poticana u kasnijim tekstovima pa tako, primjerice u Mahāparinibbānasutti (DN ii. 140) stoji :Cattārimāni, ānanda, saddhassa kulaputtassa dassanīyāni samvvejanīyāni thānāni. Katamāni cattāri? 'Idha tathägato jāto'ti, ānanda, saddhassa kulaputtassa dassanīyam saṃvejanīyam țhānaṃ. U Mv. ii. 18 navodi se da Māya nije rodila u Kapilavastuu, budući da je njezin otac zamolio Śuddhodanu da Māya rodi u očinskoj kući. Taj se podatak ne nalazi u pālijskim izvorima. 


\subsection{Začeće i rođenje Gotame Buddhe u pālijskome kanonu}

Buddhino rođenje, djetinjstvo i razdoblje prije probuđenja u kanonskoj književnosti nisu osobito zastupljeni. Naglasak je stavljen na razdoblje neposredno prije i nakon probuđenja te prve propovijedi, odnosno na događaje koji su uslijedili nakon početka javnoga djelovanja, što je, uostalom, karakteristično za opisivanje života junaka i svetaca u svim književnostima. Kako pojašnjava Oldenberg (1881/2007: 81):

Interes zajednice nije ležao toliko na zemaljskoj osobi djeteta i mladića iz kuće Sakya koliko na osobi "uzvišenog, svetog, univerzalnog Buddhe". Htjelo se znati što je on govorio od trenutka kad je postao buddha; svaki drugi interes, pa čak i interes za njegovu borbu oko postizanja budnosti, stupio je u pozadinu.

Aććhariyabbhutadhammasutta (MN, sutta br. 123) ili Sutta o čudesnome i zadivljujućem jedina je sutta unutar pālijskoga kanona koja je, izuzev kratka odlomka na samome kraju, u cijelosti posvećena Gotaminu začeću i rođenju. Te događaje redovnicima okupljenima u parku trgovca Anāthapiṇụike pripovijeda redovnik Ānanda.

MN iii. 119-124

Sammukhā me tam, bhante, Bhagavato sutaṃ, sammukhā pațiggahītaṃ: Sato sampajāno uppajjamāno, Ānanda, Bodhisatto Tusitam kāyam uppajjīti; yam pi, bhante, sato sampajāno Bodhisatto Tusitạ̣ kāyam uppajji, idam ahaṃ, bhante, Bhagavato acchariyam abbhutadhammam dhāremi.

Sammukhā me taṃ, bhante, Bhagavato sutam sammukhā pațiggahītaṃ; Sato sampajāno, Ānanda, Bodhisatto Tusite kāye ațthāsīti; yam pi, bhante, sato sampajano Bodhisatto Tusite kāye ațthāsi, idam p'; aham, bhante, Bhagavato acchariyam abbhutadhammam dhāremi.

Sammukhā me tam, bhante, Bhagavato sutam sammukhā pațiggahītam:-- Yāvatāyukam, Ānanda, Bodhisatto Tusite kāye ațthāsīti; yam pi, bhante, yāvatāyukạ̣ Bodhisatto Tusite kāye ațthāsi, idam p'; aham, bhante, Bhagavato acchariyam abbhutadhammam dhāremi.

Sammukhā me taṃ, bhante, Bhagavato sutam sammukhā pațiggahītaṃ:-- Sato sampajāno, Ānanda, Bodhisatto Tusitā kāyā cavitvā mātu kucchị̣ okkamīti; yam pi, 
bhante, sato sampajāno Bodhisatto Tusitā kāyā cavitvā mātu kucchim okkami, idam p'; aham Bhagavato acchariyam abbhutadhammam dhāremi.

Sammukhā me tam, bhante, Bhagavato sutam sammukhā pațiggahītaṃ:-- Yadā, Ānanda, Bodhisatto Tusitā kāyā cavitvā mātu kucchị̣ okkami, atha sadevake loke samārake sabrahmake sassamaṇabrāhmaṇiyā pajāya sadevamanussāya appamāno uḷāro obhāso pātubhavati atikkamm'; eva devānam devānubhāvaṃ. Yā pi tā lokantarikā aghā asamvutāa andhakārā andhakāratimis $\bar{a}$, yattha $p^{\prime} ;$ ime candimasuriyā evammahiddhikā evam mahānubhāvā ābhāya nānubhonti, tattha pi appamāno uḷāro obhāso pātubhavati atikamm' eva devānam devānubhāvamp; ye pi tattha sattā upapannā, te pi ten'; obhāsena añ̃amannam sañjānanti: Añ̃̃e pi kira bho santi sattā idh'; upapannā. Ayañ ca dasasahassīlokadhātu

saṃampati sampakampati sampavedhati, appamāno ca uḷāro obhāso loke pātubhavati atikkamm'; eva devānam devānubhāvan ti. Yam pi, bhante, . . . idạ̣ p'; aham,

bhante, Bhagavato acchariyam abbhutadhammam dhāremi.

Sammukhā me tam, bhante, Bhagavato sutam sammukhā pațiggahītam:-- Yadā, Ānanda, Bodhisatto mātu kucchị̣ okkanto hoti, cattāro nan devaputtā catuddisārakkhāya upagacchanti: Mā nam kho Bodhisattam vā Bodhisattamātaram va manusso vā amanusso vā koci vā vihețhesīti. Yam pi, bhante, ... idam; p'; ahaṃ, bhante, Bhagavato acchariyam abbhutadhammam dhāremi.

Sammukhā me tạ̣, bhante, Bhagavato sutam sammukhā pațiggahītaṃ:-- Yadā, Ānanda, Bodhisatto mātu kucchiṃ okkanto hoti, pakatiyā sīlavatī Bodhisattamātā hoti,

viratā pānātipātā viratā adinnādānā viratā kāmesu micchācārā viratā mus $\bar{a} v a \bar{d} \bar{a}$ viratā surāmerayamajjapamādatțhānā ti. Yam pi, bhante, ... idam ahaṃ, bhante, Bhagavato acchariyam abbhutadhammam dhāremi.

Sammukhā me tam, bhante, Bhagavato sutam sam mukhā pațiggahìtaṃ:-- Yadā, Ānanda, Bodhisatto mātu kucchim okkanto hoti, na Bodhisattamātu purisesu mānasam uppajjati kāmaguṇūpasaṃhitam, anatikkaman̄̄yā ca Bodhisattamātā hoti kenaci purisena rattacittenāti. Yam pi, bhante, . . . idam p'; aham, bhante, acchariyam abbhutadhammam dhāremi. 
Sammukhā me tạ̣, bhante, Bhagavato sutam sammukhā pațiggahītaṃ:-- Yadā, Ānanda, Bodhisatto mātu kucchị̣ okkanto hoti, lābhinā Bodhisattamātā hoti pañcannam kāmaguṇānaṃ, sa pañcahi kāmaguṇehi samappitā samañgibhūtā parivāretīti. Yam pi, bhante ... idam p' ahaṃ, bhante, Bhagavato acchariyam abbhutadhammam dhāremi.

Sammukhā me tam, bhante, Bhagavato sutam sammukhā patigghītaṃ:-- Yadā, Ānanda, Bodhisatto mātu kucchim okkanto hoti, na Bodhisattamātu kocid eva ābādho uppajjati, sukhin̄̄ Bodhisattamātā hoti akilantakāyā, Bodhisattã̃ ca Bodhisattamātā tirokucchigatam passati sabbañga-paccañgam abhinindriyaṃ. Seyyathāpi, Ānanda, maṇi veluriyo subho jātimā ațthamso suparikammakato; tatr'; assa suttam āvutam nīlam vā pìtam vā lohitam vā odātam vā paṇusuttam vāa tam enam cakkhumā puriso hatthe karitvā paccavekkheyya: Ayam kho maṇi veluriyo subho jātimā ațthamso suparikammakato, tatr'; idam suttam āvutam nīlam vā pīta vā lahitam vā odātam vā paṇụsuttam vā ti;-- evam eva kho, Ānanda, yadā Bodhisatto mātu kucchim okkanto hoti, na Bodhisattamātu kocid eva ābādho uppajjati, sukhin̄̄ sattamātā tirokucchigatam passati sabban்gapaccan்gạ abhinindriyam. Yam pi, bhante, ... idam p'; aham, bhante, Bhagavato acchariyam abbhutadhammam dhāremi.

Sammukhā me taṃ, bhante, Bhagavato sutam sammukhā pațiggahītam:-- Sattāhajāte, Ānanda, Bodhisatte Bodhisattamātā kālam karoti, Tusitam kāyaṃ uppajjatīti.

Yam pi, bhante, .. . idam p'; aham, bhante, Bhagavato acchariyam abbhutadhammam dhāremi.

Sammukhā me tam, bhante, Bhagavato sutam sammukhā pațiggahītaṃ:-- Yathā kho pan', $\bar{A}$ nanda añ̃ā itthikā nava vā dasa vā māse gabbham kucchinā pariharitvā vijāyanti, na h'; evam Bodhisattam Bodhisattamātā vijāyati; das'; eva māsāni Bodhisattam Bodhisattamātā kucchinā pariharitvā vijāyatīti. Yam pi, bhante, . . . idam p'; aham, bhante, acchariyam abbhutadhammam dhāremi.

Sammukhā me taṃ, bhante, Bhagavato sutam sammukhā pațiggahītaṃ:-- Yathā kho pan', $\bar{A}$ nanda, añ̃̃a itthikā nisinnā vā nipannā vā vijāyanti, na $h^{\prime}$; evam Bodhisattam Bodhisattamātā vijāyati; țitāa va Bodhisattam Bodhisattamātā vijāyatīti. Yam pi, bhante, ... idam p' ahaṃ, bhante, acchariyam abbhutadhammam dhāremi. 
Sammukhā me tạ̣, bhante, Bhagavato sutam sammukhā pațiggahītaṃ:-- Yadā, Ānanda, Bodhisatto mātu kucchismā nikkhamati, devā pațamam pațiggaṇhanti

pacchā manussā ti. Yam pi, bhante, ... idam p'; aham, bhante, Bhagavato acchariyam abbhutadhammam dhāremi.

Sammukhā me taṃ, bhante, Bhagavato sutam sammukhā pațiggahītaṃ:-- Yadā, Ānanda, Bodhisatto mātu kucchismā nikkhamati, appatto va Bodhisatto pațavim hoti;

cattāro nan devaputtā pațiggahetvā mātu purato țhapenti: Attamanā devī hohi, mahesakkho te putto upapanno ti. Yam pi, bhante, .. . idam p'; aham, bhante, Bhagavato acchariyam abbhutadhammam dhāremi.

Sammukhā me tạ̣, bhante, Bhagavato sutam sammukhā pațiggahītaṃ:-- Yadā, Ānanda, Bodhisatto mātu kucchismā nikkhamati, visado va nikkhamati amakkhito uddena amakkhito semhena amakkhito ruhirena amakkhito kenaci asucinā suddho visado. Seyyathāpi, Ānanda, maṇiratanam kāsike vatthe nikkhittam, n'; eva maṇiratanam kāsikam vattham makkheti nāpi kāsikam vattham maṇiratanam makkheti;-- tam kissa hetu? ubhinnam suddhattā; -- evam

eva kho, Ānanda, yadā Bodhisatto mātu kucchismā nikkhamati, visado va nikkhamati amakkhito uddena amakkhito semhena amakkhito ruhirena amakkhito kenaci asucinā

suddho visado ti. Yam pi, bhante, . . . idam p'; aham, bhante, Bhagavato acchariyam abbhutadhammam dhāremi.

Sammukhā me tạ̣, bhante, Bhagavato sutam sammukhā paṭiggahītam:-- Yadā, Ānanda, Bodhisatto mātu kucchismā nikkhamati, dve udakassa dhārā antalikkhā pātubhavanti, ekā sìtassa ekā uṇhassa, yena Bodhisattassa udakakiccam karonti \{mātucāti.\} Yam pi, bhante, ...

idam p'; aham, bhante, Bhagavato acchariyam abbhutadhammam dhāremi.

Sammukhā me taṃ, bhante, Bhagavato sutam sammukhā pațiggahītam:-- Sampatijāto, Ānanda, Bodhisatto samehi pādehi pațițthahitvā uttarābhimukho sattapadavītihāre gacchati, setamhi chatte anubhiramāne sabbā ca disā viloketi, āsabhiñ ca vācam bhāsati; Aggo 'ham asmi lokassa, settho 'ham asmi lokassa, jettho 'ham asmi lokassa, ayam antimā 
jāti, na 'tthi dāni punabbhavo ti. Yam pi, bhante, .. . idam p'; ahaṃ, bhante, Bhagavato acchariyam

abbhutadhammam dhāremi.

Sammukhā me tam, bhante, Bhagavato sutam sammukhā pațiggahītam:-- Yadā, Ānanda, Bodhisatto mātu kucchismā nikkhamati, atha sadevake loke samārake sabrahmake sassamaṇabrāhmaṇiyā pajāya sadevamanussāya appamāno ularo obhāso pātubhavati atikamm'; eva devānam devānubhāvam, yā pi tā lokantarikā aghā asaṃvutā an-

dhakāra andhakāratimisā, yatthā $p^{\prime}$; ime candimasuriyā evam mahiddhikā evam mahānubhāvā ābhāya nānubhonti, tattha pi appamāṇo uḷāro obhāso pātubhavati atikamm'; eva devānam devānubhāvaṃ; ye pi tattha sattā upapannā te pi ten'; obhāsena añ̃amañ̃am sañjānanti: Añ̃ne pi kira bho santi sattā idhūpapannā ti. Ayam pi ca dasasahassīlokadhātu

saṃkampati sampakampati sampavedhati appamāṇo ca uḷāro obhāso loke pātubhavati atikamm'; eva devānam devānubhāvan ti. Yam pi, bhante, . . . idam p'; aham, bhante,

Bhagavato acchariyam abbhutadhammam dhāremīti.

Prijevod

Ovo sam, o poštovani, izravno čuo i primio izravno od Blaženoga: "Sabran i svjestan, o Ananda, pojavio se Bodhisatta u nebesima Tusita". ${ }^{104}$ Ovo da se, poštovani, Bodhisatta sabran $i$ svjestan pojavio u nebesima Tusita, pamtim, poštovani, kao čudesnu $i$ zadivljujuću osobinu Blaženoga.

Ovo sam, o poštovani, izravno čuo i primio izravno od Blaženoga: "Sabran i svjestan, o Ananda, boravio je Bodhisatta u nebesima Tusita". ${ }^{105}$ Ovo da je, poštovani, Bodhisatta

${ }^{104}$ Tusitakāya, skt. tușitakāya. Tusital tușita je naziv klase nebeskih bića. Drugi dio složenice (-kāya) najčešće znači "tijelo" pa Ježić (usmena preporuka) predlaže sljedeći prijevod: $u(z a)$ šao je Bodhisatta u (nebesničko) tijelo Tusita. S druge strane, prema SED, str. 274, kāya može imati i značenje 'house, habitation' pa se kāya može prevesti i kao prebivalište. Tusita/ Tușita jedno je od ukupno šest buddhističkih nebesa ili božanskih prebivališta. Harvey (1990/2013: 35) pojašnjava: The fourth heaven is that of the Tusita (Skt Tuṣita, Contented) gods, being the realm in which Bodhisattas spend their penultimate life, and in which Metteya (Skt Maitreya), set to be next Buddha, now dwells.

105 Ježić (usmena preporuka): stanovao je u tijelu Tusita. 
sabran $i$ svjestan boravio u nebesima Tusita pamtim, poštovani, kao čudesnu $i$ zadivljujuću osobinu Blaženoga.

Ovo sam, o poštovani, izravno čuo i primio izravno od Blaženoga: "Duljinu je života, o Ananda, Bodhisatta proveo u nebesima Tusita”. Ovo da je, poštovani Bodhisatta proveo duljinu života u nebesima Tusita pamtim, poštovani, kao čudesnu i zadivljujuću osobinu Blaženoga.

Ovo sam, o poštovani, izravno čuo i primio izravno od Blaženoga: "Sabran i svjestan, o Ananda, napustio je Bodhisatta nebesa Tusita i spustio se u majčinu utrobu”. Ovo da je, poštovani, sabran i svjestan Bodhisatta napustio nebesa Tusita i spustio se u majčinu utrobu pamtim, poštovani, kao čudesnu i zadivljujuću osobinu Blaženoga.

Ovo sam, o poštovani, čuo i primio izravno od Blaženoga: "Kada se, o Ānanda, napustivši nebesa Tusita, Bodhisatta spustio u majčinu utrobu, tada se u svijetu sa njegovim nebesnicima, Mārom i Brahmanom, u kojem postoje naraštaji isposnika $i$ brahmana, nebesnika i ljudi pojavila neizmjeran i uzvišen odsjaj koji nadilazi nebesnike $i$ njihovu velebnost. Čak se $u$ onim podzemnim griješnim neobuzdanim tminama $i$ paklovima gdje se ne slute sjajem ni ovako velemoćni i velebni Mjesec i Sunce, pojavio neizmjeran i uzvišen odsjaj koji nadilazi nebesnike i njihovu velebnost. Čak su se i u tom svijetu rođena bića, na tom odsjaju, međusobno prepoznala: Gle, postoje, zaista, i druga bića ovdje rođena! Zatresao se i zadrhtao snažno taj svemir sačinjen od deset tisuća svjetova $i$ pojavio se neizmjeran $i$ uzvišen odsjaj koji nadilazi nebesnike $i$ njihovu velebnost”. Ovo da je... također, poštovani, pamtim kao čudesnu i zadivljujuću osobinu Blaženoga.

Ovo sam, o poštovani, izravno čuo i izravno primio od Blaženoga: “Kada je, o Ānanda, Bodhisatta sišao u majčinu utrobu, četiri su se nebesnička sina uputila na četiri strane svijeta kako bi ga štitila [govoreći]: Neka Bodhisattu i Bodhisattinu majku ljudsko ili neljudsko biće ili ma tko drugi ne ozlijedi!’. Ovo da je... također, poštovani, pamtim kao čudesnu i zadivljujuću osobinu Blaženoga.

Ovo sam, o poštovani, izravno čuo i izravno primio od Blaženoga: "Dok je, o Ananda, Bodhisatta bio sišao u majčinu utrobu, Bodhisattina je majka bila po naravi kreposna, suzdržavajući se od nanošenja boli živim bićima, suzdržavajući se od uzimanja onoga što nije dano, suzdržavajući se od uživanja u požudi, suzdržavajući se od lažna govora $i$ 
suzdržavajući se od uživanja u opojnim pićima koja vode do nemara”. Ovo da je... također, poštovani, pamtim kao čudesnu i zadivljujuću osobinu Blaženoga.

Ovo sam, o poštovani, izravno čuo i izravno primio od Blaženoga: "Dok je, o Ānanda, Bodhisatta bio sišao u majčinu utrobu, u srcu Bodhisattine majke nije se javljala želja povezana sa žudnjom spram muškaraca i bila je nedostupna ikojemu muškarcu kojemu je na umu bila tjelesna požuda”. Ovo da je... također, poštovani, pamtim kao čudesnu $i$ zadivljujuću osobinu Blaženoga.

Ovo sam, o poštovani, izravno čuo i izravno primio od Blaženoga: "Dok je, o Ānanda, Bodhisatta bio sišao u majčinu utrobu, Bodhisattina je majka bila obdarena užitcima pet osjetila. Ona ih je, dohvaćena [petorim] užitcima, prigrljivala”. Ovo da je... također, poštovani, pamtim kao čudesnu i zadivljujuću osobinu Blaženoga.

Ovo sam, o poštovani, izravno čuo i izravno primio od Blaženoga: "Dok je, o Ānanda, Bodhisatta bio sišao u majčinu utrobu, Bodhisattinoj majci se nije dogodila nikoja bolest, bila je sretna i odmorna tijela. Bodhisattina je majka vidjela Bodhisattu Ljasno kao da je] izvan utrobe, sa svim njegovim velikim i malim udovima, i savršenim osjetilima.

Zamisli, o Ānanda, dragi kamen beril, blještav i dobroga podrijetla, vješto obrađen, $s$ osam [savršenih] ploha i kroz njega provučenu plavu, žutu, crvenu, bijelu i smeđkastu nit. I kad bi ga čovjek oštra oka uzeo u ruku i pažljivo promotrio [rekao bi]: Ovo je, zaista, dragi kamen beril, blještav, dobroga podrijetla, vješto obrađen, s osam [savršenih] ploha, kroz kojega je provučena plava, žuta, crvena, bijela i smeđkasta nit. Zaista, upravo je tako, o Ānanda, dok je Bodhisatta bio sišao u majčinu utrobu, Bodhisattinoj majci se nije dogodila nikoja bolest, bila je sretna i odmorna tijela $i$ vidjela je Bodhisattu [jasno kao da je] izvan utrobe, sa svim njegovim velikim i malim udovima i savršenim osjetilima." Ovo da je... također, poštovani, pamtim kao čudesnu $i$ zadivljujuću osobinu Blaženoga.

Ovo sam, o poštovani, izravno čuo i izravno primio od Blaženoga: "Sedam dana, o Ananda, nakon poroda Bodhisatte, Bodhisattina je majka došla do konca svoga vremena i rodila se na nebesima Tusita“. Ovo da je... također, poštovani, pamtim kao čudesnu $i$ zadivljujuću osobinu Blaženoga. 
Ovo sam, o poštovani, izravno čuo i izravno primio od Blaženoga: „I štoviše, o Ānanda, Bodhisattina majka ne rađa kao što rađaju druge žene koje čuvaju plod u utrobi devet ili deset mjeseci. Bodhisattina majka rađa Bodhisattu nakon što ga je u utrobi čuvala deset mjeseci”. Ovo da je... također, poštovani, pamtim kao čudesnu i zadivljujuću osobinu Blaženoga.

Ovo sam, o poštovani, izravno čuo i izravno primio od Blaženoga: "Također, o Ānanda, Bodhisattina majka ne rađa kao druge žene koje rađaju sjedeći ili ležeći. Bodhisattina majka rađa Bodhisattu stojeći”. Ovo da je... također, poštovani, pamtim kao čudesnu i zadivljujuću osobinu Blaženoga.

Ovo sam, o poštovani, izravno čuo i izravno primio od Blaženoga: "Kada je, o Ānanda, Bodhisatta izašao iz majčine utrobe najprije su ga prihvatili nebesnici, a tek potom ljudi". Ovo da je ... također, poštovani, pamtim kao čudesnu i zadivljujuću osobinu Blaženoga.

Ovo sam, o poštovani, izravno čuo i izravno primio od Blaženoga: “Kada je, o Ānanda, Bodhisatta izašao iz majčine utrobe nije se dotaknuo zemlje. Četiri su ga nebesnička sina primila i položila pred majku [govoreći]: Budi radosna, kraljice! Rodio ti se sin velike moći”. Ovo da je... također, poštovani, pamtim kao čudesnu i zadivljujuću osobinu Blaženoga.

Ovo sam, o poštovani, izravno čuo i izravno primio od Blaženoga: "Kada je, o Ānanda, Bodhisatta izašao iz majčine utrobe, izašao je čist, neuprljan vodom, neuprljan tjelesnim izlučevinama, neuprljan krvlju ili bilo kojom drugom nečisti - neuprljan i čist. Kao, o Ānanda, dragi kamen položen na tkaninu iz grada Kāsī; niti dragi kamen prlja tkaninu iz. grada Kāsī, niti tkanina iz grada Kāsī prlja dragi kamen. Što je tomu uzrok? Oboje je čisto. Upravo tako, o Ānanda, kada je Bodhisatta izašao iz majčine utrobe, izašao je čist, neuprljan vodom, neuprljan tjelesnim izlučevinama, neuprljan krvlju ili bilo kojom drugom nečisti - neuprljan i čist”. Ovo da je ... također, poštovani, pamtim kao čudesnu i zadivljujuću osobinu Blaženoga.

Ovo sam, o poštovani, izravno čuo i izravno primio od Blaženoga: “Kada je, o Ānanda, Bodhisatta izašao iz majčine utrobe, potekla su iz neba dva mlaza vode; jedan hladne, a drugi tople kako bi obredno oprali Bodhisattu \{i njegovu majku\}”. Ovo da je... također, poštovani, pamtim kao čudesnu i zadivljujuću osobinu Blaženoga. 
Ovo sam, o poštovani, izravno čuo i izravno primio od Blaženoga: "Tek rođen, o Ānanda, stao je Bodhisatta čvrsto ravnim stopalima na zemlju. Lica okrenuta sjeveru učinio je hod od sedam koraka. Poslužen bijelim suncobranom promotrio je sve smjerove $i$ snažan kao bik izgovorio riječi: Ja sam iskonski na svijetu! Ja sam najsjajniji na svijetu! Ja sam najstariji na svijetu! Ovo je [moje] posljednje rođenje, [za mene] nema ponovnih rođenja!’. Ovo da je... također, poštovani, pamtim kao čudesnu i zadivljujuću osobinu Blaženoga.

Ovo sam, o poštovani, izravno čuo i izravno primio od Blaženoga: "Kada je, o Ānanda, Bodhisatta napustio majčinu utrobu, tada se u svijetu sa njegovim nebesnicima, Mārom i Brahmanom, u kojem postoje naraštaji isposnika i brahmana, nebesnika i ljudi pojavio uzvišeni odsjaj koji nadilazi nebesnike i njihovu velebnost. Čak se u onim podzemnim griješnim neobuzdanim tminama, paklovima gdje se ne slute sjajem ni ovako velemoćni $i$ velebni Mjesec i Sunce pojavio neizmjeran i uzvišen odsjaj koji nadilazi nebesnike $i$ njihovu velebnost. Čak su se $i$ u tom svijetu rođena bića, na tom odsjaju, međusobno prepoznala: Gle, postoje, zaista, i druga bića ovdje rođena!. Zatresao se i zadrhtao snažno taj svemir sačinjen od deset tisuća svjetova i pojavio se neizmjeran i uzvišen odsjaj koji nadilazi nebesnike i njihovu velebnost." Ovo da je... također, poštovani, pamtim kao čudesnu i zadivljujuću osobinu Blaženoga.

Aṅguttaranikāya također sadrži poglavlje o čudesnim pojavama koje prate četiri odlučujuća trenutka u životu Tathāgate. Niže je iznesen dio koji se odnosi na prva dva trenutka, odnosno na začeće i rođenje (preostala se dva odnose na probuđenje i prvu propovijed).

\section{AN ii. $130-132$}

Tathāgatassa bhikkhave arahato sammāsambuddhassa pātubhāvā cattāro acchariyā abbhutā dhammā pātubhavanti. Katame cattāro?

Yadā bhikkhave bodhisatto Tusitā kāyā cavitvā sato sampajāno mātukucchiyam okkamati atha sadevake loke samārake sabrahmake sassamaṇabrāhmaṇiyā pajāya sadevamanussāya appamāṇo uḷāro obhāso pātubhavati atikkamm'; eva devānam devānubhāvanam. Yā pi tā lokantarikā aghā asamvutā andhakārā andhakāratimis $\bar{a}$ yattha p'; imesam candimasuriyānam evam mahiddhikānam evam mahānubhāvanam ābhā nānubhonti, tattha pi appamāno uḹaro obhāso pātubhavati atikkamm' eva devānam devānubhāvanaṃ. 
Ye pi tattha sattā uppannā te pi ten'; obhāsena aññamañnam sañjānanti--añ̃̃e pi kira bho santi sattā idh'; uppannā ti. Tathāgatassa bhikkhave arahato sammāsambuddhassa pātubhāvā ayam pațamo acchariyo abbhuto dhammo pātubhavati.

Puna ca param bhikkhave yadā bodhisatto sato sampajāno mātu kucchismā nikkhamati atha sadevake loke samārake sabrahmake sassamaṇabrāhmaṇiyā pajāya sadevamanussāya appamāṇo uḷāro obhāso pātubhavati atikkamm'; eva devānam devānubhāvanam. Yā pi tā lokantarikā . . . tattha pi appamāṇo uḷāro obhāso pātubhavati atikkamm'; eva devānam devānubhāvanam Ye pi tattha sattā . . . [127.1] . . . idh'; uppannāti. Tathāgatassa bhikkhave arahato sammāsambuddhassa pātubhāvā ayam dutiyo acchariyo abbhuto dhammo pātubhavati.

\section{Prijevod}

$S$ pojavom Tathāgate, Arahanta, Savršeno probuđenoga, pojavljuju se, o redovnici, $i$ četiri čudesne i zadivljujuće pojave. Koje četiri?

Kada, o redovnici, Bodhisatta, napustivši nebesa Tusita, silazi sabran $i$ svjestan $u$ majčinu utrobu, tada se u svijetu sa njegovim nebesnicima, Mārom i Brahmanom, u kojem postoje naraštaji isposnika i brahmana, nebesnika i ljudi pojavio uzvišeni odsjaj koji nadilazi nebesnike $i$ njihovu velebnost. Čak se $i$ u onim podzemnim griješnim neobuzdanim tminama i paklovima gdje se ne slute sjajem ni ovako velemoćni i velebni Mjesec $i$ Sunce, pojavio neizmjeran i uzvišen odsjaj koji nadilazi nebesnike i njihovu velebnost. Čak su se i u tom svijetu rođena bića, na tom odsjaju, međusobno prepoznala: Gle, postoje, zaista, i druga bića ovdje rođena! To je prva čudesna i zadivljujuća pojava koja se javlja s pojavom Tathāgate, Arahanta, Savršeno probuđenoga.

I opet, o redovnici, kada Bodhisatta, sabran i svjestan, napušta majčinu utrobu, tada se u svijetu sa njegovim nebesnicima, Mārom i Brahmanom, u kojem postoje naraštaji isposnika i brahmana, nebesnika i ljudi pojavio uzvišeni odsjaj koji nadilazi nebesnike $i$ njihovu velebnost. Čak se $i$ u onim podzemnim griješnim neobuzdanim tminama $i$ paklovima gdje se ne slute sjajem ni ovako velemoćni i velebni Mjesec i Sunce, pojavio neizmjeran i uzvišen odsjaj koji nadilazi nebesnike i njihovu velebnost. Čak su se i u tom svijetu rođena bića, na tom odsjaju, međusobno prepoznala: Gle, postoje, zaista, i druga bića ovdje rođena! To je druga čudesna i zadivljujuća pojava koja se javlja s pojavom Tathāgate, Arahanta, Savršeno probuđenoga. 
Začeće i rođenje nalaze se opisani i u Mahāpadānasutti ili Velikom izlaganju o predajama (legendama). ${ }^{106}$ Tu se iznosi razgovor između Gotame Buddhe i njegovih učenika koji se odvio u gradu Sāvatthī. Na samome početku toga razgovora sljedbenici mole Gotamu da im održi izlaganje o životima prethodnih buddha. ${ }^{107}$ Nakon što nabroji šest svojih prethodnika poimence (Vipassin, Sikhin, Vessabhū, Kakusandha, Konāgamana i Kassapa), Gotama ukratko iznosi i osnovne podatke o njihovu podrijetlu, duljini života, mjestu probuđenja, učenicima, broju sljedbenika i vladarima koji su u njihovo vrijeme vladali. U drugome dijelu razgovora, Gotama iznosi tijek života (isključujući smrt) buddhe Vipassina. Prijevod ulomka je izostavljen budući da je gotovo u cijelosti jednak gore prevedenoj Aććhariyabbhutadhammasutti. Razlika, je međutim, u naglasku na činjenici da se pojavljivanje buddha u svijetu odvija uvijek na isti način - ayamettha dhammatā, ${ }^{108}$ odnosno "takva je priroda dhamme" ili "takvo je pravilo", o čemu Gokhale (1965: 357) kaže:

This term is first used to explain certain occurrences associated with the birth of the Bodhisatta. The term may be simply translated as a rule or a norm but has shades of meaning far beyond the ordinary meaning attached to rule or norm. Dhammatā is an unvarying, inexorable, cyclical sequence of events, in a way comparable to the Vedic ṛta. It is the law of nature, a cosmic law. It is the principle of order that makes the world a cosmos and not chaos. [...] The appearance of a Buddha is not an accident of history but an event conditioned by an inexorable law. ${ }^{109}$

Također, za razliku od prikaza u Aććhariyabbhutadhammasutti, u Mahāpadānasutti se ne spominje da se Bodhisatta na nebesima Tusita pojavljuje i u njima boravi svjestan i sabran niti da je u njima proveo cijelu duljinu života.

Ukratko, u toj sutti Gotama iznosi šesnaest pravila koja se odnose na začeće i rođenje svih buddha, ilustrirajući ih na primjeru buddhe Vipassina. Pravila iznesena u ovoj sutti su sljedeća:

\footnotetext{
${ }^{106}$ DN ii. 1-54. Walland je (1914: 661 i d.) pokušao dokazati da je izvorni naslov sutte Mahāpadhānasutta, odnosno "Sutta of the highest being". S njegovom se pretpostavkom ne slaže Winternitz (1933/1999: 41, bilj. 2) koji nadodaje: However, he may be right in assuming that this Sutta and the Lalitavistara can be traced back to a common source, and that the Sutta corresponds to the tradition of about the 3rd to the 1st century B.C.

107 U Mahāpadānasutti se (DN ii. 10) nalazi objašnjenje za Gotamino poznavanje života prethodnih buddha: Tathāgatass' ev'esā bhikkhave dhamma-dhātu suppațividdhā... Devatā pi Tathāgatassa etam attham ārocesum (Tathāgata vrlo dobro poznaje temelje dhamme... a i nebesnici su mu to obznanili).

${ }^{108}$ Dhammatā (skt. dharmitā), prikladnost, opće pravilo, uobičajena ili općeprihvaćena praksa, viši zakon. V. PED, str. 339.

109 V. i Rahula (1974).
} 
1. Svaki bodhisatta, prije negoli se spusti u majčinu utrobu boravi u nebesima Tusita.

2. U trenutku ulaska u majčinu utrobu pojavljuju se potres i snažna svjetlost koja obasjava sve svjetove uključujući i paklove.

3. Za vrijeme boravka u utrobi, budućega buddhu i njegovu majku štite četiri božanstva raspoređena na četiri strane svijeta.

4. Majke bodhisatti, za vrijeme trudnoće, postaju kreposne.

5. Majke bodhisatti, za vrijeme trudnoće, ne osjećaju tjelesnu požudu.

6. Majke bodhisatti, za vrijeme trudnoće, uživaju u pet vrsta osjetilnih zadovoljstava.

7. Majke bodhisatti, za vrijeme trudnoće, ne pate od umora ili bilo kakve tegobe i mogu jasno vidjeti bodhisattu u svojoj utrobi.

8. Pravilo je, također, da sve majke bodhisatti umiru sedam dana nakon poroda $\mathrm{i}$ da se ponovno rađaju na nebesima Tusita.

9. Majka bodhisatte nosi plod punih deset mjeseci.

10. Majka bodhisattu rađa stojeći.

11. Po izlasku iz majčine utrobe svakog bodhisattu primaju nebesnici, potom ljudi.

12. Nakon izlaska iz utrobe bodhisatta ne dotiče zemlju, majci ga na ruke daju nebesnici.

13. Ni jedan se bodhisatta ne rađa umrljan tjelesnim izlučevinama.

14. Odmah po rođenju, iz ozračja se pojavljuju dva mlaza vode kako bi obredno oprali tek rođenoga bodhisattu i njegovu majku.

15. Svaki bodhisatta čini sedam koraka uz proglas da je iskonski, najsjajniji i najstariji na svijetu te da je to njegovo posljednje rođenje.

16. U trenutku rođenja budućega buddhe u pravilu se pojavljuje i snažno svjetlo koje obasjava sve svjetove.

Mahāpadānasutta donosi i proročanstvo o dvije moguće sudbine ili dva životna izbora bodhisatte.

DN ii. 16

'Jāte kho pana bhikkhave Vipassimhi kumāre, Bandhumato rañño pațivedesum: "Putto te deva jāto, tam devo passatūti." Addasā kho bhikkhave Bandhumā rājā Vipassīkumāram, disvā nemitte brāhmaṇe āmantāpetvā etad avoca: Passantu bhonto nemittā 
brāhmaṇā kumāran ti." Addasāsum kho bhikkhave nemittā brāhmaṇā Vipassī-kumāram, disvā Bandhumam rājānam etad avocum: "Attamano deva hohi, \{mahesakkho\} te deva putto uppanno. Lābhā te Mahārāja, suladdham te Mahārāja, yassa te kule evarūpo putto uppanno. Ayam hi deva kumāro dvattimsa Mahāpurisa-lakkhaṇehi samannāgato, yehi samannāgatassa Mahāpurisassa dve gatiyo bhavanti anañ̃̄ā. Sace agāram ajjhāvasati, rājāa hoti cakka-vatti dhammiko dhamma-rājā cāturanto vijitāvi janapadatthāvariyappatto satta-ratana-samannāgato.

Tass'; imāni satta ratanāni bhavanti, seyyathīdam cakkaratanam hatthi-ratanam assaratanam maṇi-ratanam itthiratanam gahapati-ratanam parị̄āyaka-ratanam eva sattamam. \{Paro-\}sahassam kho pan'; assa puttā bhavanti sūrā vīrañga-rūpā parasenappamaddanā. So imam pațhavim sāgara-pariyantam adanḍena asatthena dhammena abhivijiya ajjhāvasati. Sace kho pana agārasmā anagāriyam pabbajati, araham hoti \{sammā-sambuddho\} loke vivattacchaddo.

Prijevod

Kada je, o redovnici, rođen kraljević Vipassin, kralju Bandhumantu su rekli: "Rodio ti se sin, kralju! Pogledaj ga, kralju!” Pogledao je, zaista, o redovnici, kralj Bandhumant kraljevića Vipassina $i$, pogledavši ga, dao je sazvati brahmane vrsne u tumačenju znakova pa im je ovako rekao: "Poštovani brahmani vrsni u čitanju znakova! Promotrite kraljevića!" Promotrili su, zaista, o redovnici, brahmani vrsni u čitanju znakova kraljevića Vipassina pa su, promotrivši ga, ovako rekli kralju: "Poštovani, budi radostan! Rodio ti se, poštovani, sin \{velike moći\}. Veliki kralju, blago tebi, jer je, veliki kralju, u tvojoj obitelji rođen takav sin! Taj je kraljević, o kralju, obdaren s tridesetidva obilježja velika čovjeka. Čovjek obdaren tim obilježjima ima samo dva puta i ni jedan drugi. Ako ostane živjeti u kući, postat će kralj, ćakkavattin, ${ }^{110}$ pravedan vladar, pobjednik na četiri strane, koji je postigao da su mu podanici i zemlja zaštićeni, obdaren sa sedam bogatstava. On ima sedam bogatstava, a ta su sljedeća: bogatstvo bojnih kola, bogatstvo slonova, bogatstvo konja, bogatstvo dragog kamenja, bogatstvo žena, bogatstvo pučanstva, bogatstvo savjetnika, tih sedam. On ima i više od tisuću hrabrih sinova junačkih tijela koji razbijaju neprijateljske vojske. On vlada zemljom okruženom

\footnotetext{
${ }^{110}$ Ćakkavattin (skt. ćakravartin), dosl. koji pokreće kotač, gospodar kočije, vladar.
} 
morem pokorivši ju pravdom (dhammom) bez palice i mača. Ali, ako ode od kuće u beskućništvo, postat će arahant, savršeno probuđeni, koji odmiče veo sa svijeta."

Nabrajaju se potom tridesetidva obilježja savršena ili velika čovjeka (mahāpurisa), što uz isticanje mogućnosti da Gotama postane univerzalni vladar (ćakkavattin) može biti znak relativno kasnoga datuma te sutte. Za razliku od ove sutte, u Nālakasutti Suttanipāte ${ }^{111}$ proročanstvo ne sadrži mogućnost da novorođeni Gotama postane univerzalni vladar iz čega se, s oprezom, može pretpostaviti da su niže prevedeni stihovi nastali u razdoblju prije vladavine Aśoke.

Sn. 686-693

686. Tato kumāram jalitam iva suvaṇnam

ukkāmukhe va sukusalasampahațtham

daddallamānam siriyā anomavaṇnam

dassesu puttam Asitavhayassa Sakyā. || Sn. 3,11.8 ||

687. Disvā kumāram sikhim iva pajjalantạ̣

tārāsabham va nabhasigamam visuddham

suriyan tapantam sarada-r-iv'; abbhamuttam

ānandajāto vipulam alattha pītim. $\|$ Sn. 3,11.9 || [...]

689. Disvā jați Kaṇhasirivhayo isi

suvaṇnanekkhạ viya paṇdukambale

setañ ca chattam dhariyanta muddhani

udaggacitto sumano patiggahe. || Sn. 3,11.11 ||

690. Pațiggahetvā pana Sakyapungavam

jigiṃsako lakkhañamantapāragū

pasannacitto giram abbhudīrayi:

"anuttar' āyam dipadānam uttamo". || Sn. 3,11.12 ||

691. Ath'; attano gamanam anussaranto

akalyarūpo galayati assukāni,

\footnotetext{
${ }^{111}$ Sn. 3.11. Unutar Suttanipāte, proročanstvo se o dvije moguće životne sudbine nalazi u Selasutti (3. 7). Selasutta se nalazi i u MN br. 92. Proročanstvo se nalazi se opisano i u Mv. ii. 30 i d., ĐātA. I. 54, Buddhaćarita I. 69-76, Lv. 101 i d.
} 
disvāna Sakyā isim avocum rudantam:

"no ce kumāre bhavissati antarāyo". || Sn. 3,11.13 ||

692. Disvāna Sakye isi-m-avoca akalye:

"nāham kumāre ahitam anussarāmi,

na cāpi-m-assa bhavissati antarāyo,

na orak'; āyam, adhimanasā bhavātha. || Sn. 3,11.14 ||

693. Sambodhiyaggam phusissat'; āyam kumāro, so dhammacakkam paramavisuddhadassī vattessat'; āyaṃ bahujanahitānukampī,

vitthārik'; assa bhavissati brahmacariyam. || Sn. 3,11.15 ||

Prijevod

686. Tad su kraljevića, sina, sjajnog kao zlato

Što ga obrađuje vješt zlatar u žar-peći

Sjajnog od krasote, besprijekorne boje

Pokazali Sakye [mudracu] zvanom Asita.

687. Vidjevši kraljevića sjajećeg ko' plamen

čista ko Mjesec što bikje među zvijezdama,

Slična Suncu koje sja kroz jesenje oblake,

Razveseljen, ispuni se posve ushitom. [...]

689. Vidje ga asket, vidjelac zvan $i$ Kan̈hasiri,

Slična zlatnu uresu na svijetlu platnu.

Nad glavom mu držeć bijeli krović,

primi ga ushićen i sretna srca.

690. Primivši njega, bika među Sakyama

Sa čežnjom, znalac mantra i znakova,

Mirnoga srca podigne glas i reče:

"Nenadmašan! Među ljudima ${ }^{112}$ najbolji!"

691. Al’ prisjećajući se svoga odlaska

${ }^{112}$ Dvipād, dosl. među dvonošcima. 
Oneraspoložen on stade liti suze.

Rekoše Sākye vidjevši ga uplakanog:

"Da neće štogod stati na put kraljeviću?"

692. Vidjevši Sākye tužne reče im vidjelac:

“Ne razmišljam ja o zloj kobi kraljevića.

Zaista, neće bit prepreke kraljeviću.

Nije nevrijedan, budite uvjereni!

693. Stić' će taj mladac do krajnjega probuđenja,

Uviđajući najčišće, on će pokrenuti

Kotač nauka brinući se za dobro mnogih.

Bit će mu život u čistoći nadaleko znan."

\subsection{Začeće i rođenje u Nidānakathi}

U Nidānakathi je pripovijest o začeću i rođenju obogaćena detaljima koji se ne susreću u prve četiri nikāye Suttapitake kao što je, primjerice, Māyin san u kojem Bodhisatta u trenutku začeća ulazi u njezinu utrobu u obličju bijeloga slona. ${ }^{113}$ Slijedi opis začeća.

ĐātA. I. 50

Tadā kira kapilavatthunagare āsāḷhinakkhattam ghuțtham ahosi. Mahājano nakkhatam kīlati. Mahāmāyā devī pure puṇnamāya sattamadivasto pațthāya vigatasurāpānam mālāgandhavibhūtisampannam nakkhattakīlam anubhavamānā sattamadivase pāto va utțhāya gandhodakena nahāyitvā cattāri satasahassāni vissajettvā mahādānam datvā sabbālamikāravibhūsitā varabhojanam bhuñjitvā uposathañgāni adhiț̣hāya

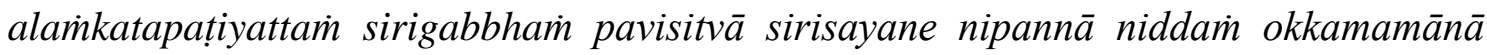

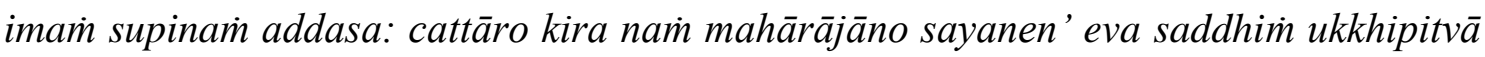
Himavantai் netvā sațthiyojanike Manosilātale sattayojanikassa mahāsālarukkhassa

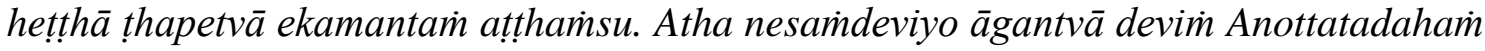
netvā manussamalaharanattham nahāpetvā dibbavattham nivāsāpetvā gandhehi vilimpāpetvā dibbapupphāni pilandhāpetvā - tato avidūre Rajatapabbato, tassa anto

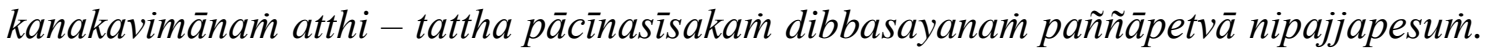
Atha Bodhisatto setavaravāraṇo hutvā - tato avidūre eko Suvaṇnapabbato - tattha

\footnotetext{
${ }^{113}$ San se spominje u Lv. 55 i Buddhaćariti I. 4.
} 
caritvā tato oruyha Rajatapabbatam abhirūhitvā uttardisato āgamma rajatadāmavaṇnāya soṇ̣̂̄ya setapadumam gahetvā koñcanādam naditvā kanakavimānam pavisitvā mātusayanam tikkhatum padakkhinam katvā dakkhinapassam tạletvā kucchim paviț̣asadiso ahosi. Evaṁ uttarasālhanakkhattena pațisandhim gaṇhi. Punadivase pabuddhā devī tam supinaṁ rañño ārocesi.

Prijevod

U to je vrijeme, u gradu Kapilavatthuu, proglašena proslava zviježđa Așạ̄̂he sredinom ljeta $^{114} i$ veliko je mnoštvo sudjelovalo u slavlju. Počevši od sedmoga dana prije punoga Mjeseca kraljica je Mahāmāyā, ne uzimajući opojnih pića, uživala u slavlju zviježđa prepunom vijenaca cvijeća, mirisa i sjaja. Sedmoga je dana ustala u zoru i, okupavši se u mirisnoj vodi, podijelila četiri stotine tisuća [novčića?] davši time velik dar. Nakon uživanja u probranim jelima, ukrašena svim uresima, usmjerila je svoje misli na zavjete propisane za svetkovinu $i$ ušla u ukrašenu i pripremljenu spavaonicu. Legla je na kraljevski ležaj $i$, nadvladana snom, usnila ovaj san: Četiri su je velika kralja, skupa s ležajem, podigla i odnijela na Himālayu. Spustivši je na grimizno tlo široko šezdeset yođana, ${ }^{115}$ ispod velika stabla sāla ${ }^{116}$ visokog sedam yođana, odmaknuli su se u stranu. Potom su prišle njihove kraljice $i$, odvevši ju na jezero Anottata, okupale su ju da s nje speru ljudsku prljavštinu. Dale su joj da obuče božansku odjeću, da se pomaže mirisima i ukrasi božanskim cvijećem. Nedaleko [od toga mjesta] bila je srebrna planina i na njoj zlatna palača u kojoj su ju, pokazavši joj ga, polegle na božanski ležaj, glave okrenute u smjeru istoka. U to je vrijeme Bodhisatta, koji se bio pretvorio u lijepoga bijeloga slona, koračao po obližnjoj zlatnoj planini. Spustivši se [sa zlatne planine], popeo se na srebrnu planinu, došavši sa sjeverne strane. Držeći u surli srebrne boje bijeli cvijet lotusa, oglasio se snažno i ušao u zlatnu palaču. Potom je obišao majčin ležaj tri puta, držeći ju s desne strane. Dotaknuo ju je i kao da je ušao u [njezinu] utrobu. Tako je uzeo ponovno utjelovljenje sa zviježdem Uttara-Aṣādha. Sljedećega je dana, probudivši se, kraljica taj san ispričala kralju.

Ukratko, čuvši Māyin san, kralj je dao sazvati šezdeset i četiri ugledna brahmana koji su protumačili taj san rekavši da će dijete začeto te noći postati ili sveopći vladar ili buddha. Slijedi

\footnotetext{
${ }^{114} \bar{a} s \bar{a} l h \bar{l}, \bar{a} s \bar{a} ! h \bar{a}$ (skt. $\bar{a} s ̣ \bar{a} h h a$ ), mjesec u godini koji odgovara prijelazu s lipnja na srpanj.

115 Yođana, mjerna jedinica za duljinu, otprilike $1.6 \mathrm{~km}$.

${ }^{116}$ Sāla (skt. śāla), Shorea robusta.
} 
potom opis potresa, svjetlosti i mnogih čudesnih pojava koje su se u tom trenutku očitovale. ${ }^{117}$ Ističe se, također, da su se u tom trenutku na tijelu novorođenoga pojavila i tridesetidva znaka savršenstva, kao i da su majku i dijete, u svakome trenutku, štitila četiri nebesnika s mačem u rukama kako ne bi bili niti na koji način pozlijeđeni. Slijedi opis samoga rođenja.

ĐātA. I. 52-53

Mahāmāyāpi dev̄̄ pattena telà̇ viya dasamāse kucchiyā Bodhisattam pariharitvā paripuṇnagabbhā ñātigharai் gantukāmā Suddhodanamahārājassam ārocesi: ,, icchām ’ aham deva kulasantakam Devadahanagaram gantun" ti. Rājā „sādhü" 'ti

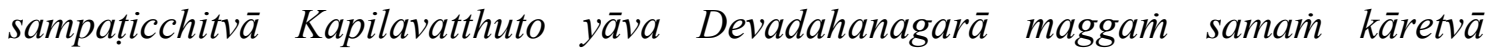
kadalipuṇnaghațadhaja- pațākādīhi alamikārāpetvā devim sovaṇnasivikāya nisīdāpetvā amaccasahassena ukkhipāpetvā mahantena parivārena pesesi. dvinnam pana

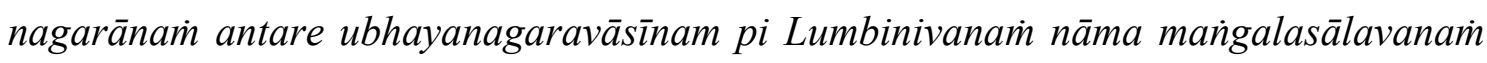
atthi. Tasmim samaye mūlato pațthāya yāva aggasākhā sabbamekaphāliphullä̇ ahosi sākhantarehi c’ eva pupphantarehi ca pañcavaṇnabhamaragaṇā nānappakārā ca

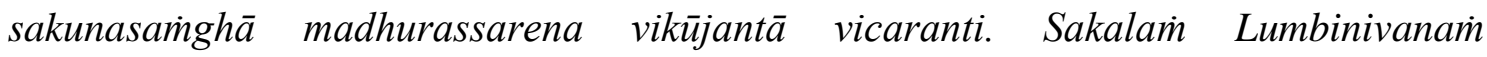
cittalatāvanasadisam mahānubhāvassa rañ̃̃o susajjita āpānamaṇdalam viya ahosi. Deviyā taì disvā sālavanakīlà̇ kịlitukāmatā udapādi. Amaccā devim gahetvā


Sālasākhā suseditavettaggam viya onamitvā deviyā hatthapathai் upagañchi. Sā hatthai் pasāretvā sākham aggahesi. Tāvad eva c' assā kammajavātā calimisu. Ath' assā sāṇim parikkhipitvā mahājano pațikkami. Sālasākhaì gahetvā tiț̣amānāya eva c' assā gabbhavuț̣̂ānam ahosi. Tam khaṇam yeva cattāro pi suddhacittā Mahābrahmāno suvaṇnajālam ādāyo sampattā tena suvaṇnajālena Bodhisattam sampațicchitvā mātu purato thapetvā ,attamanā devi hohi mahesakkho te putto upanno" ti āhamsu. Yathā pana añ̃̃e sattā mātukucchito nikkhamantā pațikkūlena asucinā makkhitā nikkhamanti na evam Bodhisatto. Bodhisatto pana dhammāsanato otaranto dhammakathiko viya nissenito otaranto puriso viya ca dve ca hatthe dve ca pāde pasāretvā thitako mātukucchisambhavena kenaci asucinā amakkhito suddho visado kāsikavatthe nikkhittamaṇiratanam viya jotanto mātukucchito nikkhami. Evam sante pi Bodhisattassa ca Bodhisattamātuyā ca sakkāratthaì ākāsato dve udakadhārā nikkhamitvā Bodhisattassa ca mātu c' assa sarīre utum gāhāpesum._Atha nam suvaṇnajālena

\footnotetext{
117 ĐātA. I. 51.
} 
pațigahetvā thitānam Brahmānam hatthato cattāro mahārājāno mañgalasammatāya sukhasamphassāya ajinappaveṇiya gaṇhimsu tesam hatthato manussā dukūlacumbațakena manussānam hatthato muccitvā pațaviyam patițthāya puratthimadisam olokesi. Anekāni cakkavālasahassāni ekañgaṇāni ahesum. Tattha devamanussā gandhamālādīhi pūjayamānā ,,Mahāpurisa idha tumhehi sadiso añ̃̃o $n$, atthi kut' ettha uttaritaro “ ti āhamsu. Evam catasso disā ca catasso anudisā ca hetțhā uparīti dasa pi disā anuviloketvā attano sadisam adisvā „ayam uttarā dis $\bar{a}$ “ ti sattapadavītihārena agamāsi Mahābrahmanā setacchattaì dhāriyamāno Suyāmena vālavījanim aññehi ca devatāhi sesarājakakudhabhaṇ̣ahatthāhi anugammamāno tato sattamapade thito "aggo 'ham asmi lokassā" 'ti ādikam āsabhim vācam nicchārento sīhanādaì nadi.

\section{Prijevod}

Čuvala je kraljica Mahāmāyā Bodhisattu deset mjeseci u utrobi poput ulja u posudi. Kad je osjetila da se bliži vrijeme porodu, željna odlaska roditeljskoj kući, rekla je velikomu kralju Suddhodani: "Kralju, želim otići u porodičnu kuću, u grad Devadahu." "U redu" - složio se kralj i dao poravnati put od Kapilavatthua do grada Devadahe i ukrasiti ga stablima banana širokih listova, ${ }^{118}$ posudama punim vode, zastavama $i$ barjacima. Posadio je kraljicu u zlatnu nosiljku koju je pridržavalo tisuću ljudi pa ju je odaslao na put, okruženu velikom pratnjom. Između dva grada bijaše ugodan nasad stabala sāla zvan Lumbinī, a kojega su djelili stanovnici oba grada. U to su vrijeme od korijena pa do najviših grana stabla bila u punome cvatu, a među granama i cvijetovima komešali su se rojevi raznobojnih pčela i jata raznovrsnih ptica koje su slatko i opojno pjevale. Cijeli je gaj Lumbin̄ nalikovao na šumu zadivljujućih povijuša, na lijepo uređenu gostinsku dvoranu kakva moćna kralja. Ugledavši taj [gaj] javila se u kraljici želja da se u tom nasadu sāla razonodi, pa je pratnja, povedovši kraljicu, zašla u gaj. Prišla je [kraljica] korijenu krasnoga stabla sāla i poželjela se primiti za njegovu granu. [Tada se] grana sāla, kao vlažan izdanak bambusa, povila i spustila do [kraljičine] ruke. Kada je ispružila ruku i primila se za granu, došlo je vrijeme za porođaj. ${ }^{119}$ Zaklonivši ju zastorom, veliko se mnoštvo povuklo. Porodila se stojeći i držeći se za granu sāla. U tom su se baš trenutku

\footnotetext{
${ }^{118}$ Kadalī (skt. kadala), Musa sapientum.

${ }^{119}$ Kammajavātā calimisu, relativno doslovan prijevod bio bi “započeli su porođajni grčevi ili trudovi” ali takav bi prijevod asocirao na porođajne muke ili bolove pri porodu što bi bilo u proturječju s cjelokupnom slikom bezbolnoga Bodhisattinog rođenja.
} 
pojavila četiri Mahābrahmana čistoga uma noseći zlatnu mrežu. Tom su zlatnom mrežom prihvatili Bodhisattu i položili ga pred majku [rekavši]: "Budi radosna, kraljice! Rodio ti se sin velike moći." Druga bića koja izlaze iz majčine utrobe izlaze uprljana nečistima $i$ prljavštinom, ali ne $i$ bodhisatta. Bodhisatta se spušta kao propovjednik $s$ propovjedaonice, kao čovjek s ljestava: uspravan, pružajući dvije ruke i dvije noge, neuprljan nečistima majčine utrobe, čist, jasan kao dragi kamen položen na tkaninu iz grada Kāsī. Sjajeći se izlazi iz majčine utrobe. Iako su [oboje] bili takvi, dva su se mlaza vode spustila s neba u znak dobrodošlice spram Bodhisatte i Bodhisattine majke i dala prigodu osvježenja tijelima Bodhisatte i majke. Iz ruku prisutnih Brahmana koji su ga primili zlatnom mrežom, četiri su ga velika kralja, odajući mu počast, primila prostirkom ugodnom na dodir, načinjenom od kože antilope. Iz njihovih su ga ruku primili ljudi na mekom jastuku, a Bodhisatta je, oslobodivši se ruku ljudi, stao na zemlju i pogledao prema istoku. Tisuće različitih svjetova otvorilo se kao jedan prostor. Mirisnim vijencima i drugime štovali su ga nebesnici i ljudi pa rekli: “O, Veliki! Nitko ti nije ravan, kako bi bio veći od tebe?" Promotrivši četiri glavna smjera, četiri sporedna smjera, zenit i nadir, ukupno deset smjerova i ne vidjevši sebi ravna, [rekao je]: "Ovo je smjer sjevera". Načinio je hod od sedam koraka dok je Mahābrahman, praćen Suyāmom koji je u ruci držao lepezu načinjenu od repa jaka i ostalim nebesnicima koji su nosili ostala kraljevska obilježja, [nad njim] držao bijeli suncobran. Na sedmome je koraku zastao i, prvo ispustivši bikovski muk, zarikao rikom lava: "Ja sam najiskonskiji na svijetu!"

U kontekstu rođenja Nidānakathā (ĐātA. I. 54) također donosi pripovijest o posjetu mudraca novorođenomu Bodhisatti koja se u nekim detaljima razlikuje od gore prevedenoga ulomka iz Nālakasutte Suttanipāte. U Nidānakathi se spominje dolazak osobnoga savjetnika kralja Suddhodane trapljenika (tāpasa) Kāḷe Devale (Kāla znači isto što i Asita “Crni”). Kralj naređuje da se Bodhisatta dovede kako bi se poklonio trapljeniku. Bodhisatta tom prilikom stavlja noge na glavu trapljenika budući da na svijetu ne postoji nitko vrijedan Bodhisattina naklona.

\subsection{Začeće i rođenje u Mahāvastuu}

Mahāvastu sadrži četiri pripovijesti o začeću i rođenju Bodhisattve. ${ }^{120}$

Prva se pripovijest o začeću i rođenju Gautame nalazi u prvome dijelu Mahāvastua (Mv. i. 98-100), uklopljena u izlaganje o četvrtome polju ili razvojnom stupnju bodhisattve

\footnotetext{
${ }^{120}$ Mv. i. 98-100, 142-153, 197-227 i Mv. ii. 1-30. Valja napomenuti da se unutar ovdje nabrojanih ulomaka začeće i rođenje nerijetko iznose po nekoliko puta zaredom, s blagim varijacijama u opisima. Opis se trenutka Buddhina rođenja, sveden na svega nekoliko rečenica, nalazi i u Mv. ii. 298-299.
} 
(bhūmi). ${ }^{121}$ Navodi se kako je Bodhisattva napustio nebesa Tușita vidjevši bića opijena strašću i ispunjena sumnjama. $U$ trenutku njegova spuštanja u obličju bijeloga slona u utrobu kraljice Māye, cijela se zemlja zatresla i na taj način iskazala svoje poštovanje. Kada je došlo vrijeme za porođaj, kraljica je otišla u gaj zvan Lumba i tamo se razonodila. Zadovoljna i sretna, u jednome se je trenutku uhvatila za granu stabla (Mahāvastu na ovome mjestu tvrdi da riječ o stablu lumbinī) i porodila. U trenutku Gautamina rođenja nebesnici su s nebesa pustili dva mlaza vode kako bi se majka i dijete oprali. Novorođeni je potom napravio sedam koraka, proglasio se najiskonskijim na svijetu i izjavio da je to njegovo posljednje rođenje. Cijeli je događaj popraćen kišom cvijeća, grmljavinom nebeskih bubnjeva, kišom praha sandalovine i otkrivanjem i izbijanjem do tada skrivenih blaga.

U drugoj se pripovijesti o rođenju (Mv. i. 142-153), koja se odvija na desetome polju, navodi kako je Bodhisattva prije napuštanja nebesa izabrao majku i ušao u njezinu utrobu. Opisuju se potom položaj koji Bodhisattva zauzima u majčinoj utrobi i štovanje koje nebesnici iskazuju majci i Bodhisattvi. Ističe se da začeće i rođenje bodhisattvi nije rezultat spolnoga čina oca i majke već da je to rezultat njihovih zasluga. Po isteku desetoga mjeseca od začeća, kraljica je otišla u gaj Lumbinī i, uhvativši se za granu, bezbolno porodila. ${ }^{122}$ Bodhisattva je izašao iz desne majčine strane, ${ }^{123}$ a nakon rođenja Śuddhodānu i novorođenoga posjetili su nebesnici koji su protumačili znakova savršenstva vidljive na tijelu Bodhisattve. Navodi se također da su bodhisattve odmah po rođenju vični svim ljudskim umijećima i da nemaju strasti.

Treća se pripovijest (Mv i. 197-227) odnosi na začeće i rođenje buddhe Dīpañkare. Prije negoli je napustio nebesa bodhisattva Dīpan̉kara razmotrio je vrijeme, kontinent, mjesto i obitelj u kojoj će se roditi. Naglašava se da obitelj u kojoj se budući buddha rađa uvijek pripada kasti brahmana ili kšatrija. Za roditelje je izabrao kralja Arćimanta i kraljicu Sudīpu. U majčinu je utrobu ušao u liku bijeloga slona sa šest kljova, a navodi se kako ga je u trenutku začeća Sudīpā vidjela u snu. U trenutku začeća zemlja se zatresla šest puta. Sljedećega je jutra kraljica taj san ispričala suprugu koji je dao sazvati tumače koji su mu obznanili da će dijete biti obilježeno sa trideset i dva znaka savršenstva i da će postati ili moćan vladar ili Probuđeni. Sudīpa ga je porodila u gaju Padmini, uhvativši se za granu stabla. Ističe se da se bodhisattve

\footnotetext{
${ }^{121}$ Bhūmi, u doslovnome prijevodu znači tlo, zemlja ili polje, a u ovome se kontekstu odnosi na deset polja, stupnjeva ili stepenica u razvoju bodhisattve. U svakome od tih polja ili razvojnih stupnjeva bodhisattva usavršuje i vježba određene vrline koje će ga, u konačnici, dovesti do probuđenja.

${ }^{122} \mathrm{Na}$ ovome se mjestu navodi kako je riječ o stablu plākṣnā. Na drugim je mjestima (v. npr. niže u Mv. ii. 19. 17) riječ o stablu pilakṣa. U Lv. 83 također se spominje plakṣavṛșa.

${ }^{123}$ Mv. i. 150. 6: dakṣiṇapārśvena. Pārśsa, rebro, područje rebara, strana (tijela) pa se može reći i da je izašao iz predjela (desnih) rebara, v. SED, str. 622.
} 
rađaju iz desne majčine strane i da je rođenje bodhisattve za majku bezbolno budući da se bodhisattve rađaju s tijelom načinjenim od uma (manomayena kāyena). U trenutku rođenja pojavila su se i dva mlaza vode za pranje bodhisattve i majke. Odmah po rođenju bodhisattva je učinio sedam koraka, izjavivši da je to njegovo posljednje rođenje.

Gautaminim začećem i rođenjem započinje druga knjiga Mahāvastua koja sadržajno odgovara drugom dijelu Nidānakathe, odnosno dijelu u kojemu se pripovijedaju događaji iz "ne tako daleke prošlosti” (avidūre nidāna). Kako bi se izbjegla brojna ponavljanja i opširni opisi radosti koja je zavladala u svijetu nebesnika, niže su izneseni i prevedeni odabrani ulomci iz Mv. ii. 1-30.

Mv ii. 8- 10 (začeće)

eșo cyavāmi iti muṃci girāṃ śubham vacanaṃ udīrayi ... . /

atha supinaṃ jananī jinasya tasmị̣ kṣaṇe paśyati varavipākaphalạ̣

// himarajatanibho me șaḍvișāno sucaraṇacārubhujo suraktaśīrṣo /

udaram upagato gajapradhāno lalitagatih anavadyagātrasandhị //

na khalu bodhisatvā kālapakṣe matu kukṣiṃ okrāmanti // atha khalu pūrṇāyām pūrṇamāsyām puṣyanakṣatrayogayuktāyām rātryām bodhisatvā mātuḥ kukṣim avakrāmanti /upoṣadhikāyām

(2.9) pramadottamāyām sananditāyām avilakșitāyām akṣudrāvacarāyām prāsadikāyām śucigātrāyām mandarāgāyā̄m jātisampannāyām kulasampannāyām rūpasampannāyām varṇasampannāyām nāmasampannāyām ārohasampannāyām parịnāhasampannāyām

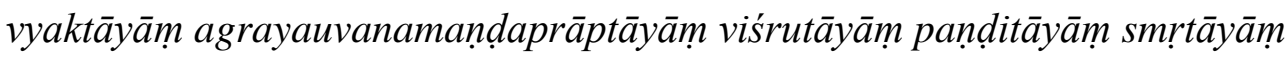
samprajānāyām pradakșiṇacittāyām sarvākārasampannāyāṃ sarvākāraparipūrnāāyām pramadottamāyām bodhisatvā mātuḥ kukșim avakrāmanti // bodhisatvena prabhā osṛștā yāye prabhāye sarvam buddhakṣetram avabhāsitam / devaputro devaputram prcchati //

kiṃ kāraṇam suravareṇa prabhā pramuktā

candrāmśúsítalatarā kanakāvadātā /

yenāsureśvaragaṇā manujeśvarāśs ca

prahlāditā ca narakā jvalanāgnikalpāh //

so dāni āha //

ye tatra tatra janatām pratipālayanti saṃsārapaṃjaragatām madanābhibhūtām / 
teșạ̣̄ vimokṣakaraṇena mahāyaśena

āmantraṇārtham anaghena prabhā pramuktā //

bodhisatva āha //

muñcatha amarā purāṇi na kila prāmodyasya ayaṃ kālo /

jarāmaraṇapurạ̣ bhettum kālo jñānaprahāreṇa //

bodhisatvo smṛto samprajāno pradakșinacitto mātuh kukṣiṃ okrānto //

iti sa nadiya siṃhanādam narasiṃho cyavanakālasamayasmị̣ /

antarahito kṣaṇena narendrabhavane samupapadyi //

(2.10) yo so tușitam kāyaṃ obhāseti śubhena varṇena /

devapurāc cyavamāno tam anativaram jinam vande //

sabrahmakạ̣ ca lokạ̣ saśramaṇabrāhmaṇịn prajạ̄n sarvām /

varnen'; obhāsayati anativaro lokapradyoto //

āścaryam adbhutam idam paśyatha yāvat maharddhikaḥ śāstāa /

smṛtimām susamprajāno mātuḥ kukṣismim okrānto //

yāvac ca narapravaro uttamalakṣaṇasamangi asthāsi /

mātāye kukșismim smṛtimatimām samprajāno ca //

samanantar'; okrānte ca bodhisatve iyam mahāprrthivī atīva șaḍvikāram kampe

saṃkampe prakampe saṃharșaṇīyam ca kampayati modanīyam ca prahlāditam ca

nirvarṇanīyam ca ullokanīyam ca āsecanakạ̣ ca apratikūlaṃ ca prāmodikạ̣ ca

prasādanīyam ca nirudvegam ca niruttrastam ca / kampamānā ca punar na kaṃcit

satvam vyāpādayati yam idam calam vā sthāvaram vā //

tato ayam sāgaramerumaṇdalā

prakampitā șaḍvidham āsi medin̄̄ /

krtā lokā vimalā manoramā

mahāndhakārāpanudasya tejas̄̄ //

yāvattakā nāgarājāno nāgādhipatayo rakșāvaraṇaguptaye autsukyam samāpadyensu //

caturo pi lokapālā rakṣām akarensu lokanāthasya /

mā kocī ahiteșī namucibalanudam vihimseyā //

Prijevod

“Eto, silazim”- oglasi se i izusti lijepu riječ [Bodhisattva]. 
U tom je trenu Pobjednikova majka u snu vidjela njega sazrjelih plodova: ulazi mi u utrobu najodličniji slon, [boje] nalik na snježno bijelo srebro, sa šest kljova, sa surlom koja se dražesno njiše, ljupke glave, zaigrana koraka i besprijekorna tijela.

Bodhisattve se ne spuštaju u majčinu utrobu za vrijeme tamne polovice mjeseca, već se u majčinu utrobu spuštaju u noći punoga Mjeseca, kada je Mjesec združen sa zviježđem Pauṣa. Bodhisattve ulaze u utrobu majke koja se pridržava zavjeta [koji se daju na uposathu],

(2.9) najodličnije među mladim ženama, radosne, iznimne, koja se ne upušta u ono što je nisko, ljubazne, blistavih udova, blage naravi, dobra podrijetla i iz dobre obitelji, lijepa tijela, lijepe puti, dobra imena, skladna stasa i struka, učene, koja je dosegla ures prve mladosti, poštovane, učene, sabrane $i$ svjesne, ispravna mišljenja $i$ u svakom pogledu obdarene $i$ od koje je svaki vid ispunjen, najodličnije među mladim ženama. Iz Bodhisattve je potekla svjetlost koja je obasjala cijelo polje buddhe.

Jedan nebesnički sin upita drugoga:

"Zašto se oslobodila svjetlost iz odličnoga Sure (božanstva)

Koja osvježava više od mjesečeve zrake, sjajna poput zlata, I koja razveseljava gospodare Asura i gospodare ljudi Pa i paklove užarene od ognja?"

Onaj drugi sad odgovori:

“Bezgrješni je, velesjajni koji donosi oslobođenje,

Oslobodio svjetlost na pozdrav onima

Koji štite narod ovdje $i$ ondje

Uhvaćen u mrežu ponovnih rođenja i nadvladan strastima.,

Bodhisattva reče:

"Napustite gradove besmrtnici! Nije ovo vrijeme za razonodu Vrijeme je da se razore utvrde starosti i umiranja udarima znanja!" Bodhisattva se spustio u majčinu utrobu sabran i svjestan, ispravna mišljenja. On, čovjek-lav, oglasio se lavljim rikom kada je došao trenutak za silazak, I u jednome je trenutku i nestao i ponovno se pojavio u palači kralja. 
(2.10) Slavim njega, nenadmašnog pobjednika koji silazeći iz grada nebesnika,

Obasjava cijela nebesa Tușita divnim sjajem,

I sav svijet s Brahmanom, sve ljude s isposnicima i brahmanima

Nenadmašan kao svjetlo svijeta obasjava sjajem.

Pogledajte to čudo i divotu kako se je Učitelj velikih moći,

Sabran i svjestan, spustio u majčinu utrobu!

I kako je najbolji među ljudima, obilježen najodličnijim znakovima

svjestan i sabran, zauzeo mjesto u majčinoj utrobi!

Čim se Bodhisattva spustio, ova se je velika Zemlja na šest načina snažno stresla, zatresla i zadrhtala, potreseno proglašavajući [nešto] radosno, oduševljavajuće, ugodno, što treba gledati, vrijedno divljenja, orošavajuće, što ne vrijeđa, što veseli, što razvedrava, umirujuće i ohrabrujuće. Potresajući se nije ozlijedila ni jedno biće, ni životinju, ni biljku.

Zatresla se je ta Zemlja okružena morem i s planinom Meru

Na šest načina,

A od sjaja njega koji raspršuje gustu tamu

Svjetovi su postali čisti i zadivljujući.

Svi su se kraljevi $i$ vladari nāga žustro zajedno pojavili kako bi branili $i$ zakrivali [Bodhisattvu].

I četiri su čuvara svijetova štitila Zaštitnika svijeta

Kako netko zlonamjeran ne bi naudio Razaratelju Namućieve ${ }^{124}$ snage.

\section{$[\ldots]$}

Mv. ii. 18-24 (rođenje)

sarveșām bodhisatvānām mātā pratipūrne daśame māse prajāyati // subhūtinā śākyena preșitam rājñ̃o / āgacchatu devī iha prajāyișyati // rājā pratibodhayati // āgamiṣyati sālabhaṃjakam ca kariṣyati // lumbinivanam sucapalam apagatatṛnakhāṇdapatrasaṃkhāram /

\footnotetext{
${ }^{124}$ Namući, jedno od Mārinih imena. Negacija $n a+\sqrt{ } m u c ́$, dosl. koji ne pušta, ne oslobađa.
} 
varasurabhikusumanikaram karotha gandhodakasugandham //

lumbinivane va vātā tamālapatragandhavāsitaśarīrā /

vāyantu amṛtagandhām madajananā ca palāyantu //

agaruvaradhūpagandhā samonamantu nabhato jaladharā tam /

lumbinivanam chādetum varacūrṇarasākulam kṣipram //

ekaikạ̣ cañkramavaraṃ dukūlapațtorṇākośikārehi /

kalpayatha kalpavṛșām yatha divi devapradhānasya //

devā ca devakanyā ca gandhamālyam gṛhya luṃbinīvanam āgacchanti //

(2.19) sphaṭikamaṇikuṇ̣̂aladharā vigalitavasanā pralambamaṇihārā /

ādāya gandhamālyam gaganapathagatā praḍīyanti //

mandāravāna bharitā kācit śamgeriyo grhītvāna /

haricandanasya kācit kāci punah kalpaduṣyāṇām //

sthalajajalajam ca mālyam gṛhītvā apsarā muditacittāḥ /

ratanā ābharaṇāni ca jambudvīpe abhimukhīyo //

caturāśitim anūnā chatrasahasrāṇi devakanyāyo /

kanakaratanāmayāni ādāya nabhe praḍ̄yanti //

kūṭāgārasamehi ca sphațikamaṇimusālagalvehi citrehi /

bharitam api antarīkșam duṣyaśatasamucchritapatākam //

gajaśvasanasannikāśā śāradameghā khagapathe virocanti /

varasurabhikusumagandhā kamalotpalacampakavimiśrāḥ //

bhujagapatino pramuditā meghehi sugandhatoyabharitehi /

abhyokiranti nagaraṃ anyāni ca adbhutaśatāni //

avagāhya tạ̣ vanavaram māyā sakhisaṃvṛtā jinajinetrī /

vicarati cittarathe devi amaravadhū yatha ratividhijñā//

sā krị̄̂̄rtham upagatā pilakṣaśakhām bhujāya avalambya /

pravij̣mbhitā salīlā tasya yaśavato jananakāle //

atha vā navati sahasrā marukanyā āśur eva sannipatitā /

māyāṃ kṛtāṃalipuṭā idam avaca prasannasaṃkalpā //

(2.20) adya jarāvyādhimathanaṃ janayiṣyasi amaragarbhasukumāraṃ /

devī divi bhuvi mahitam hitaṃ hitakaram naramarūṇām //

mā khalu janaya viṣādam parikarma vayam tavam karișyāmah /

yam kartavyam udīraya dṛśyatu kṛtam eva tatsarvam //

atha caturi lokapālā saparivārāa āśur eva sannipatitā /

divyapraveṇihastā devim upagatā pradakșiṇato // 
sarve pi devasaṃghā māyām paricārayitva ākāśe /

sthitā mālyagandhahastā svaparivāreṇa upaśobhanti //

na khalu punar bodhisatvāmātā bodhisatvam janeti śayānā niṣaṇnikā vā yathānyāḥ

striyo // atha khalu bodhisatvamātā sthitikā eva bodhisatvam samjaneti // bodhisatvo

smṛto samprajāno mātaram abādhayamāno dakșiṇapārśvena prādurbhavati //

dakṣiṇena hi pārśvena jāyante puruṣottamāh /

sarve puruṣaśārdūlā bhavanty atravihāriṇạ̣ //

kim tan na bhidyate pārśvam vedanā ca na jāyate /

tasyā jinajanetrīye janetvā puruṣottamam //

manomayena rūpeṇa prādurbhonti tathāgatā /

evam na bhidyate pārśvam vedanā na ca jāyati //

bodhisatvo garbhāvāsapariśrānto sapta padāni kramati //

jātamātro ca vikrame sapta vikramate bhuvi /

diśām ca praviloketi mahāhāsam ca ūhati //

$[\ldots]$

(2.22) jātamātrasya me cāhuḥ devatā mārakāyikāḥ /

caturdvīpo mahākośo cakravartī bhaviṣyasi //

athāsya hāso saṃbhavati na me satvā_vijānatha /

sarvajño sarvadarśāvī bhaviṣyam puruṣottamah //

$[\ldots]$

(2. 23) sampratijāte sugate jñātī udakārthikā vidhāvensuh /

atha purato udupānā pūrā mukhato viṣyandensuh //

duve vāridhārā udgami ekā sítasya ekā uṣnasya /

yatra snapayensu sugatam vigraham iva jātarūpasya //

\section{$[\ldots]$}

(2.24) tato jātamātro kule śākiyānām

atikramya dhīro padānīha sapta /

samolokayitvā diśā ūhasāsi

ayam dānim eko bhavo paścimo ti //

Prijevod 
Majka svih bodhisattva rađa po isteku desetoga mjeseca. Śākya Subhūti ${ }^{125}$ zatražio je od kralja: "Neka kraljica dođe i ovdje rodi". Kralj je odgovorio: "Doći će i slomiti granu sāla”. ${ }^{126}$

Žustro očistite gaj Lumbin̄̄ od suhe trave, oštećenoga lišća i otpadaka I učinite da bude namirisan mirisnom vodom i [ukrašen] mnoštvom krasna mirisna cvijeća!

Neka u gaju Lumbin̄̄ povjetarci ispunjeni mirisom listova tamāle Šire miris nektara besmrtnosti! Neka se uklone mirisi koji izazivaju omamu! Neka se oblaci [puni] mirisa i arome aloje hitro spuste s neba $i$ Nadsvode gaj Lumbinī [kako bi se] ispunio prahom izvrsnih mirisa.

Prekrijte svaki puteljak mekim, vunenim i svilenim tkaninama Da budu nalik na stabla kalpa ${ }^{127}$ kakva su u nebesima gospodara nebesnika. Noseći mirisne vijence, došli su u gaj Lumbinī nebesnici i nebeske djevojke.

(2.19) Lete nebeskim stazama noseći vijence cvijeća noseći naušnice od kristala i dragulja, spuznule odjeće, s visećim ogrlicama od bisera,

Neki [su došli]noseći mnoštvo cvjetova koraljnoga stabla, neki žute sandalovine, a neki tkanina s drveta kalpataru. Razveseljene apsare okrenule su lica prema Đambudvīpi, noseći nakit od dragulja i ukrašene vijence od vodenoga i poljskoga cvijeća.

Nebesničke djevojke lete u nebu noseći

Ne manje od osamdesetičetiri tisuće suncobrana načinjenih od zlata i dragulja.

Ozračje je napunjeno [štapovima] zastava koji su podupirali stotine tkanina sa šarenim kristalima, biserima i koraljima koji su ih natkrivali.

Po nebeskim putevima sjajili su se jesenji oblaci nalik na dah slonova, [Noseći] mirise krasna miloduha cvijeća, mješavinu ružičastoga i plavoga lotosa $i$ žute ćampake.

Razdragani su gospodari zmija škropili grad oblacima Ispunjenima mirisnom vodom, a bilo još $i$ stotine drugih čudesa. Māyā, roditeljica Pobjednika, okružena pratiljama, uronivši u taj krasni gaj,

\footnotetext{
${ }^{125}$ U Mv. i. 355 navodi se kako je Subhūti poglavar śākyanskoga grada Devaḍahe i otac pet kćeri među kojima su i Gautamina majka Māyā i pomajka Mahāprađāpatī.

${ }^{126}$ ĐātA. I. 52 također spominje stablo sāla, ali se u nastavku ove pripovijesti spominje stablo pilakṣa.

${ }^{127}$ Kalpavṛsșa, jedno od pet nebeskih stabala koje, prema vjerovanju, ispunjava sve želje. V. SED, str. 262.
} 
Obilazi ga na krasnim kolima, kraljica, kao žena nebesnika koja zna pravila užitka.

Radi igre, ona je prišla, rukom se ovjesila o granu stabla pilakṣe

Pa se, zaigrano, rastegnula u času rođenja Sjajnoga.

U taj se tren sletjelo devedeset tisuća nebesničkih djevojaka

koje su, čistih namjera, sklopile ruke [u znak poštovanja] pred Māyom i ovako rekle:

(2.20) "Danas ćeš, kraljice, roditi

otresatelja starosti i bolesti, plemenitog kraljevića iz besmrtničke utrobe,

veličanoga i na nebu i na zemlji kao dobroga dobrotvorca ljudi i nebesnika!

Ne dopusti da se rodi bojazan! Mi ćemo te služiti.

Reci što treba biti učinjeno i gle! sve je učinjeno."

U taj su se tren sletjela $i$ četiri čuvara svijeta s pratnjom

I prišla kraljici s poštovanjem s desne strane s nebeskim prostirkama u rukama.

Uz to su blistale sve skupine nebesnika, koje su, s pratnjom, stajale s mirisnim vijencima u rukama, okružujući Māyu iz zraka.

I opet, majka bodhisattve ne rađa bodhisattvu ležeći ili sjedeći kao druge žene. Majka bodhisattve rađa bodhisattvu stojeći. Bodhisattva se, sabran i svjestan, pojavljuje, ne pozljeđujući pritom majku, iz desnoga [njezina] rebrišta.

Upravo se iz desnoga rebra rađaju najodličniji muževi,

Jer upravo tamo borave svi muževi-tigrovi.

Kako to da se rebro te roditeljice Pobjednika ne lomi i da nema boli

Kada rodi najodličniju osobu?

Tathāgate se pojavljuju s oblikom tvorenim od uma -

Zato se niti bok lomi, niti se javlja bol.

Umoran od boravka u utrobi, Bodhisattva čini sedam koraka.

Tek rođen, kroči na zemlji sedam koraka,

Razgleda smjerove pa pušta glasan smijeh.

$[\ldots]$

(2.22) Odmah po rođenju, rekli su mu nebesnici iz Mārine pratnje:

"Postat ćeš svevladar na četiri kontinenta, s velikom riznicom".

On se [na to] nasmijao [i rekao]: "Ne poznajete me uistinu!

Postat ću najodličnija osoba, Sveznajući i Svevideći”!

(2.23) Odmah po rođenju Sugate, rodbina se rastrčala pripremiti vodu. 
Onda su pred njima potekli puni izvori vode.

Izvrela su dva mlaza vode; jedan hladne, jedan tople,

Kako bi oprali Sugatu kao zlatni ures.

$[\ldots]$

(2.24) I čim je rođen u porodici Śākya

Učinio je ovdje, odlučan sedam koraka.

Promotrivši smjerove, proglasio je:

"Ovo je, sada, moje jedino, posljednje bivanje!"

Mahāvastu također sadrži dvije pripovijesti, u prozi i stihu, o posjetu Asite novorođenomu Gautami. ${ }^{128}$ U prvoj se navodi kako je tamnoputi (śyāma) vidjelac (rși) Asita, podrijetlom iz grada Uđđen̄̄, boravio u gorju Vindhya kada je od nebesnika primio vijest o rođenju budućega buddhe. Magičnim je moćima poletio i stigao do Kapilavastua. U drugoj se verziji Asita naziva Kāla Asita.

\subsection{Zaključna razmatranja}

Začeće i rođenje Gotame Buddhe u svim su korištenim izvorima opisani kao nesvakidašnji događaji, popraćeni brojnim očitovanjima natprirodnih sila. Treba istaknuti da su u buddhističkoj tradiciji začeće i rođenje vrhunac neizmjerna vremena koje im je prethodilo i u kojem je Gotama, u različitim svojim prethodnim životima, usavršavao vrline koje će ga učiniti dostojnim da se u određenom trenutku pojavi u "našem" svijetu i nedavnome vremenu i dosegne probuđenje. Životopis Gotame Buddhe ne započinje tako trenutkom njegova rođenja ili čak začeća, već mnogo ranije kada je, u jednoj u od svojih prijašnjih egzistencija kao isposnik Sumedha ili Megha, dao zavjet ondašnjemu buddhi Dīpan̉kari.

Gore su izdvojeni ulomci u kojima se donosi opis Gotamina posljednjega začeća i rođenja. ${ }^{129}$ Međutim, bilo bi nerealno, čak i u najstarijim slojevima pālijskoga kanona, nadati se opisu rođenja lišenom "čudesnoga i zadivljujućega". ${ }^{130}$ Kako ističe T. Rhys Davids (1896/1907: 94), osvrćući se na prikaz začeća i rođenja u Aććhariyabbhutadhammasutti,

\footnotetext{
${ }^{128}$ Mv. ii. 30-33 i Mv. ii. 33-43.

${ }^{129}$ Iznimno su u ovo poglavlje uvršteni i opisi začeća i rođenja buddhe Vipassina i buddhe Dīpañkare budući da su njihovi životopisi u velikoj mjeri nalik Gotaminom.

${ }^{130}$ U ovome je pogledu zanimljivo pismo R. Chalmersa upućeno 1894. godine na Royal Asiatic Society u kojem, priloživši sažetak Aććhariyabbhutadhammasutte, izražava svoju začuđenost činjenicom da Mađđhimanikāya sadrži suttu koja proturječi uvriježenom mišljenju prema kojem se čudesne i zadivljujuće pojave koje prate začeće i rođenje nalaze samo u kasnijim komentarima i djelima kao što su Lalitavistara i Nidānakathā.
} 
Such legends are indeed of the greatest possible historical value from the comparative point of view. Similar legends are related to all the founders of great religions, and even of the more famous kings and conquerors in the ancient world. In a certain stage of intellectual progress, it is a necessity of the human mind that such legends should grow up.

Legende o silasku s nebesa Tusita (skt. Tușita) u majčinu utrobu javljaju se već u ranim tekstovima kao što je, primjerice, Suttanipāta. ${ }^{131}$ Ulomci iz Aććhariyabbhutadhammasutte i Mahāpadānasutte spominju nebesa Tusita samo kao mjesto boravka prije začeća, ali kasniji tekstovi donose i opis razgovora među nebesnicima i događaja u tim nebesima, a koji su prethodili Bodhisattinu silasku u majčinu utrobu. ${ }^{132}$ Ukratko, prije negoli napusti nebesa, Bodhisatta pažljivo razmatra, i konačno odabire vrijeme, kontinent, mjesto i obitelj u kojoj će se roditi. ${ }^{133}$ U Nidānakathi se tvrdi da je Gotama začet u noći punoga mjeseca u mjesecu āsāḷhā (skt. āṣạ̣̄ha), dok se u Mahāvastuu spominje mjesec pauṣa. ${ }^{134}$

U ulomcima iz Dīgha- i Mađđhimanikāye ne spominje se podatak da je budući buddha u majčinu utrobu ušao u obličju bijeloga slona, ali začetak se te legende nalazi u ranome kanonskom tekstu. ${ }^{135}$ Nidānakathā i Mahāvastu spominju ulazak Bodhisatte u majčinu utrobu u obličju bijeloga slona, ali je jasno istaknuto da se taj događaj zbio isključivo u snu. ${ }^{136}$ Sénart je (1882: 255), oslanjajući se na prikaz silaska u majčinu utrobu u Lalitavistari i potkrijepljujući svoje mišljenje navodom iz Gubernatisa (1872: 92) koji kaže:

The elephant generally represents the sun as it shuts itself up in the cloud or the darkness, or comes out of it, shooting forth rays of light or flashes of lightening (which were also supposed to be caused by the friction on the axle of the wheel of the sun's chariot),

poistovjetio sliku bijeloga slona sa slikom bijelih oblaka zaključujući:

\footnotetext{
${ }^{131}$ Sn. 955.

${ }^{132}$ Mv. ii. 3-4, ĐātA. I. 47-50.

${ }^{133}$ U Nidānakathi (JātA. I. 48-50) se navodi kako je bodhisatta, uz vrijeme, kontinent, mjesto i obitelj, u obzir uzeo i duljinu majčina života. V. i Mv. ii. 2.

134 ĐātA. I. 50, Mv. ii. 8.

135 Thag. 968.

${ }^{136}$ ĐātA. I. 50, Mv. i. 205, ii. 8, 11-12, 13. U Mv. i. 143 Māyin se san ne spominje. Buddhaćarita I. 4 također navodi kako se Bodhisattvin silazak u obličju slona dogodio u majčinu snu. U Lv. 55 Bodhisattva ulazi u majčinu utrobu kroz desnu stranu obličju mladunčeta bijeloga slona sa šest zlatnih kljova. Taj se podatak prvo navodi kao činjenica, a potom kao Māyin san. Najstariji se prikaz Māyina sna nalazi na medaljonu iz 2. st. pr. n. e., pronađenom u Bhārhutu.
} 
Il est bien évident que cet "Élephant divin" (āsuro hastin) a une certaine signification mythologique, et s'il exprime à la fois et résume la force ou la splendeur du soma, du soleil et du feu, aucune conception n'en saurait mieux rendre compte que celle du nuage où s' enveloppent et le soleil et la pluie et le feu du ciel. ${ }^{137}$

Windisch (1908: 176) odbacuje Senartovo shvaćanje Gautame kao utjelovljenja solarna božanstva i donosi sljedeće tumačenje:

Der Elephant im Traume deutet zunächst auf die Königswürde hin, wie denn auch die Wahrsager von dem Kinde im Leibe der Māyā prophezeien, dass es entweder ein weltbeherrschender König oder der Buddha sein werde, s. oben S. 160. Man darf nicht ausser acht lassen, dass Buddha in einem königlichen Gesclechte geboren worden ist.

Māyina se tjelesna i moralna čistoća, kao i izostanak bilo kakva znaka tjelesne požude ističu u svim tekstovima, a Mahāvastu štoviše naglašava da je noć začeća, na vlastiti zahtjev, provela bez supruga Śuddhodhāne. ${ }^{138} \mathrm{Na}$ dva se mjesta u Mahāvastuu navodi kako se bodhisattve ne rađaju kao rezultat spolnoga odnosa oca i majke već da se rađaju svojevoljno, ${ }^{139}$ na temelju svojih prijašnjih zasluga ${ }^{140}$. Također, naglašava se da Māya, od trenutka začeća do poroda, nije imala tjelesnih tegoba. U Nidānakathi i Aććhariyabbhutadhammasutti Māyinu trudnoću nadgledaju samo četiri nebesnika, dok Mahāvastu spominje na desetke tisuća različitih nebeskih bića koja su se okupila u gaju Lumbin̄̄ i, lebdeći u zraku, iščekivala Māyin porođaj. ${ }^{141}$

Dok pālijski tekstovi navode kako Māya u svakom trenutku može jasno vidjeti Bodhisattu u svojoj utrobi, Mahāvastu prilaže detaljan opis njegova položaja u utrobi i nadodaje kako i Bodhisattva može vidjeti svoju majku, kao i tisuće nebeskih bića koje, podižući desnu ruku, svakodnevno pozdravlja. ${ }^{142}$

\footnotetext{
${ }^{137}$ Sa Senartom mišljenje dijeli i T. Rhys Davids (1877/1912: 184): Many of these beliefs again were borrowed from the older sun-worship, white elephant for instance, like the white horse, being an emblem of the sun, the universal monarch of the sky. V. i Rhys Davidsovu bilješku uz MPS 3.15 (1910/2007: 116, bilj. 1).

${ }^{138}$ Mv. i. 145 , ii. 5.

${ }^{139}$ Mv. i. 145,153 .

${ }^{140} \mathrm{U}$ Mv. i. 145. 4 upapāduka, u Mv. i. 153.16 aupapāduka. Senart (1882: 490): Impliquée dans les récits mêmes de la légende, cettte notion ainsi dégagée et érigée en théorie est sans doute propre à l'école des Lokottaravādins, elle montre du moins un accord tout spécial avec leur doctrine.

${ }^{141}$ Mv. ii. 11.

${ }^{142}$ Mv. i. 213, ii. 16.
} 
Svi izdvojeni tekstovi donose i opis zadivljujućih pojava koje su popratile trenutak začeća, odnosno pojavu zasljepljujuće svjetlosti i snažnoga potresa. ${ }^{143}$ Nidānakathā i Mahāvastu u mnogo više riječi opisuju trenutak začeća negoli je to slučaj u suttama Suttapițake, pa se tako npr. u Nidānakathi pripovijeda kako su u tom trenutku "slijepi progledali, gluhi začuli buku, nijemi progovorili, grbavi se ispravili, zatočeni se oslobodili okova, bolesni ozdravili, glazbala prosvirala bez svirača, rijeke zaustavile svoj tok, mora postala slatka...”. Nadogradnje poput ove ne predstavljaju znatan odmak od onoga što bismo mogli nazvati jezgrom pripovijesti o začeću, već jasno ilustriraju jedan od načina na koji je, s vremenom, "kvantitativno" i gradacijski rasla pripovijest o životu Gotame Buddhe.

Popularna se predaja o izlasku iz utrobe kroz desno rebro ili bok (skt. dakṣiṇapārśva) ne nalazi u pālijskim kanonskim tekstovima, međutim Mahāvastu donosi upravo tu tvrdnju ${ }^{144} \mathrm{i}$ stavlja naglasak na shvaćanje da majke ne bivaju ni na koji način ozlijeđene ili povrijeđene tijekom rođenja budući da se tathāgate rađaju s oblikom ili tijelom tvorenim od uma (manomayena rūpena). ${ }^{145}$ Nakamura (2002/2002: 66) tvrdi da se pripovijest o izlasku iz utrobe kroz desno rebro javlja tek u mahāyānskim sūtrama nastalima tijekom dinastije Gupta (nakon 320. godine). Silk (2003: 868) smatra kako je pripovijest o bezbolnom izlasku kroz desno rebro vjerojatno nastala kako bi se opravdala tvrdnja da je Gotama rođen potpuno svjestan, sabran i s jasnim sjećanjem na prethodne živote:

As Hara has so convincingly demonstrated, the Buddha's special status of being fully aware and mindful, just as he was before birth, may be attributed to his avoidance of the traumas of normal birth, a torturous process that deprives the individual of the mindfulness he had as a fetus. ${ }^{146}$

Rođenje pod stablom ne spominje se u prve četiri nikāye Suttapiṭake kao ni u Suttanipāti. U Nidānakathi se tvrdi da se Bodhisattina majka porodila držeći se za granu sāla, dok Mahāvastu spominje stabla lumbinī i plakșa (pilakșa). Međutim, u Aććhariyabbhutadhammasutti se kaže da majka bodhisattve rađa stojeći, što je ipak dio slike držanja za granu stabla.

\footnotetext{
${ }^{143}$ Na nekoliko se mjesta u kanonu navodi kako se svjetlost i potresi neizostavno javljaju u četiri slučaja: u trenutku začeća, rođenja, probuđenja i u trenutku pokretanja Kotača nauke. V. npr. AN ii. 130-13. U Mahāparinibbānasutti se (DN ii. 108) navodi kako u životu Tathāgate postoji šest povoda za pojavu potresa: začeće, rođenje, probuđenje, pokretanje kotača nauka, odluka o ulasku u konačnu nibbānu i konačna nibbāna.

${ }^{144}$ Mv. i. 148, 218, 221, Mv. ii. 20.

145 Mv. ii. 20.

146 Ježić (usmena komunikacija) napominje: Ako takvu predodžbu treba tumačiti, može se pomišljati $i$ na neki mitski obrazac koji se primjenjuje na životopis Buddhe. Sénart nije uvjerljiv s tezom o tome da se životopis Buddhe svodi na solarni mit, ali to ne znači da se se nešto u životopisu nije moglo književno i vjerski stilizirati po kakvu obrascu mita.
} 
Svjetlost i snažni potresi prate i sve opise rođenja. ${ }^{147}$ Svi navedeni tekstovi spominju i dva mlaza vode koja su se pojavila neposredno nakon rođenja kako bi očistila novorođenoga Bodhisattu i njegovu majku. Iako se donekle razlikuju u detaljima, Nidānakathā i Mahāvastu navode kako su se u trenutku Bodhisattina rođenja u svijetu pojavila i druga bića i blaga, a koja će imati značenja u kasnijem životu Gotame, što je detalj koji nije potvrđen u prve dvije nikāye Suttapitake. ${ }^{148}$ U Nidānakathi su to buduća Gotamina supruga, sluga Ćhanna, konj Kanthaka, ministar Kāḷdāyi, stablo pod kojim će Gotama dosegnuti probuđenje i četiri vrča ispunjena blagom (ćattāro nidhikumbhiyo), dok Mahāvastu navodi kako se u tom trenutku pojavilo pet stotina mladića na čelu sa Sundaranandom, pet stotina djevojaka na čelu s Yaśodharom, pet stotina sluga na čelu s Ćhandakom, pet stotina konja na čelu s Kạ̣ṭhakom, pet stotina slonova na čelu s Ćandanom, pet stotina blaga i pet stotina izaslanika različitih kraljeva koji su došli odati počast novorođenomu. Iako taj detalj nije od osobita značaja, on lijepo ilustrira jedan od načina koje autor ili kompilator Mahāvastua koristi kako bi postigao što veću težinu teksta ili osjećaj zadivljenosti kod čitatelja. U tome se pogledu može reći da Nidānakathā, bez obzira na vrijeme nastanka, ne predstavlja po stilu kasniji stupanj mijena Buddhina životopisa (peti po Lamotteu (1958/1988: 648), nego manje promijenjeni, odnosno raniji stupanj nego Mahāvastu.

Svi se tekstovi slažu i da tek rođenoga Bodhisattu primaju prvo nebesnici pa tek potom ljudi. Nidānakathā navodi da su tek rođenoga Bodhisattu prihvatila četiri nebesnika, odnosno četiri Mahābrahmana, u čem Nakamura (2000/2002: 65) vidi utjecaj hinduizma na izvorno buddhističku predaju.

Predaja o sedam koraka u smjeru sjevera koje čini novorođeni Bodhisatta također je prisutna u svim navedenim tekstovima, osim u pripovijesti u Mv. i. 142-153. Nakamura (2000/ 2002: 67), koji Suttanipātu datira u otprilike 3. st. pr. n. e., zaključuje da je predaja o sedam koraka vjerojatno oblikovana nakon toga razdoblja budući da ju Suttanipāta ne sadrži.

Svi se navedeni tekstovi (osim pripovijesti u Mv. i. 142-153) slažu i u podatku da je novorođeni progovorio i proglasio se "najiskonskijim na svijetu". ${ }^{149}$

Slažu se i u tvrdnji da je Gotamina majka umrla sedam dana nakon poroda. Kada je riječ o Māyinoj preuranjenoj smrti, tekstovi donose različita objašnjenja. Dok se u navedenim suttama Suttapitake ne navodi razlog smrti, u Mahāvastuu se tvrdi da majke umiru budući da

\footnotetext{
${ }^{147}$ Za usporedbu začeća i rođenja Gotame Buddhe i Mahāvire v. Bollée (2005). Za mogući utjecaj grčke mitologije na pripovijest o Gotaminu rođenju v. Derret (1992).

${ }^{148}$ ĐātA. I. 54, Mv. ii. 25.

149 Silk (2003: 864) ističe paradoks sadržan u činjenici da je tek rođeni bodhisatta sveznajuć i svjestan svoga poslanja ali se u mladenačkoj dobi čudi starosti, bolesti i smrti.
} 
im ne doliči da se, nakon rođenja bodhisattve, ponovno prepuštaju putenim užitcima. ${ }^{150} \mathrm{U}$ Nidānakathi stoji da je utroba bodhisattine majke poput hrama i ne može ponovno primiti drugo biće. ${ }^{151}$ Tu se paralela može povući sa shvaćanjem kršćanskih teologa da Marija nije imala druge djece nakon Isusa.

Oblježja se tjelesnoga savršenstva ne spominju u Aććhariyabbhutadhammasutti kao ni u Nālakasutti Suttanipāte. Mahāpadānasutta donosi popis obilježja, dok se u Nidānakathi samo spominje da su se u trenutku začeća i rođenja očitovala trideset i dva oblježja. ${ }^{152}$ Mahāvastu također, u kontekstu rođenja, donosi popis obilježja. ${ }^{153}$ Zanimljivo je primjetiti da je u pālijskim suttama i Nidānakathi uloga tumača znakova dana brahmanima dok se u Mahāvastuu navodi kako su Buddhina tjelesna obilježja protumačili nebesnici maheśvare koji su stigli kako bi preduhitrili nevješte (akuśala) brahmane (dviđasaṃghā). ${ }^{154}$

Proročanstvo se o sudbini ili životnome pozivu Bodhisatte ne nalazi $u$ Aććhariyabbhutadhammasutti ali se nalazi u Mahāpadānasutti gdje, neposredno nakon rođenja, brahmani izriču proročanstvo. Opis se dvaju mogućih sudbina onih koji posjeduju tridesetidva zna savršenstva nalazi i u Selasutti Suttanipāte i Mađđđhimanikāye.

Različite verzije pripovijesti o posjetu mudraca Asite novorođenomu Bodhisatti analizirao je Thomas (1927/2000: 38-43) koji zaključuje da je verzija prisutna u Suttanipāti najstarija. Sa Suttanipātom veći stupanj sličnosti dijele dvije pripovijesti u Mahāvastuu nego verzija prisutna u Nidānakathi. U sva se tri izvora nećak Asite naziva Nālaka iako se u drugom prikazu te epizode u Mahāvastuu naziva i Nārada i poistovjećuje s (Mahā-) Katyāyanom. ${ }^{155}$

Unutar prve četiri nikāye Suttapițake, Mahāpadānasutta donosi najcjelovitiji životopis buddhe. Unatoč činjenici da su događaji pripisani buddhi Vipassinu, ta predaja sadrži brojne detalje koji se ne nalaze drugdje u kanonu, a koji će s vremenom biti uklopljeni u sustavne životopise Gotame Buddhe i naći svoj izraz u prikazima epizoda Gotamina života na brojnim reljefima i skulpturama buddhističke umjetnosti. Ostaje, naravno, otvoreno pitanje je li predaja o Vipassinu utjecala na oblikovanje Gotamina životopisa ili su razbacani fragmenti Gotamina životopisa sistematizirani u predaji o Vipassinu. Mahāpadānasutta je vjerojatno nastala tijekom

\footnotetext{
${ }^{150}$ Mv. i. 199, ii. 3.

${ }^{151}$ ĐātA. I. 52. U Lv. 98 se navodi kako majka bodhisattve umire zato što ne bi mogla podnijeti kasniji njegov odlazak u beskućništvo.

${ }^{152}$ DN ii. 16-19, ĐātA. I. 54.

${ }^{153}$ Mv. ii. 29-30.

${ }^{154}$ Mv. ii. 27. 1-4.

${ }^{155}$ U Lv. 111 naziva se Nāradatta.
} 
razdoblja Aśokine vladavine i, nešto kasnije, zadobila kanonski status. Windisch (1908: 104) smatra da je Mahāpadāna sutta i u njoj sadržan životopis buddhe Vipassina, jasan pokazatelj u kolikoj je mjeri, do vremena njena nastanka, nabujala legenda o životu Gotame.

Nidānakathā predstavlja razvijeni tip životopisa i dugo se je smatrala prototipom za sve buduće životopise Gotame Buddhe. Mahāvastu sadrži sve elemente predaje sadržane i u Nidānakathi ali je gotovo svaki detalj “predimenzioniran”. Tako, primjerice, sâm spomen Māye postaje prilikom za dugi opis njezine božanske ljepote, bogatstva ukrasa na tijelu, mekoće tkanina koje nosi, nenadmašna stasa i ljupka stava; trenutak začeća ne prate samo svjetlost koja obasjava sve svjetove i paklove i snažni potresi, već i okupljanje nebeskih bića koja sipaju vijence cvijeća, miomirise, sandalovinu i bez prekida sviraju i pjevaju u čast Bodhisattve i njegove majke. K tomu, Mahāvastu donosi i neke nove detalje. Spominje se tako štovanje Bodhisattve za vrijeme njegova boravka u utrobi koje se, tijekom svih deset mjeseci, odvija u svjetu deva, nāga, yakșa, māruta, piśáća i apsarasi. ${ }^{156}$ Važan je i prvi Bodhisattvin susret s demonima iz svijeta Māre koji ga, odmah po rođenju, pokušavaju zavesti govoreći mu da će postati Univerzalni vladar. ${ }^{157}$ Zanimljiv je i detalj kojega nema u pālijskim izvorima, a riječ je o Bodhisattvinu posjetu hramu božice Abhaye nedugo nakon rođenja. ${ }^{158}$ Naime, tek rođeni Bodhisattva odveden je u hram kako bi se poklonio Abhayi, međutim, pri susretu s božicom ispružio je prema njoj noge na što se Abhayā naklonila pred djetetom. ${ }^{159}$

Pojedini su autori istaknuli razliku između usputnih primjetaba o podrijetlu Gotame i opisa njegova rođenja u, primjerice, Mahāpadānasutti, proizvoljno određujući da su sažetiji i kraći opisi stariji i time izvorniji. ${ }^{160}$ Kada je riječ o tekstovima u kojima se pripovijest o začeću i rođenju budućega buddhe pojavljuje, treba istaknuti da ne posjedujemo niti jedan tekst koji je lišen čudesnih, zadivljujućih ili natprirodnih pojava. Kako tvrdi Campbell (1949/1973: 319):

\footnotetext{
${ }^{156}$ Mv. ii. 17.

157 Mv. ii. 22.

${ }^{158}$ Mv. i. 223, ii. 26.

${ }^{159}$ Lv. 120 također donosi, u zasebnom poglavlju, pripovijest o događaju hramu i pruža slikovit primjer razvoja legende. Naime, u tom se poglavlju pripovijeda kako su u trenutku bodhisattvina ulaska u hram sve kamene skulpture božanstava kao što su Śiva, Skanda, Nārāyaṇa, Kubera, Ćandra, Sūrya, Vaiśravaṇa, Śakra i Brahman oživjele (!) i ustale se sa svojih postolja kako bi se naklonile Bodhisattvi. Cijeli je događaj popraćen potresima, kišom cvijeća i pjesmom triju milijuna nebesničkih sinova.

${ }^{160}$ Npr. Thomas (1927/2000: 36) smatra da odlomak u Sonadaṇḍasutti (DN i. 113), u kojem se navodi samo kako je Gotama potekao iz dobre obitelji s obje strane, predstavlja najstariji sloj teksta. Vjerujem da nemamo razloga smatrati tu suttu starijom od primjerice Aććhariyabbhutadhammasutte isključivo na temelju njene sažetosti. Uostalom, brahman Sonadaṇ̣a ne dolazi u posjet Gotami kako bi se raspitao o njegovu podrijetlu pa tako u ovoj sutti nema mjesta za opširnu pripovijest o Gotaminu rođenju. V. i Rhys Davidsov predgovor ovoj sutti u Rhys Davids (1910/2007: 1-3).
} 
[T]he tendency has always been to endow the hero with extraordinary powers from the moment of birth or even the moment of conception. The whole hero-life is shown to have been a pageant of marvels with great central adventure as its culmination.

Također, valja istaknuti i sljedeće: iako nas na prvi pogled pripovijesti o začeću i rođenju kakve nalazimo u Nidānakathi i Mahāvastuu zasljepljuju blještavim opisima, preciznim detaljima i čudesima koja se gomilaju bez mjere, Nidānakathā i Mahāvastu u svojoj biti slijede skicu zacrtanu već u Aććhariyabbhutadhammasutti i Mahāpadānasutti. Iako su u tim kasnijim djelima dodani novi detalji, niti jedan kanonski detalj nije ispušten. Sistematizirana pravila vezana uz začeće i rođenje iznesena u Mahāpadānasutti, i vjerojatno opće poznata već u 3. st. pr. n. e., u kasnijim su djelima u cijelosti ispoštovana. Ostaje, naravno, dojam, da je obaviještenost $\mathrm{i}$ upućenost autora-kompilatora u najsitnije detalje, pa čak i u razgovore u svijetu nebesnika, s protokom vremena bila sve veća. 


\section{ODLAZAK U BESKUĆNIŠTVO}

Pālijski kanon donosi vrlo malo podataka o Gotaminu djetinjstvu i mladenaštvu. Tekstovi iz različitih izvora slažu se da je Gotamina majka Māyā umrla sedam dana nakon poroda i nadodaju da je on bio dodijeljen na skrb majčinoj sestri Mahāpađāpat̄̄ Gotamī (skt. Mahāprađāpatī Gautamī). ${ }^{161}$ U Mahāsaćakkasutti Mađđhimanikāye navodi se kako je Gotama već u ranoj dobi pokazivao sklonost prema zadubljenju. ${ }^{162}$ Tu se Gotama prisjeća kako je, dok je njegov otac bio zaokupljen nekim poslom, po prvi puta osjetio ushit i zadovoljstvo proisteklo iz osame i zadubljenja. U Nidānakathi se taj šturi odlomak preoblikovao u pripovijest o čudesnom događaju koji se zbio za vrijeme proslave prvoga dana oranja. ${ }^{163}$ Pripovijest se, dodatno urešena, nalazi i u Mahāvastuu. ${ }^{164}$ Kako će se pokazati u prijevodu pojedinih ulomaka, pripovijeda se da je živio lagodnim životom, pažljivo i brižno odgajan. Također, imao je suprugu Yasodharu (Yaśodharā) ${ }^{165}$ i sina Rāhulu ${ }^{166}$. Nerijetko se ističu i Gotamino dobro obrazovanje, poznavanje mnogih vještina kao i njegova omiljenost među podanicima. ${ }^{167}$ Ukratko, tekstovi nam pružaju sliku bezbrižna života ispunjena raznovrsnim užitcima. Ipak, Gotama je napustio taj lagodni život i otišao iz sigurnosti i udobnosti doma u beskućništvo. Unutar tekstova pālijskoga kanona razloge za odlazk u beskućništvo moguće je ugrubo podijeliti u dvije skupine. U prvoj se skupini navodi odbojnost prema životu domaćina, dok se u drugoj skupini nalaze promišljanja o neizbježnosti starenja, oboljevanja i umiranja. Ta će se pak promišljanja s vremenom preoblikovati u popularnu predaju o "četiri izlaska" koja se unutar Suttapițake nalazi samo u Mahāpadānasutti gdje su opisani događaji pripisani životopisu buddhe Vipassina.

\footnotetext{
${ }^{161}$ Ime Gotamine pomajke nalazi se u: MN iii. 254, Buddhaćarita II. 19, Lv. 100, Mv. ii. 165, AN i. 25, AN iv. 274, AN i. 25, Vin. ii. 253 (Ćullavagga X. 1, 1).

${ }^{162} \mathrm{MN}$ i. 246.

${ }^{163}$ ĐātA. I. 57-58.

${ }^{164}$ Mv. ii. 45-48. Pripovijest je sažeto iznesena i u Mv. ii. 130. V. i Lv. 263.

${ }^{165}$ Yaśodharom se naziva i u Buddhaćariti II. 46. Bhv. XXVI. 15 navodi kako su imena Gotamine supruge i sina bila Bhaddakaććā i Rāhula. Pod imenom Bhaddakaććā spomenuta je i u AN i. 25 kao jedna od trinaest redovnica. U Lv. 157 njeno je ime Gopā. Često se naziva i Rāhulamātā, odnosno majka Rāhule, npr. u: ĐātA. I. 54, 60.

${ }^{166}$ U Mv. i. 153 i Mv. i. 170 implicira se da je Rāhula začet bezgrješno budući da ni jedan tathāgata ne osjeća tjelesnu požudu ili strast.

${ }^{167}$ V. npr. Mv. i. 153, ii. 73-77, 423, Lv. 123 i d., 136 i d. Vrline, znanja i vještine bodhisattva pobrojane su i u Mv. i. $133-136$.
} 
Gotama je napustio dom u dobi od dvadestidevet godina ${ }^{168}$ i ostatak života proveo putujući, propovijedajući i vodeći zajednicu redovnika koji su prihvatili njegovo učenje.

\subsection{Odlazak u beskućništvo u pālijskome kanonu}

\subsubsection{Odbojnost spram života u domaćinstvu}

Pālijski kanon sadrži nekoliko ulomaka u kojima se opisuje Gotamina nesklonost domaćinskom životu, a ti su, u pravilu, kratki i lišeni detalja. U pojedinim je dijelovima teksta napuštanje doma uzrokovano osjećajem sputanosti, zagušljivosti i prenapučenosti. Kao primjer može poslužiti ulomak iz Suttanipāte.

Sn. $405-408$

405. Pabbajjam kittayissāmi, yathā pabbaji cakkhumā, yathā vīmaṃsamāno so pabbajjạ̣ samarocayi, || Sn_III,1.1 ||

406. 'Sambādho 'yam gharāvāso rajassāyatanam'; iti 'abbhokāso ca pabbajjā'; iti disvāna pabbaji, || Sn_III,1.2 ||

407. pabbajitvāna kāyena pāpakammam \{vivajjayi\} vacīduccaritam hitvā àjīvam parisodhayi. || Sn_III,1.3 || 408. Agamā Rājagaham Buddho Magadhānam Giribbajaṃ, piṇ̣̂āya abhihāresi ākiṇnavaralakkhaṇo. || Sn_III,1.4 ||

Prijevod

405. Opjevat ću put u beskućništvo Vidom obdarenoga, kako je, promišljajući, našao mir u odlasku. 406. "Guši život u kući, mjesto je to puno prašine. Beskućništvo je svjež zrak”- uvidjevši, otišao je. 407. Otišavši, odrekao se griješenja tijelom, Napustio je zlogovor pa prečistio življenje. 408. Dođe Buddha u Giribbađu, Rāđagahu Magadhe. Obilježen krasnim znakovima, tražio je milodare.

I u Soṇadaṇḍasutti se navodi da je Gotama, odrekavši se udobnosti doma, otišao u beskućništvo.

DN i. 115

\footnotetext{
${ }^{168}$ DN ii. 151: Ekūnatiṃso vayasā Subhadda, yam pabbajim kiṃ-kusalānuesī [...]. Usp. Mv. ii. 299. 6-7: ekūnatrimiśo vayasānuprāpto paripācayitvā jagadbodhisatvo / tyajitva rājyam ratanavarān ca sapta kāṣāyavastro abhu bodhisatvo //
} 
Samaṇo Gotamo mahantam ñāti-saṃghạn ohāya pabbajito. Samaṇo khalu bho Gotamo pahūtam hirañ̃̃a-suvaṇnam ohāya pabbajito bhümi-gatañ ca vehāsaț̣hañ ca. Samaṇo khalu bho Gotamo daharo va samāno susukāla-keso bhadrena yobbanena samannāgato paṭhamena vayasā agārasmā anagāriyam pabbajito.

Samaṇo khalu bho Gotamo akāmakānam mātā-pitunnam assu-mukhānaṃ rudantānam kesa-massum ohāretvā kāsāyāni vatthāni acchādetvā agārasmā anagāriyam pabbajito.

Prijevod

Trapljenik je Gotama napustio mnoštvo svoje rodbine i otišao u beskućništvo.

Zaista je trapljenik Gotama ostavio obilno bogatstvo u zlatu, i zakopano i na otvorenu.

Zaista je trapljenik Gotama kao mladić vrlo tamne kose, obdaren sretnim mladenaštvom, u cvijetu mladosti, otišao od kuće u beskućništvo.

Zaista je trapljenik Gotama, usprkos željama oca i majke koji su naricali uplakanih lica, obrijao kosu i bradu i, navukavši žuti ogrtač, otišao od kuće u beskućništvo.

Sličan se opis susreće i i u Mahāsaććakasutti.

MN i. $240^{169}$

Idha me, Aggivessana pubbe va sambodhà anabhisambuddhassa bodhisattass' eva sato etadahosi: 'sambādho gharāvāso rajāpatho, abbhokāso pabbajjā, na-y-idam sukaram agāram ajjhāvasatā ekantaparipuṇnam ekantaparisuddham sañkhalikhitam brahmacariyam caritum, yan-nūnāham kesamassum ohāretvā kāsāyāni vatthāni acchādetvā agārasmā anagāriyam pabbajeyyan'ti. So kho aham Aggivessana aparena samayena daharo va samāno, susukālakeso bhadrena yobbanena samannāgato pațhamena vayasā, akāmakānam mātāpitūnam assumukhānam rudantānam, kesamassuṃ ohāretvā kāsāyāni vatthāni acchādetvā agārasmā anagāriyam pabbajịn.

Prijevod

Evo, o Aggivessana, prije moga probuđenja, ovako sam, dok sam bio neprobuđeni bodhisatta, mislio: "Skučen je život u domaćinstvu, prašnjav put. Odlazak u beskućništvo pak svježi zrak. Nije lako domaćinu koji boravi [u kući] voditi usredotočeno ispunjen, usredotočeno čist poput ulaštena sedefa zavjetovani život. Bih li ja sada, obrijavši kosu i

\footnotetext{
${ }^{169}$ Usp. niže MN i. 163.
} 
bradu i, navukavši žuti ogrtač, otišao od kuće u beskućništvo?” I tako sam ja, o Aggivessana, potom, mlad, vrlo tamne kose, obdaren sretnim mladenaštvom, u cvijetu mladosti, usprkos željama oca i majke koji su naricali uplakanih lica, obrijao kosu i bradu $i$, navukavši žuti ogrtač, otišao od kuće u beskućništvo.

\subsubsection{Promišljanja o neizbježnosti starenja, oboljevanja i umiranja}

U nekoliko se sutta unutar pālijskoga kanona nalazi opis Gotamina života prije negoli je, duboko potresen spoznajom neizbježnosti starenja, oboljevanja i umiranja, odustao od lagodna života u zamjenu za izlaz iz kruga patnje. Kao primjer naveden je ulomak iz Añguttaranikāye. ${ }^{170}$

AN i. 145

Sukhumālo aham bhikkhave paramasukhumālo accantasukhumālo. Mama sudam bhikkhave pitu nivesane pokkharaṇīyo kāritā honti, ekattha sudam uppalam pupphati ekattha padumam ekattha puṇdarīkam yāvad eva mama atthāya. Na kho pan'; assāham bhikkhave akāsikam candanam dhāremi, kāsikam su me tạ̣ bhikkhave vețanam hoti kāsikā kañcukā kāsikaṃ nivāsanam kāsiko uttarāsañgo.

Rattindivaṃ kho pana su me tam bhikkhave setacchattam dhāriyati, mā nam phussi sìtam vā uṇhạ̣ vā rajo vā tịnam vā ussāvo vā ti. [...] Yathā kho pana bhikkhave aññesam nivesanesu dāsakammakaraporisassa kaṇajakaṃ bhojanam diyyati bilañgadutiyam evam evassu me bhikkhave pitu nivesane dāsakammakaraporisassa sālimaṃsodano diyyati.

Tassa mayham bhikkhave evarūpāya iddhiyā samannāgatassa evarūpena ca accantasukhumālena etad ahosi:-assutavā kho puthujjano attanā jarādhammo samāno jaram anatīto param jịnnam disvā atțiyati harāyati jigucchati attānam yeva atisitvā. Aham pi kho 'mhi jarādhammo jaram anatīto, ahañ c'; eva kho pana jarādhammo samāno jaraṃ anatīto param jiṇnam disvā ațiyyeyyam harāyeyyaṃ jiguccheyyam. Na me tam assa pațirūpan ti. Tassa mayham bhikkhave iti pațisañcikkhato yo yobbane yobbanamado so sabbaso pahiyyi. [...]

\footnotetext{
${ }^{170}$ Spomen se Gotamina raskošnoga života i triju palača sagrađenih njemu za uživanje nalazi i u MN i. 504. V. i niže DN ii. 21.
} 
Tassa mayhạ̣, bhikkhave, evarūpāya iddhiyā samannāgatassa evarūpena ca sukhumālena etadahosi: 'assutavā kho puthujjano attanā jarādhammo samāno jaram anatīto param jịnnạ̣ disvā atțīyati harāyati jigucchati attānamyeva atisitvā ahampi khomhi jarādhammo jaram anatīto. Ahañceva kho pana jarādhammo samāno jaram anatīto param jịnnam dịsvā aț̣̂̄yeyyam harāyeyyam jiguccheyyam na metam assa patirūpan'ti. Tassa mayhaṃ, bhikkhave, iti pațisañcikkhato yo yobbane yobbanamado so sabbaso pahīyi.

\section{Prijevod}

Bio sam, o redovnici, razmažen, jako razmažen, beskrajno razmažen. U kući moga oca, o redovnici, načinjena su jezerca s lotosima: u jednome cvatu plavi, u jednome crveni, $u$ jednome bijeli lotosi, samo radi mene. Nadalje, o redovnici, nisam uzimao sandalovinu ako nije došla iz grada Kāsī. Iz Kāsì je bila [tkanina] za moje pokrivalo za glavu, iz Kāsī je bila košulja, iz Kāsī je bilo rublje, iz Kāsī ogrtač.

Noću i danju nada mnom su držali bijeli suncobran kako me ne bi dotakla ni hladnoća ni žega ni prašina ni korov ni vlaga [...]

Dok su u drugim kućama robovi, radnici i sluge dobivali ostatke riže i kiselu kašu, u kući moga oca dobivali su cjelovita zrna riže, meso i rižu kuhane na mlijeku.

Onda sam, o redovnici, obdaren takvim blagodatima ${ }^{171}$ i takvim pažljivim odgojem, ovako pomislio: "Zaista, običan i neuk čovjek, iako i sâm osuđen na starost i nije se oslobodio starenja, vidjevši drugoga ostarjeloga osjeća tjeskobu, sram i gađenje, previđajući samoga sebe. Međutim, i ja sam osuđen na starost $i$ nisam oslobođen starenja. Zaista, $i$ ja sam osuđen na starost i nisam se oslobodio starenja, pa kada bih takav, osuđen na starost $i$ ne oslobodivši se starenja vidjevši drugoga ostarjeloga osjetio tjeskobu, sram $i$ gađenje, to za mene ne bi bilo dolično”. I kada sam o tome promislio, sva je u mladosti opijenost mladošću nestala. [...] (Isti tijek misli odnosi se, dalje u tekstu, i na opijenost zdravljem i životom.)

171 evarūpāya iddhiyā. iddhi (skt. r̆ddhi) u ovome se kontekstu odnosi na četverostruki iddhi mlada plemića ili mladića iz plemenite obitelji. Sastoji se od: 1. mogućnosti korištenja lijepo uređenoga vrta ili perivoja, 2. dobre i kvalitetne ishrane, 3. posjedovanja više kuća ili palača za različita godišnja doba i 4. posjedovanje meke i ugodne odjeće. 
Završetak sutte čine četiri strofe u kojima Gotama sažima svoje zaključke vezane uz promišljanja o mladosti, zdravlju i životu, a posljednja strofa donosi i konačnu odluku o odlasku od kuće:

\author{
Nāham bhabbo etarahi, \\ Kāmāni pațisevitum \\ Anivatti bhavissāmi, \\ Brahmacariyaparāyaṇo"ti. \\ Ne mogu više uživat’ \\ U ugodi osjetila. \\ Nema mi više povratka! \\ Krepostan život bit će mi cilj.
}

Gotama je, prema dostupnim nam izvorima, već u mladosti stekao čvrsto uvjerenje da su ljudske želje i strasti izvor patnje i da ne donose spokoj ili više dobro (pāli santatara) kao i da ne vode do izbavljenja. ${ }^{172}$ Ariyapariyesanāsutta ${ }^{173}$ donosi najvažniji prikaz Gotamine potrage za izbavljenjem prije negoli su promišljanja o neizbježnosti starenja, oboljevanja i smrti zasjenjena slikovitim opisom Gotaminih sudbonosnih susreta s bolesnikom, starcem i mrtvacem. U toj sutti o plemenitom (ariya) stremljenju (pariyesanā) Gotama redovnicima objašnjava razliku između plemenita i ne-plemenita (anariya) stremljenja. Povod je to za autobiografsko izlaganje vlastitoga puta ili vlastite potrage u kojem Gotama opisuje događaje od odluke o odlasku u beskućništvo, naukovanja pod vodstvom dvojice isposnika, Āḷāre Kālāme i Uddake Rāmaputte, pa sve do probuđenja i pokretanja kotača nauka. Niže je iznesen i preveden ulomak koji se odnosi na promišljanja prije odlaska u beskućništvo.

MN i. 163

Aham-pi sudam bhikkhave pubbe va sambodhā anabhisambuddho bodhisatto va samāno attanā jātidhammo samāno jātidhammañ-ñeva pariyesāmi, attanā jarādhammo samāno jarādhammañ-ñeva pariyesāmi, attanā byādhidhammo . .., attanā marañadhammo . . .,

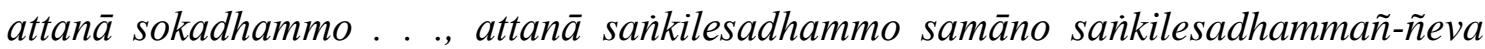
pariyesāmi.

\footnotetext{
${ }^{172}$ V. npr. MN i. 91 i d., MN i. 505-506.

${ }^{173}$ MN i. 160-175. Usp. i MN i. 237-251, DN i. 132-133. O samoj sutti v. Pande (1957: 123), Rhys Davids (1896/1907: 102).
} 
Tassa mayham bhikkhave etad-ahosi: Kin-nu kho ahạ̣ attanā jātidhammo samāno jātidhammañ-ñeva pariyesāmi, attanā jarādhammo samāno --pe-- attanā sañkilesadhammo samāno san்kilesadhammañ-ñeva pariyesāmi; yan-nūnāham attanā jātidhammo samāno jātidhamme ādīnavam viditvā ajātam anuttaram yogakkhemam nibbānam pariyeseyyam, attanā jarādhammo . . ajaram . . . pariyeseyyam, attanā byādhidhammo . . abyādhim . . pariyeseyyam, attanā maraṇadhammo . . amatam . . . pariyeseyyam, attanā sokadhammo . . . asokam . . . pariyeseyyam, attanā san்kilesadhammo samāno san்kilesadhamme ādīnavam viditvā asan்kiliț̣̂m anuttaram yogakkhemam nibbānam pariyeseyyan-ti.

So kho aham bhikkhave aparena samayena daharo va samāno susu kālakeso bhadrena yobbanena samannāgato paṭamena vayasā akāmakānam mātāpitunnam assumukhānam rudantānam kesamassum ohāretvā kāsāyāni vatthāni acchādetvā agārasmā anagāriyam pabbajim.

\section{Prijevod}

Čak sam i ja, o redovnici, prije probuđenja, [dok sam bio] neprobuđeni bodhisatta, i sâm podložan zakonu rođenja, težio onomu što je, također, podložno zakonu rođenja.; i sâm podložan zakonu starenja, težio sam onomu što je, također, podložno zakonu starenja; $i$ sâm podložan zakonu bolesti, težio sam onomu što je, također, podložno zakonu bolesti; i sâm podložan zakonu umiranja, težio sam onomu što je, također, podložno zakonu umiranja; i sâm podložan zakonu patnje, težio sam onomu što je, također, podložno zakonu patnje; i sâm podložan zakonu ukliještenja, težio sam onom što je podložno zakonu ukliještenja. Tada sam ovako razmotrio: „Zašto ja, i sâm podložan zakonu rođenja, težim onomu što je, također, podložno zakonu rođenja; i sâm podložan zakonu starenja, težim onomu što je, također, podložno zakonu starenja; i sâm podložan zakonu bolesti, težim onomu što je, također, podložno zakonu bolesti; i sâm podložan zakonu umiranja, težim onomu što je, također, podložno zakonu umiranja; i sâm podložan zakonu patnje, težim onomu što je, također, podložno zakonu patnje; i sâm podložan zakonu ukliještenja, težim onomu što je je podložno zakonu ukliještenja? A da ja, podložan zakonu rađanja, spoznavši jad u onome što je podložno zakonu rađanja, potražim rađanju nepodložnu, od vezanosti slobodnu i najvišu nibbānu?A da ja, podložan zakonu starenja, spoznavši jad u onome što je podložno zakonu starenja, potražim starenju nepodložnu, od vezanosti slobodnu i najvišu nibbānu? A da ja, podložan zakonu bolesti, spoznavši jad 
u onome što je podložno zakonu bolesti, potražim bolesti nepodložnu, od vezanosti slobodnu i najvišu nibbānu? A da ja, podložan zakonu umiranja, spoznavši jad u onome što je podložno zakonu umiranja, potražim umiranju nepodložnu, od vezanosti slobodnu i najvišu nibbānu? A da ja, podložan zakonu patnje, spoznavši jad u onome što je podložno zakonu patnje, potražim patnji nepodložnu, od vezanosti slobodnu i najvišu nibbānu? Što kad bih ja, podložan zakonu ukliještenja, spoznavši jad u onome što je podložno zakonu onečišćenja, potražio ukliještenju nepodložnu, od vezanosti slobodnu $i$ najvišu nibbānu?" I tako sam, o redovnici, potom, mlad i vrlo tamne kose, obdaren sretnim mladenaštvom, u cvijetu mladosti, usprkos željama oca i majke koji su naricali uplakanih lica, obrijao kosu i bradu $i$, navukavši žuti ogrtač, otišao od kuće u beskućništvo.

To repetitivno, mehaničko izlaganje s vremenom je izraslo u popularnu i živopisnu predaju o četiri izlaska koja se u pālijskome kanonu nalazi u Mahāpadānasutti, no pripisana buddhi Vipassinu. Pripovijest ima svoju paralelu u Nidānakathi, Mahāvastuu, Lalitavistari i Buddhaćariti. ${ }^{174}$

\section{DN ii. $21-30$}

Atha kho bhikkhave Bandhumā rājā Vipassissa kumārassa tayo pāsāde kārāpesi, ekam vassikam ekam hemantikam ekam gimhikam, pañca kāma-guṇāni upațthāpesi. Tatra sudam bhikkhave Vipassī kumāro vassike pāsāde vassike cattāro māse nippurisehi turiyehi parivārayamāno na hețthā pāsādam orohati. Atha kho bhikkhave Vipassī kumāro bahunnam vassānam bahunnam vassa-satānam bahunnam vassasahassānam accayena sārathịn āmantesi:

Yojehi samma sārathi bhaddāni bhaddāni? yānāni, uyyāna-bhumim gacchāma \{bhūmim\}\} dassanāyāti. "Evam devāti" kho bhikkhave sārathi Vipassissa kumārassa pațissutvā bhaddāni bhaddāni yānāni yojāpetvā Vipassissa kumārassa pațivedesi: "Yuttāni kho te deva bhaddāni bhaddāni yānāni, yassa \{dāni\} kālạ̣ mañ̃asīti."

Atha kho bhikkhave Vipassī kumāro bhaddam yānam abhiruhitvā bhaddehi bhaddehi yānehi uyyānabhumị̣ niyyāsi. Addasā kho bhikkhave Vipassī kumāro uyyānabhūmim

\footnotetext{
${ }^{174}$ Lv. 186-193, Buddhaćarita III. 25-65, susret s isposnikom tu je izostavljen. Za Nidānakathu i Mahāvastu v. niže.
} 
niyyanto purisam jịnnam gopānasi-vañkam bhoggam dạ̣da-parāyanam pavedhamānam gacchantam āturạ̣ gata-yobbanaṃ. Disvā sārathim āmantesi:

"Ayam pana samma sārathi puriso kim kato, kesā pi 'ssa na yathā aññesam, kāyo pi 'ssa na yathā aññesan ti?"

"Eso kho deva jiṇno nāmāti.

"Kim pan'; eso samma sārathi jịnno nāmāti?"

"Eso kho deva jịnno nāma: Na dāni tena ciram jūvitabbạ̣ bhavissatīti."

"Kim pana samma sārathi aham pi jarā-dhammo jaram anatītā ti.?"

"Tvañ ca deva mayañ c'; amhā sabbe jarā-dhammā jaram anatītā ti."

"Tena hi samma sārathi alan dān' ajja uyyāna-bhūmiyā, ito va antepuram paccaniyyāhìti."

'Evam devāti" kho bhikkhave sārāthi Vipassissa kumārassa pațissutvā tato va antepuram paccaniyyāsi.

Tatra sudạ bhikkhave Vipassī kumāro antepura-gato dukkhī dummano pajjhāyati: "\{Dhi-r-atthu\} kira bho jāti nāma, yatra hi nāma jātassa jarā pañ̃āayissatīti." [...]

Atha kho bhikkhave Vipassī kumāro bahunnam vassānam ... pe

Addasā kho bhikkhave Vipassī kumāro uyyānabhūmim niyyanto purisam ābādhikam dukkhitạ̣ bālha-gilānam sake mutta-karīse palipannam semānam aññehi vuțthāpiyamānam añ̃ehi saṃvesiyamānaṃ. Disvā sārathị̣ āmantesi: "Ayam pana samma sārathi puriso kim kato [...]

Tatra sudạ̣ bhikkhave Vipassī kumāro antepura-gato dukkhī dummano pajjhāyati: "Dhi-r-atthu kira bho jāti nāma, yatra hi nāma jātassa jarā paññāyissati vyādhi pañ̃̄āyissatīti." [...]

Atha kho bhikkhave Vipassī kumāro bahūnam vassānam ... pe ...

"Addasā kho deva kumāro uyyāna-bhūmim niyyanto mahājana-kāyam sannipatitam nānārattānañ ca dussānam milātam kayiramānam. Disvā mam etad avoca: 'Kin nu kho 
so samma sārathi mahājana-kāyo sannipatito nānārattānañ ca dussānam milātam kayiratīti?'; 'Eso kho deva kālakato nāmāti.'; 'Tena hi samma sārathi yena so kālakato tena ratham pesehīti.'; 'Evam devāti'; kho aham deva Vipassissa kumārassa paṭissutvā yena so kālakato tena ratham pesesim. Addasā kho deva kumāro petam kālakatam. Disvā mam etad avoca: 'Kim panāyam samma sārathi kālakato nāmāti?' [...]

So kho deva kumāro antepuragato dukkhī dummano pajjhāyati: 'Dhi-r-atthu kira bho jāti nāma, yatra hi nāma jātassa jarā pañ̃āyissati, vyādhi paññāyissati, maraṇạ̣ pañ̃āayissatīti.' [...]

Atha kho, bhikkhave, vipassī kumāro bahūnaṃ vassānam ...pe...

'Addasā kho bhikkhave Vipassī kumāro uyyānabhūmim niyyanto purisaṃ bhaṇdụ̣ pabbajitạ̣ kāsāyavasanaṃ. Disvā sārathim āmantesi:

"Ayam pana samma sārathi puriso kim kato, sīsam pi 'ssa na yathā aññesaṃ, vatthāni pi 'ssa na yathā añ̃̃esan ti?"

"Eso kho deva pabbajito nāmāti."

"Kim pan'; eso samma sārathi pabbajito nāmāti?"

"Eso kho deva pabbajito nāma: sādhu dhammacariyā sādhu sama-cariyā sādhu kusalakiriyā sādhu puñ̃a-kiriyā sādhu avihiṃsā sādhu bhütānukampā ti." [...]

'Atha kho bhikkhave Vipassī kumāro sārathim āmantesi:

"Tena hi samma sārathi ratham ādāya ito va antepuram paccaniyyāhi. Aham pana idh'; eva kesa-massum ohāretvā kāsāyāni vatthāni acchādetvā agārasmā anagāriyam pabbajissāmīti."

"Evam devāti" kho sārathi Vipassissa kumārassa pațissutvā, ratham ādāya tato va antepuram paccaniyyāsi. Vipassī pana kumāro tatth'; eva kesa-massum ohāretvā kāsāyāni vatthāni acchādetvā agārasmā anagāriyam pabbaji.

Prijevod

Potom je, o redovnici, kralj Bandhumant dao podići tri palače za kraljevića Vipassina; jednu za razdoblje kiša, jednu za zimu i jednu za razdoblje vrućina. Pobrinuo se i za 
zadovoljstva pet osjetila. Četiri mjeseca kišnoga razdoblja proveo je kraljević Vipassin u odgovarajućoj palači, okružen glazbalima na kojima su svirale djevojke bez muškaraca, a palaču nije napuštao.

Onda je, o redovnici, kraljević Vipassin, nakon što je proteklo mnogo godina, mnogo stotina i tisuća godina, rekao kočijašu: "Upregni, kočijašu, najodličnija kola! Idemo u perivoj da ga pogledam."

"U redu, kraljeviću!" - rekao je, o redovnici, kočijaš čuvši [naredbu] kraljevića Vipassina. Upregnuvši najodličnija kola, obavijestio je kraljevića Vipassina: “Upregnuta su, o kraljeviću, najodličnija kola za ono za što misliš da je sada čas. ” Popeo se je, o redovnici, kraljević Vipassin na odlična kola i uputio prema perivoju, [praćen mnogim drugim] odličnim kolima.

Obilazeći po perivoju, ugledao je, o redovnici, kraljević Vipassin čovjeka ostarjeloga, povinutoga kao prelomljeni krov i zgrbljenoga, koji je hodao drhteći, oslanjajući se na štap, jadnoga i nestale mladosti. Vidjevši ga, upitao je kočijaša: "Reci, kočijašu! Kakav je to čovjek? Njegova kosa nije kao kod drugih, njegovo tijelo nije kao kod drugih!"

"Takav se čovjek, o kraljeviću, naziva starac."

"Zašto se, o kočijašu, takav čovjek naziva starac?"

"Zato što mu, o kraljeviću, sada nije više preostalo mnogo života."

“Zar sam i ja, kočijašu, osuđen na starost, zar čak ni ja nisam oslobođen starenja?”

"I ti i ja, svi smo mi, kraljeviću, osuđeni na starost i nismo oslobođeni starenja."

"Kočijašu, dosta mi je danas perivoja. Kreni odavde natrag u palaču!"

"U redu, kraljeviću!" - poslušao je, o redovnici, kočijaš naredbu kraljevića i krenuo odatle natrag do unutrašnjih odaja.

Kada je došao u unutrašnje odaje, kraljevića je, tužanoga i neraspoloženoga, nadvladao očaj: “Bijedno je zaista, to rođenje kad će se svemu rođenom ukazati starost!” [...] 
Onda je, o redovnici, kraljević Vipassin, nakon što je proteklo mnogo godina, mnogo stotina i tisuća godina, rekao kočijašu: "Upregni, kočijašu, najodličnija kola! Idemo u perivoj da ga pogledam."

Obilazeći po perivoju, ugledao je kraljević Vipassin čovjeka bolesna i ispaćena, onemoćala od bolesti, kako leži okružen vlastitom mokraćom i izmetom. Jedni su ga pokušavali podići, drugi poleći na ležaj.

Vidjevši ga, upita kočijaša: "Kočijašu, kakav je to čovjek?” [....]

Kada je došao u palaču, kraljevića je, tužnoga i neraspoloženoga, nadvladao očaj: “Bijedno je zaista, to rođenje kad će se svemu rođenom ukazati starost i bolest!” [...]

Onda je, o redovnici, kraljević Vipassin, nakon što je proteklo mnogo godina, mnogo stotina i tisuća godina, rekao kočijašu: "Upregni, kočijašu, najodličnija kola! Idemo u perivoj da ga pogledam."

Obilazeći po perivoju, ugledao je kraljević Vipassin okupljeno mnoštvo ljudi [odjeveno u] raznobojnu odjeću, a utučeno. Vidjevši [ih], upita kočijaša: "Zašto je, kočijašu, to mnoštvo ljudi [odjeveno u] raznobojnu odjeću utučeno?"

“Taj se, kraljeviću, naziva mrtvac."175

"Onda, kočijašu, povezi kočiju onamo gdje je mrtvac."

“U redu, kraljeviću!” - poslušao je kočijaš naredbu kraljevića Vipassina i povezao kočiju onamo gdje je mrtvac.

Ugledao je kraljević Vipassin mrtvaca, pa upita kočijaša: "Zašto se taj, kočijašu, naziva mrtvac?" $[\ldots]$

Kada je došao u palaču, kraljevića je, tužnoga i neraspoloženoga, nadvladao očaj: "Bijedno je zaista, to rođenje kad će se svemu rođenom ukazati bolest, starost i smrt!" $[\ldots]$

\footnotetext{
${ }^{175}$ Dosl. "onaj kojemu je vrijeme isteklo".
} 
Onda je, o redovnici, kraljević Vipassin, nakon što je proteklo mnogo godina, mnogo stotina i tisuća godina, rekao kočijašu: "Upregni, kočijašu, najodličnija kola! Idemo u perivoj da ga pogledam."

Obilazeći po perivoju, ugledao je kraljević Vipassin čovjeka obrijane glave, koji je otišao u beskućništvo, u žutoj halji. Vidjevši [ga], upita kočijaša: "Kakav je to, kočijašu, čovjek? Njegova glava nije kao kod drugih, njegova odjeća nije kao kod drugih."

“Taj se, kraljeviću, naziva nesvjetovnjak.”

"Zašto se, reci kočijašu, naziva nesvjetovnjak?”

"Nesvjetovnjakom se naziva takav čovjek jer pravo slijedi dhammu, pravo živi u miru, pravo čini dobra djela, pravo čini djela koja donose zasluge, jer je nenasilan i jer je uistinu suosjećajan prema bićima.” [...]

Potom je, o redovnici, kraljević Vipassin naredio kočijašu: “Uzmi, kočijašu, kočiju i kreni natrag u palaču, a ja ću ovdje obrijati kosu i bradu, ogrnuti se žutim haljama i otići od kuće u beskućništvo."

"U redu, kraljeviću!” - rekao je, o redovnici, kočijaš poslušavši naredbu kraljevića Vipassina. Uzeo je kočiju i krenuo natrag u palaču. Kraljević je Vipassin, na tom mjestu, obrijao kosu i bradu i, ogrnuvši se žutim haljama, otišao od kuće u beskućništvo.

Konačni rezultat tih sudbonosnih susreta sažet je u sljedećem odlomku te sutte.

DN ii. 30

Atha kho, bhikkhave, vipassissa bodhisattassa vāsūpagatassa rahogatassa pațisallinassa evam cetaso parivitakko udapādi: 'kiccham vatāyam loko āpanno, jāyati ca jūyati ca mīyati ca cavati ca upapajjati ca, atha ca panimassa dukkhassa nissaraṇạ̣ nappajānāti jarāmaraṇassa, kudāssu nāma imassa dukkhassa nissaraṇạ̣ pañ̃̄āyissati jarāmaraṇassā'ti?

\section{Prijevod}

Tada je, o redovnici, kada se je smjestio, povukao u pustoš i ostao sam, ovako u duhu razmišljao bodhisatta Vipassin: “Jao, svijet je zadesila nevolja! Rađa se, stari i umire pa 
prelazi i ponovno postaje. Ne zna [svijet] kako naći izlaz iz te patnje - starosti i umiranja. Kada će prepoznati izlaz iz te patnje što se naziva starost i umiranje?”

\subsection{Odlazak u beskućništvo u Nidānakathi}

Nidānakathā također sadrži pripovijest o četiri izlaska iz palače i primjenjuje ju na Gotamu. ${ }^{176}$ Ističe se, međutim, da su starac, bolesnik, mrtvac i isposnik prerušeni nebesnici koji su odlučili da je došlo vrijeme da se Gotami ukažu znakovi koji će ga potaknuti da ostvari svoju sudbinu. Za razliku od pripovijesti u Mahāpadānasutti, Gotama ne odlazi od kuće neposredno nakon ta četiri sudbonosna susreta. Nidānakathā, dodatno razrađujući pripovijest, donosi i neke nove detalje u kojima se jasno očituje želja autora da trenutak odluke uokviri što upečatljivijim i dramatičnijim događajima. Ukratko, nakon sudbonosnih susreta nebesnik Sakka šalje izaslanika da, prerušen u kraljevskoga brijača, omota oko Gotamine glave raskošnu tkaninu kako bi posljednji dan u domaćinstvu proveo obavijen raskoši i bogatstvom. Božanskim se moćima na Gotaminoj glavi pojavljuju desetci tisuća nabora nalik na raskošne cvjetove. I sâm se autor pita kako je moguće da na malenoj glavi stane toliko nabora i zaključuje da to nadilazi svaku maštu. Gotama je upravo na putu za palaču kada prima vijest da mu se je rodio sin: Rođen je Rāhula, rođena je spona - izgovara Gotama primivši vijest. ${ }^{177}$ Ulazak u grad još je jedna prilika da se istakne naizgled sretan život kojega se Gotama sprema odreći. Naime, s vrha ga je neke palače ugledala žena imena Kisā Gotamī i izgovorila sljedeće stihove:

$$
\begin{gathered}
\text { Nibbutā } \overline{1}^{178} \text { nūna sā mātā } \\
\text { Nibbuto nūna so pitā } \\
\text { Nibbutā nūna sā nāri } \\
\text { yassāyam ìdiso patīti. }{ }^{179}
\end{gathered}
$$

Prijevod

$$
\begin{aligned}
& \text { Blažena zaista majka, } \\
& \text { Blažen je zaista otac, } \\
& \text { Blažena zaista žena }
\end{aligned}
$$

Koja ima takva muža.

\footnotetext{
${ }^{176}$ ĐātA. I. 59-65.

${ }^{177}$ ĐātA. I. 60: Rāhulo jāto, bandhanam jātanti. U Mv. ii. 159 navodi se kako je Rāhula, ne rođen, već začet u noći Gautamina odlaska.

${ }^{178}$ Skt. nirvṛta. V. nibbuta u: PED str. 366.

${ }^{179}$ ĐātA. I. 60.
} 
Te riječi podsjećaju Gotamu da je istinsko blaženstvo stanje koje se pojavljuje nakon što se ugase sve strasti. Potom sa svoga vrata trga vrijednu bisernu ogrlicu i šalje ju Kisi Gotamī kao nagradu za vrijednu poduku. U palači ga čekaju plesačice i sviračice, ali ih Gotama, u kojem sazrijeva odluka o odlasku, ne primjećuje i tone u san. Probudivši se, ugledao je zaspale žene otkrivenih tijela koje su "slinile, škripale zubima, hrkale i mrmljale u snu" pa zgađen tim prizorom, poziva kočijaša da mu osedla konja. ${ }^{180}$ Ta se epizoda susreće i u pālijskoj Vinayi, no tu je pripisana Yasi, mladiću iz bogate obitelji koji odlazi u beskućništvo nakon gađenja koje ga obuzima pri pogledu na zaspale žene. Thomas (1927/2000: 90, bilj. 1) kaže:

Much of the circumstances and language of the description of his flight are identical with the story of the Great Renunciation, which Rhys Davids held was modeled on this story of Yasa. This certainly deprives the legend of Buddha's flight of any claim to be history, but it is not easy to decide which story was the model.

Prije odlaska poželio je primiti sina, ali ga je majka držala u zagrljaju pa se, ne želeći ju probuditi i riskirati da ga ona odgovori od odlaska, iskrao iz palače. ${ }^{181}$

Prikaz je događaja, od sudbonosnih susreta do trenutka izlaska iz palače, naveden ovdje kao ilustracija rasta i sistematiziranja predaje. Na jednome su mjestu slikovito prikazane sve zamke lagodna života, a koje je Gotama morao izbjeći ukoliko je želio ostvariti svoj poziv. Naime, četiri sudbonosna susreta služe kao poticaj za donošnje odluke o odlasku u beskućništvo i ujedno pokazuju put kojim treba krenuti. Bogatstvo ukrasa i nakita na Gotaminu tijelu pokazatelj su raskoši koju je spreman ostaviti i ljepote svoga (ali i ženskoga tijela) koju je spreman zaboraviti (trganje skupocijene biserne ogrlice i darivanje žene koja je u njega zaljubljena lijepo ilustrira njegovu ravnodušnost). Putenost i tjelesni užitci utjelovljeni su u slici zaspalih i razgolićenih žena, dok je dužnost spram obitelji utjelovljena u slici njegove supruge i tek rođenoga sina. Slijedi opis odlaska uz palače.

ĐātA. I. 62-65

\footnotetext{
${ }^{180}$ ĐātA. I. 61.

${ }^{181}$ Napuštanje doma nalazi se opisano i u Vinayi škole mūlasarvāstivāde. Epizodu je u tome djelu analizirao Strong (1997: 114-115) koji, kada je riječ o oproštaju od Yaśodhare, piše sljedeće: To begin with, it makes no mention of Bodhisattva's touching farewell to his sleeping wife and son. The reason for this is not hard to find: in this tradition, Rähula has not yet been born. Indeed, the night of the Great Departure marks not the birth but the conception of the Buddha's son, for far from not waking his wife on his way out the door, the Bodhisatva decides to make love to her. The Sanghabhedavastu is explicit about this: „,Lest others say that the prince Sákyamuni was not a man (apumān - eunuch) and that he wandered forth without paying attention to Yaśodharā, Gopikā, Mrgajā, and his other sixty thousand wives [...].
} 
Evam Bodhisatto pāsādatalā otaritvā assasamīpaì gantvā evam āha: „tāta Kanthaka,

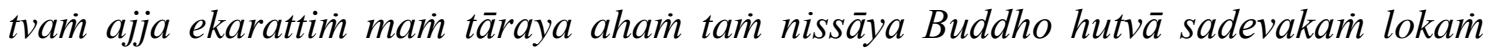
tāressāmīti " tato ullamghitvā Kanthakassa pițthim abhirūhi. Kanthako gīvato pațthāya āyāmena ațthārasahattho hoti tadanucchavikena ubbedhena samannāgato thāmajavasampanno sabbaseto dhotasamkhasadīso. So sace hasseya vā pādasaddaì kareyya vā saddo sakalanagaram avatthareyya tasmā devatā attano ānubhāvena tassa yatthā no koci suṇāti evam hasitam saddam sannirumbhitvā akkamaṇapadavāre hatthatālani upanāmesum. Bodhisatto assavarassa pițthivaramajjhagato Channam assassa vāladhim gāhāpetvā aḍ̣̂arattasamaye mahādvārasamīpaì patto. Tadā pano rājāa: „evam Bodhisatto yāya kāyaci velāya nagaradvāram vivaritvā nikkhamitum na sakkhissātīti" dvīsu dvārakavātesu ekekam purisasahassena vivaritabbaì kārāpesi. Bodhisatto thāmabalasampanno hatthigananāya koṭisahassahatthīnam balä̇ dhāreti purisagaṇanāya dasapurisakoțisahassassa. So cintesi: ,, sace dvāraṁ na avāpurīyati ajja Kanthakassa pițthe nissino va vāladhim gahetvā thitena Channena saddhim yeva

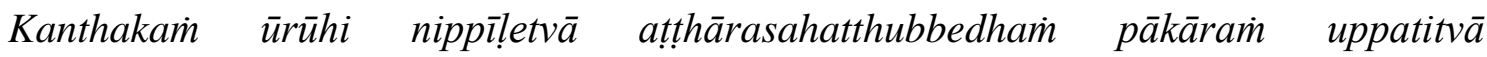
atikkamissāmīti “. Channo cintesi: ,, sace dvāraṁ na vivarīyati aham ayyaputtam khandhe nisīdāpetvā Kanthakām dakkhinahatthena kucchiyam parikkhipanto upakacchantare katvā pākārà̇ uppatitvā atikkamissāmīti“. Kanthako pi cintesi: „sace dvāraì na vivarīyati aham attano sāmikam piț̣hiyam yathānisnnam eva Channena vāladhim gahetvā thitena saddhim yeva ukkhipitvā pākāram uppatitvā atikkamissāmīti “. Sace dvāram na avāpurīyittha yathācintitai் eva tīsu janesu añnataro sampādeyya. Dvāre adhivatthā devatā pana dvāram vivari. Tasmim yeva khaṇe Māro „Bodhisattam nivattessāmīti“ "āgantvā ākāse thito āha: „,mārisa mā nikkhami ito te sattame divase cakkaratanam pātubhavissati dvisahassaparittadīpaparivārānam catunnam mahādīpānaì rajjam kāressasi nivatta mārisā" 'ti āha. „Ko si tvan“ ti. „,Ahaì

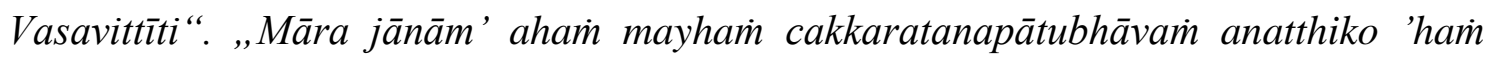
rajjena dasasahassilokadhātum unnādetvā Buddho bhavissāmīti “ āha. Māro , ito dāni te

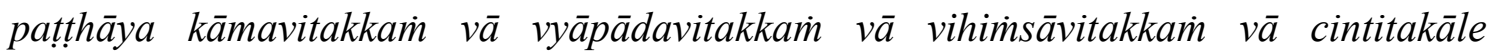
jānissāmìti" otārāpekho chāyā viya anupagacchanto anubandhi. Bodhisatto pi hatthagatam cakkavattirajjam khelapindaim viya anapekho chaḍdetvā mahantena sakkārena nagarā nikkhamitvā āsālhipuṇnamāya uttarāsāḷanakkhatte [...]

Iminā sirisobhaggena gacchanto Bodhisatto ekaratten' eva tīni rajjāni atikkamma timsayojanamatthake Anomānāmanadītīram pāpuṇi. „, Kim pana asso tatoparaṁ gantum 
na sakkotīti“. Nona sakkoti so hi ekacakkavālagabbham nābhiyā thitacakkassa nemivațtim maddanto viya antantena caritvā pure pātarāsam eva āgantvā attano sampāditam bhattam bhuñjitum samattho. Tadā pana devatānāgasupaṇnādīhi ākāse thatvā ossațthehi gandhamālādīhi yāva üruppadesā sañchannam sarīram äkaḍ̣̂itvā gandhamālājațam chindantassa atipapañco ahosi, tasmā timsayojanamattam eva

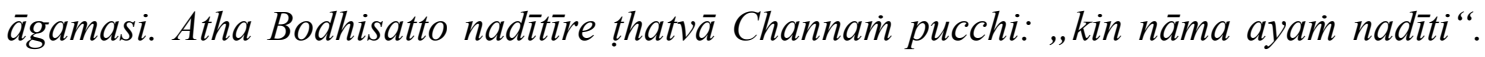
„Anomā nāma devā" 'ti. „Amhākam pi pabajjā anomā nāma bhavissatīti“. [...]

[Bodhisatto]cintesi: „,ime mayham kesā samaṇasāruppā na hontīti añ̃̃o Bodhisattassa kese chinditum yuttarūpo n' atthi tato sayam eva khaggena chindissāmìti “ dakkhina hatthena asim gaṇitvā vāmahatthena moliyā saddhim cūlạm gahetvā chindi. Kesā dvaìgulamattā hutvā dakkhinato āvattamānā sīsam allīyimsu, tesam yāvajīvaì tad eva pamāṇam ahosi, massuñ ca tadanurūpam ahosi. [...]

Bodhisatto saha molinā cūlam gahetvā ,, sac' āham Buddho bhavissāmi ākāse titṭatu no ce bhūmiyam patatū" 'ti antalikkhe khipi, taim cūlāmaṇivețanam yojanappam țānam gantvāa ākāse atțāsi. Sakko devarājā dibbacakkhunā oloketvā yojaniyaratanacamigotakena sampați-cchitvā Tāvatimsabbhavane cūlāmaṇicetiyan nāma patițthāpesi:

$$
\begin{aligned}
& \text { „Chatvāna molim varagandhavāsitaim } \\
& \text { vehāsāyam ukkhipi aggapuggalo } \\
& \text { sahassanetto sirasā patiggah̄ } \\
& \text { suvaṇnacamgoṭavarena Vāsavo "ti (272) }
\end{aligned}
$$

Puna Bodhisatto cintesi: , imāni kāsikavatthāni mayham na samaṇasāruppānīti “. Atth ’ assa Kassapabuddhakāle purāṇasahāyako Ghațīkāro Mahābrahmā ekam Buddhantaram jaram appattena mittabhāvena cintesi: „ajja me sahāyako mahābbhinikkhamanaì nikkhanto, samaṇaparikkhāram assa gahetvā gacchisāmīti “:

Ticìvarañ ca patto ca

Vāsi sūciñ ca bandhanam

Parissāvanena atțh' ete

Yuttayogassa bhikkhuno " ti (273)

Prijevod 
Potom se Bodhisatta, spustio iz palače, otišao do konja i rekao: "Dragi Kanthaka, prevezi me danas, jednu noć, a ja ću, oslonivši se na tebe, postavši Probuđeni prevesti [preko patnje] svijet i nebesnike!" Zatim se je skočivši popeo konju na leđa. Kanthaka je, počevši od vrata, bio dug osamnaest lakata i obdaren toj duljini prikladnom visinom. Sav bijel poput ulaštene školjke, bio je obdaren izdržljivošću i brzinom. Da samo zarže ili nogom topne, jeka bi se prostrla čitavim gradom. Zato su nebesnici, svojim duhovnim utjecajem prigušivši zvuk rzaja, podmetali dlanove pod njegova kopita kako je koračao da ga nitko ne bi čuo. Sjedeći na snažnim leđima rasnoga konja, rekavši Ćhanni da se uhvati za rep konja, našao se je Bodhisatta u ponoć pred glavnim vratima grada. U ono je vrijeme kralj naredio na dvjema stražarnicama uz gradska vrata da svaku mora braniti tisuću ljudi, misleći: "Ovako Bodhisatta ni u jednom trenutku neće moći otvoriti vrata i otići." Bodhisatta je bio izdržljiv i snažan; računajući po snazi slona, bio je snažan kao tisuću koția slonova, a računajući po snazi muškarca, bio je snažan kao deset tisuća koṭia [muškaraca]. ${ }^{182}$ Razmišljao je: "Ne otvore li se sada vrata, ja ću, sjedeći na leđima Kanthake i skupa s Ćhannom koji će se držati za njegov rep, stiskom [svojih] bedara [natjeravši Kanthaku u trk], preskočiti bedem visok osamnaest lakata pa izaći." Ćhanna je mislio: "Ne otvore li se vrata, ja ću gospodara podići na ramena, desnom ću rukom obgrliti Kanthakin trbuh oko struka, preskočiti bedem pa izaći." A Kanthaka je mislio: "Ne otvore li se vrata, ja ću, s gospodarem na svojim leđima, kako sjedi, i skupa s Ćhannom kako stoji držeći se za [moj] rep, odrazivši se preskočiti bedem pa izaći." I zaista, da vrata nisu bila otvorena, netko bi od njih trojice već ostvario ono što je naumio, ali vrata su otvorila božanstva koja u njima borave.

U tom se baš trenutku [pojavio] Māra [misleći]: "Odvratit ću Bodhisattu." Prišao je i, lebdeći u zraku, rekao: "Menedostojniče, ${ }^{183}$ ne idi! Za sedam će se dana pred tobom pojaviti dragulj od kotača, postat ćeš vladar četiriju kontinenata i dviju tisuća otoka koji im pripadaju. Vrati se, menedostojniče!” Tako je rekao, [a Bodhisatta ga upita]: “Tko si ti?"”

“Ja sam Vasavattin.",184

\footnotetext{
${ }^{182}$ Koți, sto tisuća. Ježić (usmena napomena): Ova rečenica ne služi pripovijedanju, možda je i naknadno umetnuta od nekoga pripovjedača, no oslikava kako su se postupno u predaji pripisivale nadnaravne osobine Bodhisattvi.

${ }^{183}$ Po Ježićevoj usmenoj preporuci za mārisa.

${ }^{184}$ Vasavattin (skt. Vaśavartin), koji ima moć (nad svijetom), koji upravlja voljom (svijeta), (sve)moćan.
} 
"Māro! Znam da mi se dragulj od kotača pojavljuje, ali nisam željan kraljevanja. Postat ću Probuđeni, od čega će odjeknuti svemir od deset tisuća svjetova” - reče Bodhisatta.

Māra pomisli: "Od ovoga trenutka, čim se [u Bodhisatti] javi pomisao na požudu, zlobu ili okrutnost, ja ću odmah znati”- i čekajući tu priliku, slijedio ga je [Māra] kao sjena. Ravnodušan spram vladanja kotačem svijeta koje mu je bilo na dohvat ruke, Bodhisatta ga je ispljunuo kao grumen sluzi iz grla i, [praćen] mnoštvom blagoslova, napustio je grad u mjesecu Āsāḍha kada je Mjesec bio pun u zviježđu Uttarasāḍa [...]

Išao je Bodhisatta, [praćen] sjajem i dobrim usudom. U samo jednoj je noći prešao tri kraljevstva i našao se, nakon trideset prevaljenih yođana, na obali rijeke zvane Anomā. Ali zašto konj nije mogao ići dalje? Nije da nije mogao. On je, naime, bio sposoban prijeći unutrašnjost jednoga [cijeloga] svjetskoga kruga beskrajem, kao da [tko] gazi oplatak kotača koji stoji na glavčini, prije jutarnjega obroka tako da stigne pojesti pripremljeno mи jelo.

Ali je [konj] vukao tijelo pokriveno do bedara vijencima cvijeća koje su slali, u zraku lebdeći nebesnici, nāge $i$ krilata bića pa je bio pretjerano zapriječen probijajući se kroz preplet vijenaca cvijeća. Iz toga je razloga prešao udaljenost od samo trideset yođana. Došavši na obalu rijeke, Bodhisatta upita Ćhannu: "Kako se zove ova rijeka?",

"Ime joj je Anomā, kraljeviću."

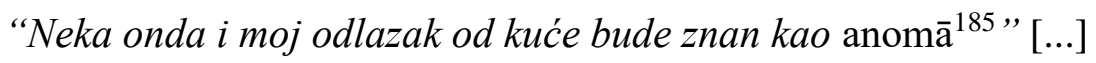

Pomislio je [Bodhisatta]: "Ova moja kosa ne pristaje isposniku, a budući da nema nikoga drugoga prikladna da odreže kosu bodhisatti, sâm ću ju mačem odrezati”. U desnu je ruku uzeo mač, a u lijevu spletene uvojke pa ih, skupa s ukrasom za glavu, odreza. Kosa postade dva prsta kratka, priljubljena uz glavu i svinuta u desno. ${ }^{186}$ Kao i brada, ostala je te duljine cijeli život.

Držeći uvojke i ukras za glavu Bodhisatta [pomisli]: "Ako ću ja zaista postati Probuđeni neka ostanu stajati u zraku, a ako neću, neka padnu na tlo." [To pomislivši] bacio je u

\footnotetext{
${ }^{185}$ Anoma [an + oma], pridj., ne-inferioran, savršen, vrhunski, besprijekoran, potpun.

${ }^{186}$ Ovo je u skladu s prikazima Gotame Buddhe na kojima mu je kosa podijeljenja u kovrče svinute u desno, a najraniji takvi prikazi potječu iz 2. st.
} 
zrak uvojke i skupocjeni ukras za glavu, a oni su odletjeli i ostali stajati u zraku na visini od yođane. Ugledao ih je kralj nebesnika Sakka [svojim] božanskim okom pa ih je primio, na visini od yođane, košarom ukrašenom dragim kamenjem i odložio u Svetiše skupocjenih uvojaka, na nebesima Tāvatimsa ${ }^{187}$ :

Odrezavši [svoje] miomirisne uvojke,

Bacio ih je u zrak Najodličniji.

Primi ih tisućooki Vāsava na glavu

Najizvrsnijom, zlatnom košarom. (272) 188

Ponovno je Bodhisatta pomislio: "Ova moja odjeća iz grada Kāsī ne pristaje isposniku.” U tom je trenutku Mahābrahman Ghāțikāra, njegov prijatelj od davnina, još iz vremena buddhe Kasappe, s osjećajem prijateljstva koje nije izblijedjelo [cijelo] staro razdoblje [od] jednoga Buddhe [do drugoga], pomislio: "Danas je moj prijatelj otišao u u veliki odlazak. Uzet ću za njega opremu za isposnika i otići [do njega]":

Tri ogrtača i zdjela,

britva, igla i opasač.

S cjedilom osam je to [dijelova opreme]

isposnika koji je spregom spregnut. (273)

Opis Gotamina odlaska od kuće, kako je prikazan u Nidānakathi, jasno daje do znanja da autoru-kompilatoru unutrašnja previranja, moguća tjeskoba od spoznaje da je svako biće, $u$ konačnici, osuđeno na propast ne znače mnogo naspram prilike da se napuštanje doma ureže slušatelju ili čitatelju duboko u sjećanje. Ne nalazimo tu ni sistematizirano i hladno izlaganje misli čovjeka koji se pokušava uhvatiti u koštac s egzistencijalnim pitanjima već živopisan opis događaja koji se odvijaju izvan "njegove glave". Uzme li se u obzir da je za opstanak redovničke zajednice bio nužan priljev novih redovnika i da je utjecaj zajednice uvelike ovisio o broju njezinih članova, može se i pod tim vidom razumjeti naglasak stavljen na čudesnost i izvanrednost čina napuštanja svjetovnoga života. Međutim, za razliku od Nidānakathe, u kojoj je pripovijest o napuštanju doma zamijenjena bajkom, u Mahāvastuu je još uvijek moguće naći tragove egzistencijalnih previranja koja su prethodila odluci o napuštanju doma.

\footnotetext{
${ }^{187}$ Boravište tridesetitri boga među kojima je glavni Sakka. V. PED, str. 300.

${ }^{188}$ Usp. Mv. ii. 165-166.
} 


\subsection{Odlazak u beskućništvo u Mahāvastuu}

Napuštanje doma i odlazak u beskućništvo u Mahāvastuu se nalaze opisani na šest mjesta, a pojedini su ulomci podudarni s ulomcima u pālijskome kanonu i Nidānakathi.

U Mv. i. 154-158 iznosi se jednostvna i sažeta pripovijest u kojoj naglasak nije stavljen na Bodhisattvu već na kočijaša Ćhandaku. ${ }^{189}$ Vidjevši da mu se gospodar sprema napustiti dom, kočijaš se pita: "Koga da probudim? Ima li koga da mi pomogne?" 190 Pojavljuju se u tom trenu nebeska bića koja uvjeravaju Ćhandaku da je odluka, uz blagoslov svih nebesnika, u budućem buddhi sazrjela. Uplakani kočijaš dovodi potom konja Kạ̣ṭaku "bijeloga poput ljiljana ili cvijeta jasmina, krasnoga poput punoga Mjeseca" i predaje ga Bodhisattvi koji odlazi iz grada praćen mnogobrojnim nebesnicima. Izašavši, Bodhisattva "lavljega srca" okrenuo se još jednom da pogleda grad, zaklevši se da će se vratiti nakon što nadiđe moć starosti i smrti. U odlomku se, čini se, implicira da je Gautamina majka, kraljica Māyā, u trenutku njegova odlaska živa, unatoč brojnim primjerima potkrijepljenom shvaćanju da je umrla sedam dana nakon poroda:

$$
\begin{gathered}
\text { sā dāni tasya mahiși manujeśvarasya } \\
\text { mātā savatsalaviśālasucārunetrā/ } \\
\text { saṃpaśyamāna }{ }^{191} \text { karuṇaṃ priyaviprayogaṃ } \\
\text { nidrābhibhūta na vijānati ālapantam // }
\end{gathered}
$$

Prijevod

Ona, glavna kraljica, toga gospodara ljudi, Mati vrlo ljupkih očiju, širokih i nježnih prema čedu, Unatoč tomu što vidi kako je tužna odvojenost od dragoga,

Nadvladana snom, ne prepoznaje onoga koji govori.

U Mv. i. 227-228 nalazi se vrlo kratak odlomak posvećen odlasku u beskućništvo buddhe Dīpan̉kare. Navodi se da je Dīpañkarin otac, kralj Arćimant, dao za kraljevićevu razonodu sagraditi tri palače, urediti perivoj s jezerom te dovesti žene kako bi ga zabavljale. Jednom su prilikom, nakon dana provedena u vožnji čamcima po jezeru, djevojke izašle na obalu i

\footnotetext{
${ }^{189}$ Pripovijest o napuštanju doma na ovome je mjestu uklopljena u opis događaja koji se odvijaju na desetome i konačnom polju / stupnju (bhümi).

${ }^{190}$ Kočijaševo se protivljenje, u svega nekoliko redaka, opisuje i u Mv. ii. 159. U Lalitavistari se pak kočijaševo protivljenje i pokušaj odgovaranja Bodhisattve od napuštanja doma protežu na nekoliko stranica i povod su za detaljno opisivanje svega bogatstva i raskoši kojima je Bodhisattva obdaren (Lv. 211-218).

${ }^{191}$ sampaśyamāna umjesto sampaśyamānā (m.c.).
} 
iscrpljene zaspale. Prizor tih djevojaka podsjetio je Dīpañkaru na groblje. ${ }^{192} \mathrm{Na}$ ovome mjestu odlomak naglo završava i slijedi novo poglavlje u kojem se opisuje trenutak probuđenja.

Druga knjiga Mahāvastua sadrži četiri poglavlja posvećena napuštanju doma. ${ }^{193}$

Pripovijest, koja se nalazi u Mv. ii. 115-134, svojevrsna je kompilacija nekoliko ulomaka koje znamo iz pālijskoga kanona, i obuhvaća događaje od trenutka odlaska iz doma do probuđenja.

Mv. ii. 115-118 odgovara gore prevedenomu ulomku iz Anguttaranikāye. ${ }^{194}$ Uvodna rečenica "bio sam razmažen, jako razmažen" (sukumāro ham bhikșavo paramasukumāro), u Mahāvastuu je iskorištena čak šesnaest puta kao povod za opisivanje sve raskoši i svih blagodati kojima je bodhisattva, prije negoli je napustio palaču, bio okružen. Primjerice, dok se u Anguttaranikāyi samo spominju tri palače za tri godišnja doba, u Mahāvastuu je taj podatak postao prilikom da se palače opišu do najsitnijih detalja. Saznajemo tako da su, zahvaljujući čvrstim vratima, bile sigurne od propuha, da su ležajevi bili ukrašeni dragim kamenjem, prekriveni sa šesnaest raznobojnih prekrivača i grimiznim jastucima i da su u sobama postavljene bijele prostirke. Ipak, u svojoj biti, ulomak u Mahāvastuu odgovara ulomku u Anguttaranikāyi. Na kraju toga iscrpnoga opisa nalazi se Gautamina izjava o odluci o odlasku, koja svoju paralelu ima u Mađđhima- i Dīghanikāyi. ${ }^{195}$

Mv. ii. 117

saṃbādho punar ayam gṛhavāso abhyavakāśam pravrajya ${ }^{196}$ tu / na śakyam agāram adhyāvasatā ekāntasamlikhitam ${ }^{197}$ ekāntānavadyam pariśuddham paryavadātam brahmacaryam caritum yam nūnāham agārasyānagāriyam pravrajeyam // sa khalv aham bhikṣavaḥ akāmakānām mātāpitṝnām aśrukaṇthānām rudanmukhāṇām alūham ${ }^{198}$ gṛhavāsam hastoktam ${ }^{199}$ cakravartirājyam apahāya [...]//

Prijevod

\footnotetext{
${ }^{192}$ Usporedba zaspalih žena s mrtvim tijelima ili grobljem nalazi se i u Nidānakathi (v. g.) i Lv. 206

${ }^{193}$ Mv. ii. 115-134, 140-167, 189-210, 299-300.

194 AN i. 145.

${ }^{195} \mathrm{MN}$ i. 240, DN i. 62. Usp. i Sn. 406.

196 Pāli: abbhokāso pabbajā.

197 saṃlikhita umjesto śankhalikhita (pāli: sankhalikhita).

${ }^{198}$ Negacija $a+$ lūha (skt. rūkșa, pāli lūkha. V PED str. 585, Jones (1952/2006: 63).

${ }^{199}$ Za hastatvaì (skt. hasta-sthā, pāli hatthathha). V. PED str. 728.
} 
Skučen je, nadalje, ovaj život u domaćinstvu. Odlazak u isposništvo je svježzrak. Ne može domaćin koji boravi [u kući] voditi zavjetovani život, usredotočeno [sjajan] poput ulaštena sedefa, usredotočeno besprijekoran, čist i ostvaren. A da ja sada odem iz kuće u beskućništvo? I tako sam ja, o redovnici, napustio neskromni dom, usprkos željama oca $i$ majke uplakanih lica i jecajućega glasa, odbacivši i kraljevanje nad krugom [cijeloga] svijeta [koje je bilo] nadohvat ruke [...].

Mv. ii. 118-121 sadrži opis Gautamina naukovanja pod vodstvom dvojice učitelja, Ārāḍe Kālāme i Udrake Rāmaputre, i odustajanja od toga naukovanja, što odgovara odlomku u Ariyapariyesanāsutti. ${ }^{200}$ Potom se, u Mv. ii. 121-124, iznose tri Gautamine usporedbe ili parabole $(\text { upama })^{201}$ do kojih spontano dolazi nakon odlaska od dvojice učitelja, a iste se parabole nalaze i u Mahāsaććakasutti iznesene, također, neposredno nakon odluke o napuštanju naukovanja. ${ }^{202}$ Ostatak toga poglavlja (Mv ii. 124-134) donosi opis isposničkih trapnja kojima se Gautama podvrgnuo, kao i opis samoga probuđenja.

Sljedeće poglavlje posvećeno odlasku u isposništvo (Mv. ii. 140-167) također je kompilacija nekolicine tekstva od kojih se neki susreću i u pālijskim izvorima.

U Mv. ii. 140-150 iznosi se razgovor između Gautame i njegova oca, kralja Śuddhodane u dvije verzije. U tome razgovoru Śuddhodana obećava ispuniti svaku želju u zamjenu za kraljevićev ostanak u palači. Taj se razgovor ne nalazi u pālijskome kanonu, niti u Nidānakathi. Slijede izvorni tekst i prijevod druge i ujedno kraće verzije toga razgovara.

Mv. ii. 146

rājā āha // ākhyāhi me putra śīghrạ̣ kīdṛsáme așta varāṇi yānīcchasi yadi śaktir vā balam vā asti tato te pradāsyāmi / kim putra mama rājyam parihāyiṣyati yad aham tava putra varam na pradāsyāmi //

kumāra āha // imāni me tāta aṣta varāṇi anuprayacchāhi // yadi me yauvanam jarā nākrameyā / yadi ārogyam vyādhir nākrameyā / yadi me jūvitam maraṇam na hareyā / yadi me tvayā sārdham viprayogo na bhave / edriśam ${ }^{203}$ antahpuram apsarasādṛ́am

\footnotetext{
${ }^{200} \mathrm{MN}$ i. 163-167.

${ }^{201}$ V. PED, str. 145 i SED, str. 203.

${ }^{202} \mathrm{MN}$ i. 240-243. Parabole se ne nalaze u Ariyapariyesanāsutti.

${ }^{203}$ Pāli edisa, skt. īdrśa.
} 
vistīrṇo ca jñātivargo na vipraveśeya ${ }^{204}$ rājyāto ca aiśvaryāto ca na vipariṇāmānyārtībhāvo bhaveyā / ye pi satvā mama jātamātreṇa amṛtasukhena abhinimantritā teșām pi sarveșām kleśapraśamo bhaveyā / mamāpi jātijarāmaraṇasya anto bahveyā // rājā śuddhodano āha // putra kuto mama edṛśam va śaktir vā balam vā asti yad aham imāme edṛ́ām aṣța varā prayaccheyaṃ /

Prijevod

Kralj reče: "Reci mi brzo, sine, kojih je to osam želja što ih priželjkuješ? Ako [ovise o mojoj] moći ili snazi, ja ću ih tebi ispuniti. Što ću [ti] sine svoje kraljevstvo prepustiti, ako [ti], sine, ne [mogu] ispuniti želju?"

Kraljević reče: "Ispuni mi, onda, ovih osam želja! Neka starost ne pogazi moju mladost; neka bolest ne pogazi zdravlje; neka mi smrt ne odnese život; neka ne dođe do rastanka s tobom; neka ovaj unutarnji stan sa ženama nalik na apsare $i$ mnoštvo rodbine ne nestane; neka kraljevsto i [njegovo] gospodstvo ne zadese propadanje i druge nedaće; neka se smire ukliještenja svih koji su pri mome rođenju bili dodirnuti besmrtnom srećom; neka dođe kraj mojim rođenjima, starosti i smrti!"

Kralj Śuddhodana reče: "Sine, odakle meni takva moć ili snaga da ti ostvarim takvih osam želja?"

$\mathrm{Na}$ taj se razgovor nadovezuje popularna predaja o četiri izlaska iz palače. ${ }^{205} \mathrm{U}$ svome se temelju pripovijest u Mahāvastuu ne razlikuje od pripovijesti u pālijskoj Mahāpadānasutti ili Nidānakathi, međutim, u Mahāvastuu je obogaćena brojnim novim detaljima i opširnim opisima grada, perivoja kao i ljudi koje Gautama susreće. Kao ilustracija te "barokne kićenosti" kojom se Mahāvastu odlikuje, poslužit će sljedeći odlomak.

Mv. ii. $150-151$

bodhisatvo pitaram abhimantrayati udyānabhūmim niryāsyāmīti // rājñ̄à śuddhodanena amātyā ānattāa // yāvad rājakulạ̣ yāvac ca udyānabhūmim atrāntare pratijāgratha siktasamșșṣtam vitatavitānam citradușyaparikșiptam osaktapaț̣adāmakalāpam

\footnotetext{
204 Jones (1952/2006: 141, bilj. 2): The context shows that this must mean something like "dissapear", but it is not easy to see how a compound of viś, "to enter" (here causative from primary), even granting a wholly negative force to the prefiy vi-, can have this sense. The reading may be regarded as highly doubtful. The sense of context could be secured by simple emendation into vipravaseyā from vipravasati (Pali vippavasati) "to be away from home", "be absent", hence "to disappear".
}

${ }^{205}$ Mv. ii. 150-158. 
dhūpitadhūpanạ̣ muktapuṣpāvakīrṇnam deśedeśeṣu dhūpayantrāṇi mālyayantrāṇi națanartaka-ṛllamallapāṇisvaryākumbhatūṇ̄ mānāpikāni rūpaśabdagandhāni upasthāpetha amānāpikāni udvartāpetha / yathā kumāro udyānabhūmīm abhinișkrānto na kị̣cid amanāpam paśyeya // evam rājño vacanamātreṇa amātyehi yāvac ca rājakulam yāvac ca tām kumārasya udyānabhūmim yathāṇattạ̣ mārgạ̣ pratijāgritam deśedeśeșu ca puruṣā sthāpitā yathā kumārasya purato na kiṃcij jīrṇo vṛddho vyādhito vā kāṇo vā khădo vā darduro vā kaṇ̣̂̄lo vā kacchulo vā vicarciko vā anyo vā kimcid amanāpam kumārasya udyānam abhiniṣkramantasya purato tiṣtheyā //

evaṃ kumāro mahārheṇa saptaratnacitreṇa yānena mahatā rājānubhāvena mahatā rājarddhīye mahatīye vibhūṣāye udyānabhūmim niryāntasya rājapuruṣā vāmadakșinena utsāraṇām karontā gacchanti yathā kumāro na kiṃcid amanāpam paśyeyā // evam kumāro mānāpikāni rūpāṇi paśyanto mānāpikāni śabdāni śṛnvanto mānāpikāni gandhāni ghrāyanto ubhayato vāmadakșiṇena amjalīśatasahasrāṇi pratīchanto vividhāni ca cūrṇavarṣāṇi pratīchanto kapilavastuto udyānabhūmim nirdhāvantasya ghațikāreṇa kumbhakāreṇa śuddhāvāsadevaputrabhūtena tathānyehi ca śuddhāvāsakāyikehi devaputrehi jīrṇo purușo purato abhinirmito jīrṇo vṛddho mahallako adhvagatạ̣ vayamanuprāpto śvetaśiro tilakāhatagātro bhagno gopānasīvakro puratoprāgbhāro dạ̣ḍmaștabhyamānair (2.151) gātrair gacchanto // bodhisatvo tạ̣ dṛștvā sārathim pṛcchati / kim imo puruṣo evam pratikūlo jīrṇo vṛddho mahallako adhvagatavayamanuprāptaḥ śvetaśiro tilakāhatagātro bhagno gopānasīvakro purataḥpāäbhāro daṇdam avaștabhya prakhalamānair gātraih gacchati // sārathi āha // kumāro kiṃca te etena prcchitena eșa puruṣo jīrṇo nāma vayaparigataśarīro / gacchāma udyānabhūmim tahim devakumāra paṃcahi kāmaguṇehi krị̄̂ahi ramāhi pravicārehi // kumāro āha // bho bhaṇe sārathi vayam api jarādharmā jarādharmatāyām anatītāh / yatra nāma jātasya jarā prajñāyati atra paṇditasya kā rati // kumāro āha // sārathi nivartehi ratham alạ̣ udyānagamanāye //

\section{Prijevod $^{206}$}

Bodhisattva se obratio ocu: "Izaći ći u perivoj!"

\footnotetext{
${ }^{206}$ Prijevod se ovoga odlomka nalazi i u Grabovac (2013).
} 
Kralj Śuddhodana naredio je pratiocima: "Pobrinite se da je sve od palače do perivoja poškropljeno i sakupljeno, natkriveno platnima, ogrnuto sjajnim tkaninama, povezano snopovima finih tkanina $i$ vrpca, namirisano mirisima, posuto rascvjetanim cvijećem. Posvuda postavite držače za mirise $i$ držače za [cvjetne] vijence, plesače, glumce, natjecatelje, rvače, svirače $u$ dlanove, bubnjare, ugodne oblike, zvukove $i$ mirise, a neugodno izbacite tako da kraljević, kada bude ulazio u perivoj, ne vidi ništa neugodno." Po kraljevoj su zapovijedi pratioci nadgledali put od palače do kraljevićeva perivoja kako je naređeno. Na sve su strane postavljeni redari da se ispred kraljevića, kada bude ulazio u park, ne pojavi nikakav nemoćnik, starac, bolesnik, jednook čovjek, šepavac, gubavac, svrabljivac, kožni bolesnik, šugavac, ni bilo što drugo neugodno.

Tako, kada se se kraljević zaputio u perivoj veličanstvenom kočijom svjetlucavom od sedam dragulja is velikim kraljevskim dostojanstvom, velikim bogatstvom i skupocjenim ukrasima, kraljevski su redari išli praveći prolaz, razmičući [ljude] s lijeva is desna kako kraljević ne bi vidio štogod neugodno. Dok je kraljević gledao ugodne oblike, slušao ugodne zvukove, mirisao ugodne mirise i primao i s lijeva i s desna stotine tisuća pozdrava i kišu raznovrsnih mirisnih prahova i napredovao tako od Kapilavastua do perivoja, po Ghațikāri lončaru, koji je postao božanski sin s čistim prebivalištem i ostalim božanskim sinovima utjelovljenima u čistome prebivalištu, pričinio se je ispred [njega] star čovjek: onemoćao, star, u poodmaklim godinama, koji je dosegnuo duboku starost, sjedokos, tijela prekrivena pjegama, pogrbljen, prelomljen kao krov, nagnut prema naprijed. Hodao je, oslanjajući udove na štap,

(2.151) posrćućim nogama. Vidjevši ga, Bodhisattva upita kočijaša: “Tko je taj odbojni čovjek, onemoćao, star, u poodmaklim godinama, koji je dosegnuo duboku starost, sjedokos, tijela prekrivena pjegama, pogrbljen prelomljen kao krov, nagnut prema naprijed, koji, oslonivši se na štap, hoda posrćućim nogama?” Kočijaš reče: "Kraljeviću, čemu to pitanje? Takav se čovjek zove starac, tijelu mu je protekao vijek. Pođimo u perivoj! Ondje, kraljeviću, uživaj i i razonodi se zabavama za pet osjetila!"

Kraljević reče: "O kočijašu kažem ti, i mi smo podložni starenju, nismo nadišli podložnost zakonu starenja. Zaista, u čemu je užitak mudraca kada spozna da svako rođeno biće stari?" Kraljević reče: "Kočijašu, okreni kočiju! Dosta mi je posjeta perivoju!" 
Na početku ulomka dani opis priprema za Bodhisattvin izlazak prethodi i ostalim sudbonsonim susretima pri kojima će Bodhisatva spoznati još i bolest, smrt i mogući put koji vodi do oslobođenja od patnja. Na samome se kraju te pripovijesti susreću stihovi prisutni i u Nidānakathi, ali ih ovdje ne izgovara Kisā Gotamī, već žena imenom Mṛ̂ī.

Mv. ii. 157

$$
\begin{gathered}
\text { nirvṛta khalu te mātā pitā punạ̣ te nirvṛto / } \\
\text { nirvṛtā punaḥ sā nārī yasya bhartā bhaviṣyasi // }
\end{gathered}
$$

bodhisatvasya nirvāṇaśabdam śrutvā nirvāṇasmịn eva manam prasīde tișthe

$$
\begin{gathered}
\text { sampraskande // } \\
\text { nirvānaghoṣam śrutvāna nirvāṇe śrotram ādade / } \\
\text { nirvāṇam anuttaram dṛșțā dhyāyate akutobhayam // }
\end{gathered}
$$

kumāreṇa tạn nirvāṇam dhyāyantena mrgō śākyakanyā nāvalokitā nābhāṣța // tasyā

dāni mrgīsáăkyakanyāye daurmanasyam samjātam // ettakasya janakāyasya madhyato mayā kumāro abhistuto na cānena aham avalokitāpi //

Prijevod

$$
\begin{gathered}
\text { "Blažena }{ }^{207} \text { je zaista majka i blažen je tvoj otac, } \\
\text { Blažena je žena čiji ćeš suprug potom postati!” } \\
\text { Čuvši riječ nirvāna, bodhisatvin se um staložio u nirvāṇi, zastao i poskočio. } \\
\check{C} u v \text { ši riječ nirvāṇa, primio je čuto u nirvāṇi. }
\end{gathered}
$$

Vidjevši nenadmašnu nirvāṇu, zadubio se bez straha.

Kraljević zadubljujući se u nirvāṇu nije pogledao niti oslovio Mṛgī, ženu iz porodice

$$
\text { Sákya. }
$$

Na to se Mrgī, žena iz porodice Śākya, rastužila: "Usred tako velike gomile ljudi odala sam počast kraljeviću, a on me nije čak ni pogledao. "208

U Mv. ii. 158-167 iznosi se pripovijest o bijegu iz palače pod okriljem noći što sadržajno odgovara dijelu Nidānakathe koji se nalazi u ĐātA. I. 62-65. U Mahāvastuu su, međutim, opisi mnogo detaljniji, a posvećena je i veća pažnja ponovnom isticanju svih blagodati kojih se Bodhisattva sprema odreći. Također, Mv ii. 160-164, sadrži i opširan opis radosti koja je

\footnotetext{
207 Nirvrta.

208 Na ovome mjestu Foucher (1949/2003: 73) primjećuje: The Singhalese tradition had the prince send her a string of pearls from around his own neck, a gesture she took to be a sign of love, while the Mahāvastu's writer, fearing all women, did not even grant her a glance from Siddhärtha.
} 
zavladala u svijetu nebesnika kao i svih čudesa, potresa i mlazova svjetlosti koji su se pojavili u trenutku Bodhisattvina odlaska u isposništvo. Zanimljiv je i detalj kojega nema u pālijskim izvorima a riječ je o molbi koju Gautami u trenutku izlaska iz grada upućuje božica ili zaštitnica Kapilavastua (nagaradevatā):

Mv. ii. $164^{209}$

nagaradevatā bodhisatvasya gacchataḥ purataḥ sthitvā dīnamanā āha //

$$
\begin{gathered}
\text { nāga nāga avalokayāhi me } \\
\text { siṃha siṃha avalokayāhi me // } \\
\text { satvasāra avalokayāhi me } \\
\text { sārthavāha avalokayāhi me // }
\end{gathered}
$$

kapilāhvayāto nirgamya avalokiya puravaram puruṣasiṃho śākyakulānandajanano imāṇ girām abhyudīrayati //

api narakam prapateyam vișam ca khādetum bhojanaṃ bhuṃje // na tu punar iha praviśy $a^{210}$ aprāpya jarāmaraṇapāram //

Prijevod

Božica grada stala je ispred Bodhisattve koji je odlazio i rastužena rekla:

“ $O$ Nāgo, $o$ nāgo! $O$, pogledaj me!

O Lavu, o lavu! O, pogledaj me!

Od svih bića najbolji! Pogledaj me!

Vodiču karavane! Pogledaj me!”

Izašav̌̌i iz [grada] zvanog Kapila, čovjek-lav, radost porodice Śākya, pogledao je divni grad i izrekao ovu kiticu:

"Da padnem u pakao, da se nahranim i pojedem otrovnu hranu,

Neću ponovno tu ući dok ne nadiđem starost i smrt!”

Poglavlje o odlasku završava sljedećim stihovima:

Mv. ii. 166

pravrajyām kīrtayiṣyāmi yathā pravraji cakșumām //

jūrṇam kālagatam dṛștvā samvegam alabhe muniḥ //

\footnotetext{
${ }^{209}$ Epizoda se susreće i u Lv. 272.

${ }^{210}$ Fut. 1. 1. jedn. Praviśya za praviśyam. Gubljenje završnoga nazala uobičajena je pojava u Mv. BHSG $\S 31.30$, 31.33 .
} 
yoniśo labdhasaṃvego mahāprajño vipaśyako //

dṛștvā ādīnavam loke pravraji anagāriyam //

avahāya mātāpitaram jūātisamgamanam tathā //

niryāsi kapilavastuto aśvam abhiruhya kaṇthakam //

avahāyāśvacchandake chittvāna gṛhabāndhanām //

sarvam etam avastrjya anapekṣo (e)va prakramet ${ }^{211} / /$

Prijevod

Opjevat ću odlazak Uvidom obdarenoga.

Vidjev starca i umrlog osjeti dirnutost Mudrac.

Iznutra dirnutost ćuteć, velike proznaje zrelac,

Vidjevši patnju u svijetu, napusti kuću i ode.

Napusti oca i majku, rodbinske susrete $k$ tomu.

Uzjahav Kaṇthaku konja, napusti Kapilavastu.

Konja i Ćhandaku pusti i sreza svezu sa domom.

Otpustivši dakle sve to, ne obzrev se naprijed krenu. ${ }^{212}$

Mv. ii. 189-210 također sadrži prikaz od vremena odlaska od kuće, preko ranih lutanja i probuđenja pa sve do prve propovijedi, odnosno pokretanja kotača nauka. Zanimljivo je da tu odlazak u beskućništvo opisuje konj Kaṇṭhaka. On se, nakon Gautamina odlaska, razbolio od tuge, preminuo i potom se ponovno rodio među nebesnicima, u nebesima Trāyastrimísa, pa Gautamin odlazak čitatelj ima priliku doživjeti i iz perspektive tugujućega konja. ${ }^{213}$

Mv. ii. 195-198 donosi razgovor između Gautame i isposnika Vasișthe. Na Vasișṭino pitanje tko je i što traži, Gautama odgovara:

Mv. ii. 197

ikṣvākuvamśaprabhavaḥ śuddhodananrpātmajaḥ /

vihāya pṛthivīm rājyam ujjhitvā mokșam āsthitah //

lokan tu bahubhir duhkhair dṛștvaivam samabhidrutam /

mokṣārtham abhiniṣkrānto jātivyādhijarādibhị̣ //

\footnotetext{
${ }^{211}$ Nastavak -e(t) u preteritu rijetko se susreće, iako je uobičajen u Mahāvastuu. V. BHSG 32.87-32.90.

${ }^{212}$ Usp. gore prevedeni ulomak iz Sn. 405-408. Za analizu trećega poglavlja Suttanipāte i u njemu sadržanih strofa i njihovih paralela u Mahāvastuu v. Franke (1909).

${ }^{213}$ Kaṇṭhaka se u ulozi pripovjedača nalazi i u Vimānavatthu 81 (Vv. 118).
} 
yatra sarvam na bhavate yatra sarvam nirudhyate / yatropaśāmyate sarvam tat padam prārthayāmy aham //

Prijevod

Potomak sam Ikṣvakua i sin kralja Śuddhodane, Napustiv zemlju i pustiv vlast, spasenje sada tražim ja.

Krenuh za oslobođenjem, vidjev kako je mučen svijet, mnogim patnjama napadan, rađanjem, boljkom, starošću.

Gdje baš ništa ne nastaje i gdje se sve obustavlja, gdje se sve, baš sve smiruje - to mjesto sada tražim ja.

Mv. ii. 299-300 sažima napuštanje doma i odlazak u beskućništvo na svega nekoliko rečenica u kojima se navodi kako je Gautama u trenutku odlaska bio u dobi od dvadeset i devet godina, da je ostavio kraljevstvo, otišao u Magadhu i proveo šest godina u trapnji odlučan da postane Probuđeni.

\subsection{Zaključna razmatranja}

Najvažniji pālijski izvor za proučavanje razdoblja od Gotamina odlaska u beskućnišvo do njegova probuđenja jest Mađđhimanikāya i u njoj sadržane Ariyapariyesanāsutta, Bhayabheravasutta, Dvedhāvitakkasutta i Mahāsaććakasutta. ${ }^{214}$ Dvedhāvitakkasutta sadrži sljedeće Gotamino promišljanje o odlasku u beskućništvo:

MN i. 116

Tassa mayham, bhikkhave, evam appamattassa àtāpino pahitattassa viharato uppajjati nekkhammavitakko. So evam pajānāmi: 'uppanno kho me ayam nekkhammavitakko. So ca kho nevattabyābādhāya saṃvattati, na parabyābādhāya saṃvattati, na ubhayabyābādhāya saṃvattati, pañ̃̄āvuddhiko avighātapakkhiko nibbānasamvattaniko'.

Prijevod

I dok sam tako boravio, trijezan, zažaren i spremna duha, javilo mi se razmišljanje o napuštanju svjetovnoga. Ovako sam uviđao: “Javilo mi se ovo razmišljanje o napuštanju svjetovnoga. Ono ne vodi do pozljeđivanja mene, niti do pozljeđivanja drugih, niti do pozljeđivanja obojih. Ono povećava mudrost, ne uzrokuje muku i vodi do nibbāne.”

\footnotetext{
${ }^{214}$ Usp. Thomas (1927/2000: 229): Of his six years' striving we know only what Majjhima tells us.
} 
Za razliku od Dvedhāvitakkasutte i Bhayabheravasutte u kojima se ne spominje konačni trenutak odlaska u beskućništvo, Ariyapariyesanāsutta i Mahāsaććakasutta donose istovjetan prikaz toga trenutka:

I tako sam, o redovnici, potom, mlad $i$ vrlo tamne kose, obdaren sretnim mladenaštvom, u cvijetu mladosti, usprkos željama oca i majke koji su naricali uplakanih lica, obrijao kosu i bradu i, navukavši žuti ogrtač, otišao od kuće u beskućništvo. ${ }^{215}$

Razlozi za napuštanje doma i odlazak u beskućništvo, a koji se nalaze u spomenutim suttama Mađđhimanikāye, jesu sljedeći: živeći svjetovnim životom, u domaćinstvu, teško je voditi zavjetovani život, tj. život u skladu sa zavjetima pañćasīla, a napuštanje svjetovnoga života ne vodi do muke (vyābādha) već do nibbāne (Dvedhāvitakkasutta), napuštanje svjetovnoga života jedini je način da se dosegne stanje nepodložno starenju, bolesti i propadanju, sloboda od vezanosti, odnosno nibbāna (Ariyapariyesanāsutta).

Među tim suttama biografski ulomci koji se susreću u Ariyapariyesanāsutti predstavljaju, po svem sudeći, najraniji sloj predaje. Pande (1957: 124) tvrdi: [A]n earlier form of this biographical tradition is not discoverable in the canon. ${ }^{216}$ Walters (1999) također smatra da ova sutta predstavlja najraniji sloj predaje, odnosno temeljni predložak na kojega su se oslanjali kasniji životopisi:

[...] this portion of the narrative is repeated almost verbatim at other points in the Tipitaka. The whole narrative is repeated in three other suttas of the Majjhimanikāya while other parallels are found elsewhere in the Tipitaka (some of the narrative has been joined with an early Mārakathā to create the opening of the Mahāvagga of the Pāli Vinaya, while the words uttered to Upaka the Ajivika reappear often in the form of quotation). (Walters 1999: 253)

[...] the use of actual phrases or scenes from NQ [Noble Quest =Ariyapariyesanāsutta $]$ and parallel Majjhimanikāya suttas betrays the reliance of later Buddha biographies on the Pāli or Pālioriginal. (Walters 1999: 255)

U toj je sutti poticaj za napuštanje doma i odlazak u beskućništvo dalo promišljanje o neizbježnosti starenja, oboljevanja i smrti i iz tih promišljanja proistekla je želja za pronalskom puta koji vodi iz kruga ponovnih rođenja. Ipak, treba ukazati i na neke detalje koji ostavljaju mjesta za daljnje propitivanje. Ariyapariyesanāsutta navodi kako je Gotama od kuće otišao vrlo

\footnotetext{
${ }^{215} \mathrm{MN}$ i. $163=\mathrm{MN}$ i. $240=\mathrm{MN}$ ii. $93=\mathrm{DN}$ i. $115=$ Mv. ii. 117 . V. gore.

${ }^{216}$ Usp. i Walters (1999:252, 255), Rhys Davids (1896/1907: 102), Thomas (1927/2000: 62, bilj. 1).
} 
mlad. Prema općeprihvaćenom uvjerenju Gotama je u isposništvo otišao u dobi od dvadesetidevet godina pa naglasak stavljen na Gotaminu mladost izaziva sumnju u čitatelja, ${ }^{217}$ osim ako to pripovijeda Buddha u starosti. Tvrdnja da je otišao "usprkos željama oca i majke" problematična je budući da je u skladu s tradicijom Gotamina majka umrla sedam dana nakon poroda pa je teško mogla stajati uplakanoga lica u trenutku njegova odlaska, dvadestidevet godina kasnije. ${ }^{218}$ Postoji i mogućnost da se misli na pomajku Māhāpađāpatī, a Ježić (usmena napomena) napominje da je moguće da je predaja o smrti Māye nastala nešto kasnije iz dogmatskih ili kakvim mitskim obrascem uvjetovanih razloga. Također, u suttama se Mađđhimanikāye ne spominje da je u trenutku odlaska iza sebe ostavio suprugu i sina. Ipak, svi kasniji životopisi donose podatak da je imao suprugu i sina. Oldenberg (1881/2007: 103) ne dovodi u pitanje istinitost toga podatka ali ostaje otvorena mogućnost da je taj podatak naknadno dodan kako bi se Gotamin odlazak u beskućništvo uskladio s vjerovanjem prema kojem čovjek-domaćin (grhastha) vraća dug (rṇa) pretcima (pitr) kroz ženidbu i rađanje potomstva. U skladu s Manuovim zakonikom tek nakon što "vrati dug" prepustivši domaćinstvo sinu, domaćin se može povući iz života, prestati se brinuti za svjetovno i posvetiti onomu što je dobro ili prikladno za njega. ${ }^{219}$ Minoru Hara (2009: 221) navodi i sljedeće moguće objašnjenje: As a matter of fact, one of the biographies preserved in Chinese says that his marriage is necessary to prove that the Buddha was not an impotent man.

Unutar pālijskoga kanona, Mahāpadānasutta predstavlja sljedeću fazu u razvoju predaje o Gotaminu odlasku u beskućništvo. Tu se jasno vidi kako su promišljanja o neizbježnosti starenja, oboljevanja i umiranja preoblikovana u slikovitu pripovijest o sudbonosnim susretima sa starcem, bolesnikom i mrtvacem. O popularnosti te pripovijesti jasno govori i pažnja koju su autori kasnijih Gotaminih životopisa posvetili upravo ovomu dijelu njegova života. Mahāvastu i potom Nidānakathā slijede u svome temelju Mahāpadānasuttu, međutim oba su ta djela otišla dalje u svome pokušaju da te trenutke oslikaju što življim bojama. Riječi Delehayea (1907: 40): The idea may fade quickly away, but the picture remains [...], mogu se, više negoli i na jednu drugu, primjeniti upravo na ovu epizodu Gotamina života. Budući da je odlazak u beskućništvo

\footnotetext{
217 Doduše, pojedini kineski tekstovi navode da je napustio dom u dobi od devetnaest godina, u: Nakamura (2000/2002: 105, bilj. 68).

218 Također, kada je riječ o odlasku „usprkos željama oca i majke“ zanimljiva je Rațthapālasutta (MN, br. 82). U toj sutti, naime, mladić imenom Rațțhapāla dolazi do Gotame moleći da ga zaredi. Gotama ga pita: "Jesi li, Rațthapālo, dobio dopuštenje od oca i majke da odeš od kuće u beskućništvo?" Rațthapāla odgovara: "Ne, poštovani. Nisam dobio dopuštenje od oca i majke da odem od kuće u beskućništvo." Gotama odbija mladićevu molbu riječima: "Tathāgata, o Raț̣hapālo, ne dopušta odlazak u beskućništvo sinu koji nema dopuštenje oca i majke".

${ }^{219}$ Manu 4. 257, 258 u: Bühler (1886/1969). V. i Burghart (1983: 638).
} 
prvi i kvalificirajući korak na dugom putu do spasenja ili izlaska iz vječnoga kruga ponovnih rođenja, sasvim je razumljiva potreba da se taj trenutak ovjekovječi slikom koja zaokuplja maštu i lako ostaje urezana u sjećanje. Djela kao što su Nidānakathā, Mahāvastu, Lalitavistara i Aśvaghoṣina Buddhaćarita vrlo su jasno naglasila kontrast između svega bogatstva, sjaja i udobnosti koje je budući buddha ostavio za sobom i šest narednih godina koje je proveo u krajnjem siromaštvu i trapljenju. U Mahāvastuu se naglašuje da odlazak nije bio potaknut siromaštvom ili tugom zbog gubitka rodbine i prijatelja, što može biti i ukazivanje na krive razloge za odlazak u isposništvo. ${ }^{220}$ Bez obzira na moguću motivaciju autora koji su prenosili i dodatno kitili ovu epizodu Gotamina života, ostaje činjenica da spomenuti kontrast svakako pridonosi uzvisivanju Gotamina odlaska u beskućništvo. Nidānakathā u svojoj verziji događaja zaostaje donekle u rječitosti i slikovitosti za Mahāvastuom, Lalitavistarom i Buddhaćaritom ali zato sadrži iznimno dopadljivu pripovijest o samom trenutku odlaska u kojoj glavni protagonisti - Gotama, konj Kanthaka i kočijaš Ćhanna, pod okriljem noći i uz svesrdnu pomoć brojnih nebesnika, bježe iz grada. Također, u kasnijim je životopisima naglašeno i Gotamino gađenje spram ženskoga tijela. ${ }^{221}$ Zanimljivo je pritom naglasiti i da u tim životopisima Gotamino gađenje slijedi nakon opisa sudbonosnih susreta s starcem, bolesnikom i mrtvacem i predstavlja zadnju "kap u čaši" prije konačne odluke o napuštanju doma. Tako istaknuto mjesto ovoga dijela pripovijesti sugerira da je seksualnost možda najveća prepreka (ili možda čak bitan razlog/ povod) kada je riječ o napuštanju svjetovnoga života. Čini se da je opisivanje ružnoće i nedoličnosti gola ženskoga tijela i usporedba zaspalih žena s truplima razbacanima po groblju imalo za cilj ne samo učvrstiti redovnike u čuvanju zavjeta čistoće, što je jedan od najvažnijih uvjeta za ostanak u redovničkoj zajednici, već i izazvati sličan osjećaj u onih koji se tek spremaju uzeti utočište u Buddhi, Dhammi i Saṅghi, imajući pritom Gotamu kao najviši ideal.

Ostavivši po strani razloge za napuštanje doma, valja za kraj još jednom istaknuti upadljivu razliku između kanonskih sutta u Mađđhimanikāyi u kojima se navodi jednostavna činjenica da je Gotama, usprkos željama oca i majke, odrezao kosu i bradu, navukao žuti ogrtač i otišao od doma i kasnijih tvorevina koje se susreću u Mahāpadānasutti, Nidānakathi, Mahāvastuu, Lalitavistari i Buddhaćariti. U tim je potonjim prikazima šturi opis kakav se susreće u suttama Mađđhimanikāye zaogrnut dramatičnom i slikovitom pripoviješću u kojoj se, od glasnih hvalospjeva tisuća nebesnika i gomile mirisnih vijenaca i cvjetnoga praha, vrlo teško

\footnotetext{
${ }^{220}$ Mv. ii. 161-163.

${ }^{221}$ Mv. ii. 159, Lv. 206 i d., ĐātA. I. 61, Buddhaćarita V. 48-67.
} 
dolazi do onoga što bi se moglo nazvati povijesnom jezgrom. Oldenberg je (1881/2007: 107), oslanjajući se na neurešeni prikaz kakav se susreće u suttama Mađđhimanikāye, zaključio:

Nužno je da pored živopisnog pjesništva, kojim su kasniji nasljednici oblikovali povijest Buddhina odlaska iz Kapilavatthua, ne zaboravimo ovo malo neukrašenih ruševina onoga što je stariji naraštaj znao o tim stvarima ili mislio da zna.

Preobrazba neukrašena prikaza suočavanja s neizbježnosti starenja, oboljevanja i umiranja kakav se susreće Ariyapariyesanāsutti, vjerojatno najvažnijem izvoru za proučavanje ovoga dijela Gotamina života, u razrađenu, raskošnu i slikovitu pripovijest o četiri kraljevićeva izlaska iz palače i uzbudljivu pripovijest o savladavanju prepreka i bijegu od doma pod budnim okom nebesnika jedan je od najboljih primjera razvoja životopisa i nadogradnje temeljenoga predloška. 


\section{PROBUĐENJE}

\subsection{Probuđenje u pālijskim izvorima}

Napustivši obiteljski dom, Gotama je prešao rijeku Anomu (Anomā) i ostao sedam dana u gaju Anūpiya. ${ }^{222}$ Potom se uputio u magadhsku prijestolnicu Rāđagahu (skt. Rāđagṛha), gdje se je susreo s kraljem Bimbisārom. ${ }^{223}$ Tražeći put izbavljenja pridružio se je prvo učitelju Ālāri Kālāmi (skt. Ārāḍa), ${ }^{224}$ a potom učitelju Uddaki Rāmaputti (skt. Udraka Rāmaputra) ${ }^{225}$. Nezadovoljan postignutim, napustio je vodstvo oba učitelja i zaputio se je u Uruvelu gdje je narednih šest godina ${ }^{226}$ proveo prakticirajući različite vrste trapnja ${ }^{227} \mathrm{u}$ društvu petorice isposnika. Došavši gotovo na rub smrti, odrekao se trapnje. Nidānakathā donosi sažet opis trenutka te odluke.

ĐātA. I. 67

So „Ayam dukkarakārikā nāma bodhāya maggo na hotīti“ oḷārikai் āhārai் āhāretum gāmanigamesu piṇ̣̂āya caritvā āhāraṁ āhāri.

Prijevod

[Pomislivši:] „Ova teška trapnja nije put do probuđenja“, otišao je u sela i trgovišta sakupljati milodare kako bi se nahranio običnom hranom pa se nahranio hranom.

${ }^{222}$ ĐātA. I. 65. U Mv. ii. 166 naselje Anomiya.

${ }^{223}$ Sn. 405-424 (Sn. 3. 1, Pabađđāsutta), ĐātA. I. 65, Vin. i. 35-39 (Mahāvagga, I. 22, 1-16), Buddhaćarita X-XI, Mv. ii. 198-200. Prikaz je toga susreta u Mahāvastuu i Suttanipāti gotovo identičan. Razlika je, međutim da se u Suttanipāti Gotama naziva "Buddha", dok se u Mahāvastuu naziva "Bodhisattva". Nakamura (2000/2002: 121) smatra kako u ranome razdoblju buddhizma nije postojala jasno utvrđena razlika. V. i Rhys Davids, T. W. (1908: 37-38). U Mhv. II. 25 i Dpv. III. 50-57 navodi se kako su Gotama i Bimbisāra bili prijatelji od djetinjstva zahvaljujući poznanstvu svojih očeva. U Mv. ii. 117-121 ne spominje se susret s Bimbisārom.

${ }^{224}$ Buddhaćarita VII. 54 navodi kako je u to vrijeme Ālāra Kālāma boravio u gorju Vindhya (Vindhyakoștha).

${ }^{225}$ Različiti se izvori slažu da je Uddaka Rāmaputta boravio u Rāđagahi. Za Uddaku v. Wynne (2005: 59-61). Za razlikovanje Uddake Rāmaputte i Rāme v. Skilling (1982). O vremenu provedenom s dvojicom učitelja v. MN i. 163-167, Mv ii. 198, 200. Nidānakathā (ĐātA. I. 66) sažima vrijeme provedeno u naukovanju u svega nekoliko rečenica. Vetter (1988: xxii) smatra da se naukovanje pod vodstvom dvojice učitelja ne može smatrati povijesnom činjenicom, usp. i Bronkhorst (2000b: 96), Thomas (1927/2000: 184, 229), Foucher (1949/2003: 96-97). S druge strane, Wynne (2007: 3) tvrdi: [I]t is quite likely that the Bodhisatta really was taught meditation by these two men. Usp. i Walters (1999: 264).

${ }^{226}$ Pojedini izvori spominju sedam godina provedenih u trapnji. V. SN i. 122, Sn. 446.

${ }^{227}$ Za živopisan opis trapnji v. npr. MN i. 242-247, MN i. 16 i d., MN i. 77-82, ĐātA. I. 67, Buddhaćarita XII. 88-97, Mv. ii. 124-130, 231-233. 
Vidjevši da se Gotama odrekao trapnje kao puta spasenja, ${ }^{228}$ petorica su ga isposnika napustila. Gotama se pak uputio prema obali rijeke Nerañđare i pronašao stablo smokve ${ }^{229}$ u čijem će podnožju doživjeti probuđenje ${ }^{230}$. To stablo koje će u buddhističkoj umjetnosti postati simbolom Gotamina probuđenja ne spominje se u suttama Mađđhimanikāye, gdje se navodi samo kako je pronašao ljupko i ugodno mjesto pored rijeke. ${ }^{231}$

Unutar pālijskoga kanona postoje četiri sutte koje donose opis probuđenja i koje se, uz određenu mjeru opreza, mogu smjestiti u prva dva stoljeća nakon Buddhine smrti. To su ranije spomenute Bhayabherava-, Dvedhāvitakka-, Ariyapariyesanā- i Mahāsaććakasutta. ${ }^{232}$ Kasnijega su nastanka opisi u Vinayapiṭaki (Mahāvagaga, I. 1-24) i Mahāpadānasutti koji su se vjerojatno oblikovali do vremena kralja Aśoke. ${ }^{233}$

U Ariyapariyesanāsutti probuđenje je opisano kao stjecanje nepokolebljiva uvjerenja da je dosegnuto što ne stari, ne oboljeva i ne umire, odnosno da je dosegnuta nibbāna.

MN i. 167

So kho aham bhikkhave attanā jātidhammo samāno jātidhamme ādīnavaṃ viditvā ajātam anuttaram yogakkhemam nibbānam pariyesamāno ajātam anuttaram yogakkhemam nibbānam ajjhagamam, attanā jarādhammo samāno jarādhamme ādīnavam viditvā ajarạ̣ anuttaram yogakkhemạ̣ nibbānam pariyesamāno ajaram anuttaram yogakkhemam nibbānam ajjhagamam, attanā byādhidhammo samāno byādhidhamme àdīnavam viditvā abyādhim anuttaram yogakkhemam nibbānam pariyesamāno abyādhim anuttaram yogakkhemam nibbānam ajjhagamam, attanā maraṇadhammo samāno maraṇadhamme ādīnavam viditvā amatam anuttaram yogakkhemam nibbānam pariyesamāno amatam anuttaram yogakkhemam nibbānam ajjhagamam, attanā sokadhammo samāno sokadhamme ādīnavam viditvā asokam anuttaram yogakkhemam nibbānam pariyesamāno asokam anuttarạ̣ yogakkhemam nibbānam ajjhagamam,

\footnotetext{
${ }^{228}$ Npr. MN i. 247, Mv. ii. 130-131.

${ }^{229}$ Assattha (skt. aśvattha), naziva se još i piphala (skt. pippala), Ficus Religiosa, Bhv. XXVI. 20.

${ }^{230}$ Mhv. I. 12 navodi kako je probuđenje dosegao u noći punoga Mjeseca, u mjesecu vesākha (skt. vaiśākha).

${ }^{231}$ MN i. 163, MN ii. 93: ramaṇīyo vata bho bhūmibhāgo, pāsādiko ca vanasaṇụ, nadī ca sandati setakā supatitthā raman̄īyā, samantā ca gocaragāmo. Alam vatidam kulaputtassa padhānatthikassa padhānāyā'ti. Usp. i Mv. ii. 123: tatrādrākșìt vṛsșamūlāni prāsāâjikāni darśan̄ȳāni prāntāni viviktāni vigatavyasanāni vigatajanapadāni manojñahradasayyakāni pratisaṃlayane ārūpyāṇi // samantena ca gocaragrāmāṇi nātidūrāṇi nātyāsannāni āgamanagamanasampannāni samam ca bhūmibhāgaṃ nadīṇ ca nairaṃjanām samām setakạ̄̄ sampannārthām șucisampannatoyām syandamānām dṛșțā ca punaḥ me atīva manah prasāde.

${ }^{232}$ Ulomci Mahāsaććakasutte nalaze se i u MN ii. 209-214 (Sangāravasutta) i MN ii. 91-98

(Bodhirāđakumārasutta). Identičan se opis probuđenja nalazi i u AN iv. 178.

${ }^{233}$ Reynolds (1976: 46).
} 
attanā san்kilesadhammo samāno san்kilesadhamme ādīnavam viditvā asan்kilițtham anuttaram yogakkhemam nibbānam pariyesamāno asañkiliț̣am anuttaram yogakkhemam nibbānam ajjhagamaṃ. Ñānañ-ca pana me dassanam udapādi: Akuppā me vimutti, ayam-antimā jāti, na-tthi dāni punabbhavo ti.

Prijevod

Tako sam, o redovnici, i sam podložan zakonu rađanja, uvidjevši jad u onome što je podložno zakonu rađanja, tražeći rađanju nepodložnu, najvišu, od upregnutosti slobodnu nibbānu, dosegao rađanju nepodložnu, najvišu i od upregnutosti slobodnu nibbānu. I sam podložan zakonu starenja, uvidjevši jad u onome što je podložno zakonu starenja, tražeći starenju nepodložnu, najvišu, od upregnutosti slobodnu nibbānu, dosegao rađanju nepodložnu, najvišu i od upregnutosti slobodnu nibbānu. I sam podložan zakonu bolesti, uvidjevši jad u onome što je podložno zakonu bolesti, tražeći bolesti nepodložnu, najvišu, od upregnutosti slobodnu nibbānu, dosegao rađanju nepodložnu, najvišu $i$ od upregnutosti slobodnu nibbānu. I sam podložan zakonu umiranja, uvidjevši jad u onome što je podložno zakonu umiranja, tražeći umiranju nepodložnu, najvišu, od upregnutosti slobodnu nibbānu, dosegao umiranju nepodložnu, najvišu i od upregnutosti slobodnu nibbānu. I sam podložan zakonu patnje, uvidjevši jad u onome što je podložno zakonu patnje, tražeći patnji nepodložnu, najvišu, od upregnutosti slobodnu nibbānu, dosegao patnji nepodložnu, najvišu i od upregnutosti slobodnu nibbānu. I sam podložan zakonu ukliještenja, uvidjevši jad u onome što je podložno zakonu ukliještenja, tražeći ukliještenju nepodložnu, najvišu, od upregnutosti slobodnu nibbānu, dosegao ukliještenju nepodložnu, najvišu i od upregnutosti slobodnu nibbānu. Pojavilo se u meni znanje i uvid: „Nepokolebljivo je moje oslobođenje. Ovo je posljednje rođenje, nema više ponovnih bivanja!“

U Ariyapariyesanāsutti se nalazi i opis naukovanja pod vodstvom dvojice učitelja koje je prethodilo probuđenju, kao i opis događaja nakon samoga probuđenja (oklijevanje prije odluke o obznanjivanju nauka, silazak Brahmana Sahampatia, pridobivanje i zaređenje petorice isposnika).

Bhayabherava-, Dvedhāvitakka- i Mahāsaććakasutta probuđenje opisuju kao dosezanje četiri stupnja zadubljenja (đhāna, skt. dhyāna) i tri viša znanja (teviđđ̄a, skt. trividyāa). U Bhayabheravasutti opis je probuđenja uklopljen u razgovor o teškoćama života u osami i divljini, a koji se odvija između Gotame i brahmana Đāṇussoṇia u Sāvatthī. Istovjetan se opis 
probuđenja, uklopljen u donekle drugačiji kontekst, nalazi u Dvedhāvitakkasutti ${ }^{234}$ kao i u Mahāsaććakasutti ${ }^{235}$. Niže je izdvojen i preveden ulomak iz Bhayabheravasutte.

MN i. $21-23^{236}$

$\bar{A}$ raddham kho pana me brāhmaṇa viriyam ahosi asallīnam, upațthitā sati asammutțhā, passaddho kāyo asāraddho, samāhitam cittam ekaggaṃ. So kho ahạ̣ brāhmaṇa vivicc' eva kāmehi vivicca akusalehi dhammehi savitakkam savicāram vivekajam pītisukham pațhamam jhānam upasampajja vihāsiṃ; vitakkavicārānam vūpasamā ajjhattam sampasādanam cetaso ekodibhāvam avitakkam avicāram samādhijam pịtisukham dutiyam jhānaṃ upasampajja vihāsiṃ. pītiyā ca virāgā upekhako ca vihāsiṃ sato ca sampajāno sukhañ-ca kāyena pațisaṃvedesim yantam ariyā ācikkhanti: upekhako satimā sukhavihārī ti tatiyam jhānaṃ upasampajja vihāsiṃ; sukhassa ca pahānā dukkhassa ca pahānā pubbe va somanassadomanassānam atthagamā adukkham asukham upekhāsatipārisuddhim catuttham jhānam upasampajja vihāsiṃ. So evam samāhite citte parisuddhe pariyodāte anaìgaṇe vigatūpakkilese mudubhūte kammaniye thite ānejjappatte pubbenivāsānussatiñāṇāya cittam abhininnāmesiṃ. So anekavihitam pubbenivāsam anussarāmi, seyyathīdam: ekam-pi jātim dve pi jātiyo tisso pi jātiyo catasso pi jātiyo pañca pi jātiyo dasa pi jātiyo vīsatim-pi jātiyo timsam-pi jātiyo cattārīsam-pi jātiyo pañ̃̄āsam-pi jātiyo jātisatam-pi jātisahassam-pi jātisatasahassampi, aneke pi samvatțakappe aneke pi vivațtakappe aneke pi samvațavivațtakappe; amutr' āsị̣ evannāmo evamgotto evamvaṇno evamāhāro evam sukhadukkhapațisamved̄̄ evamāyupariyanto, so tato cuto amutra udapādim, tatra $p^{\prime}$ āsim evannāmo evamgotto evaṃvaṇno evamāhāro evam sukhadukkhapațisamvedī evamāyupariyanto, so tato cuto idhūpapanno ti. Iti sākāram sa-uddesaṃ anekavihitạ̣ pubbenivāsaṃ anussarāmi. Ayam kho me brāhmaṇa rattiyā pațhame yāme pațamā vijjā adhigatāa avijjā vihatā vijjā uppannā, tamo vihato āloko uppanno, yathā tam appamattassa ātāpino pahitattassa viharato. So evam samāhite citte parisuddhe pariyodāte anañgaṇe vigatūpakkilese mudubhūte kammaniye thite ānejjappatte sattānam cutūpapātañānāya cittam abhininnāmesim.

\footnotetext{
${ }^{234} \mathrm{MN}$ i. $117-118$.

${ }^{235} \mathrm{MN}$ i. 247-250.

${ }^{236}$ Usp. DN i. $73-84$, DN i. 209, MN i. $182-184$, MN i. $347-348$, AN i. 163 i d., AN ii. 211 i d.
} 
So dibbena cakkhunā visuddhena atikkantamānusakena satte passāmi cavamāne upapajjamāne, hīne paṇite suvaṇne dubbaṇne sugate duggate, yathākammūpage satte pajānāmi [...] Ayaṇ kho me brāhmaṇa rattiyā majjhime yāme dutiyā vijjā adhigatā, avijjā vihatā vijjā uppannā, tamo vihato āloko uppanno, yathā tam appamattassa àtāpino pahitattassa viharato. So evam samāhite citte parisuddhe pariyodāte anangaṇe vigatūpakkilese mudubhūte kammaniye thite ānejjappatte āsavānam khayañāṇāya cittam abhininnāmesiṃ. So idam dukkhan-ti yathābhūtam abbhaññāsim, ayam dukkhasamudayo ti yathābhūtam abbhaññassim. ayam dukkhanirodho ti yathābhūtam abbhaññāsiṃ. Tassa me evam jānato evam passato kāmāsavā pi cittam vimuccittha. bhavāsavā pi cittam vimuccittha.

avijjāsavā pi cittam vimuccittha, vimuttasmim vimuttam-iti ñānam ahosi; khịnā jāti, vusitam brahmacariyam, katam karaṇīyam nāparạ̣ itthattāyāti abbhaññāsiṃ. Ayam kho me brāhmaṇa rattiyā pacchime yāme tatiy $\bar{a}$ vijjā adhigatā, avijjā vihatā vijjā uppannā, tamo vihato āloko uppanno, yathā tam appamattassa àtāpino pahitattassa viharato.

\section{Prijevod}

Moja smionost, o brahmane, postade odlučna i nepokolebljiva, moja pozornost prisutna i jasna, tijelo mirno i spokojno, a svijest sabrana i usredotočena. Potom sam, o brahmane, odijeljen od želja i odijeljen od nedobrih predmeta misli dosegao prvo zadubljenje [koje prate] razabiranje, razumijevanje $i$ radost $i$ sreća proistekle iz razlučivanja $i$ u njem boravio. Umirenjem razabiranja i razumijevanja dosegao sam drugo zadubljenje [koje prate] unutarnja staloženost svijesti, usredotočenost, odsutnost razabiranja $i$ razumijevanja, radost $i$ sreća proistekle iz zadubljenja $i$ u njem boravio. Oslobođen žudnje za radošću, boravio sam ravnodušan, svjestan i pozoran, pa osjetih zadovoljstvo tijela. Dosegao sam treće zadubljenje, [zadubljenje] za koje plemeniti kažu: "Boravi u sreći ravnodušan i pozoran “, i u njem boravio. S otpuštanjem sreće i otpuštanjem patnje prije toga, pa zalaskom tuge i zadovoljstva, dosegao sam četvrto zadubljenje, oslobođeno sreće i patnje, pročišćeno ravnodušnošć i pozornošću i u njemu boravio.

I onda, kada je moja usredotočena svijest postala pročišćena, jasna, neumrljana, neprikliještena, omekšana, podatna, postojana i staložena, usmjerio sam [ju] prema spoznaji sjećanja na ranije živote. Sjetio sam se, tada, mnogovrsnih ranijih života, odnosno - jedno rođenje, dva rođenja, tri rođenja, četiri rođenja, pet rođenja, deset rođenja, dvadeset rođenja, trideset rođenja, četrdeset rođenja, pedeset rođenja, stotinu 
rođenja, tisuću rođenja, stotinu tisuća rođenja u mnogobrojnim razdobljima nastajanja svijeta, u mnogobrojnim razdobljima nestajanja svijeta, u mnogobrojnim razdobljima nastanka i nestanka svijeta. Tamo sam se tako i tako zvao, bio takva i takva podrijetla, takva i takva staleža, takve i takve ishrane, takvo je i takvo bilo moje iskustvo sreće i tuge, takva je i takva bila duljina moga života, a tu preminuvši ondje sam se rodio. I tu sam se tako i tako zvao, bio takva i takva podrijetla, takva i takva staleža, takve i takve ishrane, takvo je i takvo bilo moje iskustvo sreće i tuge, takva je i takva bila duljina moga života, a tu preminuvši ovdje sam se rodio. Sjetio sam se, dakle, raznovrsnih ranijih života s njihovim obilježjima i pojedinostima. Tako mi je, o brahmane, u prvome dijelu noći došlo prvo znanje; neznanje je poraženo i pojavilo se znanje, poražena je tama i pojavila se svjetlost, kako biva kad se ostaje nepomućen, revan i odlučna duha.

I onda, kada je moja usredotočena svijest postala pročišćena, jasna, neumrljana, neprikliještena, omekšana, podatna, postojana i staložena, usmjerio sam [ju] prema spoznaji nestanka pa ponovnih rađanja bića. Vidio sam pročišćenim božanskim vidom koji nadilazi ljudski umiruća i iznova nastajuća bića, bijedna i uzvišena, lijepa i ružna, sretnih i nesretnih sudbina. Razumio sam kako bića bivaju podvrgnuta posljedicama svojih djela [...] Tako mi je, o brahmane, u središnjem dijelu noći došlo drugo znanje; neznanje je poraženo i pojavilo se znanje, poražena je tama i pojavila se svjetlost, kako biva kad se ostaje nepomućen, revan i odlučna duha.

I onda, kada je moja usredotočena svijest postala pročišćena, jasna, neumrljana, neprikliještena, omekšana, podatna, postojana i staložena, usmjerio sam [ju] prema spoznaji poništenja priljeva. ${ }^{237}$ "To je patnja”- spoznao sam ju kakva jest, "to je uzrok patnje” - spoznao sam ga kakav jest, "to je nestanak patnje” - spoznao sam ga kakav jest, “to je put koji vodi do nestanka patnje” - spoznao sam ga kakav jest.

Kad sam tako spoznao i tako vidio, moja se je svijest oslobodila priljeva žudnja, oslobodila se je priljeva bivanja, oslobodila se je priljeva neznanja. Kada se [um] oslobodio pojavilo se znanje: "Oslobođena je u [meni] oslobođenome”. Spoznao sam: "Iscrpljeno je rađanje, ispunjen je zavjetovani život, učinjeno je što je trebalo biti

\footnotetext{
${ }^{237} \bar{A}$ sava, skt. āsrāva, [...] certain specified ideas which intoxicate the mind (bemuddle it, befoozle it, so that it cannot rise to higher things). Freedom from the 'Asavas' constitues Arhantship, \& the fight for the extinction of these a savas forms one of the main duties of man. ", PED, str. 114-115. Za detaljnije v. Schmithausen (1992: 123129).
} 
učinjeno, nema više dolaska u ovdašnjost”. Tako mi je, brahmane, u zadnjem dijelu noći došlo treće znanje; neznanje je poraženo i pojavilo se znanje, poražena je tama i pojavila se svjetlost, kako biva kad se ostaje nepomućen, revan i odlučna duha.

Valja napomenuti da se ni u jednoj od ove četiri ranije sutte ne spominje susret s Mārom, ni da je sam trenutak obilježen pojavom natprirodnih ili čudesnih događaja. Probuđenje je jasno definirano kao savladavanje četiriju stupnjeva zadubljenja, ${ }^{238}$ potpuno razumijevanje triju viših znanja i svijest o konačnom izlasku iz kruga života, patnje i smrti.

U Vinayapiṭaki, točnije na početku Odsječaka (Khandhaka, skt. Skandhaka) nalazi se prikaz Gotamina života od događaja neposredno nakon probuđenja pa do obraćenja Sāriputte i Moggallāne. To je ujedno i jedna od najdužih pripovijesti o životu Gotame koja se susreće u prve dvije zbirke pālijskoga kanona. Iako nije cjelovita, ipak predstavlja svojevrsni pokušaj sistematiziranja događaja koji su uslijedili nakon probuđenja. Na samome se početku toga prikaza probuđenje opisuje kao potpuno razumijevanje dvanaest karika lanca uvjetovanoga nastanka. $^{239}$

Vin. i. 1-2 (Mahāvagga I. 1. 1-7) $)^{240}$

Tena samayena buddho bhagavā Uruvelāyam viharati najjā Nerañjarāya tīre bodhirukkhamūle pathamābhisambuddho. atha kho bhagavā bodhirukkhamūle sattāham ekapallaìkena nisīdi vimuttisukhapațisamvedī. ||1 || atha kho bhagavā rattiyā paṭhamam yāmam paṭiccasamuppādam anulomapațilomam manas' ākāsi: avijjāpaccayā saṃkārāā, saṃkhārapaccayā viñ̃āṇam, viñ̃āñapaccayā nāmarūpam, nāmarūpapaccayā salāayatanam, saḷayatanapaccayā phasso, phassapaccayā vedanā, vedanāpaccayā tanhhā, taṇhāpaccayā upādānam, upādānapaccayā bhavo, bhavapaccayā jāti, jātipaccayā jarāmaranam sokaparidevadukkhadomanassupāyāsā sambhavanti. evam etassa kevalassa dukkhakkhandhassa samudayo hoti. avijjāya tv eva asesavirāganirodhā saṃkhāranirodho, saṃkhāranirodhā viñ̃āṇanirodho, viññānanirodhā nāmarūpanirodho, nāmarūpanirodhā saḷayatananirodho, saḷāyatananirodhā

\footnotetext{
${ }^{238}$ U opisu probuđenja u Ariyapariyesanāsutti ne opisuju se četiri stupnja zadubljenja ni tri viša znanja. Ipak, četiri su stupnja zadubljenja u toj sutti opisana u pouci koju Gotama daje petorici isposnika u Isipatanu. Za pobliže određenje pojma đhāna (skt. dhyāna) v. Cousins (1973) u: Williams (ur.).

${ }^{239} \mathrm{Na}$ pojedinim se mjestima u kanonu ovih dvanaest karika nalazi uklopljeno u nauk o četiri plemenite istine kao što je to primjerice u AN i. 177. V. i SN ii. 1-4. V. Vetter (1988: 45 i d.).
}

${ }^{240}$ Gotovo se identičan opis nalazi i u Ud. 1-3. Za usporedbu oba teksta v. Nakamura (2000/2002: 198-212). 
phassanirodho, phassanirodhā vedanānirodho, vedanānirodhā tạnhānirodho, tạnhānirodhā upādānanirodho, upādānanirodhā bhavanirodho, bhavanirodhā jātinirodho, jātinirodhā jarāmaraṇam sokaparidevadukkhadomanassupāyāsāa nirujjhanti. evam etassa kevalassa dukkhakkhandhassa nirodho hotīti. ||2|| atha kho bhagavā etam attham viditvā tāyam velāyam imam udānam udānesi: yadā have pātubhavanti dhammā àtāpino jhāyato brāhmanassa ath' assa kañkhā vapayanti sabbā yato pajānāti sahetudhamman ti. ||3|| atha kho bhagavā rattiyā majjhimam yāmam pațiccasamuppādam anulomapaṭilomam manas'; ākāsi: avijjāpaccayā saṃkhārā, saṃkhārapaccayā viññānam, viñ̃̃annapaccayā nāmarūpam --la-- evam etassa kevalassa dukkhakkhandhassa samudayo hoti --pa-- nirodho hotīti. ||4|| atha kho bhagavā etam attham viditvā tāyam velāyam imam udānam udānesi: yadā have pātubhavanti dhammā àtāpino jhāyato brāhmaṇassa ath'; assa kan்khā vapayanti sabbā yato khayam paccayānam avedīti. $\|5\|$ atha kho bhagavā rattiyā pacchimam yāmam pațiccasamuppādam anulomapaṭilomam manas'; ākāsi: avijjāpaccayā saṃkhārā, saṃkhārapaccayā viñ̃ānam --gha-- evam etassa kevalassa dukkhakkhandhassa samudayo hoti --pa-- nirodho hotīti. $\| 6||$ atha kho bhagavā etam attham viditvā tāyam velāyam imam udānam udānesi: yadā have pātubhavanti dhammā àtāpino jhāyato brāhmaṇassa vidhūpayam tiț̣hati Mārasenam suriyo 'va obhāsayam antalikkhan ti. ||7||

Prijevod

$U$ to je vrijeme blaženi Buddha, netom probuđeni, boravio u Uruveli, na obali rijeke Nerañjare, u podnožju stabla bodhi. Sjedio je Blaženi sedam dana prekriženih nogu, $u$ podnožju stabla bodhi $i$ uživao u blaženstvu oslobođenja. Potom je Blaženi, u prvome dijelu noći, unaprijed $i$ unazad, razložio lanac uvjetovanoga nastanka:

Neznanje uvjetuje ustrojnice, ustrojnice uvjetuju svijest, svijest uvjetuje ime i oblik, ime $i$ oblik uvjetuju šest osjetila, ${ }^{241}$ šest osjetila uvjetuju dodir[osjetila i predmeta], dodir uvjetuje osjećaj, osjećaj uvjetuje žeđ, žeđ uvjetuje prianjanje, prianjanje uvjetuje postanak, postanak uvjetuje rođenje, rođenje uvjetuje pojavljivanje starosti, smrti, tuge, oplakivanja, patnje, jada i nemira. U tome je rast svekolika debla patnje.

Ali, s potpunim zaustavljanjem i odricanjem od neznanja zaustavljaju se ustrojnice, sa zaustavljanjem ustrojnica zaustavlja se i svijest, sa zaustavljanjem svijesti zaustavljaju se

\footnotetext{
${ }^{241}$ Pet osjetila i razum.
} 
ime $i$ oblik, sa zaustavljanjem imena $i$ oblika zaustavlja se $i$ šest osjetila, sa zaustavljanjem šest osjetila zaustavlja se i dodir, sa zaustavljanjem dodira zaustavlja se i osjećaj, sa zaustavljanjem osjećaja zaustavlja se žeđ, sa zaustavljanjem žeđi zaustavlja se prijanjanje, sa zaustavljanjem prijanjanja zaustavlja se i postajanje, sa zaustavljanjem postojanja zaustavlja se rođenje, sa zaustavljanjem rođenja zaustavljaju se starost, smrt, tuga, oplakivanje, patnja, jad i nemir. $U$ tome je zaustavljanje svekolika debla patnje. $U$ trenutku u kojem je razumio smisao [toga lanca uvjeta], Blaženi je, nadahnuto, obznanio:

\footnotetext{
"Kada se otkriju predmeti znanja

Revnu, usredotočenu brahmanu,

Raspršuju se sve njegove sumnje jer spoznaje predmete s uzrocima."
}

Potom je Blaženi, u središnjem dijelu noći, unaprijed $i$ unazad, razložio lanac uvjetovanoga nastanka: Neznanje uvjetuje ustrojnice, ustrojnice uvjetuju svijest, svijest uvjetuje ime i oblik... U tome je rast svekolika debla patnje... u tome je zaustavljanje... $U$ trenutku u kojem je razumio smisao [toga lanca uvjeta], Blaženi je, nadahnuto, obznanio:

\footnotetext{
"Kada se otkriju predmeti znanja

Revnu, usredotočenu brahmanu,

Raspršuju se sve njegove sumnje

jer spoznaje ustavljanje uvjeta."
}

Potom je Blaženi, u posljednjem dijelu noći, unaprijed $i$ unazad, razložio lanac uvjetovanoga nastanka: Neznanje uvjetuje ustrojnice, ustrojnice uvjetuju svijest, svijest uvjetuje ime i oblik... U tome je izvor svekolika polja patnje... u tome je zaustavljanje... $U$ trenutku u kojem je razumio smisao [toga lanca uvjeta], Blaženi je, nadahnuto, obznanio:

\footnotetext{
"Kada se otkriju predmeti znanja

Revnu, usredotočenu brahmanu,

Stoji, raspršuje Mārinu vojsku

kao što Sunce obasjava sav zrak.”
}

Kada je riječ o prvim riječima koje Gotama izgovara nakon probuđenja zanimljivo je da se u Mahāvastuu u jednom od prikaza probuđenja stavlja naglasak ne na samu spoznaju već na zasluge prikupljene u mnogobrojnim prijašnjim životima koje će u kasnijem buddhizmu postati 
iznimno važan uvjet za postizanje konačna oslobođenja. ${ }^{242} \mathrm{~S}$ druge strane, u Mv. ii. 416-117 nalaze se tri strofe identične onima u pālijskoj Vinayi s tom razlikom da postoji i četvrta u kojoj se, također, uzdiže stjecanje zasluga kroz mnogobrojne egzistencije, a koje dovode do savršena mira.

Na ovome mjestu nije potrebno ulaziti dublje u samu narav ili sadržaj dvanaest karika lanca uvjetovanoga nastanka, ali valja istaknuti da razrađen i sistematiziran sustav dvanaest karika svjedoči, po mišljenju istraživača, o relativno kasnom postanku prikaza probuđenja kakav se susreće u Vinayapiṭaki.

U Vinayapițaki, nakon opisa probuđenja, slijedi pripovijest o preobraćenju dvojice laika, Tapusse i Bhallike, kao i pripovijesti o Gotaminu oklijevanju da propovijeda i silasku vrhovnoga boga Brahmana Sahampatia da ga nagovori da poučava što je spoznao. Za razliku od pripovijesti u Vinayi, u Ariyapariyesanāsutti oklijevanje i pojava Brahmana Sahampatia slijede odmah nakon opisa probuđenja dok se preobraćenje dvojice laika ne spominje. ${ }^{243}$ Također, u suttama Mađđhimanikāye nema spomena o nekoliko tjedana koji se spominju u Vinayapițaki, a koje je Probuđeni proveo pod različitim stablima uživajući u blaženstvu svoje spoznaje.

Mahāpadānasutta opisuje probuđenje (doduše buddhe Vipassina) kao jasno razumijevanje lanca uvjetovanoga nastanka. $U$ tome se lancu ne spominju neznanje ni ustrojnice, pa je karika deset.

\section{DN ii. $34-35$}

Atha kho bhikkhave Vipassissa Bodhisattassa etad ahosi: "Adhigato kho myāyam vipassanā-maggo bodhāya, yadidạ̣ nāmarūpa-nirodhā viññāna-nirodho, viñ̃āṇanirodhā nāmarūpa-nirodho, nāmarūpa-nirodhā saḷayatana-nirodho, saḷayatana-nirodhā phassa-nirodho, phassa-nirodhā vedanā-nirodho, vedanā-nirodhā taṇhānirodho, tanhhānirodhā upādāna-nirodho, upādāna-nirodhā bhava-nirodho, bhava-nirodhā jātinirodho, jāti-nirodhā jarā-maraṇam soka-parideva-dukkha-domanass-upāyāsā nirujjhanti, evam etassa kevalassa dukkha-kkhandhassa nirodho hoti.

\footnotetext{
${ }^{242}$ V. niže. V. i Thomas (1927/2000: 76-77).

${ }^{243} \mathrm{MN}$ i. $168-170$.
} 
"Nirodho nirodho ti" kho bhikkhave Vipassissa Bodhisattassa pubbe ananussutesu dhammesu cakkhum udapādi, ñānam udapādi, pañ̃̄ā udapādi, vijjā udapādi, āloko udapādi.

Prijevod

Potom je, o redovnici, ovako pomislio buddha Vipassin: "Pronašao sam put koji, kroz razmatranje, vodi do probuđenja, što znači: sa zaustavljanjem imena i oblika zaustavlja se svijest, sa zaustavljanjem svijesti zaustavljaju se ime i oblik; sa zaustavljanjem imena i oblika zaustavlja se šest polja osjetila; sa zaustavljanjem šest polja osjetila zaustavlja se $i$ dodir[osjetila i predmeta]; sa zaustavljanjem dodira zaustavlja se i osjećaj; sa zaustavljanjem osjećaja zaustavlja se $i$ žeđ; sa zaustavljanjem žeđi zaustavlja se $i$ prianjanje; sa zaustavljanjem prianjanja zaustavlja se i postajanje; sa zaustavljanjem postajanja zaustavlja se i rođenje; sa zaustavljanjem rođenja zaustavljaju se $i$ starost $i$ umiranje, zaustavljaju se tuga, oplakivanje, patnja, jad i nemir. Tako dolazi do zaustavljanja toga cijeloga debla patnje”.

“Zaustavio je! Zaustavio je!” - dosegao je, o redovnici, buddha Vipassin Vid, Znanje, Proznaju, Uvid i Gledanje prije nečuvenih predmeta spoznaje.

Mahāpadānasutta u cijelosti ignorira popularnu epizodu o Māri, ali donosi opis silaska i molbe Mahābrahmana, o čem će riječi biti u sljedećem poglavlju.

Za razliku od ostatka pālijskoga kanona, u Nidānakathi je sasvim očigledno da su filozofska pozadina ili sadržaj probuđenja pali u drugi plan naspram potrebe da se pripovijest o Gotaminu probuđenju iznese što je moguće živopisnije. U Nidānakathi nema mjesta za filozofska razmatranja i detaljne raščlambe ključnih pojmova buddhističke misli, što dovoljno govori o naravi djela. Ono, naime, očigledno nije služilo obrazovanju ili upućivanju slušatelja/čitatelja u ključne pojmove buddhističkoga nauka, već, između ostaloga, poticanju (vjerskoga) zanosa i oduševljenja spram lika Velikoga učitelja čiji život, ukoliko njime želimo nekoga zapanjiti, ne može biti drugačiji već satkan od guste mreže natprirodnih i čudesnih događaja. Dovoljno je reći da je sâm sadržaj probuđenja u Nidānakathi sveden na svega nekoliko redaka naspram petnaestak stranica Rhys-Davidsova prijevoda događaja koji su ga okružili.

ĐātA. I. 75 
Evam dharamāne yeva suriye Mahāpuriso Mārabalam vidhametvā cìvarüparipatamānehi bodhirukkhamkurehi rattapavāladalehi viya püjayamāno pațame yāme pubbenivāsañānam majjhimayāme dibbacakkhum visodhetvā pacchimayāme pațiccasamuppāde ñāṇam otāresi. Ath' assa dvādasapadikam paccayākāram vațtavivațtavasena anulomapațilomato sammasantassa sammasantassa dasasahassilokadhātu udakapariyantaì katvā dvādasakkhattuṁ samkkampi.

Prijevod

Sunce još bilo na obzoru kada je veliki junak natjerao u bijeg Mārine snage. I dok su ga izdanci stabla bodhi častili sipajući po [njegovu] ogrtaču latice crvene poput koralja, dosegao je, u prvome dijelu noći znanje o prethodnim životima. U središnjem dijelu noći pročistio je Božanski vid, a u posljednjem je dijelu noći dosegao znanje o uvjetovanom nastanku. Kada je on potpuno razumio oblik uvjetovanosti u dvanaest koraka, slijedeći ga i vraćajući se, unaprijed i unazad, [svemir od] deset tisuća svijetova zatresao se je dvanaest puta, sve do ruba mora.

Slijedi opširan opis čudesnih pojava koje su popratile probuđenje, a završetak epizode o probuđenju i ujedno druge knjige u kojoj se pripovijedaju događaji "iz ne tako daleke prošlosti” jest sljedeći:

ĐātA. I. 76

Evam aparimānena sirivibhavena püjayamāne nekappakāresu acchariyadhammesu pātubhūtesu sabbaññutañ̃̄ānam pațivijjhitvā sabbabuddhānam avijahitam udānam udānesi:

anekajātisamsāram

sandhāvissam anibbisam

gahakārakam gavesanto,

dukkhā jāti punappunaim. (278)

Gahakāraka ditțho si, Puna gahaì na kāhasi,

Sabbā te phāsukā bhaggā,

gahakūtam visamkhitam, visamikhāragatam cittaim 
taṇhānaṁ khayam ajjhagā ti $(279)^{244}$

\title{
Prijevod
}

Kada su se očitovale mnoge i raznovrsne čudesne pojave kojima je štovan, uz neizmjeran je sjaj i krasotu dosegao sveznanje i nadahnuto, kao i svaki buddha [prije njega], izjavio:

\author{
“Krugom bezbrojnih rođenja \\ lutao sam tražeći al' \\ ne nalazeć' tvorca kuće. \\ Stalna rođenja patnja su. \\ O tvorče kuće, spazih te! \\ Nećeš opet gradit' kuću! \\ Grede su ti sve slomljene, \\ I središnji stup prelomljen. \\ Um nadide ustrojnice \\ I dođe do kraja žudnje."
}

Za razliku od samoga probuđenja, kojemu se u Nidānakathi posvećuje svega nekoliko gore prevedenih redaka, događajima koji su mu prethodili posvećeno je mnogo više pažnje. Među njima valja istaknuti pripovijest o Suđāti koja slijedi odmah nakon rečenice u kojoj se kazuje kako su petorica isposnika napustila Gotamu te služi kao uvod u događaje neposredno prije probuđenja. ${ }^{245}$ Nidānakathā kazuje kako je djevojka imenom Suđātā, izvršavajući ranije dan zavjet, pripremila hranu i odnijela ju Gotami koji je sjedio u podnožju stabla, zamijenivši ga pritom za šumsko božanstvo. Pripremu hrane nadziru sami nebesnici i cijeli je proces obilježen brojnim natprirodnim očitovanjima pa je Suđātā primorana ustvrditi da nikada nije vidjela toliko čudesa u jednom danu. Zlatnu posudu koju je primio od te djevojke Gotama nakon jela baca u rijeku tražeći da, ukoliko će zaista postati Probuđeni, otpluta uzvodno. Putujući uzvodno, posuda stiže do palače Kāḷe Nāgarāđe koji, čuvši da Gotamina posuda udara u posude prijašnjih buddha, izjavljuje: "Jučer se pojavio buddha, danas se opet pojavljuje". ${ }^{246}$ Pripovijest se o Suđāti ne nalazi unutar pālijskoga kanona ${ }^{247}$ ali, s obzirom na istaknutost ove epizode u sklopu

\footnotetext{
${ }^{244}$ Usp. Dhmp. 153, 154, Thag. 183, 184.

${ }^{245}$ U Mv. ii. 205 navodi se kako je Sujātā u svojim prethodnim životima bila Gautamina majka. V. i Mv. ii. 263, 299. Lv. 265 donosi imena deset djevojka koje su služile Gautamu, među kojima je i Suđātā.

246 ĐātA. I. 70.

${ }^{247}$ Njezino se ime, međutim, spominje u AN i. 26.
} 
opisa probuđenja, valja pretpostaviti da je, u kasnijem razdoblju u razvoju buddhizma, imala važnu svrhu. Naime, darivanje hrane temeljni je uvjet opstanka svih onih koji su se odlučili za život isposnika, pa tako i redovničke zajednice u cjelini. Naglašavanje činjenice da je Gotama doživio probuđenje zahvaljujući između ostaloga i okrijepi koja je stigla iz Suđātinih ruku podsjeća na važnost takva darivanja. ${ }^{248}$ Penner (2009: 203) smatra kako je ova epizoda ključna za razumijevanje temelja redovničke zajednice, kao i kasnijega stavljanja naglaska na nužnost darivanja zajednice u zamjenu za dobre zasluge. Penner dalje naglašava kako Gotamina "karijera" i započinje i završava primanjem obroka od laika:

If Sujata's gift marks the beginning of the Buddha's Awakening, Cunda's invitation to a meal marks the end of the Buddha's enlightened life. [...] The point of this focus on Sujata and Cunda is that the "origin" of Buddhism from this point of view stresses two legendary events that involve the giving of a gift, in this instance the gift of a meal, "more fruitful than any other."

\subsection{Probuđenje u Mahāvastuu}

Gautamino je probuđenje u prve dvije knjige Mahāvastua opisano na nekoliko mjesta. ${ }^{249}$ Pripovijesti su, u pravilu, duge, zamršene i ispresjecane digresijama, a čitanje dodatno otežavaju brojna ponavljanja, čas u prozi, čas u stihovima. Opis naravi samoga probuđenja u drugome je planu budući da najveći dio, kada je riječ o opisu događaja koji ga okružuju, zauzimaju nabrajanja Gautaminih odlika i savršenstava, opisi Mārinih pokušaja da onemogući Gautamu u dosezanju cilja kao i hvalospjevi bezbrojnih nebesnika koji slave središnji trenutak Gautamina života.

U Mv. i. 228-231 opis je probuđenja pripisan buddhi Dīpaṃkari. Probuđenje se opisuje kao savladavanje četiri stupnja zadubljenja i dosezanje triju viših znanja pa sadržajno odgovara pojedinim, gore navedenim, ulomcima iz pālijskoga kanona.

Četiri se zadubljenja i tri viša znanja nalaze opisani i u Mv. ii. 131-133. Na tu se pripovijest nadovezuju opisi snova ili vizija koje su, neposredno prije probuđenja, imali

\footnotetext{
${ }^{248}$ U Nidānakathi (ĐātA. I. 71) postoji još jedan primjer u kojem se naglašava uloga laika u Gotaminom dosezanju Probuđenja. Naime, nakon što se osvježio u rijeci, Gotama se uputio prema stablu bodhi. Na putu je prema tomu stablu susreo kosca imenom Sotthiya koji mu je ponudio osam snopova otkošene trave kako bi si Gotama napravio sjedalo. Gotama prima taj skromni dar koji će se, čudesno i sam od sebe, poslužiti u golemo prijestolje koje "ne bi mogao izraditi ni najvještiji obrtnik". Sotthiya se spominje na nekoliko mjesta i u Mahāvastuu (Mv. ii. 131, 264, 399) pod imenom Svāstika Yāvasika. U Lv. 286-289 se iznosi podulji razgovor između Gautame i Svāstike u kojem Gautama obećava da će čim dosegne probuđenje javno obznaniti put koji vodi do oslobođenja.
}

${ }^{249}$ Mv. i. 228-231, ii. 131-133, 263-271, nastavak u 276-288, 300-349, 397-420. 
Śuddhodana, Yaśodharā i sam Gautama. Gautama je imao pet snova koji se susreću i u pālijskim izvorima. ${ }^{250}$

Najdetaljniji se opis probuđenja nalazi u Mv. ii. 283-287, ${ }^{251}$ uklopljen u izlaganje Prve Avalokitasūtre. ${ }^{252}$ Opis Gautamina i probuđenja buddhe Dīpaṃkare gotovo je u cijelosti identičan. Međutim, dok u opisu probuđenja buddhe Dīpạ̣kare nakon opisa četiri stupnja zadubljenja i sadržaja triju viših znanja slijedi opis čudesa i radosti koja je zavladala u svijetu nebesnika, tu se opis Gautamina probuđenja nastavlja izlaganjem četiriju plemenitih istina i karika lanca uvjetovanoga nastanka.

Mv. ii. 284-286

atha khalu bhikṣavo abhīto acchambhī vigatabhayaromaharṣo rātryā paścime yāme aruṇodghātasamaye nandīmukhāyām rajanyām yat kị̣cit puruṣeṇa satpuruṣeṇa mahāpuruṣeṇa puruṣarṣabheṇa puruṣadravyeṇa puruṣaśūrena puruṣavīreṇa puruṣanāgena puruṣasiṃhena puruṣapadumena puruṣakumudena puruṣapuṇdarīkena purușājāneyena puruṣadhaureyeṇa anuttareṇa puruṣadamyasārathinā nikrāntena vikrāntena parākrāntena arthikena apramattena

(2.285) ātāpinā prahitātmena vyapakṛștena viharantena gatimatānusmṛtidhṛtimatā buddhimatā prajñāmatā sarvaśo sarvatratāye jñātavyam prāptavyam boddhavyam abhisaṃboddhavyam sarvantam ekacittakșaṇasamāyuktayā prajñayā anuttarām samyaksambodhim abhisaṃbuddhe / sayyathīdam idam duḥkham ayam duḥkhasamudayo ayam duḥkhanirodho ayam duhkhanirodhagāmin̄̄ pratipat ${ }^{253}$ / ime āśravā imo àśravasamudayo ayam āśravanirodho ayaṃ àśravanirodhagāmin̄̄ pratipat / iha àśravā aśeșā niravaśeșā nirudhyanti vyupaśāmyanti prahāṇam astamgacchanti / yad idam imasya sato idam bhavati imasya asato idam na bhavati / imasyotpādād idam utpadyate / imasya nirodhād idam nirudhyati iti pi / avidyāpratyayāh saṃskārāh saṃskārapratyayam vijñānam vijñānapratyayam nāmarūpam nāmarūpapratyayam șaḍāyatanam ṣaḍ̄yatanapratyayam sparśah sparśapratyayā vedanā vedanāpratyayā

\footnotetext{
${ }^{250}$ AN iii. 240 i ĐātA. I. 69. Epizoda se susreće i u Lv. 194 i d. Detaljnije o epizodi u Saṅghabhedavastuu Vinaye mūlasarvāstivādina u: Strong (1997: 115-116).

${ }^{251}$ Usp. gore prevedeni ulomak: MN i. 21-23.

${ }^{252}$ U Mahāvastuu postoje dvije Avalokitasūtre (Mv. ii. 257-271, nastavak u ii. 276-294 i Mv. ii. 294-398). U prvoj je naglasak stavljen na Gautaminu pobjedu nad Mārom, dok je druga sūtra posvećena opisivanju Buddhinih vrlina i zbog mnogih se svojih odlika može smatrati (proto-) mahāyānskom sūtrom. Kult štovanja stūpe također je jasno izražen. V. Ray (1994/1999: 329-330).

${ }^{253}$ Pāli pațipadā.
} 
tṛ̣nāa tṛṣnāpratyayam upādānam upādānapratyayo bhavo bhavapratyayā jāti jātipratyayā jarāmaraṇaśokaparidevaduḥkhadaurmanasyopāyāsā bhavanti / evam asya kevalasya mahato duhkhaskandhasya samudayo bhavati / ity api avidyānirodhāt saṃskāranirodhạ̣ saṃskāranirodhād vijñānanirodhaḥ vijñānanirodhāt nāmarūpanirodhah nāmarūpanirodhāt șad̄āyatananirodhaḥ ṣaḍayatananirodhāt sparśanirodhaḥ sparśanirodhād vedanānirodhaḥ vedanānirodhāt tṛ̣ṇānirodhah tṛṣnānirodhād upādānanirodhaḥ upādānanirodhād bhavanirodhaḥ bhavanirodhāj jātinirodhaḥ jātinirodhāj jarāmaranaśokaparidevaduḥkhadaurmanasyopāyāsā nirudhyante / evam asya kevalasya mahato duhkhaskandhasya nirodho bhavati // sarvasaṃskārā anityāh sarvasamskārā duḥhā sarvadharmā anātmānah // etam śāntam etam praṇitam etam yathāvad etạ̣ aviparītam yam idạ̣ sarvopadhipratinihsargo sarvasaṃkāarasamathā dharmopacchedo tṛṣnākṣayo virāgo nirodho nirvāṇam //

Prijevod

Potom se je, o redovnici, Bodhisattva, bez straha i bojazni, nestala straha i uzbuđenja, $u$ posljednjem dijelu noći, u vrijeme jutarnjega rumenila, noću u cik zore, probudio na nenadmašno obuhvatno probuđenje, uvidom [do kojega je došao] usredotočene proznaje u jednom trenutku svijesti, [spoznavši] sve što čovjek, istinski čovjek, velik čovjek, čovjekbik, čovjek u biti, snažan čovjek, hrabar čovjek, čovjek-slon, čovjek-lav, čovjek-lotos, čovjek-crveni lotos, čovjek-bijeli lotos, čovjek dobra podrijetla, najodličniji čovjek, nenadmašni kolovozac za [konje] koje treba obuzdati, nadmoćan, moćan, nesavladiv, koji ima cilj, ${ }^{254}$ nepomućen,

(2.285) prijegoran, odlučan, koji je otišao [u osamu], koji zna put, ${ }^{255}$ nepokolebljiv u sabranosti, obdaren budnošću, obdaren proznajom, treba sasvim i u cijelosti spoznati, dosegnuti, uvidjeti i potpuno shvatiti. Odnosno: ovo je patnja, ovo nastanak patnje, ovo zaustavljanje patnje, ovo put koji vodi do zaustavljanja patnje. Ovo su priljevi činā, ovo je nastanak priljevā činā, ovo nestanak priljevā činā, ovo je put koji vodi do nestanka priljevā činā. Ovdje se zaustavljaju svi priljevi činā, u cijelosti se i bez ostatka smiruju u napuštenosti i zalaze. To je ovo: kad ovo postoji, tad to nastaje; kad ovo ne postoji, tad to ne nastaje. S nastankom ovoga to nastaje, sa zaustavljanjem ovoga to se zaustavlja. Neznanje uvjetuje ustrojnice svijesti, ustrojnice svijesti uvjetuju svijest, svijest uvjetuje

\footnotetext{
${ }^{254}$ Arthika, v. BHSD str. 67.

255 Gatima(nt), v. BHSD str. 209.
} 
ime $i$ oblik, ime $i$ oblik uvjetuju šest osjetila, šest osjetila uvjetuje dodir [osjetila $i$ predmeta], dodir uvjetuje osjećanje, osjećanje uvjetuje žeđ, žeđ uvjetuje prianjanje, prianjanje uvjetuje bivanje, a bivanje uvjetuje rođenje. Rođenje uvjetuje starost, smrt, tugu, oplakivanje, patnju, jad i nemir. Tako se izdiže ovo cijelo veliko deblo patnje. Ali sa zaustavljanjem neznanja zaustavljaju se i ustrojnice svijesti, sa zaustavljanjem ustrojnica zaustavlja se i svijest, sa zaustavljanjem svijesti zaustavljaju se i ime i oblik, sa zaustavljanjem imena i oblika zaustavlja se i šest osjetila, sa zaustavljanjem šest osjetila zaustavlja se i dodir, sa zaustavljanjem dodira zaustavlja se i osjećanje, sa zaustavljanjem osjećanja zaustavlja se $i$ žeđ, sa zaustavljanjem žeđi zaustavlja se $i$ bivanje, sa zaustavljanjem bivanja zaustavlja se i rođenje, sa zaustavljanjem rođenja zaustavljaju se i starost, smrt, tuga, oplakivanje, patnja, jad i nemir. Tako se zaustavlja ovo cijelo veliko deblo patnje. Sve su ustrojnice svijesti nestalne, sve su ustrojnice svijesti podložne patnji, svi su predmeti svijesti bez sopstva. To je smireno, to je uzvišeno, to je istinsko, to je neizvrnuto [stanje], to, naime, što je ovo napuštanje svih navezanosti, umirenje svih ustrojnica svijesti, odsjecanje svih predmeta svijesti, poništenje žeđi, bežudnost, zaustavljanje, nirvāṇa.

Mv. ii. 397-420 sadrži podulji prikaz probuđenja u kojem su svoje mjesto našli i stihovi koji se susreću u Vinayapiṭaki ${ }^{256}$ sa sljedećim dodatkom:

Mv. ii. 417. 13-15

atha khalu bhagavān prathamasambodhiprāpto tāye velāye imam udānam udānaye // sukho vipāko punyānām abhiprāyaś ca ṛdhyati / kṣipram ca paramām śāntim nirvṛtim cādhigacchati //

Prijevod

Zaista, u trenutku kada je Blaženi dosegao prvo probuđenje izrekao je nadahnuto ovo:

"Sretno je dozrijevanje zasluga, cilj se približava, Brzo se dostiže najviši mir i spokoj."

U tom se opisu susreće i paralela sa stihovima u Udāni (7.2) gdje nisu vezani uz probuđenje. Thomas (1927/2000: 78) smatra kako je starija i izvorna pālijska verzija u sanskrtskim tekstovima prilagođena kako bi se uklopila u kontekst probuđenja.

\footnotetext{
256 Vin. i. 3. V. gore.
} 
Mv. ii. 416. 6-7

chittvā tṛ̣nāạn vijahāmi rajam śuṣkāśravāṇi na sravanti chinnam vartmam na vartati / eșaiva anto duhkhasya //257

Prijevod

Presjekavši žeđ, ostavio sam uzvitlanost. Priljevi činā koji su presušili ne teku. Odrezan je put $i$ više ga nema. To je, upravo, kraj patnje.

\subsection{Borba s Mārom}

Središnji i najvažniji trenutak Gotamina života s vremenom je zasjenjen uzbudljivim i slikovitim opisima Gotamine borbe s demonom Mārom. U kasnijim je djelima, kao što su Mahāvastu, Nidānakathā, Lalitavistara i Buddhaćarita, posvećena velika pažnja nadmudrivanju i borbi dvojice suparnika koja će u konačnici iznjedriti kao pobjednika Gotamu. Upravo je tu borbu Oldenberg (1881/2007: 89-95) uzeo kao primjer kako bi pokazao neadekvatnost Senartova pristupa u opisivanju života Gotame Buddhe. Za razliku od Senarta koji se je oslanjao na kasnije, sjevernoindijske sanskrtske tekstove, Oldenberg čvrsto vjeruje u autoritet pālijskoga kanona u kojem Māra igra sporednu ulogu:

Što je na dotičnom zbivanju bitno za predodžbu stare zajednice? Nadasve samo to da Buddha, sjedeći pod jednim drvetom i prolazeći kroz niz stanjâ zadubljenosti, kroz tri noćna bdjenja, te jedne odlučujuće noći dostiže trostruko sveto znanje o tome da se njegova duša oslobađa od sve nečistoće i da mu biva podareno izbavljenje zajedno sa spoznajom o njegovu izbavljenju. Ovi čisto teološki elementi pripovijesti znatno pretežu po važnosti u staro doba naspram borbe $\mathrm{s}$ Mārom; tamo gdje se u pālijskim tekstovima pripovijeda o postizanju budnosti, nigdje ili skoro nigdje nema govora o Māri. (Oldenberg 1881/2007: 90)

Već spomenute četiri sutte Mađđhimanikāye, a u kojima se donosi opis probuđenja, zaista ne spominju Māru ali se u Suttanipāti, točnije u Padhānasutti, nalazi jedan od najranijih opisa susreta Māre (Namući) i Gotame prije njegova probuđenja. Dijelovi se Padhānasutte nalaze i u Mahāvastuu, ${ }^{258}$ a paralelni su dijelovi izneseni u bilješkama pod tekstom.

Sn. $425-449$

\footnotetext{
${ }^{257}$ Ud 7.2: \{acchejji\} vatțam \{vyagā $\}$ nirāsam, visukkhā saritā na sandati, chinnam vațtam na vattati, es' ev' anto dukkhassā 'ti. ||2|| Usp. i Lv. 355.

${ }^{258}$ Mv. ii. 238-241. V. i Lv. 327 i d.
} 
425. Tam mam padhānapahitattam nadim Nerañjaram pati ${ }^{259}$

viparakkamma jhāyantam yogakkhemassa pattiyā || Sn_III,2.1 ||

426. Namucī karuṇam vācam bhāsamāno upāgami:

"kiso tvam asi dubbaṇno, santike maraṇan tava. ${ }^{260} \|$ Sn_III,2.2 ||

427. Sahassabhāgo maraṇassa, ekaṃo tava jīvitam,

j̄̄va bho, jūvitam seyyo, jīvam puññāni kāhasi ${ }^{261}$. || Sn_III,2.3 ||[...]

436. Kāmā te pațamā senā, dutiyā arati vuccati,

tatiyā khuppipāsā te, catutthī taṇhā pavuccati, ${ }^{262} \|$ Sn_III,2.12 ||

437. pañcamì thīnamiddham te, \{chațthā bhīrū\} pavuccati,

sattamī vicikicchā te, makkho thambho te ațthamo, ${ }^{263}||$ Sn_III,2.13 || [...]

440. Esa muñjam parihare, dhi-r-atthu idha jīvitam,

saìgāme me matam seyyo, yañce jīve parājito. || Sn_III,2.16 || [...]

446. "Satta vassāni Bhagavantạ̣ anubandhim padā padam,

otāram nādhigacchissam Sambuddhassa satīmato. || Sn_III,2.22 ||

447. Medavaṇnam va pāsāṇạ̣ vāyaso anupariyagā:

'ap'; ettha mudu vindema, api assādanā siyā,'; || Sn_III,2.23 ||

448. Aladdhā tattha assādam vāyas'; etto apakkami, --

kāko va selam āsajja nibbijjhāpema Gotamaṃ". ${ }^{264}$ || Sn_III,2.24 ||

449. Tassa sokaparetassa vīnā kacchā abhassatha,

tato so dummano yakkho tatth'; ev'; antaradhāyathā ti ${ }^{265}$ || Sn_III,2.25 ||

\footnotetext{
${ }^{259}$ Mv. ii. 238. 3: uruvilvāya sāmante prahāṇaṃ prahitam mayā //

${ }^{260}$ Mv. ii. 238. 5-6: krśso tvam asi durvarṇo santike maranam tava /

${ }^{261}$ Mv. ii. 238. 8-9: jūvitaṃ te hitam śreștham jūvan punyāni kāhisi /

${ }^{262}$ Mv. ii. 240. 3-4: kāmā te prathamā senā dvitīyā ārati vuccati /

tritīyā kṣutpipāsā ca caturthī tṛṣnā vuccati //
}

${ }^{263}$ Mv. ii. 240. 5-6: paṃcamā styānamiddham te șașthī bhīru pravuccati / saptamā vicikitsā te mānārtho bhoti aștamā /

${ }^{264} \mathrm{Za} \mathrm{Sn.} 447$ i 448 usp. SN i. 124.

${ }^{265}$ Usp. SN i. 122, Mv. ii. 240. 16-17: tasya śokaparītasya vināśam gacchi ucchriti / tataś ca durmano yakșo tatraivāntarahāyithā // 
Prijevod

(Pripovijeda bodhisattva:)

(425) “Došao sam na Nerañđaru, odlučan u stremljenju,

Razmatrajući hrabro da postignem odmor od napora.

(426) Prišao je Namući govoreći suosjećajno:

'Mršav si i blijed. Blizu je tvoja smrt.

(427) Tisuć dijelova ima smrt, tvoj je život samo jedan dio.

Živi, dragi! Život je bolji. Živ ćeš zasluge stjecati'.,

(Bodhisattva odgovara:)

(436) “Želja je tvoja prva vojska, druga se zove odbojnost.

Treća je glad $i$ žeđ, a četvrta se naziva žuđenje. ${ }^{266}$

(437) Peta je tromost i klonulost, šesta se naziva strah.

Sedma ti je sumnja, osma licemjerje i tvrdo srce.

(440) Da uzmem snop muñđe? ${ }^{267}$ Do bestraga s mojim životom!

Bolje da umrem u borbi nego da živim poražen."

(Māra/ Namući govori sebi:)

(446) "Sedam godina Blaženoga gonim stopu po stopu.

Nije bilo prilike za poraz Pozornoga, Prebudnoga.

(447) Ptica je kružila oko kamena misleć' grumen je masla:

Možda tu nađemo nešto meko, možda bude što slatko.

(448) Ne nalazeći tamo slatkoću, ptica je odatle otišla.

Kao što vrana kljuca kamen, izbadali smo Gotamu."

(449) Ispala je lutnja ispod ruke oneraspoloženoga.

Nestade s tog mjesta yakkha zlovoljni.

\footnotetext{
${ }^{266}$ U Mārasamyutti (SN i. 124) želja, nezadovoljstvo i glad utjelovljene su u živopisnoj slici Mārinih triju kćeri imenom Ragā, Arati i Taṇhā. Ovdje su to "vojske” Iskušavatelja. To pokazuje metaforičnost pripovijedanja.

${ }^{267}$ Vrsta trave, trstike (Saccharum munja), obilježje ratnika.
} 
Za razliku od Padhānasutte, u Mārasaṃyutti se susreti dvaju protivnika odvijaju nakon probuđenja. ${ }^{268}$ Kao primjer razgovora naveden je sljedeći ulomak:

SN i. 103

1. Evam me sutam ekạ̣ samayam Bhagavā Uruvelāyam viharati najjā Nerañjarāya tīre Ajapāla-nigrodha-mūle pathamābhisambuddho \|

2. Atha kho Bhagavato rahogatassa pațisallīnassa evam cetaso parivitakko udapādi Mutto vatamhi tāya dukkarakārikāya || sādhu mutto vatamhi tāya anattha-saṃhitāya dukkara-kārikāya || sādhu thito sato bodhim samajjhagan ti $\|$

3. Atha kho Māro pāpimā Bhagavato cetasā ceto-parivitakkam añ̃āya yena Bhagavā ten-upasan்kami || upasan்kamitvā Bhagavantam gāthāya ajjhabhāsi || ||

Tapo kammā apakkamma || yena sujjhanti mānavā \| asuddho mañ̃̃ati suddho \|| suddhimaggam aparaddho ti \| \|

4. Atha kho Bhagavā Māro ayam pāpimā iti viditvā Māram pāpimantam gāthāhi paccabhāsi || ||

Anattha-sañhitam ñatvā || yam kiñ̃i aparam tapam || sabbānatthāvaham hoti || piyārittam va dhammanim || || sīlam samādhi-pañ̃̃añca || maggam bodhāya bhāvayam \| patto-smi paramam suddhim || nihato tvam asi antakāti || ||

5. Atha kho Māro pāpimā jānāti mam Bhagavā jānāti mạ̣ Sugato ti dukkhī dummano tatth-ev-antaradhāyiti $\|\mid\|$

Prijevod

Ovako sam čuo. Jednom je prilikom Blaženi, netom Probuđeni, boravio u Uruveli, na obali rijeke Nerañđare, $u$ podnožju stabla kozareva banyana. ${ }^{269}$ Tada se u umu Blaženoga, koji se je povukao u samoću i u osamu, pojavilo ovo promišljanje: "Oslobođen sam toga činjenja loših djela. Zaista, oslobođen sam toga činjenja loših djela koje nije usklađeno sa svrhom. Zaista, pravo stojim. Dosegao sam probuđenje”.

\footnotetext{
${ }^{268}$ SN i. 103-124. Pojedini se dijelovi Mārasamyutte nalaze i u Mahāvastuu. Za njihovu usporedbu v. Charpentier (1909).

${ }^{269}$ Ađapālanigrodha. U Mahāparinibbanasutti (DN ii. 112-113) Gotama pripovijeda Ānandi kako ga je pod ovim stablom Māra nagovarao da se da se odrekne podučavanja i uđe u konačnu nibbānu: parinibbātu dāni, bhante, bhagavā, parinibbātu sugato, parinibbānakālo dāni, bhante, bhagavato'ti.
} 
Tada je Māra Grešni, spoznavši umom što Blaženi promišlja u duši, otišao onamo gdje je bio Blaženi i prišavši, oslovio Blaženoga stihom:

"Napustiv trapnju i djela koja ljude pročišćuju,

I nečist se smatraš čistim, put čistoće promašivši."

Tada je Blaženi uvidjevši: "To je Māra Grješni”, oslovio Māru Grješnoga stihovima:

"Spoznav da ne vodi svrsi koja god trapnja buduća,

Sve su bez smisla ko veslo i kormilo na suhom tlu.

Ćudoređe, zadubljenje spoznaja - put je k budnosti!

Dosegoh krajnju čistoću. Sad si mrtav, Smrtonošo!”

Tada [shvati] Māra Grješni: “Prepoznaje me Blaženi! Poznaje me Sretni!” pa, tužan i ucviljen, nestade s toga mjesta.

Valja napomenuti da su unutar pālijskoga kanona, kako pokazuju gore navedeni primjeri, Gotamini susreti s Mārom svedeni na razgovore u kojima Māra iskušava Gotamu pokušavajući ga pokolebati u odluci da dosegne oslobođenje ili u osjećaju da je zaista oslobođen. ${ }^{270} \mathrm{Ti}$ su razgovori, u pravilu, uljudni i svima im je zajedničko da u njima Gotama lako i bez prevelike muke navodi Māru da ustvrdi Blaženi me poznaje, Sretni me poznaje i da, tužan i poražen, nestane bez traga. Također, na pojedinim je mjestima u pālijskome kanonu Māra nije ništa drugo doli personifikacija posljedica loših osobina ili djela. Tako, primjerice, u Dhammapādi stoji sljedeće:

$$
\begin{aligned}
& \text { Kao kad bira cvijeće, } \\
& \text { Čovjeka prožetog žudnjom } \\
& \text { Nosi Smrt }{ }^{271} \text { kao velika } \\
& \text { Poplava zaspalo selo. }{ }^{272}
\end{aligned}
$$

U svome članku Boyd (1971: 73-74) naglašava sljedeće:

On the mythological level, Mara is the source of disruption and offensiveness. However, the external conditions which interrupt meditation or incline man toward morally harmful thoughts

\footnotetext{
${ }^{270}$ Za mogući utjecaj pripovijesti o Mārinim iskušenjima na evanđelja v. Garbe (1914).

${ }^{271}$ Maccu (skt. mrtyu), smrt, jedno od Mārinih imena.

272 Dhmp. 47: Pupphāni heva pacinantam byāsattamanasam naraṃ, suttam gamam mahoghova, maccu ādāya gacchati.
} 
and actions constitute very mundane circumstances, such as malicious brahmins, wandering buffaloes, etc. Although all of these episodes are described as deeds of Mara the Evil One, this mythological association is nothing more than a means of identifying different kinds of experiences that have the same negative result, that of destroying "all good works, qualities, and even the root of the Dharma itself". ${ }^{273}$

Dok u najvećem dijelu pālijskoga kanona Māra ne igra značajnu ulogu, ${ }^{274} \mathrm{u}$ kasnijim djelima kao što su Nidānakathā i Mahāvastu, Māra je stvaran, otjelovljen i moćan protivnik kojega su kasniji autori, dopustivši mu da nadraste ulogu dodijeljenu mu u pālijskome kanonu, iskoristili za skretanje pozornosti s filozofskih i često repetativno iznesenih učenja na živopisne opise dinamične bitke koji lako zaokupljaju maštu slušatelja/ čitatelja. Kao primjer poslužit će ulomak iz Nidānakathe.

ĐātA. I. 71-72

Tasmim samaye Māro devaputto: ,,Siddhatthakumāro mayham vasai் atikkamitukāma na dāni 'ssa atikkamitum dassāmīti“. Mārabalassa santikam gantvā etam atthaì ārocetvā Māraghosanaì nāma ghosāpetvā Mārabalài ādāya nikkhami. Sā Mārasenā Mārassa purato dvādasa yojanāni hoti, pachato yāva cakkavālapariyantaì katvā thitā, uddhai் navayojanubbedhā, yassā unnadantiyā unnādasaddo yojanasahassato pațthāya pațhavīudrīyanasaddo viya sūyati. Atha Māro devaputto diyaḍ̣ayojanasatikam

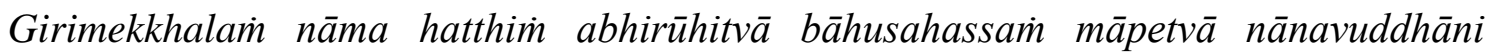
aggahesi. Avasesāya pi Māraparisāya dve janā ekasadisakaì āvudham na gaṇhimisu nānapakkāravaṇnā nānāppakāramukhā hutvā Mahāsattam ajjhottharamānā āgamimsu. $[\ldots]$

Prijevod

U tome je trenutku nebesnički sin, Māra [pomislio]: "Kraljević Siddhattha želi izmaknuti mojoj volji. Neću mu dozvoliti da izmakne." Otišao je do svoje vojske i objavio im nakanu. Oglasivši se se Mārinim [ratničkim] poklikom, izveo je vojsku. Ta se Mārina vojska protezala ispred [njega] dvanaset yođana, a iza je stajala sve do ruba planina koje okružuju svijet. U visinu [se protezala] devet yođana, a zvuk njena poklika dok se glasa

\footnotetext{
${ }^{273}$ Usp. i Gethin (1997: 190-191).

274 Oldenberg (1881/2007: 295) dopušta mogućnost da su Gotamini razgovori s Mārom svojevrsne halucinacije i ne slaže se s Windischem (1895: 213) koji te razgovore svodi na poetski način izražavanja koji je s vremenom shvaćen doslovno i preoblikovan u legende. Mv. ii. 277-228 donosi sljedeće Mārine riječi: Tijelo isposnika Gautama poteklo je od oca i majke [...] dok je moje tijelo načinjeno od uma (manomayo kāyo)“.
} 
čuo se na tisuću yođana kao zvuk zemlje koja se otvara. Nebesnički se sin Māra uspeo na dvije stotine i pedest yođana visokoga slona zvanog Girimekkhala ${ }^{275}$ pa je, stvorivši si tisuću ruku, uzeo raznovrsno oružje. U ostatku Mārine pratnje dvojica nisu uzela isto oružje, već su, postavši različitih boja i različitih oblika, krenuli prema Velikomu biću kako bi ga nadvladali. [...]

S ovim se uvodom priprema pozornica za veliku bitku koja će odviti između Gotame i Mārinih snaga. Okupljaju se i nebesnici iz deset tisuća svjetova koji napeto promatraju razvoj događaja ali, na prvi znak napada Mārine vojske, prestrašeni bježe. Gotama, naprotiv, ostaje mirno sjediti usredotočen na deset savršenstava. Māra napada devet puta: prvo šalje snažan vjetar koji može otkinuti vrhove planina, razrušiti gradove i sela, iščupati korijenje stabala; potom šalje oblake koji obilnom kišom potapaju zemlju, slijede udari stijenama koji se pred bodhisattom pretvaraju u cvjetne vijence i raznovrsnim oružjem, ugljenom i žeravicama koji se odreda čudesno pretvaraju u glavice cvijeća. Potom šalje snažnu pješčanu oluju i navalu blata te podiže neprobojnu tamu koja u dodiru s bodhisattom nestaje kao "tama pred blještavilom Sunca". 276 Neuspješan u naumu da ga pokoleba, Māra prilazi Gotami i zahtijeva njegovo sjedalo tvrdeći da mu pripada, ne ustezajući se pritom od novih napada. Gotama odgovara: "Meni pripada sjedalo [svih] bodhisatta koji su na dan potpuna probuđenja postigli sva savršenstva". ${ }^{277}$

Bitka se seli na polje morala kada Māra traži Gotamu da mu pokaže svjedoke svoje darežljivosti. Gotama odgovara:

ĐātA. I. 74

Mahāpuriso: „tuyhai் tāva dānassa dinnabhāve sacetanā sakkhino, mayham pana imasmim thāne sacetano koci sakkhī nāma n' atthi, tițthatu tāva me avasesattabhāvesu dinnadānam Vessantarattabhāve pana țatvā sattasatakamahādānassa tāva dinnabhāve

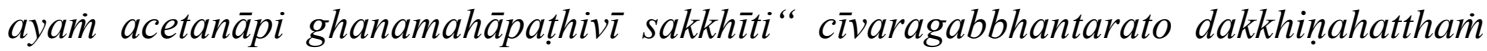
abhin̄̄haritvā „Vessantarattabhāve thatvā mayham sattasatakamahādānassa dinnabhāve tvaì sakkh̄̄ na sakkhīti“ mahāpațavīabhimukkham hatthaì pasāresi. Mahāpaṭavī ,, ahan te tadā sakkhīti. “

Prijevod

\footnotetext{
${ }^{275}$ Girimekkhala, dosl. kojega su pojas planine.

276 ĐātA. I. 73.

277 ĐātA. I. 74: Pūritapāramīnaṁ Bodhisattānaṁ abhisambujjhanadivase pattapalaìkaṁ mayham pāpunātīti.
} 
Veliki muž [odgovori]: "Ti imaš žive svjedoke za davanje milodara, a u ovome kraju nema niti jedna živa svjedoka za moje [davanje milodara]. Na stranu milodari dani u ostalim prethodnim životima, ali velika i čvrsta Zemlja, iako nesvjesna, svjedok je davanja sedam stotina velikih milodara koje sam dao kada sam bio [rođen kao] Vessantara” pa, izvukavši desnu ruku [koja je bila] ispod ogrtača, pruži ju je prema Velikoj Zemlji [rekavši]: "Jesi li ili nisi svjedok sedam stotina velikih milodara koje sam dao kada sam bio [rođen kao] Vessantara?" Velika Zemlja [odgovori]: "Ja sam ti svjedok".

Epizoda je detaljno opisana u Lalitavistari na koju se, kako Lamotte misli (1958/1988: 661), kasnija Nidānakathā uvelike oslanja. ${ }^{278} \mathrm{~S}$ druge strane, ova se epizoda, koja je svoj izraz pronašla u popularnom prikazu bhūmisparśamudre ili "pokreta doticanja zemlje" u buddhističkoj ikonografiji, ne spominje ni u Buddhaćariti (2. st.) ni u Mahāvastuu, gdje se samo navodi kako je Bodhisattva dodirnuo zemlju koja se je potom zatresla šest puta uz prodoran zvuk nalik onom koji nastane kada se snažno udari metalna posuda. ${ }^{279}$ Maria Spagnoli (2005) usporedila je prikaze ove epizode u različitim umjetničkim školama i zaključila da je, po svem sudeći, motiv pozivanja Zemlje za svjedoka u buddhističkoj književnosti preuzet iz figurativnih prikaza kakvi su se razvili u gandhārskoj umjetničkoj školi (1-5. st.) koja je, pak, bila pod snažnim grčkim utjecajem. ${ }^{280}$ Kada je riječ o izostanku ove epizode u Mahāvastuu, Spagnoli (ibid. 335) navodi:

At the same time, as stated, in the Mahāvastu the gesture of touching the ground is not related to asking the goddess Earth to bear witness in Siddhārtha's favour (Jones 1949: Vol. II, 313). Moreover, the whole dispute between the Bodhisattva and Māra preceding the request to bear witness is overlooked, so that the act of touching the ground remains wholly unexplained. At this point, it could be assumed that the author of the text took the gesture from another source that recounted the episode in its entirety, but did not repeat the whole story. Neither can we exclude the possibility that the mudrā was taken solely from a figurative account. ${ }^{281}$

\footnotetext{
${ }^{278}$ Lv. 318-320.

${ }^{279}$ V. niže. Usporedba se nalazi i u Lv. 318.

${ }^{280}$ U području Gandhāre u to je doba bilo središte škole sarvāstivāda kojoj Lalitavistara pripada, pa to može ojačati pretpostavku da je ta tradicija mogla na neki način utjecati na Nidānakathu.

${ }^{281}$ Spagnoli se (2005: 330) poziva na rad Giueseppea Tuccija (Earth in India and Tibet. Eranos Jahrbuch, XXII, 1954, str. 324) koji pronalazi samo dva primjera pozivanja Zemlje za svjedoka u indijskoj književnoj tradiciji. Uz buddhističku predaju, Tucci navodi još samo primjer iz Rāmāyane (Uttarakāṇḍa, XCVII: 17-20).
} 
Mārini pokušaji da obeshrabri ili odvrati Gautamu u pokušaju da dosegne ili da uživa u blaženstvu spoznaje u Mahāvastuu se nalaze opisani na nekoliko mjesta. ${ }^{282}$ Niže je iznesena pripovijest o konačnom porazu Māre prije Gautamina dosezanja probuđenja. ${ }^{283}$

Mv. ii. 281-283

atha khalu bhikṣavo māro pāpīmām duhkhī daurmanasyajāto antahśsalyaparidāghajāto

(2.282) mahatīm caturamginīm senām sannāhayitvā yena bodhiyaștis tenopasaṃkamitvā bodhisatvasya purato sthitvā mahāntam ghoṣam mahāntam śabdaninādam \{Senart śandaninādam\} akārșīt // sayyathīdam imam haratha imam niharatha imạ̣ vadhatha māragaṇā bhadram astu vo // atha khalu bhikșavo bodhisatvo abhīto acchambhī vigatabhayaromaharșo suvarṇavarṇabāhām cīvarāto nirnāmayitvā jālinā hastaratnena tāmranakhena sucitrarājikena lākșārasaprasekavarṇena mṛunā tūlasparśopamena anekakalpakoțīkuśalamūlasamanvāgatena dakṣinena triṣkrtvo śiram anuparimārje dakṣiṇena pāṇinā paryaṃkam parimārjayitvā dakșinena pāninā prithivīm parāhanati // atha khalu bhikṣavo bodhisatvena pāṇinā śīrșe parāmrșțe dakșiṇena pāṇinā paryaṃke parāmrșțe dakșiṇena pāṇinā prthivīyam parāhatāyāṃ iyam mahāpṛthivī gambhīrabhìmarūpam anunade anuraṇe / sayyathāpi nāma bhikṣavo mahatīye māgadhikāye kaṃsapātrīye girikandaragatāye sillāpaț̣e samparāhatāye gambhīro bhịṣmarūpo ghoṣo anunade anuraṇe evam eva bhikṣavo bodhisatvena dakṣinena pāṇinā śire parāmrșțe dakșiṇena pāṇinā paryamke parāmrșțe dakṣinena pāṇinā prithivīyam parāhatāyam (iyam mahāprthivī gambhīrabhīmarūpam anunade anuraṇe) // sā mārasenā tāvat susamrddhā tāvat susamnaddhā bhītā trastā vyathitā samvignā saṃhrșțtaromajātā tena vicarensu tena vilayensu hastino pi sānam saṃsīdensuḥ aśvā pi sānam saṃsīdensuḥ rathā pi sānam saṃsīdensuḥ padātā pi sānam saṃsīdensuh praharaṇā pi sānaṃ saṃsīdenasuḥ / apare hasteșu prapatensuḥ

(2.283) apare omuddhakā prapatensuh apare apakubjakā prapatensuh apare uttānakā prapatensuḥ apare vāmena pārśvena prapatensuh apare dakṣinena pārśvena prapatensuḥ / māro ca pāpīmām duḥkhī daurmanasyajāto antahśalyaparidāghajāto

\footnotetext{
${ }^{282}$ Mv. ii. 237-241, 276-284, 315-344, 404-416, iii. 281-287 (usp. SN i. 124), 415-419.

${ }^{283}$ Za usporedbu ostalih epizoda vezanih uz Mārina iskušenja u Mahāvastuu i Mārasamiyutti Saṃyuttanikāye v. Charpentier (1909).
} 
ekamante pradhyāye kāṇ̣ena bhūmim vilikhanto // śramaṇo me gautamo viṣayam atikramișyatīti //

\section{Prijevod $^{284}$}

Tada je, o redovnici, Māra Grješni, zlosretan i zlovoljan, kojega je pekao trn u utrobi, okupio

(2.282) veliku čeverostruku vojsku i uputio se na mjesto gdje je stajalo stablo bodhi. Stao je ispred Bodhisattve i oglasio se snažno, moćnim poklikom: "Zgrabite ga! Odnesite ga! Ubijte ga! O, Mārine čete, neka vam je sa srećom!” A Bodhisattva je, o redovnici, neustrašen i neprestrašen, lišen straha i uzbuđenja, izvukao iz ogrtača ruku zlatne boje $i$ tom je desnom dragulj-rukom s mrežicom [među pristima], čiji su nokti bili bakrenasti, ispresjecanom svijetlim linijama, koja je odisala ljekovitim biljem, na dodir mekom kao pamuk, a obdarenom korijenom vrlina iz nebrojenih razdoblja svijeta, tom je desnicom tri puta dotaknuo svoju glavu, desnom je pešću potom dotaknuo svoje sjedalo, i tom desnom pešću lupnuo zemlju. Kada je, o redovnici, Bodhisattva dotaknuo pešću glavu, desnom pešću dotaknuo sjedalo i desnom pešću lupnuo zemlju, tada se ta velika zemlja oglasila i odjeknula dubokom i strašnom tutnjavom. Kao što, o redovnici, odzvanja dubokim $i$ strašnim zvukom u Magadhi izrađena velika mjedena posuda kada se $u$ planinskoj spilji udari o kamenu ploču, tako se baš, o redovnici, kada je Bodhisatva dotaknuo pešću glavu, desnom pešću dotaknuo sjedalo i desnom pešću lupnuo zemlju, ta velika zemlja oglasila i odjeknula dubokom i strašnom tutnjavom. Od toga se je ona toliko dobro pripremljena i toliko dobro opremljena Mārina vojska razbježala i raspršila prestrašena, uplašena, potresena, uznemirena i nakostriješena od straha. Pali su njezini slonovi, pali su njezini konji, pale su i njezine kočije, pala je njezina pješadija i oružje je njezino palo. Jedni su pali na ruke,

(2.283) jedni na glavu, jedni licem na zemlju, jedni na grbu, jedni su pali nauznak, jedni na lijevu stranu, jedni na desnu stranu. Māra Grješni, zlosretan i zlovoljan, kojega je pekao trn u utrobi, [stao je] na stranu i duboko se zamislio rišući štapom po tlu: "Izmaknut će mojoj vlasti trapljenik Gautama”.

\footnotetext{
${ }^{284}$ Prijevod se odlomka, s manjim modifikacijama, nalazi i u Grabovac (2020).
} 
Za razliku od pālijskoga kanona u kojem Māra igra sporednu ulogu, u kasnijim su djelima Gotmini susreti s Mārom prerasli u živopisnu i iznimno popularnu pripovijest čiji se figurativni prikazi mogu pronaći na reljefima i skulpturama buddhističke umjetnosti. Uspoređujući reljefe nastale od 1. stoljeća nadalje, a na kojima su prikazani Gautamini susreti s Mārom, Malandra (1981: 129) zaključuje:

As might be expected, the reliefs from central and south-eastern India share elements with the Nidānakathā and Mahāvastu, texts associated with either that area or with a sect found in the region. By contrast, the reliefs from Mathurā and Gandhāra have more in common with the Buddhacarita and Lalitavistara, associated with a sect that was dominant in the northwest. Yet as all the reliefs vary in detail, so do the texts, which describe the army more or less graphically. While a few elements are common to most versions, like the Bodhisattva seated with his hands in bhūmisparsamudrā, the army of grotesque-faced soldiers, and Māra shown twice, a large number are different. This suggests that the iconography of this scene was not canonized, but rather responded to various current oral and/or written versions of the story. And the question must remain open whether images were always influenced by the texts, or whether in some cases, images inspired the written story.

Također, valja istaknuti da se kasniji prikazi borbe s Mārom mogu iščitati i kao prikaz borbe za vlast nad svijetom u kojoj Buddha, kao duhovni lik kojemu bi odgovaro svjetovni univerzalni vladar (ćakkavattin), poražava Mārinu vojsku i uspostavlja vladavinu dhamme, o čem Bloss (1978: 157) kaže:

[C]onfrontation of Māra and the bodhisattva according to early Buddhist sources can be read as a conflict over world sovereignty and that the defeat of Māra, centering on the witness of the earth to the bodhisattva's virtues, signals a new reign. Through this confrontation, the Buddha comes to encompass rulership which orders the world by righteous conduct. This perspective is strengthened through discussions of the relationship of the Buddha and cakravartin (world monarch, wheel-turning ruler), the early Buddhist belief in the selfless ruler who guarantees an abundant realm $[\ldots]$

\subsection{Zaključna razmatranja}

Bodhi, probuđenje, savršeno, potpuno znanje ili mudrost, imenica je izvedena iz glagolskoga korijena buddh; probuditi se, biti probuđen, razumjeti, spoznati, biti svjestan. Iskustvo probuđenja koje je Gotamu obilježilo, oslobodilo patnje i vječnoga kruga ponovnih rođenja i preobrazilo u Savršeno probuđenoga (sammāsambuddha) od važnosti je ne samo u pokušaju 
opisivanja njegova života već i za razumijevanje začetka buddhizma kao duhovnoga pokreta. Ipak, narav je toga iskustva u pālijskim kanonskim tekstovima nedovoljno jasna. Norman (1997: 29-20) piše:

It is not at all clear what gaining bodhi means. We are accustomed to the translation enlightenment for bodhi, but this is misleading for two reasons. First, it can be confused with the use of the word to describe the development in European thought and culture in the eighteenth century, and second, it suggests that light is being shed on something, whereas there is no hint of the meaning "light" in the root budh- which underlies the word bodhi.[...] It is not clear what the Buddha was awakened to, or at what particular point the awakening came. In some texts, he stated that he was awakened to the destruction of the āsavas "the influxes". He was therefore khịnāsava "one who has destroyed his āsavas", an epithet of an arahat. Elsewhere the Buddha said that he was awakened to the knowledge and insight that this was his last existence.

U Ariyapariyesanāsutti iskustvo je probuđenja opisano na sljedeći način: "Tako sam, o redovnici, i sam podložan zakonu rađanja, uvidjevši jad u onome što je podložno zakonu rađanja, tražeći rađanju nepodložnu, najvišu, od upregnutosti slobodnu nibbānu, dosegao rađanju nepodložnu, najvišu i od upregnutosti slobodnu nibbānu” [...]. Takav se prikaz ne nalazi u drugim suttama Mađđhimanikāye u kojima se donosi opis probuđenja. S druge strane, formula iznesena na kraju opisa dosezanja nibbāne u kojoj se iznosi uvjerenje o konačnom oslobođenju - "Pojavilo se u meni znanje i uvid: Nepokolebljivo je moje oslobođenje. Ovo je posljednje rođenje, nema više ponovnih bivanja!", susreće se nerijetko u kanonu. ${ }^{285}$ Osvrćući se na posebitost Ariyapariyesanāsutte (izostanak opisa trapnji i četiri stupnja zadubljenja) u kontekstu Gotamina probuđenja Wynne (2007: 17) kaže sljedeće:

[T]he description of the awakening in the APS [Ariyapariyesanāsutta] is unique in the early Buddhist literature. Indeed, the passage simply says that the Bodhisatta 'attained Nirvāna'. The expression 'to attain nibbāna' (nibbānam+adhi- $\sqrt{\text { gam }}$ ) is not exclusive to the APS, but there is no other similar description of the awakening. This peculiarity may be due to the fact that the biographical account in the APS predates the development of a literary tradition, one in which the various pericopes describing the process of awakening had been standardized. [...]

Taking all these observations into consideration, the account of the awakening that is most likely to be the oldest, and which may even go back to the Buddha himself, is the one contained in the APS. This account is certainly not a theory (what doctrinal point does it make?), but a very simple

\footnotetext{
${ }^{285}$ V. MN iii. 162, SN ii. 171, 172, SN iii. 28, SN iv 8, 9, 10, SN v. 204, 423, AN i. 259, iv. 56, iv. 448.
} 
description. It is the only account of the awakening that uses apophatic language; the account in the MSS et al. seems extremely complex and theoretical in comparison. It is quite possible that the MSS account is a theoretical elaboration of an earlier description of liberating insight, such as the description found in the APS. (Wynne, 2007: 21)

Za razliku od Ariyapariyesanāsutte, Bhayabheravasutta i Mahāsaććakasutta opisuju probuđenje kao dosezanje četiri stupnja zadubljenja i stjecanje triju viših znanja (teviđđāa, skt. trividyā), odnosno stjecanje jasnoga sjećanja na prethodne živote, razumijevanja ciklusa nestajanja i ponovnih nastajanja bića i svijesti o uništenju priljeva žeđi i činā (pāli āsava, skt. āśrava), do kojega se dolazi kroz razumijevanje plemenitih istina. Schmithausen (1981: 205), o probuđenju kakvo je opisano primjerice u Bhayabheravasutti, kaže sljedeće:

In spite of the fact that this description, as the basis of so many enlarged or recast versions, must be comparatively old, it too cannot be accepted as representing the original account of Enlightenment, for the fourfold set of insight into the Cankers, their origination, etc., which is, by the way, missing in some versions has, obviously for the sake of symmetry, been modeled on the fourfold pattern of the Noble Truths, although this pattern hardly makes sense in the case of the Cankers as they are specified immediately afterward in our text.

Daljnji je razvoj buddhističkoga nauka utjecao na prikaze probuđenja pa tako pojedine sutte u Samyuttanikāyi uz probuđenje vezuju nauk o karikama uvjetovanoga nastanka (pāli patiććasammuppāda, skt. pratītyasamutpāda) koji se susreće u Vinayapiṭaki i ostalim tekstovima relativno kasnoga postanka. ${ }^{286}$ Nakamura (2000/2002: 203) tvrdi:

A far simpler doctrine of dependent origination is presented in an older stratum of the early sutras. The fully articulated twelve-linked chain of dependent origination that appears in the Vinaya and other works dates from a comparatively late stage in the development of the early sutras and must have been inserted into the description of the Buddha's Enlightenment. [...] Since early Buddhist literature exhibits a number of simpler forms of the doctrine, on the basis of which more complex forms were expounded, leading to the final form that became the established Buddhist doctrine, we cannot consider the above descriptions of the enlightenment as historical fact. ${ }^{287}$

\footnotetext{
${ }^{286}$ V. npr. SN ii. 10 i d., SN ii. 104-105.

${ }^{287}$ Bapat (1926: 9): [..] the Mahānidāna Sutta, treats of the Buddhist Law of Paticcasamuppāda, but it is worth noting that the Law of Causation was not yet complete with all its twelve factors. We do not meet with the first two factors of Avijjā and Samkhāras, the absence of which, the commentator has tried to explain, but, it may perhaps, be supposed that it had not yet reached its full development. The Buddhists were content with saying that Viñ̃āna (consciousness) depends upon Nāmarūpa [(Name and form) and Nāmarūpa upon Viññaña. In the Brahmajāla
} 
Nakamura (2000/2002: 213) i Vetter (1998: xxii) slažu se da različiti prikazi Gotamina probuđenja odražuju bitnu osobinu samoga buddhizma, a koja se sastoji od nepostojanja čvrsto definiranih dogmā ili doktrina što je, u konačnici, omogućilo neprestani rast i razvoj nauka. Glavnina je tekstova posvećenih probuđenju, najvažnijemu i odlučujućemu trenutku Gotamina života, postala tako mjestom za daljnju razradu buddhističkoga nauka. Osim toga, ne treba zanemariti činjenicu da je Gotamino preobražavajuće iskustvo s vremenom urešeno živopisnim opisima čudesnih događaja kao što su primjerice potresi, hvalopjevi bezbrojnih nebesnika, kiše cvjetnih glavica koje zasipaju stablo pod kojim je Probuđeni sjedio i borba s Mārom, u čem se, u većoj ili manjoj mjeri, osjeća težnja autora-kompilatora da pri opisivanju sadržaja probuđenja, koliko je to moguće, stave naglasak na zadivljujuće pojave koje su ga popratile. To se posebno odnosi na opis kakav se susreće u Mahāvastuu i Nidānakathi. Međutim čak ni Ariyapariyesanāsutta nije lišena detalja (kao što je, primjerice razgovor s Brahmanom Sahampatiem nedugo nakon probuđenja) koje su pojedini autori odbacili kao kasnije tvorevine. ${ }^{288}$ Waltersov (1999: 257-258) je odgovor sljedeći:

These elements are integral to the narrative in all its appearances and in most of its supplements, meaning that there is no basis for trying to portray them as later accretions from which an even more original core can be separated out. Their presence casts doubt on a historicist reading of the fragment, for it suggests that something more than a commonsense nineteenth-century "objectivity" was at work in the original composition.

Ranije je pokazano kako je probuđenje u Nidānakathi svedeno na svega nekoliko rečenica u kojima se tvrdi da je Gotama, porazivši Mārinu vojsku, u tri dijela noći stekao znanje o prethodnim životima (pubbenivāsañāna), božansko oko ili vid (dibbacakkhu) i razumio lanac uvjetovanog nastanaka (pațiccasamuppāda). S obzirom na narav ovoga djela, čitatelja ne treba čuditi da se dvanaest karika koje čine taj lanac uopće ne spominju. S druge strane, iz Mahāvastua je moguće iščitati sadržaj četiriju zadubljenja, triju znanja i dvanaest karika uvjetovanoga nastanka. Ipak, teško je oteti se dojmu da autoru Mahāvastua sadržaj probuđenja, koliko god neizbježan bio u iznošenju života velikoga učitelja, nije bio u središtu pažnje. Opisi su probuđenja ispresjecani hvalopjevima upućenima Gautami, dramatičnim opisima Mārinih pokušaja da spriječi neizbježno, detaljnim opisima nebesnika razveseljenih tim Gautaminim iskustvom, pa čak i opširnim opisom izgleda stabla bodhi koji se proteže na tri stranice Jonesova

Sutta (1. 3. 71 ), the first five factors are omitted and in the Mahāpadāna and Mahānidāna suttas the first two are omitted. Usp. i Frauwallner (1956: 163-164) i Norman (1997: 32-33).

${ }^{288}$ V. Walters (1999: 258, bilj. 25). 
prijevoda. ${ }^{289}$ Ipak, treba naglasiti da je jedno pitanje što su najstarije verzije teksta o Buddhinu probuđenju, a da je drugo pitanje što je, na temelju tekstova, bio sadržaj toga probuđenja. Buddhina potraga očito je bila potraga za oslobođenjem od patnje u rođenju, starenju, bolesti i smrti. Tu patnju izaziva slijeđenje žeđi, odnosno djelovanje prema njenoj volji, a koja se može dočarati vlašću Māre nad našom voljom. Put do oslobođenja od žeđi i onda patnje formulirao se je u nauku o četirima plemenitim istinama, međutim ta formulacija, kao i razrada Buddhina zadubljenja, ima svoje razvojne stupnjeve i povijest koju treba i dalje istraživati. Isto vrijedi i za verzije tekstova u kojima je pripovijest o Buddhinu probuđenju s vremenom postajala sve slikovitija i nadnaravnim elementima bogatija. Oba pitanja, i kako je glasio najstariji tekst i što je bio sadržaj probuđenja, otvorena su za daljnja istraživanja, a u ovome je poglavlju ocrtano što se može istražiti, misliti i znati o povijesti izvješća o tome ključnome događaju u Buddhinu životu.

\footnotetext{
${ }^{289}$ Jones (1952/2006: 291-294).
} 


\section{POKRETANJE KOTAČA NAUKE}

\subsection{Molba Brahmana Sahampatia ${ }^{290}$}

Pālijska Vinaya navodi kako je nakon probuđenja Gotama proveo sedam dana pod stablom bodhi, uživajući u blaženstvu svoje spoznaje i razlažući, unaprijed i unazad, lanac uvjetovanog nastanka. ${ }^{291}$ Potom je proveo još četiri tjedna, sjedeći svaki tjedan pod drugim stablom. Prvi je Gotamin tjedan, proveden pod stablom kozareva banyana (ađapāla), obilježio susret $\mathrm{s}$ brahmanom kojemu je Probuđeni izložio karakteristike istinskoga brahmana. ${ }^{292}$ Drugi je tjedan Gotama proveo pod stablom mućalinde gdje mu je u pomoć pritekao kralj nāga Mućalinda. Želeći ga zaštititi od snažne kiše, zmijoliki se Mućalinda obavio oko Probuđenoga i natkrilio ga, štiteći ga tako od hladnoće i vlage punih sedam dana. ${ }^{293}$

Treći se tjedan Probuđeni uputio prema stablu rāđāyatane, ispod kojega su mu hranu ponudili trgovci Tapussa i Bhallika, ${ }^{294}$ a koji će ujedno postati i prvi laički sljedbenici, uzevši utočište u Buddhi i Dhammi (iako dhamma u tom trenutku još nije bila obznanjena). U Nidānakathi i Mahāvastuu ta je pripovijest dodatno urešena i obogaćena detaljem kojega nema u pālijskoj Vinayi, a riječ je o molbi dvojice trgovaca koji mole Gotamu da im udjeli nešto što bi mogli štovati. Gotama im je dao nekoliko vlasi svoje kose, a trgovci su, vrativši se u svoj grad, sagradili svetište položivši u njega Gotamin dar. ${ }^{295}$

Četvrti je tjedan Probuđeni proveo u podnožju stabla kozareva banyana gdje će se odviti susret s Brahmanom Sahampatiem.

U pālijskome se kanonu na nekoliko mjesta pripovijeda kako je nakon probuđenja Gotama bio nevoljan poučavati znanje koje je stekao. Vjerujući da će sadržaj njegove spoznaje biti teško razumljiv ljudima bio je spreman zadržati to znanje za sebe.

\footnotetext{
${ }^{290}$ Oldenberg i Rhys-Davids (1882/1974: 86, bilj. 1) u svojem prijevodu Vinayapitake napominju ovo: It is difficult to believe that tha Pāli name of Brahma Sahampati, the ruler of the Brahma world is not connected with the Brahman Svayambhū of the Brahmanical literature. Perhaps the Sanskrit equivalent of sahampati might be svayampati. V. i Wogihara (1902: 423-424).

${ }^{291}$ Vin. i. 1-2 (Mahāvagga I. 1, 1-3).

${ }^{292}$ U SN i. 122-124 navodi se kako je pod ovim stablom Gotama porazio Māru, a u nastavku se pripovijesti pojavljuju i tri Mārine kćeri, usp. i Lv. 378. U DN ii. 112 (MPS) Gotama pripovijeda Ānandi kako ga je pod ovim stablom Māra pokušavao nagovoriti da dosegne konačno oslobođenje ili parinibbānu, usp. i Lv. 377.

${ }^{293}$ Usp. Ud. 2.1, Mućalindasutta. Mv. ii. 301, ĐātA. I. 80.

${ }^{294}$ Kao prvi laici koji uzimaju utočište u Buddhi i Dhammi, Tapussa se i Bhallika spominju i u AN i. 25-26. V. i Buddhaćarita XIV. 105, Lv. 392, Mv. iii. 310.

${ }^{295}$ ĐātA. I. 80-81, Mv. iii. 310.
} 


\section{Vin. i. 4-5 (Mahāvagga I. 5, 2-4)}

atha kho bhagavato rahogatassa pațisallīnassa evam cetaso parivitakko udapādi: adhigato kho my àyam dhammo gambhìro duddaso duranubodho santo pan̄ito atakkāvacaro nipuṇo paṇ̣̂tavedanīyo. ālayarāmā kho panāyam pajā àlayaratā ālayasammuditā. ālayarāmāya kho pana pajāya ālayaratāya ālayasammuditāya duddasạ̣ idam țhānam yad idam idappaccayatā pațiccasamuppādo, idam pi kho țānam sududdasam yad idam sabbasaṃkārasamatho sabbūpadhipaținissaggo taṇhakkhayo virāgo nirodho nibbānaṃ. ahañ ceva kho pana dhammam deseyyam pare ca me na ājāneyyum, so mam'; assa kilamatho, sā mam'; assa vihesā 'ti. ||2|| api 'ssu bhagavantam imāa anacchariyā gāthāyo pațibhamsu pubbeassuta pubbāa: kicchena me adhigatam halam dāni pakāsitum,

rāgadosaparetehi nāyam dhammo susambudho. | pațisotagāmi nipuṇam gambhīram duddasam aṇuṃ rāgarattā na dakkhanti tamokhandhena āvuțā 'ti. \|3\|

iti ha bhagavato pațisañcikkhato appossukkatāya cittam namati no dhammadesanāya.

Prijevod

Tada je Blaženi, koji se je povukao u samoću i u osamu, ovako pomislio: "Dhamma koju sam spoznao duboka je, teško ju je vidjeti, teško iskusiti, smirena je i uzvišena, teško ju je razlagati $i$ [toliko je] istančana da je razumljiva samo mudrima. S druge strane, ljudi nalaze zadovoljstvo $u$ želji, veselje $u$ želji, ugodu u želji. Tim će ljudima, koji nalaze zadovoljstvo $u$ želji, veselje $u$ želji $i$ ugodu u želji, ovo stajalište, ovako razložen lanac uvjetovanoga nastanka biti težak za vidjeti. Bit će im teško vidjeti i ovo stajalište, naime smirenje svih ustrojnica svijesti, napuštanje svih oslonaca, ${ }^{296}$ nestanak žeđi, bežudnost, zaustavljanje [uvjetovanosti], nibbānu! A kad bih ja poučavao dhammu, a drugi me ne bi razumijeli, to bi mi donijelo samo umor i muku”. U tom su trenu Blaženomu na um došli ovi stihovi, nepoznati i nikad ranije čuti:

\section{“Čemu poučavati to što sam s mukom spoznao?}

Nije lako spoznatljiva ova dhamma za nadvladane mržnjom i požudom.

To što ide protiv struje, čisto je, duboko, nevidno i tanahno.

\footnotetext{
${ }^{296} \mathrm{Tj}$. žene, djece, imutka i sl.
} 
Obavijeni tamom, obuzeti požudom ne vide."

Tako razmišljajući, Blaženomu je srce naginjalo nevoljkosti, a ne naučavanju dhamme.

Vidjevši da će svijet zadesiti propast ukoliko Probuđeni ne podijeli svoje znanje, Brahman Sahampati silazi s nebesa i pojavljuje se pred Gotamom, moleći ga promijeni svoje mišljenje.

Vin. i. 5-6 (Mahāvagga I. 5, 4-7) $)^{297}$

atha kho Brahmuno Sahampatissa bhagavato cetasā cetoparivitakkam aññaya etad ahosi: nassati vata bho loko, vinassati vata bho loko, yatra hi nāma tathāgatassa arahato sammāsambuddhassa appossukkatāya cittam namati no dhammadesanāyā 'ti. ||4|| atha kho Brahmā Sahampati, seyyathāpi nāma balavā puriso sammiñjitam vā bāham pasāreyya pasāritam vā bāham sammiñjeyya, evam eva Brahmaloke antarahito bhagavato purato pāturahosi. ||5|| atha kho Brahmā Sahampati ekaṃsam uttarāsañgam karitvā dakkhinañ jānumaṇdalam paṭhaviyam nihantvā yena bhagavā ten' añjalim pan̄āmetvā bhagavantam etad avoca: desetu bhante bhagavā dhammam, desetu sugato dhammam, santi sattā apparajakkhajātikā assavanatā dhammassa parihāyanti, bhavissanti dhammassa añ̄̃ātāro 'ti. \|6\|

idạ̣ avoca Brahmā Sahampati, idam vatvā athāparam etad avoca:

pāturahosi Magadhesu pubbe dhammo asuddho samalehi cintito,

apāpur'; etam amatassa dvāram suṇantu dhammam vimalenānubuddham |

sele yathā pabbatamuddhini thito yathāpi passe janatam samantato,

tath' ūpamam dhammamayam sumedha pāsādam āruyha samantacakkhu

sokāvatiṇnañ janatam apetasoko avekkhassu jātijarābhibhūtaṃ. |

uț̣hehi vīra vijitasamgāma satthavāha anaṇa vicara loke,

desetu bhagavā dhammam añ̃̄ātāro bhavissantīti. ||7||

Prijevod

Tada je Brahman Sahampati, uvidjevši umnim sposobnostima, čemu naginje Blaženi, ovako [pomislio]: “Jao, svijet nestaje! Jao, svijet propada, ako Tathāgati, Arahantu, Savršeno probuđenomu srce naginje nevoljkosti a ne naučavanju dhamme”! Tada se

\footnotetext{
${ }^{297}$ Za ostala mjesta u kanonu v. MN i. 168, MN ii. 93-94, SN i. 136, v. 167, 232, DN ii. 35 i d., ĐātA. I. 81. Brahman Sahampati pojavljuje se ispred Gotame nakon njegova probuđenja i u AN ii. 20 ali tu ne dolazi moliti Gotamu da poučava, već pohvaliti njegovu odluku da iznad svega poštuje dhammu.
} 
Brahaman Sahampati, kako bi snažan čovjek ispružio savijenu i savio ispruženu ruku, tako je za toliko iščezao iz svijeta Brahmana i pojavio se pred Blaženim. Onda Brahman Sahampati, prebacivši ogrtač na jedno rame, desno koljeno spustivši na zemlju, naklonivši se sklopljenih ruku onamo gdje je Blaženi, ovo rekao Blaženomu: "Poučavaj dhammu, Poštovani! Poučavaj, Blaženi! Poučavaj, Sretni, dhammu! Postoje bića kojima um nije posve zamagljen. Ne čuju li dhammu propast će! Ima bića koja su se rodila sa malo zamagljenosti, a ne čuvši dhammu propadaju, ona će spoznati dhammu”!

To je rekao Brahman Sahampati, pa tako rekavši, nastavi:

"Pojavi se prije u Magadhi dhamma nečista, koju izmisliše okaljani.

Nek’ se čuje dhamma koju spozna Neokaljani, otvoriše se vrata Besmrtnosti!

Kao što bi onaj koji stoji na stijeni, na vrhu planine pogledao sav taj narod uokolo,

Tako, o, mudri, svevideći, popevši se na ovu palaču dhamme,

ti koji si napustio patnju, spusti pogled na narod preplavljen patnjom i moren rađanjem i starenjem!

Diži se junače, pobjedniče u bitci! Vođo karavane, oslobođeni duga, pođi svijetom!

Neka Blaženi poučava dhammu, bit će onih koji će spoznati!”

Nakon još dva puta ponovljene molbe, Gotama spusti buddhinski pogled na narod i, iz suosjećanja spram ljudi, pristane podijeliti s ljudima svoje znanje i tako im pružiti priliku za oslobođenje od vječnoga kruga ponovnih rođenja i patnje. ${ }^{298}$ Ista se epizoda nalazi i u Nidānakathi, međutim, tu je svedena na sljedećih nekoliko rečenica.

\section{ĐātA. I. 81}

Atha Brahmā Sahampati: „, nassati vata bho loko, vinassati vata bho loko“ ti dasahi cakkavālasahassehi Sakka Suyāma Santusita Sunimmita Vasavatti Mahābrahmuno $\bar{a}$ āya Satthu santikam gantvā ,desetu bhante Bhagavā dhammaim, desetu bhante

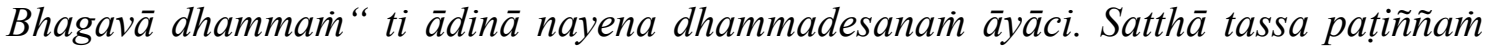
datvā , kassa nu kho aham pațamai் dhammam desseyan “ ti cintento [...]

Prijevod

\footnotetext{
298 Vin. i. 6 (Mahāvagga I. 5, 10): Atha kho bhagavā brahmuno ca ajjhesanam viditvā sattesu ca kāruñ̃atam pațicca buddhacakkhunā lokam volokesi.
} 
Tada je Brahman Sahampati [pomislio]: “Jao, svijet nestaje! Jao, svijet propada”! Povevši [sa sobom vladare] deset tisuća svjetova; Sakku, Suyāmu, Santusitu, Vasavattija i Mahābrahmana, otišao je do Učitelja: "Poučavaj, Poštovani i Blaženi, dhammu! Poučavaj, Poštovani i Blaženi, dhammu”! - molio je ovim [i drugim] načinima da poučava dhammu. Učitelj je dao pristanak misleći: "Koga da prvo poučim dhammi?" $[\ldots]$

Mahāvastu (Mv. iii. 314-320) sadrži tri verzije toga događaja. U prvoj, tek probuđenomu Gautami, s molbom da pokrene kotač nauka prilazi nebesnik Śakra, praćen stotinama drugih nebesnika.

Mv. iii. 315. 14-15

utthehi vijitasaṃrāma pūrṇabharo ${ }^{299}$ tvam aṇ̣na vicara loke I cittạ̣ hi te viśuddhạ̣ yatha candro pamcadaśarātre //

Prijevod

Ustani pobjedniče u bitci! Pun si blaga i nemaš duga. Pođi svijetom!!

Svijest ti je jasna poput Mjeseca u petnaestoj noći. ${ }^{300}$

Gautama ne daje svoj pristanak na što Śakra moli Mahābrahmana ${ }^{301}$ da posjeti i ohrabri nevoljkoga Gautamu. Gautama, međutim, ostaje pri svojoj odluci pa nebesnici odlaze ražalošćeni. Za razliku od prikaza u Vinayi, gdje Sahampati tri puta ponavlja svoju molbu, ovdje ju Mahābrahman izgovara samo jedanput. Također, gdje pālijska verzija sadrži Bhagavān, u Mahāvastuu se nalazi Sugata.

U drugoj verziji događaja Mahābrahman posjećuje Gautamu, moleći ga da propovijeda. Gautama na molbu odgovara sljedećim stihovima:

Mv. iii. 316. 20-21

pratiśrotagāmiko mārgo gambhīro durdṛśo [mama] / rāgaraktā na drakṣyanti alạ̣ brahme prakāsitum //

\footnotetext{
${ }^{299} \mathrm{Na}$ ovom je mjestu u pālijskom tekstu satthavāha. Senart (1897: 506) smatra da bi na ovom mjestu prikladniji izraz bio prajñākaro, tvorac znanja. Jones (1956/2007b: 304, bilj. 4) tvrdi da se pūrnabharo (dosl. pun tereta) može razumijeti budući da je satthavāha, predvodnik karavane ili bogat trgovac upravo onaj čija su kola puna tereta ili robe.

${ }^{300}$ Usp. g. Vin. i. 6 (Mahāvagga I. 5, 7). Petnaesta je noć noć punoga Mjeseca.

301 Za razliku od prikaza u Vinayi i Ariyapariyesanāsutti (MN i. 169), u Mahāvastuu, Lalitavistari (Lv. 393) i Mahāpadānasutti (DN ii. 36) se ne spominje Brahman Sahampati.
} 
Prijevod

[Moj] put ide protiv struje, dubok je, teško ga vidjeti,

Žudnjom pijani ne vide. Brahmane, zalud pouke! $!^{302}$

Treća verzija (Mv iii. 318-320) donosi najopširniji prikaz događaja i završava Guataminim pristankom da poučava dharmu i, konačno, opisom radosti koja je zavladala u svijetu nebesnika.

Mv. iii. 318-319

atha khalu bhagavām aniyatam rāssim ārabhya māgadhānām ca brāhmaṇagṛhapatikānām ity evaṃrūpāṇi pāpāny akuśalāni dṛșțīgatāni utpannāni viditvā mahābrahmaṇo cābhiyācanām viditvā saptāsaṃkhyeyakalpasamudānītasamutpannam cātmanạ̣ praṇidhānam viditvā satveșu ca mahākaruṇān okrāmetvā ime ca me maheśākhyā devādhipatayo lokeśvarā upasaṃkrāntā āryadharmacakrapravartanam yācanti atha khalu bhagavām mahābrahmaṇo avakāśam akārșīt āryadharmacakrapravartanāya //

Prijevod

Tada je Blaženi, prihvativši da postoji neodredivo mnoštvo, vidjevši pokvarene $i$ nevaljane nazore koji su se pojavili među brahmanima i domaćinima u Magadhi, ${ }^{303}$ vidjevši molbu Mahābrahmana, sjetivši se svoga zavjeta danoga i ispunjavanoga tijekom sedam neizmjernih razdoblja, dopustivši da se u njega spusti veliko suosjećanje prema bićima, [misleći:] “Ovi me gospodari nebesnika zvani velmože, vladari svjetova, prišavši mole da pokrenem plemeniti kotač nauke”. Tada je Blaženi prihvatio Mahābrahmanov poticaj da pokrene plemeniti kotač nauke.

Odlomak je naveden budući da je suosjećanje, uz mudrost, jedna od temeljnih Buddhinih vrlina. Također, pojedini autori ističu stavljanje naglaska na suosjećanje kao bitnu odliku mlađega tzv. mahāyānskoga buddhizma. P. Williams (1989/2009: 195) tako naglašava: Compassion is the basis and motivating force of the Bodhisattva. From it, therefore, springs the entire edifice of the Mahāyāna. Gombrich (2005: 151) kaže sljedeće:

The Mahāyāna emphasizes the virtue of compassion, the second in the set of four boundless states, while the Theravāda tends rather to speak of the first, kindness. This is hardly more than a purely

\footnotetext{
${ }^{302}$ Usp. g. Vin. i. 5 (Mahāvagga I. 5, 3).

${ }^{303}$ Ni pālijski kanon ni Mahāvastu ne govore o kakvim je točno krivovjerjima riječ, ali Mv. iii. 317 donosi opis posljedica krivih učenja koji se susreće i u Lv. 398.
} 
verbal difference. Moreover, Mahāyāna exegesis presents as the supreme case of compassion the fact that the Buddha took the trouble to preach the truth that he discovered, thus enabling living beings to find an escape from suffering.

Ipak, koliko god da je epizoda naglasila suosjećanje kao temeljnu Gotaminu motivaciju za podučavanje, ona je buddhistima ipak predstavljala svojevrsni problem o čemu Walters (1999: 252, bilj. 11) piše:

Many later Buddha biographies wrestle with this incident, which suggests that it did not sit comfortably with the Buddhists who inherited it. Thus Buddhavamsa omits it in the biography of Gotama proper (and does not make it a stock category in the many Buddha biographies it narrates) [...] Aśvaghoșa's Buddhacarita has God come in exalted company, more as a social call than an actual plea; the Buddha already knows he is going to preach his message before God arrives. A similar move is also made in later texts such as Nidānakathā of the Jātakațthakathā. In the Lotus Sūtra, the Buddha not only knows he will preach before God arrives but knows it from the veritable beginning of time.

\subsection{Traženje prvih slušatelja}

\subsubsection{Traženje prvih slušatelja u pālijskim izvorima}

U suttama se Mađđhimanikāye ne spominju četiri tjedna koje je Gotama nakon probuđenja, prema Vinayapițaki, proveo pod različitim stablima. Kasnija djela produljuju to razdoblje i spominju ukupno sedam tjedana provedenih u uživanju u blaženstvu spoznaje. ${ }^{304}$

Nakon što je u njemu sazrijela konačna odluka da znanje koje je stekao propovijeda $u$ nadi da će biti onih koji će ga razumijeti, Gotama traži prve slušatelje. Ariyapriyesanāsutta iznosi taj trenutak sljedećim riječima:

MN i. 169-171 = Vin. i. 7-8 (Mahāvagga I. 6, 1-6): $:^{305}$

Tassa mayham, bhikkhave, etadahosi: 'kassa nu kho aham paṭhamam dhammam deseyyaṃ; ko imam dhammam khippameva àjānissatī’ti? Tassa mayhaṃ, bhikkhave, etadahosi: 'ayam kho ā lāro kālāmo paṇ̣ito viyatto medhāvī dīgharattam apparajakkhajātiko. Yannūnāham ālārassa kālāmassa pațamam dhammạ̣ deseyyam. So imam dhammam khippameva ājānissatī'ti. Atha kho mam, bhikkhave, devatā upasañkamitvā etadavoca: 'sattāhakālañkato, bhante, ālāro kālāmo'ti. Ñānaña pana me dassanam

\footnotetext{
${ }^{304}$ Mv. iii. 303, ĐātA. I. 80, Lv. 381.

305 Gdje u Ariyapariyesanāsutti stoji zamjenica "ja” u Vinayi stoji “Bhagavant”. V. i ĐātA. I. 81.
} 
udapādi: 'sattāhakālañkato ālāaro kālāmo'ti. Tassa mayham, bhikkhave, etadahosi: 'mahājāniyo kho ālāro kālāmo. Sace hi so imam dhammam suṇeyya, khippameva ājāneyyā'ti.

Tassa mayham, bhikkhave, etadahosi: 'kassa nu kho aham paṭamam dhammam deseyyaṃ; ko imam dhammam khippameva ājānissatīti? Tassa mayham, bhikkhave, etadahosi: 'ayam kho udako rāmaputto paṇdito viyatto medhāvī dīgharattạ̣ apparajakkhajātiko. Yannūnāham udakassa rāmaputtassa pațhamam dhammam deseyyaṃ. So imaṃ dhammam khippameva ājānissatī'ti. Atha kho mam, bhikkhave, devatā upasan்kamitvā etadavoca: 'abhidosakālan்kato, bhante, udako rāmaputto’ti. Ñānañanca pana me dassanam udapādi: 'abhidosakālañkato udako rāmaputto'ti. Tassa mayham, bhikkhave, etadahosi: 'mahājāniyo kho udako rāmaputto. Sace hi so imam dhammam suneyya, khippameva ājāneyyā'ti.

Tassa mayham, bhikkhave, etadahosi: 'kassa nu kho aham paṭamam dhammam deseyyaṃ; ko imam dhammam khippameva ājānissatī'ti? Tassa mayham, bhikkhave, etadahosi: 'bahukārāa kho me pañcavaggiyā bhikkhū, ye mam padhānapahitattam upaț̣hahiṃsu. Yannūnāham pañcavaggiyānam bhikkhūnam paṭhamam dhammam deseyyan'ti. Tassa mayham, bhikkhave, etadahosi: 'kahaṃ nu kho etarahi pañcavaggiyā bhikkhū viharantī'ti? Addasam kho aham, bhikkhave, dibbena cakkhunā visuddhena atikkantamānusakena pañcavaggiye bhikkhū bārāṇasiyam viharante isipatane migadāye. Atha khvāhaṃ, bhikkhave, uruvelāyam yathābhirantam viharitvā yena bārānasī tena cārikam pakkamim.

Prijevod

Tada sam, o redovnici, ovako [pomislio]: "Komu da najprije izložim dhammu? Tko će brzo razumijeti dhammu”? Tada sam, o redovnici, ovako [pomislio]: "Ālāra Kālāma je zaista pametan, učen i mudar. Davno se je on rodio gotovo oslobođen zamagljenosti. Da ja sada Ālāru Kālāmu prvoga poučim dhammi! On će dhammu brzo razumijeti”. Ali tada su mi, o redovnici, prišli nebesnici ${ }^{306}$ i ovo rekli: "Sedam je dana, Poštovani, prošlo otkako je isteklo vrijeme Ālāri Kālāmi”. Javilo se u meni znanje i viđenje: "Sedam je

\footnotetext{
${ }^{306}$ Dok u Ariyapariyesanāsutti i Vinayi vijest o smrti prijašnjih učitelja Gotama prima od nebesnika, u Nidānakathi, Mahāvastuu, Lalitavistari (Lv. 403-404) i Buddhaćariti (XIV. 106) Gotami više nije potrebno posredstvo nebesnika kako bi znao da su učitelji preminuli.
} 
dana prošlo otkako je isteklo vrijeme Ālāri Kālāmi”. Tada sam, o redovnici, ovako [pomislio]: "Velik je to gubitak za Āḷâru Kālāmu. Zaista, on bi čuvši dhammu brzo razumio”.

Tada sam, o redovnici, ovako [pomislio]: "Komu da najprije izložim dhammu? Tko će brzo razumijeti dhammu”? Tada sam, o redovnici, ovako [pomislio]: “Udaka Rāmaputta je zaista pametan, učen i mudar. Davno se je on rodio gotovo oslobođen zamagljenosti. Da ja sada Udaku Rāmaputtu prvoga poučim dhammi! On će dhammu brzo razumijeti”. Ali tada su mi, o redovnici, prišli nebesnici i ovo rekli: "Prošle je noći, Poštovani, isteklo vrijeme Udaki Rāmaputti". Javilo se u meni znanje $i$ viđenje: "Prošle je noći isteklo vrijeme Udaki Rāmaputti”. Tada sam, o redovnici, ovako [pomislio]: “Velik je to gubitak za Udaku Rāmaputtu. Zaista, on bi čuvši dhammu brzo razumio”.

Tada sam, o redovnici, ovako [pomislio]: "Komu da najprije izložim dhammu? Tko će brzo razumijeti dhammu”? Tada sam, o redovnici, ovako [pomislio]: "Skupina od pet isposnika, koji su bili pored mene dok mi je duh bio predan trapnji, bila je od velike pomoći. Da ja sada skupinu od pet isposnika prvo poučim dhammi”! Tada sam, o redovnici, ovako [pomislio]: "Gdje sada boravi skupina od pet isposnika”? Vidio sam, o redovnici, čistim božanskim okom koje nadilazi ljudsko, da skupina od pet isposnika boravi u Vārānasīi, u Gaju jelena, u Isipatani. Potom sam, o redovnici, nauživavši se boravka u Uruveli, krenuo na put prema Vārānasī.

Susretu s petoricom isposnika prethodio je susret s isposnikom Upakom, pripadnikom sljedbe āđīvika. ${ }^{307}$ Zadivljen Gotaminim plemenitim izgledom, Upaka mu je prišao i upitao ga tko mu je učitelj i koji nauk naučava. Epizoda je na ovome mjestu izdvojena ne samo kao ilustracija Gotamine samouvjerenosti i odlučnosti da propovijeda već i zbog činjenice da predstavlja jedan od rijetkih primjera u predaji, u kojima Gotama ne uspijeva zadobiti odobravanje i divljenje slušatelja.

MN i. $170-172=$ Vin. i. 8 (Mahāvagga I. 6, 7-9): $:^{308}$

Addasā kho mạ̣ bhikkhave Upako àjūviko antarā ca Gayam antarā ca bodhim addhānamaggapațipannam, disvāna mam etad-avoca: Vippasannāni kho te āvuso indriyāni, parisuddho chavivaṇno pariyodāto; kam si tvam āvuso uddissa pabbajito, ko

\footnotetext{
${ }^{307}$ O sljedbi ađivika u: Charpentier (1913), Basham (1951), Bronkhorst (2000a).

${ }^{308}$ U Ariyapariyesanāsutti pripovijest je iznesena u prvom licu, u Vinayapiṭaki u trećem.
} 
vā te satthā, kassa vā tvam dhammam rocesīti. Evam vutte aham bhikkhave Upakam ājūvikam gāthāhi ajjhabhāsiṃ:

Sabbābhibhū sabbavidū 'ham-asmi,

sabbesu dhammesu anūpalitto,

sabbamjjaho tanhakkhaye vimutto,

sayam abhiñ̃̃āya kam-uddiseyyam.

Na me àcariyo atthi, sadiso me na vijjati,

sadevakasmim lokasmim na-tthi me pațipuggalo.

Aham hi arahā loke, aham satthā anuttaro,

eko 'mhi sammāsambuddho, sìtibhūto 'smi nibbuto.

Dhammacakkam pavattetum gacchāmi Kāsinam puraṃ,

andhabhūtasmim lokasmim āhañcham amatadundubhinti.

Yathā kho tvaṃ āvuso pațijānāsi arahasi anantajino ti. --

Mādisā ve jinā honti ye pattā āsavakkhayam,

jitā me pāpakā dhammā, tasmā 'ham Upakā jino ti.

Evam vutte bhikkhave Upako àjīviko: Huveyya p' āvuso ti vatvā sīsam okampetvā ummaggạ̣ gahetvā pakkāmi.

\section{Prijevod}

Dok sam putovao putom između mjesta probuđenja i Gaye, vidio me je, o redovnici, āđivika Upaka. Vidjevši me, ovako je rekao: "Tvoje su sposobnosti, prijatelju, jasne. Koža ti je sjajna i čista. Pod kim si, prijatelju, otišao u beskućništvo? Tko ti je učitelj? U čijem nauku nalaziš zadovoljstvo"? Tako oslovljen, ja sam, o redovnici, odgovorio āđ̄̄viki Upaki stihovima:

"Sve sam nadišao, sve sam spoznao,

Među svim sam stvarima neukaljan.

Sve pustiv, odriješen nestankom žeđi.

Spoznavši sve sam, tko da me pouči?

Nemam učitelja, ne postoji nitko poput mene.

U svijetu s nebesnicima nema meni ravna.

Ja sam Arahant i učitelj bez premca u svijetu

Samo sam ja Potpuno probuđen - miran sam i blažen. 
Ja idem u grad Kāsī pokrenuti Kotač nauka.

U slijepom svijetu, udarit ću bubanj besmrtnosti."

"Prema onom što, prijatelju, tvrdiš, ti si dostojan da budeš beskrajni pobjednik" [odgovorio je Upaka].

"Pobjednici su kao i ja, u kojih kušnje nestanu!

Pobijedih grješne porive, stog sam, Upako, Pobjednik."

Pošto je dobio takav odgovor, o redovnici, āđivvika Upaka [odgovori]: "Možda je, prijatelju, tako”! pa, odmahnuvši glavom, krenu sporednim putem.

U Nidānakathi se također spominje susret s Upakom ali se prešućuje Upakina ravnodušnost. ${ }^{309}$ Međutim, čini se kako su se kasnije generacije buddhista ipak "obračunale" s drskim isposnikom. Nakamura (2002: 234), navodeći kineske izvore, kaže sljedeće:

A later commentary says that Upaka later went to the country of Vanga, married, and had a child. Unable to stand the violence of his wife, Cāpā, he went in search of the Buddha to be liberated by the "unlimited victor" (anantajina). Eventually, he became the Buddha's disciple and attained enlightenment.

\subsubsection{Traženje prvih slušatelja u Mahāvastuu}

Mahāvastu sadrži sve elemente predaje vezane uz razdoblje između probuđenja i prve propovijedi, međutim, dodatno razrađujući pripovijest donosi detalje kojih nema u pālijskim izvorima. Tako, primjerice, nakon prihvaćanja molbe Mahābrahmana da propovijeda i širi nauk, Blaženi se pita kakva su bića dostojna pokrenuti kotač nauka.

Mv. iii. 320-321

(3.320) atha khalu bhagavām pravartanasya samaye kevarūpā satvā āryadharmacakram pravartayantīti // ye te satvā pürvayogasampannā bhavanti te āryadharmacakram pravartenti / ahạ̣ khalu pūrvayogasampanno tenārahāmy aham āryadharmacakram pravartayitum / ye te satvā anuttarācārasampannā bhavanti evamrūpā satvā āryadharmacakrạ̣ pravartenti / ahạ̣ khalu punaḥ anuttarācārasampanno arahāmy

\footnotetext{
${ }^{309}$ ĐātA. I. 81.
} 
aham āryadharmacakram pravartayitum / ye te satvā nivāsānuttaryasampannā bhavanti evaṃūpā satvāryadharmacakram pravartenti / ye te satvā āveṇikā bhavanti evaṃūpāh satvā āryadharmacakram pravartenti / ye te satvā cyutisampannā bhavanti evaṃrūpāh satvā āryadharmacakram pravartenti / ye te satvā garbhāvakrāntisampannā bhavanti evaṃrūpāh satvā āryadharmacakram pravartenti / ye te satvā garbhasthitisampannā bhavanti ye te satvā jātisampannā bhavanti ye te satvā lakṣaṇasampannā bhavanti ye anuvyamjanasampannā bhavanti ye kuśalasampannā bhavanti ye dhṛtisampannāh smrtisampannāḥ ye pratyupasthitadharmasampannāh ye 'duṣyadharmasampannāḥ ye loke agrā bhavanti ye loke lokapravicayasampannāh satvasārasampannā bhavanti ye sthānam ca sthānato asthānam cāsthānato samyakprajñayā prajānanti ye sarvatragāminīpratipadān tatratatragāminīpratipadām yathābhūtam samyakprajñayā prajānanti ye nānādhātukā ca loke anekadhātukā ca loke yathābhūtam samyakprajñayā prajānanti ye parasatvānāṃ parapudgalānām indriyavīryavaimātratām yathābhūtaṃ

\section{(3.321) samyakprajānanti te eva dharmacakram pravartenti /}

\section{Prijevod}

(3.320) U vrijeme pokretanja [kotača nauka] Blaženi je [razmišljao]: "Kakva bića pokreću plemeniti kotač nauke? Bića koja su se usavršila u prethodnim utjelovljenjima pokreću plemeniti kotač nauka. I ja sam se, zaista, usavršio u prethodnim utjelovljenjima pa sam, stoga, dostojan pokrenuti plemeniti kotač nauke. Upravo bića, usavršena u besprijekornu vladanju, pokreću plemeniti kotač nauke. I ja sam, zaista, usavršen u besprijekornu vladanju i stoga sam dostojan pokrenuti plemeniti kotač nauke. Bića koja su se usavršila nenadmašnošću [prijašnjih] obitavališta pokreću plemeniti kotač nauke. Bića koja posjeduju posebna obilježja pokreću plemeniti kotač nauke. Bića koja su se spustila s nebesa pokreću plemeniti kotač nauke. Bića koja su se spustila u [majčinu] utrobu pokreću plemeniti kotač nauke. Bića koja su se usavršila za boravka u utrobi, koja su usavršena pri rođenju, bića obdarena sa tridesetidva obilježja savršenstva, obdarena s osamdeset manjih znakova, obdarena zaslugama, bića obdarena ustrajnošću, bića obdarena pozornošću, usavršena u sadašnjim osobinama, usavršena u nepokvarljivim osobinama, u svijetu najodličnija, koja - usavršena u svijetu $i$ u istraživanju svijeta bivaju obdarena srži [svih] bića, koja obuhvatnom proznajom proznaju što stoji po tome što stoji $i$ što ne stoji po tome što ne stoji, koja obuhvatnom proznajom proznaju onako kako jest, put koji vodi do svega i put koji vodi amo i tamo, koja obuhvatnom proznajom 
proznaju onako kako jest, ono što u svijetu ima raznovrsne $i$ ono što u svijetu ima mnogobrojne sastavnice,

(3.321) koja obuhvatno proznaju onako kako jest razmjere sposobnosti i snaga drugih bića i osoba - upravo ta bića pokreću kotač nauke”.

Nakon što je zaključio da je dostojan pokrenuti kotač nauka, Blaženi se pita tko će biti u stanju razumjeti njegovu pouku. Za razliku od pālijskoga kanona u kojem vijest o smrti dvojice prijašnjih učitelja Gotama prima od nebesnika, u Mahāvastuu se nebeski glasnici ne spominju - Blaženi već zna da su obojica preminula. ${ }^{310}$ Prisjeća se potom isposnika koji su ga ranije napustili i kreće na put prema Gaju jelena, u Ṛșipatanu. U pālijskim izvorima slijedi opis susreta s Upakom, ali u Mahāvastuu je izlaganje prekinuto nebesničkom intervencijom i opisom puta kojim će Blaženi krenuti.

\section{Mv. iii. 323}

atha khalu saṃbahulā maheśākhyā śuddhāvāsakāyikā devā yena bhagavāns tenopasaṃkramitvā bhagavataḥ pādau śirasā vanditvā ekānte asthānsuḥ / ekāntasthitās te bhagavantam etad uvāca // yam bhagavato antevāsinām abhijñātam parijiñātam pratibalāś ca punar vayam bhagavato vividhāni vicitrāṇi ṛddhiprātihāryāṇi kartum / yena bhagavān mārgeṇa bodhito vārāṇasyām gamiṣyati ṛ̦ipatanam mrgadāvam anuttaram dharmacakram pravartayitum tato vayam bhagavato yāvac ca bodhi yāvac ca vārānasī mārgam pratijāgariṣyāmah samam asamaviṣamam pānitalajātam vitatavitānam citradūṣyaparikṣiptam osaktapațadāmakalāpam siktasammrșțtam dhūpitadhūpanam muktapuṣpāvakīṇam suvarṇavālikā-saṃstṛtam divyamuktācūrṇasamstṛtam divya-sphațikacūrṇasamstṛtam divyamusāragalvacūrṇasaṃstṛtam divyalohitikācūrṇasamstṛtam / [...]

tatra ca vayam bhagavan mārge yāva ca bodhir yāva ca vārānasāi divyāni cchattrāṇi abhinirminitvā divyāni dhvajāni abhinirminiṣyāmah / divyāni kūtāāgārāṇi abhinirminiṣyāmaś citrāṇi darśanīyāni saptānām ratnānām suvarṇasya rūpyasya muktāyā vaị̂ūryasya sphațikasya musāgalvasya lohitikāyā // bhagavato gacchantasya gamișyanti tiṣthantasya tișthanti purato ca varșavalāhakā devaputrā divyāni puṣpāṇi prākiriṣyanti mandam mandạ̣ ca devā prasārayiṣyantil/ bhagavati bodhito vārānasīim

\footnotetext{
${ }^{310}$ U pālijskome kanonu stoji kako je Ālāra Kālāma preminuo sedam dana ranije, a Uddaka Rāmaputta noć prije. U Mv. iii. 322 navodi se kako je Udraka preminuo sedam, a Ārāḍa tri dana ranije.
} 
rșipatanam mrgadāvam prasthite anuttaram dharmacakram pravartayitum śuddhāvāsehi devehi mārgo pratijāgṛto / [...]

atha khalu bhagavām mahatīye parișāye anekaśatāye anekasahasrāye anekaśatasahasrāyepuraskṛto parivārito uruvilvāto gayām gacchati gayāto aparagayām gacchati //

Prijevod

Tada su mnogobrojni nebesnici iz skupine Śuddhāvāsa [zvani] velmože prišli Blaženomu $i$, iskazavši mu poštovanje [prislonivši] glavu na [njegova] stopala, stali na jednu stranu. Stojeći po strani, oni su Blaženomu ovako rekli: "Što će biti dobro poznato i znano učenicima Blaženoga, mi smo u stanju za Blaženoga učiniti različite i zadivljujuće moći $i$ čudesa. Kada Blaženi bude išao putem od stabla bodhi $u$ Vārānasī, u R̦șipatanu, u Gaj jelena, pokrenuti nenadmašni kotač nauke, tada ćemo se mi pobrinuti da za Blaženoga, na putu od stabla bodhi do Vārāṇasī, sve što je grubo i neravno bude učinjeno ravnim poput dlana ruke, prostrto prostirkama, pokriveno raznovrsnim tkaninama, omotano snopovima finih tkanina i vrpcama, poškropljeno i pometeno, namirisano miomirisima, posuto rascvalim cvijećem, posuto zlatnim pijeskom, prahom nebeskih bisera, prahom nebeskih kristala, prahom nebeskih koralja i prahom nebeskih rubina. [...]

Tamo ćemo mi, o Blaženi, na putu od stabla bodhi do Vārāṇasī, podići nebeske suncobrane i nebeske barjake. Od sedam dragulja; zlata, srebra, bisera, berila, kristala, koralja i rubina, sagradit ćemo nebeske palače, sjajne i oku ugodne. Kako Blaženi bude išao, ići će $i$ one, kada stane $i$ one će stati. Nebeski sinovi iz skupine nebesnika Varṣavalāhaka pred [Blaženoga] će nježno sipati nebeske cvjetove, nježno će ih nebesnici prosipati”. Kada se Blaženi uputio od stabla bodhi u Vārānasī, u R̦̣ipatanu, u Park jelena pokrenuti kotač nauka, nebesnici iz skupine Śuddhāvāsa već su [mu] pripremili put. $[\ldots]$

Išao je tako Blaženi, slavljen i okružen velikom skupinom od nekoliko stotina, nekoliko tisuća, nekoliko stotina tisuća [nebesnika], od Uruvilve do Gaye, od Gaye do Aparagaye.

U Aparagayi Blaženi je prihvatio poziv i objedovao s kraljem nāga imenom Sudarśana. Potom se je uputio u mjesto zvano Vaśālā gdje je prihvatio gostoprimstvo nekoga domaćina, nakon čega je otišao u Ćundadvīlu gdje će se odviti, u ovom slučaju, srdačan susret s āđīvikom 
Upakom. ${ }^{311} \mathrm{U}$ istom je mjestu Blaženi prihvatio poziv na objed yakṣe Ćunde i ostao jednu noć. U mjestu Lohitavastuka, objedovao i prespavao u domu kralja nāga Kamaṇḍaluke. Sljedećega je dana objedovao i prespavao u domu yakșe Kandhe u mjestu Gandhapura. Uputio se zatim u Sārathipuru gdje je objedovao i prespavao u kući nekog domaćina, odakle se je sljedećega dana uputio prema obali Gange. ${ }^{312}$

Mv. iii. $328^{313}$

tatrāpi bhagavām ekarātroṣito kṛtabhaktakrtyo sārathipurāto gaṃgātīram anuprāpto // nāviko dāni āha // dehi tarapanyam // bhagavān āha // kuto mama samaleștukāmcanasya vyapagatajātarūparajatasya tarapanyam // nāviko āha // yadi me desi tarapanyantarīhasi ${ }^{314}$ atha na dadāsi na tarīhasīti // bhagavān āha //

no haṃso narmadātīre nāvikam pariprcchati /

svakena bāhuvīryeṇa haṃso tarati narmadām //

iti vaditvāna saṃbuddho hamsarājeva prakrame ${ }^{315} /$

gaṃgāyā tīre asthāsi oghatīrno mahāmuni //

bhagvām dāni gaṃā̄m uttīrṇo vārāṇasīm anuprāptah / saṃkhamedhīyam asthāsi bhagavām kālam āgameti vārāṇasyām pịnḍāya caritum /

Prijevod

Tamo je Blaženi ostao jednu noć i bio poslužen pripremljenim obrokom. Iz Sārathipure, stigao je na obalu Gange. Skelar [mu] reče: “Daj skelarinu”! Blaženi odgovori: “Odakle mi novac za skelarinu kad [mi je] novac isto što i grumen blata i kada sam se odrekao zlata i srebra”? Skelar reče: “Ako daš skelarinu, prijeći ćeš. Ako ne daš, nećeš prijeći”". Blaženi reče:

"Ni labud na obali Narmade ne pita skelara,

Već on snagom svojih krila ${ }^{316}$ prelazi na drugu stranu."

\footnotetext{
${ }^{311}$ Mv. iii. 325. Pālijski izvori ne navode mjesto susreta.

312 Taj se putni itinerarij ne susreće u pālijskim izvorima.

${ }^{313}$ Epizoda se susreće i u Lv. 407.

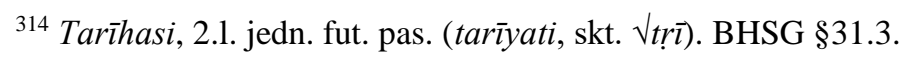

315 BHSG §32.85: [O]ur language uses original optative forms, or forms identical to optatives, as aorists, or at least in the meaning od past indicatives. Especially are common forms in e [...].

${ }^{316}$ Dosl. snagom svojih ruku.
} 
Reče to Probuđeni pa kao labuđi kralj krenu.

Prešavši Gangu, zastade mudrac na drugoj obali.

Prešao je tako Blaženi Ganges i došao do Vārānasī. Stao je u [mjestu] Saṃkhamedhī, a [u podobno je] vrijeme došao u Vārānasī tražiti milodare.

\section{3. Susret s petoricom isposnika}

\subsubsection{Susret s petoricom isposnika u pālijskim izvorima}

MN i. $171-173=$ Vin. i. 8-9 (Mahāvagga I. 6, 10-12) $)^{317}$

Atha khvāham bhikkhave anupubbena cārikam caramāno yena Bārāṇasī Isipatanam migadāyo yena pañcavaggiyā bhikkhū ten' upasañkamim. Addasāsum kho mạ̣ bhikkhave pañcavaggiyā bhikkhū dürato va āgacchantam, disvāna añ̃amañ̃am saṇthapesuṃ: Ayam āvuso samaṇo Gotamo āgacchati, bāhuliko padhānavibbhanto $\bar{a}$ vatto bāhullāya, so $n^{\prime}$ eva abhivādetabbo na paccuțthātabbo, nāssa pattacīvaram pațiggahetabbam, api ca kho āsaṇam țhapetabbaṃ, sace ākañkhissati nisīdissatīti. Yathā

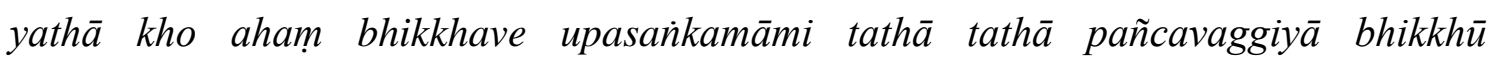
nāsakkhimsu sakāya katikāya sanțhātum; app-ekacce mam paccuggantvā pattacīvaram pațiggahesuṃ, app-ekacce āsanam pañ̃āapesum, app-ekacce pādodakam upaț̣̂āpesuṃ, api ca kho mam nāmena ca āvusovādena ca samudācaranti. Evam vutte aham bhikkhave pañcavaggiye bhikkhū etadavocaṃ: Mā bhikkhave Tathāgatam nāmena ca āvusovādena ca samudācarittha. Araham bhikkhave Tathāgato sammāsambuddho.

Odahatha bhikkhave sotam, amatam-adhigatam, aham-anusāsāmi, ahạ̣ dhammam desemi, yathānusiț̣ham tathā pațipajjamānā nacirass' eva yass' atthāya kulaputtā samma-d-eva agārasmā anagāriyam pabbajanti tad-anuttaram brahmacariyapariyosānam diț̣he va dhamme sayam abhiñ̃̃a sacchikatvā upasampajja viharissathāti. Evam vutte bhikkhave pañcavaggiyā bhikkhū mam etad-avocuṃ: Tâya pi kho tvam āvuso Gotama iriyāya tāya pațipadāya tāya dukkarakārikāya nājjhagamā uttarim manussadhamma alamariyañānadassanavisesam, kim-pana tvam etarahi bāhuliko padhānavibbhanto āvatto bāhullāya adhigamissasi uttarim manussadhammā

\footnotetext{
${ }^{317}$ U Vinayi je pripovijest iznesena u trećem licu.
} 
alamariyañānadassanavisesan-ti. Evam vutte aham bhikkhave pañcavaggiye bhikkhū etad-avocam:

Na bhikkhave Tathāgato bāhuliko na padhānavibbhanto na āvatto bāhullāya. Araham bhikkhave Tathāgato sammāsambuddho. Odahatha bhikkhave sotam, amatamadhigatam, aham-anusāsāmi, aham dhammam desemi, yathānusiț̣ham tathā pațipajjamānā nacirass' eva yass' atthāya kulaputtā samma-d-eva agārasmā anagāriyam pabbajanti tad-anuttaram brahmacariyapariyosānam dițthe va dhamme sayam abhiñña sacchikatvā upasampajja viharissathāti.

\section{Prijevod}

I tako sam, o redovnici, putujući, kroz neko vrijeme stigao u Vārānasī, u Park jelena $u$ Isipatanu, gdje je boravila ona skupina od pet isposnika. Ugledala me je, o redovnici, skupina od pet isposnika kako izdaleka prilazim. Vidjevši me, među sobom su se složili: “Evo, prijatelji, dolazi isposnik Gotama koji uživa u raskoši, koji se odrekao napora pa se vratio obilju. Ne treba ga osloviti, niti se ustati [pred njim u znak poštovanja], niti mu treba primiti ogrtač i zdjelu. Ali neka mu se pripremi sjedalo; ako će htjeti, sjest će". 318 Ali, o redovnici, kako sam se približavao, tako je skupina od pet isposnika sve manje bila u stanju držati se svoga dogovara - neki među njima su mi prišli i uzeli ogrtač i zdjelu, neki pripremili sjedalo, neki, pak, postavili vodu za pranje stopala. Ali, oslovili su me imenom i rječju starino. ${ }^{319}$

Kad su me tako oslovili, ja sam, o redovnici, ovako rekao skupini od pet isposnika: "Ne oslovljavajte, o isposnici, Tathāgatu imenom i rječju starino! Ja sam, o isposnici, Arahant, Tathāgata, Savršeno probuđeni. Otvorite, o isposnici, uši! Nađeno je besmrtno! Ja ću [vas] uputiti, ja ću [vas] poučiti dhammi. Slijedeći [put] kojemu ste poučeni $i$ vidjevši svojim očima i sami razumijevši dhammu, pristupivši [u zajednicu], boravit ćete uskoro u tom krajnjem savršenstvu zavjetovana života zbog kojega mladi plemići bespovratno odlaze iz domaćinskoga života u beskućništvo”.

Tako oslovljena, o redovnici, rekla mi je ovako skupina od pet isposnika: "Gotama, starino! Onim stavom, onim putem dosezanja cilja, onim teškim trapnjama nisi dosegao

\footnotetext{
${ }^{318}$ Nidānakathā (ĐātA. I. 81) navodi kako su isposnici odlučili pripremiti sjedalo iz osjećaja poštovanja spram Gotamina plemenita podrijetla. V. niže.

$319 \bar{A}$ vuso (vok. množ., m.r.), āyasmant (skt. āyușmat) - dosl. dugovječan, star, zdrav. Izraz uljudna oslovljavanja među redovnicima. U PED, str. 113: "a form of polite address: friend, brother, Sir".
} 
nadljudsko stanje ni odličnost u zaista plemenitom znanju i jasnom uvidu. Kako bi sada ti, koji uživaš u obilju, koji si se odrekao napora pa se vratio obilju, mogao dosegnuti nadljudsko stanje $i$ odličnost u zaista plemenitom znanju $i$ jasnom uvidu”? Tako oslovljen, ja sam, o redovnici, ovako rekao skupini od pet isposnika: "Ne uživa, o isposnici, Tathāgata u obilju, niti se odrekao napora pa vratio obilju. [Ja sam], o isposnici, Arahant, Tathāgata, Savršeno probuđeni. Otvorite, o isposnici, uši! Nađeno je besmrtno! Ja ću [vas] uputiti, ja ću [vas] poučiti dhammi. Slijedeći [put] kojemu ste poučeni $i$ vidjevši svojim očima i sami razumijevši dhammu, pristupivši [u zajednicu], boravit ćete uskoro u tom krajnjem savršenstvu zavjetovana života zbog kojega mladi plemići bespovratno odlaze iz domaćinskoga života u beskućništvo”.

Nakon što još dva puta istim riječima iskažu sumnju, petorica će isposnika prihvatiti Gotamine riječi i "otvoriti uši” za nauk koji donosi oslobođenje. Nakon Gotamine izjave "uspio sam uvjeriti skupinu od pet isposnika", prikazi u Ariyapariyesanāsutti i Vinayi značajno se razlikuju. Iako se začetak nauka o četiri plemenite istine nazire u Ariyapariyesanāsutti, on se ne spominje izričito, kao ni nauk o srednjem putu. Za pretpostaviti je, dakle, da Ariyapariyesanā sutta donosi prikaz dolaska u Vārānasīi i susreta s petoricom isposnika prije negoli je nauk o plemenitim istinama i srednjem putu sistematiziran. Ono što se u toj sutti nalazi jest sljedeće:

MN i. 173

Asakkhim kho aham bhikkhave pañcavaggiye bhikkhū sañ̃āpetum. Dve pi sudam bhikkhave bhikkhū ovadāmi, tayo bhikkhū piṇdāya caranti, yam tayo bhikkhū piṇ̣̂àya caritvā āharanti tena chabbaggo yāpema. Tayo pi sudam bhikkhave bhikkhū ovadāmi, dve bhikkhū piṇ̣̂ya caranti, yam dve bhikkhū piṇ̣̂ya caritvā āharanti tena chabbaggo yāpema. Atha kho bhikkhave pañcavaggiyā bhikkhū mayā evam ovadiyamānā evam anusāsiyamānā attanā jātidhammā samānā jātidhamme ādīnavaṃ viditvā ajātam anuttaram yogakkhemam nibbānam pariyesamānā ajātam anuttaram yogakkhemam nibbānam ajjhagamaṃsu, attanā jarādhammā samānā . . . ajaram . . ., attanā byādhidhammāa samānā . . abyādhim . . ., attanā maraṇadhammā samānā . . amatam . . ., attanā sokadhammā samānāa . . asokam . . ., attanā san்kilesadhammā samānā sañkilesadhamme ādīnavam viditvā asañkilițtham anuttaram yogakkhemam nibbānam pariyesamānā asañkilițtham anuttaram yogakkhemam nibbānam ajjhagamamsu. Ñāṇañ- 
ca pana nesam dassanam udapādi: Akuppā no vimutti, ayam-antimā jāti, na-tthi dāni punabbhavo ti. ${ }^{320}$

\section{Prijevod}

Uspio sam, o redovnici, uvjeriti skupinu od pet isposnika. Dok bih poučavao dva isposnika, o redovnici, tri su isposnika odlazila sakupljati milodare. Od milodara koje su trojica, otišavši sakupljati donijela, živjeli smo nas šestorica. Dok bih poučavao tri isposnika, o redovnici, dva su isposnika odlazila sakupljati milodare. Od milodara koje su dvojica, otišavši sakupljati, donijela, živjeli smo nas šestorica.

Tada je, o redovnici, pet isposnika, koje sam tako uputio i poučio i koji su i sami bili podložni zakonu rađanja, uvidjevši jad u zakonu rađanja i tražeći rađanju nepodložnu, najvišu i od vezanosti slobodnu nibbānu, doseglo rađanju nepodložnu, najvišu i od vezanosti slobodnu nibbānu! I sami podložni zakonu starenja, uvidjevši jad u zakonu starenja i tražeći starenju nepodložnu, najvišu i od vezanosti slobodnu nibbānu, dosegli su starenju nepodložnu, najvišu i od vezanosti slobodnu nibbānu! I sami podložni zakonu oboljevanja... I sami podložni zakonu umiranja... I sami podložni zakonu patnje... I sami podložni zakonu ukliještenja, uvidjevši jad u zakonu ukliještenja i tražeći neukliještenu, najvišu i od vezanosti slobodnu nibbānu, dosegli su neukliještenu, najvišu i od vezanosti slobodnu nibbānu. Pojavilo se u njima znanje i uvid: „Naše je oslobođenje sigurno, ovo je posljednje rođenje, nema više ponovnoga bivanja!“

Susret $\mathrm{s}$ petoricom isposnika i trenutak pokretanja kotača nauka nalaze se opisani i u Nidānakathi. Valja istaknuti da se u Nidānakathi, kao što je slučaj i u Ariyapariyesanāsutti, ne navodi sadržaj prve propovijedi. Razlozi su, međutim, za taj izostanak različiti. Kako je ranije rečeno, može se pretpostaviti da do vremena nastanka prikaza u Ariyapariyesanāsutti nauk o četiri plemenite istine i osmerostrukome putu nije bio sistematiziran i da se iz toga razloga ne spominje. S druge strane, do vremena nastanka Nidānakathe, nauk je bio općepoznat ali je izostavljen, po svem sudeći, iz istoga razloga iz kojega je izostavljen opis naravi ili sadržaja probuđenja. U Nidānakathi je, naime, naglasak stavljen na samorazumljivu izvanrednost Gotamine pojave u svijetu budući da ona svoj temelj ima kudikamo više u zaslugama prikupljenima u mnogobrojnim prijašnjim egzistencijama negoli u rezultatu tjelesnoga $i$ intelektualnoga napora upregnutoga u posljednjoj egzisteniciji.

\footnotetext{
${ }^{320}$ Isti se ulomak nalazi i u MN ii. 93-94.
} 


\section{ĐātA. I. 81-82}

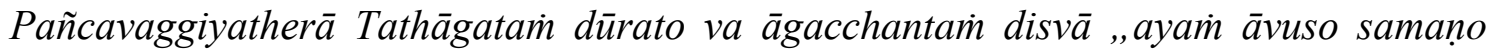
Gotamo paccayabāhullāya āvatittvā paripuṇnakāyo phītindriyo suvaṇnavaṇno hutvā āgacchati, imassa abhivādanādīni na karissāma mahākulappasūto kho pan' esa

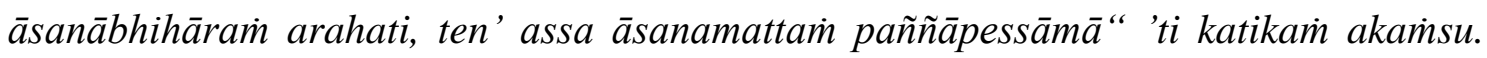
Bhagavā sadevakassa lokassa cittācāram jānanasamatthena ñānena ,,kin nu kho ime cintayimsūu" 'ti àvajjitvā cittam añ̃̃āsi. Atha ne sabbadevamanussesu anodissakavasena pharaṇasamattham mettacittam samkhipitvā odissakavasena mettacittam phari. Te Bhagavatā mettacittena phuțthā Tathāgate upasamkamante upasaimkamante sakāya katikāya sanțhātum asakkontā abhivādanapaccuțthānādīni sabbakiccāni akamisu, Sambuddhabhāvam pan' assa ajānamānā kevalà̇ nāmena ca āvusovādena ca samudācaranti. Atha ne Bhagavā ,mā bhikkhave Tathāgatà̇ nāmena ca āvusovādena ca samudācaratha, aham bhikkhave Tathāgato Sammāsambuddho" ti attano Buddhabhāvam sañ̃̄āpetvā paññattavarabuddhāsane nisinno Uttarāsālhanakkhattayoge vattamāne ațthārasahi Brahmakoțihi parivuto Pañcavaggiye there āmantetvā Dhammacakkappavattanasuttam desesi. Tesu Añ̃̄ākonḍaññathero desanānusārena ñānam pesento suttapariyosāne aț̣̂̄ārasahi Brahmakoțīhi saddhim sotāpattiphale patițthāsi. Satthā tatth' eva vassam upagantvā punadivase Vappatheram ovadanto vihāre yeva nisīdi. Sesā cattāro piṇ̣̂̄yo carimsu. Vappathero pubbañhe yeva sotāpattiphalaì pāpuṇi. Eten' eva upāyena punadivase Bhaddiyatheram punadivase Mahānāmatheram punadivase Assanjitheran ti sabbe sotāpattiphale patițthāpetvā pañcamiyam pakkhassa pañca pi jane sannipātetvā Anattalakkhaṇasuttantam desesi, desanāpariyosāne pañca pi therā arahattaphale patițthahimsu.

\section{Prijevod}

Skupina se petorice starješina, ugledavši Tathāgatu kako izdaleka prilazi, dogovorila: "Dolazi, prijatelji, onaj isposnik Gotama koji se održava obiljem pa je popunio tijelo, okrijepio snage i pozlatio put. Nećemo ga osloviti ni drugim počastiti, ali, budući da je sin plemenite obitelji, dostojan je da mu se pripremi sjedalo pa ćemo mu ga pokazati”. Blaženi je, sposobnošću da zna misli [cijeloga] svijeta s njegovim nebesnicima, upitavši se "Što su oni pomislili?", saznao što oni misle. Potom je, usmjerivši osjećaj 
dobronamjernosti, ${ }^{321}$ koji se mogao proširiti na sve ljude i bogove uopće, [taj] osjećaj dobronamjernosti upravio posebice na njih [petoricu]. Oni su ga, dirnuti osjećajem dobronamjernosti Blaženoga, koji se je sve više približavao, ne mogavši se držati svojega dogovara, pozdravili, ustali se i učinili sve što je trebalo biti učinjeno. Ali, budući da nisu znali za njegovo savršeno probuđenje, oslovili su ga samo imenom i riječju 'starino'. Tada [im] je Blaženi [rekao]: "Ne oslovljavajte, o isposnici, Tathāgatu imenom i riječju 'starino'. Ja sam, o isposnici, Tathāgata, Savršeno probuđeni”. Uvjerivši ih u svoje probuđenje, sjeo je, okružen sa osamnaest neizmjernih mnoštava nebesnika, na pripremljeno mu izvrsno sjedalo za buddhe, u trenutku kada je Mjesec bio u položaju Uttarāsạ̄̂ha i, oslovivši petoricu poštovanih, iznio im propovijed Pokretanje kotača nauka. Među njima je, starješina Añ̃̃ākondañña, usmjerivši znanje u skladu s poukom, po završetku pouke, zajedno sa osamnaest neizmjernih mnoštava nebesnika, dosegao plod [koji donosi] stupanje na put. Sljedećega je dana Učitelj, koji je upravo tamo provodio razdoblje kiša, otišao u boravište (vihāra) i tamo sjeo davajući pouku starješini Vappi. Preostala su četvorica otišla sakupljati milodare. [Toga je] jutra poštovani Vappa dosegao plod [koji donosi] stupanje na put. Na isti način, sljedećega dana starješina Bhaddiya, sljedećega dana starješina Mahānāma, sljedećega dana starješina Assanđi, svi su dosegli plod [koji donosi] stupanje na put. Petoga je dana te polovice mjeseca, pozvavši petoricu na stranu, izložio propovijed o obilježjima bessopstvenosti. Po završetku pouke, sva su petorica starješina dosegla plod [koji donosi] stupanje na put.

\subsubsection{Susret s petoricom isposnika u Mahāvastuu}

Mv iii. 328-330

rș̣ipatane paṃcakā bhadravargìya viharanti ājñātakauṇ̣inyo aśvakī bhadrako (3.329) vāṣpo mahānāmo // bhagavām vārānasīto piṇ̣̂āya caritvā krtabhaktakṛtyo rșsipatanam gacchati // paṃcakehi bhadravargīyehi bhagavān dṛșto / dūrato evāgacchantạ̣ dṛștvā bhagavantam kriyākāram karonti // ayam śramaṇo gautamo āgacchati śaithiliko bāhuliko prahāṇavikrānto na kenacit pratyutthātavyam // bhagavām cāgacchati te ca svakeșu sthāneșu na ramanti / sayyathāpi nāma śakuntā nī dagatā vā

\footnotetext{
${ }^{321}$ Mettaćittena. Mettā (skt. maitrī), ljubav, dobronamjernost, dobrohotnost, osjećaj prijateljstva. Uz suosjećanje (karunāa), radost (muditā) i nepristranost (upekhāa upekkhā), jedan je osjećaja ili vrlina koje valja njegovati kako bi se došlo do plemenita ili uzvišena stanja uma (brahmavihāra). Za mjesta u pālijskome kanonu na kojima se susreće izraz brahmavihāra v. Miller (1979: 218-219).
} 
vṛkșaśăkhāgatā vā heștato agninā saṃtāpiyamānā utpatensuh evam eva paṃakā bhadravargīyā dūrato evāgacchantasya svakasvakeșv āsaneșu ratim avindantā bhagavantam pratyutsthāyensuḥ pratyudgamensuḥ / ehi āyuṣmam gautama svāgatam āyuṣmato gautamasyānurāgatam āyușmato gautamasya // bhagavān āha // bhagnā vo bhikșavaḥ bhadravargīyā pratijña $m \bar{a}$ bhikșavo bhadravargīyā tathāgatam āyuṣmaṃvādena samācaratha // teșām dāni bhagavatā śikṣāvādenābhāṣțānām yat kiṃcit tīrthikalimgam tīrthikagupti tīrthikakalpam sarvam samantarahitam tricīvarā ca prādurbhavensuh sumbhakā ca pātrā prakrtisvabhāvasaṃsthitā ca keśā ìryāpatho ca sānam saṃsthihe sayyathāpi nāma varșaśatopasampannānām bhikșūnām / eṣa āyuṣmantānām pạ̣cānām bhadravargīyānām pravrajyopasampadā bhikṣubhāvo // te dāni pakvatailena bhagavantam nimantrayensuh // buddhavicīrṇā nāma puṣkirị̣i tahim bhagavām snāto jānantā ca buddhā bhagavanto // atha khalu bhagavatạ̣ etad abhūṣi // katamasmim pṛthivīpradeśe purimakāh samyaksaṃbuddhā dharmacakram pravartayensuh // saha cittotpādena bhagavato tạ̣ prthivīpradeśam onasati

(3.330) ca // atha khalu bhagavata etad abhūṣi // kị̣ nu khalu purimakāh samyaksambuddhāh gacchantakā dharmacakram pravartenti tișthanto vā niṣaṇna vā śayantakā vā // saha cittotpādena bhagavato rșivadane ${ }^{322}$ pamca āsanā prādurbhūtāni //

Prijevod

U R̦sipatani je boravila ona dobra ${ }^{323}$ skupina petorice [isposnika]: Āđ̃ñatakauṇdinya, Aśvakin, Bhadraka,

(3.329) Vāṣpa i Mahānāma. ${ }^{324}$ Blaženi je, sakupivši milodare, objedovao i krenuo iz Vārānasī do Rșipatane. Vidjela je Blaženoga skupina petorice isposnika i, vidjevši Blaženoga kako izdaleka prilazi, dogovorila se: "Prilazi onaj isposnik Gautama,

\footnotetext{
${ }^{322}$ Ṛșivadana = R̦șipatana. V. Senart (1882: 631, bilj. 17).

${ }^{323}$ Dok se u Mahāvastuu nalazi pamcakā bhadravargiyā u Vin. i. 8 (Mahāvagga I. 6, 5) i MN i. 171 stoji pañcavaggīya $\bar{a}$ bhikkhü. Skt. bhadra, poštovan, sretan, dobar, ljubazan, ugodan. S obzirom da je riječ o petorici isposnika koji su Gotamu prvo napustili pa ga odlučili hladno dočekati, pridjev bhadra teško je objasniti. U Vin. i. 23 (Mahāvagga I. 14, 1) spominje se skupina isposnika opisana kao bhaddavaggīya a, ali tu nije riječ o ovoj petorici. V. i Jones (1956/2007b: 313, bilj. 2).

324 Što uglavnom odgovara imenima petorice isposnika u pālijskim izvorima: Aññātakoṇdañña, Assađi, Bhaddiya, Vappa, Mahānāma (npr. ĐātA I. 81-82). Prvi bi se morao zvati na pāliu Aññātakoṇ̣añña, kako je navedeno, a drugi na sanskrtu Aśvađit.
} 
raspuštenjak i obilnik, koji se odrekao napora ${ }^{325}$ pa neka se nitko [pred njim] ne ustane”. [Ali, kako je] Blaženi prilazio, tako oni nisu ostali na svojim mjestima. Kao što bi ptice, sjedeći u gnijezdima ili na granama stabla, ako ih pali vatra ispod njih, poletjele uvis, tako se je upravo dobra skupina petorice isposnika, vidjevši ga kako izdaleka prilazi i ne nalazeći mira svaki na svojem sjedalu, ustala i krenula Blaženomu u susret. ${ }^{326}$ "Dođi, starino Gautama! Dobrodošao, starino Gautama! Pozdravljen si, starino Gautama!" Blaženi reče: "O, dobra skupino isposnika! Prekršen je vaš dogovor. O, dobra skupino isposnika! Ne oslovljavajte Tathāgatu rječju 'starino','. U trenutku u kojem im je Blaženi uputio riječi pouke, nestao je svaki znak, trag i svako obilježje druge sljedbe, a pojavili su se po tri ogrtača te zdjele za milodare. Kosa [im se] vratila u prirodno stanje i njihovo držanje postade kao da su redovnici zaređeni već stotinu godina. Takvi su bili odlazak u bekućništvo, zaređenje i postajanje redovnicima starinā braće iz dobre skupine petorice isposnika. Ponudili su Blaženoga tada pripremljenim uljem. [lacuna]

Tamo je bilo lopoč-jezero zvano Buddhavićîrṇā [u kojem se je] Blaženi okupao, a blaženi buddhe znaju [lacuna].

Tada je Blaženi ovako [pomislio]: "Na kojem su dijelu zemlje prijašnji savršeno probuđeni pokrenuli kotač nauka"? Čim se u Blaženom pojavila misao, taj je dio zemlje nestao.

(3.330) Tada je Blaženi ovako [pomislio]: “Jesu li prijašnji savršeno probuđeni pokrenuli kotač nauka hodajući, stojeći, sjedeći ili ležeći”? Čim se u Blaženom pojavila misao, pojavilo se u Rṣivadani pet sjedala. ${ }^{327}$

\section{4. Pokretanje kotača nauke}

\subsubsection{Pokretanje kotača nauke u pālijskim izvorima}

\footnotetext{
325 Prahānavikrānto, u pālijskom tekstu padhānavibbhanto. Vikrānta, pridj. (vi- $\sqrt{\text { kram }}$ ), snažan, hrabar, moćan što ne odgovara kontekstu. Jones (1956/2007b: 320, bilj. 7): The right reading is evidentely vibhrānto corresponding to the Pali vibbhanto in the same expression, i.e. the participle of vibhramati, or we could restore the synonymous vibhrașțo (vi-bhraṃś) as at Lal. Vist. 407.

${ }^{326}$ Usporedba petorice isposnika s pticama koje polijeću mučene vatrom nalazi se i u Lv. 408.

${ }^{327}$ Pet sjedala za trojicu buddha (Krakutsanda, Konākamuni, Kāśyapa) koji su se pojavili prije Gautame u tzv. Pușpakakalpi, jedno za Gautamu Buddhu i jedno za budućeg buddhu Maitreyu. U Mahāvastuu se, međutim, samo nekoliko redaka dalje tvrdi da se u tom razdoblju pojavljuje tisuću buddha. Lv. 410 također donosi podatak da se netom prije početka pokretanja kotača nauka pojavilo tisuću sjedala načinjenih od sedam različitih dragulja.
} 
Sadržaj prve propovijedi iznesen je u Vinayapițaki kao i u Sutti o pokretanju kotača nauka (Dhammaćakkappavattanasutta). ${ }^{328}$ Prijevod Dhammaćakkappavattanasutte iznesen je u cijelosti.

SN v. 420 i d. (SN 56. 11) = Vin. i. 10-12 (Mahāvagga I. 6, 17-32) $)^{329}$

Evam me sutạ̣ ekam samayam Bhagavā Bārāṇasiyam viharati Isipatane Migadāye || ||

Tatra kho Bhagavā pañcavaggiye bhikkhū āmantesi || ||

Dve me bhikkhave antā pabbajitena na sevittabbā || Katame dve || ||

Yo cāyạ̣ kāmesu kāmesu khallikānuyogo hīno gammo puthujjanīko anariyo anatthasaṃhito || yo cāyam attakilamathānuyogo dukkho anariyo anatthasaṃhito || || Ete te bhikkhave ubho ante anupakamma majjhimā pațipadā Tathāgatena abhisambuddhā cakkhukaraṇī ñạnakaraṇī upasamāya abhiñ̃̃āya sambodhāya nibbānāya saṃvattati || ||

Katamā ca sā bhikkhave majjhimā pațipadā Tathāgatena abhisambuddhā cakkhukaraṇ̄ ñānakaraṇi upasamāya abhiñ̃āya sambodhāya nibbānāya saṃvattati || || Ayam eva


sammākammanto sammāājīvo sammāvāyāmo sammāsati sammāsamādhi || || Ayam kho sā bhikkhave majjhimā paṭipadā Tathāgatena abhisambuddhā cakkhu- ñana- karaṇ̄ upasamāya abhiñ̄̄āya sambodhāya nibbānāya saṃvattati || |

Idạ̣ kho pana bhikkhave dukkham ariyasaccam || || Jāti pi dukkhā jarā pi dukkhā vyādhi pi dukkhā maranam pi dukkham sokaparidevadukkhadomanassupāyāsā pi dukkhā || appiyehi sampayogo dukkho piyehi vippayogo dukkho \| yam piccham na labhati tam pi dukkhaṃ || saṃkhittena pañcupādānakkhandhā pi dukkhā || ||

Idam kho pana bhikkhave dukkhasamudayam ariyasaccam \| \| Yāyam tạnhā ponobbhavikā nandī rāgasahagatā tatra tatrābhinandin̄̄ || seyyathīdam || || Kāmataṇhā bhavataṇhā vibhavataṇhā || ||

\footnotetext{
${ }^{328}$ U Mahāpadānasutti se nalazi prikaz prve propovijedi buddhe Vipassina. Propovijed je održana u Bandhumatī, u Parku jelena zvanom Khema, pred budućim učenicima i redovnicima Khaṇḍom i Tissom.

${ }^{329}$ Uvodna se rečenica ne nalazi u Vinayapițaki budući da ovdje propovijed nije iznesena kao zasebna sutta, a mjesto susreta s petoricom isposnika i izlaganja prve propovijedi naznačeni su ranije (Mahāvagga I. 6, 10).
} 
Idạ̣ kho pana bhikkhave dukkhanirodham ariyasaccam || || Yo tassā yeva tạ̣hāya asesavirāganirodho cāgo paținissaggo mutti anālayo \|| ||

Idam kho pana bhikkhave dukkhanirodhagāminī pațipadā ariyasaccam

|| || Ayam eva ariyo aț̣hangiko maggo ||seyyathīdam || sammādițthi || la-pe || sammāsamādhi \| \|

Idam dukkham ariyasaccan ti me bhikkhave pubbe ananussutesu dhammesu cakkhum udapādi ñāṇam udapādi pañ̃̃ā udapādi vijjā udapādi āloko udapādi || || Tam kho panidam dukkham ariyasaccam pariññeyyan ti me bhikkhave pubbe || la || pariñ̃āatan ti me bhikkhave pubbe ananussutesu dhammesu cakkhum udapādi || pe || āloko udapādi || |l

Idam dukkhasamudayam ariyasaccan ti me bhikkhave pubbe ananussutesu dhammesu cakkhum udapādi ñāṇam udapādi pañ̃āa udapādi vijjā udapādi āloko udapādi || || Tam kho panidam dukkhasamudayam ariyasaccam pahātabban ti me bhikkhave pubbe || la-pe || pahīnan ti me bhikkhave pubbe ananussutesu dhammesu cakkhum udapādi \| pe || āloko udapādi \| \|

Idam dukkhanirodham ariyasaccan ti me bhikkhave pubbe ananussutesu dhammesu cakkhum udapādi ñāṇam udapādi pañ̃̃ā udapādi vijjāa udapādi āloko udapādi \| \| Tam kho panidam dukkhanirodham ariyasaccam sacchikātabban ti me bhikkhave pubbe || la-pe || sacchikatan ti me bhikkhave pubbe ananussutesu dhammesu cakkhum udapādi || pe || āloko udapādi $\|$ ||

Idạ̣ dukkhanirodhagāmin̄̄ pațipadā ariyasaccan ti me bhikkhave pubbe ananussutesu dhammesu cakkhum udapādi ñānam udapādi pañ̃āa udapādi vijjā udapādi āloko udapādi || || Tam kho panidam dukkhanirodhagāminī pațipadā ariyasaccam bhāvetabban ti me bhikkhave || pa || bhāvitan ti me bhikkhave pubbe ananussutesu dhammesu cakkhum udapādi ñāṇam udapādi pañ̃āa udapādi vijjā udapādi āloko udapādi || ||

Yāva kīvañca me bhikkhave imesu catusu ariyasaccesu evam tiparivațtam dvādasākāram yathābhūtam ñānadassanam na suvisuddham ahosi || neva tāvāham bhikkhave sadevake loke samārake sabrahmake sassamaṇabrāhmaṇiyā pajāya sadevamanussāya anuttaram sammāsambodhim abhisambuddho ti paccañ̃̃āsim 
Yato ca kho me bhikkhave imesu catusu ariyasaccesu evam tiparivațtam dvādasākāram yathābhūtam ñaṇadassanam suvisuddham ahosi || athāham bhikkhave sadevake loke samārake sabrahmake sassamaṇabrāhmaniyā pajāya sadevamanussāya anuttaram sammāsambodhim abhisambuddho ti paccañ̃̄āsim \|| ñānañca pana me dassanam udapādi Akuppā me cetovimutti ayam antimā jāti natthidāni punabbhavo ti || ||

Idam avoca Bhagavā || attamanā pañcavaggiyā bhikkhū Bhagavato bhāsitam abhinandum || imasmim ca pana veyyākaraṇasmim bhaññamāne āyasmato Koṇ̣̂añ̃assa virajam vītamalam dhammacakkhum udapādi || yam kiñci samudayadhammam sabban tam nirodhadhamman ti $\|||$

Evam pavattite ca pana Bhagavatā dhammacakke Bhummā devā saddam anussāvesum $\|$ II Etam Bhagavatā Bārānasiyam Isipatane Migadāye anuttarạ̣ dhammacakkam pavattitam appativattiyam samaṇena vā brāhmaṇena vā devena vā Mārena vā Brahmunā vā kenaci vā lokasmin $t i\|\|$

Bhummānam devānam saddam sutvā Cātummahārājikā devā saddam anussāvesum || || Etam Bhagavatā Bārānasiyam Isipatane Migadāye anuttaram dhammacakkam pavattitam appativattiyam samaṇena vā brāhmaṇena vā devena vā Mārena vā Brahmun̄ā vā kenaci vā lokasmin $t i \|||$

Cātummahārājikānam devānam saddam sutvā Tāvaținssā devā Yāmā devā Tusitā devā Nimmānaratī devā Paranimmittavasavattino devā Brahmakāyikā devā saddam anussāvesuṃ || || Etam Bhagavatā Bārāṇasiyam Isipatane Migadāye anuttaram dhammacakkam pavattitam appativattiyam samaṇena vā brāhmaṇena vā devena vā Mārena vā Brahmunā vā kenaci vā lokasmin ti \|| ||

Iti ha tena khaṇena tena layena tena muhuttena yāva Brahmalokā saddo abbhuggacchi || ayañ ca dasasahassī lokadhātu saṃkampi sampakampi sampavedhi || appamāṇo ca uḷāro obhāso loke pātur ahosi atikkamma devānam devānubhāvan ti || ||

Atha kho Bhagavā udānam udānesi || || Añ̃̃āsi vata bho \{Koṇ̣̂añ̃̃o\} añ̃āasi vata bho Koṇdañño ti || || Iti hidam āyasmato Koṇdañ̃assa Añ̃āata-Konḍñ̃̃̃o tveva nāmam ahosī $t i\|\|$ 
Prijevod

Tako sam čuo. Jednom je prilikom Blaženi boravio u Vārānasī̄ u Gaju jelena, u Isipatani. Tamo je Blaženi rekao skupini od pet isposnika: "Dvije su, o isposnici, krajnosti kojima otišli od kuće u beskućništvo ne trebaju služiti. Koje dvije? Prepuštanje svjetovnim strastima u zadovoljstvu osjetila što je nisko, prosto, nedolično, neplemenito i beskorisno i pribjegavanje samomučenju što je bolno, neplemenito i beskorisno. Držeći se podalje od obje te krajnosti, Tathāgata je spoznao srednji put; on vodi do uvida, znanja, smirujuće spoznaje, probuđenja, nibbāne.

Koji je to, o isposnici, srednji put spoznao Tathāgata, koji vodi do uvida, znanja, smirujuće spoznaje, probuđenja, nibbāne? To je, upravo, plemeniti osmerostruki put, odnosno - obuhvatan nazor, obuhvatno htijenje, obuhvatan govor, obuhvatno djelovanje, obuhvatno življenje, obuhvatno nastojanje, obuhvatna pozornost, obuhvatno zadubljenje. To je, redovnici, taj srednji put koji vodi do uvida, znanja, smirujuće spoznaje, probuđenja, nibbāne.

Ovo je, o isposnici, plemenita istina o patnji: rođenje je patnja, starost je patnja, bolest je patnja, umiranje je patnja, združenost s nevoljenim je patnja, razdvojenost od voljenoga je patnja, ne dobiti željeno je patnja. Ukratko, pet je debala prianjanja uz postojanje patnja. ${ }^{330}$ Ovo je, o isposnici, plemenita istina o nastanku patnje: to je ona žed koja vodi do ponovnih postajanja, praćena ugodom i požudom, koja tu i tamo nalazi zadovoljstvo, odnosno - žeđ za užitcima, žeđ za bivanjem, žeđ za nebivanjem. ${ }^{331}$ Ovo je, o isposnici, plemenita istina o zaustavljanju patnje: to je potpuna besstrasnost $i$ zaustavljanje žeđi, ostavljanje, otpuštanje, oslobođenje [od žeđi], nepohranjivanje [žeđi]. Ovo je, o isposnici, plemenita istina o putu koji vodi do zaustavljanja patnje, odnosno: obuhvatni nazor, obuhvatno htijenje... obuhvatno zadubljenje". 332

"To je plemenita istina o patnji”- tako se je pojavio vid za ranije nikad čute stvari, pojavilo se znanje, pojavila se proznaja, pojavio se uvid, pojavilo se zrenje. "Ta plemenita istina o patnji treba biti potpuno spoznata"!- tako se je pojavio vid za ranije

\footnotetext{
330 Odnosno pet upādāna-khandha (skt. skandha): rūpa (vidljivo), vedanā (osjećaj), sañ̃̃ā (zamjećivanje), saṃkhāra (ustrojnice svijesti), viñ̃̃āna (svijest). Propovijed o nestalnosti khandha (Anattalakkhaṇa sutta) nalazi se u Vin. i. 13 (Mahāvaggi I. 6, 38 i d.).

${ }^{331}$ Vibhavataṇhā, craving for life to end, desire for non-existence, u: PED, str. 629.

${ }^{332}$ SN v. 433-434 (SN 56.24) također sadrži kratku suttu o plemenitim istinama.
} 
nikad čute stvari, pojavilo se znanje, pojavila se proznaja, pojavio se uvid, pojavilo se zrenje. "Ta je plemenita istina o patnji potpuno spoznata"- tako se je pojavio vid za ranije nikad čute stvari, javilo se znanje, pojavila se proznaja, pojavio se uvid, pojavilo se zrenje.

“To je plemenita istina o uzroku patnje”- tako se je pojavio vid za ranije nikad čute stvari, pojavilo se znanje, pojavila se proznaja, pojavio se uvid, pojavilo se zrenje. "Ta plemenita istina o uzroku patnje treba biti napuštena”- tako se je pojavio vid za ranije nikad čute stvari, pojavilo se znanje, pojavila se proznaja, pojavio se uvid, pojavilo se zrenje. "Ta je plemenita istina o uzroku patnje napuštena"- tako se je pojavio vid za ranije nikad čute stvari, pojavilo se znanje, pojavila se proznaja, pojavio se uvid, pojavilo se zrenje.

“To je plemenita istina o zaustavljanju patnje”- tako se je pojavio vid za ranije nikad čute stvari, pojavilo se znanje, pojavila se proznaja, pojavio se uvid, pojavilo se zrenje. "O toj se plemenitoj istini o zaustavljanju patnje treba osvjedočiti”- tako se je pojavio vid za ranije nikad čute stvari, pojavilo se znanje, pojavila se proznaja, pojavio se uvid, pojavilo se zrenje. "O toj sam se plemenitoj istini o zaustavljanju patnje osvjedočio” tako se je pojavio vid za ranije nikad čute stvari, pojavilo se znanje, pojavila se proznaja, pojavio se uvid, pojavilo se zrenje.

"To je plemenita istina o putu koji vodi do zaustavljanja patnje"- tako se je pojavio vid za ranije nikad čute stvari, pojavilo se znanje, pojavila se proznaja, pojavio se uvid, pojavilo se zrenje. "Ta plemenita istina o putu koji vodi do zaustavljanja patnje treba biti ozbiljena”- tako se je pojavio vid za ranije nikad čute stvari, pojavilo se znanje, pojavila se proznaja, pojavio se uvid, pojavilo se zrenje. "Ta plemenita istina o putu koji vodi do nestanka patnje je ozbiljena” - tako se je pojavio vid za ranije nikad čute stvari, pojavilo se znanje, pojavila se proznaja, pojavio se uvid, pojavilo se zrenje.

Sve dok zaista, o isposnici, trostruko raščlanjeno $i$ u dvanaest obrata jasno znanje $i$ uvid o četirima plemenitim istinama nisu bili sasvim pročišćeni, nisam, u svijetu s Mārom, $s$ Brahmanom, s naraštajima trapljenika i brahmana, nebesnika i ljudi, tvrdio: "[Dosegao sam] najviše probuđenje, [ja sam] Savršeno probuđeni”. 
Ali kada su, o isposnici, trostruko raščlanjeno i u dvanaest obrata jasno znanje i uvido četirima plemenitim istinama postali sasvim pročišćeni, ja sam, u svijetu s Mārom, s Brahmanom, s naraštajima isposnika, brahmana, nebesnika i ljudi, potvrdio: "[Dosegao sam] najviše probuđenje, [ja sam] Savršeno probuđeni”. Pojavilo se meni znanje i uvid: "Moje je oslobođenje nepotresivo! Ovo je moje posljednje rođenje, nema ponovnih postajanja”! - tako je rekao Blaženi, a zadivljena je skupina od pet isposnika našla zadovoljstvo u riječima Blaženoga.

Dok je trajalo izlaganje, javilo se u poštovanom Koṇ̦aññassi čisto i bez mrlja oko dhamme: "Sve što je podložno zakonu nastanka, podložno je i zakonu nestanka".

Kada je Blaženi pokrenuo kotač nauka, na zemlji boraveći nebesnici pronijeli su riječ: "Pokrenuo je Blaženi, u Vārāṇasī, u Gaju jelena, u Isipatani, nenadmašni kotač nauke koji ne može zaustaviti ni jedan trapljenik, ni brahman, ni nebesnik, ni Māra, ni Brahman, ni bilo tko drugi u svijetu”. Čuvši riječ na zemlji boravećih nebesnika, nebesnici Četiri velika kralja pronijeli su glas: "Pokrenuo je Blaženi, u Vārāṇasī, u Gaju jelena, u Isipatani, kotač nauka koji ne može zaustaviti ni jedan trapljenik, ni brahman, ni nebesnik, ni Māra, ni Brahman, ni bilo tko drugi u svijetu”! Čuvši riječ nebesnika Četiri velika kralja, u nebesima Tāvatimsa boraveći nebesnici ... nebesnici iz svijeta Yame ... u nebesima Tusita boraveći nebesnici ... nebesnici iz skupine Nimmānarati ... nebesnici iz skupine Paranimmitavasavattin ... nebesnici iz pratnje Brahmana pronijeli su glas: "Pokrenuo je Blaženi, u Vārāṇasī, u Gaju jelena, u Isipatanu, kotač nauka kojega ne može zaustaviti ni jedan isposnik, ni brahman, ni nebesnik, ni Māra, ni Brahman, ni bilo tko drugi u svijetu"!

U tom se trenutku, u tom trenu, u tom času, pronio glas sve do svijeta Brahmana. Zatresao se, zadrhtao i snažno zadrmao ovaj sustav svemira sačinjen od deset tisuća svjetova $i$ pojavila se u svijetu neizmjerna i uzvišena svjetlost koja je nadišla nebesnike i njihovo nebesničko veličanstvo.

Tada je Blaženi ovako nadahnuto izjavio: "Koṇ̣̂ñ̃na je spoznao, Koṇ̣añna je zaista

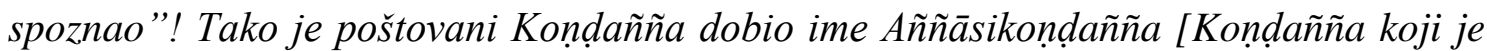
spoznao].

Tu završava Dhammaćakkappavattanasutta, ali u Vinayi se prikaz nastavlja. 
Vin. i. 12 (Mahāvagga I. 6, 32)

atha kho āyasmā Añ̃̄atakoṇ̣añ̃̃o dițthadhammo pattadhammo viditadhammo pariyogālhadhammo tịnnavicikiccho vigatakathaṃkatho vesārajjappatto aparappaccayo satthu sāsane bhagavantam etad avoca: labheyyāham bhante bhagavato santike pabbajjam, labheyyam upasampadan ti. ehi bhikkhū 'ti bhagavā avoca, svākkhāto dhammo, cara brahmacariyam sammā dukkhassa antakiriyāyā 'ti. sā 'va tassa āyasmato upasampadā ahosi. ||32||

Prijevod

A poštovani je Añ̃̃āsikoṇ̣añña, vidjevši dhammu, primivši dhammu, spoznavši dhammu, uronivši u dhammu, nadvladavši sumnju, nadišavši upitnost, zadobivši potpuno $i$, neovisno o ikom drugom, pouzdanje ${ }^{333}$ u nauku Učitelja, ovako rekao Blaženom: "Poštovani, neka u prisustvu Blaženoga poduzmem odlazak u beskućništvo, neka primim zaređenje”. Blaženi odgovori: “Dođi, redovniče! Dobro je izložena dhamma. Vodi u cijelosti zavjetovani život s ciljem obuhvatna okončanja patnje”! Takvo, zaista, bijaše zaređenje poštovanog [Añ̃̄āsikoṇ̣añ̃̃e].

U nastavku se pripovijeda kako su i preostala četvorica isposnika, na isti način, primila zaređenje. Slijedi, potom, propovijed o besopstvu (Anattalakkhaṇasutta), ${ }^{334}$ a poglavlje završava sljedećim riječima:

Vin. i. 14 (Mahāvagga I. 6, 47)

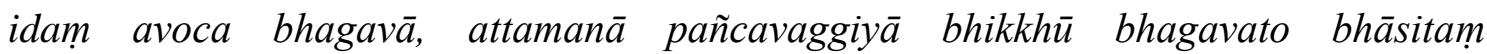
abhinandanti. imasmiñ ca pana veyyākaraṇasmịn bhaññamāne pañcavaggiyānam bhikkhūnam anupādāya āsavehi \{cittāni\} vimuccimsu. tena kho pana samayena cha loke arahanto \{honti.\} $\|47|| 6\|$

Prijevod

Tako je govorio Blaženi. Zadovoljna se skupina od pet isposnika obradovala riječima Blaženoga. Dok je trajalo to izlaganje, svijesti su se petorice isposnika, ne prionuvši [više uz svjetovno], oslobodile priljeva [žudnja]. U tom je trenutku na svijetu bilo šest dostojnika.

\footnotetext{
${ }^{333}$ Vesārađđa, četverovrsno samopouzdanje, V. MN i. 71, 380, DN i. 110.

${ }^{334}$ Vin. i. 13-14 (Mahāvagga I. 6, 38 i d.). Anattalakkhạ̣asutta nalazi se i u SN iii. 66-69.
} 
Vinayapițaka (Mahāvagga, Mārakathā) donosi i pripovijest o susretu Māre i Gotame koji se zbio nedugo nakon prve propovijedi. Niže je iznesena u cijelosti ne samo kao potvrda vjerovanja da i Savršeno probuđeni mogu biti mučeni sumnjama i Mārinim kušnjama već i zbog činjenice da se u toj pripovijesti donosi i opis začetka misionarskog aspekta buddhizma.

\section{Vin. i. 20-21 (Mahāvagga I. 11, 1-2) $)^{335}$}

atha kho bhagavā bhikkhū āmantesi: mutt'; āham bhikkhave sabbapāsehi ye dibbā ye ca mānusā. tumhe pi bhikkhave muttā sabbapāsehi ye dibbā ye ca mānusāa caratha bhikkhave cārikam bahujanahitāya bahujanasukhāya lokānukampāya atthāya hitāya sukhāya devamanussānam. mā ekena dve agamittha. desetha bhikkhave dhammam ādikalyānam majjhekalyāṇam pariyosānakalyānạn sāttham savyañjanam kevalaparipuṇnam parisuddham brahmacariyam pakāsetha. santi sattā apparajakkhajātikā assavanatā dhammassa parihāyanti, bhavissanti dhammassa añ̃ātāro. aham pi bhikkhave yena Uruvelā yena Senāninigamo ${ }^{336}$ ten'; $^{2}$ upasaṃkamissāmi dhammadesanāyā 'ti. ||1 || atha kho Māro pāpimā yena bhagavā ten'; upasaṃkami, upasaṃkamitvā bhagavantam gāthāya ajjhabhāsi:

baddho 'si sabbapāsehi ye dibbā ye ca mānusā, mahābandhanabaddho 'si, na me samaṇa mokkhasìti.

mutt'; āhạ̣ sabbapāsehi ye dibbā ye ca mānusā, mahābandhanamutto 'mhi, nihato tvam asi Antakā 'ti. | antalikkhacaro pāso yv' āyam carati mānaso tena tạ̣ bādhayissāmi, na me samaṇa mokkhasīti. rūpā saddā gandhā rasā phoț̣habbā ca manoramā ettha me vigato chando, nihato tvam asi Antakā 'ti.

atha kho Māro pāpimā jānāti mam bhagavā, jānāti mam sugato 'ti dukkhī dummano tatth'; ev'; antaradhāyitit. ||2||

\section{Prijevod}

Tada je Blaženi rekao tim redovnicima: "Oslobođen sam, o redovnici, svih spona, $i$ nebesničkih i ljudskih. I vi ste, o redovnici, oslobođeni svih spona, i nebesničkih i ljudskih.

\footnotetext{
${ }^{335}$ Usp. SN i. 105-106. Pripovijest se nalazi i u Mv. iii. 415-417.

336 Rhys Davids i Oldenberg (1882/1974: 113, bilj. 1): The correct spelling of this name appears to be Senāninigama (The General's Town), and not Senānigama (The Army's Town).
} 
Uputite se na put, o redovnici, za dobrobit mnogih ljudi, za sreću mnogih ljudi, iz suosjećanja sa svijetom, za dobro, dobrobit i sreću ljudi i nebesnika. Neka dvojica ne idu istim putem. Poučavajte, o redovnici, dhammu koja je krasna na početku, krasna u sredini, krasna na kraju, krasna i po smislu i u riječi. Obznanite [što je] potpuno ispunjen i čist zavjetovani život. Postoje bića koja nisu sasvim zasljepljena ali, ne čuju li dhammu, propast će. Bit će onih koji će spoznati dhammu. Ja ću se pak, o redovnici, uputiti u vojvodski grad Uruvelu da tamo propovijedam dhammu”. Tada se Māra Grješni uputio prema mjestu [na kojem je boravio] Blaženi i, prišavši, oslovio Blaženoga stihom:

"Vezan si svima uzama, i nebeskim i ljudskima.

Čvrsto si vezan, trapniče. Nećeš mi oslobodit se!”

[Blaženi odvrati:]

"Slobodan od svih uza sam, i nebeskih i ljudskih ja.

Od čvrstih uza slobodan! Sad si mrtav, Smrtonošo!"

[Māra reče:]

"Ova kroz pamet uzica ko da ozračjem prolazi.

Njom te, trapniče, vežem ja, Nećeš mi oslobodit se!"

[Blaženi odvrati:]

"Oblici, riječi, mirisi, okusi, dodir, ugode -

Želja za njima prošla me! Sad si mrtav, Smrtonošo!"

Tada [reče] Māra Grješni: "Prepoznao me Blaženi! Poznaje me Sretni”! pa, zlosretan i zlovoljan iščeznu odatle.

\subsubsection{Pokretanje kotača nauke u Mahāvastuu}

Za razliku od prikaza u pālijskoj Vinayi u kojoj se prva propovijed nadovezuje na događaje koji su joj prethodili, u Mahāvastuu je naracija prekinuta, a prva je propovijed umetnuta kao zasebna sūtra, kao što je slučaj i u Samyuttanikāyi. Sadržaj se prve propovijedi u Mahāvastuu (Mv iii. 330-334) ne razlikuje od onoga u Samyuttanikāyi ili pālijskoj Vinayi i obuhvaća nauk o izbjegavanju krajnosti, nauk o osmerostrukom putu i četiri plemenite istine. Završetak je prve propovijedi u Mahāvastuu sljedeći: 
Mv. iii. 333-334

idam avocad bhagavām vārāṇasyām viharanto rṣivadano mrgadāve imasmị̣ ca punạ̣ vyākaraṇe āyuṣmato ājñātakauṇdinyasya virajam vigatamalạ̣ dharmeșu dharmacakṣurviśuddhạ̣

(3.334) aștāâdaśānām ca devakoțīnām virajo vigatamalạ̣ dharmeșu dharmacakșurviśuddham/

Prijevod

Tako je govorio Blaženi dok je boravaio u Vārāṇasī, u Rṣivadani, u Gaju jelena. A dok je trajalo izlaganje, poštovanomu se je Āãnātakauṇdinyi pročistilo oko nauke da vidi bez zamagljenosti i bez mrlja predmete spoznaje. ${ }^{337}$

(3.334) I u osamnaest stotina tisuća nebesnika pročistilo se je oko nauke da vide bez zamagljenosti i bez mrlja predmete spoznaje.

(Slijedi opis čudesnih pojava koje su se u tom trenutku očitovale.)

U Mahāvastuu je propovijed o bessopstvenosti izložena u zasebnoj sūtri, dok ista propovijed u Vinayi slijedi nakon opisa zaređenja petorice isposnika. Također, dok prikaz druge propovijedi u Vinayi završava tvrdnjom da je u tom trenutku postojalo ukupno šest dostojnika oslobođenih āsava, Mahāvastu nadodaje da je u istom trenutku, oslobođenje doseglo i tridest koția, odnosno tristo milijuna nebesnika. Pouka o nestalnosti skandha također je, za razliku od prikaza u Vinayi, uvrštena kao zasebna sūtra. ${ }^{338}$

Mv. iii. 340-341 donosi još jedan, u ovom slučaju, vrlo sažet prikaz pokretanja kotača nauka:

atha khalu bhagavām āṣā ḍhamāsasya uttarapakṣe dvādaśīyam paścābhaktaḥ purastāt saṃmukho niṣaṇno dhyardhapauruṣāyām chāyāyām anurādhe nakșatre vijaye muhūrte anuttaram dharmacakram pravartitam ${ }^{339}$ // na khalu punar buddhā bhagavanto

\footnotetext{
337 dharmeșu dharmaćakșus.

${ }^{338} \mathrm{Na}$ ovom mjestu Jones (1956/2007b: 333, bilj. 1) primjećuje: This sūtra on the impermanence of the skandhas has a closer resemblance to the latter half of the Attadipa-sutta of the S. 2.42 than to the discourse on the same subject in the Mahāvagga (V. I. 14) and the Pañca-sutta at S. 5. 66. The first part of the Attadipa-sutta is given in the following sūtra of the Mhvu. but S. locates the delivery of it at Sävatthi. It should be noted also that each of the sūtras into which the second sermon is divided in the Mhvu. has an allusion to the effect that preaching of it had on the five monks. The Pali text, having only two separate discourses, refer to them only twice.
}

${ }^{339}$ Umjesto pravartesi. 
suvarnamayam vā dharmacakram pravartenti rūpyamayam vā muktāmayam vā vaị̣ūryamayạ̣ vā sphațikamayam vā musāragalvamayam vā lohitikāmayam

(3.341) vā rîtikāmayam vā tāmramayam vā lohamayạ̣ vā śailamayam vā dārumayam vā mṛttikāmayam vā / atha khalv imāny eva catvāry āryasatyāni triparivartam dvādaśākāram dharmacakram // pravartite prathamam dharmacakrapravartanasūtre āyuṣmato ājñātakauṇdinyasya virajo vigatamalạ̣ dharmeșu dharmacakṣur viśuddham aștāadaśānām devakoținām ca / yạ̣ ca mahāpṛthivī atiriva șaḍikāraṃ kampe prakampe samprakampe vedhe pravedhe sampravedhe [...]

\section{Prijevod}

Tada, uistinu, dvanasetoga dana druge polovice mjeseca Āṣạdha, kada je sjena bila duljine jednoga i pol čovjeka, kada je zviježđe Anurādha bilo u uzlaženju, u vrijeme jedanaestoga časa ${ }^{340}$ u času pobjede, Blaženi je, nakon vremena objeda, sjedeći licem okrenut u smjeru istoka, pokrenuo nenadmašni kotač nauka. Kotač nauke, zaista, kojega pokreću blaženi buddhe nije načinjen od zlata, ni srebra, ni bisera, ni krizoberila, ni kristala, ni koralja, ni željeza,

(3.334) ni bronce, ni bakra, ni željeza, ni kamena, ni drveta, ni gline već je, zapravo, tri puta okrenut i dvanaesto-dijelni kotač nauka [načinjen]od četiri plemenite istine. Kada je sūtra „Pokretanje kotača nauka“ po prvi puta iznesena, poštovanomu Ajjñātakauṇ̣inyi, kao i stotini i osamdest milijuna nebesnika, pročistilo se je oko nauke da vide bez zamagljenosti i bez mrlja predmete spoznaje.

Velika je zemlja, na šest načina silno zadrhtala, uzdrhtala, podrhtala, zatresla se je, ustresla i potresla... [...]

Slijedi opis potresa, pojave neizmjerne svjetlosti i ostalih zadivljujućih pojava koje su popratile taj trenutak.

U Mahāvastuu je velika pažnja posvećena isticanju detalja koji za sam životopis naizgled nisu od osobita značenja. Ipak, uzme li se u obzir da najveći dio Mahāvastua zauzimaju nabrajanja mnogobrojnih Gautaminih savršenstava i nenadmašnih osobina, čitatelja ne treba čuditi da je prva propovijed iskorištena kao prilika da se u tančine opiše glas kojim je Gautama pokrenuo kotač nauka.

\footnotetext{
${ }^{340}$ Muhūrta, mjerna jedinica za vrijeme, trideseti dio dana ili 48 minuta.
} 
Završetak poglavlja posvećenoga pokretanju kotača nauka završava silaskom nebesnika Śikharadhare i pohvalnim riječima upućenim Gautami. ${ }^{341}$

Mv iii. 345-346:

sādhu te sādhurūpasya vyāmaprabhā pratipadyate /

sādhu arthānvitam sādhyam vacanam te manoramam //

(3. 346) sādhu aratisaṃyogaḥ sarvasandhiguṇānvitah̆ /

sādhu catvāri satyāni satyam pravadase mune //

sādhu te devagandharvā pibanti madhurām girām /

sādhu apratimam cakram pravartesi apravartiyam //

tuhyạ̣ loke samo nāsti rūpe varṇe kule tathā /

ìryāpathe ca vīrye ca dhyāne jūāne tathaiva ca //

adya aștâdaśa vìra koțīyo prathame phale /

vinītā devaputrāṇām āsane ${ }^{342}$ prathame muni //

trimíac ca koțīyo punar vinītā prathame phale /

dvitīya āsane vīra devaputrāṇa mārișa //

paṃcāśa koțīyo bhūyo āsane tṛtīye punah /

vinìtā devaputrāṇām apāyeșu vimocitā //

aśîti koțīyo bhūyo śrotāpattiphale vibhu /

caturthe āsane nītà durgatīṣu vimocitāa //

tasmāt te sadṛ́o nāsti maitryāya puruṣottama /

karuñāya ca kāruṇiko akutobhaya nararșabha //

diștyā purușaśārdūla utpanno lokasundaro /

hitāya sarvasatvānām ciran tișța mahāmune //

acirasya rājasuta utpanno si nararșabha /

praṇetā vipraṇaștānām andhānām nayanam dadā //

nāsmāsu kadācid bhūtvā gurur antarahāyatu /

Prijevod

Dobro se oko lika tvog do sežnja pruža svjetlokrug!

Dobroj ti riječi ugodnoj doseći treba smisao!

\footnotetext{
${ }^{341}$ Nebesnik Śikharadhara spominje se i u Mv. i. 174-176 gdje također dolazi neposredno nakon pokretanja kotača nauka pozdraviti i pohvaliti Buddhu.

${ }^{342} \mathrm{Za}$ śāsane. V. Mv. i. 174.
} 
(3.346) Dobro si žudnjom nespregnut, slogom sa svime krjepostan! ${ }^{343}$

Dobre četiri istine, istinu učiš, mudrače!

Dobro gandharve i bozi piju med tvoga govora!

Dobar kotač nenadmašni, nezaustavljiv pokrećě̌!

Nema na svijetu ravna ti likom, puti ni plemenom,

Putom kud stupaš, hrabrošću, zadubljenjem ni spoznajom!

Danas osamnaest koțija prvi je plod dosegnulo

Sinova neba, mudrače, tek prvu čuvši pouku!

Potom trideset koṭija prvi je plod dosegnulo

Sinova neba, junače, drugu još čuvši pouku!

Potom pedeset kotija sinova neba vođenih

Poukom trećom još se svih prolaznosti odriješi!

Još osamdeset koṭija plod u struju ulaska

Četvrtom steče poukom, odriješeno zlih usuda!

Stog tebi ravna, najviši junače, nema po sućuti,

Dobrohotnosti, sućutni, moćni, bez straha iotkud!

Srećom se tigar rodio međ ljudima, očarav svijet,

Dobro izboriv bića svih. Dugo nam živi, mudrače!

Nedugo rođen kraljević, ti posta bik med ljudima,

Izgubljenomu stadu vođ. Vid očni dadi slijepcima!

Postavši nama učitelj, nikada nas ne napusti!

\subsection{Daljnja obraćenja i jačanje zajednice}

Nakon zaređenja petorice isposnika usljedila su daljnja obraćenja. Pālijska Vinaya donosi pripovijest o obraćenju i zaređenju Yase, mladića iz bogate trgovačke obitelji, što je prvi primjer zaređenja laika. ${ }^{344}$ Uslijedilo je potom obraćenje Yasinih roditelja, supruge i zaređenje još pedeset i četiri Yasina prijatelja. U tome je trenutku, navodi Vinaya, na svijetu bio šezdest i jedan dostojnik. Budući da je rastao broj pojedinaca koji su željeli pristupiti redovničkoj zajednici, Gotama je prenio ovlasti na redovnike, pojednostavivši tako proceduru zaređenja. Iz Vārāṇasī, Gotama se uputio u Uruvelu, gdje je, izvevši 3500 čuda, preobratio trojicu braće

\footnotetext{
343 Sādhu aratisamyogaḥ sarvasandhiguṇānvitah. Nejasna rečenica. Senart (1897:510) početno a uzima kao negaciju obje složenice. Jones (2007, sv. 3: 342, bilj. 3) predlaže: It is, perhaps, better to make a slight emendation and read (for sarvasandhi-) sarvāsandhi-, that is, ,every non-attachmnet“.

${ }^{344}$ Vin. i. 15-18 (Mahāvagga I. 7, 1-15).
} 
Kassapa (skt. Kāśyapa) i njihovih tisuću sljedbenika. ${ }^{345}$ Preobraćenje braće Kāśyapa nalazi se opisano i u Mahāvastuu. ${ }^{346}$ U Rāđagāhi se Gotama susreo s kraljem Bimbisārom koji je, prihvativši Gotamin duhovni autoritet, postao laički sljedbenik. ${ }^{347}$ Bimbisāra je redovničkoj zajednici darovao perivoj Veḷuvanu, nakon čega je Gotama dopustio redovnicima da prihvaćaju zemljišne donacije. U Nidānakathi je to darivanje dodatno istaknuto:

Kralj, davši velik dar zajednici na čijem je čelu bio Buddha, [reče]: "Poštovani, ja ne mogu živjeti bez Tri dragulja. [Ovako] ću u bilo koje doba dolaziti do Blaženoga. Perivoj zvan Lațthivana jako je daleko, ali ovaj moj perivoj, zvan Veluvana, nije jako daleko, prikladan je za dolaske i odlaske i za stanovanje, dostojan je Buddhe. Neka Blaženi prihvati taj moj [dar]”. Poklanjajući perivoj Veluvanu, iz zlatnoga je vrča, na ruke Desetomoćnoga izlio vodu svjetlucavu poput dragulja i namirisanu cvijećem. U trenutku u kojem je prihvatio ugodni gaj, zatresla se je velika Zemlja [kao da govori]: "Učenje je Buddhe pustilo korijenje", 348

U Rāđagāhi su zaređeni i Sāriputta i Moggallāna (skt. Śāriputra i Maudgalyāyana), ${ }^{349}$ sljedbenici učitelja Sañđaye, kao i još dvije stotine i pedeset njegovih sljedbenika. Sāriputta, poštovan zbog svoje mudrosti i Moggallāna, poznat po svojim nadljudskim moćima, ubrajaju se među najistaknutije Gotamine učenike.

Ali, sve je veći broj zaređenika izazvao u Magadhi negodovanje:

U to su vrijeme mnogi vrlo poštovani sinovi magadhskih obitelji vodili zavjetovani život [pod vodstvom] Blaženoga. Ljudi su negodovali, uzrujavali se i ljutili se [govoreći]: "Isposnik Gotama čini [da ostajemo] bez sinova, isposnik Gotama [čini žene] udovicama, isposnik Gotama razara obitelji. Zaredio je tisuću đațila i onih dvije stotine

\footnotetext{
${ }^{345}$ Vin. i. 24-34 (Mahāvagga I. 15-20), ĐātA. I. 82.

${ }^{346}$ Mv. iii. 424 i d.

347 Vin. i. 35-39 (Mahāvagga I. 22), ĐātA. I. 82- 85. Gotama se nekoliko puta susreo s Bimbisārom. V. npr. Vin. i. 73 i d. (Mahāvagga I. 40). Obraćenje se Bimbisāre nalazi opisano i u Mv. iii. 436. i d.

348 ĐātA. I. 85: Rājā buddhapamukhassa saṃghassa mahādānam datvā "aham bhante tīni ratanāni vinā vattitum na sakkhissāmi, velāya vā avelāya vā Bhagavato santikam āgamissāmi, Lațthivanuyyānañ ca nāma atidūre idam pan', amhākam Veḷvanam nāma uyyānam nātidūre, gamanāgamanasampannam buddhāraham senāsanam idam me Bhagavā patigaṇhatū" ti suvaṇnabhimkārena pupphagandhavāsitamaṇivaṇnaudakam ādāya Veḷvanuyyānam pariccajanto Dasabalassa hatthe udakam pātesi. Tasmịn ārāmapațiggahaṇe Buddhasāsanassa mūlāni otiṇnānīti mahāpaṭavī kampi.

${ }^{349}$ Vin. i. 39-44 (Mahāvagga I. 2-24), ĐātA. I. 85, Mv. iii. 56-67.
} 
i pedest lutajućih trapljenika koji su sljedili Sañđayu. Vrlo ugledni sinovi magadhskih obitelji vode zavjetovani život [pod vodstvom] isposnika Gotame”. 350

Također, rast je redovničke zajednice uvjetovao i sve veći broj propisa, koji se u Vinayi iznose zajedno s opisom prijestupa koji je doveo do uvođenja novoga propisa. Sažet prikaz razdoblja od probuđenja do Gotamina dolaska u Rāđagāhu nalazi se u Nidānakathi. ${ }^{351}$

Iz Rāđagāhe se Gotama uputio u Kapilavatthu. Nidānakathā sadrži detaljniju verziju Gotamina posjeta očinskom gradu negoli je to ona u Vinayi i, između ostaloga, pripovijeda kako je Gotama, u pratnji dvadeset tisuća redovnika, otišao u Kapilavatthu na nagovor Suddhodānina podanika Udāyina ${ }^{352}$ (koji je i sam postao redovnik), nakon što je ranije preobratio pet stotina muškaraca iz klana Sakya. ${ }^{353}$ Zaređenje su, tijekom toga Gotamina posjeta, primili i njegov polu-brat Nanda, sin Rāhula, ${ }^{354}$ a duhovni Gotamin autoritet prihvatili su i kralj Suddhodāna i Rāhulina majka. ${ }^{355}$

Zaređenje drugih poznatih učenika Ānande, Upālia i Devadatte nalazi se opisano u Vinayapițaki. ${ }^{356}$

Zajednica redovnika okupljenih oko Gotame jačala je i zahvaljujući donacijama bogatih građana. ${ }^{357}$ Među najpoznatijim darivateljima bio je Sudatta, trgovac iz Sāvatthī, poznatiji pod imenom Anāthapiṇ̣̣ika. ${ }^{358}$ Sāvatthī je bio prijestolnica Pasenadia, kralja Kosale, također zaštitnika Gotamine zajednice. U Saṁyuttanikāyi se iznosi nekoliko Gotaminih razgovora s Pasenadiem, a u jednome od njih Gotama kaže kralju da ga ne treba shvaćati olako samo zato što je mlad. ${ }^{359}$ Mađđđhimanikāya donosi sljedeće riječi Pasenadia:

\footnotetext{
${ }^{350}$ Vin. i. 43 (Mahāvaga I. 24, 5): ena kho pana samayena abhiñ̃āatāabhiññātā Māgadhikā kulaputtā bhagavati brahmacariyam caranti. manussā ujjhāyanti khīyanti vipācenti: aputtakatāya pațipanno samaṇo Gotamo, vedhavyāya pațipanno samano Gotamo, kulupacchedāya pațipanno samano Gotamo. idāni anena jațilasahassạ

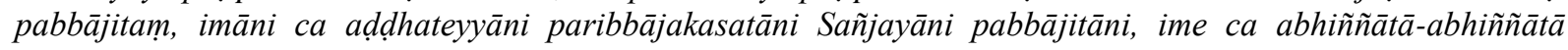
Māgadhikā kulaputtà samane Gotame brahmacariyam carantīti.

${ }^{351}$ ĐātA. I. 86.

352 Pod imenom Kāḷudāyin spominje se i u AN i. 25.

${ }^{353}$ ĐātA. I. 86-92, Mv iii. 176-182.

${ }^{354}$ Vin. i. 82-83 (Mahāvagga I. 54), Mv. iii. 268-271.

355 Pripovijest se o posjetu očinskom gradu nalazi i u Mv. ii. 233 i d., iii. 91 i d.

${ }^{356}$ Vin. ii. 180 i d. (Ćullavagga, VII). U Mahāvastuu je zaređenje Upālia opisano u Mv. iii. 179-182.

357 Jedan od primjera darivanja nalazi se i u Vin. ii. 146-151 (Ćullavagga, VI. 1-2) gdje se pripovijeda kako je neki trgovac iz Rāđagahe u jednom danu sagradio i poklonio zajednici šezdeset mjesta za odmor. Gotama tom prilikom odabrava primanje pet vrsta mjesta za boravak.

${ }^{358}$ U AN i. 26 spomenut je kao najistaknutiji darivatelj zajednice. Pripovijest o preobraćenju Anāthapiṇdike i njegovu darivanju zajednice nalazi se u Vin. Ii. 154-156 (Ćullavagga, VI. 4, 1-4), SN i. 210-212, ĐātA. I. 92 i d. ${ }^{359}$ SN i. 68-69.
} 
I nadalje, o poštovani, Blaženi je kšatrija i ja sam kšatrija; Blaženi je iz Kosale i ja sam iz Kosale; Blaženi ima osamdeset godina i ja imam osamdeset godina. I zato što je, o poštovani, Blaženi kšatrija i što sam ja kšatrija, što je Blaženi iz Kosale i što sam i ja iz Kosale, što Blaženi ima osamdeset godina i što ja imam osamdeset godina, prikladno je da iskažem Blaženomu iznimno poštovanje i izrazim [mu svoje] prijateljstvo. ${ }^{360}$

Iz tih se ulomaka može zaključiti da je Gotama bio u prijateljskim odnosima s kraljem Pasenadiem veći dio svoga života.

Gotama se nerijetko upuštao u razgovore s pripadnicima drugih sljedaba. U Dīghanikāyi se iznose imena i sažetci učenja najistaknutijih onovremenih učitelja, a ti su Pūrạ̣a Kassapa (skt. Pūraṇa Kāśyapa), Makkhali Gosāla (Maskarin Gośālīputra), Ađita Kesakambalin (Ađita Keśakambala), Pakudha Kaććāyana (Kakuda Kātyāyana), Niganṭha Nātaputta (Nigrantha Đñātiputra) i Sañđaya Belațthaputta (Sañđayin Vairaț̣īputra). ${ }^{361}$ Ambatṭha-, Sonadanḍa-, Teviđđa-, Đīvaka- i Mahāsakuludāyisutta samo su neke od sutta koje mogu poslužiti kao primjeri tih razgovora. Također, pālijski kanon sadrži i sutte u kojima se opisuju pokušaji nanošenja štete Gotami i njegovoj zajednici. ${ }^{362}$ Među najpoznatijim je podrivateljima Gotamina autoriteta i ugleda svakako Devadatta koji je, napustivši Gotamino vodstvo i povevši sa sobom pet stotina redovnika, osnovao novu zajednicu. ${ }^{363}$

Gotama je četrdesetipet godina svoga života nakon probuđenja proveo lutajući, propovijedajući i poučavajući i brinući se za potrebe redovnika pod svojim vodstvom. Najveći dio svojega vremena proveo je u blizini tada bogatih i razvijenih gradova kao što su Rāđagaha, Vesālī i Sāvatthī. Iz sutta u pālijskome kanonu nije moguće iščitati precizan slijed njegovih putovanja i prilika u kojima je izrekao pojedinu poduku ili pravilo budući da većina tekstova započinje riječima Tako sam čuo. Jednom prilikom Blaženi je boravio u... Također, često se ista propovijed ili razgovor iznosi u drugome kontekstu ili s drugim sugovornikom, što dodatno otežava pokušaje precizna određenja slijeda događaja u Gotaminu životu. Ako je suditi po pālijskome kanonu i ostalim djelima buddhističke književne tradicije, rastu i jačanju zajednice

\footnotetext{
${ }^{360}$ MN ii. 124: Puna ca param, bhante, Bhagavā pi khattiyo, aham pi khattiyo, Bhagavā pi Kosalako, aham pi Kosalako, Bhagavā pi āsītiko, aham pi āsītiko. Yam pi bhante Bhagavā pi khattiyo aham pi khattiyo, Bhagavā pi Kosalako aham pi Kosalako, Bhagavā pi āsītiko aham pi āsītiko, iminā evāhaṃ, bhante, Bhagavati paramanipaccākāram kattum, mittūpahāram upadaṃsetum .

${ }^{361}$ V. Samañ̃̃aphalasutta (DN i. 47 i d.) Istim su redoslijedom pobrajani i u Sn. 509.

${ }^{362}$ V. npr. Abhayasutta MN i. 392 i d.

363 Vin. ii. 180 i d. (Ćullavagga, VII). Za Devadattu v. npr. Thomas (1927/2000: 131 i d. ), Deeg (1999), Ray (1994/1999: 162-178). O Devadattinim prijašnjim rođenjima u ĐātA u: Appleton (2019).
} 
najviše su doprinjeli snaga Gotamina duhovnoga autoriteta, iznimno samopouzdanje kao i vještina u raspravljanju i prilagođavanju svojih učenja slušateljima. Ne treba zaboraviti da je ugled zajednice rastao i zahvaljujući velikodušnim donacijama bogatih građana Magadhe i Kosale i naroda Vađđia (Vṛđđi), kao i pokroviteljstvu kraljeva Magadhe Bimbisāre i Ađātasattua i kralja Kosale Pasenadia.

\subsection{Zaključna razmatranja}

Pojedini buddhistički izvori, kao što je već navedeno, tvrde da Gotama nakon probuđenja nije bio voljan poučavati, vjerujući da će znanje koje je stekao biti teško razumljivo drugim ljudima i da će mu to nerazumijevanje donijeti samo muku i zamor. Ta nevoljkost koju je osjetio četiri tjedna nakon probuđenja, sjedeći pod stablom ađapāle, u proturječju je s pojedinim drugim kanonskim ulomcima u kojima se tvrdi da je već prvi tjedan nakon probuđenja bio odlučan širiti stečeno znanje. U Saṁyuttanikāyi se pripovijeda kako mu je u tome prvom tjednu prišao Māra i, između ostaloga, rekao sljedeće:

\section{Ako je stvarno spoznat put smiren, što vodi k besmrtnom, \\ Kreni pa idi njime sam! \\ Čemu druge poučavaš? ${ }^{364}$}

Gotama je na tu kušnju odgovorio:

\section{Kad ljudi željni nadići}

ištu što smrt ne dohvaća,

upitan, ja im kazujem:

Što zaista jest bez žeđi je. ${ }^{365}$

U Mahāparinibbānasutti Gotama pripovijeda kako ga je, u vrijeme kada je nakon probuđenja sjedio pod stablom ađapāle, Māra pokušao navesti da stupi u konačnu nibbānu. Gotama mu je odgovorio:

\footnotetext{
${ }^{364} \mathrm{SN}$ i. 123 :
}

Sace maggam anubuddham,

khemam amatagāminam/

Apehi gaccha tvameveko,

kimañ̃namanusāsasīti.//

${ }^{365}$ Amaccudheyyam pucchanti,

ye janā pāragāmino/

Tesāham putțho akkhāmi,

yam saccam tam nirūpadhinti.// 
Neću ući, o Grješni, u konačnu nibbānu sve dok ne budem imao redovnike i učenike koji će biti odlučni, ćudoredni, iskusni, koji su se obrazovali mnogo slušajući, koji će poznavati dhammu, koji će biti usavršeni u poznavanju dhamme i onoga što je s njom u skladu, ispravni u življenju, koji će hoditi putem u skladu s dhammom. Primivši [znanje]od svojega učitelja, oni će [ga] razmatrati, poučavati, proglašavati, uspostavljati, otkrivati, razjašnjavati, razlagati. Dhammom obuzdavajući lažna učenja koja su se pojavila, poučavat će čudesnu dhammu. ${ }^{366}$

Takva se proturječja nerijetko susreću unutar pālijskoga kanona (i općenito buddhističke književne tradicije) i sasvim su razumljiva, uzme li se u obzir da sadržani tekstovi pripadaju različitim starosnim slojevima i da je kanon rastao i prenosio se usmenim putem stoljećima prije negoli je zapisan. Upletanje Brahmana Sahampatia koji nagovara Gotamu da propovijeda Nakamura (2000/2002: 228-229) objašnjava jednostavno: That this deity was brought into legend may also display a wish to assert Buddhism's authority. ${ }^{367}$ Ipak, Gotamino je oklijevanje bilo "sitan kamen u cipeli" o čem svjedoče preinake te epizode u kasnijim djelima. Buddhavaṃsa ju tako u cijelosti prešućuje, u Nidānakathi se tvrdi kako svaki buddha osjeća sumnju, ${ }^{368}$ dok se u Buddhaćariti Gotama, nakon trena oklijevanja, prisjeća svojega davno danoga zavjeta i mijenja mišljenje (dva nebesnika dolaze samo pohvaliti Gotaminu odluku) ${ }^{369}$. Lalitavistara detaljno opisuje oklijevanje, ali navodi kako je Gautama odlučio propovijedati pod uvjetom da mu se pokloni sam Brahman, moleći ga da propovijeda nauku. ${ }^{370}$

Svi se gore prevedeni tekstovi slažu da je Gotama, prije negoli se je uputio prema Gaju jelena, poželio svoj nauk prvo izložiti dvojici svojih prijašnjih učitelja. Za razliku od pojedinih autora koji su odbacili mogućnost da su Āḷāra Kālāma i Uddaka Rāmaputta povijesne ličnosti, Walters (1999: 264) tvrdi:

This narrative fragment was composed when Ālāa Kālāma and Uddaka Rāmaputta were not yet the faceless "Yogic masters" whom later tradition, and Western scholarship, would leave them;

\footnotetext{
${ }^{366}$ DN 16, ii. 104 (MPS 3. 7): na tāvāham, pāpima, parinibbāyissāmi, yāva me bhikkhū na sāvakā bhavissanti viyattā vinītā visāradā bahussutā dhammadharā dhammānudhammappatipannā sāmīcippațipannā anudhammacārino, sakam àcariyakam uggahetvā ācikkhissanti desessanti pañnapessanti pațthapessanti vivarissanti vibhajissanti uttān̄̄karissanti, uppannam parappavādam sahadhammena suniggahitam niggahetvā sappātihāriyam dhammam desessantī'ti.

367 V. i Jones (2009).

368 ĐātA. I. 81.

${ }^{369}$ XIV. 97.

${ }^{370}$ Lv. 393.
} 
it was composed when these teachers were still known, when it still mattered that the Buddhist program is more complete than theirs, when it still mattered that they acknowledged the Bodhisatta's superiority $[\ldots]$

Saznavši da su obojica učitelja ranije preminula, Gotama je krenuo na put prema Vārāṇasī. Pālijski izvori ne opisuju postaje toga puta, iako je Gotama, s obzirom na to da je Vārāṇasī od Gāye udaljen više od dvije stotine kilometara, morao negdje noćiti i objedovati. Ta je praznina u Mahāvastuu ispunjena popisom mjesta u kojima je Gautama noćio i imenima dobročinitelja koji su mu ponudili obrok. Lalitavistara također donosi popis Gautaminih postaja. ${ }^{371}$ Susret s Upakom, ${ }^{372}$ koji se zbio na putu prema Vārāṇasī, zanimljiv je iz nekoliko razloga. Prvo, Upakina je znatiželja dala poticaj Gotami da prvi put javno obznani svoje probuđenje i odlučnost da propovijeda. Također, zanimljivo je da su buddhistički tekstovi prenosili predaju o tom susretu iako Gotamu ne oslikava u najboljem svjetlu. Upakina je ravnodušnost, kako je ranije rečeno, mučila kasnije naraštaje, o čem svjedoče brojni pokušaji da se Gotamin neuspjeh prešuti ili zamijeni povoljnijom slikom. Tako se, primjerice, u Nidānakathi navodi kako je Gotama Upaki samo obznanio svoje probuđenje i nastavio put. ${ }^{373} \mathrm{U}$ Mahāvastuu je susret prikazan kao ugodan i srdačan razgovor. ${ }^{374} \mathrm{U}$ Lalitavistari Upaka, prije negoli krene drugim putem, izražava nadu u Gotamino ostvarivanje nakane, ${ }^{375}$ dok je u Budhaćariti Upaka prikazan kako se još dugo i pod dubokim dojmom osvrće za Gotamom, očiju punih divljenja i čežnje ${ }^{376}$. Taj je usputni susret primjer preinake temeljnoga predloška ali i načina na koji je tradicija pojedine događaje u životu Gotame pokušavala prikazati u što je moguće povoljnijem svjetlu.

Svi se gore prevedeni tekstovi slažu u tome da je skupina od pet isposnika Gotamu isprva hladno dočekala smatrajući da je Gotamino odustajanje od teških trapnja znak njegove mentalne i tjelesne slabosti kao i u tome da su, nedugo zatim, promijenivši mišljenje, prekršili međusobni dogovor o neiskazivanju poštovanja spram Gotame. ${ }^{377}$ Mahāvastu nadodaje da su

\footnotetext{
${ }^{371}$ U Lv. 406 se tvrdi da je Gotama zastao u sljedećim mjestima: Rohitavastu, Uruvela-Kalpa, Anāla, Sārathi. Također, navodi se da su ga u svakom od tih mjesta građani pozvali da se osvježi i prenoći.

372 Bareau (1963, sv. 1: 156 i d.) smatra kako epizoda predstavlja kasniji dodatak. Madhupiṇdikasutta (MN i. 108109, sutta br. 18) donosi opis slična Gotamina susreta s čovjekom zvanim Daṇḍapāni, a koji se odvio u Kapilavatthuu.

${ }^{373}$ ĐātA. I. 81.

${ }^{374}$ Mv. iii. 325-327.

${ }^{375}$ Lv. 406.

376 Buddhaćarita XV. 13.

377 Bareau (1963, sv. 1: 168-170) pretpostavlja da Gotama prije susreta u Parku jelena nije poznavao petoricu isposnika.
} 
isposnici, nedugo po susretu s Gautamom, čudesno se preobrazivši, postali nalik redovnicima zaređenima stotinu godina. Prve riječi koje Gotama upućuje petorici isposnika: $N e$ oslovljavajte, o isposnici, Tathāgatu imenom i rječju 'starino’! Ja sam, o isposnici, Arahant, Tathāgata, Savršeno probuđeni, pojedini su autori odbacili, smatrajući ih kasnijim dodatkom pa Nakamura (2000/2002: 245) tako kaže:

It is difficult to imagine that Gotama himself was so proud as to reject Indian usage in this matter. The section is obviously an addition from a later time when people had begun to deify Gotama.

Moguće je, naravno, da su te riječi, a koje se današnjem čitatelju mogu činiti grube i hvalisave, naknadno umetnute s ciljem da naglase Gotaminu posebitost ali i da podsjete redovnike i laike na ispravan način oslovljavanja učitelja. Buddhaćarita tako objašnjava:

$[\mathrm{H}] \mathrm{e}$ ever acts for the good of all beings; and the Law is cut off from him who maliciously calls his guru by his name, just as in the case of disrespect to parents. ${ }^{378}$

S druge strane, može biti da su, promotrene u kontekstu u kojem su izgovorene, sasvim opravdane. ${ }^{379}$ Postoji mogućnost da je, prožet posvemašnjom uvjerenošću u nenadmašnost svoje spoznaje kao i svoje propovijedničko poslanje, Buddha bio odlučan postati Učiteljem i da su te riječi (ili njima slične) kao i autoritativan stav bili presudni za pridobivanje prvih sljedbenika.

Valja također istaknuti da Brahman Sahampati, dvojica Gotaminih učitelja, ađīvika Upaka i petorica isposnika pripadaju duhovnim pokretima koji su u vrijeme ranoga buddhizma bili glavna konkurencija sljedbenicima Gotamina nauka. Molbu Brahmana Sahampatia, nadilaženje nauke dvojice brahmanskih učitelja i potom suosjećanje spram njih, nesposobnost ađīvike Upake da prepozna istinski nauk, kao i preobraćenje petorice isposnika Walters (1999: 262-263), oslanjajući se na pojedine zaključke Grega Baileyja (1995), tumači na sljedeći način:

Indeed, the whole narrative is one of triumph over these non-Buddhists, who are however treated reverentially, with a healthy dose of pity for their less exalted state (except perhaps the Jains, who would have been the early Buddhists' closest competitors, whose texts are most directly intertextual with Buddhist texts, and who appear to be attacked directly as a result).

Walters (1999: 263) zaključuje:

\footnotetext{
${ }^{378}$ Buddhaćarita XV. 23. Prijevod preuzet iz: Johnson (2004, III: 10).

${ }^{379}$ Usp. Vetter (1988: 8).
} 
[T]he points raised by Thomas and Foucher become, rather than "faults of our biographers", rather clever strategies in early Buddhist attempts at self-definition and promotion vis-a-vis their own rivals.

Kada je riječ o samoj prvoj propovijedi istraživači se slažu da je sadržaj, kako je prikazan u Vinayi i Dhammaćakappavattanasutti, kasnijega postanka i da predstavlja sistematizaciju različitih učenja, odnosno učenja koje su sastavljači smatrali temeljnima. ${ }^{380}$ Schmithausen (1981: 202), pozivajući se na Frauwallnera i Bareaua, tvrdi:

The Pāli version of this text, as is well known, has been transmitted in the Mahāvagga portion of the Vinaya (I 10 ff.) as well as in the Samyuttanikāya (56.11); the latter seems to have taken over the text from the Vinaya, for it includes, apart from the Sütra proper, also a portion of the narrative framework in which it is embedded in the Vinaya. In this form, the Sūtra probably belongs to a period at least more than one hundred years later than the Buddha's Nirvāṇa.

Kao i u slučaju sadržaja spoznaje pri Buddhinu probuđenju, i u ovome slučaju sadržaja prve propovijedi može vrijediti načelo da o pravome sadržaju možda više govore drugi Buddhini govori i razgovori kako su upamćeni i preneseni u Suttapițaki, nego samo izvješće o prvoj propovijedi. To je izvješće vjerojatno više trebalo sačuvati uspomenu na prijelomni događaj nego izložiti Buddhihu nauku. Ipak, predaja je u različitim granama na različite načine odlučivala što će od nauke u tu propovijed uključiti ili samo naznačiti kao njen sadržaj.

Svi gore navedeni prikazi prve propovijedi uključuju i opis čudesnih pojava koje prate pokretanje kotača nauke (potresa i snažne svjetlosti). Mahāvastu dodatno urešava pripovijest opisom "kotača" nauka i Gautamina glasa, čudesnim pojavljivanjem sjedala za prethodne buddhe i hvalopjevom nebesnika.

Formulom Ehi bhikkhū označen je pak početak Gotamina javnoga djelovanja koje će potrajati sve do njegove smrti i začetak organizirane zajednice redovnika okupljenih oko Gotamina nauka i snage njegova autoriteta. ${ }^{381}$

380 Oldenberg (1881/2007: 127-128), Nakamura (2000/2002: 248), Gombrich (1988/2006: 61), Thomas (1927/2000: 86), Karetzky (1995). To bi značilo da je i pouka o oslovljavanju Tathāgate nešto što su ti sistematizatori i sastavljači smatrali potrebnim umetnuti kao pouku za redovnike.

${ }^{381}$ Horner (1951/1971: ix- x) smatra kako je ta formula vrlo brzo zamijenjena načinom zaređenja u kojem kandidat tri puta potvrđuje uzimanje trostrukoga utočišta u Buddhi, Dhammi i Sanghi. Treću fazu Horner opisuje na sljedeći način: [T] hat of the Order ordaining a candidate, presented by his preceptor, by means of a formal act (kamma) consisting of a motion and a resolution proclaimed three times (ñatticatuttha). This means that it is now Order alone which has the authority, the power and the legal right to ordain. 


\section{ULAZAK U KONAČNU NIBBĀNU}

Pālijska Mahāparinibbānasutta (MPS), ${ }^{382}$ u kojoj se iznose posljednji Gotamini dani, njegova smrt i razdoblje nedugo nakon smrti, najdulja je sutta pālijskoga kanona. Sanskrtske recenzije analizirao je Ernst Waldschmidt (1950-1951), a Lamotte (1988: 651), na temelju njegove analize, tvrdi:

If an authentic tradition did ever exist, in the course of time it was subjected to considerable alternations. It is represented more faithfully, it seems, by the Sanskrit version than by Pāli one.

U svome je uvodu u prijevod Mahāparinibbānasutte Rhys Davids (1910/2007: 72) pokazao da je sutta kompozitno djelo čiji se dijelovi mogu naći u drugim knjigama pālijskoga kanona i da dijelovi teksta koji se nalaze samo u Mahāparinibbānasutti ne sačinjavaju više od jedne trećine ukupnoga teksta. 383

Pande (1957: 96), pozivajući se na Winternitza (1933/1999: 38), smatra kako su sutte koje u svojem naslovu imaju prefiks mahā- svoj konačan oblik zadobile proširivanjem i nadogradnjom ranijih i kraćih izvornika. Kada je riječ o Mahāparinibbānasutti, Pande (1957: 101) tvrdi:

The main tendencies that were, thus, responsible for the elaboration of the originally plain and personal narrative of the last journey and death of Buddha may be thus indicated: the desire to interpolate later doctrines so as to give them the appearance of greater authenticity $[\ldots]$.

Oldenberg je još 1879. godine uočio sadržajnu podudarnost između završnih poglavlja Mahāparinibbānasutte i dijela Ćullavagge u kojem se nalazi izvještaj o prva dva buddhistička sabora. Odbacujući povijesnost prvoga sabora kao pure invention and, moreover, an invention of no very ancient date, poziva se na sadržaj sutte u kojem se ne spominje prvi sabor i zaključuje:

There is not the slightest trace of any such allusion to this Council. This silence is as valuable as the most direct testimony: it shows that the author of the Mahāparinibbāna sutta did not know anything of the first Council. ${ }^{384}$

\footnotetext{
${ }^{382}$ DN ii. $72-167$.

${ }^{383}$ V. i Thomas (1927/2000: 156).

${ }^{384}$ Oldenberg (1880/1964b: xxviii). Thomas (1927/2000: 165) se ne slaže s Oldenbergom i tvrdi: It may be the case that the incident of Subhadda was not the actual occasion of the Council. This does not prove that the Council was a fiction, but only that the inference of the Cullavagga as to its cause was a mistake.
} 
Za razliku od Oldenberga, Frauwallner je (1956: 46-47), pozivajući se na zaključke Finota (1932), pokušao dokazati da su Mahāparinibbānasutta i prikaz prva dva sabora, u svome izvornom obliku, činili cjelinu:

The story of the death of the Buddha and the account of the two earliest councils formed originally one single narrative. This narrative, according to the evidence of the great majority of the sources, was a fixed composition of the Vinaya. It belonged to the Vinaya already in its earliest form recognizable to us and had its place at the end of the Skandhaka. [...] Its first portion, the tale of the death of the Buddha, has been in most cases cut loose and included as a Sūtra in the collection of the Long Sūtras of the Sūtrapitaka. We can observe a process of crumbling away, as it were. 385

Frauwallnerovu tezu da je na početku Odsječaka stajao cjelovit Gotamin životopis koji je obuhvaćao razdoblje od rođenja do razdiobe relikvija i završavao prikazom prva dva sabora, osporio je 1958. godine Lamotte.

Usprkos činjenici da je sutta $\mathrm{u}$ obliku u kojem ju danas posjedujemo nedvojbeno mješavina starijih i mlađih slojeva, pojedini se autori slažu da u nekim svojim dijelovima donosi uvjerljiv prikaz Gotaminih posljednjih dana i smrti. ${ }^{386}$ Winternitz (1933/1999: 38) tako tvrdi:

That precisely the memory of the last days of the master and his last speeches got firmly fixed in the minds of his disciples and that they were preserved and transmitted by them with faithfulness, full of love, is fully understandable. And we do not hesitate to see the early beginnings of a Buddha biography in the earliest part of this sutta. ${ }^{387}$

Prikaz se Gotamine smrti ne nalazi u Nidānakathi koja završava donacijom parka redovničkoj zajednici niti u Mahāvastuu koji završava obraćenjima trojice braće Kāśyapa i kralja Bimbisāre. Ipak, u Mahāvastuu se nalazi opis događaja koji su uslijedili nakon Buddhine smrti.

\subsection{Posljednje putovanje: od Rāđagahe do Kusināre}

Mahāparinibbānasutta započinje posjetom Vassakāre, ministra kralja Ađātasattua, Gotami koji je u tom trenutku, okružen učenicima boravio u okolici Rāđagāhe, na brdu Giđđhakūṭi. ${ }^{388}$

\footnotetext{
385 S Frauwallnerom se slaže i Norman (1983: 37) koji tvrdi: It fits together so closely with the story, related in the Cullavagga of the Vinaya-pitaka, of the first council held immediately after his death, that it seems clear that both stories are based upon what was originally one connected narrative.

${ }^{386}$ Oldenberg (1881/2007: 185-186) i Geiger (1943/1996: 12).

${ }^{387}$ Usp. S. Dutt (1957: 46) i Hinüber (2008: 207).

${ }^{388}$ DN ii. 72-76 (MPS 1. 1-6), AN iv. 16-24.
} 
Razgovor s ministrom koji je došao obavijestiti Gotamu da se Ađātasattu sprema napasti pleme Vađđia, povod je za kasniju Gotaminu pouku redovnicima o uvjetima opstanka redovničke zajednice. ${ }^{389}$ Po analogiji s dobrim običajima Vađđia koje je hvalio pred Vassakārom, Gotama, nakon njegova odlaska, drži govor redovnicima i ostavlja im u zalog odgovarajuća pravila: 1 . da održavaju redovite zborove, 2. da na njima zajedno odlučuju o zadatcima redovničke zajednice, 3. da čuvaju pouku kako im je dana i ne uvode nove zasade, 4. da se sustežu od spolnosti i svake žeđi, 5. da poštuju starješinstvo (po vremenu od pristupanja redu), 6. da njeguju duhovne zasade i vježbaju u šumi duhovno poniranje, 7. da pomažu jedni drugima u duhovnoj potrazi za oslobođenjem. Taj je dio Mahāparinibbānasutte dragocjeno povijesno svjedočanstvo o društvenome kontekstu ugroženosti plemenskih društava, u kojem su formulirana redovnička pravila sangghe. ${ }^{390}$

Gotama i učenici odlaze potom u Ambalaț̣hiku, odakle kreću prema Nālandi. U Nālandu je stigao i Sāriputta koji pred Gotamom očituje svoju nepokolebljivu vjeru. ${ }^{391} \mathrm{U}$ Pāṭaligāmi Gotama izriče proročanstvo o budućoj slavi toga grada. ${ }^{392}$ Sljedećega je dana prihvatio poziv magadhskih ministara na objed, a oni su odlučili da će gradska vrata i prijelaz preko Gange nazvati Gotaminim imenom. ${ }^{393}$ Gotama čudesnim moćima prelazi na drugu obalu Gange, čime završava prvo poglavlje.

Gotama potom kreće prema Koṭigami gdje će redovnike podsjetiti na četiri plemenite istine. ${ }^{394}$ U mjestu zvanom Nādika dao je Ānandi tzv. Ogledalo dhamme (dhammapariyāya) ${ }^{395}$ koje se sastoji od čvrste vjere u Buddhu, nauku i redovničku zajednicu. U Vesalī je prihvatio poziv kurtizane Ambapālī, ${ }^{396}$ nakon čega je otišao u Beluvu i tamo ostao do završetka kišnoga razdoblja. U Beluvi se je razbolio, ali je bolest obuzdao snagom volje. ${ }^{397}$ Nakon što mu je prišao zabrinuti Ānanda tražeći daljnje upute za život zajednice, Gotama je odgovorio:

\footnotetext{
${ }^{389}$ Dn ii. 76-81 (MPS 1. 6-11).

390 V. Ježić (1983).

${ }^{391}$ DN ii. 82-83 (MPS 1. 16-17). V. i Sampasādanīyasutta (DN, sutta br. 28), SN v. 159-161.

${ }^{392}$ DN ii. 87-88 (MPS 1. 28). V. i Ud. 8. 6, Vin. i. 231 (Mahāvagga, VI. 28).

393 Thomas (1927/2000: 144) ne sumnja da su se u vrijeme nastanka ove pripovijesti ta mjesta tako zvala.

${ }^{394}$ DN ii. 90 (MPS 2. 2-3). V i SN v. 431-432.

${ }^{395}$ DN ii. 93 (MPS 2. 9). Povod za ovu pouku bila je Ānandina želja da sazna u kojem su se stanju ponovno rodili nedavno preminuli redovnici i redovnice. Pripovijest se, dodatno razrađena, nalazi i u Đanavasabhasutti (DN, sutta br. 18). V. i SN v. 356-359.
}

${ }^{396}$ DN ii. 95-99 (MPS 2. 14-20). Susret s Ambapālī, ali u različitom kontekstu, susreće se i u Vin. i. 231-233 (Mahāvagga, VI. 30).

${ }^{397}$ DN ii. 99 (MPS 2. 23). V. i SN v. 152-153. 
DN ii. 100 (MPS 2. 25-26)

'Kim pan'; Ānanda bhikkhu-saṃgho mayi paccāsimsati? Desito Ānanda mayā dhammo anantaram abāhiram karitvā, na tatth'; Ānanda Tathāgatassa dhammesu ācariya-muțthi. Yassa nūna Ānanda evam assa "Aham bhikkhu-samgham pariharissāmīti" vā "Mam'; uddesiko bhikkhu-saṃho" ti vā, so nūna Ānanda bhikkhu-samgham ārabbha kiñcid eva udāhareyya.

Tathāgatassa kho Ānanda na evam hoti "Aham bhikkhusaṃgham pariharissāmīti" vā "Mam'; uddesiko bhikkhusaṃho" ti vā. Kị̣ Ānanda Tathāgato bhikkhusaṃham ārabbha kiñcid eva udāharissati? Ahạ̣ kho pan'; Ananda etarahi jịnno vuddho mahallako addha-gato vayo anuppatto, asītiko me vayo vattati. Seyyathā pi Ānanda jarasakațạ̣ vegha-missakena yāpeti, evam eva kho Ānanda vegha-missakena mañ̃̃e Tathāgatassa kāyo yāpeti. Yasmim Ānanda samaye Tathāgato sabbanimittānam $\{$ amanasikārā \} ekaccānam vedanānam nirodhā animittam ceto-samādhị̣ upasampajja viharati, phāsukato Ānanda tasmịn samaye Tathāgatassa kāyo hoti.

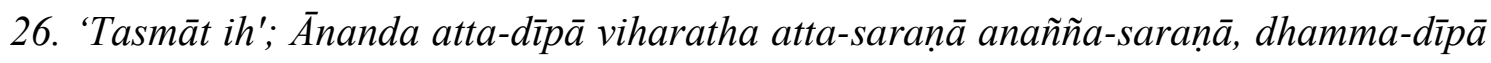
dhamma-saraṇā anaññasaraṇā.

Prijevod

Što još, o Ānando, zajednica redovnika očekuje od mene? Poučavao sam, o Ānanda, dhammu, ne čineći razliku između javnoga i skrovitoga. Nije, o Ānanda, u pitanjima dhamme Tathāgata bio učitelj stisnute šake. Ali, o Ānanda, ako netko ovako [kaže] "Ja ću voditi zajednicu redovnika” ili "Zajednica se redovnika ne mene poziva”, onda taj, o Ānanda, neka daje upute vezane uz zajednicu redovnika. Tathāgata, o Ānando, nije [govorio] "Ja ću voditi zajednicu” niti "Zajednica se redovnika na mene poziva”. Zašto bi onda, o Ānando, Tathāgata davao upute vezane uz zajednicu redovnika? Ja sam, o Anando, zaista ostario, star sam, veoma star, došao sam do kraja svojega puta, dosegao sam svoj vijek. Teče mi osamdeseta godina. I kao što se, o Ānando, islužena kola mogu voziti samo uz pomoć užadi, tako se, o Ānanda, mislim, Tathāgatino tijelo održava u pokretu samo uz pomoć poveza. ${ }^{398}$ Samo kada, o Ānando, Tathāgata, odvraćanjem pažnje od svih podražaja i zaustavljanjem pojedinih osjeta, miruje dosegavši stanje zadubljenja svijesti u kojem nema podražaja, tada je, o Ānando, tijelo Tathāgate spokojno. Zato, o

\footnotetext{
${ }^{398}$ Veghamissakena, v. PED, str. 646. Izraz je nejasan, v. Rhys Davids (1910/2007: 107, bilj. 3).
} 
Ānando, budite svjetiljke samima sebi, utočište samima sebi, nemajte drugog utočišta! [Neka vam] dhamma bude svjetiljka, [neka vam] dhamma bude utočište, nemajte drugog utočišta!

To je iznimno važan odlomak u kojem Gotama najavljuje svoj odlazak, a upućuje Ānandu i preko njega sve druge redovnike i sljedbenike, da im je ostavio dhammu koja će im svijetliti i biti im utočište kada on ode. Od triju buddhističkih utočišta (Buddha, dhamma, sanigha), drugo će zamijeniti prvo. Dolazi vrijeme dhamme.

Treće poglavlje mijenja ton, jače je obojeno religijskim predodžbama i izrazima žaljenja što Učitelj odlazi. Započinje u Vesālī gdje Gotama Ānandi kaže da bi, po želji, mogao produljiti svoj život ali je Ānanda, ne razumijevajući smisao Gotaminih riječi, propustio zamoliti odgodu Gotamina ulaska u konačnu nibbānu. ${ }^{399}$ Ubrzo nakon toga razgovora, Gotami je prišao Māra, tražeći ga da uđe u konačnu nibbānu. ${ }^{400}$ Gotama je odbio Mārin prijedlog, ali je istovremeno najavio svoju smrt. ${ }^{401} \mathrm{U}$ tom se je trenutku, u kojem se je Gotama svjesno odlučio ući u konačnu nibbānu, dogodio potres, što je bio povod za Gotamino izlaganje o osam uzroka potresa. ${ }^{402}$ Istom se prilikom prisjetio i susreta s Mārom nedugo nakon svojega probuđenja. ${ }^{403} \mathrm{U}$ mjestu zvanom Mahānāma, Gotama je održao posljednju propovijed. ${ }^{404}$ Između ostaloga, pripisane su mu i sljedeće riječi u stihovima:

DN ii. 120-121 (MPS 3. 51)

Paripakko vayo mayham, parittam mama jīvitam,

Pahāya vo gamissāmi, katam me saraṇam attano, Appamattā satīmanto susīlā hotha bhikkhavo

Susamāhita-saṃappā sacittam anurakkhatha.

Yo imasmim dhamma-vinaye appamatto vihessati

Pahāya jāti-samsāaram dukkhass'; antam karissatīti.'

\footnotetext{
${ }^{399}$ DN ii. 102-105 (MPS 3. 3-6), SN v. 259-260, Ud. 6.1, AN iv. 309-310. Gotama će ga kasnije oštro prekoriti za taj propust (DN ii. $115=$ MPS 3. 40).

${ }^{400}$ DN ii. 104-105 (MPS 3. 7-8), SN v. 260-262, AN iv. 309-311.

${ }^{401}$ DN ii. 106 (MPS 3. 9), SN v. 262, AN iv. 311.

${ }^{402}$ DN ii. 106 (MPS 3. 10). Među tim su uzrocima i bodhisattino začeće, rođenje, probuđenje, pokretanje kotača nauka, trenutak odluke o ulasku u konačnu nibbānu i sama parinibbāna. SN v. 262, AN iv. 312-313.

${ }^{403}$ DN ii. 113-114 (MPS 3. 34-36).

${ }^{404}$ DN ii. 119-120 (MPS 3. 50-51). Rhys Davids (1910/2007: 128-129, bilj. 2): This, however, is in the form of summary, consisting of enumeration of certain aggregates, the details of which must have been familiar to the early Buddhists.
} 
.Prijevod

Ja sam već dobi prezrele, malo života osta mi.

Napustit ću vas, otići ću; sam utočište sebi bjeh.

Budite trijezni, krjeposni, o redovnici, pozorni!

I sabrani u naumu, bdijte nad svojim mislima!

U toj stezi i nauci tko trijezan sveđer ustraje

Napustiv krug prerađanja, kraj će patnji učiniti!

Tim stihovima završava treća knjiga Mahāparinibbānasutte.

Pogledavši posljednji put Vesālī, krenuo je dalje i prošao kroz Bhaṇḍagamu, Hatthigamu i stigao u Bhoganagar gdje je poučio redovnike načinima provjere ispravnosti učenja (ćatumahāpadesa). ${ }^{405}$ U Pāvi je prihvatio poziv kovača Ćunde i objedovao u njegovoj kući. ${ }^{406}$ Nakon objeda, Gotama se razbolio ${ }^{407}$ i bolestan krenuo na put prema Kusināri na kojem će, svojim čudesnim moćima, pretvoriti nečistu vodu u pitku ${ }^{408}$ i primiti zlatni ogrtač od Pukkuse, sljedbenika nauka Āḷāre Kālāme. Taj će zlatni ogrtač, u doticaju s Gotaminom zlatnom kožom, izgubiti svoj sjaj. ${ }^{409}$ Gotama je zadivljenom Ānandi objasnio da njegova koža postaje zlatne boje u dvije prilike; u noći probuđenja i u noći ulaska u konačnu nibbānnu. ${ }^{410}$ Četvrta knjiga završava pohvalom vrijednosti davanja milodara redovnicima.

\subsection{U Kusināri}

Peta knjiga započinje Gotaminim dolaskom u Kusināru.

DN ii. 137-138 (MPS 5. 1-3)

5.1. Atha kho Bhagavā āyasmantam Ānandam āmantesi: 'Āyām' Ānanda yena Hirañ̃avatiyā nadiȳa pārimatīram yena \{Kusinārā $\}$ Upavattanam Mallānam sālavanam ten'; upasaṃkamissāmāti.'

'Evam bhante'; ti kho āyasmā Ānando Bhagavato paccassosi.

\footnotetext{
${ }^{405}$ DN ii. 123-126 (MPS 4. 7-11), AN ii. 168-170.

${ }^{406}$ DN ii. 126-127 (MPS 4. 14-19), Ud. 8. 5.

${ }^{407}$ U tekstu se kaže da je Ćunda za Gotamu pripremio obrok sūkaramaddava. Za moguća značenja i prijevode v. Thomas (1927/2000: 149, bilj. 3), Wasson, O’Flaherty (1982).

${ }^{408}$ DN ii. 129 (MPS 4. 25).

${ }^{409}$ DN ii. 133 (MPS 4. 37).

${ }^{410}$ DN ii. 133 (MPS 4. 37).
} 
Atha kho Bhagavā mahatā bhikkhu-saṃghena saddhị yena Hiraññavatiyā nadiyā pārima-tīram yena \{Kusinārā $\}$ Upavattanam Mallānam sāla-vanam ten'; upasaṃkami, upasaṃkamitvā āyasmantam Ānandam āmantesi:

'Ingha me tvam Ānanda antarena yamaka-\{sālānaṃ\} uttara-sīsakam mañcakam pañ̃̄āpehi, kilanto 'smi Ānanda, nipajjissāmīti.'

'Evam bhante'; ti kho āyasmā Ānando Bhagavato pațissutvā antarena yamaka-sālānam uttara-sīsakam mañcakam paññapesi. Atha kho Bhagavā dakkhinena passena sīhaseyyam kappesi pāde pādam accādhāya sato sampajāno.

2. Tena kho pana samayena yamaka-sālā sabba-phāliphullā honti akāla-pupphehi. Te Tathāgatassa sarīram okiranti ajjhokiranti abhippakiranti Tathāgatassa pūjāya.

Dibbāni pi mandārava-pupphāni antalikkhā papatanti, tāni Tathāgatassa sarīram okiranti ajjhokiranti abhippakiranti Tathāgatassa pūjāya. Dibbāni pi candana-cuṇñāi antalikkhā papatanti, tāni Tathāgatassa sarīram okiranti ajjhokiranti abhippakiranti Tathāgatassa pūjāya.

Dibbāni pi turiyāni antalikkhe vajjenti Tathāgatassa pūjāya. Dibbāni pi sañgìtāni antalikkhe vattanti Tathāgatassa püjāya. [...]

Na kho Ānanda ettāvatā Tathāgato sakkato vā hoti garukato vā mānito vā püjito vā apacito vā. Yo kho Ānanda bhikkhu vā bhikkhunī vā upāsako vā upāsikē vāa dhammānudhamma-pațipanno viharati $\{$ sāmīci\}-pațipanno anudhamma-cārī, so Tathāgatam sakkaroti garukaroti māneti pūjeti paramāya pūjāya. Tasmāt ih'; Ānanda "dhammānudhamma-pațipannā viharissāma $\{$ sāmīci\}-pațipannā anudhamma-cārino" $t i$, evam hi vo Ānanda sikkhitabban'; ti.

\section{Prijevod}

Tada je Blaženi rekao poštovanom Ānandi: "Uputimo se, Anando, onamo gdje je druga obala rijeke Hiraññavatī, stignimo onamo gdje je gaj drveća sāla kamo navraćaju Malle iz Kusinare”. Poštovani je Ānanda odgovorio Blaženomu “Dobro, poštovani”. Potom je Blaženi, praćen velikom zajednicom redovnika, stigao onamo gdje je druga obala rijeke Hirañ̃avatī, gdje je gaj drveća sāla, kamo navraćaju Malle iz Kusinare. Stigavši, rekao je poštovanomu Ānandi: "Gle, Ānanda, prostri mi ovdje ležaj s uzglavljem prema sjeveru, između dvaju jednakih [stabala] sāla. Umoran sam, o Annanda, pa ću leći”. Složio se 
Ānanda rekavši "Dobro, poštovani” pa je prostro za Blaženoga ležaj s uzglavljem prema sjeveru, između dvaju jednakih [stabala] sāla. Tada je Blaženi legao na desnu stranu, pruživši se kao lav, položivši jednu nogu na drugu. Bio je sabran i svjestan.

U to su vrijeme oba jednaka [stabla] sāla bila u punome cvatu, [prepuna] cvijetova, a nije bilo vrijeme cvata. Ti su [cvjetovi], u počast Tathāgati, padali, prosipali se $i$ prekrivali tijelo Tathāgate. Božanski su cvjetovi mandarāve, u čast Tathāgate, padali iz zraka i sipali, prosipali se i prekrivali tijelo Tathāgate. I božanski je prah sandala, $u$ počast Tathāgati, padao iz zraka i sipao se, prosipao se i prekrivao tijelo Tathāgate. Božanska su glazbala, u počast Tathāgati, svirala u zraku. Javila se u zraku, u počast Tathāgati, božanska pjesma [...]

“O, Ānando! Čak se ni Tathāgata štuje na ovoliko mnogo [načina], ne uvažava, ne poštuje, ne časti niti [mu se ovako iskazuje] počast. Redovnik ili redovnica, svjetovni sljedbenik ili sljedbenica, koji, o Ānando, živi usavršen u dhammi $i$ svemu što je s njom $u$ skladu, postigavši obuhvatnost slijedeći što je u skladu s dhammom, taj štuje, uvažava, poštuje, časti i iskazuje počast Tathāgati radi nenadmašne počasti. Zato, o Ānando, živite usavršeni u dhammi $i$ svemu što je s njom u skladu, postigavši obuhvatnost slijedeći što je u skladu s dhammom! Upravo tako, o Anando, vi trebate poučavati”!

Gotamu su, po posljednji puta, došli vidjeti brojni nebesnici među kojima su neki, duboko potreseni naricali i izvikivali: Prebrzo će Blaženi ući u konačnu nibbānu, prebrzo će Sretni ući u konačnu nibbānu, prebrzo će nestati Oko u svijetu! “411

Sljedeći ulomak pokazuje da je Ānanda (i najvjerojatnije ostatak zajednice) bio zabrinut za opstanak zajednice suočene s izglednošću gubitka vođe čiji je autoritet povezivao i držao na okupu lutajuće redovnike:

DN ii. 140-141 (MPS 5. 7-8)

Pubbe bhante disāsu vassaṃ vutthā bhikkhū āgacchanti Tathāgatam dassanāya, te mayạ̣ labhāma manobhāvanīye bhikkhū dassanāya labhāma payirupāsanāya.

Bhagavato pana mayam bhante accayena na labhissāma manobhāvanīye bhikkhū dassanāya na labhissāma payirupāsanāyāti.'

\footnotetext{
${ }^{411}$ DN ii. 139-140 (MPS 5. 6): atikhippam bhagavā parinibbāyissati, atikhippam sugato parinibbāyissati, atikhippam cakkhum loke antaradhāyissatī'ti.
} 
8. 'Cattār'; imāni Ānanda saddhassa kula-puttassa dassanīyāni saṃvejanīyāni țā̄nāni. Katamāni cattāri?

"Idha Tathāgato jāto" ti Ānanda saddhassa kulaputtassa dassanīyam samvvejanīyam thānam.

"Idha Tathāgato anuttaram sammā-sambodhim abhisambuddho" ti Ānanda saddhassa kula-puttassa dassanīyam saṃvejanīyam țhānaṃ.

"Idha Tathāgatena anuttaram dhamma-cakkam pavattitan" ti Ānanda saddhassa kulaputtassa dassanīyam saṃvejanīyam țhānaṃ.

"Idha Tathāgato anupādisesāya nibbāna-dhātuyā parinibbuto" ti Ānanda saddhassa kula-puttassa dassanīyam saṃvejanīyam țhānaṃ.

Imāni kho Ānanda cattāri saddhassa kula-puttassa dassan̄̄yāni saṃvejan̄̄yāni țhānāni. $\bar{A}$ gamissanti kho Ānanda saddhā bhikkhu-bhikkhuniyo upāsaka-upāsikāyo "Idha Tathāgato jāto" ti pi, "Idha Tathāgato anuttaram sammā-sambodhim abhisambuddho" ti pi, "Idha Tathāgatena anuttaram dhamma-cakkam pavattitan" ti pi, "Idha Tathāgato anupādisesāya nibbānadhātuyā parinibbuto" ti pi.

'Ye hi keci Ānanda cetiya-cārikam āhiṇ̣̂tantā pasannacittā kālam karissanti, sabbe te kāyassa bhedā param maraṇā sugatim saggam lokam uppajjissantīti. ${ }^{412}$

Prijevod

[Ānanda:]

Prije su, o Poštovani, redovnici dok su provodili kišno doba, dolazili iz svih smjerova vidjeti Tathāgatu. Mi smo primali te poštovane redovnike koji su došli vidjeti i [slušati] sjedeći uokolo [učitelja]. Ali, o Poštovani, nakon što Blaženi ode, mi nećemo [moći] primati poštovane redovnike koji su došli vidjeti i [slušati] sjedeći uokolo [učitelja].

[Buddha:]

Četiri su mjesta, o Ānando, koja ugledan čovjek, koji ima vjeru, može vidjeti i koja ga mogu potresti. Koja četiri? “Ovdje je Tathāgata rođen”, mjesto je to koje ugledan čovjek može vidjeti i koje ga može potresti. "Ovdje je Tathāgata, Savršeno probuđeni dosegao

\footnotetext{
${ }^{412}$ Nakamura (2000/2005: 141): The absence of this passage in the other texts shows that it is a later teaching.
} 
nenadmašno savršeno probuđenje”, mjesto je to koje ugledan čovjek može vidjeti i koje ga može potresti. “Ovdje je Tathāgata pokrenuo nenadmašni kotač nauka”, mjesto je to koje ugledan čovjek može vidjeti i koje ga može potresti. "Ovdje je Tathāgata dosegao stanje nibbāne $u$ kojem nema ostatka dodavanja, i u cijelosti se razriješio”, mjesto je to koje ugledan čovjek može vidjeti i koje ga može potresti. To su, o Anando, četiri mjesta koja ugledan čovjek može vidjeti i koja ga mogu potresti.

Dolazit će, o Ānando, vjerni redovnici, redovnice, svjetovni sljedbenici i sljedbenice [i govoriti]:"Ovdje je rođen Tathāgata, ovdje je Tathāgata dosegao nenadmašno probuđenje, ovdje je Tathāgata pokrenuo nenadmašni kotač nauke, ovdje je Tathāgata dosegao stanje nibbāne u kojoj nema ostatka dodavanja, i u cijelosti se razriješio ". A oni, o Ānando, kojima istekne vrijeme dok budu na putu do ćetiye, a svijest im bude razbistrena, ti će se svi, nakon rastanka s tijelom i nakon smrti, ponovno roditi u sretnom nebeskom svijetu.

Buddhi je tu stavljeno u usta predviđanje glavnih kasnijih buddhističkih hodočastilišta vezanih uz njegov život. To jesu mjesta kamo su poslije hodočastili štovatelji iz svih buddhističkih zemalja, a ta su hodočašća bila bitno obilježje kasnijega buddhizma u povijesnim razdobljima kada su bila moguća.

Tathāgata je također vrijedan spomenika za tjelesne ostatke (relikvije), odnosno thūpe (skt. stūpa). Gotami je u usta stavljeno i objašnjenje uloge koju će thūpa imati nakon njegove smrti:

DN ii. 142 (MPS 5.12)

Tathāgato Araham Sammā-Sambuddho thūpāraho, Pacceka-Buddho thūpāraho, Tathāgata-sāvako thūpāraho, rājā cakkavattī thūpāraho.

'Katamañ c'; Ānanda attha-vasam paṭicca Tathāgato Araham Sammā-Sambuddho thūpāraho? "Ayam tassa Bhagavato arahato Sammā-Sambuddhassa thūpo" ti Ānanda bahujano cittam pasādeti, te tattha cittam pasādetvā kāyassa bhedā param maraṇā sugatim saggam lokam uppajjanti. Idam kho Ananda attha-vasam paṭicca Tathāgato Araham Sammā-Sambuddho thūpāraho. 
Prijevod

Tathāgata, Arahant, Savršeno probuđeni dostojan je thūpe. I onaj koji je samo za sebe Probuđeni dostojan je thūpe. Učenik Tathāgate dostojan je thūpe. Kralj ćakkavattin dostojan je thūpe.

Na temelju je kojega razloga, Tathāgata, Arahant, Savršeno probuđeni, dostojan thūpe? “To je thūpa njega Blaženoga, Arahanta, Savršeno probuđenoga” - [tako govoreći], o $\bar{A}$ nando, mnogi će razbistriti svijest. Ti će se, razbistivši svijest na tome mjestu, nakon rastanka s tijelom i nakon smrti ponovno roditi u sretnom nebeskom svijetu. Radi toga je upravo razloga, o Ānando, Tathāgata, Arahant, Savršeno probuđeni dostojan thūpe.

U odlomku su nabrojane tri vrste buddha: onaj koji je sam došao do probuđenja i prenosi nauku drugima, onaj koji je sam za sebe probuđen, ali ne prenosi drugima, i onaj koji nije sam, nego slijedeći nauku kao učenik, postao probuđen. Predviđa se da će buddha dobiti nadgrobni humak kao i kralj (u idealnome slučaju svevladar). Monumentalni humci vjerojatno i jesu preuzeti od običaja kako su neki, vjerojatno i pretci Sākya, sahranjivali poglavare.

Buddhi je stavljeno u usta i pravilo za ponašanje redovnika u društvu žena, ${ }^{413}$ kao i upute vezane uz njegov pogreb koji je trebao biti izvršen u skladu s propisima za pogreb svevladara (ćakkavattin).

DN ii. 141-142 (MPS 5. 11) 414

Yathā kho Ānanda rañ̃̃o cakkavattissa sarīre pațipajjanti, evam Tathāgatassa sarīre pațipajjitabban'; ti.

'Katham pana bhante rañño cakkavattissa sarīre \{pațipajjantīti\}'; ?

'Rañño Ānanda cakkavattissa sarīram ahatena vatthena vețenti. Ahatena vatthena vethetvā vihatena kappāsena vethenti, vihatena kappāsena vețetvā ahatena vatthena vethenti.

Etena upāyena pañcahi yuga-satehi rañño cakkavattissa sarīram vețhetvā āyasāya teladoṇiyā pakkhipitvā añ̃issā āyasāya doṇiyā pațikujjetvā sabbagandhānam citakam

\footnotetext{
${ }^{413}$ DN ii. 141 (MPS 5. 9).

${ }^{414}$ V. i DN ii. 161-162 (MPS 6. 17).
} 
karitvā rañ̃̃o cakkavattissa sarīram jhāpenti, cātummahāpathe rañño cakkavattissa thūpam karonti. Evam kho Ānanda rañño cakkavattissa sarīre pațipajjanti.

'Yathā kho Ānanda rañño cakkavattissa sarīre pațipajjanti evam Tathāgatassa sarìre pațipajjitabbaṃ. Cātummahāpathe Tathāgatassa thūpo kātabbo. Tattha ye mālam vā gandhạ̣ vā vannakam vā āropessanti abhivādessanti vā, cittam vā pasādessanti, tesam tạ̣ bhavissati dīgharattam hitāya sukhāya.

Prijevod

"Kako se, o Anando, [ljudi] odnose spram tijela kralja kraljeva ćakkavattina, tako se trebaju odnositi i spram tijela Tathāgate."

"A kako se, Poštovani, odnose spram tijela kralja kraljeva?"

“Omotavaju, o Ānando, tijelo kralja kraljeva ćakkavattina novom tkaninom. Omotavši ga novom tkaninom, omotavaju ga opranom pamučnom tkaninom. Omotavši ga opranom pamučnom tkaninom, omotavaju ga novom tkaninom. Omotavši na taj način tijelo kralja kraljeva u pet stotina slojeva obje tkanine, polažu ga u posudu za ulje od kovine $i$ prekrivaju ga poklopcem od kovine. Načinivši lomaču od različitih vrsta mirisnoga [drveta] spaljuju tijelo kralja kraljeva. Grade [potom] thūpu na raskrižju četiriju velikih puteva. Tako se, o Ānando, odnose spram tijela kralja kraljeva. Kako se, o Ānando, odnose spram tijela kralja kraljeva, tako se trebaju odnositi i spram tijela Tathāgate. Thūpa Tathāgate treba biti sagrađena na raskrižju četiriju velikih puteva. Koji će tamo ostavljati vijence [cvijeća] ili mirise ili obojane prahove ili iskazivati poštovanje ili razbistravati svijest, tima će to dugo biti na dobrobit i sreću."

Odlomak potvrđuje da je podizanje humka (thüpa, stūpa) nad zemnim ostatcima buddhe zamišljeno po uzoru na podizanje humka poglavaru. No taj se poglavar ovdje zamišlja kao cakkavattin/ćakravartin. Moguće je da se takva predodžba temelji na običaju potvrđivanja vlasti u okolnim područjima kao pri aśvamedhi, a možda je dobila nov poticaj u doba moćne loze vladara Maurya, osobito velikoga buddhističkoga vladara Aśoke. ${ }^{415}$

Sutta donosi i dirljiv prikaz Ānandine tuge, koji suočen s neminovšću Gotamine smrti uviđa i teškoću daljnjega duhovnoga usavršavanja bez vodstva učitelja. ${ }^{416}$ Gotamine ljubazne

\footnotetext{
415 Ježić (usmena komunikacija).

${ }^{416}$ DN ii. 143-144 (MPS 5. 13).
} 
riječi i ukazivanje na dobre osobine Ānandine pred ostatkom zajednice ostavljaju dojam iskrenoga prijateljstva dvojice dugogodišnjih suputnika. ${ }^{417}$

$\mathrm{Na}$ Ānandinu molbu da Gotama ne uđe u konačnu nibbānu u malenom i beznačajnom mjestu kao što je Kusināra, Gotama odgovora cijelom đātakom u kojoj pripovijeda kako je Kusināra nekoć bio prijestolnica kralja kraljeva (ćakkavattina) Mahāsudassane. ${ }^{418}$

Peta knjiga završava dolaskom brojnih stanovnika Kusināre koji odaju počast Gotami ${ }^{419}$ i zaređenjem Subbhade, ${ }^{420}$ posljednjeg redovnika kojega će Gotama osobno uvesti u zajednicu.

Šesta i ujedno posljednja knjiga Mahāparinibbānasutte započinje sljedećim vrlo jednostavnim, a vrlo znatnim Gotaminim riječima upućenima Ānandi:

DN ii. 154 (MPS 6. 1)

\subsection{Atha kho Bhagavā āyasmantam Ānandam āmantesi:}

'Siyā kho pan'; Ananda tumhākam evam assa: "Atītasatthukam pāvacanam, $n$ ' atthi no Satthā" ti. Na kho pan'; etam Ānanda evam dațthabbaṃ. Yo vo Ānanda mayā Dhammo ca Vinayo ca desito paññatto, so vo mam' accayena Satthā.

Prijevod

Tada je Blaženi ovako rekao poštovanom Ānandi: “Moglo bi biti, o Ānanda, da među vama bude ovako: 'Nestala je riječ Učitelja, nemamo Učitelja'. Ali, o Ānanda, ne treba to tako gledati. Nauka i redovnička pravila kojima sam vas poučio i koja sam obznanio bit će vam, nakon mojega odlaska, učitelj”.

\subsection{Ulazak u konačnu nibbānu $u^{421}$}

DN ii. 154-156 (MPS 6. 5-9)

Atha Bhagavā bhikkhū āmantesi:

'Siyā kho pana bhikkhave eka-bhikkhussa pi kan்khā vā vimati vā Buddhe vā dhamme vā saṃghe vā magge vā pațipadāya vā. Pucchatha bhikkhave. Mā pacchā vippațisārino

\footnotetext{
${ }^{417}$ DN ii. 144-146 (MPS 5. 14-16).

${ }^{418}$ DN ii. 146-147 (MPS 5. 17-189. Za detaljniju verziju ove đātake v. Mahāsudassanasutta (DN, sutta br. 17). Usp. i Mahāsudassanađātaka u ĐātA. I. 391 i d. (br. 95).

${ }^{419}$ DN ii. 147-149 (MPS 5. 19-22).

${ }^{420}$ DN ii. 148-154 (MPS 5. 23-30).

421 Jezgra se pripovijesti nalazi i kao zasebna sutta u SN i. 157-159. Tu su opisani događaji od Gotaminih posljednjih riječi do pripovijedanja o tome kako su ga oplakivali Brahman Sahampati, Sakka, Ānanda i Anuruddha.
} 
ahuvattha: "Sammukhī-bhūto no Satthā ahosi, na mayam sakkhimha Bhagavantam sammukhā pațipucchitun"'; ti.

Evaṃ vutte te bhikkhū tuṇhī ahesuṃ.

Dutiyam pi kho Bhagavā. ...

Tatiyam pi kho Bhagavā bhikkhū āmantesi: 'Siyā kho pana bhikkhave eka-bhikkhussa pi kan்kha vā vimati vā Buddhe vā dhamme vā samghe vā magge vā pațipadāya vā. Pucchatha bhikkhave. Mā pacchā vippațisārino ahuvattha: "Sammukhī-bhūto no Satthā ahosi, na mayam sakkhimha Bhagavantam sammukhā pațipucchitun"'; ti.

Tatiyam pi kho te bhikkhū tuṇhī ahesuṃ.

Atha kho Bhagavā bhikkhū āmantesi:

'Siyā kho pana bhikkhave Satthu-gāravena pi na puccheyyātha. Sahāyako pi bhikkhave sahāyakassa ārocetūti.'

Evam vutte te bhikkhū tuṇhī ahesuṃ. 6. Atha kho āyasmā Ānando Bhagavantam etad avoca:

'Acchariyam bhante abbhutam bhante! Evam pasanno aham bhante imasmim bhikkhusamghe, $n^{\prime}$ atthi eka-bhikkhussa pi kan̈khā vā vimati vā Buddhe vā dhamme vā samghe vā magge vā pațipadāya $v \bar{a}^{\prime} ; t i$.

'Pasādā kho tvam Ānanda vadesi. \{Ñ̄anam\} eva h'; ettha Ānanda Tathāgatassa: "N'; atthi imasmim bhikkhusaṃghe, n'; atthi eka-bhikkhussa pi kan்khā vā vimati vā Buddhe vā dhamme vā samghe vā magge vā pațipadāya vā. Imesam hi Ānanda pañcannam bhikkhusatānam yo pacchimako bhikkhu so sotāpanno avinipāta-dhammo niyato sambodhiparāyano'; ti.

7. Atha kho Bhagavā bhikkhū àmantesi:

'Handa dāni bhikkhave āmantayāmi vo: "Vayadhammā samkhārā, appamādena sampādethāti." Ayam Tathāgatassa pacchimā vācā.

8. Atha kho Bhagavā pațhamajjhānam samāpajji. Pațhamajjhānā vuțthahitvā dutiyajjhānam samāpajji. 
Dutiyajjhānā vuț̣hahitvā tatiyajjhānam samāpajji.

Tatiyajjhānā vuț̣̂hahitvā catutthajjhānam samāpajji.

Catutthajjhānā vutthahitvāa ākāsānañcāyatanam samāpajji. $\quad\{\bar{A} k \bar{a} s \bar{a} n a \tilde{n} c \bar{a} y a t a n a\}-$ samāpattiyā vuțthahitvā viñ̃̄āṇañcāyatanam samāpajji. Viñ̃āṇañcāyatana-samāpattiyā

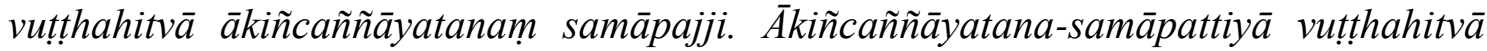


vuț̣hahitvā sañ̃̄ā-vedayita-nirodham samāpajji.

Atha kho āyasmā Ānando \{āyasmantam\} Anuruddham etad avoca:

'Parinibbuto bhante Anuruddha Bhagavā'; ti.

'Na āvuso Ānanda Bhagavā parinibbuto, sañ̃̃ā-vedayita-nirodham samāpanno'; ti.

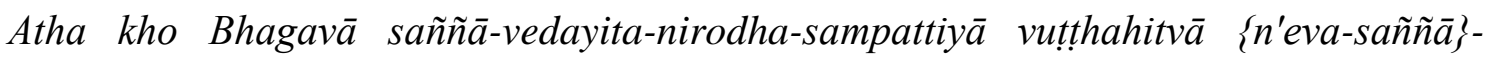
nāsañ̃āàatanam samāpajji.

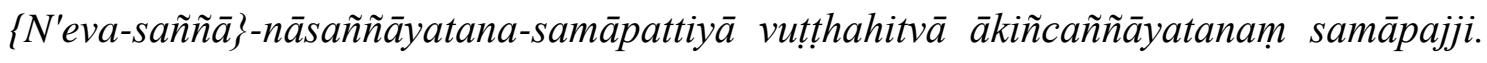
Ākiñcañ̃āyatana-samāpattiyā vuț̣hahitvā viñ̃ānañãcāyatanam samāpajji. Viñ̃ānanañcāyatana-samāpattiyā vuț̣hahitvā ākāsānañcāyatanam samāpajji. $\bar{A} k \bar{s} \bar{a} n a \tilde{n} c \bar{y} y a t a n a-s a m \bar{a} p a t t i y \bar{a}$ vuțthahitvā catutthajjhānam samāpajji. Catutthajjhānāa vuț̣hahitvā tatiyajjhānam samāpajji. Tatiyajjhānā vuțthahitvā dutiyajjhānam samāpajji. Dutiyajjhānā vuț̣hahitvā pațhamajjhānam samāpajji. Paṭhamajjhānā vuțthahitvā dutiyajjhānam samāpajji. Dutiyajjhānā vuțthahitvā tatiyajjhānam samāpajji. Tatiyajjhānā vuț̣hahitvā catutthajjhānam samāpajji. Catutthajjhānā vuțthahitvā samanantarā Bhagavā parinibbāyi.

Prijevod

Tada se Blaženi obratio redovnicima: "Moglo bi, o redovnici, biti da je neki redovnik nesiguran ili sumnja $u$ dhammu ili Buddhu ili redovničku zajednicu ili put ili način. Pitajte, redovnici, da ne požalite što niste pitali: 'Jao, učitelj nam je bio licem u lice, a mi se, dok nam je Blaženi bio licem u lice, nismo usudili pitati’”. Tako oslovljeni, redovnici su šutjeli. Po drugi se put Blaženi... Po treći se put Blaženi obratio redovnicima: "Moglo bi, o redovnici, biti da je neki redovnik nesiguran ili sumnja u dhammu ili Buddhu ili redovničku zajednicu ili put ili način. Pitajte, redovnici, da ne 
požalite što niste pitali: 'Jao, učitelj nam je bio licem u lice, a mi se, dok nam je Blaženi licem u lice, nismo usudili pitati'”. I treći su put redovnici šutjeli. Opet se Blaženi obratio redovnicima: "Moglo bi, redovnici, biti da ne pitate iz poštovanja spram učitelja. Neka se onda, redovnici, prijatelj povjeri prijatelju”. Tako oslovljeni, redovnici su šutjeli. Tada je poštovani Ānanda ovako rekao Blaženomu: “Čudesno je, poštovani, zadivljujuće je, poštovani! Sretan sam, poštovani, jer u ovoj zajednici nema redovnika koji je nesiguran ili sumnja u dhammu ili Buddhu ili redovničku zajednicu ili put ili način”. "Ti, Annanda, govoriš zbog svoje razbistrenosti, a Tathāgata zna da u ovoj redovničkoj zajednici ni jedan redovnik nije nesiguran niti sumnja $u$ dhammu ili Buddhu ili redovničku zajednicu ili put ili način. Među pet stotina redovnika, Ananda, čak je i posljednji redovnik stupio na put, i ne može pasti u propast, spregnut je i napreduje prema probuđenju.",

Tada je Blaženi rekao redovnicima: "Da vam, redovnici, sada još kažem: Ustrojnice svijesti podložne su zakonu prolaznosti. Nastojte pozorno da stignete do cilja!" To su bile posljednje riječi Tathāgate.

Potom je Blaženi dosegao prvo zadubljenje. Uzdigavši se iz prvoga zadubljenja, dosegao je drugo zadubljenje. Uzdigavši se iz drugog zadubljenja, dosegao je treće zadubljenje. Uzdigavši se iz trećega zadubljenja, dosegao je četvrto zadubljenje. Uzdigavši se iz četvrtoga zadubljenja, dosegao je stanje iskustva beskonačnosti prostora. Uzdigavši se iz dosezanja stanja iskustva beskonačnosti prostora, dosegao je stanje iskustva beskonačne svijesti. Uzdigavši se iz dosezanja stanja iskustva beskonačne svijesti, dosegao je stanje iskustva beskonačne praznine. Uzdigavši se iz dosezanja stanja iskustva beskonačne praznine, dosegao je stanje iskustva u kojem nema ni zamjećivanja ni nezamjećivanja. Uzdigavši se iz dosezanja stanja iskustva u kojem nema ni zamjećivanja ni nezamjećivanja, dosegao je stanje u kojem su zaustavljeni i zamjećivanje i osjećaj.

Tada je poštovani Ānanda ovako rekao poštovanom Anuruddhi: "Razriješio se je, o poštovani Anuruddha, Blaženi”!

“O, prijatelju Ānanda, nije se još Blaženi razriješio već je dosegao stanje u kojem su zaustavljeni i zamjećivanje i osjećaj."

Tada se je Blaženi uzdigao iz dosezanja stanja u kojem su zaustavljeni i zamjećivanje $i$ osjećaj $i$ dosegao stanje iskustva u kojem nema ni zamjećivanja ni nezamjećivanja. Uzdigavši se iz dosezanja stanja iskustva u kojem nema ni zamjećivanja ni 
nezamjećivanja, dosegao je stanje iskustva beskonačne praznine. Uzdigavši se iz stanja iskustva beskonačne praznine, dosegao je stanje iskustva beskonačne svijesti. Uzdigavši se iz stanja iskustva beskonačne svijesti, dosegao je stanje iskustva beskonačnosti prostora. Uzdigavši se iz stanja iskustva beskonačnosti prostora, dosegao je četvrto zadubljenje. Uzdigavši se iz četvrtoga zadubljenja, dosegao je treće zadubljenje. Uzdigavši se iz trećega zadubljenja, dosegao je drugo zadubljenje. Uzdigavši se iz drugoga zadubljenja, dosegao je prvo zadubljenje. Uzdigavši se iz prvoga zadubljenja, dosegao je drugo zadubljnje. Uzdigavši se iz drugoga zadubljenja, dosegao je treće zadubljenje. Uzdigavši se iz tré́ega zadubljenja, dosegao je četvrto zadubljenje. U trenu u kojem se je uzdigao iz četvrtoga zadubljenja u cijelosti je ušao u konačnu nibbānu. ${ }^{422}$

U opisu ulaska u konačnu nibbānu izvješće govori o slijedu stupnjeva poniranja (samādhi) u koja je Buddha ulazio. Spoznaja i ćudoređe iz osmorostrukoga puta postignuti su u životu, a duhovno poniranje treći je vid toga puta, koji treba u životu vježbati da bi u trenu odlaska iz svijeta njime bilo moguće osloboditi se od smrti i ponovnih rođenja. Ovdje se spominju samo najdublji i najzahtjevniji stupnjevi poniranja (samādhi), a to su četiri zadubljenja (đhāna/ dhyāna) i četiri dosezanja (samāpatti). Buddhin je odlazak iz svijeta opisan kao prolaženje kroz četiri zadubljenja i četiri dosezanja i, opet, povratak kroz četiri dosezanja te ponovni prolaz kroz četiri zadubljenja. Moguće je i da je u buddhističkoj predaji postojala podvojenost u tome jesu li dublje četiri vježbe zadubljenja ili četiri vježbe dosezanja pa da zato izvješće prvo navodi prve prije drugih, a zatim, u skladu s drugim shvaćanjem, druge prije prvih. Možda imamo i trag te razlike u izraženim mišljenjima Ānande i Anuruddhe o tome u tekstu. Bilo kako bilo, Buddhin se odlazak iz svijeta ne opisuje kao smrt, nego kao poniranje svijesti koje vodi do odriješenja od smrti i ponovnih rođenja.

\subsection{O događajima nakon Gotamina ulaska u konačnu nibbānu}

DN ii. 156-158 (MPS 6. 10)

10. Parinibbute Bhagavati saha parinibbānā mahā \{bhūmi-cālo\} ahosi bhimsanako lomahamso deva-dundubhiyo ca phalimsu. Parinibbute Bhagavati saha parinibbānā Brahmā Sahampati imam gātham abhāsi:

Sabbe 'va nikkhipissanti bhūtā loke samussayam,

\footnotetext{
${ }^{422}$ DN ii. 156 (MPS 6. 7-9), SN i. 157-159, V. i AN iv. 409-410.
} 
Yathā etādiso Satthā loke appatipuggalo

Tathāgato balappatto sambuddho parinibbuto'; ti.

Parinibbute Bhagavati saha parinibbānā Sakko devānam indo imaṃ gātham abhāsi:

Aniccā vata saṃkhārā uppāda-vaya-dhammino,

Uppajjitvā nirujjhanti, tesam vupasamo sukho'; ti.

Parinibbute Bhagavati saha parinibbānā āyasmā Anuruddho imā gāthāyo abhāsi:

Nāhu assāsa-passāso thita-cittassa tādino.

Anejo santim ārabbha yam kālam akarī munī

Asallīnena cittena vedanam ajjhavāsayi:

Pajjotass'; eva nibbānam vimokho cetaso ahūti.'

Parinibbute Bhagavati saha parinibbānā āyasmā Ānando imam gātham abhāsi:

Tadā 'si yam bhiṃsanakam tadā 'si loma-haṃsanạ̣

$\{$ Sabbākāra\}-varūpete Sambuddhe parinibbute'; ti.

Parinibbute Bhagavati tattha ye te bhikkhū avìta-rāgā \{app ekacce\} bāhā paggayha kandanti, chinna-papātam papatanti āvațtanti vivaț̣anti: 'Atikhippaṃ Bhagavā parinibbuto, atikhippam Sugato parinibbuto, atikhippam cakkhum loke antarahitan'; ti.Ye pana te bhikkhū vìta-rāgā te satā sampajānā adhivāsenti, 'Aniccā saṃkhārāa, tam kut' ettha labbhā'; ti.

Prijevod

Kada se je Blaženi u cijelosti odriješio, u trenutku parinibbāne dogodio se je velik $i$ strašan potres od kojega se tijelo kostriješilo i prolomila se nebesnička grmljavina. Kada se je Blaženi u cijelosti razriješio, Brahman je Sahampati u trenutku parinibbāne izrekao ovu kiticu:

"Svako biće na tom svijetu svoje tijelo napustit će

Kada se takav Učitelj, bez takmaca u svijetu tom,

Probuđeni Tathāgata, pun moći, razriješio”!

Kada se je Blaženi u cijelosti razriješio, Sakka je, vođa nebesnika, u trenutku parinibbāne, izrekao ovu kiticu:

"Nestalne su ustrojnice sve; nužno postaju, nestaju.

Nastavši brzo prestaju. Sreća je kad se smire sve."

Kada se je Blaženi u cijelosti razriješio, poštovani je Anuruddha u trenutku parinibbāne izrekao ove kitice: 
"Nema udaha, izdaha otkad je svijest ustavio,

Spokoj dosegnu, netreman, kad mudrac vijek svoj dovrši

Neraspuštene svjesnosti izdržao je nevolju.

Oslobođenje svijesti bi ko ugasnuće svjettila."

Kada se je Blaženi u cijelosti razriješio, poštovani je Ananda u trenutku parinibbāne izrekao ovu kiticu:

“Zastrašujuće bješe to, to bijaše jezovito

Posve Probuđeni kad, u svem najbolji, iščeznu." 423

Kada se je Blaženi u cijelosti razriješio, neki su redovnici, u kojima je još bilo strasti, plakali uzdignutih ruku, padali kao presječeni, njihali se naprijed-nazad [naričući]: "Prebrzo je Blaženi iščezao, prebrzo je Sretni iščezao, prebrzo je nestalo Oko u svijetu!" A redovnici oslobođeni strasti, ostali su svjesni i sabrani: "Nestalne su sve ustrojnice, kako bi ovdje bile zadržane”?

Ānanda je sljedećega jutra pozvao pripadnike plemena Malla iz Kusināre koji su, došavši pred tijelo Gotame, iskazali svoje poštovanje. Pripreme za obred spaljivanja Gotaminih posmrtnih ostataka održane su sedmi dan po uputama koje je Gotama ostavio Ānandi. U to su vrijeme Mahākasspa i skupina od pet stotina redovnika putovali prema Kusināri i na tome su putu primili vijest o Gotaminoj smrti. Tom je prilikom redovnik Subhadda rekao: Dosta, prijatelji! Ne tugujte i ne jadikujte! Dobro je da smo se oslobodili toga velikog isposnika. Bili smo ugnjetavani: "To ti doliči, to ti ne doliči”. Od sada ćemo činiti što želimo, a što ne želimo nećemo činiti! “. ${ }^{424}$ Slijedi opis dolaska Mahākassape i ceremonije spaljivanja.

DN ii. 163-164 (MPS 6. 22-23)

22. Atha kho āyasmā Mahā-Kassapo yena \{Kusinārāâ Makuța-bandhanam Mallānam cetiyam yena Bhagavato citako ten'; upasaṃkami, upasaṃkamitvā ekaṃsam cīvaram

\footnotetext{
${ }^{423}$ Snellgrove (1973: 405), pozivajući se na radove Waldschmidta i Przyluskoga, ističe da se stihovi pripisani Ānandi u tibetskoj recenziji Vinaye i kineskim prijevodima nalaze pripisani Aniruddhi, a da se u tim izvorima navedeni stihovi pripisani Ānandi ne susreću u pālijskoj verziji. Snellgrove smatra da je povezivanje Ānande s osjećajem straha i jeze connected with the early tendancy to denigrate Ananda, which is one of the most significant features of early Buddhist 'history', or at least of some of its interpreters.

${ }^{424}$ DN ii. 1162 (MPS 6. 20): alam, āvuso, mā socittha, mā paridevittha, sumuttā mayam tena mahāsamaṇena. Upaddutā ca homa: 'idạ̣ vo kappati, idạ̣ vo na kappat̄̄ti. Idāni pana mayam yam icchissāma, tạ̣ karissāma, yam na icchissāma, na tạ̣ karissāmāti. Epizoda se nalazi i u Vin. ii. 284-285 (Ćullavaga XI.1). Za usporedbu v. Oldenberg (1880/1964b: xxvi-xxvii).
} 
katvā \{añjaliṃ\} paṇāmetvā tikkhattum citakam padakkhinam katvā, pādato vivaritvā Bhagavato pāde sirasā vandi.

Tāni pi kho pañca bhikkhu-satāni ekaṃsam cīvaram katvā añjalim paṇāmetvā tikkhattum citakam padakkhinam katvā Bhagavato pāde sirasā vandimsu. Vandite ca pan'; āyasmatā Mahā-Kassapena tehi ca pañcahi bhikkhu-satehi, sayam eva Bhagavato citako pajjali. 23. Jhāyamānassa pana Bhagavato sarīrassa, yam ahosi chavīti vā camman ti vā mamsan ti vā nahārūti vā lasikā ti vā tassa n' eva chārikā pañ̃āyittha na masi, sarīrān' eva avasissimsu.

Seyyathā pi nāma sappissa vā telassa vā jhāyamānassa n' eva chārikā pañ̃āyati na masi, evam eva Bhagavato sarīrassa jhāyamānassa yaṃ ahosi chavīti vā camman ti vā mamsan ti vā nahārūti vā lasikā ti vā tassa n'; eva chārikāa paññayittha na masi, sarīrān' eva avasissimsu.

Tesañ ca pañcannam dussa-yuga-satānam dve va dussāni dayhiṃsu yañ ca sabbaabbhantarimam yañ ca bāhiraṃ.

Daḍ̣he kho pana Bhagavato sarīre antalikkhā udakadhārā pātu bhavitvā Bhagavato citakam nibbāpesi,udakasālato pi abbhunnamitvā Bhagavato citakam nibbāpesi.

Kosinārakā pi Mallā sabba-gandhodakena Bhagavato citakaṃ nibbāpesuṃ.

Atha kho Kosinārakā Mallā Bhagavato sarīrāni sattāham santhāgāre satti-pañjaram karitvā dhanu-pākāram parikkhipitvā naccehi gītehi vāditehi mālehi gandhehi sakkariṃsu parikariṃsu mānesuṃ püjesuṃ.

Prijevod

Tada je poštovani Mahākasspa stigao u Kusināru, u ćetiyu zvanu Makuțabandhana u zemlju Malla, gdje je bila pogrebna lomača Blaženoga. Prišav̌̌i, prebacio je ogrtač preko jednoga ramena, sklopio ruke u znak pozdrava, tri puta obišao lomaču držeći ju s desne strane pa, odgrnuvši stopala, iskazao poštovanje položivši glavu na stopala Blaženoga. I onih je pet stotina redovnika prebacilo ogrtač preko jednog ramena, sklopilo ruke u znak pozdrava, tri puta obišlo lomaču držeći ju s desne strane pa iskazalo poštovanje položivši glavu na stopala Blaženoga. Nakon što su poštovani Mahākassapa i pet stotina redovnika iskazali poštovanje, pogrebna se lomača Blaženoga, sama od sebe, zapalila. Kada je tijelo Blaženoga izgorjelo, nije se vidio ni pepeo ni prašina od onoga 
što je bilo koža, koža s unutarnje strane, meso, tetiva ili tekućina u zglobovima; ostale su samo kosti. Baš kao što se iza sagorenoga ulja ili pročišćenoga maslaca ne vidi pepeo ili prašina, upravo tako, kada je izgorjelo tijelo Blaženoga, od onoga što je bilo koža, koža s unutarnje strane, meso, tetiva ili tekućina u zglobovima, nije se vidio ni pepeo ni prašina; ostale su samo kosti. I od onih pet stotina dvovrsnih tkanina, i ona najunutarnjija i ona vanjska su izgorjele. Kada je izgorjelo tijelo Blaženoga, pojavio se iz ozračja mlaz vode koji je ugasio lomaču Blaženoga. Izbila je $i$ voda iz vrela $i$ ugasila lomaču Blaženoga. Kusinārsko pleme Malla ugasilo je lomaču Blaženoga mirisnom vodom. Potom je kusinārsko pleme Malla, u sabornici grada, okružilo kosti Blaženoga ogradom [načinjenom od] strijela i lukova i sedam ih dana častilo, štovalo, darivalo prinosima $i$ slavilo plesom, pjesmom, glazbom, vijencima cvijeća i miomirisima.

\subsection{O događajima nakon Gautamina ulaska u konačnu nirvāṇu u Mahāvastuu}

Opis se događaja nakon Gautamina ulaska u konačnu nirvāṇu nalazi u prvoj knjizi Mahāvastua i uvod je u opisivanje deset polja ili stadija (bhümi) u razvoju bodhisattve. Prikaz događaja započinje Kāśyapinom spoznajom da je Gautama preminuo i završava pozivom na zajedničko okupljanje na prvome saboru, kako bi se utvrdio i sačuvao Buddhin nauk.

Mv. i. $64-70^{425}$

1.64 nirvṛte kanakarāśisannibhe

śākyanandijanane tathāgate /

kaṃpi medini saśailakānanā

sāgarāṃbaradharā saparvatā //

kampitam paramaromaharșaṇam

bhūmikampam anudṛśsa dāruṇam /

kāśyapo dhūtagunāgrapārago

cittam abhyupagatah tadā abhūt //

kị̣ nu adya dharaṇi saparvatā

sāgarāmbaradharā vasundharā /

kampate paramadāruṇasvaram

nūnam nirvritim gatah tathāgatah //

\footnotetext{
${ }^{425}$ Prijevod je iznesen u prozi.
} 
so ca divyanayanas tathāgatam

devakinnaravarehi vanditam

1.65 dṛ́sya sarvabhavabandhanāntakam

nirvṛtam yamakaśāla-antare //

na khalu me samucitam tathāgatam

rddhiye samanugantu gautamam /

padbhir eva vadatān varam munim

draștum apratimam pravrajāmy ahạ̣ //

so ca matva tvaramāṇo sūrī

kāśyapo mathitamānaso bhikṣuh /

bhikṣubhih bahubhih uttamo pari-

nirvrtabhuvam anupūrvam āgami //

tasya ca praṇidhir āsi uttamā

kāśyapasya jinapādavandane /

tau .... carañau mahāmune

mūrdhinā upanipīẹya vanditum //

saṃgrhyolkām vipulām atha catasro

mallakā upagatā balavantah /

vījitām paramamallavinītām

dagdhaḍalkām abhiprāṇamayensuḥ // \{Lies: dagdha-ulkāṃ\}

taiś citām abhimukham upanìtā

taih parākramabalai rathaśūraih /

1.66 nirvrtā ca . . s sā samakālam

prāpya vāripariṣekam ivolkā //

samiśayam vimatimadhyam upetya

mallā divyanayanam aniruddham /

gauravā nataśirā suvinītā

praśnam . . idam pariprcche //

ko nu hetur iha pratyayo ca ko

yen'; imā jinasutā upanìtā /

nirvrtiṃ upagatā sahasolkā 
brūhi kāraṇam ihārya yathāvat //

devatā khalu prasannā kāśyape

tasya eșa khalu ṛddhibhāvanā /

naiva tāva jvalano jvaliṣyati

yāva nāgato agrapāragaḥ //

tasya caișa praṇidhiḥ samrdhyati

kāśyapasya dhutadharmadhāriṇaḥ /

tau kramau daśabalasya śrimatah

vanditum hi śirasā mahāmune //

so ca bhikṣugaṇasampuraskṛtah

kāśyapo dhutarajo jinātmajaḥ /

prāmjalī jinacitām upāgato

gauravā pranataśīișamānasaḥ //

1.67 driśya tam pravararūpadhārinạn

kāṣthasaṃcayagatam tathāgatam /

dhig bhavān iti girām udīraȳ

darśitaprakrtibhāvalakṣaṇām //

ko nu so bhavam upetya prāṇako

yo na mrtyuvaśam āgamișyati /

yatr'; ayam jualanakāmcanopamo

nirvṛto śikhir ivendhanam vinā //

krtva aṃjalipuṭam mahāyaśo

pādato jinavarasya kāśyapo /

mūrdhinā nipatito maharșiṇo ${ }^{426}$

paścimam idam namasyate mune //

tau ca cakravaralakșitau kramau

devadānavavarehi vanditau /

niḥstrtau tatha vidārya tām citām

devayakșabhujagānubhāvitau //

tau kramau śirasi sannipātiya

pāṇibhiḥ samanugrhhya cā mune /

\footnotetext{
${ }^{426}$ Gen. jedn. BHSG $§ 10.81$.
} 
ālape śrutidharam maharșinạm

antikāvacarah ${ }^{427}$ kāśyapas tadā //

1.68 kim tv imau śrutidhara kramau mune

dhyāmatām upagatau na suprabhau /

brūhi kāraṇam aśeșam āhvaya

yen'; imau na nayanābhinandinau //

etaṃ śrutva śrutasaṃcayaṃdharo

kāśyapam idam uvāca paṇdito /

aśruvegaduṣitā va śocatām

roditehi mathitā h'; imau kramau //

ten'; imau kramavarau mahāmuneh

rodanena janatābhipīditau /

no vibhānti munino ${ }^{428}$ yath $\bar{a}$ purā

evam etad anupaśya suvrata //

so nipatya śirasā punaḥ punaḥ

tau kramau pravaracakralakșaṇau /

karatalehi abhipīdayet mune

śāstu gauravaparāya buddhiye $e^{429} / /$

vanditau ca dhutadharmadhāriṇ̄

tau kramau guṇadhareṇa śāstuno ${ }^{430} /$

lokanāthacitakāṣtha tejasā

vāyuvegavidhutena dīpyati //

1.69 dahyamāne jinacandraśarīre

pạ̣ca tāni vaśibhūtaśatāni /

mantrayanti sahitā samupetya

nirvrtīsamayakāle samgītim //

nirvṛto pravaralakșanadhārī

yo nu śāstu sasurāsuranetā /

\footnotetext{
${ }^{427}$ Za santikāvacara (skt. sāntika), koji je u blizini, živi blizu, BHSD, str. 555.

${ }^{428}$ Munino, gen. jedn. BHSG $§ 10.81$.

${ }^{429}$ Buddhiye, instr. jedn. BHSG $§ 10.96$.

${ }^{430}$ Śāstṛ, śāstuno, gen. jedn. BHSG §13.27.
} 
ko guṇo iha ciram parivāse

vayam api adya vijahämatha ${ }^{431}$ deham //

sarvathā suparinișthitakāryāḥ

prāpya acyutam aśokam anantam /

sarvabhāvabhavavītigatā sma

eșa nirvrtim upema ihaiva //

evam ukte dhutadharmaviśuddho

kāśyapo 'bravi tadā vaśibhūtām /

na khu bhavadbhih anupādi ${ }^{432}$ vimukti

nirvertī samanugamya ihaiva //

tīrthikā ca bahidhānugatās ${ }^{433} \mathrm{ca}$

kreyur ${ }^{434}$ apratimaśāsanadoṣam /

dhūmakālikam iti śramaṇasya

etat eva ca tu raksañiyam no //

lokanātha bahavo narasimhhā

1.70 ye c'; anāgata mahāmatiśūūā /

te hi no upapadeyur udagrā

yadi na samkaliye ${ }^{435}$ śāsanam śāstuḥ //

tena apratihatāh susamagrāh

gāyathā sugataśāsanam agryam /

yathā idạ̣ suparigīta yathārtham

cirataram naramarūṣu viroce //

Prijevod

Kada je Tathāgata, koji je donio radost porodici Śäkya, nalik zlatnomu zviježđu, ušao u konačnu nirvāṇu, zatresla se je tada Zemlja noseći mora kao odjeću, sa svojim stijenama, šumama $i$ planinama. Osjetivši drhtanje i strašan zemljotres od kojega se tijelo kostriješilo, Kāśyapi se, najusavršenijim u odricanju od svijeta, javila tada misao: "Zašto prostrana Zemlja, blagonosnica, noseći mora kao odjeću danas drhti skupa sa svojim

\footnotetext{
${ }^{431} V i \sqrt{ } h \bar{a}$, imp. 1. 1. množ. BHSG $§ 26.8-10$.

${ }^{432} \mathrm{Za}$ anupāāàya. BHSD str. 30.

${ }^{433}$ Bahidhā, m.c. za skt. bahirdhā. BHSD str. 398.

${ }^{434}$ Kreyur, 3. 1. množ. opt. za krāyur, kareyur ili kāryur (pāli kayirā = karyāt). BHSG §29.47.

435 Saṃkaliyati, pasiv od skt. saṃkalayati. Saṃkaliye, opt. 3.1. jedn. (?), BHSD str. 545.
} 
planinama i odjekuje prestrašnim zvukom? Zasigurno, Tathāgata je otišao u konačnu nirvāṇu”. Obdaren božanskim okom

1.65 vidio je Tathāgatu između dvaju jednakih stabala sāla, otišloga u konačnu nirvāṇu $i$ dokrajčenih svih spona s postojanjem gdje ga slave nebesnici i nebeski glazbenici. „Uistinu, ne priliči mi da odem do Tathāgate Gautame [koristeći se svojim] čarobnim moćima. Otputit ću se pješice da vidim mudraca bez premca, najodličnijega među govornicima. Odlučivši se, redovnik žalosnoga srca, s mnogim redovnicima koji su ga kao najodličnijega redom slijedili, mudri je Kāśyapa, žureći se, stigao tako do otišloga u konačnu nirvāṇu. Kāśyapi se javila snažna želja da iskaže poštovanje stopalima Pobjednika, i da ta stopala Velikoga mudraca, položivši na njih glavu, počasti. Četiri su snažna pripadnika plemena Malla prišla noseći veliku baklju. Tu upaljenu baklju, koju su [prije toga] pripremili i raspalili najistaknutiji pripadnici plemena Malla, prinjeli su prema lomači ti hrabri i snažni junaci-borci s bojnih kola, ali, u trenutku kad su ju prinjeli, baklja se je

1.66 ugasila isti čas kao natopljena vodom. U sumnji i zbunjenosti, spuštene glave, puni poštovanja i vrlo ponizni, prišli su pripadnici plemena Malla Aniruddhi obdarenom božanskim okom $i$ postavili ovo pitanje: "Baklja koju su donijeli i prinjeli sinovi pobjednika iznenada se ugasila. Tko je onaj koji ju je ugasio? Reci sada, plemeniti, razlog kako jest”! [Aniruddha je odgovorio:] "Nebesnici su, uistinu, naklonjeni Kāśyapi. On posjeduje moći i plamen se, sigurno, neće upaliti sve dok ne pristigne najusavršeniji [trapljenik]”. Ispunila se želja Kāśsyapi koji je imao osobine čovjeka koji se odrekao svijeta da iskaže poštovanje stopalima Velikog mudraca, Sjajnoga i Desetomoćnoga [dodirom] glave. Cijenjen od redovničke zajednice, otresavši zamagljenost, duhovni sin Pobjednika, prišao je Kāśyapa pogrebnoj lomači Pobjednika sklopljenih ruku, dostojanstveno spuštene glave i ponizna srca.

1.67 Vidjevši [tijelo] Tathāgate koje je zadržalo ljepotu svoje pojave i položeno na gomilu drva, podigao je glas: "Do bestraga s postojanjem koje objelodanjuje obilježja svoje prave naravi! Koje biće, kada dođe u postojanje, ne dolazi pod vlast smrti kada je i ovaj, koji je bio poput usijanoga zlata, ugasnuo poput vatre bez goriva”? Kāśyapa velikoga sjaja sklopio je ruke, pao [dotičući] glavom stopala najvećega Pobjednika i posljednji put iskazao svoje poštovanje velikom vidiocu i mudracu. Ta su dva stopala, obilježena savršenim znacima kotača, koja su hvalili nebesnici $i$ dānave $i$ štovali nebesnici, yakșe $i$ 
zmijolika božanstva, izašla na vidjelo, rastvorivši pogrebni pokrov. ${ }^{436}$ Uzevši u ruke ta stopala Mudraca, položio ih je na [svoju] glavu. Upitao je tada Käśyapa učenoga $i$ velikoga vidioca koji je bio u blizini:

1.68 "Zašto su, o učeni, ova stopala Mudraca potamnila i zašto ne sjaje? Reci, objasni bez zadrške, uzrok tomu! Zašto ova stopala ne vesele oči”? Kad je to čuo mudrac, znalac mnogih čutih govora, ovako je odgovorio Käśyapi: "Ta su stopala nagrđena potocima suza $i$ do boli uznemiravana oplakivanjem.......Ta su lijepa stopala velikoga mudraca pritiskana oplakivanjem naroda i zato [stopala] mudraca ne sjaje kao ranije. Shvati to upravo tako, dobri zavjetovaniče”. On je, pavši glavom [na stopala], iznova i iznova ta mudračeva stopala obilježena savršenim znacima kotača pritiskao dlanovima, $s$ namjerom da iskaže najveće poštovanje Učitelju. Kada je tim stopalima Učitelja [Kāśyapa] obdaren vrlinama i osobinama čovjeka koji se odrekao svijeta iskazao poštovanje, zapalila se pogrebna lomača Gospodara svijeta plamenom potaknutim naletom vjetra.

1.69 Dok je gorilo sjajno tijelo Pobjednika, okupilo se pet stotina [redovnika] ukroćenih strasti koji su zajedno recitirali pjesmu u trenutku iščeznuća: "Iščezao je nositelj izvrsnih obilježja koji je bio naš Učitelj i vođa nebesnika (sura) i ne-nebesnika (protunebesnika, asura). Koja je dobrobit od našeg ostanka na ovome svijetu? Napustimo sada i mi tijelo! Na svaki smo način dobro ispunili dužnosti i dosegavši neprolazno, nebolno i beskrajno, došli smo do dobiti od bivanja svih bivših života. Stoga pristupimo sada razrješenju”! Kada su tako rekli, Kāśyapa je, pročišćen u vrlinama čovjeka koji se odrekao svijeta, rekao [redovnicima] ukroćenih strasti: "Vi ne smijete ovdje pristupiti razrješenju, oslobođenju uslijed neprianjanja! Krivovjerci i sljedbenici izvanjskih učitelja mogli bi nanijeti štetu nenadmašnomu učenju Trapljenika [govoreći]: 'To je učenje prolazno kao dim'. I upravo zato to [učenje] trebamo zaštititi. Mnogi budući gospodari svijeta, ljudilavovi

1.70 i junaci velikih misli neće nam se uzvišeni pojaviti ako Učiteljev nauk ne bude objedinjen! Zato, nepomućeni i posve složni kazujte Sugatin iskonski nauk kako bi taj

\footnotetext{
${ }^{436}$ To se čudesno ukazivanje stopala ne spominje u pālijskoj verziji.
} 
dobro kazivan [nauk], u skladu sa svojom svrhom, još dugo izazivao radost u ljudima $i$ bogovima".

\subsection{Začetak kulta thūpa i štovanja relikvija}

Mahāparinibbānasutta završava opisom raspodjele Gotaminih relikvija.

DN ii. 166-167 (MPS 6. 27)

27. Atha kho Rājā Māgadho Ajātasattu Vedehi-putto Rājagahe Bhagavato sarīrānam thūpañ ca \{mahañ\} ca akāsi. Vesālikā pi Licchavī Vesāliyam Bhagavato sarīrānam thüpañ ca mahañ ca akaṃsu.

Kāpilavatthavā pi Sakyā Kapilavatthusmim Bhagavato sarīrānam thūpañ ca mahañ ca akamsu.

Allakappakā pi Bulayo \{Allakappe\} Bhagavato sarīrānam thūpañ ca mahañ ca akaṃsu. Rāmagāmakā pi Koliyā Rāmagāme Bhagavato sarīrānam thūpañ ca mahañ ca akaṃsu. Vețhadīpako pi brāhmaṇo Vețhadīpe Bhagavato sarīrānam thūpañ ca mahañ ca akāsi. Pāveyyakā pi Mallā Pāvāyam Bhagavato sarīrānaṃ thūpañ ca mahañ ca akaṃsu.

Kosinārakā pi Mallā Kusinārāyam Bhagavato sarīrānaṃ thūpañ ca mahañ ca akaṃsu. Doṇo pi brāhmaṇo kumbhassa thūpañ ca mahañ ca akāsi.

Pipphalivaniyā pi Moriyā Pipphalivane à̃gārānam thūpañ ca mahañ ca akaṃsu.

Iti aț̣th'; assa sarīra-thūpā navamo kumbha-thūpo dasamo à்gāra-thūpo.

Evam etam bhüta-pubban ti.

Prijevod

Tako je Ađātasattu, kralj Māgadhe, sin [kraljice] iz Videhe, podigao u Rāđagahi thūpu za relikvije Blaženoga i priredio slavlje. Pleme Liććhavi iz Vesālī podiglo je u Vesālī thūpu za relikvije Blaženoga i priredilo slavlje. Pleme Sakya iz Kapilavatthua podiglo je u Kapilavatthuu thūpu za relikvije Blaženoga i priredilo slavlje. Pleme Bul̄ iz Allakappe podiglo je u Allakappi thūpu za relikvije Blaženoga i priredilo slavlje. Pleme Koliyā iz Rāmagāme podiglo je u Rāmagāmi thūpu za relikvije Blaženoga i priredilo slavlje. Brahman iz Vețthadīpe podigao je u Vețthadīpi thūpu za relikvije Blaženoga i priredio slavlje. Pleme Malla iz Pāve podiglo je thūpu za relikvije Blaženoga i priredilo slavlje. Pleme Malla iz Kusināre podiglo je u Kusināri thūpu za relikvije Blaženoga i priredilo slavlje. Brahman Doṇa podigao je thūpu za posudu [kojom su relikvije bile sakupljene] $i$ priredio slavlje. Pleme Moriya iz Pipphalavane podiglo je u Pipphalavani thūpu za 
ugarke i priredilo slavlje. Bilo je osam thūpa za relikvije, deveta je bila za posudu, deseta za ugarke. Upravo je tako tada bilo. ${ }^{437}$

U Mahāvastuu opis raspodjele relikvija nije uključen u pripovijest o događajima neposredno nakon Buddhine smrti, ali se na drugim mjestima nerijetko ističu zasluge koje proizlaze iz štovanja stūpa i relikvija. Tako se, primjerice, navodi kako štovatelj stūpa stječe poštovanje nebesnika, yakṣa i rakṣasa, ljepotu kao i obilježja savršenstva, bogatstvo, plemenitost, hrabrost, moralnost i mudrost. Štovatelji se stūpa rađaju u plemenitim ili bogatim trgovačkim obiteljima, mogu postati kraljevi ili sveopći vladari, a nakon smrti ponovno se rađaju na nebesima te se čak mogu ponovno pojaviti u svijetu nebesnika kao njihovi vođe. Također, štovatelj stūpe ne može oslijepiti, oslabiti, postati hrom ili grbav niti mu mogu nauditi strijele, otrovi ili vatra. Štovatelji stūpa uvijek umiru prirodnom smrću, poštovani i slavljeni. ${ }^{438} \mathrm{~S}$ druge strane, iskazivanje bilo kojega oblika nepoštovanja spram Buddhe ili njegove stūpe vodi do ponovnoga rođenja u nekom od paklova, sljepoće, bolesti, bespomoćnosti, gladi, žeđi i ludila. U Mahāvastuu se navodi da nema razlike u štovanju Buddhe za njegova života i nakon njegove smrti. 439

U novije je vrijeme kultu Buddhinih relikvija najveću pažnju posvetio John S. Strong koji se u svojoj se knjizi The Relics of the Buddha (2004) dotiče donedavnoga zanemarivanja uloge koju su relikvije i štovanje thūpa imali u razvoju buddhizma:

Championing the claim that the Buddha, after his final nirvāna, was totally removed from any relationship to this world, scholars tended to see Buddhist objects of devotion such as images and relics not as embodying the impossible presence of a deceased Master, but as mere mnemonics devices for recalling his teachings and his example. The Buddha was to be found primarily in his doctrine; to think of him as present elsewhere, in statues or relics, for instance, was an aberration to be condemned [...] In more recent times, however, a pendulum swing away from such opinions has taken place in the study of Buddhism. (Strong, 2004: 2) (40 $^{40}$

\footnotetext{
${ }^{437}$ Bhv. XXVIII sažeto opisuje razdiobu relikvija i ne odstupa od Mahāparinibbānasutte. Donosi, međutim, i nove podatke. Tvrdi se tako (Bhv. XXVIII. 6-13) da su podijeljena još i četiri Gotamina očnjaka, četrdeset njegovih zubi, kosa, dlake s Gotamina tijela, njegova zdjela za milodare, štap, halja, prekrivač za ležaj, posuda za vodu, opasač, tkanina za kupanje (āyudakasāțiyaṃ), dlačice između obrva, žuta halja itd.

Za opis razdiobe relikvija u Divyāvadāni, Buddhaćariti, Dīpavaṃsi i Mahāvaṃsi v. Fleet (1906) i Fleet (1907).

${ }^{438}$ Navedeno je samo nekoliko primjera, a za puni popis zasluga i nagrada koje se stječu štovanjem stūpa v. Mv. ii. $363-397$.

${ }^{439}$ Mv. ii. 362.

440 Strong (2004: 3) daje i pregled novijih istraživanja vezanih uz kult štovanja relikvija i thūpa u buddhizmu. Schober se (1997b: 273) također osvrće na manjak istraživanja vezanih uz kult thūpa i relikvija i nudi moguće objašnjenje: Until recently, Theravāda textual scholarship explored only reluctantly cultic veneration of the
} 
U Mahāparinibbānasutti se implicira da su briga oko posmrtnih Gotaminih ostataka, kao i kult štovanja thūpa i hodočašća namijenjeni prvenstveno laicima, a ne članovima redovničke zajednice. Kada Ānanda pita što treba učiniti s tijelom Tathāgate nakon njegove smrti, Gotama odgovara:

Ne brinite se, o Ānando, za posmrtni obred (sarīrapūđā). Gledajte, o Ānando, da se posvetite i težite dobroj svrsi, da živite marljivi, revni i odlučni za dobru svrhu. Postoje, o Ānando, učeni plemići, učeni brahmani, učeni domaćini koji imaju vjere u Tathāgatu. Oni će se pobrinuti za Tathāgatin posmrtni obred. ${ }^{441}$

Pojedini su autori složenicu sarīrapūđā preveli s "štovanje posmrtnih ostataka/ relikvija", a cijeli je ulomak nerijetko služio kao potvrda teze da je, u svojoj biti, buddhizam dvovrstan redovnički i laički. Prema takvu je tumačenju buddhizma kult štovanja thūpa i relikvija namijenjen isključivo laičkim sljedbenicima, ne članovima redovničke zajednice. Takvo su shvaćanje buddhizma možda ponajbolje iznjeli Lamotte (1958/1988: 644) i Hirakawa (1963/2005: 211) koji piše:

The Vinayas further explain that dance and music were parts of the offerings made to the stūpa. It is a well-known fact the bhikșus are forbidden to perform or watch dances or musical entertainment, and they are not permitted to touch silver, gold, or other treasures. [...] Consequently, the dance and musical entertainments and the handling of silver, gold, and jeweled ornaments were duties of the householder. It is clear that the bhikṣus could not have had a leading role in such a stūpa worship, and it is difficult to conceive of stūpa worship arising from such a situation. ${ }^{442}$

Ipak, Gregory Schopen je u nekoliko navrata pokazao kako se iz gore navedenoga ulomka ne može ekstrahirati pravilo kojim se redovnicima zabranjuje štovanje relikvija i stūpa. ${ }^{443}$

Buddha. Several reasons may account for this. For one, traditional Päli scholarship sought to distance "true" Theravāda texts from the cultic veneration of the Buddha in the form of relics or images. Takav stav Fogelin (2003: 131) objašnjava na sljedeći način: Based upon readings of this literature some scholars argued that stupa worship was initially the exclusive domain of the laity (see Coomaraswamy 1927, Lamotte 1988). The establishment of stupa worship among monks and nuns, and eventually the worship of Buddhist images, was argued to be the result of the clergy's contamination by the vulgar practices of the laity.

${ }^{441}$ DN ii. 141-142 (MPS 5. 10): Avyāvațā tumhe Ānanda hotha Tathāgatassa sarīra\{́pūjāya\}, ingha tumhe Ānanda sadatthe ghațatha, sadattham anuyuñjatha, sadatthe appamattā ātāpino pahitattā viharatha. Sant', Ānanda khattiya-paṇditā pi brāhmaṇapaṇ̣itā pi gahapati-paṇditā pi Tathāgate abhippasannā, te Tathāgatassa sarīrapūjam karissantīti.'

${ }^{442} \mathrm{Na}$ Hirakawino se stajalište osvrnuo i Silk (2002: 379-382).

${ }^{443}$ V. npr. Schopen $(1988,1991)$. 
Potkrjepljujući svoje stajalište epigrafskim dokazima i ukazujući na neadekvatnost oslanjanja isključivo na tekstualne izvore, Schopen (1997: 31) tvrdi:

[W]e know for certain from inscriptions that from ca. 150 B.C.E.- that is to say, from our earliest knowable donative inscriptions and well before we can have any definite knowledge of the textual tradition - monks and nuns formed a substantial proportion of those involved in donative, meritmaking activities connected with the stūpa cult and, somewhat later, the cult of images, and that this proportion increased continually as time passed. [...]

Ostavivši oba stajališta po strani, Strong je (2004: 98-123) detaljno analizirao sadržaj Mahāparinibbānasutte vezan uz pripreme za spaljivanje i razdiobu Gotaminih relikvija, a svoju je pažnju usredotočio na legendary and cultic traditions about relics of the Buddha's physical body i ulogu koju su relikvije imale u daljnjem razvoju Buddhina životopisa. ${ }^{444}$ Autor (2004: 229) zaključuje:

Relics of the Buddha, as we have seen, are more spreaders and continuators of the Buddha's presence than incarnations of him. Connected to this is the second implicit understanding that the Buddha's life story does not stop with his death, just as it does not begin with his birth. ${ }^{445}$

Kult relikvija i štovanja thūpa i poticanje hodočašća u mjesta vezana uz ključne trenutke Gotamina života na neki su način, kako to formulira Strong (2004: 7), extensions of the Buddha's biography ili očitovanje težnje redovničke zajednice da se Gotama i njegov autoritet održe na životu. Slična je stava i Walters (1997) koji piše:

The participants in the stūpa cult thus participate in an unbroken continuation of the pious activities that Buddhists did before Gotama was transformed in Parinirvāṇa: give food, garlands, flowers, scents, fences, stairways, walkways, houses, umbrellas, seats, clothes, flags, service,

\footnotetext{
${ }^{444}$ Strong (2004: 232) također ističe iznimno važnu ulogu koju su relikvije imale u širenju buddhizma:

Whether discovered or transported, however, relics were usually among the first objects featured by Buddhist missionaries in new lands. They were often presented as impressive and effective sources of magical power, but part of their lure, as John Kieschnick (2003: 52) has pointed out, was that they were "a distinguishing characteristic of Buddhist devotion that no other religious tradition could match". In other words, relics came to be seen not just as spreaders of the presence of the Buddha, but also as exotic emblems of the uniqueness of this new religion of Buddhism - something that brahmanism, Confucianism, or Shintō did not have.

${ }^{445}$ Usp. Collins (1992: 235), Schpen (1997: 148-161), Ray (1993: 175) i Boucher (1991: 1-2): The Buddhist tradition has since the death of the Buddha, or perhaps more precisely, because of the death of the Buddha, wrestled between two tendencies: to locate the Buddha in his corporeal body, especially as left behind in his relics, or to locate the true Buddha in the dharma, his teachings. This dichotomy manifested itself in two directions: the cult of the stüpa, which venerated the physical remains of the Buddha, and the equation of the Buddha and his teaching in such passages as Samyutta-Nikāya III, 120, where the Buddha states: He who sees the dhamma, Vakkali, sees me, he who sees me, sees the dhamma.
} 
worship, praise, and memory to the Buddha himself, conceived as a participant in the present. (Walters, 1997: 174-175)

\subsection{Zaključna razmatranja}

Narativni okvir Mahāparinibbānasutte čini sedmomjesečno Gotamino putovanje od Rāđagahe do Kusināre. Svaka epizoda započinje Gotaminim prijedlogom kojim poziva Ānandu (i ostale redovnike) da se upute prema novomu odredištu. Stilizirani poziv služi kao uvod u epizodu i jasan je primjer tradicije u kojoj svaka sutta započinje navođenjem mjesta u kojem je izrečena (isto vrijedi i za navođenje mjesta u kojem je izrečeno pojedino redovničko pravilo). ${ }^{446}$

Pande je (1957: 101-106) analizirao sadržaj Mahāparinibbānasutte i pokušao razlučiti mlađe i starije slojeve tekstova. Među najmlađe dijelove teksta ubraja Gotamino "proročanstvo" o budućoj slavi Pāṭaliputte (MPS 1. 26-32), ${ }^{447}$ razgovor s Ānandom u kojem tvrdi da bi mogao produljuti svoj život (MPS 3. 1-51), ${ }^{448}$ četiri kriterija za razlikovanje izvornoga učenja (mahāpadesa) (MPS 4. 7-12), dva čudesna događaja koja su se zbila na putu prema Kusināri (MPS 4. 22-38), apoteozu Buddhe (MPS 5. 1-7), Gotamino traženje pogrebnoga obreda u skladu s običajima vezanim uz pogreb ćakkavattina, razlikovanje sammāsambuddhe i paććekabuddhe (MPS 5. 10-12) i snažan utjecaj mitskih i čudesnih elemenata (MPS 5. 11-28).

Kada je, pak, riječ o starijim dijelovima teksta, Winternitz (1933/1999: 38-39) kaže sljedeće:

Old and original are certainly such passages as those in the second section where the story is told of Buddha's first illness, which befell him at Belua and which he fought with the power of his will, where he assures Ānanda that he is not one of those preachers "with a closed fist" keep back something for themselves but that he proclaimed the whole truth and where he turns down the idea that he ever wanted to proclaim himself a leader of the community. [...] And equally old and original is certainly also the text in the fifth part where we read how Ānanda cannot

\footnotetext{
${ }^{446}$ Usp. R. Williams (1970: 163).

${ }^{447}$ Fleet (1906: 668): Unless this passage is an interpolation, which does not seem probable, the work cannot have been composed until after the prophecy had been so far fulfilled that the village Pạtaligrāma had become the leading city, the capital Pātaliputra. [...] S druge strane, Hinüber (2008: 207) tvrdi da je sutta nastala prije dolaska Ćandragupte Maurye na vlast i piše: [...] the latest date for the composition of the Mahāparinibbānasuttanta, at least for this part of it, is around 350 to 320 BC.

448 Slaže se i Bapat (1926: 10).

${ }^{449}$ S druge strane, R. Williams (1970: 166) piše: Buddha's rejection of 'the closed fist of the teacher' is suspect as just the sort of interpolation which an earnest Theravada monk would insert in order to discredit the claim of Mahayanists to possess esoteric teaching from the Buddha ".
} 
contain himself any longer in his grief over the impending demise of the Master [...] Also the verses strewn all over the Sutta bear the stamp of very great antiquity.

Iako se kroz cijelu suttu proteže slika Gotame koja današnjega čitatelja nerijetko zapanjuje svojom jednostavnošću i uvjerljivošću, nasuprot se te ovozemaljske slike pruža i njoj sasvim oprečna. Bareau (1971: 10) tako piše:

If in the greatest part of the tale, the Beatific is depicted as a real man, submitting to most of the vicissitudes inherent in the human condition and behaving as a human being, he appears in rather numerous and especially important passages as a superman, as a divine personage - or better yet, as a being simultaneously superior to gods and men, endowed with extraordinary powers.

Gotamin čudesni prelazak nabujale rijeke, znanje o zagrobnim sudbinama preminulih redovnika, svojevoljna odluka o trenutku smrti i potres koji se u tom trenutku javlja, čudesno pretvarenje nepitke u pitku vodu, zlatni sjaj Gotamine kože, nebesko štovanje koje se javlja u trenutku u kojem Gotama liježe na posljednji ležaj u Kusināri, dolazak i oplakivanje nebesnika koji su se okupili oko Gotame odajući mu posljednju počast, potres koji se javlja u trenutku njegove smrti ili ugasnuća, upletanje nebesnika (u dva navrata) u ceremoniju spaljivanja, ${ }^{450}$ samozapaljenje pogrebne lomače ${ }^{451}$ i čudesno pojavljivanje nebeskih mlazova vode koji gase lomaču, ${ }^{452}$ primjeri su u kojima se Gotama pojavljuje kao nadnaravno biće, vrijedno divljenja, obožavanja i štovanja.

Nakamura (2000/2005: 18-19) smatra da pri čitanju Mahāparinibbānasutte treba na umu imati sljedeće:

1. Mythological coloration increases with time. Such elements, therefore, should be eliminated.

2. Passages that regard Gotama Buddha as a deified being are later additions. Nevertheless, the sūtras do preserve passages that portray Gotama as a man rather than a deity - often contrary to the intentions of later compilers - and such descriptions may closely reflect the historical man.

3. Any references to historical events after the time of the Buddha are later additions.

\footnotetext{
${ }^{450}$ DN ii. 160-161 (MPS 6. 14-16), DN ii. 163 (6. 21).

${ }^{451}$ DN ii. 163 (MPS 6. 22).

452 DN ii. 164 (MPS 6. 23).
} 
4. The doctrinal formulas prefixed with numbers (such as eight stages of effort and attainment or the four psychic powers) are more often than not later additions.

Kada je riječ o odnosu spram Gotame Buddhe Mahāparinibbānasutta, u obliku u kojem ju danas posjedujemo, pruža istovremeno dvije sasvim oprečne slike Gotame Buddhe. S jedne je strane čovjek Gotama: učitelj, vođa zajednice redovnika, neumorni putnik, propovjednik upleten u ovosvjetske brige i razmirice i čovjek podložan starosti i bolesti. S druge je strane Savršeno probuđeni, nenadmašni i sveznajući Učitelj ljudi i nebesnika koji može obuzdati bolest $\mathrm{i}$ produljiti svoj život po želji, čudotvorac kojemu se klanjaju ljudi, nebesnici i sama priroda. Mahāparinibbānasutta, više negoli i jedna druga sutta pālijskoga kanona, objedinjuje na jednom mjestu obje te slike, a o tome Hinüber (2008: 207-208) piše:

So, even if there had been the will or at least the intention of the early Buddhist authors of the Mahāparinibbānasuttanta to portray a more or less exact historical record of the nirvāṇa, miraculous and supernatural events were impossible to avoid in an environment in which the practice of all sorts of yogic achievements was commonplace. Miracles simply were part of the worldview of the authors of the Mahāparinibbānasuttanta.

Nidānakathā završava Anāthpiṇ̣ikinim darivanjem parka redovničkoj zajednici pa ne sadrži prikaz Gotamine smrti. U Mahāvastu su, kako je pokazano, događaji koji su se odvili nakon Gautamine smrti povod za okupljanje redovnika na prvome saboru. Mahāvastu donosi prikaz dolaska Mahākaśyape na ceremoniju spaljivanja Buddhina tijela, ali opisuje i čudesno ukazivanje Buddhinih stopala koje se ne spominje u pālijskoj verziji. Epizodu je, pozivajući se na Bareaua i Waldschmidta, izdvojio i Strong (2004: 113):

The miracle of the feet, moving of their own accord after the Buddha's death, is significant because it is the first graphic example of of the Buddha's ongoing magical powers (rddhi) after his parinirvāṇa. As such, it foreshadows similar magical movements, which, as we shall see, will commonly be exhibited by the Buddha's relics.

Mahāparinibbānasutta donosi i opis pogrebnih obreda i raspodjelu Buddhinih relikvija čime je označen, ali ujedno i opravdan (kanoniziran) začetak kulta Buddhina tijela i osobnosti. Štovanje relikvija, thūpa i poticanje hodočašća u mjesta koja su obilježena ključnim događajima Buddhina života predstavljaju tako pokušaj očuvanja uspomene na učitelja kao i način jačanja zajednice kroz osjećaj da dio Buddhe, na neki način, i dalje “živi” u relikvijama. Uzme li se u obzir da je buddhistička književna tradicija, stoljećima nakon Buddhine smrti, nastavila 
proizvoditi sasvim nove biografske epizode, kao i da su Buddhinim relikvijama također pripisani svojevrsni “životopisi”, može se zaključiti da za buddhiste i u okvirima buddhističke književnosti Gotamin životpis ne završava njegovom smrću kao što niti ne započinje njegovim rođenjem. 


\section{MIJENE U ŽIVOTOPISU GOTAME BUDDHE}

U narednim će potpoglavljima biti izdvojeni najistaknutiji i svim korištenim izvorima zajednički elementi Buddhina životopisa. Riječi će biti o Buddhinim epitetima, isticanju njegova tjelesnoga i duhovno-intelektualnoga savršenstva, stavljanju naglaska na čudesne i zadivljujuće pojave koje su popratile njegov život te uspostavljanju predodžbe o njegovoj nadmoći nad nebesnicima. Pažnja će se posvetiti i povećanju broja prethodnih buddha i prethodnih rođenja Gotame Buddhe.

\subsection{Epiteti i svojstva pripisivani Gotami Buddhi}

Prije negoli je dosegao probuđenje, Gotama je bio bhikkhu (skt. bhikșu); prosjak u duhovnoj potrazi, onaj koji luta i prima milodare (uglavnom hranu) i samaṇa (skt. śramaṇa); lutajući isposnik, trapljenik. Na mnogobrojnim se mjestima u pālijskome kanonu trapljenikom naziva i nakon probuđenja i osnivanja redovničke zajednice ali tim ga izrazom oslovljavaju isključivo laici i pripadnici drugih sljedaba. Kao primjer, navodim odlomak iz Suttanipāte:

Taj je trapljenik Gotama na čelu zajednice i ima sljedbenike, učitelj je i vođa sljedbenika. Poznat je kao sjajni gazotvorac, ${ }^{453}$ mnogi ga visoko cijene [...]. ${ }^{454}$

U razdoblju prije svoga probuđenja, Gotama je i bodhisatta (skt. bodhisattva), biće u čijoj je naravi probuđenje ili biće predodređeno za probuđenje. ${ }^{455}$ Epitet bodhisatta u tome se značenju upotrebljava u prve četiri nikāye Suttapițake, to je izvorno značenje. Tako primjerice, u Mahāsaććakasutti stoji:

Evo, o Aggivessana, prije mojega probuđenja, ovako sam, neprobuđeni bodhisatta, mislio $[\ldots]{ }^{456}$

Gotama se Buddha naziva bodhisatttom i kada je riječ o njegovim prijašnjim egzistencijama, točnije o egzistencijama koje su uslijedile nakon trenutka u kojem se je zavjetovao da će postati Probuđeni i stupio na put probuđenja s kojega nije više skrenuo. Takva je uporaba češća u kasnijim djelima pālijske kanonske književnosti kao što su Ćariyāpiṭaka, Apadāna i

\footnotetext{
${ }^{453}$ Pāli titthakaro, skt. tīrthamkara.

${ }^{454}$ Sn. 509 [...] ayampi kho samaṇo gotamo sanghī ceva gaṇi ca gaṇācariyo ca ñāto yasassī titthakaro sādhusammato bahujanassa [...].

455 Za ostala tumačenja složenice bodhisattva v. Dayal (1932/1970: 4-9).

${ }^{456} \mathrm{MN}$ i. 240: Idha me, aggivessana, pubbeva sambodhā anabhisambuddhassa bodhisattasseva sato etadahosi $[\ldots]$.
} 
Nidānakathā, a posebno je istaknuta u Mahāvastuu koji je u cijelosti prožet đātakama, odnosno pripovijestima u kojima se opisuju događaji iz Buddhinih prijašnjih rođenja.

U pālijskom se kanonu bodhisattama nazivaju i prijašnji buddhe prije probuđenja. Tako se, primjerice, u Mahāpadānasutti bodhisattom naziva i Vipassin u razdoblju prije probuđenja, dok se u Samyuttanikāyi koristi za svih šest Gotaminih prethodnika. ${ }^{457}$ Endo (1997/2002: 220 221) tvrdi:

It is an extended usage of the first meaning of bodhisatta. This development is no doubt a result of the apotheosis of Buddhas and culminates in the concept of dhammata (general nature) common to all Buddhas.

On je i satthāa (skt. śāstṛ), učitelj, a valja istaknuti da se izraz satthā u pālijskim tekstovima koristi isključivo za Gotamu. ${ }^{458}$ Gaṇācariya, predvodnik/ vođa/ učitelj zajednice, koristi se u nešto manjoj mjeri. ${ }^{459}$

Nakamura (2000/2005: 203-211), između ostaloga, navodi sljedeće epitete: isil mahesi (vidjelac/ veliki vidjelac), muni/ mahāmuni (mudrac/ veliki mudrac), kevalin (onaj koji je dosegao cjelovito znanje), vedagū/ viditaveda (poznavatelj Veda, znalac znanja, učen), ganin (vođa, predvodnik zajednice), satthar (Učitelj), saććavādin (izricatelj istine), đina (pobjednik), vīra (junak), ćakkhumat (obdaren okom, uvidom), antimadehadhārin (koji je u svojem posljednjem tijelu, za kojega nema ponovnih rođenja), dhammappati (gospodar dhamme), sumedha (vrlo mudar). Nakamura tvrdi da se ti epiteti vežu uz Gotamu u ranim suttama i zaključuje:

The various epithets of Gotama just discussed could be applied to the Buddha or any religious practioner, for both were equally human with essentially no difference between them. (Nakamura, 2000/2005: 209)

Upālisutta donosi niz od gotovo stotinu epiteta koje laik Upāli izgovara hvaleći Gotamu. ${ }^{460}$ Između ostalih, to su primjerice vigatamoha (bez zablude), viđitaviđaya (pobjedonosni), susamaćitta (staložene svjesnosti), rućira (sjajan), vimala (neokaljan, čist), mudita (zadovoljan,

\footnotetext{
457 SN ii. 5.

${ }^{458}$ DN ii. 90, 93, 120, Thīg. 336 itd.

${ }^{459}$ Npr. Thag. 284. U pālijskome kanonu postoje još dva termina u značenju 'učitelj’. To su āćariya i upađđhāya, s tim da se potonji nikada ne koristi za Gotamu, dok āćariya, kada se odnosi na Gotamu, dolazi samo u složenicama. V. Stoezs (1978).

${ }^{460} \mathrm{MN}$ i. $386-387$.
} 
radostan ili sretna srca), sārathivara (najodličniji vozar kola tj. učitelj), vīra (junak), nisabha (bik među ljudima, najbolji među ljudima), gambhīra (duboki), dhammaț̣ha (onaj kojemu je svrha dhamma).

Kao kazivač Puta (maggakkhāyin), ${ }^{461}$ Gotama je postao onaj koji poznaje svijet $(\text { lokavidu })^{462}$. Posjedovao je najviše znanje kojemu su se drugi mogli tek nadati i za čije im je razumijevanje i dosezanje Buddhina riječ bila neophodna pa je stoga bio vrijedan poštovanja (pūđāraha). ${ }^{463}$ Izdržavši neizdrživo (asahyasāhin) ${ }^{464}$ oslobodio se strahova sa svih strana $(\text { akutobhaya })^{465}$. Njegovo ga je znanje obdarilo posebnom mudrošću i djelima (viđđāćaraṇasampanna) koji su mu omogućili da prijeđe na "drugu stranu" (pāragata), i time je postao "takoiđa, takogređa" (tathāgata), što je osobito čest naslov.

Gotama Buddha je arahant (skt. arhant), dostojan, vrijedan, dostojnik. ${ }^{466} \mathrm{U}$ pojedinim tekstovima unutar pālijskoga kanona ideal arahanta dostiže se relativno lako i brzo ${ }^{467}$ dok je na drugim, pak, mjestima, ideal arahanta opisan kao rezultat dugotrajna $\mathrm{i}$ iscrpna usavršavanja $u$ višoj moralnosti (adhisīla), zadubljenju (adhićitta) i mudrosti (adhipañña ${ }^{468}$. Ovo drugo više služi pouci o putu, a ono prvo vjerojatno veličanju čudesne blagotvornosti Učitelja.

U pālijskome se kanonu vrlo često susreće sljedeća formula:

Imesañhi, vāsețtha, catunnam vaṇnānam yo hoti bhikkhu araham khịnāsavo vusitavā katakaraṇīyo ohitabhāro anuppattasadattho parikkhīṇabhavasaṃyojano sammadañ̃̄āvimutto, so nesam aggam akkhāyati dhammeneva, no adhammena. ${ }^{469}$

\footnotetext{
${ }^{461}$ MN iii. 6: Maggakkhāȳ̄, brāhmaṇa, Tathāgato ti.

${ }^{462} \mathrm{DN}$ ii. $76, \mathrm{SN}$ i. 62 , Sn. 103.

463 Dhmp. 194.

464 Thag. 536.

${ }^{465}$ Sn 561, Thag. 289, 510, 831, 911, SN i. 192.

$466 \sqrt{ }$ arh, biti vrijedan, dostojan. Detaljnije o idealu arahanta u: Horner (1936), Bond (1984), Katz (1979, 1982)

467 Tako, primjerice, mladić Yasa postaje arahant odmah po završetku Gotamine poduke:
}

Seyyathāpi nāma suddham vattham apagatakālakam sammadeva rajanam paṭiggaṇheyya, evameva yasassa kulaputtassa tasmimyeva āsane virajam vītamalam dhammacakkhum udapādi-yam kiñci samudayadhammam sabbam tạ̣ nirodhadhammanti. (Vin., Mahāvagga, I. 7, 6) V. i Anatalakkhaṇasutta (SN iii. 66-69). U Ādittapariyāyasutti (SN iv. 19 i d.) tisuću redovnika doseže status arahanta odmah po završetku Gotamine pouke. ${ }^{468}$ V. npr. MN i. 344 i d., MN iii. 33 i d., AN i. 239, SN v. 406: appakā te, bhikkhave, bhikkhū ye āsavānam khayā

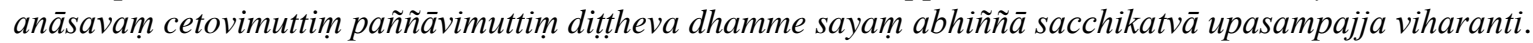

${ }^{469}$ DN iii. 83. V. i MN i. 4, SN i. 71, AN i. 144. Za ostala mjesta u Suttapițaki v. Katz (1982: 2 i d.). 
Prijevod

Iz bilo koje od četiri varṇe, o Vāsețtha, tko postane redovnik, arahant koji je uništio āsave, koji se usavršio u kreposnu životu, koji je izvršio što je trebalo učiniti, koji je odložio teret, koji je dosegao dobru svrhu, koji je prekinuo lanac bivanja, koji je oslobođen kroz savršeno znanje, toga se, među tima, naziva prvim u skladu s dhammom, a ne s nedhammom.

Sljedbenici su Gotamu počeli nazivati buddhom vjerojatno vrlo rano. U svome najjednostavnijem značenju buddha ${ }^{470}$ znači probuđeni, osviješteni, spoznali, nasuprot onomu koji je $m \bar{u} \not ̣ h a$ - zbunjen ili zasljepljen. Osnivač đinizma, Mahāvīra, također se naziva buddhom. Štoviše, u đinističkim se tekstovima svaki mudrac bez obzira na sljedbu naziva buddhom. ${ }^{471}$

Epitet tathāgata u doslovnome prijevodu znači "tako došao" (skt. tathā + àgata), "tako otišao" (tath $\bar{a}+$ gata) ili "tako ne-otišao" (tath $\bar{a}+$ agata $).{ }^{472}$ Isprva se, kao i u đinizmu, odnosio na istaknute učitelje ili sljedbenike nekoga nauka o čem svjedoče i neki buddhistički tekstovi ${ }^{473}$ dok se u kasnijem razdoblju odnosi isključivo na Gotamu. Oldenberg i Rhys Davids (1882/1974: 82) napominju da se epitet tathāgata vezuje isključivo za sammāsambuddhe i da se u pitakama pojavljuje na mjestima u kojima Buddha govori o sebi u trećem licu. $U$ Sundarikabhāradvāđāsutti tathāgata je vrijedan štovanja na temelju svoje moralne izvrsnosti, potpuna oslobođenja i posjedovanja najvišega znanja i mudrosti. ${ }^{474}$

Iz brahmanističke su tradicije preuzeti načini oslovljavanja učitelja titulom brāhmaṇa 475 (brahman) i bhagavā (od skt. osnove bhagavant, poštovani, blaženi). Bhagavā, uz saṃbuddha (Probuđeni, koji je ispravno razumio) i nešto kasniji sammāsaṃbuddha (obuhvatno, potpuno, savršeno probuđeni), među najzastupljenijim su epitetima koji se vezuju uz osnivača

\footnotetext{
${ }^{470}$ Skt. $\sqrt{ }$ budh, 1- probuditi se, biti budan, motriti, razumijevati pa s time u skladu budan, probuđen.

${ }^{471}$ Usp. Rhys Davids (1910/2007: 2): The teacher never called himself a Buddha (as distint from an Arahant). When addressed as Buddha, or spoken of as such, by his followers, it is always doubtful whether anything more is meant than an enlightened Arahant.

472 Za daljnja tumačenja i mjesta u kanonu na kojima se objašnjava značenje toga izraza v. Chalmers (1898). V. i Griffiths (1994: 60-61) Za Buddhaghosino tumačenje izraza v. Chalmers (1898: 105-108). Za različite interpretacije u pālijskoj komentatorskoj književnosti v. Endo (1997/2002: 201 i d.). Hopkins (1911: 208) predlaže i sljedeće moguće tumačenje: There is, however, the chance that this was an euphemistic title bestowed upon him after his death by followers avoiding to say dead- iako se u tekstovima najčešće ne može tako razumjeti ni prevoditi.

${ }^{473}$ Npr. Thag. 280. V. Nakamura (2000/2005: 216).

${ }^{474}$ Sn. 455 i d.

${ }^{475}$ Nakamura (2000/2005: 204) smatra da se taj način oslovljavanja javlja u najranijim slojevima teksta budući da su u ranome razdoblju buddhizma brahmani bili cijenjeni u svim slojevima društva. U kasnijem razdoblju, kada je buddhizam stekao ugled, nije bilo potrebe usavršenu osobu oslovljavati tim izrazom.
} 
buddhizma. S vremenom su se pojavili i oni koji su proistekli iz same buddhističke tradicije kao što je primjerice sugata, koji je dobro otišao (na drugu stranu), sretan.

Buddha je i teviđđa, troznalac. ${ }^{476}$ Isprva se pojam teviđđāa (skt. trividyā) odnosio na poznavanje triju Veda, ali u buddhizmu podrazumijeva trovrsno znanje: sjećanje na prijašnja rođenja (pubbenivāsānussati ñāna), božansko oko ili vid (dibba ćakkhu) kojim se vidi nevidljiva istina i znanje o uništenju svih onečišćenja / priljeva žeđi ili činā (āsavakkhāya ñāna). Ovo posljednje znanje ujedno je okarakterizirano kao lokuttara, onosvjetsko, i kao uvjet za postizanje stanja arahanta.

Jedno od bitnih obilježja Buddhinih jest i njegovo sveznanje ${ }^{477}$ pa se među Buddhinim epitetima susreću sabbañ̃̄̄, sabbadassāvin, ${ }^{478}$ sabbavidu ${ }^{479}$. Analizirajući sutte pālijskoga kanona i komentare u kojima se raspravlja o mogućnosti sveznanja, Anālayo (2006: 11-12) zaključuje:

The attribution of omniscience to the Buddha appears to be the outcome of a historically later development which in all traditions tended to emphasize the divine against the human in the person of Gotama Buddha. A factor contributing to the attribution of omniscience to the Buddha could have been the Jaina claim of omniscience for their teacher Niganțha Nāthaputta, in the face of which later Buddhist generations might have felt a need to similarly enhance the status of their own teacher.

Sličnoga je mišljenja i Jayatilleke (1980: 380):

[...] we have the positive claim on the part of the Buddha that he should be regarded not as one who is omniscient all the time but as one who has 'a three-fold knowledge', which even others can develop. This attitude of not claiming omniscience for the Buddha seems to have been maintained right up to the time when the Vibhanga was composed for this book gives the most elaborate account of the ten cognitive powers of the Buddha with no mention of his alleged omniscience. In the Nikāyas, we find a list of ten verses, containing no less than a hundred epithets of the Buddha, where the epithets sabbannū (omniscient) or sabba-dassāvi (all-seeing) or any of its synonyms are conspicuous by their absence (v. M. I.386).

\footnotetext{
${ }^{476} \mathrm{SN}$ i. $192, \mathrm{AN}$ i. $165, \mathrm{MN}$ i. $386, \mathrm{MN}$ i. 482: Teviđđo samaṇo Gotamo ti.

${ }^{477}$ U MN ii. 127 Buddha potvrđuje da je moguće steći sveznanje, ali tvrdi da nije moguće sve znati u isto vrijeme.

${ }^{478}$ ĐātA. I. 214, MN i. 482: samaṇo Gotamo sabbañ̃̄ī sabbadassāūi.

${ }^{479}$ Sn. 177,211 , Vin. i. 8.
} 
Gotama Buddha je i ćakkhumant (koji posjeduje oko, vid, uvid, znanje). ${ }^{480}$ U Nidānakathi i Mahāvastuu se Buddha naziva ćakkhumant, odnosno ćakṣumant na samo po jednome mjestu. ${ }^{481}$ Na pojedinim mjestima u kanonu vid je trovrstan: tjelesni, fizički vid (maṁsaćakkhu), božanski vid (dibbaćakkhu) i vid mudrosti (pañ̃̃ā́akkhu). ${ }^{482} \mathrm{U}$ kasnijim je tekstovima Buddha opisan kao posjedovatelj pet vrsta očiju ili vida (pañćaćakkhu). ${ }^{483} \mathrm{U}$ Mahāvastuu je u listu pet Buddhinih vidova uvršten i tzv. vid dharme (dharmaćakṣu) koji je poistovjećen s posjedovanjem deset moći. ${ }^{484}$

Buddhi su pripisivane i različite moći ili mentalne sposobnosti pa se naziva balapatta, onaj koji je stekao moći. ${ }^{485} \mathrm{~S}$ svremenom su te sposobnosti sistematizirane i standardizirane pa je Buddha postao dasabala, posjedovatelj deset moći. ${ }^{486}$

Buddhi su također pripisani i epiteti kojima se je uzdigao do, pa čak i iznad, statusa nebesnika. Buddha tako postaje atideva (nad-nebesnik) i devadeva (nebesnik nebesnika). ${ }^{487}$

Odlike koje Buddhu čine buddhom možda su najbolje izražene u nauci o devet Buddhinih osobina (navaguna):

Blaženi je arahant, potpuno probuđen, obdaren znanjem i [ispravnim] djelovanjem, koji ide pravo, poznavatelj svijeta, nenadmašan vozar koji upravlja ljudima koji trebaju biti ukroćeni, ${ }^{488}$ učitelj nebesnika i ljudi, probuđen i blažen. ${ }^{489}$

U Nidānakathi je zamjetna ograničena uporaba epiteta. U prvome dijelu (dūre nidāna), gdje se pripovijeda o prethodnim životima, i u drugome dijelu (avidūre nidāna), u kojem se prepričavaju događaji od boravka u nebesima Tusita, preko začeća, rođenja, odlaska u

\footnotetext{
${ }^{480}$ Sn. 160, 540, 562, Dhmp. 273, SN i. 27, 121, 185, AN i. 116, 124, iv. 106. Za ostala mjesta v. PED, str. 260.

${ }^{481}$ ĐātA. I. 66, Mv. ii. 46. 16.

482 Npr. DN iii. 219.

${ }^{483}$ V. Endo (1997/2002: 24).

${ }^{484}$ Mv. i. 158. V. niže.

${ }^{485}$ Sn. 192, DN ii. 157.

486 Thag. 457, SN ii. 27, 130, ĐātA. I. 84. Moći se nalaze pobrojane u, primjerice, Mahāsīhanādasutti (MN i. 69 i d., sutta br. 12). V. dalje u tekstu.

${ }^{487}$ Npr. Thag. 489 (atideva), 1279 (devadeva).

488 Purisadammasārathī. Složenica je nastala po uzoru na složenicu assadammasārathī, vozar kola, koji pripitomljuje konje, v. PED, str. 469.

${ }^{489}$ Npr. DN i. 49, AN i. 168, Sn. 103, DN i. 115: Iti pi so Bhagavā araham sammāsaṃbuddho vijjācaraṇasampanno sugato lokavidū anuttaro purisadammasārathī satthā devamanussānam buddho Bhagavā $t i$. Usredotočenjem na te Buddhine osobine (buddhānussati), prema pojedinim suttama, postiže se pročišćenje uma i jasniji uvid (Npr. MN i. 37). Također, u SN i. 219 se tvrdi da podsjećanje na te Buddhine osobine lišava čovjeka straha.
} 
beskućništvo sve do probuđenja, Gotama se naziva bodhisatta. U trećem dijelu (santike nidāna) koje započinje događajima neposredno nakon probuđenja i završava Anāthapiṇ̣̣ikinim darivanjem redovničke zajednice Gotama se naziva bhagavā, tathāgata i, u nešto manjoj mjeri, mahāpurisa.

Među epitete koji su zajednički pālijskomu kanonu i Mahāvastuu ubrajaju se (mahā-) śramaṇa ${ }^{490}{ }^{20}$ mini, ${ }^{491}$ mahāmuni, ${ }^{492}$ śākyamuni, ${ }^{493}$ (mahā) rșii, ${ }^{494}$ śāstr ${ }^{495} \mathrm{i}$ arhant ${ }^{496}$. Među najzastupljenijim epitetima u Mahāvastuu jesu bhagavant, tathāgata, samyaksaṃbuddha i sugata. Epitet bodhisattva koristi se uglavnom u značenju koje ima i u prve četiri nikāye pālijskoga kanona iako se u drugoj Avalokitasūtri na dva mjesta bodhisattvom naziva i nakon probuđenja. ${ }^{497}$ U Mahāvastuu se također, na nekoliko mjesta, susreće formula u kojoj su nabrojani najistaknutiji Buddhini epiteti:

On je tathāgata, arhant, potpuno probuđen, obdaren znanjem i [ispravnim] djelovanjem, koji ide pravo, poznavatelj svijeta, nenadmašan vozar koji upravlja ljudima koji trebaju biti ukroćeni, učitelj nebesnika i ljudi. ${ }^{498}$

Ipak, u potonjem su djelu težnje autora ili kompilatora da Buddhi pridodaju što je više moguće štovanja vrijednih osobina došle do svojega punoga izražaja tako da Mahāvastu obiluje dugim i detaljnjim nabrajanjima epiteta, a koja nerijetko otežavaju čitanje. Budući da bi nabrajanje svih epiteta koji se susreću u Mahāvastuu nadraslo okvire ovoga potpoglavlja, u nastavku će se iznijeti samo neki od njih (među njima se mnogi, kako je rečeno, susreću i u pālijskome kanonu).

Buddha je, primjerice, čovjek-nāga (purușanāga), čovjek-lav (puruṣasiṃha), čovjekbik (purușarșabha), ${ }^{499}$ gospodar životinja/ lav (mrgādhipa) ${ }^{500}$ onaj koji vuče rudo (prvi) među

\footnotetext{
${ }^{490}$ Mv. ii. 265. 8, 268.15, 278. 7, 400. 15, iii. 62. 9, 63. 7 i d.

${ }^{491}$ Mv. i. 9. 5, 44. 2, 65. 5, 68. 11, 163. 17 i d. Mv. ii. 21. 3, 166. 4 i d.

492 Mv. i. 99. 2, 99. 10, 123. 11, 123. 19 i d. Mv. ii. 46. 11, 55. 2, 61. 8 i d.

${ }^{493}$ Mv. i. 1. 5, 1. 6, 2. 4, 2. 9, 47. 13, 48. 15, 57. 8, 111. 5, 136. 9, 161. 7 i d.

${ }^{494}$ Mv. i. 169. 11, 188. 10, ii. 25. 8, 135. 11, 231. 16, 232. 4 i d.

${ }^{495}$ Mv. i. 4. 13, 10. 17, 13. 9, 34. 2, 38. 12, 49. 1, ii. 10. 5, 40. 20, iii. 89. 9 , 98.3 i d.

${ }^{496}$ Mv. i. 2. 6, 47. 13, 50. 1, 57. 11, 60. 3, 62. 17, ii. 258. 12, iii. 200.1 i d.

${ }^{497}$ Mv. ii. 351.12 i 14.

498 Mv. i. 47, 48, 57, 61, 238, 239, 330, 332, 335, 336, iii. 378: [...] tathāgato 'rham samyaksambuddho vidyācaraṇasampanno sugato lokavid anuttaraḥ puruṣadamyasārathih śāstā devānām ca manuṣānām ca.

${ }^{499}$ Mv. i. 229. 7-8: [...] puruṣanāgena puruṣasiṃhena puruṣarṣabheṇa [...].

${ }^{500}$ Mv. ii. 198. 20.
} 
ljudima (puruṣadhaura), ${ }^{501}$ najodličniji među ljudima (narottama), ${ }^{502}$ najbolji među dvonošcima (dvipadaśreștha), ${ }^{503}$ čovjek plemenita podrijetla (puruṣađāneya), ${ }^{504}$ čovjek-lotos (puruṣapaduma), ${ }^{505}$ čovjek-bijeli lotos (puruṣapunḍarīka), ${ }^{506}$ istinski čovjek (satpuruṣa), ${ }^{507}$ okomica među ljudima (naralambaka), ${ }^{508}$ veliki čovjek (mahāpuruṣa), ${ }^{509}$ čovjek-Sunce $(\text { narāditya })^{510}$. On je i lav među govornicima (vādisiṃha), ${ }^{511}$ tigar među govornicima $\left(v \bar{a}\right.$ diśärdūla), ${ }^{512}$ najbolji među govornicima (vadatām varam), ${ }^{513}$ izricatelj istine (satyavādin), ${ }^{514}$ junak i veliki junak (vīra, mahāvira), ${ }^{515}$ gospodar nebesnika i ljudi, vođa i iscjelitelj (marumanuṣyānām nātha netā ćikitsakah), ${ }^{516}$ vozar ljudi koji trebaju biti ukroćeni (puruṣadamyasārathi), ${ }^{517}$ poznavatelj svijeta (lokavid), ${ }^{518}$ sveznajući (sarvađña) ${ }^{519}$ i svevideći (sarvadarśin), ${ }^{520}$ veliki vođa svijeta i učitelj gospodara ljudi (mahālokanātho narendrāṇa $\left.s^{\prime} \bar{a} s t \bar{a}\right)^{521}$. Svjetlo svijeta (lokapradyota), ${ }^{522}$ svjetlotvorac (prabhamkara), ${ }^{523}$ hram svijeta

\footnotetext{
${ }^{501}$ Mv. ii. 133. 8. Dhaura za skt. dhaureya, BHSD, str. 287.

${ }^{502}$ Mv. i. 47.2, 104. 17, 291.1, ii. 41. 2, 44. 17, 193. 19, 294. 10, 307. 15 i d.

${ }^{503}$ Mv. ii. 355. 10, 365. 12, 367. 10, Mv. iii. 270. 12.

${ }^{504}$ Mv. ii. 133. 9, 284. 18, 415. 20.

${ }^{505}$ Mv. i. 229. 7, ii. 133. 9.

${ }^{506}$ Mv. i 229. 8, ii. 133. 9, 284. 18, 415. 20.

${ }^{507}$ Mv. i 299. 11, ii. 133. 9, 142. 9, 284. 16, 415. 4, iii. 109. 2.

${ }^{508}$ Mv. ii. 26. 15.

${ }^{509}$ Mv. i. 142. 14, 197. 8, 366. 10, ii. 7. 11, iii. 377. 17.

${ }^{510}$ Mv. i 187. 2, 188. 7.

${ }^{511}$ Mv. i. 118. 8, 178. 4.

${ }^{512}$ Mv. i. 113. 9, 157. 10, 188. 2, 191. 13.

${ }^{513}$ Mv. i. 219. 19, ii. 21. 20, 355. 10, iii. 137. 10.

${ }^{514}$ Mv. ii. 378. 15, iii. 225.7.

${ }^{515}$ Mv. ii. 12. 10, 22. 8, 158. 11, 201.3, 232. 17, 266-267 i d.

${ }^{516}$ Mv. i. 191. 10.

${ }^{517}$ Mv. i. 4. 9, 47. 14, 48. 18, 57. 12, 62. 17, ii. 133. 9, 284. 19, 330. 2, iii. 138. 10 i d.

${ }^{518}$ Mv. i. 38. 12, 39. 10, 50. 1, 330. 2, iii. 138. 10.

${ }^{519}$ Mv. i. 192. 13, 219. 14, 220. 4, 254. 3, ii. 3. 3, 13. 3, 21.16 i d.

${ }^{520}$ Mv. i. 220. 4, 254. 4, ii. 13. 3, 22.5

${ }^{521}$ Mv. i. 330. 2, ii. 26. 8..

${ }^{522}$ Mv. i. 206. 8, 206. 10, 337. 8, ii. 10. 4, 294. 8, 302. 21, 303. 1.

${ }^{523}$ Mv. ii. 296. 12, 353. 2, iii. 277. 5.
} 
(lokasya ćetiya), ${ }^{524}$ samobitni (svayambhū),${ }^{525}$ onaj kojemu je sopstvo dharma (dharmātma), ${ }^{526}$ istinitoga imena (satyanāma), ${ }^{527}$ iznimno pročišćeno biće (suviśuddhasattva), ${ }^{528}$ bez ikoga tko bi mu bio nalik (asadṛśa), ${ }^{529}$ obdaren vrlinama (punyavat), ${ }^{530}$ prekriven izvrsnim obilježjima (ākīrnavaralakṣaṇa), ${ }^{531}$ nadmoćan svim dharmama (sarvadharmavaśavartin), ${ }^{532}$ veliki mudrac (munivara), ${ }^{533}$ predvodnik karavane (sārthavāha), ${ }^{534}$ vođa svijeta (lokanāyaka), ${ }^{535}$ Gospod i gospodar triju svjetova (trilokapatir iśvarah), ${ }^{536}$ posjedovatelj deset moći (daśabala) ${ }^{537}$ koji je ostvario sve težnje (sarvārthasiddha) ${ }^{538}$ prvi među nebesnicima i ljudima, najprvi/ iskonski čovjek, veliki mudrac, najbolje utočište i prabiće/ vrhovno biće (so hi devamanujāna uttamo so hi agrapuruṣo mahāmunih / so hi nihśaranạ̣ uttamam prabhuh $)^{539} \mathrm{i}$ usavršen u beskrajnim vrlinama (anantagunasampanna), ${ }^{540}$ samo su neki od epiteta koji se susreću u Mahāvastuu.

Buddhi se, u skladu s naukom škole kojoj Mahāvastu pripada, pridaje i epitet, lokottara ${ }^{541}$ nadnaravan, nadsvjetski, transcendentan:

Mv i. 159

nahi kiṃcit samyaksaṃbuddhānām lokena samam // atha khalu sarvam eva maharșin̄ạm lokottaram // tathā hi samyaksaṃbuddhānām samudāgamah so pi lokottaro //

\footnotetext{
${ }^{524}$ Mv. ii. 294. 14, 349. 6, 359. 8.

${ }^{525}$ Mv. i. 175. 11, ii. 115. 3, 294. 15, 309. 2.

${ }^{526}$ Mv. ii. 196. 1.

${ }^{527}$ Mv. iii. 109. 10. Pāli, saććanāma, AN iii. 346, iv. 285.

${ }^{528}$ Mv. ii. 315. 16.

${ }^{529}$ Mv. ii. 299. 1, 328. 15, 332. 18, 375. 7.

${ }^{530}$ Mv. ii. 286. 6, 20. 19, 327. 21, 336. 1.

${ }^{531}$ Mv. ii. 198. 4, 198. 7.

532 Mv. ii. 41. 4.

${ }^{533}$ Mv. ii. 361. 19.

${ }^{534}$ Mv. ii. 330. 5, 361. 20, 376. 10, 393. 1.

535 Mv. iii. 347. 1, 365. 16, iii. 94-95

536 Mv. ii. 197. 1..

${ }^{537}$ V. Mv. i. 159. 10, 338. 9, ii. 29. 15, 295. 5, 296. 1, 297. 1 itd. V. i Jones (2007, sv. 1: 126, bilj. 4).

${ }^{538}$ Mv. ii. 26. 15, iii. 112. 1.

${ }^{539}$ Mv. i. 73. 4-5.

${ }^{540}$ Mv. iii. 347. 13.

${ }^{541}$ Mv. i. 48. 15, 159. 3, 167-168, 186. 14, ii. 219. 17, 220.9 i d.
} 
Prijevod

Savršeno Probuđeni nemaju ništa što je jednako sa svijetom. Uistinu, sve je u velikih vidjelaca nadsvjetsko. Potpuno iskustvo savršeno Probuđenih također je nadsvjetsko (transcendentno: skt. lokottara).

Potrebno je naglasiti da se u Mahāvastuu epitet lokottara javlja samo sporadično i da je ulomak iz kojega je ovaj navod preuzet jedino mjesto u ovome djelu u kojem se razrađuje ideja transcendentne naravi Buddhine.

\section{2. Savršenstva Gotame Buddhe}

\section{2. 1. Duhovno-intelektualno savršenstvo Gotame Buddhe}

Gotama je Buddha, ako je suditi po buddhističkim tekstovima, posjedovao šest viših znanja (ćhalabhiñ̃̃a $)^{542}$ što je kasnija nadogradnja ranijega pojma teviđđā (trividyā). ${ }^{543} \mathrm{U}$ Nidānakathi se također navode tri znanja koje je Buddha stekao u noći probuđenja: božanski vid, znanje o prethodnim egzistencijama i znanje o uvjetovanom nastanku. Uz navedena tri znanja na listu šest viših znanja pridodane su još i nadnaravne moći (iddhividdhā), božansko uho ili sluh (dibbasota) i sposobnost prodiranja u misli drugih (ćetopariya-/ ćetopariyāya-ñāna). U Mahāvastuu se također navodi da buddha posjeduje šest viših znanja, ${ }^{544}$ iako se na jednom mjestu spominje pet znanja ${ }^{545}$.

Prva tri znanja Gotama je stekao u noći probuđenja. Sposobnost da se prisjeti svojih prijašnjih egzistencija poslužila je kao temelj brojnim đātakama u kojima se pripovijedaju događaji iz neke od njegovih prijašnjih egzistencija.

U Mahāparinibbānasutti se nalazi i jedan od primjera Gotamina poznavanja karmičkih ishoda djelovanja svih bića, što je predmet božanskoga vida. ${ }^{546} \mathrm{Tu}$ Gotama Ānandi opisuje sudbine preminulih redovnika, a koji su svojim trudom i uništenjem āsava zaslužili da budu ponovno rođeni u nebeskom svijetu ili da se nikada ne vrate u stanje patnje. ${ }^{547}$ Uvjerenje u konačno uništenje āsava učinilo je Gotamu dostojnim statusa arahanta.

\footnotetext{
${ }^{542} \mathrm{DN}$ iii. 281. Pojedinačna se znanja nalaze opisana npr. u MN i. 34, AN i. 255, 258, AN iii. 17. Za ostala mjesta v. PED, str. 64.

${ }^{543}$ Sn. 656, AN i. $164-165,167$.

${ }^{544}$ Mv. iii. 246.

${ }^{545}$ Mv. i. 107. 2: buddhānāṃ paṃćābhiđñā bhavanti te.

${ }^{546}$ DN ii. 92-93 (MPS 2. 7).

${ }^{547}$ V. i MN i. $482-483$.
} 
Svih je šest je znanja opisano u Sāmaññaphalasutti. ${ }^{548}$ Budući da je sadržaj prva tri znanja ranije iznesen, ${ }^{549}$ niže će se iznijeti sadržaji preostalih triju znanja kako su dani u spomenutoj sutti. ${ }^{550}$

Božansko uho ili sluh (dibbasota)

So evam samāhite citte parisuddhe pariyodāte anañgaṇe vigatūpakkilese mudu-bhūte kammaniye thite ānejjappatte dibbāya sota-dhātuyā cittam abhinīharati abhininnāmeti. So dibbāya sotadhātuyā visuddhāya atikkantamānusikāya ubho sadde suñāti, dibbe ca mānuse ca, ye dūre santike ca.

\section{Prijevod}

I onda on, kada mu je um usredotočen, pročišćen, čist, neumrljan, neukliješten, umekšan, obradiv, staložen $i$ nepomičan, usmjerava $i$ navodi um prema božanskome sluhu. Pročišćenim božanskim sluhom, koji je nadmoćan ljudskomu, on čuje i ljudske i nebeske zvukove, $i$ one u blizini i one u daljini. ${ }^{551}$

Sposobnost prodiranja u misli drugih (cetopariya-ñāna)

So parasattānam parapuggalānam cetasā ceto paricca pajānāti - sarāgam vā cittam 'sarāgam cittan'ti pajānāti, vìtarāgam vā cittam 'vītarāgam cittan'ti pajānāti, sadosam vā cittam 'sadosam cittan'ti pajānāti, vìtadosam vā cittạ̣ 'vītadosam cittan ’ti pajānāti, samoham vā cittam 'samoham cittan'ti pajānāti, vītamoham vā cittam 'vītamoham cittan'ti pajānāti, saìkhittam vā cittam 'san்khittam cittan'ti pajānāti, vikkhittam vā cittam 'vikkhittam cittan'ti pajānāti, mahaggatam vā cittam 'mahaggatam cittan'ti pajānāti, amahaggatam vā cittạn 'amahaggatam cittan'ti pajānāti, sauttaram vā cittam 'sa-uttaram cittan'ti pajānāti, anuttaram vā cittam 'anuttaram cittan'ti pajānāti, samāhitam vā cittam 'samāhitam cittan'ti pajānāti, asamāhitam vā cittam 'asamāhitam cittan 'ti pajānāti, vimuttam vā cittam 'vimuttam cittan'ti pajānāti, avimuttam vā cittam 'avimuttạ̣ cittan'ti pajānāti. ${ }^{552}$

\footnotetext{
${ }^{548}$ DN i. 81-84. V. i DN ii. 232 i d., MN ii. 18-22.

${ }^{549} \mathrm{~V}$. poglavlje o probuđenju.

${ }^{550} \mathrm{Za}$ ta tri znanja v. i MN i. 69.

${ }^{551}$ DN i. 79. Jedan od primjera Gotamina božanskoga sluha nalazi se u MN i. 503: Assosi kho bhagavā dibbāya sotadhātuyā visuddhāya atikkantamānusikāya bhāradvājagottassa brāhmaṇassa māgaṇịiyena paribbājakena saddhim imaṃ kathāsallāpam.

${ }^{552}$ DN i. 79-80. Umješnost u čitanju misli drugih ljudi nerijetko se spominje, a jedan se od od primjera nalazi u MN ii. 61: Atha kho bhagavā āyasmato rațthapālassa cetasā ceto paricca manasākāsi. Yathā bhagavā añ̃āāsi:
} 
Prijevod

Zahvativši [svojim] umom um drugih bića i osoba, on proznaje: proznaje um obuzet strašću "Um je obuzet strašću”, proznaje um lišen strasti “Um je lišen strasti”, proznaje um obuzet mržnjom "Um je obuzet mržnjom”, proznaje um lišen mržnje "Um je lišen mržnje”, proznaje zaluđeni um “Um je zaluđen”, proznaje um oslobođen zaluđenosti “Um je oslobođen zaluđenosti", proznaje skučeni um "Um je skučen”, proznaje prošireni um “Um je proširen”, proznaje osnaženi um “Um je osnažen”, proznaje oslabljeni um “Um je oslabljen”, proznaje nadmašivi um "Um je nadmašiv”, proznaje nenadmašan um “Um je nenadmašan”, proznaje usredotočeni um "Um je uredotočen”, proznaje neusredotočeni um "Um je neusredotočen”, proznaje oslobođeni um "Um je oslobođen”, proznaje neoslobođeni um "Um je neoslobođen".

Vrste nadnaravnih moći (iddhividdhañāṇa)

So anekavihitam iddhividham paccanubhoti-ekopi hutvā bahudhā hoti, bahudhāpi hutvā eko hoti, āvibhāvam tirobhāvam tirokuțtam tiropākāram tiropabbatạ̣ asajjamāno gacchati seyyathāpi ākāse, pathaviyāpi ummujjanimujjạ̣ karoti seyyathāpi udake, udakepiabhijjamāne gacchati seyyathāpi pathaviyā, ākāsepi pallaìkena kamati seyyathāpi pakkhī sakuṇo, imepi candimasūriye evammahiddhike evammahānubhāve pāṇinā parāmassati parimajjati, yāva brahmalokāpi kāyena vasam vatteti. ${ }^{553}$

Prijevod

On posjeduje različite vrste nadnaravnih moći: bivši jedan postaje mnogostruk, bivši mnogostruk, postaje jedan, pojavljuje se i nestaje, ide, neometan, kroz pregradu, kroza zid, kroz planinu kao kroza zrak, izranja i uranja u zemlju kao u vodu, hoda po vodi koja se ne rastvara kao po zemlji, putuje zrakom prekriženih nogu kao krilata ptica, rukom dodiruje i miluje tako moćne i silne Sunce i Mjesec, tijelom se po volji kreće sve do svijeta Brahmana.

Valja imati na umu da se nadnaravne moći (iddhi, skt. $r d d h i)$ poput Gotaminih ${ }^{554}$ pripisuju i drugim usavršenim pojedincima. ${ }^{55}$ Pravilo u Vinayapiṭaki kojim se zabranjuje pokazivanje

\footnotetext{
“abhabbo kho rațthapālo kulaputto sikkhạ̣ paccakkhāya hīnāyāvattitun”ti, atha kho bhagavā āyasmantam rațthapālam etadavoca: "Yassadāni tvaṃ, rațthapāla, kālaṃ mañ̃asī”ti

553 DN i. 78.

${ }^{554} \mathrm{MN}$ i. 69, DN ii. 78. V. PED, str. 120.

555 Oldenberg (1881/2007: 89) smatra da u pālijskom kanonu Buddhu nad-čovjekom ne čine njegove magične sposobnosti koje, uostalom, u indijskome kontekstu nemaju auru nad-ljudskosti već njegovo znanje koje ga je
} 
takvih sposobnosti Gotama je uveo nakon što su dva redovnika, Piṇ̣̣ola Bhāradvāđa i Moggallāna, javno pokazala svoju sposobnost izvođenja čuda. Gotama objašnjava da pokazivanje moći niti jača vjeru onih koji vjeruju niti čini da povjeruju oni koji ne vjeruju. ${ }^{556}$

U Kevaț̣hasutti pripisuju mu se sljedeće riječi: I zato što u čudima $i$ čudotvorstvu vidim opasnost, ja sam zabrinut, stidim ih se i gnušam ih se. ${ }^{557}$

U Mahālisutti se potvrđuje mogućnost izvođenja čuda i navodi kako je vjerovanje u čudesa i razna nebeska očitovanja općeprihvaćeno, međutim tu Gotama izričito kaže da se njegovim sljedbenikom ne postaje stjecanjem magičnih moći već slijeđenjem puta koji je propovijedao. ${ }^{558}$

$\mathrm{Na}$ nekoliko mjesta $\mathrm{u}$ kanonu Buddha objašnjava vrste čuda (pāṭihariya, skt. pratihārya). ${ }^{559} \mathrm{U}$ Kevatṭhasutti se nalazi sljedeći ulomak:

Tri su, Kevaț̣a, vrste čuda koje sam sâm spoznao i obznanio. Koje tri? Čudo proisteklo iz nadnaravnih moći (iddhipāṭihāriya), čudo čitanja misli [drugih ljudi] (ādesanāpāṭihāriya) $i$ čudo pouke (anusāsanīpātịhāriya). ${ }^{560}$

Uz ove tri vrste, u buddhističkim se kanonskim tekstovima susreću još i dvojno čudo (yamakapāțihāriya), odnosno sposobnost istovremena izvođenja dvaju čuda ${ }^{561}$ i pokazivanje cijeloga svemira (lokavivaraṇapātihāriya) ${ }^{562}$ koji se sastoji od nebesa (saggaloka), zemlje (manussaloka) i paklova (nirayaloka).

Iako ne treba zaboraviti da je Buddhi pripisan stav prema kojem je od svih najveće čudo pouke, ${ }^{563}$ valja na umu imati da u kanonskim tekstovima ne manjka primjera u kojima Buddha pokazuje svoje nadnaravne moći. Primjerice, odmah po rođenju, Gotama očituje snagu svoje

oslobodilo āsava. Buddhine su moći svojevrsna nuspojava višegodišnjega trapljenja. Usp. Xing (2009: 393). S druge strane, s vremenom je jačala predožba o Gotami kao nenadmašnome čudotvorcu pa se tako u Bhv. I. 39 Gotama naziva iddhibalena asamo, odnosno bez premca u magičnim moćima.

${ }^{556}$ Vin. ii. 112 (Ćullavagga V. 8. 2).

${ }^{557}$ DN i. 213: Imam kho aham iddhi-pātịhāriye ādīnavam sampassamāno iddhi-pāțihāriyena atțiyāmi harāyāmi jigucchāmi.

${ }^{558}$ DN i. 155.

${ }^{559}$ Za pregled mogućih interpretacija i značenja pojmova koji označavaju čudesno v. Fiordalis (2008: 47-55).

${ }^{560} \mathrm{DN}$ i. 211 i d. ista se podjela nalazi i u AN i. 170 i d. i u Mv. i. 238. V. i Mv. iii. 137-138. Ta su čuda gore navedena prema Samaññaphalasutti (DN, sutta br. 2).

${ }^{561}$ DN iii. 27. Za opis dvojnoga čuda izvedenoga u Sāvatthī i analizu reljefenih prikaza u Bhārhutu i Sānćhī v. Brown (1984).

${ }^{562}$ Dojmljiv se primjer nalazi u Bhv. I. 1-48.

${ }^{563}$ V. npr. AN iv. 177-178, Mv. i. 238, iii. 137-138, DN i. 211, AN i. 170-171, DN iii. 4. 
moći, staje čvrsto objema nogama na zemlju, čini sedam koraka i proglašava se najodličnijim na svijetu uz tvrdnju da je to njegovo posljednje rođenje. U Vinayapițaki se pripovijeda kako je mladića Yasu, u želji da ga sakrije pred ocem, učinio nevidljivim. ${ }^{564}$ Okorijeloga razbojnika i ubojicu Aṅgulimālu zadivio je i preobratio pokazivanjem svojih moći. ${ }^{565}$ Vinayapiṭaka sadrži i podulje poglavlje (Uruvelapațihāriyakathā) o mnogobrojnim očitovanjima Gotaminih čudesnih moći. U Vinayi se tvrdi da ih je u konačnici izveo ukupno tri tisuće i pet stotina. ${ }^{566}$ Poglavlje završava preobraćenjem trojice braće Kassapa i tisuću njihovih sljedbenika. Epizoda se nalazi i u Mahāvastuu, u donekle izmjenjenom obliku. Pišući o razlikama u ta dva izvora Fiordalis (2010: 398) kaže sljedeće:

Kāśyapa is not converted by the snake-taming miracle, however. Only in the version found in the Mahāvastu is Kāśyapa converted by the snake-taming miracle, but that version differs from the others in several other important respects as well. For one thing, the snake-taming miracle occurs at the end of the sequence of miracles, not the beginning. Another important difference is that, in the Mahāvastu, the Buddha and Kāśyapa both display their superhuman powers in a wonderworking contest, which the Buddha eventually wins. Most versions suggest, on the contrary, that Kāśyapa does not display his own powers.

U Mahāparinibbānasutti se navodi kako je Gotama, vinuvši se čudesnim moćima u zrak, prešao preko nabujale rijeke, ${ }^{567}$ kao i da je nepitku vodu pretvorio u čistu i pitku ${ }^{568}$. U Upālisutti se nalazi ulomak u kojem je iznesen stav ne-pripadnika Gotamine sljedbe:

Jer isposnik je Gotama opsjenar (māyāvin) i time što poznaje iluziju pridobiva sljedbnike drugih sljedaba. ${ }^{569}$

Buddhine se nadnaravne moći ističu i u Nidānakathi i Mahāvastuu. U Nidānakathi se pripovijeda kako je nedugo nakon rođenja ponovo potvrdio svoju izvanrednost. Naime, kada ga je došao obići isposnik Kāla Devala, Gotama je naprijed ispružio svoje noge i položio ih na glavu isposnika. U Nidānakathi se daje objašnjenje za taj čin: položi li se budući buddha ikome

\footnotetext{
${ }^{564}$ Vin. i. 16 (Mahāvagga, I. 7, 8).

${ }^{565} \mathrm{MN}$ ii. $97-100$.

${ }^{566}$ Opširnije o toj epizodi u Fiordalis (2008: 73 i d.), Talim (2002/2003).

${ }^{567}$ DN 16, ii. 89 (MPS 1. 33).

${ }^{568} \mathrm{DN}$ 16, ii. 129 (MPS 4. 25).

${ }^{569} \mathrm{MN}$ i. 375: samaṇo hi bhante Gotamo māyāvī, āvaț̣anim māyaṃ jānāti yāya añ̃äatitthiyānam sāvake āvațtetīti.
} 
pred noge, glava će se toga, zbog buddhine moći, raskoliti na dva dijela. ${ }^{570}$ U Nidānakathi se, kao i u Mahāvastuu, donosi opis Gotamina prvoga zadubljenja. Navodi se kako je sjena stabla, pod utjecajem Gotaminih velikih moći, ostala stajati na mjestu iako se Sunce pomicalo. Stigavši pred stablo bodhi pod kojim će doživjeti probuđenje, Gautama je zastao na trenutak, a snaga je njegovih stopala izazvala strašan potres od kojega se tijelo kostriješilo. ${ }^{571}$ Sedam dana nakon probuđenja, Gotama je izveo svoje prvo čudo kao Probuđeni. Nidānakatha navodi kako je izveo dvojno čudo. ${ }^{572}$ Prilikom posjete rodnomu gradu, Gotama je pridobio naklonost svoje rodbine podigavši se u zrak i izazvavši kišu koja je padala samo po onima koji su to htjeli. ${ }^{573} \mathrm{U}$ Mahāvastuu se pripovijeda kako je u Vaiśâlī umnogostručio svoj lik šest tisuća i šest puta kako bi njegov lik zauzeo mjesto ispod toliko suncobrana koje su nosili nebesnici njemu u čast. ${ }^{574}$ Ovdje su izneseni samo neki od primjera čuda koje je izveo Gotama u tekstovima korištenima za proučavanje njegova životopisa. Cilj toga gore iznesenoga pregleda nije ni iscrpnost ni sustavnost već ukazivanje na činjenicu da je, usprkos stavovima koji se susreću u primjerice Kevațtasutti ili zabranama u Vinayapițaki, Gotamina sposobnost izvođenja čuda za dio njegovih sljedbenika i tvoraca predaje bitan dio njegove usavršenosti i dokaz njegove superiornosti. Kako piše Fiordalis (2008: 108):

[...] the Buddha's motivations for teaching the Dharma and displaying his superhuman powers both speak to the significance of the Buddha's mission to lead other beings to freedom from suffering and rebirth. Moreover, the Buddha's miracles, as exemplified by the theme of conflict between rival teachers and the narrative form of the crescendo of miracles, serve to demonstrate the Buddha's supreme holiness.

Nadalje, Gotama je Buddha i dasabala (daśabala), odnosno posjeduje deset moći koje su pobrojane u Mahāsīhanādasutti. ${ }^{575}$

\footnotetext{
${ }^{570}$ ĐātA. I. 54.

${ }^{571}$ Mv. ii. 300.

572 ĐātA. I. 77.

${ }^{573}$ ĐātA. I. 88.

${ }^{574}$ Mv. i. 264-266.

${ }^{575} \mathrm{MN}$ i. $68-83$.
} 
MN i. 69 i d.

Dasa kho panimāni, sāriputta, tathāgatassa tathāgatabalāni yehi balehi samannāgato tathāgato āsabham thānam pațijānāti, parisāsu sīhanādam nadati, brahmacakkam pavatteti. Katamāni dasa?

Idha, sāriputta, tathāgato țānañca thānato aț̣̂̄̄nañca ațthānato yathābhūtam pajānāti. Yampi, sāriputta, tathāgato thānañca țhānato ațthānañca ațthānato yathābhūtam pajānāti, idampi, sāriputta, tathāgatassa tathāgatabalam hoti yạ̣ balạ̣ āgamma tathāgato āsabham țhānam pațijānāti, parisāsu sīhanādam nadati, brahmacakkam pavatteti.

Puna caparaṃ, sāriputta, tathāgato atītānāgatapaccuppannānam kammasamādānānam țhānaso hetuso vipākam yathābhūtam pajānāti. Yampi, sāriputta, tathāgato atītānāgatapaccuppannānam kammasamādānānam thānaso hetuso vipākam yathābhütam pajānāti, idampi, sāriputta, tathāgatassa tathāgatabalam hoti yam balam āgamma tathāgato āsabham țā̄nam pațijānāti, parisāsu sīhanādam nadati, brahmacakkaṃ pavatteti.

Puna caparaṃ, sāriputta, tathāgato sabbatthagāminị̣ pațipadam yathābhūtam pajānāti. Yampi, sāriputta, tathāgato sabbatthagāminim pațipadạn yathābhūtam pajānāti, idampi, sāriputta, tathāgatassa tathāgatabalam hoti yam balam āgamma tathāgato āsabham țhānam pațijānāti, parisāsu sīhanādam nadati, brahmacakkạ̣ pavatteti.

Puna caparam, sāriputta, tathāgato anekadhātunānādhātulokam yathābhūtam pajānāti. Yampi, sāriputta, tathāgato anekadhātunānādhātulokam yathābhūtam pajānāti, idampi, sāriputta, tathāgatassa tathāgatabalam hoti yam balạ̣ āgamma tathāgato āsabham thānam pațijānāti, parisāsu sīhanādam nadati, brahmacakkaṃ pavatteti.

Puna caparam, sāriputta, tathāgato sattānam nānādhimuttikatam yathābhūtam pajānāti. Yampi, sāriputta, tathāgato sattānam nānādhimuttikatam yathābhūtam pajānāti, idampi, sāriputta, tathāgatassa tathāgatabalam hoti yam balam āgamma tathāgato āsabham țhānaṃ pațijānāti, parisāsu sīhanādaṃ nadati, brahmacakkạ̣ pavatteti.

Puna caparaṃ, sāriputta, tathāgato parasattānam parapuggalānam indriyaparopariyattam yathābhūtam pajānāti. Yampi, sāriputta, tathāgato parasattānaṃ parapuggalānam indriyaparopariyattạ̣ yathābhūtam pajānāti, idampi, sāriputta, tathāgatassa 
tathāgatabalam hoti yaṃ balaṃ āgamma tathāgato āsabham ț̣ānam pațijānāti, parisāsu sīhanādam nadati, brahmacakkam pavatteti.

Puna caparaṃ, sāriputta, tathāgato jhānavimokkhasamādhisamāpattīnam sañkilesam vodānam vuț̣hānam yathābhūtam pajānāti. Yampi, sāriputta, tathāgato jhānavimokkhasamādhisamāpattīnam saìkilesam vodānam vuț̣̂ānam yathābhūtam pajānāti, idampi, sāriputta, tathāgatassa tathāgatabalam hoti yam balam āgamma tathāgato āsabham țhānam pațijānāti, parisāsu sīhanādaṃ nadati, brahmacakkaṃ pavatteti.

Puna caparam, sāriputta, tathāgato anekavihitam pubbenivāsam anussarati, seyyathidạ̣ -ekampi jātim dvepi jātiyo tissopi jātiyo [...]Yampi, sāriputta, tathāgato anekavihitam pubbenivāsam anussarati, seyyathidam - ekampi jātim dvepi jātiyo tissopi jātiyo [...] idampi, sāriputta, tathāgatassa tathāgatabalạ̣ hoti yam balam àgamma tathāgato āsabham thānam pațijānāti, parisāsu sīhanādam nadati, brahmacakkam pavatteti.

Puna caparaṃ, sāriputta, tathāgato dibbena cakkhunā visuddhena atikkantamānusakena satte passati cavamāne upapajjamāne hīne paṇite suvaṇne dubbaṇne sugate duggate yathākammūpage satte pajānāti [...] ${ }^{576}$ 'Yampi, sāriputta, tathāgato dibbena cakkhunā visuddhena atikkantamānusakena satte passati cavamāne upapajjamāne hīne paṇite suvaṇne dubbaṇne sugate duggate yathākammūpage satte pajānāti [...] Idampi, sāriputta, tathāgatassa tathāgatabalam hoti yam balam āgamma tathāgato āsabham thānam pațijānāti, parisāsu sīhanādam nadati, brahmacakkam pavatteti.

Puna caparam, sāriputta, tathāgato āsavānam khayā anāsavam cetovimuttim pañ̃̃āvimuttim dițtheva dhamme sayam abhiñ̃̃a sacchikatvā upasampajja viharati. Yampi, sāriputta, tathāgato āsavānam khayā anāsavam cetovimuttim paññ̄àvimuttim dițtheva dhamme sayam abhiñ̃̄a sacchikatvā upasampajja viharati, idampi, sāriputta, tathāgatassa tathāgatabalam hoti yam balam āgamma tathāgato āsabham thānam pațijānāti, parisāsu sīhanādam nadati, brahmacakkaṃ pavatteti.

\footnotetext{
${ }^{576}$ Kao u MN i. 22-23.
} 
Imāni kho, sāriputta, dasa tathāgatassa tathāgatabalāni yehi balehi samannāgato tathāgato āsabham țhānam pațijānāti, parisāsu sīhanādam nadati, brahmacakkam pavatteti.

Prijevod

Tathāgata zaista, o Sāriputta, posjeduje ovih deset tathāgatinih moći. Obdaren tim moćima, Tathāgata polaže pravo na vodstvo, među [različitim] skupinama ${ }^{577}$ oglašava se lavljom rikom, pokreće Brahmanov kotač. ${ }^{578}$ Kojih deset?

Evo, o Sāriputta, Tathāgata spoznaje, kako jest, moguće iz mogućega i nemoguće iz nemogućega. To što, o Sāriputta, Tathāgata razlikuje, kako jest, moguće iz mogućega $i$ nemoguće iz nemogućega jest Tathāgatina moć tathāgate. Zahvaljujući toj moći, Tathāgata polaže pravo na vodstvo, među [različitim] skupinama oglašava se lavljom rikom, pokreće Brahmanov kotač.

I nadalje, o Sāriputta, Tathāgata spoznaje, kakvo jest, dozrijevanje plodova djelovanja poduzetih u prošlosti, budućnosti i sadašnjosti, njihove mogućnosti i uzročnost. To što, o Sāriputta, Tathāgata spoznaje, kakvo jest, dozrijevanje plodova djelovanja poduzetih u prošlosti, budućnosti i sadašnjosti, njihove mogućnosti i uzročnost, jest Tathāgatina moć tathāgate. Zahvaljujući toj moći, Tathāgata polaže pravo na vodstvo, među [različitim] skupinama oglašava se lavljom rikom, pokreće Brahmanov kotač.

I nadalje, o Sāriputta, Tathāgata spoznaje odredište, kakvo jest, svih puteva. To što, o Sāriputta, Tathāgata spoznaje odredište, kakvo jest, svih puteva jest Tathāgatina moć tathāgate. Zahvaljujući toj moći, Tathāgata polaže pravo na vodstvo, među [različitim] skupinama oglašava se lavljom rikom, pokreće Brahmanov kotač.

I nadalje, o Sāriputta, Tathāgata spoznaje, kakav jest, svijet mnogobrojnih i raznolikih sastavnica. To što, o Sāriputta, Tathāgata spoznaje, kakav jest, svijet mnogobrojnih $i$ raznolikih sastavnica jest Tathāgatina moć tathāgate. Zahvaljujući toj moći, Tathāgata

\footnotetext{
577 Parisāsu, lok. množ. od parisā. Prema pojedinim kanonskim tekstovima postoji osam skupina ili vrsta skupova. To su khattiya-, brāhamaṇa-, gahapati-, samaṇa-, Ćāttumahārāđika-, Tāvatimssa-, Māra- i Brahmaparisā (npr. DN ii. 109, MN i. 72, AN iv. 307). Na drugim se mjestima spominju četiri skupine Buddhinih sljedbenika: bhikkhu, bhikkhūni-, upasaka- i upasikāparisā (SN ii. 218, AN v. 10). V. PED, str. 437.

${ }^{578}$ Brahmaćakka, izvrstan kotač, Buddhin nauk.
} 
polaže pravo na vodstvo, među [različitim] skupinama oglašava se lavljom rikom, pokreće Brahmanov kotač.

I nadalje, o Sāriputta, Tathāgata spoznaje, kakve jesu, različite sklonosti bića. To što, o Sāriputta, Tathāgata spoznaje, kakve jesu, različite sklonosti bića jest Tathāgatina moć tathāgate. Zahvaljujući toj moći, Tathāgata polaže pravo na vodstvo, među [različitim] skupinama oglašava se lavljom rikom, pokreće Brahmanov kotač.

I nadalje, o Sāriputta, Tathāgata spoznaje, kakva jest, usmjerenost na ovaj i onaj svijet spoznajnih moći drugih bića i drugih osoba. To što, o Sāriputta, Tathāgata spoznaje, kakva jest, usmjerenost na ovaj i onaj svijet spoznajnih moći drugih bića i drugih osoba jest Tathāgatina moć tathāgate. Zahvaljujući toj moći, Tathāgata polaže pravo na vodstvo, među [različitim] skupinama oglašava se lavljom rikom, pokreće Brahmanov kotač.

I nadalje, o Sāriputta, Tathāgata spoznaje, kakvi jesu, ukliještenje, pročišćenje $i$ pojavljivanje zadubljenja, oslobođenja, poniranja i postignuća. To što, o Sāriputta, Tathāgata spoznaje kakvi jesu, ukliještenje, pročišćenje i pojavljivanje zadubljenja, oslobođenja, poniranja i postignuća jest Tathāgatina moć tathāgate. Zahvaljujući toj moći, Tathāgata polaže pravo na vodstvo, među [različitim] skupinama oglašava se lavljom rikom, pokreće Brahmanov kotač.

I nadalje, o Sāriputta, Tathāgata se sjeća mnogih $i$ različitih prijašnjih egzistencija odnosno, ovo je jedno rođenje, dva rođenja, tri rođenja [...] To što se, o Sāriputta, Tathāgata sjeća mnogih i različitih prijašnjih egzistencija odnosno, ovo je jedno rođenje, dva rođenja, tri rođenja [...] jest Tathāgatina moć tathāgate. Zahvaljujući toj moći, Tathāgata polaže pravo na vodstvo, među [različitim] skupinama oglašava se lavljom rikom, pokreće Brahmanov kotač.

I nadalje, o Sāriputta, Tathāgata vidi prečistim božanskim okom koje nadilazi ljudsko umiruća i iznova nastajuća bića, bijedna i uzvišena, lijepa i ružna, sretnih i nesretnih sudbina i spoznaje kako bića bivaju podvrgnuta posljedicama svojih djela. To što, o Sāriputta, Tathāgata vidi prečistim božanskim okom koje nadilazi ljudsko umiruća $i$ iznova nastajuća bića, bijedna $i$ uzvišena, lijepa $i$ ružna, sretnih $i$ nesretnih sudbina $i$ spoznaje kako bića bivaju podvrgnuta posljedicama svojih djela [...] jest Tathāgatina moć 
tathāgate. Zahvaljujući toj moći, Tathāgata polaže pravo na vodstvo, među [različitim] skupinama oglašava se lavljom rikom, pokreće Brahmanov kotač.

I nadalje, o Sāriputta, Tathāgata, boravi [u miru] osvjedočivši se sam prepoznajom $i$ zadobivši, pošto je vidio dhammu, uslijed propasti priljeva oslobođenje proznaje, oslobođenje svijesti. To što, o Sāriputta, Tathāgata, boravi [u miru] osvjedočivši se sam prepoznajom $i$ zadobivši, pošto je vidio dhammu, uslijed propasti priljeva (žeđi) oslobođenje proznaje, oslobođenje svijesti jest Tathāgatina moć tathāgate. Zahvaljujući toj moći, Tathāgata polaže pravo na vodstvo, među [različitim] skupinama oglašava se lavljom rikom, pokreće Brahmanov kotač.

Usitinu, o Sāriputta, to je deset Tathāgatinih moći tathāgate. Obdaren tim moćima, Tathāgata polaže pravo na vodstvo, među [različitim] skupinama oglašava se lavljom rikom, pokreće Brahmanov kotač.

U istoj se sutti navodi kako Buddha posjeduje i četiri iskusnosti (ćattāri vesārađđāni), a to su iskusnost $\mathrm{u}$ dosezanju savršenoga probuđenja, u uništenju svih āsava, u potpunome razumijevanju prepreka (antarāyikā dhammā) i u učinkovitosti propovijedanja dhamme u svrhu okončanja patnje. ${ }^{579}$ Četiri se iskusnosti ili razloga za neustrašivost (vaiśāradya) nalaze pobrojane i u Mahāvastuu. ${ }^{580}$ U Nidānakathi se ne spominju četiri iskusnosti, ali se Gotami nalaze pripisane $u$ Lomahaṃsađātaki. ${ }^{581}$

Mahāsakuludāyisutta donosi pet skolastički pobrojanih razloga zbog kojih učenici štuju Buddhu: (1) Buddha posjeduje izvrsnost u ćudoređu (adhisīla), (2) obdaren je znanjem i uvidom (ñạnadassana), (3) posjeduje izvrsnost u mudrosti (adhipañña), (4) poučava četiri plemenite istine (ariyasaććāni) i (5) posjeduje tridesetisedam vrlina ili osobina koje vode do probuđenja (bodhipakkhīyadhammāa), raskinuo je veze sa svijetom (vimokkhā), savladao je osam stupnjeva u postupku ovladavanja osjetilima (abhibhāyatanā), deset stupnjeva koji vode do zadubljenja (kasināyatanā), dosegao je četiri zadubljenja (đhānāni) i šest viših znanja (ćhalabhiñ̃āa). ${ }^{582}$

\footnotetext{
${ }^{579} \mathrm{MN}$ i. $71-72$.

${ }^{580}$ Mv. i. 38. 15, 335. 14, iii. 64. 5

${ }^{581}$ ĐātA. I. 390 (đātaka br. 4).

${ }^{582} \mathrm{MN}$ ii. 9-22.
} 
Buddha također posjeduje i deset savršenstava (pāramī, pāramitā). ${ }^{583}$ Kao dasadhammā, taj se pojam pojavljuje tek u Buddhavamsii. ${ }^{584}$

Deset savršenstava Buddhinih, kako se navode u Buddhavamsi, čine usavršenost u:

1. velikodušnosti, darivanju (dāna), Bhv. II. 117

2. krjeposti, ispravnom djelovanju (sīla), Bhv. II. 122

3. odricanju od svjetovnoga života (nekkhamma), Bhv. II. 127

4. mudrosti, uvidu (pañ̃̃a), Bhv. II. 132

5. naporu, trudu (viriya), Bhv. II. 137

6. strpljenju (khanti), Bhv. II. 142

7. iskrenosti, istinoljubivosti (saćća), Bhv. II. 147

8. odlučnosti (adhiț̣hāna), Bhv. II. 152

9. ljubaznosti, dobronamjernosti (mettā), Bhv. II. 157

10. smirenosti, ravnodušnosti (upekhā), Bhv. II. 162

U Ćariyapiṭaki se navodi sedam savršenstava: dāna, sīla, nekkhama, saćća, adhiț̣hāna, mettā i upekkhāa, dok se u kasnijim komentarima (npr. Vsm. 203, ĐātA. I. 25, 73) spominju tri skupine (pāramī, upapāramī, paramatthapāramī) od kojih svaka obuhvaća deset savršenstava. Te se tri skupine spominju međutim i u Buddhavaṃsi. I. 76-77. U Mahāvastuu je pobrojano šest savršenstava: dāna-, śīla-, kṣānti-, vīrya-, dhyāna- i prađ̃̃āāāramitāa. ${ }^{585}$

Buddhino se neizmjerno suosjećanje spram svih osjećajućih bića nerijetko naglašava $u$ buddhističkoj književnosti, a kao primjer navodim ulomak iz Anguttaranikāye:

AN i. 22

Ekapuggalo bhikkhave loke uppajjamāno uppajjati bahujanahitāya bahujanasukhāya lokānukampāya atthāya hitāya sukhāya devamanussānaṃ. Katamo ekapuggalo: tathāgato

araham sammāsambuddho. Ayam kho bhikkhave ekapuggalo loke uppajjamāno uppajjati

\footnotetext{
${ }^{583}$ Za tumačenja v. Dayal (1932/1970: 165-166). U sjevernoindijskim sanskrtskim tekstovima lista obuhvaća šest savršenstava. Dayal (1932/1970: 168-169) smatra sljedeće: The origin of pāramitās must be sought in the early Buddhist triad, śīla (virtuous conduct), samādhi (concentration) and prajñā (wisdom), which are known as three skandhas (groups constituting the factors of spiritual progress) and also as the three śikșās (branches of instruction, the threefold training and discipline).

${ }^{584}$ Bhv. II. 116-188, ĐātA. I. 20-25, Apd. 69-72.

${ }^{585}$ Mv. iii. 226. 3-4.
} 
bahujanahitāya bahujanasukhāya lokānukampāya atthāya hitāya sukhāya devamanussānanti. ${ }^{586}$

Prijevod

Jedna se osoba na svijetu, o redovnici, pojavljujući rađa za dobrobit mnogih, za sreću mnogih, iz suosjećanja spram svijeta, za korist, dobrobit i sreću nebesnika i ljudi. Koja [je to] jedna osoba? [To je] Tathāgata, Arahant, Savršeno probuđeni. To je zaista, o redovnici, ta jedna osoba na svijetu koja se pojavljujući rađa za dobrobit mnogih, za sreću mnogih, iz suosjećanja spram svijeta, za korist, dobrobit i sreću nebesnika i ljudi.

U Mahāvastuu postoji zasebno poglavlje posvećeno Buddhinim osobinama. ${ }^{587}$ Navodi se kako Savršeno probuđeni (samyaksaṃbuddha) posjeduje pet očiju ili pet vrsta vida (māmssaćakṣu, divyaćakșu, prađñāćakșu, dharmaćakșu, buddhaćakșu) koja ga razlikuju od ostalih bića, sljedbenika, arhanta i pratyekabuddha. Pet se Buddhinih vidova nalazi opisano i u pālijskome kanonu. ${ }^{588}$ Tjelesno oko (māmsaćakṣu) opisano je u Mahāvastuu na sljedeći način:

Mv. i. 158

tatra bho dhutadharmadhara mānsacakșus tathāgatānām // yāye prabhāye samanvāgatam yāye śūkșmadarśanāye samanvāgatam yāye tattvadarśanāye samanvāgatam tan mānsacakṣu anyasya satvasya satvakāye nāsti // prāpte ca sarvadarśitve bodhisatvā yāvattakam avakāśam avalokayitum icchanti tam darśanam tatra apratihatam pravartate // kiṃ kāraṇaṃ // vipulakuśalasaṃcitatvāt//

Prijevod

A tjelesno oko tathāgata koje odražuje vrline čistoga čovjeka obdareno je takvim sjajem, obdareno je takvom[moći]zapažanja tanahnoga, obdareno je takvom [moći] zapažanja sućinskoga da se ne nalazi na tijelu niti jednoga drugoga bića. Kada bodhisattve dosegnu [sposobnost] sveviđenja, pogled im, neometan, seže do bilo koliko daleka mjesta koje žele promotriti. Koji je razlog tomu? Sakupljno obilje vrlina.

\footnotetext{
${ }^{586}$ V npr. i DN ii. 222, MN i. 21, MN i. 169, Mv. ii. 2, 136, 138, 220, 221, 258, 289, 340-341, 362. Mv. iii. 91 , 92, 98, 121, 321, 355, Bhv. II. 56, ĐātA. I. 48.

${ }^{587} \mathrm{Mv}$ i. 158 i d.

${ }^{588}$ Za mjesta u kanonu v. PED, str. 259.
} 
Nebesko oko ili nebeski vid (divyaćakṣuh) jednak je vidu nebesnika koji prebivaju na zemlji, vidu yakșa, rākṣasa i nebesnika koji pripadaju skupinama Kāmāvacara i Rūpāvacara, s naglaskom da je Buddhin vid nadmoćan.

Oko ili vid mudrosti (prađ̃̃āáakșu) jednak je kao i u arhanta ali je jasniji.

Oko ili vid dharme (dharmaćakṣu) sastoji se od deset moći (daśabalāni). Kao što će se pokazati u prijevodu, nabrojane moći u Mahāvastuu nisu u cijelosti podudarne s moćima kako su nabrojane u pālijskim izvorima.

Mv. i. $159-160$

sthānāsthānam vetti prathamaṃ balam aprameyabuddhīnām /

sarvatragāminīn ca pratipadạ̣ vetti balam dvitīyam // nānādhātukam lokam vidanti ${ }^{589}$ khyātam balam tṛtīyam /

adhimuktinānātvam vetti caturtham balam bhavati //

parapuruṣacaritakuśalāni vetti tat paṃcamaṃ balam ca /

(1.160) karmabalam pratijānanti śubhāśubham tad balạ̣ șaștham //

kleśavyavadānam vetti saptamam balam dhyānasamāpattim vetti /

aștamam balam pūrvanivāsam vetti bahuprakāram //

balam navamam bhavati pariśuddhadivyanayanā bhavanti /

sarvakleśavināśam prāpnonti daśamam balạ̣ bhavati //

etāni manovibhubalāni yaih sarvadarśī divi bhuvi ca jātakīrtị̣ daśabala ity evam ākhyāto //

Prijevod

Zna što su mogućnost i nemogućnost [To je] prva moć beskrajno umnih.

Zna odredište svih puteva. [To je] druga moć.

Poznaje da svijet ima različite sastavnice. [To se] naziva trećom moći.

Poznaje raznolikost sklonosti [bića]. [To je] četvrta moć.

Poznaje zasluge načina života drugih ljudi. To je peta moć.

Poznaje povoljan i nepovoljan utjecaj djelovanja činā. To je šesta moć.

Zna [što je] odstranjenje ukliještenja i zna što je postignuće zadubljenja. [To je] sedma moć.

Zna mnoge vrste prijašnjih egzistencija. [To je] osma moć.

$589 \sqrt{ }$ vid, 3. 1. množ. za 3. 1. jedn. BHSG §25. 30. 
[Buddhe] posjeduju čisto božansko oko. [To je] deveta moć.

Doseže nestanak svih ukliještenja. [To je] deseta moć.

To su prodorne umne moći na temelju kojih Svevidećega slave na nebesima i na zemlji $i$ [na temelju kojih] se naziva Desetomoćni.

Oko se ili vid buddhe (buddhaćakșu) sastoji od osamnaest posebnih obilježja (āveṇikadharma).

Mv. i. 160

tatra katamam buddhacakṣuḥ // aștādaśāvenikā buddhadharmāḥ // tadyathā atīte aṃse tathāgatasya apratihatam jūānadarśanam / anāgate aṃśe apratihatam jñānadarśanam / pratyutpanne aṃśe apratihatam jñānadarśanam / sarvam kāyakarma jñānapūrvaṃgamam jñānānuparivarti / sarvam vācākarma jñānapūrvaṃgamam jñānānuparivarti / sarvam manokarma jñānapūrvaṃgamạ̣ jñānānuparivarti / nāsti chandasya hānih̆ / nāsti vīryasya hāniḥ / nāsti smṛtiye hānih / nāsti samādhīye hāniḥ / nāsti prajñāye hānih̆ / nasti vimuktiye hāniḥ / nāsti khalitạ̣ / nāsti ravitam / nāsti mușitasmṛtitā / nāsti asamāhitam cittam / nāsti apratisaṃkhyāya upekṣā / nāsti nānātvasamjjñā // yạ̣ imeșu aṣțādaśasvāveṇikeșu buddhadharmeșu jũānam idam ucyate buddhacakșur iti //

Prijevod

Što je, potom, oko (ili vid) buddhe? Osamnaest posebnih buddhinih svojstava, a ta su: tathāgata ima neometano znanje i uvid u prošlost, neometano znanje i uvid u budućnost, neometano znanje i uvid u sadašnjost, svakomu činu tijela prethodi znanje i slijedi znanje, svakomu činu govora prethodi znanje i slijedi znanje, svakomu činu misli prethodi znanje i slijedi znanje, nema slabljenja volje, nema slabljenja snage, nema slabljenja sjećanja, nema slabljenja poniranja, nema slabljenja spoznaje, nema slabljenja oslobođenosti, nema posrtanja, nema naglosti, ${ }^{590}$ nema iskradanja pamćenja, svijest nije neusredotočena, nema nepromišljene ravnodušnosti, nema zamjećivanja mnogostrukosti. To znanje koje prožima tih osamnaest posebnih buddhinih svojstava naziva se okom (ili vidom) buddhe.

Na nekoliko se mjesta u Mahāvastuu sažimaju osobine i postignuća koji buddhu razlikuju od svih bića, a ta su: trideset i dva tjelesna obilježja, osamdeset manjih obilježja, osamnaest

\footnotetext{
${ }^{590}$ Ravita, Jones (1949/2007a, sv. 1: 127, bilj. 3), impetuosity. V. i BHSD, str. 453.
} 
posebnih obilježja, deset moći, četiri iskusnosti, pokretanje kotača nauka i bivanje na čelu skladne zajednice redovnika. ${ }^{51} \mathrm{U}$ Mahāvastuu se također na nekoliko mjesta navodi kako nije moguće spoznati sve vrline, svojstva i postignuća buddhe. ${ }^{592}$

\subsubsection{Tjelesno savršenstvo Gotame Buddhe}

Iz pālijskoga se kanona može iščitati da je tijelo Gotame Buddhe, kao i tijelo svakoga drugoga bića, bilo podložno bolovima, bolestima, starenju i propadanju. Tako se, primjerice, u Saṁyuttanikāyi nalazi ulomak u kojem Ānanda očituje svoje čuđenje i zabrinutost promjenama na Gotaminu tijelu kao što su naboranost kože, pogrbljenost, slabljenje snage osjetila i tjelesna iscrpljenost. $^{593}$ Pālijska Mahāparinibbanasutta, kao i sanskrtske recenzije, donose opis Gotamine bolesti i iscrpljenosti. Također, na nekoliko mjesta u kanonu nailazimo na potvrdu da se Buddha svojim vanjskim izgledom nije mnogo razlikovao od svojih suvremenika. Tako čitamo da je laik Pukasātti satima razgovarao s Buddhom prije negoli je shvatio da nasuprot njega sjedi veliki učitelj. ${ }^{594}$ U Mađđhimanikāyi se pripovijeda kako je jednom prilikom čuvar nekog parka zabranio Gotami ulazak u isposnički gaj tvrdeći da će omesti tamo prisutne isposnike. Gotami je dopušten ulazak u park nakon što su isposnici prišli čuvaru i objasnili mu da je Gotama njihov učitelj. ${ }^{595}$ Kralj Ađātasattu također nije prepoznao Buddhu okruženoga sljedbenicima. ${ }^{596}$

Brahmāyusutta ${ }^{597}$ donosi najdetaljniji opis profinjenosti Gotaminih kretnji i manira, međutim u cijelome tome izlaganju nema spomena ičega što bi se moglo smatrati nad-ljudskim ili božanskim. Tako se navodi kako učitelj Gotama čini prvi korak uvijek desnom nogom, ne čini ni prevelike ni premale korake, ne hoda ni prebrzo ni presporo, dok hoda pomiče mu se samo donji dio tijela, pogled mu nikada ne vrluda, okreće se cijelim tijelom, dok sjedi ne naslanja se rukom na sjedalo, ne poigrava se rukama, ne križa noge i zglobove, ne proljeva vodu dok pere posudu, dok prima obrok ne drži posudu ni previsoko ni prenisko, prije negoli proguta

\footnotetext{
${ }^{591}$ Mv. i. 38, 336, iii. 64.

592 V. npr. Mv. ii. 368. U Apd. I. 77 također se tvrdi da je nemoguće pojmiti buddhe i njihove vrline i osobine kao ni zasluge onih koji imaju vjere u buddhe: Evam acintiyā Buddhā Buddhadhammā acintiyā lacintiyesu pasannānam vipāko hoti acintiyo ti. //

${ }^{593} \mathrm{SN}$ v. 217.

${ }^{594}$ MN iii. 239.

${ }^{595} \mathrm{MN}$ iii. 155

${ }^{596} \mathrm{DN}$ i. 50.

${ }^{597} \mathrm{MN}$ ii. 137 i d.
} 
zalogaj žvače ga dva ili tri puta, nakon obroka sjedi nekolio trenutaka u tišini, ogrtač na njegovu tijelu nije ni prezategnut ni preopušten i tako dalje.

Ipak, kanon sadrži i one dijelove teksta u kojima se naglašava izuzetnost Gotamine tjelesne pojave.

Tekstovi se slažu da je Gotamino tijelo odmah po rođenju bilo izuzetne ljepote. Iz majčine je utrobe izašao neuprljan tjelesnim izlučevinama, "nalik na dragi kamen položen na čistu tkaninu", dok se u Suttanipāti tvrdi se da je po rođenju bio besprijekorne boje, sjajan poput zlata. ${ }^{598}$ Mladoga Gotamu brahman Sonadaṇḍa u Sonadaṇḍasutti Dīghanikāye opisuje na sljedeći način:

Uistinu, isposnik je Gotama vrlo lijep, dobra izgleda, ljubazan, obdaren je krasnom puti poput lotosa, sjaja i puti poput Brahmana, na očigled nije neplemenit [...]. ${ }^{599}$

U Nidānakathi i Mahāvastuu se također veliča ljepota Gotamina tijela. U potonjem se djelu nalazi sljedeći stih:

To nenadmašno Svjetlo svijeta obasjava [svojom] ljepotom [cijeli] svijet sa Brahmanom i sva rođena bića s isposnicima i brahmanima. ${ }^{600}$

Mahāvastu dalje navodi da se veličanje i štovanje Gautamine ljepote odvija i u svijetu nebesnika. ${ }^{601}$ Jedan od brojnih primjera štovanja Gautamina izgleda jest i sljedeći ulomak:

Mv. ii. 296-297

surāsuravarapüjanīyo gurukṛtavandito satkṛto maharșe prabhaṃkara dvipadendra sattvasāravara puruṣarșabha cetiyam narāṇām bhrūvivaralalāte ūrṇābhāgo yathā gagane suviśuddharaśmi rājate bhagavato yathā kārtike māse vimalo virocate candro pūrṇamāsyām // nīlavimalanetrā nāyakasya surucirotpalavarṇasamnikāśā vimalā śubhā prabhā // saṃrocate ca sukhajananā naranārīṇ̄m narendradantā vimalapāṇdarā sujātasamasahitā himavarasannikāśā

\footnotetext{
${ }^{598} \mathrm{~V}$. poglavlje o rođenju.

${ }^{599}$ DN i. 115: Samaṇo khalu, bho, gotamo abhirūpo dassan̄̄yo pāsādiko paramāya vaṇnapokkharatāya samannāgato, brahmavaṇn̄i, brahmavaccasī, akhuddāvakāso dassanāya ... pe .... Isti se opis nalazi i u MN ii. 166-167.

${ }^{600}$ Mv ii. 10. 3-4: sabrahmakam ca lokam saśramaṇabrāhmaṇīn prajām sarvām / varṇen', obhāsayati anativaro lokapradyoto // Usp. i . ĐātA. I. 60, 66.

${ }^{601}$ Mv. ii. 17.
} 
(2.297) mukham dalavarasamprakāśam daśabala tathā viśadam / te śāstunah ${ }^{602}$ taruṇasukhumaraśmībhir āstrtā vararasavatī śobhati jihvā nāyakasya prabālakasamatulyavarṇā ca divyā bahujanasaṃjñāpan̄ / sukhaṃdadam ca ābhājālena baddham lalātam sabhrūmukham ca śobhe yathaiva candramaso / sukhasamāhitanīlà daśabala bhagavato śîrșe keśā / śākyasiṃha grīvā te śobhe yathā suvarnakambu yathā ovāha ${ }^{603}$ ca jina samā / abhedyo siṃhārdhapūrvo bhagavato ātmabhāvo / prabhāsi loke diśatā samantā / viśiștavākya atulasamudra karmavipākam karohi imām girāṃ bhāṣamānạ̣ sarvas te loko abhinamate āvarjito karito prșțvā daśanakha-aṃjalīhi //

\section{Prijevod}

O veliki Vidioče, Sjajotvorče, Najodličniji među dvonošcima, Vrsna srži bića, Biče među ljudima, Ćetiyo ljudi, tebe Sure $i$ Asure trebaju štovati, slavljen si i učinjen učiteljem. Vuneni uvojak između obrva na čelu Blaženoga blista poput prečiste zrake, sja poput jasna Mjeseca, u mjesecu Kārtika, na dan puna Mjeseca. Plave i jasne oči toga Vođe nalikuju bojom na vrlo sjajne plave lotose, jasne su, lijepe i sjajne. O Desetomoćni, zubi Vođe, koji izazivaju radost muškaraca i žena: bez mrlja i bijeli, izvrsni, jednako poredani, nalik na čist snijeg, obasjavaju

(2.297) krasna usta bliješteći poput izvrsnih latica. Sja jezik Učitelja, Vođe, prekriven mekim, nježnim crtama, izvrsna osjeta okusa, bojom je nalik na koralj, božanski je $i$ poučava mnoge. Čelo obilježeno mrežom svjetla izaziva radost, zajedno s licem i obrvama sjaji poput Mjeseca. O Desetomoćni, kosa na glavi Blaženoga plavi se od crnine i skladno je skupljena. O Lave iz porodice Śākya, tvoj vrat sja poput zlatne školjke i nalik je, o Pobjedniče, na (...?). Tijelo ${ }^{604}$ Blaženoga s lavovskim prsima neslomljivo je. Obasjavaš sve smjerove na svijetu. O Vrsni u govoru, kojemu more [rječitosti] nije ravno, učini dozrijevanje plodova djela! Izgovarajući ovu hvalu, cijeli ti se svijet prignut klanja, proseći s objema rukama ${ }^{605}$ sklopljenima.

\footnotetext{
${ }^{602}$ Gen. jedn. śāstr. BHSG 13.27.

${ }^{603} \mathrm{Na}$ ovome mjestu stoji ovāhā međutim značenje je nepoznato. U svome prijevodu Jones se (1952/2006: 278, bilj. 2) poziva na mišljenje W. Stedea: Dr. W. Stede [...] made the ingenious suggestion that ovāha (ovāhāya) should be read ovahā (ovahāya) and interpreted as ,, a contaminated samprasāraṇa of vyavadhāya (vava = vo, combined vova- and then ova) from root dhā, 'to divide'. With the insertion of kāyam, dropped through the influence of-hāya (or better, perhaps, with the substitution of it for samā), we get the rendering, '(the neck) as though dividing the Conqueror's body" '.

${ }^{604} \bar{A}$ tmabhāva, BHSD str. 92.

${ }^{605}$ Dosl. s deset nokata tj. objema rukama.
} 
Glasu Učitelja također je na nekoliko mjesta posvećena pažnja. U Mađđhimanikāyi opisan je kao razgovjetan (vissațtha), razumljiv (viñ̃̃eya), milozvučan (mañđu), ugodan za slušanje (savanīya), kao kaplja (bindu), postojan (avisārin), dubok (gambhīra) i zvonak (ninnādin). ${ }^{606}$

U Mahāvastuu se također opisuje Buddhin glas. Niže je iznesen opis njegova glasa u trenutku poktretanja Kotača nauke.

Mv. iii. 342- $343^{607}$

yena svareṇa samanvāgatas tathāgato rham ${ }^{608}$ samyaksaṃbuddho vārāṇasyām rșivadane mrgadāve triparivartam dvādaśākāram anuttaram dharmacakram pravartayati so svaro șașțibhir ākāraih samanvāgataḥ / katamaiḥ șaștibhiḥ / gambhīraś ca tathāgatasvaro bhīmarūpaś ca ājñeyaś ca hṛdayaṃamaś ca

(3.343) preman̄īyaś ca asecanakaś ca aprativāṇīyaś ca viș̣̦țaś ca apratikūlaś ca avarnaś ca acchidraś ca aprāghhāraś ca akalmāṣaś ca rathanemighoṣaś ca meghastanitameghagarjitasvaraś ca vātavrșțistanitasamagarjitasvaraś ca devasvaraś ca brahmasvaraś ca anukūlasvaraś ca aduștasvaraś ca amụ̣̄asvaraś ca anutsannaś ca anutsadaś ca akșubhitaś ca arthasvaraś ca satyasvaraś ca śrimatsvaraś ca pumgavasvaraś ca siṃhasvaraś ca nāgasvaraś ca ājāneyasvaraś ca krauñcasvaraś ca kalaviṃasvaraś ca kokilasvaraś ca varṇnasvaraś ca mạ̣jusvaraś ca vijñānasvaraś ca akșarasampannaś ca vijñānasampannaś ca mṛdusampannaś ca vistārasampannaś ca kuśalajātasampannaś ca satyavistarasampannaś ca kuśalamūlajātasampannaś ca susvarasampannaś ca harṣaṇiyasampannaś ca tantrīsvaraś ca gītasvaraś ca vāditasvaraś ca kumbhasvaraś ca puruṣasvaraś ca atisvaraś ca dundubhisvaraś ca anuttarasvaraś ca tathāgatasvarah // sarvadiśạ̣̄ punas tathāgatasvarah sphurati na kahimcit pratihanyate / yena svareṇa samanvāgatah tathāgato arhan samyaksambuddho vārānasyạ̄n ṛșivadane mrgadāve triparivartam dvādaśākāram dharmacakram pravarteti so svaro ebhiḥ șaṣtibhiḥ ākāraih samanvāgatah //

Prijevod

Glas kojim je bio obdaren Tathāgata, Arhant, Savršeno probuđeni, kada je u Vārānasī̄, u Rṣivadani, u Gaju jelena, pokrenuo nenadmašni, tri puta okrenut $i$ od dvanaest žbica

\footnotetext{
${ }^{606} \mathrm{MN}$ ii. 140. U DN ii. 211 Brahman Sanaṁkumāra ima glas istih obilježja.

${ }^{607}$ Karakteristike Buddhina glasa pobrojane su i u Mv. i. 170-173.

${ }^{608}$ Gubljenje početnoga samoglasnika nakon samoglasnika koji mu prethodi uobičajena je pojava, posebice $u$ stihovima kada se samoglasnik izostavlja m.c. BHSG § 4.1, 4.9.
} 
načinjen kotač nauka, imao je šezdeset značajaka. Kojih šezdeset? Glas Tathāgate bio je dubok, silan, razumljiv, dirao je srce,

(3.343) izazivao naklonost, divan, privlačan, ${ }^{609}$ razgovjetan, prijatan, ${ }^{610}$ bez mana, ${ }^{611}$ neisprekidan, ujednačen, ${ }^{612}$ besprijekoran, poput zvuka kotača kola, poput tutnjave oblaka, poput grmljavine oblaka, poput tutnjave vjetra i kiše, nalik grmljavini, nebesnički glasan, poput glasa Brahmana, ugodna zvuka, neiskvarena zvuka, nezamršena zvuka, nepretjeran i umjeren, neuznemiren, koji oglašava smisao, koji oglašava istinu, sjajna zvuka, poput rike bika, lava ili slona, [rzaja] plemenita konja, poput [pjeva] dugovrate ptice, ${ }^{613}$ ili kukavice, ${ }^{614}$ ili crne kukavice kokile, ${ }^{615}$ zvonak, sladak, koji oglašava spoznaju, obdaren jasnim slogovima, obdaren spoznajom, mekoćom, prostiranjem, obdaren prirodnom dobrotom, širenjem istine, obdaren prirodnim korijenom dobrote, blagozvučan, ushitan, poput zvuka lutnje, poput zvuka pjesme, poput zvuka glazbala, poput zvuka [velikoga glinenoga] krčaga, muževna zvuka, izvanredna zvuka, poput zvuka bubnja, nenadmašan, kao glas tathāgate. Glas Tathāgate prožima sve smjerove i nigdje ne nailazi na prepreku. Glas kojim je Tathāgata, Arhant, Savršeno probuđeni bio obdaren, kada je u Vārāṇasī, u R̦̣̦ivadanu, u Parku jelena, pokrenuo nenadmašni, tri puta okrenut i od dvanaest žbica načinjen kotač nauka, imao je tih šezdeset značajki.

Zlatna boja kože Gotamina tijela jedno je od trideset i dva obilježja savršenstva Velika čovjeka. U Mahāparinibbānasutti se tvrdi da Gotamino tijelo postaje zlatne boje u dvije prilike: u noći probuđenja i u noći ulaska u konačnu nibbānu, ${ }^{616}$ međutim u tektovima se zlatna boja kože spominje i izvan konteksta probuđenja i konačne nibbāne. Tako, primjerice, brahman Sela, prilikom svoga posjeta Gotami, izjavljuje:

\footnotetext{
${ }^{609}$ Aprativāṇīya, dosl. koji nije odbojan, neprijatan ili mrzak. V. BHSD, str. 48.

${ }^{610}$ Apratikūla, koji se ne odupire, koji nije tvrdoglav, koji nije neprijatan

${ }^{611}$ Avarṇa, dosl. bez boje ili vanjskih obilježja

${ }^{612}$ Aprāgbhāra, v. BHSD, str. 49.

613 Šljuka (droplja, ždral), ptica iz roda Numenius.

${ }^{614}$ Ornit. Cuculus micropterus.

${ }^{615}$ Ornit. Cuculus clamosus, pjev se ove ptičje vrste često spominje u indijskoj poeziji. Vjeruje se da izaziva osjećaj nježnosti.

${ }^{616}$ DN ii. 134 (MPS 4. 37)
} 
Savršenoga si tijela, sjajan, plemenita podrijetla, užitak si za oči. Boje si zlata, o Blaženi. Vrlo si bijelih zuba i silan. ${ }^{617}$

U Nidānakathi se tvrdi da mu je tijelo postalo zlatne boje i u trenutku u kojem je odlučio, nakon šest godina krajnje trapnje, iznaći novi put do probuđenja:

Očitovala su se njemu prirođena tridest i dva obilježja Velika čovjeka, a tijelo mu postade zlatne boje. ${ }^{618}$

U Mahāvastuu se Gotamina put vrlo često povezuje s zlatnom bojom. Kao primjer navodim sljedeći ulomak teksta:

Mv ii. 195-196

bodhisattvo dharmāranyam vaśiș̣thasya ṛ̦isya āśramapadam praviștaḥ // vaśiștho pi ṛ̦i bodhisatvam dṛșțā vismito ko yam bhaviṣyati mānuṣo vā devo vā śakro vā brahmā vā yasya kāyasya prabhāye sarvam imam tapovanam obhāsitam // [...]

samudra iva gambhīro vīryavā himavān iva /

śākyarājasutam dṛștvā maharși vismito abhūt //

ko nvayam vapuṣā śrīmān jvalaty anupamadyuti /

suvarṇo dhūmāpagatah jotimāno yathānalah //

vyūạhoraskyo mahābāhuḥ supraśastakarāṃguli /

samantakukṣiś ca ślakṣno eṇavrtti kațìmahān //

kāmcanastambhasadrśso goṿ̣șākṣo mahādyutih /

śārdūlavrṣabhaskandhah padmapādakaro naghah ${ }^{619} / /$

śarīralakṣaṇair asya jātiśataguṇācitaih /

śobhato śarīram tasya nakṣatrair iva candramāḥ //

\footnotetext{
${ }^{617}$ Sn. 548: Paripuṇnakāyo suruci sujāto cārudassano suvaṇnavaṇno si Bhagavā, susukkadāṭo si viriyavā.

${ }^{618}$ ĐātA. I. 67: Ath' assa dvattimsa Mahāpurisalakkhanāṇi pākatikāni ahesum, kāyo suvaṇnavaṇno ahosi.

619 Jones (1952/2006: 187, bilj. 4) napominje: The text here is corrupt. The stanza ends padmapādakaro nagha. The last word is printed with a question mark, and is otherwise known only in a compound naghamāra. It gives no sense here. The metre is against reading okaranakkho, which would give the sense of ,, the nails on his hands and feet were like the lotus. "
} 
Prijevod

Bodhisattva je ušao u šumu dharme, ${ }^{620}$ u sklonište vidioca Vasișțe. Ugledavši Bodhisattvu, začudio se vidjelac Vasiștha: "Tko bi to mogao biti? Je li čovjek ili nebesnik ili Śakra ili Brahman čije tijelo [svojim] sjajem obasjava cijeli ovaj trapljenički gaj”? [...]

Dubok poput mora i poput snježne planine snažan.

Začudi se veliki vidjelac vidjevš’ sina kralja Śākya:

Tko to likom sjajan plamti nenadmašno blještav, zlatan kao bez dima žareća vatra,

Širokih prsa, snažnih ruku, divnih prstiju, pesti,

Ravna trbuha, vitak, hoda gazele, bedra snažna?

Nalik je stupu od zlata, bikook, velika sjaja, Trupa tigrova no nepozljeđujući, ${ }^{621}$ ruku i nogu poput lotosa.

Tjelesnim svojim obilježjima, stečenima vrlinama u stotinu rođenja, sja mu tijelo kao Mjesec sa zvijezdama.

U Buddhavaṃsi, Apadāni i Vimānavatthuu, kasnijim djelima uvrštenima u Khuddakanikāyu po prvi puta se spominje i Gotamina byāmappabhā, aureola ili krug svjetlosti oko njegova tijela koja se širi u duljinu od šest stopa. ${ }^{622}$ U Buddhavaṃsi se također tvrdi da mu tijelo isijava stotinu svjetlosnih zraka (sataramssī). ${ }^{623}$

Kada je riječ o tijelu Gotame Buddhe najistaknutija je njegova obilježenost sa trideset $\mathrm{i}$ dva znaka savršenstva koji potvrđuju njegov status Velikoga čovjeka (pāli mahāpurisa, skt. mahāpuruṣa). Lakkhaṇasutta ${ }^{624}$ donosi popis tih obilježja (dvattiṃsa-mahāpurisalakkhaṇa), a ta su redom:

1. ravna stopala (suppațthitapāda)

\footnotetext{
${ }^{620}$ Odnosno u šumu trapljenika.

${ }^{621}$ Negacija $n a+$ gha od $\sqrt{h a n}$, koji udara, ubija, ozljeđuje. SED, str. 375. Moguće je u sandhiju i anagha „,bezgrješan“.

${ }^{622}$ Bhv. I. 45, ĐātA. I. 12, 90, Vv. 213, Apd. 65.

${ }^{623}$ Bhv. I. 15.

${ }^{624}$ DN iii. 142-179 (sutta br. 30). Popis obilježja nalazi se i u DN ii. 16-19. MN ii. 136-137, ĐātA. I. 54, Mv. i. 220, 226-227, ii. 12, 29-30. U Selasutti Suttanipāte (Sn. 547) tvrdi se da tumačenje obilježja Velika čovjeka potječe iz brahmanističke tradicije.
} 
2. rođenjem otisnuti kotači s tisuću žbica, s obodom i glavčinom, ispunjeni svim oblicima, na tabanima (heț̣hāpādatalesu ćakkāni đātāni honti sahassārāni sanemikāni sanābhikāni sabbākāraparipūrāni)

3. duge trepavice (āyatapaṇhin)

4. dugi prsti (dīghaingulin)

5. meke i nježne ruke i stopala (mudutalunahatthapāda)

6. ruke i stopala prekriveni mrežicom (đālahatthapāda)

7. visoko smješteni gležnji (ussan்khapāda)

8. listovi na nogama poput antilopinih (eniđangha)

9. dlanovi ruku koji u uspravnome položaju tijela sežu do koljena (țitakova anonamanto ubhohi pānitalehi đaṇnukāni parimasati parimađđati. Dosl. prijevod: uspravan i ne pregibajući se dodiruje i trlja koljena dlanovima obiju ruku)

10. sakriven muški spolni organ (kosohitavatthaguyha)

11. vrlo svijetla i zlatna koža (suvaṇnavaṇno hoti kañćanasannibhattaćo)

12. nježna koža na koju prašina ni mokrina ne prijanja (sukhumaććhavi hoti, sukhumattā ćhaviyā rađođallam kāye na upalimpati)

13. dlake na tijelu koje izrastaju svaka iz samo jedne pore (ekekalomo hoti, ekekāni lomāni lomakūpesu đātāni)

14. plavo-crne dlake na tijelu koje rastu uspravno, kovrčajući se u desnu stranu (uddhaggalomo hoti, uddhaggāni lomāni đātāni nīlāni añđanavaṇnāni kuṇ̣alāvatṭānidakkhiṇāvattakađātāni)

15. božanski ravni udovi (brahmuđugatta)

16. sedam izbočenja na tijelu (sattussada)

17. prednji dio tijela kao u lava (sīhapubbaddhakāyo)

18. ispunjena ramena (ćitantaramso) ${ }^{625}$

19. tijelo razmjerno stablu banyana, visina tijela odgovara duljini ispruženih ruku i obratno (nigrodhaparimaṇ̦alo hoti, yāvatakvassa kāyo tāvatakvassa byāmo yāvatakvassa byāmo tāvatakvassa kāyo)

20. zaobljen trup (samavațtakkhandha)

21. savršeno osjetilo okusa (rasaggasaggin)

22. čeljust kao u lava (sīhahanu)

23. četrdeset zubi (ćattālīsadanta)

${ }^{625}$ PED, str. 265: one whose shoulder hole is heaped up, one who has shoulders well filled out. 
24. ravni zubi (samadanta)

25. gusti zubi, nepostojanje razmaka među zubima (aviraḷdanta)

26. vrlo bijeli očnjaci (susukkadāṭa)

27. dug jezik (pahūtađivha)

28. božanski glas kojim se glasa poput ptice karavīka (brahmassaro hoti karavīkabhāṇ̄)

29. oči tamno plave boje (abhinīlanetta)

30. trepavice kao u junice (gopakhuma)

31. dlačice (vunasti uvojak) koje rastu između obrva bijele boje, meke poput pamuka (uṇnā bhamukantare đātā hoti, odātā mudutūlasannibhā)

32. glava s izrastom na tjemenu koji po obliku nalikuje na turban (uṇhīsasissa $)^{626}$

U istoj se sutti naglašuje $\mathrm{i}$ da su obilježja plod dobrih djela izvršenih u prijašnjim egzistencijama. Gore nabrojani znakovi tjelesnoga savršenstva pripadaju čovjeku koji može postati ili sveopći vladar ili arahant, potpuno Probuđeni, koji odmiče veo sa svijeta. ${ }^{627}$ Stručnjaci su složni da je predodžba Velikoga čovjeka preuzeta iz brahmanističke tradicije. Endo (1997/2002: 45) tako piše:

The concept of the Great man (mahappurisa) is pre-Buddhistic and early Buddhism does not subscribe this idea to the physical characteristic only. Mahāpurisa in early Buddhism is a person of high spiritual advancement and can be equated with a worthy person (arahant). ${ }^{628}$

U kanonu postoji nekolicina primjera u kojima se pojam Velikoga čovjeka ne dovodi u vezu s tjelesnim obilježjima. Tako, primjerice, na pitanje što čini čovjeka velikim Buddha odgovara:

Što čovjeka čini velikim? Kažem, o Sariputta, da je čovjek oslobođena uma velik čovjek. Kojega um nije oslobođen taj, kažem, nije velik. ${ }^{629}$

\footnotetext{
${ }^{626}$ Skt. uṣnịșa. O teškoći prevođenja izraza, različitim tumačenjima zapadnih autora i unutar buddhističke komentatorske književnosti te prikazima Buddhine glave u buddhističkoj skulpturalnoj umjetnosti v. Lopez (2005: 13-36) u: Lopez (2005).

${ }^{627}$ DN iii. 142.

${ }^{628}$ Usp. i Nakamura (2000/2005: 221): These characteristic gained a fixed form over time and were handed down through ages, a small number are identical to those of Hindu deity Viṣnu Nārāyana, and probably originated in an early sun cult.

${ }^{629}$ SN v. 158: Vimuttacittattā khvāham, sāriputta, 'mahāpuriso'ti vadāmi. Avimuttacittattā 'no mahāpuriso'ti vadāmi.
} 
U Suttanipāti Blaženi tvrdi da je velik čovjek redovnik koji živi kreposnim životom, lišen žudnje, miran i sabran. ${ }^{630}$

Uz tridesetidva obilježja tjelesnoga savršenstva, Buddhino tjelo obilježeno je i sekundarnim obilježjima. O tome Endo (1997/2002: 47) kaže sljedeće:

In addition to the above thirty-two physical marks, late canonical texts like the Buddhavamsa and Apadāna speak of the Buddha's minor bodily marks (anuvyañjana). The Buddhavamsa refers only to the term anubyañjana while the Apadāna talks of eighty of them (asīti-anubyañjana). However, it is apparent that canonical texts are unaware of the whole of such physical marks attributed to the buddha, and these two references cited above, though in existence in actuality cannot be taken to strongly suggest the antiquity of the concept in the Canon [...]

U Mahāvastuu je, uz glavna, pobrojano i osamdeset manjih ili sekundarnih obilježja kao što su zaobljenost, bakrena boja i sjaj noktiju, vene na udovima bez čvorova, isijavanje svjetlosti, nepostojanje mrlja ili pjega na tijelu, mekan i crven jezik, dubok i pravilan pupak, nos umjerene veličine, crne i sjajne obrve, uši jednake veličine itd. ${ }^{631}$

Iako, kako je ranije spomenuto, u pālijskome kanonu postoje primjeri u kojima se potvrđuje da je Gotamino tijelo bilo poput tijela svakoga drugog bića kao i da se izgledom Gotama nije mnogo razlikovao od svojih suvremenika, kanon sadrži i one dijelove teksta u kojima se Gotamino tijelo veliča i opisuje kao obilježeno posebnim znakovima. U Nidānakathi se ne posvećuje posebna pažnja Gotaminu izgledu iako se ističe da mu je tijelo obilježeno znakovima tjelesnoga savršenstva kao i da isijava svjetlost. U Mahāvastuu je, pak, težnja za veličanjem njegova tjelesna izgleda izražena u mnogo većoj mjeri. Kao ilustracija lokottaravādinskoga tumačenja Buddhine pojavnosti niže je iznesen samo dio često navođenoga ulomka u kojem se donosi opis odnosa između buddha koji su nadnaravni i njihove pojavnosti na ovome svijetu. ${ }^{632}$

Mv. i. $168-169$

ām ca nāma dhovanti na caișām sajjate rajaḥ /

pādāh kamalapatrābhā eșā lokānuvartanā //

snāyanti nāma saṃbuddhā na caișạ̄n vidyate malo /

bimbe kanakabimbābhe eșā lokānuvartanā //

\footnotetext{
${ }^{630}$ Sn. 1041-1042. Usp. i AN ii. 36.

${ }^{631}$ Za pregled svih obilježja v. Mv. ii. 43-45.

${ }^{632}$ Prijevod je iznesen u prozi.
} 
dantadhovañ ca sevanti mukham ca utpalagandhikam /

nivasanam nivāsenti prāvāram ca tricīvaram //

cailạ̣ vātāni vāyitvā vikopenti na dehakam /

(1.169) vastram puruṣasiṃhānāạn eșā lokānuvartanā //

chāyāyām ca niṣiddanti ātapaś ca na bādhati /

buddhānām śubhaniṣyandānām eșā lokānuvartanā //

aușadham pratisevanti vyādhi caișām na vidyate /

nāyakānām phalam mahantam eșā lokānuvartanā //

prabhūśs ca karma vārayitum karmam darśayanti ca jinā /

aiśvaryam vinigūhanti eșā lokānuvartanā //

karonti nāma āhāraṃ na caișām bādhate kṣudhā /

janatāyā upadārtham eșā lokānuvartanā //

pibanti nāma pānīyam pipāsā ca na bādhate /

tad adbhutạn maharșināạn eșā lokānuvartanā //

cīvarāṇi nivāsenti sadā ca prāvṛto jinaḥ /

yathārūpo bhave devo eșā lokānuvartanā //

keśām ca orūpayanti na caișām chindate kṣurah /

keśām nīlāñjananibhām eșā lokānuvartanā //

jarām ca upadeśenti na caișām vidyate jarāa /

jinā jinaguṇopetā eșā lokānuvartanā //

Prijevod

Zaista, oni peru stopala, ali na njih prašina ne prijanja, stopala su im poput listova lopoča. [To je pranje] usklađenost ${ }^{633}$ sa svijetom.

Zaista, buddhe se kupaju, ali na njima nema nečistoće, nema nečistoće na njihovu liku koji izgleda kao zlatni lik. [To je kupanje] usklađenost sa svijetom.

Oni čiste svoje zube a usta im mirišu na plavi lotos. Oblače tkanine, ogrtač i tri halje.

Vjetar im raznosi halje ali ne škodi im tijelu. Ovo ogrtanje u njih kojih je lavovsko srce samo je usklađenost sa svijetom.

${ }^{633}$ BHS lokānuvartanā (skt. ${ }^{\circ}$ na, nt., pāli ${ }^{\circ}$ vattana), usklađenost, suglasje, oponašanje. 
Oni traže zaklon u sjeni, ali ih žega ne muči. Usklađenost je to sa svijetom u buddha čija djela imaju sretan ishod.

Oni uzimaju ljekarije, ali u njima nema bolesti jer bogat je plod u onih koji vode druge. [To je uzimanje ljekarija] samo usklađenost sa svijetom.

Iako mogu obustaviti djelovanje karmana, oni ga čine vidljivim i kao Pobjednici skrivaju svoju nadnaravnu moć. To je samo usklađenost sa svijetom.

Zaista, oni uzimaju hranu, ali ih ne mori glad. To je prilika ljudima da daju milodare $i$ usklađenost sa svijetom.

Zaista, oni piju vodu, ali ne mori ih žeđ; čudesno je to obilježje velikih vidjelaca. [To pijenje vode] samo je usklađenost sa svijetom.

Ogrću se tkaninama, ali je i bez njih Pobjednik ogrnut onako kako bi izgledao nebesnik. [To nošenje tkanina] samo je usklađenost sa svijetom.

Svoju kosu oblikuju iako oštrica ne reže njihovu crnoplavu kosu. To je samo usklađenost sa svijetom.

Prikazuju se starima, ali u njih nema starosti jer su Pobjednici obdareni krjepostima pobjednika. [To što se čine starima] samo je usklađenost sa svijetom. ${ }^{634}$

\section{3. Čudesne i zadivljujuće pojave u biografskim epizodama}

Čudesne pojave koje prate Gotamin život pripadaju tzv. abbhutadhammi, jednoj od devet (navāinga) ili dvanaest (dvādasāinga) kategorija u podjeli buddhističkih tekstova. Ključni su trenutci u životu Gotame Buddhe, kako je pokazano i u prethodnim poglavljima rada, popraćeni očitovanjima čudesnih pojava i prirodnih sila kao što su potresi, munje, mlazovi vode koji se spuštaju iz zraka, kiše cvijeća i slično. Čini se da se takvim prikazima u kojima čak i prirodne sile sudjeluju u ključnim trenutcima njegova života pokušalo pokazati ili dokazati da je pojava Buddhe u svijetu izvanredan, izniman i kolosalan događaj vrijedan čuđenja, divljenja i strahopoštovanja. Ranije je iznesen opis začeća kakav se susreće u Aćhhariyabbhutadhammasutti Mađđhimanikāye, a isti se opis vezuje i za Gotamino rođenje. Začeće i rođenje obilježeni su pojavom snažne svjetlosti i potresa ne samo u spomenutoj sutti

\footnotetext{
${ }^{634}$ Mv. i. 168-169. Potrebno je napomenuti da se navedeni ulomak ubraja među mlađe slojeve teksta, ali da predstavlja prepoznatljiv lokottaravādski nauk.
} 
Mađđhimanikāye, nego, naravno i u razmjerno mlađim tekstovima, u Mahāpadānasutti Dīghanikāye, ${ }^{635}$ Añguttaranikāyi ${ }^{636}$ i Nidānakathi ${ }^{637}$. Čudesne pojave u opisu začeća i rođenja nalaze se i u Lalitavistari, ${ }^{638}$ Buddhaćariti ${ }^{639}$ i Mahāvastuu ${ }^{640}$. Rođenje Buddhe, uz svjetlost i potres, prati i pojava mlazova vode koji se spuštaju iz zraka. ${ }^{641}$ Kada je riječ o začeću i rođenju Gotaminom niže će, kao ilustracija čudesnih i zadivljujućih pojava u njegovu životopisu, biti iznesen ulomak iz Nidānakathe koji opisuje trenutak začeća.

\section{ĐātA. I. 51 (začeće)}

dasasu cakkavālasahassesu appamāno obhāso phari, tassa tam sirim daț̣hukāmā viya andhā cakkhūni pațilabhimsu, badhirā saddai் suṇimsu, mūgā samālapimsu, khujjā ujugatā ahesum. pañgulā padasā gamanaì pațilabhimsu, bandhanagatā sabbasattā andudubandhanādīhi muccimsu sabbanarakesu aggi nibbāyi, pittivisaye khuppipāsā vūpassami, tiracchānānam bhayam nāhosi, sabbasattānam rogo vūpasami, sabbasattā

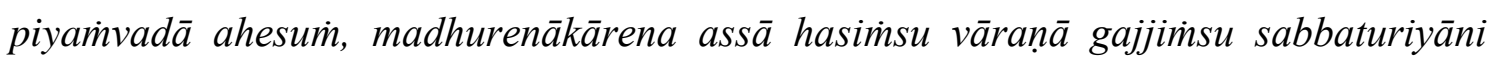
sakasakaninnādaì muñcimsu aghaț̣itāni yeva, manussānaṁ hatthupagādīni ābharanāni viravimisu, sabbadisā vippasannā ahesum, sattānam sukham uppādayamāno mudu sītalo vāto vāyi, akālamegho vassi, pațhavito pi udakam ubbhijjitvā vissandi, pakkhino $\bar{a} k \bar{a} s a g a m a n a \dot{m}$ vijahimsu, nadiyo assandamānā aț̣hamisu, mahāsamudde madhuram udakam ahosi, sabbatthakam eva pañcavaṇnehi padumehi sañchannatalo ahosi, thalajajalajādīni sabbapupphāni pupphimsu, rukkhānam khandhesu khandhapadumāni sākhāsu sākhāpadumāni latāsu latāpadumāni pupphimsu, thale silātalāni bhinditvā uparūpari satta satta hutvā daṇdapadumāni nāma nikkhamimsu, ākāse olambakapadumāni nāma nibbattimisu samantato pupphavassam vassimsu, ākāse dibbaturiyāni vajimsu, sakaladasasahassī lokadhātu vaț̣etvā vissațthamālāgulài viya uppīletvā baddhamālākalāpo viya alamikatapațiyattam mālāsanam viya ca ekamālāmālin̄̄ vipphurantavālavijan̄i pupphadhūpagandhaparivāsitā paramasobhaggappattā ahosi.

\footnotetext{
${ }^{635} \mathrm{DN}$ ii. 12.

${ }^{636}$ AN ii. 130-132.

637 ĐātA. I. 51.

${ }^{638}$ Lv. 85-86.

${ }^{639}$ Buddhaćarita I. 13, 16, 21.

${ }^{640}$ Mv. ii. 9-10, 34.

${ }^{641}$ MN iii. 123, DN ii. 15, ĐātA. I. 53, Lv 83, Buddhaćarita I. 23, Mv. ii. 23.
} 
Prijevod

U deset se tisuća svjetova rasprostrla neizmjerna svjetlost. Slijepima se vratio vid kao od želje da vide sjaj toga [događaja; gluhi su začuli zvuk; nijemi su progovorili; grbavi su se ispravili; hromi su nogama prohodali; sva su se sputana bića oslobodila lanaca i okov; u svim je paklovima ugasla vatra; u svijetu duhova utažene su glad $i$ žeđ; nestalo je straha u divljim životinjama; iscjeljene su bolesti svih bića; sva su bića postala krasnorječiva; radosno su zarzali konji i oglasili se slonovi; sva su se glazbala, sama od sebe, oglasila svojim zvukoma; zazveckale su narukvice i ostali ukrasi na ljudima; sve su se strane svijeta osvjetlile; zapuhao je blag $i$ svjež povjetarac izazivajući radost u bićima; pala je iz oblaka, u neočekivano vrijeme, kiša; iz zemlje je probila voda pa se prelila; ptice su se spustile s neba; rijeke su zaustavile svoj tijek; u velikome je moru voda postala slatka; posuvuda je površinu [vode]prekrilo pet vrsta lotosa; svi su se cvjetovi, na vodi i na zemlji, rascvali; na deblima, granama i grančicama procvjetali su lotosi; probivši se kroz kameno tlo, digli su se jedan ponad drugoga, u kiticama od sedam cvjetova, lotosi zvani daṇde; na nebu su se pojavili viseći lotosi; posvuda je pala kiša cvijeća; zasvirala su na nebu božanska glazbala. Okrenuo se cijeli sustav svjetova sačinjen od deset tisuća dijelova $i$, sjedinivši se kao rukovet raspuštenih vijenaca, nalik na svežanj sapletenih vijenaca, kao sjedalo ukrašeno vijencima, ${ }^{642}$ postao je ovjenčan jednim vijencem i hladeći kao treperava lepeza, prožet mirisom i dahom cvijeća, postigavši nenadmašno blaženstvo.

Čudesne pojave prate i ostale ključne trenutke Gotamina života, odnosno probuđenje, pokretanje kotača nauka i ulazak u konačnu nibbānu. Objašnjenje se za pojavu svjetlosti i potresa nalazi na nekoliko mjesta u kanonu. U Añguttaranikāyi se navodi kako se snažna svjetlost pojavljuje u trenutku Tathāgatina začeća, rođenja, probuđenja i prilikom pokretanja kotača nauka. ${ }^{643}$ Osam razloga za pojavu potresa nalaze se navedeni u Aṅguttaranikāyi ${ }^{644}$ i Mahāparinibbānasutti. Niže je iznesen i preveden ulomak iz Mahāparinibbānasutte.

\footnotetext{
${ }^{642}$ Mālāsana (?).

${ }^{643}$ AN ii. 130-135.

${ }^{644}$ AN iv. 312-313. Potresi kojima se slave odlučujući trenutci Gotamina života javljaju se i prije njegova posljednjega rođenja. Tako se, primjerice, potres javlja i u trenutku u kojem budući Gotama Buddha u svome posljednjem rođenju kao Vessantara dolazi do kraja dugoga puta usavršavanja deset savršenstava, v. ĐātA. I. 47.
} 


\section{DN ii. 107-109 (MPS 3. 13-20)}

Ațtha kho ime, ānanda, hetū, ațtha paccayā mahato bhümicālassa pātubhāvāya. Katame ațtha? Ayam, ānanda, mahāpathavī udake patițthitā, udakam vāte patițthitaṃ, vāto $\bar{a} k \bar{a} s a t t \underline{t h o . ~ H o t i ~ k h o ~ s o, ~ a ̄ n a n d a, ~ s a m a y o, ~ y a m ~ m a h a ̄ v a ̄ t a ̄ ~ v a ̄ y a n t i . ~ M a h a ̄ v a ̄ t a ̄ ~ v a ̄ y a n t a ̄ ~}$ udakam kampenti. Udakam kampitam pathavim kampeti. Ayam pațamo hetu pațhamo paccayo mahato bhūmicālassa pātubhāvāya.

Puna caparam, ānanda, samaṇo vā hoti brāhmaṇo vā iddhimā cetovasippatto, devo vā mahiddhiko mahānubhāvo, tassa parittā pathavīsañ̃ā bhāvitā hoti, appamānāa āposañ̃̄a. So imam pathavim kampeti sañkampeti sampakampeti sampavedheti. Ayam dutiyo hetu dutiyo paccayo mahato bhümicālassa pātubhāvāya.

Puna caparam, ānanda, yadā bodhisatto tusitakāyā cavitvā sato sampajāno mātukucchim okkamati, tadāyam pathavī kampati sañkampati sampakampati sampavedhati. Ayam tatiyo hetu tatiyo paccayo mahato bhūmicālassa pātubhāvāya.

Puna caparam, ānanda, yadā bodhisatto sato sampajāno mātukucchismā nikkhamati, tadāyam pathavī kampati sañkampati sampakampati sampavedhati. Ayam catuttho hetu catuttho paccayo mahato bhūmicālassa pātubhāvāya.

Puna caparam, ānanda, yadā tathāgato anuttaram sammāsambodhim abhisambujjhati, tadāyạ̣ pathavī kampati sañkampati sampakampati sampavedhati. Ayam pañcamo hetu pañcamo paccayo mahato bhūmicālassa pātubhāvāya.

Puna caparam, ānanda, yadā tathāgato anuttaram dhammacakkam pavatteti, tadāyam pathavī kampati sañkampati sampakampati sampavedhati. Ayam chaț̣tho hetu chațtho paccayo mahato bhūmicālassa pātubhāvāya.

Puna caparam, ānanda, yadā tathāgato sato sampajāno āyusaìkhāram ossajjati, tadāyam pathavī kampati san்kampati sampakampati sampavedhati. Ayam sattamo hetu sattamo paccayo mahato bhūmicālassa pātubhāvāya.

Puna caparam, ānanda, yad̄̄ tathāgato anupādisesāya nibbānadhātuyā parinibbāyati, tadāyam pathavī kampati sañkampati sampakampati sampavedhati. Ayam aț̣thamo hetu ațthamo paccayo mahato bhūmicālassa pātubhāvāya. Ime kho, ānanda, ațtha hetū, ațtha paccayā mahato bhūmicālassa pātubhāvāya. 


\section{Prijevod}

Osam je tih, Ananda, uzroka, osam razloga za pojavu velika potresa. Kojih osam? Ova velika Zemlja, Ananda, počiva na vodi, voda počiva na vjetru, a vjetar na nebeskom prostranstvu. Dođe vrijeme, Ananda, kada zapušu jaki vjetrovi. Puhanje jakih vjetrova potresa vodu. Voda koja se trese uzrokuje drhtanje zemlje. To je prvi uzrok, prvi razlog za pojavu velika potresa.

Nadalje, Ananda, isposnik ili brahman, koji posjeduje [nadnaravne] moći $i$ voljom vlada svojom sviješću, ili pak nebesnik, velikih nadnaravnih moći i veleiskusan, a kojemu se javi svijest o majušnosti zemlje i beskrajnosti vode, taj onda ovu zemlju strese, potrese, zatrese i dade da snažno zadrhti. To je drugi uzrok, drugi razlog za pojavu velika potresa.

Nadalje, Ānanda, kada se bodhisatta, napustivši tijelo na nebesima Tusita, svjestan $i$ sabran spušta u majčinu utrobu, tada se ova zemlja strese, potrese, zatrese $i$ snažno zadrhti. To je treći uzrok, treći razlog za pojavu velika potresa.

Nadalje, Ānanda, kada bodhisatta, svjestan i sabran, napušta majčinu utrobu, tada se ova zemlja strese, potrese, zatrese $i$ snažno zadrhti. To je četvrti uzrok, četvrti razlog za pojavu velika potresa.

Nadalje, Ānanda, kada tathāgata dosegne nenadmašno i obuhvatno probuđenje, tada se ova zemlja strese, potrese, zatrese i snažno zadrhti. To je peti uzrok, peti razlog za pojavu velika potresa.

Nadalje, Ānanda, kada tathāgata pokreće nenadmašni Kotač nauka, tada se ova zemlja strese, potrese, zatrese $i$ snažno zadrhti. To je šesti uzrok, šesti razlog za pojavu velika potresa.

Nadalje, Ānanda, kada tathāgata, svjestan i sabran, napušta ustrojnicu životnoga vijeka, tada se ova zemlja strese, potrese, zatrese i snažno zadrhti. To je sedmi uzrok, sedmi razlog za pojavu velika potresa.

Nadalje, Ānanda, kada se tathāgata u cijelosti razrješuje u stanje nibbāne bez ostatka, tada se ova zemlja strese, potrese, zatrese i snažno zadrhti. To je osmi uzrok, osmi razlog za pojavu velika potresa. To je upravo, Ānanda, osam uzroka, osam razloga za pojavu velika potresa. 
U Mahāvastuu i Nidānakathi trenutak odlaska u beskućništvo popraćen je očitovanjima čudesnih pojava. U Mahāvastuu se navodi kako se u tom trenutku, između ostaloga, zemlja zatresla šest puta i zaljuljalo more, pojavila se snažna svjetlost, obasjana su sva nebesa i paklovi, a Sunce, Mjesec i sve zvijezde zasjali su istovremeno punim sjajem. ${ }^{645}$

Iako dva gore spomenuta izvora među povode za potres navode i trenutak probuđenja, u prikazima se probuđenja u prve četiri nikāye, kao i u Mahāvaggi Vinayapiṭake potresi ne spominju. Ariyapariyesanā-, Dvedhāvitakka-, Mahāsaććaka- i Bhayabheravasutta, pa čak niti Mahāpadānasutta ne spominju, u kontekstu probuđenja, ni potrese ni pojavu bilo kojih drugih očitovanja prirodnih sila. To navodi na zaključak o razmjerno većoj starosti tih tekstova. S druge strane, Nidānakathā donosi opis zadivljujućih pojava koje su popratile najvažniji trenutak Gotamina života.

ĐātA. I. 75-76

Ath' assa dvādasapadikam paccayākāram vațtavivațtavasena anulomapațilomato sammasantassa sammasantassa dasasahassilokadhātu udakapariyantam katvā dvādasakkhattum saṁkampi. Mahāpurise pana dasasahassilokadhātum unnādetvā aruṇuggamanavelāya sabbaññūtañānam pațivijjhante sakaladasasahassilokadhātu alä̇katapațiyattā ahosi. Pācīnacakkavālamukhavațtiyam ussāpitānam dhajānam pațākānam raminsiyo pacchimacakkavālamukhavațtiyam paharanti tathā pacchimacakkavālamukhavațtiyam ussāpitānam pācīnacakkavālamukhavatțiyam uttaracakkavālamukhavaț̣iyam ussāpitānam dakkhinacakkavālamukhavațịyam dakkhinacakkavālamukhavaț̣iyam ussāpitānam uttaracakkavālamukhavaț̣iyam paharanti, pațhavitale ussāpitānam pana dhajānam pațākānam Brahmalokai் āhacca ațthamsu Brahmaloke baddhānam pațhavitale patițthahimsu, dasasahassacakkavāle

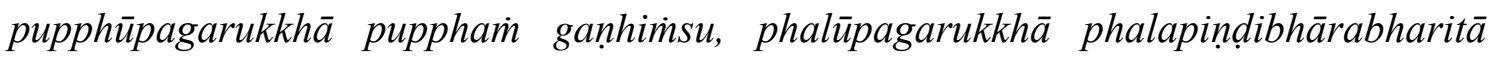
ahesum, khandhesu khandhapadumāni pupphimisu, sākhāsu sākhāpadumāni, latāsu latāpadumāni, ākāse olambakapadumāni, silātalāni bhinditvā uparūpari sattasatta hutvā daṇdakapadumāni uțthahimsu, dasasahassilokadhātu vațtetvā vissațthamālāguḹ viya susanthatapupphasanthāro viya ca ahosi, cakkavālantaresu atțhayojanasahassalokantarikā sattasuriyappabhāyapi anobhāsitapubbā ekobhāsā ahesuṁ, caturāsītiyojanasahassagambhīro mahāsamuddo madhurodako ahosi, nadiyo

\footnotetext{
${ }^{645}$ Mv. ii. $162-164$.
} 
nappavattimsu, jaccandhā rūpāni passimsu, jātibadhirā saddà̇ suṇimsu, jātipịthasappī padasā gacchimsu, andubandhanādīni chinditvā patimsu.

Prijevod

Dok je on prebirao i prebirao, vrteći i razvrćući, unaprijed $i$ unazad, lanac uzroka od dvanaest karika, zatresao se dvanaest puta sustav svjetova načinjen od deset tisuća dijelova, sve do ruba vode. Nadalje, kada je Veliki čovjek, učinivši da odjekne sustav svjetova načinjen od deset tisuća dijelova, dosegao u zoru sveznanje, cijeli se je sustav svjetova načinjen od deset tisuća dijelova ukrasio i uredio. Trake barjaka i zastava podignutih na rubu istočne sfere dotakle su rub zapadne sfere, one podignute na rubu zapadne sfere dotakle su rub istočne sfere, one podignute na rubu sjeverne sfere dotakle su rub južne sfere, one podignute na rubu južne sfere dotale su rub sjeverne sfere, trake barjaka i zastava podignute na površini Zemlje stale su dotaknuvši svijet Brahmana dok su se one pričvršćene na svijetu Brahmana spustile do površine Zemlje. U svijetu načinjenom od deset tisuća dijelova cvjetajuća su se stabla okitila cvjetovima, stabla koja nose plodove postala su teška od težine grozdova plodova, na deblima [stabala] procvjetali su lotosi koji cvatu na deblima, na granama lotosi koji cvatu na granama, na povijušama lotosi koji rastu na povijušama, na nebu [su se pojavili] viseći lotosi, lotosi [zvani] daṇde digli su se jedan ponad drugoga, u kiticama od po sedam cvjetova, probivši se kroz kamenita tla. Okrenuo se sustav svjetova načinjen od deset tisuća dijelova i postao nalik na rukovet raspuštenih vijenaca, nalik na lijepu prostirku prostrtu cvijećem. Paklovi, smješteni u prostoru između svjetova, u međuprostorima od osam tisuća yođana, ranije neosvijetljeni čak ni sjajem sedam Sunaca, osvijetlili su se svjetlom jednoga, veliko more, duboko osamdesetičetiri tisuće yođana, postalo je slatkovodno, rijeke su prestale teći, od rođenja slijepi ugledali su oblike, od rođenja gluhi začuli su zvuk, bogalji na štakama prohodali su nogama, pokidavši se, pali su lanci i okovi.

U Mahāvastuu čudesne i zadivljujuće pojave imaju veću ulogu negoli je to slučaj u pālijskome kanonu i Nidānakathi, pa će niže, kao primjer i ilustracija te tvrdnje, biti iznesen opis čudesnih pojava koje su popratile bodhisattvino probuđenje. ${ }^{646}$

Mv. ii. 349-353

\footnotetext{
${ }^{646}$ Prijevod je iznesen u prozi. Kada je riječ o čudesnim pojavama koje su se očitovale u vrijeme Gautamina probuđenja, dobar primjer pruža i opis promjena na stablu bodhi koje se čudesno okitilo tkaninama, barjacima, dragim kamenjem, nakitom, postalo nekoliko stotina tisuća yođana visoko itd. V. Mv. ii. 309-314.
} 
saptāhapūram saṃbuddho bodhim buddhitva uttamām /

āsanāto na utthesi sarvalokasya cetiyo //

devakoṭīsahasrāṇi gagaṇasmị̣ samāgatā /

puṣpavarṣam pravarṣensu saptarātram anūnakam //

utpalām padumām campām puṇ̣̂arīkām manoramām /

sahasrapatrām rucirām tatra devā pravarșiṣu //

māraś ca durmano āsi kāṇ̣̂ena likhate mahīm /

jito smi devadevena śākyasiṃhena tāpinā //

trāyastriminsa ca yāmā ca tușitā ye ca nirmitāa /

paranirmitā ye devā kāmadhātupratișthitāḥ //

lohitam candanam divyam agurum atha campakam /

divyā ca puṣpavarṣāṇi antarīkṣeṇa okiri /

akșamātrāhi dhārāhi buddhakṣetram phalì imam //

brahmakoṭisahasrāṇi gagaṇasmị̣ samāgatāḥ /

varșanti sukhumam cūrṇaṃ divyaṃ lohitacandanam //

bhūmyā devā upādāya śuddhāvāsāh svayamprabhāh /

evaṃ paraṃparā_āsi devatāhi parisphuțā //

chatradhvajapatākāhi antarīkṣam parisphuțam /

2.350) karonti pūjanāṃ śreșthām sambuddhasya śirìmato //

$\bar{a}$ bhā ca vipulā muktā buddhakșetram parisphuțam /

bhavāgrā lokadhātūyo ${ }^{647}$ gnisavarṇā bhavesi ca //

praśāntā nirayā āsi buddhakṣetrasmi sarvaśo /

śìtībhūtā ca aṃgārā satvā ca sukhitā abhū //

yeșām nairayikam duḥkham parikṣiṇam tad antaram /

nirayeșu ca satvā te deveșu upapadyișu //

saṃjīvakālasūtreșu tapane ca pratāpane /

praśānto raurave agniḥ lokanāthasya raśmibhị̣ //

avīcyām atha saṃhāte pratyekanirayeșu ca /

praśānto sarvaśo agnị̣ lokanāthasya rasmibhih //

yāvantā lokadhātūṣu pratyekanirayā abhū /

praśānto sarvaśo agnị̣ lokanāthasya rasmibhih //

ye ca tiricchānayonīyam mānsarūdhirabhojanā /

${ }^{647}$ Nom. množ. BHSG $§ 12.58$. 
maitrāya sphuțā buddhena na himsanti parasparam //

chatradhvajapatākehi bodhivṛsso alaṃḳtah /

kūṭāgārehi samchanno devaputrehi nirmitā //

khāṇū ca kaṇtakathalā ca śarkarā sikatā pi ca /

samantā bodhimaṇ̣̂āto heșțā bhūmau pratișthitāh //

ratnāmaȳyye bhūmīye $e^{648}$ bodhimaṇdam parisphuțạ /

yā iha buddhakșetrasya devaputrehi nirmitā //

(2.351) devaputrasahasrāṇi dharaṇiyam pratișthitā /

dhūpanetrām grhetvāna pūjenti lokanāyakam //

hețthā ca dharan̄i sarvā padumehi parisphuțā /

jāmbūnadasuvarṇasya buddhatejena udgatāḥ //

ye cāpi vyādhitā satvā duḥkhitā aparāyaṇāh /

arogā sukhitā bhūtā buddharasmiparisphuṭāh //

jātyandhā rūpām paśyensuḥ labdhvā cakșum viśäradam /

parasparam cālapensu bodhiprāptasya tāyino ${ }^{649} / /$

rāgāś cāpy api ca doṣā mohāś ca tanuno kṛtāh /

yam kālam śākyasiṃhena prāptā bodhi maharșiṇa //

prāsādā savimānā ca kuṭāgāramanoramāh /

sarve tatomukhā āsi bodhisatvasya tāyinah //

yāvanti buddhakṣetrasmim naranārī ca kiṃnarāḥ /

sarve tatomukhā āsi bodhisatvasya tāyinah //

devatā devaputrā ca devakanyā ca śobhanāh /

sarve tatomukhā āsi yena bodhi maharșino //

nāgā cāpy atha gandharvā yakṣa kumbhāṇdarākșasāḥ /

sarve tatomukhā āsi yena bodhi maharșinah //

dārikā dārakā caiva śayyāsanāvaśāyitāh /

tatomukhā saṃsthihensu yena bodhi maharșiṇo //

ye cāpy ābharaṇā divyā viśiștā ratanāmayāḥ /

(2.352) ābaddhā āsi devānam sarve tatomukhā abhū //

nāgānām atha yakṣāṇām piśācarākṣasāna ca /

\footnotetext{
${ }^{648}$ BHSG $\S 10.90-95$.
}

${ }^{649}$ Pāli tādi(n), skt. tādṛ́s. Jones (1952/2006: 318, bilj. 2) tvrdi: [...] identification with Pali tādin, 'such', 'of such good qualities' easily explains the use of Bsk. tāyin, in the sense of 'so great', 'mighty', etc. Usp. i BHSD, str. 251. 
teșām cābharạ̣ā sarve yena bodhi tato gatāh // devānām atha nāgānām yakṣāṇām rākșasāna ca / tatomukhā vimānābhū yena bodhi maharșiṇo // nupūrā valayā caiva atha vā parihārakāḥ / bodhiprāptasya buddhasya yena vilambitāmbarạ̣ // janāna hārā ca kaṇṭhe niṣkāni śobhanāni ca / ābaddhakā manuṣyānāạn yena bodhi nirimgitā // muktihārāśs ca ābaddhā vicitrā maṇikuṇụalā / kațakā ca mudrikā ca yena bodhi nirimgitā // yāvanti buddhakṣetrasmịn satyadhātū acintiyā / jānantā vā ajānantā yena bodhi nirimgitāa // vātā ca sítalā vāye manojñagandhā manoramāḥ / samantabuddhakșetrasmim bodhiprāptasya tāyino // yāvanti buddhakṣetrasmịn devā nāgā ca mānuṣā / asurā ca kinnarā yakșā sarve paśyanti nāyakam // dhūpanetrām grahetvāna sarve tena sukhasthitā / pūjayanti lokapradyotam bodhimaṇde pratișthitam // aṃjalīhi namasyanti gāthābhir astavensu te / (2.353) pūjām karonti buddhasya bodhimaṇ̣e pratișthitā // sarve āsannam paśyanti lokanātham prabhaṃkaraṃ / na kaścid dūre samjāne vyāmamātre yathā sthitam // na kaścit prșțhato buddham lokadhātūya paśyati / sarvā diśā hi buddhasya saṃmukhām paśyati dṛśām // vāmadakșiṇapārśvehi na kaścil lokanāyakam / saṃjānati mahāvīram sarve paśyanti nāyakam // dhūpitam buddhakṣetrasmim dhūpanam ca tad anantaram / samantā buddhakṣetrāṇām gandhena koṭiyo sphutāa // na śakyam gaṇanām kartum ettiyā satvakotiyo / paśyitvā śirim buddhasya saṃbodhim abhiprasthitāh // tṛnā ca atha kāṣ̦thā ca auṣadhīyo vanaspatī / sarve tatomukhā āsi yena bodhi maharșiṇo // ko ayam īdriśān dharmā lokanāthena darśitāị / śrunitvā na siyā tuș̣to anyatra mārapakșikāt // na śakyaṃ sarvaṃ khyāpetum vācayā ṛddhi bhāṣataḥ / 
yā śiri āsi buddhasya bodhiprāptasya tāyinah //

yehi ca dṛșto sambuddho bodhimaṇde pratișthitaḥ /

püjitaś ca mahāvīro te śrutvā tușta paṇịtāh //

śillaskandhe ca acchidre ye bhikṣu supratișthitāh /

te śrunitvā idam sūtram harșạ̣ kāhinti bhadrakam //

Prijevod

Punih se sedam dana, nakon što je dosegao nenadmašno probuđenje, Savršeno probuđeni, Ćetiya cijeloga svijeta, nije ustao sa sjedala. Tisuće koṭia nebesnika okupljenih na nebesima sipalo je svih sedam noći kišu cvijeća. Sipali su tom prilikom nebesnici plave lotose, crvene lotose, žute mirisne cvjetove, bijele lotose; predivne, tisućolatične i sjajne. A Māra je, oneraspoložen, napisao štapom po zemlji: "Porazio me je nebesnik nebesnika, lav iz porodice Śākya, trapljenik”. Nebesnici iz skupina Trāyastriṃśa, Yāma, Tușita, Nirmita, Paranirmita, nebesnici koji borave u svijetu osjetilnih užitaka, raspršivali su po nebu božansku kišu cvijeća, crvenu sandalovinu, božansku mirisnu alou i žute mirisne cvjetove. Ovo se je polje buddhe ispunilo bujicama [cvjetova] velikih poput kocaka. Tisuće koṭia brahmana okupljenih na nebesima sipalo je kišu sitnoga božanskoga praha crvene sandalovine. S nebesnicima koji prebivaju na Zemlji [bili su i] samosvjetleći nebesnici Śuddhavāse, prenapunili su se tako redovi nebesnika. Prenapunila su se nebesa suncobranima, zastavama i barjacima

(2. 350) [dok su nebesnici] odavali najodličniju počast sjajnomu Savršeno probuđenomu. Oslobodila se obilna svjetlost i preplavila polje buddhe. Najviše sfere svjetova dobile su boju vatre. U cijelome su se polju buddhe paklovi uspokojili, ohladila se žeravica, a bića postadoše sretna. Bića u paklovima koja su u međuvremenu došla do kraja patnje, rodila su se ponovno među nebesnicima. U [paklovima zvanim] Samjīva, Kālasūtra, Tapana, Pratāpana i Raurava stišao se oganj zrakama Spasitelja svijeta. U [paklovima zvanim] Avīci i Sañghāta, kao i u svim paklovima pojedince, stišao se oganj zrakama Spasitelja svijeta. U [svim] sferama svjetova, u svim se paklovima pojedince stišao oganj zrakama Spasitelja svijeta. [Bića koja su se], u zvjerskome paklu, hranila krvavim mesom, dirnuta Buddhinom dobronamjernošću, nisu ozljeđivala jedno drugo. Okitilo se stablo bodhi suncobranima, barjacima i zastavama i prekrilo paviljonima koje su sagradili nebesnici. Svi su panjevi, trnje, suha zemlja, šljunak i pijesak položeni na zemlju daleko ${ }^{650}$ od

\footnotetext{
${ }^{650}$ heștā, pril. ispod, pod, podno. Prijevod je prilagođen kontekstu.
} 
vrhunskoga stabla bodhi. Vrhunski je bodhi rastao na zemlji od dragoga kamenja, a koju su ovdje stvorili nebesnici za buddhino polja.

(2. 351) Uzevši kadila, tisuće je nebeskih sinova stalo na zemlju štujući Vođu svijeta. Sva se zemlja ispod [stabla bodhi] osula lotosima, a koji su iznikli iz sjaja Buddhe [boje] zlata iz rijeke Đambū. Dotaknuta Buddhinom zrakom, bića bolesna, napaćena i beznadna postala su zdrava i sretna. Od rođenja slijepi, zadobivši zdrav vid, ugledali su oblike, među sobom su razgovarali o Takvu koji je dosegao probuđenje. Strasti i mržnje kao $i$ zablude oslabljene su u trenutku u kojem je Veliki vidjelac, Lav iz roda Śākya dosegao probuđenje. Svi su se hramovi $i$ nebeske palače ${ }^{651}$ sa ljupkim paviljonima okrenuli pročeljem prema Takvu bodhisattvi. Svikoliki su se muškarci, žene i kiṃnare u polju buddhe okrenuli licem prema Takvu bodhisattvi. Svi su se nebesnici kao i nebeski sinovi i očaravajuće nebeske kćeri licem okrenuli prema stablu bodhi Velikoga vidioca. Potom su se $i$ svi nāge, kao $i$ gandharve, yakșe, kumbhāṇḍe $i$ rakșase okrenuli prema prema stablu bodhi Velikoga vidioca. Mladići i djevojke koji su se odmarali na sjedalima $i$ ležajima ustali su i potom okrenuli licem prema prema stablu bodhi Velikoga vidioca. Svi su se izvrsni božanski ukrasi načinjeni od dragoga kamenja

(2.352) ovješeni o nebesnike [okrenuli prema stablu bodhi Velikoga vidioca]. Svi su se ukrasi nāga, yakṣa, piśāća $i$ rakṣasa okrenuli prema stablu bodhi. Nebeske palače nebesnika, nāga, yakșa i rakșasa [okrenule su se prema stablu bodhi Velikoga vidioca]. Sve su se narukvice, nanogvice kao i ukrasi za ruke [okrenuli prema mjestu na kojem je] visio ogrtač Buddhe koji je dosegao probuđenje. Ogrlice ljudi na vratu i zlatni ukrasi ovješeni o ljude [okrenuli su se prema] nepomičnomu stablu bodhi. Niske bisera, ovješene blještave, naušnice od dragulja, prstenje i pečatnjaci [okrenuli su se prema] nepomičnomu stablu bodhi. Svakolika su se nezamisliva bića u polju budddhe, svjesno ili nesvjesno, [okrenula prema] nepomičnomu stablu bodhi. U cijelome polju buddhe, Takva koji je dosegao probuđenje zapuhali su svježi povjetarci, miomirisni i ugodni. Svikoliki su nebesnici, nāge, ljudi, asure, kinnare $i$ yakṣe $u$ polju buddhe gledali u Vođu. Razveseljeni njime, držeći kadila, štovali su Prosvjetljivatelja svijeta, naslonjena na vrhunsko stablo bodhi. Klanjali su mu se sklopljenih dlanova, veličali ga pjesmama $i$

${ }^{651}$ Vimāna. Za opširan opis v. rječničku natuknicu u PED, str. 630 i SED, str. 980. 
(2.353) prinosili Buddhi počast stojeći pokraj uzvišenoga stabla bodhi. Svi su gledali Vođu svijeta i Svjetlotvorca gdje sjedi, nitko ga ne bi zamjećivao iz daljine, niti kao da stoji udaljen, ma i za sežanj. Nitko u nekome dijelu svijeta Buddhu nije vidio s leđa, svi su smjerovi gledali Buddhu licem u lice. Nitko Vođu svijeta nije zamjećivao s desne ili lijeve strane, svi su gledali [pravo] u Velikoga junaka i Vođu. Potom je polje buddhe okađeno miomirisima, na što su se odmah i sva buddhina polja ${ }^{652}$ ispunila miomirisom. Nije moguće izbrojati toliko koția bića koja su pristupila vidjevši sjajno Savršeno probuđenje Buddhe. Sve su se trave, drveće, bilje i stabla [okrenuli prema] stablu bodhi Velikoga vidioca. Čuvši za takve očitovane značajke Vođe svijeta, tko se ne bi, osim podanika Māre, radovao? Sjaj kakav je imao Buddha kada je Takav dosegao probuđenje, ne može izreći riječju ni onaj koji govori nadnaravnom moći. ${ }^{653}$ Oni koji su vidjeli Savršeno probuđenoga, Velikoga junaka naslonjenoga na stablo bodhi, i iskazali mu počast, ti su mudri bili, čuvši [za očitovane značajke], obradovani. Redovnici čvrsto oslonjeni o deblo ćudoređa, čuvši ovu sūtru, osjetit će blaženu radost.

Pokretanje kotača nauka kakvo je opisano u Vinayapiṭaki i Dhammaćakkappavattanasutti Saṁyuttanikāye popraćeno je proglasom u svijetu nebesnika i sažetim opisom pojave potresa i svjetlosti:

U tom se trenutku, u tom trenu, u tom času, pronio glas sve do svijeta Brahmana. Zatresao se, zadrhtao i snažno zadrmao ovaj sustav svemira sačinjen od deset tisuća svjetova $i$ pojavila se u svijetu neizmjerna i uzvišena svjetlost koja je nadišla nebesnike i njihov nebesničko iskustvo. ${ }^{654}$

Pokretanju kotača nauka u Nidānakathi, kako je ranije pokazano, nije posvećeno mnogo pažnje, a čudesne su pojave u cijelosti zanemarene. Za razliku od Nidānakathe, u Mahāvastuu je, kako bi se i očekivalo, epizoda popraćena čudesnim i zadivljujućim pojavama.

Mv. iii. 334

iyam ca mahāprthivī atiriva șadvikāram kampe chinnam iva patram vedhe sampravedhe purastimaś ca anto unnamati paścimo ca anto oname paścimo ca anto unname purastimo ca anto oname dakșiṇo ca anto unname uttaro cānto oname uttaro cānto unname dakșiṇo

\footnotetext{
${ }^{652}$ buddhakșetrānam. V. Mv. i. 121-124.

${ }^{653}$ ṛddhi bhāṣatah.

${ }^{654}$ Vin. i. 12 (Mahāvagga, I. 6, 31), SN v. 424. Za pālijski izvornik v. str. 163.
} 
cānto oname madhyo ca oname anto unname anto oname madhyo unname / aprameyam ca loke obhāsam abhūṣi atikramyaiva devānām devānubhāvam nāgānām nāgānubhāvam yakṣānām yakṣānubhāvam yā pi tā lokāntarikā andhakārārpitā tamisrā tamisrārpitā aghā asamviditā asaṃviditapūrvā yatreme candramasūryā evam maharddhikā evam mahānubhāvā ābhayā ābhām nābhisaṃbhunanti ālokena vālokam sphuranti nāpi ca te obhāsena sphuțā abhūṣi / anye pi ye tatra satvā upapannā te pi tenobhāsena anyamanyaṃ saṃjānensuḥ / anye pi kila bho satvā upapannā / anye pi kila bho satvā upapannā / ekāntasukhasamarpitā ca punas tatkṣaṇam tanmuhūrtam sarvasatvā abhūnsuh ye pi avīcimahāniraye upapannā / bhūmyā ca devā ghoṣam udīrayensuh śabdam anuśrāvayensuḥ / etam māriṣa bhagavatā vārāṇasyām ṛșivadane mrgadāve triparivartam dvādaśākāram anuttaram dharmacakrạ̣ pravartitạ̣ apravartyam kenacic chramaṇena vā brāhmaṇena vā devena vā mārena vā kenacid vā punar loke saha dharmeṇa / bhaviṣyati bahujanahitāya bahujanasukhāya lokānukaṃpāya mahato janakāyasyārthāya hitāya sukhāya devānām ca manuṣyāṇām ca hāyiṣyanti āsurā kāyā divyā kāyā abhivardhișyanti //

\section{Prijevod}

Potresla se je snažno ova velika Zemlja na šest načina pa je zadrhtala i uzdrhtala poput otkinuta lista: istočni se dio uzdigao, a zapadni ulegao, zapadni se dio uzdigao, a istočni ulegao, južni se dio uzdigao, a sjeverni ulegao, sjeverni se dio uzdigao, a južni ulegao, središnji se dio uzdigao, a rub se ulegao, rub se uzdigao, a središnji se dio ulegao. Pojavila se na svijetu neizmjerna svjetlost koja je nadišla nebesko veličanstvo nebesnika, veličanstvo nāga $i$ veličanstvo yakșa. Čak se i u paklenim međusvjetovima uronjenima $u$ noć, tamnima uronjenima u tamu, grješnima, neviđenima, nikad ranije viđenima, gdje Sunce i Mjesec [koliko god bili] velemoćni i veličanstveni [svojim]sjajem ne stvaraju sjaj i [svojim] svjetlom ne šire svjetlo - čak su i ti bili prožeti svjetlošću. I tamo rođena bića na toj su se svjetlosti međusobno prepoznavala: "Gle, zaista, i druga su bića [ovdje] rođena! Gle, zaista, i druga su bića [ovdje] rođena”! U tom su trenu, u tom času, čak $i$ bića rođena u velikom paklu Avīći, bila prožeta jedinstvenom srećom. Oglasili su se na zemlji boraveći nebesnici i pronijeli glas: "O, poštovani! U Vārāṇasī, u R̦șivadani, $u$ Gaju jelena, Blaženi je pokrenuo nenadmašni, tri puta okrenuti $i$ od dvanaest žbica načinjeni kotač nauka koji ne može ponovno zaustaviti ni jedan isposnik, ni brahman, ni nebesnik, ni Māra ni bilo tko u svijetu s [tom] naukom. Bit će to za dobrobit mnogih, za 
sreću mnogih, iz suosjećanja spram svijeta, u korist velika mnoštva ljudi, za dobrobit $i$ sreću nebesnika i ljudi. Opadat će asurski zborovi, a rast će u nebeski zborovi”.

Ulasku u konačnu nibbānu prethodio je potres koji se je dogodio u trenutku u kojem je Gotama svojevoljno odlučio odreći se ostatka života, kao i kiša cvijeća koja se je spustila s nebesa kako bi pokrila tijelo Gotame koji je legao na posljednji ležaj. Sam ulazak u konačnu nibbānu također je opisan kao popraćen potresom:

Kada se je Blaženi u cijelosti razriješio, dogodio se velik $i$ strašan potres od kojega se tijelo kostriješilo i prolomila se nebeska grmljavina. ${ }^{655}$

Mahāparinibbānasutta spominje i oplakivanje u svijetu nebesnika kao i očitovanja čudesnih pojava koje su se zbile tijekom ceremonije spaljivanja Gotamina tijela kao što su kiša cvjetova mandārave, ${ }^{656}$ samozapaljenje pogrebne lomače ${ }^{657}$ i spuštanje mlazova vode koji su se spustili iz zraka kako bi ju ugasili ${ }^{658}$. Mahāvastu također spominje samozapaljanje pogrebne lomače i okupljanje nebesnika ali izostavlja pojavu mlazova vode koji su ugasili lomaču.

\subsection{Prisustvo nebesnika u ključnim trenutcima Buddhina života}

Ključni su trenutci Gotamina života obilježeni prisustvom nebesnika. Kako je već ranije pokazano, ne postoji opis Gotamina začeća i rođenja koji ne uključuje pojavu nebesnika i opis njihove radosti i iskazanoga poštovanja.

Trenutak napuštanja doma, odnosno odlaska u beskućništvo, u pojednim je suttama Mađđhimanikāye opisan šturo. U Ariyapariyesanāsutti, koja je po mnogim autorima najvažniji izvor za proučavanje toga dijela Gotamina života, i pojedinim drugim suttama Mađđhimanikāye ${ }^{659}$ iznosi se jednostavna činjenica da je Gotama u jednom trenutku svojega života donio i ostvario odluku o odlasku u beskućništvo. Međutim, Gotamina su promišljanja o starosti, bolesti i smrti s vremenom preobličena u živopisnu pripovijest o četiri sudbonosna susreta sa starcem, bolesnikom, mrtvacem i isposnikom. U Mahāpadānasutti, jedinoj sutti u prvima četirima nikāyama u kojoj se opisuju ta četiri susreta (no u pripovijesti o buddhi Vipassinu), nebesnici se ne spominju. Četiri su susreta tu prikazana gotovo kao slučajna. S

\footnotetext{
${ }^{655}$ DN ii. 156 (MPS 6. 10).

${ }^{656}$ DN 16, ii. 160-161 (MPS 6. 16).

${ }^{657}$ DN 16, ii. 163 (MPS 6. 22).

${ }^{658}$ DN 16, ii. 164 (MPS 6. 23).

${ }^{659} \mathrm{~V}$. poglavlje o odlasku u beskućništvo.
} 
druge strane, u Nidānakathi se ističe uloga koju su nebesnici odigrali u donošenju Gotamine odluke o odlasku od doma.

ĐātA. I. 59

Devatā „Siddhatthakumārassa abhisambhujjhanakālo āsanno pubbanimittam

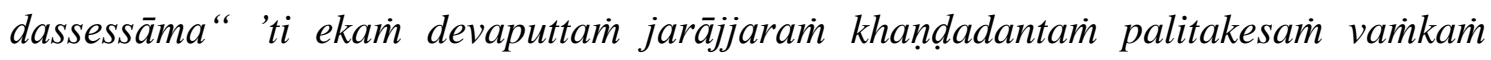
obhaggasarīram daṇdahattham pavedhamānam katvā dassesuṁ. Tam Bodhisatto c' eva sārathi ca passanti.

Prijevod

Nebesnici [pomisliše]: "Blizu je vrijeme probuđenja kraljevića Siddhatthe. Pokažimo prvo znamenje”. Pokazali su [mu] jednoga nebesničkoga sina učinivši ga nemoćnim od starosti, pokvarenih zubi, sijede kose, pogrbljenim, slomljena tijela, sa štapom u ruci $i$ drhtavim. Vidjeli su ga samo Bodhisatta i kočijaš.

Posredstvom se nebesnika pokazuju se i ostala znamenja, a nebesnici mu pomažu sve do trenutka odlaska iz palače. Dobar primjer brižnosti nebesnika u vrijeme Gotamina odlaska pruža i sljedeći primjer:

ĐātA. I. 64

Tadā kir' assa devatā purato sațthimim ukkāsahassāni dhārayimsu pacchato sațthim dakkhinapassato saț̣imì vāmapassato sațthim. Aparā devatā cakkavālamukhavațitiyam aparimāṇa ukkā dhārayimsu aparā devatā ca nāgasupaṇnādayo ca dibbehi gandhehi mālehi cuṇnehi dhūpehi pūjayamānā gacchanti [...]

Prijevod

U to su vrijeme, zaista, nebesnici ispred njega nosili šezdeset tisuća baklja, šezdeset [tisuća] iza [njega], šezdeset [tisuća] [njemu] s desne strane, šezdeset [tisuća] [njemu] s lijeve strane. Na rubu su svijeta neki nebesnici držali neizmjerne baklje, neki su nebesnici, nāge, krilata i druga bića koračali časteći ga božanskim miomirisima, vijencima [cvijeća], smrvljenim prahom i kâdom [...]

Kada je riječ o odlasku u beskućništvo, u Mahāvastuu postoje opisi koji ne uključuju četiri sudbonosna susreta i upletanje nebesnika. ${ }^{660}$ Međutim, u poglavlju u kojem se opisuju četiri

${ }^{660}$ Mv. i. $154-158$, ii. 117. 
susreta ističe se da su se starac, bolesnik, mrtvac i isposnik pojavili posredstvom nebesnika. ${ }^{661}$ Nebesnici mu se obraćaju u trenutku donošenja konačne odluke o napuštanju domaćinskoga života. Tako su mu, primjerice, nebesnici iz skupine Śuddhavāsa uputili sljedeće riječi:

Mv. ii. 158

kāle si mahāpuruṣa tuṣitakāyāc cyuto kāle si mātuḥ kukṣim okrānto kāle si jāto kālo ca te abhiniṣkramitum kālanirnāmasampanno ${ }^{662}$ cāsi mahāpuruṣa / bahu tvām janatā abhikāṃș̣anti karṣakā viya udakaparīkṣayā mahāmeghām //

Prijevod

Na vrijeme si, Mahāpuruṣo, napustio nebesa Tușita. Na vrijeme si sišao u majčinu utrobu, na vrijeme si rođen. Vrijeme ti je da napustiš dom. O, Mahāpuruṣo, došao si do obrata u pravo vrijeme! Mnogobrojni su koji te očekuju kao što ratari, za vrijeme suše, 663 [iščekuju] guste oblake.

Trenutak probuđenja u pālijskoj Vinayi, spomenutim suttama Mađđhimanikāye i Mahāpadānasutti nije obilježen pojavom nebesnika. Ipak, s vremenom je pobjeda nad Mārom postala neizostavan i vjerojatno najupečatljiviji dio pripovijesti o probuđenju. Čini se kako su se autori koji su kitili tu epizodu vodili mišlju prema kojoj je pobjeda to veća što je protivnik snažniji pa je Māra, u konačnici, postao iznimno moćan protivnik praćen stotinama tisuća sljedbenika i ratnika spremnih odvratiti budućega buddhu od njegova cilja. Pažnja posvećena upravo toj borbi dvojice protivnika, koja je u djelima kao što su Nidānakathā, Lalitavistara, Buddhaćarita i Mahāvastu izrazito slikovita, uzbudljiva i upečatljiva, svjedoči ne samo o golemoj popularnosti te pripovijesti već i o samoj namjeri autora kojima je cilj bio istaknuti da je Buddha nadmoćan Māri.

Kada je riječ o pokretanju kotača nauka, neizostavan je njegov dio pojava Brahmana Sahampatia koji Gotamu moli da propovijeda i širi znanje koje je stekao u noći probuđenja. Isticanje ponizne molbe Brahmana Sahampatia u isti je tren i svojevrsna nebeska autorizacija Gotamina propovijedničkoga poslanja ali i potvrda da je Gotama Buddha moćniji spasitelj od nebesnika. Također, za razliku od sutta pālijskoga kanona u kojima vijest o smrti svojih

\footnotetext{
${ }^{661}$ Mv. ii. 150 i d.

${ }^{662}$ Za kālajñāta ${ }^{\circ}$. V. Jones (1952/2006: 153, bilj. 7).

${ }^{663}$ udakaparīkșā. SED, str. 183.
} 
prijašnjih učitelja Gotama prima od nebesnika, u Mahāvastuu Probuđenomu pomoć nebesnika više nije potrebna.

U Mahāvastuu se dalje naglašava da su nakon prve propovijedi Buddhin nauk prihvatili mnogobrojni nebesnici koji su na taj način spašeni. ${ }^{664}$

Gotamin ulazak u konačnu nibbānu također je prilika za pojavu nebesnika i iskazivanje njihove ožalošćenosti. U Mahāparinibbānasutti, Brahaman Sahampati i gospodar nebesika Sakka posvećuju Gotami prigodne stihove u trenutku njegove parinibbāne. Nebesnici se u dva navrata upleću i u ceremoniju spaljivanja Gotamina tijela. ${ }^{665}$

Ukratko, neprestanim se upletanjem nebesnika u tijek života Gotame Buddhe dodatno ističe izuzetnost njegove pojave u svijetu, važnost njegova poslanja kao i nad-ljudski Gotamin status koji ga čini vrijednim pažnje nebesnika.

Tekstovi korišteni u ovome radu sadrže brojne primjere u kojima je Gotama Buddha prikazan ne samo kao vrijedan pažnje i pohvala nebesnika već i kao njima nadmoćan. Završne sutte drugoga dijela Dīghanikāye; Đanavasabha- (DN, sutta br. 18), Mahāgovinda- (DN, br. 19), Mahāsamaya- (DN, br. 20) i Sakkapañhasutta (DN, br. 21) ističu se kao skupina sutta u kojima je težnja za prikazivanjem Buddhine nadmoći nad nebesnicima posebno izražena. O tim suttama Rhys Davids (1910/2007: 235) kaže sljedeće:

We cannot, therefore, be surprised to find that this group of Suttantas all directed to the purpose of persuading the people that the gods were on the side of the reforming party, attained a lasting success.

Đanavasabhasutta i Mahāgovindasutta sadrže istovjetnu pohvalu nebesnika upućenu Gotami. U Đanavasabhasutti pred Gotamom se pojavljuje yakkha Đanavasabha, odnosno preminuli kralj Bimbisāra koji se nakon smrti ponovno rodio u svijetu nebesnika, ${ }^{666}$ dok se u Mahāgovindasutti pred Gotamom pojavljuje gandhabba. Oba nebesnika obavješćuju Gotamu da su mu sljedbenici ponovno rođeni u svijetu nebesnika i da svojim sjajem nadmašuju ostale nebesnike. Nebeski kralj Sakka i Brahman Sanamkumāra, zadovoljni priljevom novih nebesnika, istim stihovima iskazuju svoju radost i poštovanje spram Gotame i njegova nauka.

\footnotetext{
${ }^{664}$ V. npr. Mv. i. $174-176$.

${ }^{665}$ Usp. Mv. i. 65-66.

${ }^{666}$ Uvodni dio Đanavasabhasutte ima svoju paralelu u Mahāparinibbānasutti, u dijelu u kojem Gotama Ānandi pripovijeda sudbine redovnika i redovnica preminulih u mjestu zvanom Nādika (MPS 2.6 i d.).
} 
DN ii. $208=$ DN ii. $211=$ DN ii. $221=$ DN ii. 227

Modanti vata bho devā Tāvatimsā sahindakā,

Tathāgatam namassantā Dhammassa ca sudhammatam.

Nave va deve passantā vaṇnavante yasassino

Sugatasmim brahmacaryam caritvāna idhāgate,

Te añ̃̃e atirocanti vaṇnena yasasāyunā

Sāvakā Bhūri-paññassa visesūpagatā idha.

Idạ̣ disvāna nandanti Tāvatimsā sahindakā

Tathāgatam namassantā Dhammassa ca sudhammatan'ti.

Prijevod

Nebesnici se raduju, s Indrom Tridesettrojica,

Tathāgati se klanjaju, dobroukosti nauke,

Nove u nebu gledajuć, krasne sjajem i pojavom,

došle amo od Sugate, provevši život zavjeta.

Druge tu čak nadvisuju sjajem, vijekom i pojavom

učenici Višeznalca jer su postigli izvrsnost.

Ushićeni su vidjev to s Indrom Tridesettrojica,

Tathāgati se klanjaju, dobroukosti nauke.

Verzija pālijske Mahāgovindasutte susreće se i u Mahāvastuu. ${ }^{667}$ Od pohvalnih stihova koji se susreću u gore spomenutim suttama, u Mahāvastuu se susreće samo prvi stih:

Mv. iii. 203. 15-16

modaṃti bho punar devāḥ trayastrimśā saśakrakāḥ /

tathāgatam namasyantā dharmasya sukhadharmatā //

Prijevod

Nebesnici se raduju, s Śakrom Tridesettrojica,

Tathāgati se klanjaju, sretnoukosti nauke.

\footnotetext{
${ }^{667}$ Mv. iii. 197-224. U svome uvodu u prijevod Mahāgovindasutte Rhys Davids (1910/2007: 256) donosi tablicu paralelnih ulomaka. Jones (1956/2007: 193 bilj. 1) tvrdi: [...] the Mhvu. version is not translation from the Pali. Differences in the order of relation alone are sufficient to disprove the supposition that it is. Isto tvrdi i Rhys Davids (1910/2007: 257): It must have been from some such cognate recension, and not from our Päli text, that the Govinda story was Sanskritised. The diffrences between the Dīgha and the Mahāvastu are too great to have arisen at one stage. Sutta ima svoju paralelu u ĐātA. I. 45-46 i III. 469.
} 
Mahāsamayasutta sadrži podulju listu nebesnika i ostalih nebeskih bića koja očituju svoju naklonost Gotaminu nauku. Na samome se početku opisuje posjet nebesnika iz deset tisuća sustava svjetova Gotami koji u tome trenutku boravi u okolici Kapilavatthua. Tom prilikom jedan od nebesnika upućuje Gotami sljedeće riječi:

DN ii. 255

Ye keci Buddhaṃ saraṇaṃ gatāse na te gamissanti apāyam

Pahāya mānusam dehạ̣ deva-kāyam paripūressantīti. ${ }^{1668}$

Prijevod

Koji su god utočište u Buddhi uzeli neće [nakon smrti] u propast otići.

Napustiv ljudsko će tijelo nebeski zbor napuniti.

Isticanje izvrsnosti Gotamina nauka možda je ponajviše izraženo u Sakkapañhasutti u kojoj nebesnik Sakka, u konačnici, postaje preobraćenik i sljedbenik Gotamina nauka. ${ }^{669}$

U Mahāvastuu, očekivano, također postoje brojni primjeri isticanja Buddhine superiornosti nad nebesnicima. ${ }^{670}$

\subsection{Povećanje broja prethodnih buddha i prethodnih Buddhinih rođenja}

\subsubsection{Povećanje broja prethodnih buddha}

Gotama se Buddha dovodi u vezu i s drugim buddhama koji su se pojavljivali prije njega. ${ }^{671}$ Budući da je dhamma, koju je Gotama Buddha spoznao i proglasio, vječna i nepromjenjiva, ${ }^{672}$ otkrivali su ju prije njega i drugi, prijašnji buddhe. Mahāpadānasutta donosi listu od šest buddha koji su prethodili Gotami Buddhi. Prvi je u tome svojevrsnom rodoslovlju buddha Vipassin (skt. Vipaśyin) čiji je životopis u bitnome jednak Gotaminom, a slijede Sikhin (Śikhin), Vessabhū (Viśvabhū), Kakusandha (Krakuććhanda), Konāgamana (Konakamuni) i Kassapa

\footnotetext{
${ }^{668}$ Isti se stihovi susreću i u ĐātA. I. 97 (đātaka br. 1, Apaṇṇakađātaka).

${ }^{669}$ DN ii. 263-289. U Mahāvastuu postoji poglavlje posvećeno masovnom preobraćenju Asura (Mv. iii. 137-141).

${ }^{670}$ Npr. Mv. i 296, Mv. ii 4, 12, 17, 25, 259-260, 266, 286-287, 294, 296, 301, 314, 352-353, Mv. iii. 141 itd.

${ }^{671} \mathrm{Uz}$ sposobnost da se sjeti svojih prethodnih života, Gotama posjeduje i sposobnost da se prisjeti drugih, prijašnjih Buddha koji su se pojavljivali prije njega. V. DN ii. 15.

${ }^{672}$ Npr. MN iii. 6.
} 
(Kāśyapa). Prva se trojica spominju i u Suttavibhangi Vinayapițake ${ }^{673}$ dok se zadnja trojica spominju u Saṃyuttanikāyi ${ }^{674}$. Spomen se buddhe Kakusandhe nalazi i u Mađđhimanikāyi. ${ }^{675}$

Pripisujući izlaganje o prijašnjim buddhama Gotami, Mahāpadānasutta iznosi stereotipan prikaz životnoga tijeka šest Gotaminih prethodnika, navodeći vrijeme i mjesto njihova rođenja, imena roditelja, pripadnost kasti i porodici, vrstu stabla pod kojim je dosegnuto probuđenje, imena dvaju najvažnijih učenika, ime najbližega učenika (pratioca), ukupan broj arahanta i duljinu života. U sutti se nalazi i objašnjenje za Gotamino poznavanje života prethodnih buddha: Tathāgata je vrlo dobro prodro u korijene dhamme [...] a i nebesnici su mи to obznanili. ${ }^{676}$

Gotama potom iznosi detaljniji tijek života buddhe Vipassina koji je, kako piše Reynolds (1997: 25) model for or a model of the biography that we presently know as the biography of Gotama himself. Silazak s nebesa Tusita, rođenje obilježeno čudesnim pojavama, četiri sudbonosna susreta i odlazak u beskućništvo, probuđenje, poticanje nebesnika na obznanjivanje dhamme, prva propovijed i prikaz osnivanja redovničke zajednice elementi su životopisa buddhe Vipassina koji su po istome obrascu svoje mjesto dobili i u životopisu Gotame Buddhe.

S vremenom je broj prijašnjih Buddha sa šest narastao na dvadeset i četiri, koliko ih je nabrojano u Buddhavamsi, kasnijem kanonskom djelu, uvrštenome u Khuddakanikāyu. U uvodnome se dijelu Buddhavaṃse pripovijeda kako je Gotama, uviđajući da su među ljudima i nebesnicima malobrojni koji uviđaju moć i iznimnost buddhe, odlučio svojim moćima stvoriti raskošnu, dragim kamenjem ukrašenu i u zraku lebdeću promenadu (ratanaćaṅkama). ${ }^{677}$ Šetajući se naprijed i nazad, izvodi zadivljujuća čuda koja će poslužiti kao povod za Sāriputtinu molbu upućenu Gotami, a u kojoj ga moli da mu objasni kako je i pod kojim uvjetima izrekao zavjet da će postati Probuđeni te kako je stekao deset savršenstava. ${ }^{678} \mathrm{U}$ nastavku se iznose životi dvadeset i četiri Gotamina prethodnika, među kojima je, kao zadnjih šest, ubrojano i šest Gotaminih prethodnika koji se spominju u Mahāpadāna sutti. Imena Gotaminih prethodnika (isključujući zadnjih šest ranije spomenutih) jesu Dīpaṅkara, Koṇḍañ̃a, Mañgala, Sumana,

\footnotetext{
${ }^{673}$ Vin. iii. 7-9 (Vin. I. 3. 1-3).

${ }^{674} \mathrm{SN}$ ii. $190-193$.

${ }^{675} \mathrm{MN}$ i. 332.

${ }^{676}$ DN ii. 10: Tathāgatass' ev' esā bhikkhave dhamma-dhātu suppațividdhā... Devatā pi Tathāgatassa etam attham ārocesum.

${ }^{677}$ Bhv. I. 5 i d.

${ }^{678}$ Bhv. I. 76-77.
} 
Revata, Sobhita, Anomadassin, Paduma, Nārada, Padumuttara, Sumedha, Suđāta, Piyadassin, Atthadassin, Dhammadassin, Siddhattha, Tissa i Phussa.

Kao i u Mahāpadānasutti, o svakome su prijašnjem buddhi izneseni osnovni podatci o njegovu životu i okolnostima pod kojima se odigrao njegov susret s budućim Gotamom Buddhom. Pred svakim od svojih prethodnika budući Gotama obnavlja svoj zavjet, a svaki mu od njegovih prethodnika potvrđuje da će postati Probuđeni. Buddhavaṃsa je tako ne samo kronika Gotaminih prethodnika već i povijest njegovih egzistencija od vremena kada je kao isposnik Sumedha dao zavjet (abhinīhāra) tadašnjemu buddhi Dīpañkāri koji je prvi objasnio (vyākaraṇa) da će u dalekoj budućnosti Sumedha ispuniti svoj zavjet i, u svome posljednjem rođenju kao Gotama, doći do probuđenja. ${ }^{679} \mathrm{U}$ istome je poglavlju nabrojano i osam uvjeta ${ }^{680}$ koje mora zadovoljiti svatko na putu probuđenja (ațthadhammā) kao i deset savršenstava ${ }^{681}$. Dvadeset i šesto poglavlje posvećeno je životu Gotame Buddhe.

Bhv. XVI. 13-25

Nagarạ̣ Kapilavatthu me rājā Suddhodano pitā / mayhạ̣ janettikā mātā Māyādevī 'ti vuccati // Ekūnatiṃsavassani agāram ajjhaham vasiṃ / Rammo Surammo Subhako tayo pāsāda-m-uttamā // Cattārīsasahassāni nāriyo samalañkatā /

Bhaddakaccā nāma nārī Rāhulo nāma atrajo // Nimitte caturo disvā assayānena nikkhamim / chabbassaṃ padhānacāram acarị̣ dukkaraṃ aham //

Bārāṇasī Isipatane cakkaṃ pavattitam mayā / aham Gotamasambuddho saraṇam sabbapāṇinam //

Kolito Upatisso ca dve bhikkhū aggasāvakā / Ānando nām', upatțāko santikāvacaro mama //

Khemā Uppalavaṇṇā ca bhikkhunī aggasāvikā /

Citto ca Hatthālavako agg', upațthāk', upāsakā //

Nandamātā ca Uttarāa agg' upaț̣hik' upāsikā / aham assatthamūlamhi patto sambodhim-uttamam // Byāmappabhā sadā mayham soḷasahattham-uggatā /

\footnotetext{
${ }^{679}$ Bhv. II. 61-70.

${ }^{680}$ Bhv. II. 59.

${ }^{681}$ Bhv. II. 117-165.
} 
appaṃ vassasataṃ āyu idān', etarahi vijjati //

Tāvatā tiț̣̂māno', haṃ tāremi janatam bahum / thapayitvāna dhamm' ukkam pacchimam janabodhanam //

Aham pi na cirass', eva saddhim sāvakasañghato / idh', eva parinibbissam aggīvāhārasaìkhayā, //

Tāni ca atulatejāni imāni ca dasa balāni / ayañca guṇavaradeho dvattimsalakkhaṇācito // Dasadisā pabhāsetvā sataraṃīva chappabhā / sabbā samantarahessanti nanu rittā sabbasañkhārā 'ti //

Prijevod

Kapilavatthu moj je grad, otac mi kralj Suddhodana, A moju roditeljicu majku Māyā nazivaju.

Dvadesetdevet godina u domu ja provedoh svom. Ramma, Suramma, Subhaka bjehu tri dvora najudobnija gdje žena prekrasnih četrdeset bje tisuća.

Bhaddakaććā mi supruga, sinu ime bje Rāhula.

Vidjev četiri znamenja, odoh konju na leđima.

Mukotrpnih šest godina kročah ja putom napora.

U Benaresu pokrenuh Kotač, u Isipatani, Ja, Gotama, skroz Probuđen, zaklon sam svima bićima. Upatissa i Kolita učenika su prva dva. Ananda mi je pratitelj, uvijek uz mene najbliži. Uppalavaṇnā, Khemā još, učenice su najbolje. Hatthālavaka, Ćitta ktom, prvi pridošli laici. Nandamātā i Uttarā prve su žene-laici. Probuđenje najvrsnije stekoh pod stablom assathe. Svjetlokrug moj se prostire uvijek do šesnaest lakata. Sada je vijek moj životni svega stotinu godina. Sada toliko živeći, prevedoh k spasu premnoge, Podigavši luč nauke, za budnost svijeta budućeg. Zajednicom ću praćen ja učenika, ne zadugo, 
Zgasnut ko oganj ovdje baš kada se ogrijev iscrpi.

Ovi bez premca plameni i ovih deset moći mi,

i tijelo puno odlika s trideset dva obilježjā,

Šest svjetlosti obasjavši zrakama deset smjerova,

Sve će nestati! Nisu l' sve ustrojnice opustjele?

U dvadesetisedmome se poglavlju donose imena buddha koji su prethodili Dīpañkari (Tạ̣hañkara, Medhañkara, Saraṇaṅkara), ${ }^{682}$ međutim njihovi se životopisi u Buddhavaṃsi ne iznose. U istome se poglavlju donosi i ime budućega buddhe Metteye (skt. Maitreya) ${ }^{683}$ koji se spominje i u Ćakkavattisīhanādasutti Dīghanikāye. ${ }^{684}$

Valja istaknuti i da se u Buddhavaṃsi nerijetko ističe neizmjerno Gotamino suosjećanje spram osjećajućih bića koje je glavni razlog stupanja na put prema probuđenju. ${ }^{685}$

Na Buddhavamisu se izravno oslanja i poziva Nidānakathā čiji je prvi dio posvećen prethodnim buddhama. Nidānakatha u svome izlaganju u listu Gotaminih prethodnika uključuje i trojicu buddha spomenutih u dvadesetisedmome poglavlju Buddhavamse iako, kao ni Buddhavaṁsa, ne iznosi njihove životopise. Neizmjerno dugo razdoblje, od vremena buddhe Dīpañkare i zavjeta Sumedhe pa do trenutka kada budući buddha silazi s nebesa Tusita u utrobu kraljice Māye, čime se otvara drugi dio Nidānakathe, vremenski je okvir u kojem se zbivaju pripovijesti o Gotaminim prijašnjim egzistencijama, odnosno đātake. Uzme li se u obzir golema uloga koju je Nidānakathā imala u oblikovanju kasnijih životopisa Gotame Buddhe, ni značenje se Buddhavamise nikako ne smije podcijeniti. Naime, povećanje broja prethodnih buddha, razvoj tradicije koja prepričava Buddhine prethodne egzistencije, kao i lista deset savršenstava, novi su elementi koji se u pālijskome kanonu javljaju tek s uvrštenjem Buddhavaṃse u kanonski korpus.

U Mahāvastuu je prisutna ideja o beskonačnome broju buddha, a na jednom ih je mjestu pobrojano pet stotina poimence. ${ }^{686}$ Za razliku od pālijske Mahāpadānasutte, u kojoj je životopis buddhe Vipassina iznesen kao odraz ili uzor za Gotamin životopis, u Mahāvastuu je, kao i u Buddhavamisi, najveća pažnja, kada govori o prethodnicima, posvećena životopisu buddhe Dīpañkare, koji se proteže od njegove odluke da siđe u utrobu kraljice Sudīpe pa sve do odluke

\footnotetext{
${ }^{682}$ Bhv. XXVII. 1.

${ }^{683}$ Bhv. XXVII. 19.

${ }^{684}$ DN iii. 76.

${ }^{685}$ Npr. Bhv. I. 3, 20, 22, 40, 76, II. 57, XXVI. 7, XXVII. 19, XXVIII. 13.

${ }^{686}$ Mv. i. 136-141. Gautamini se prethodnici nabrajaju i u Mv i. 46-55, 57-63, iii. 226-250. V. i Mv. i. $124-126$.
} 
o pokretanja Kotača nauke. ${ }^{67}$ Životopisi su Gautame Buddhe i buddhe Dīpañkare u bitnome identični. U Mahāvastuu se navodi kako je u vrijeme toga buddhe budući Gotama bio mladi i vrlo učeni brahman, ovdje pod imenom Megha. Izrekavši svoj zavjet i dobivši potvrdu da će uistinu postati Probuđeni, Megha se uzdigao visoko u zrak i, lebdeći u zraku, prebacio ogrtač preko jednoga ramena, sklopio ruke i iskazao svoje poštovanje buddhi Dīpañkari i njegovim učenicima. Slijede potom opisi čudesnih pojava koji svoje paralele imaju i u pālijskome kanonu. ${ }^{688}$

\subsubsection{Povećanje broja prethodnih Buddhinih života i bujanje đātaka}

Opravdanje ili motiv za nastanak tradicije u kojoj se prepričavaju prethodni životi Gotame Buddhe nalazi se u njegovoj sposobnosti prisjećanja prošlih egzistencija, a koju je stekao u noći probuđenja:

I onda, kada je moja usredotočena svijest postala pročišćena, jasna, neumrljana, neprikliještena, omekšana, podatna, postojana i staložena, usmjerio sam [ju] prema spoznaji sjećanja na ranije živote. Sjetio sam se, tada, mnogovrsnih ranijih života, odnosno, jedno rođenje, dva rođenja, tri rođenja, četiri rođenja, pet rođenja, deset rođenja, dvadeset rođenja, trideset rođenja, četrdeset rođenja, pedeset rođenja, stotinu rođenja, tisuću rođenja [...] Tamo sam se tako i tako zvao, bio takva i takva podrijetla, takva i takva staleža, takve i takve ishrane, takvo je i takvo bilo moje iskustvo sreće i tuge, takva je i takva bila duljina moga života, a tu preminuvši ondje sam se rodio. ${ }^{689}$

Đātake, pripovijesti o prethodnim životima, imaju karakterističnu strukturu; na samome se početku donosi “priča iz sadašnjosti” (paććuppannavatthu) u kojoj se prepričavaju okolnosti u kojima je Buddha iznio događaj iz nekoga od svojih prijašnjih rođenja, potom slijedi opis toga događaja u "priči iz prošlosti” (atītavatthu). Uklopljeni u priču iz prošlosti ili nakon nje, nalaze se kanonski stihovi ( $g \bar{a} t h \bar{a})$ popraćeni komentarom (veyyākaraṇa). Te su dvije priče povezane svojevrsnim zaključkom (samodhāna) u kojem se povezuju i identificiraju likovi iz sadašnjosti i prošlosti.

\footnotetext{
${ }^{687}$ Mv. i. $193-231$.

${ }^{688}$ Mv. i. $240=$ DN ii. 15 , AN ii. 130-132, MN iii. 124. Za imena pojedinih buddha pred kojima je budući Gautama izrekao svoj zavjet v. niže.

${ }^{689}$ MN i. 22. Usp. SN iii. 21, 204, MN 26, i. 167, SN iv. 13, DN 14, ii. 10, MN 39, i. 278. Sposobnost prisjećanja prošlih egzistencija (pubbenivāsānussati, skt. pūrvanivāsānusmrtit) jedno je od viših znanja koja se mogu steći intenzivnom meditacijom. Pālijski kanon sadrži primjere u kojima i drugi usavršeni pojedinci imaju sposobnost prisjetiti se svojih prethodnih egzistencija, v. npr. Mārattađanīyasutta (MN, sutta br. 50). Za izvornik v. poglavlje Probuđenje.
} 
U đātakama se prati put bodhisatte (skt. bodhisattva), odnosno budućega Buddhe, koji u svojim prethodnim životima, bilo kao čovjek, bilo kao životinja, usavršava neku od vrlina koje će ga u konačnici, u zadnjoj egzistenciji koju će provesti kao Gotama Buddha, dovesti do probuđenja i potpuna oslobođenja. Valja napomenuti i da u pojedinim đātakama bodhisatta može imati sasvim nevažnu ulogu, odnosno da se pojavljuje kao sporedni lik ili puki promatrač događaja opisanih u đātaki. ${ }^{690}$

U prve dvije košare pālijskoga kanona pripovijesti o Gotaminim prethodnim egzistencijama nisu osobito zastupljene, ${ }^{691}$ a valja naglasiti i da se u tome dijelu kanona Gotama, u svojim prijašnjim egzistencijama, nikada ne pojavljuje kao životinja. ${ }^{692}$

Pripovijesti iz prošlosti u tome dijelu kanona mogu se podijeliti u nekoliko skupina. ${ }^{693}$ U prvoj su skupini pripovijesti bez stihova i u kojima se Gotama ne poistovjećuje ni s jednim od likova, međutim to su pripovijesti koje svoju paralelu imaju u kanonskoj knjizi đātaka. Primjeri se takvih pripovijesti mogu pronaći u Pāyāsisutti, ${ }^{694}$ Samyuttanikāyi $^{695}$ i Vinayapițaki ${ }^{696}$.

U tome se dijelu kanona nalaze i pripovijesti sa stihovima koji se susreću i u kanonskoj knjizi đātaka, ali u kojima se Gotama ne poistovjećuje ni s jednim od likova. Tako npr. u Sakkasamyutti Gotama redovnicima pripovijeda o bitci koja se je davno u prošlosti odigrala između deva i asura i u kojoj su, u konačnici, pobijedili nebesnici na čelu sa Sakkom. ${ }^{697}$ Uklopljeni u tu pripovijest nalaze se i stihovi koji se nalaze u Kulāvakađātaki u kojoj se Gotama poistovjećuje sa Sakkom. ${ }^{698}$

U Mahāsudassanasutti (DN, sutta br. 17), Makhādevasutti (MN, br. 83), Mahāgovindasutti (DN, br. 19), Kūṭadantasutti (DN, br. 5) i Ghațīkārasutti (MN, br. 81)

\footnotetext{
${ }^{690}$ Za primjere takvih đātaka v. Appleton (2010: 36-37).

${ }^{691}$ Popis đātaka koje se nalaze u starijim dijelovima kanona donio je Rhys Davids (1903/1911: 195). Detaljnije u Appleton (2010: 47-51). U starijim dijelovima kanona postoje i pripovijesti o Gotaminim prijašnjim egzistencijama a koje se ne susreću u zbirci đātaka. V. u DN i. 127 i d., AN i. 110 i d.

${ }^{692}$ Izuzetak je pripovijest koja se susreće u Vin. iv. 6, 1 gdje se implicira da je bik koji se u njoj pojavljuje Gotama u svojoj prethodnoj egzistenciji.

${ }^{693}$ Podjela se oslanja na Appleton (2010: 47 i d.).

${ }^{694}$ DN ii. 342-349 (DN, sutta br. 23). Redovnik Kassapa daje princu Pāyāsiu parobolu kojoj je svrha ukazati na opasnost koja slijedi iz zanemarivanja ispravnoga djelovanja u ovome svijetu. Parabola se preobličena u đātaku nalazi u ĐātA. I. 95.i d. (br. 1, Apaṇṇakađātaka).

${ }^{695}$ SN v. $146-148$ = ĐātA. II. 58 i d. (br. 168, Sakuṇagghiđātaka).

${ }^{696}$ Vin. i. 337 i d. (Mahāvagga X) = ĐātA. III. 211 i d. (br. 371, Dīghitikosalađātaka).

${ }^{697} \mathrm{SN}$ i. 222 i d.

${ }^{698}$ ĐātA. I. 198 i d. (br. 31). Za ostale primjere v. Appleton (2010: 47, bilj. 20).
} 
Gotama se poistovjećuje s nekim velikim kraljem, brahmanom ili mudracem iz prošlosti, međutim, valja istaknuti da se u tim pripovijestima Gotama u svojoj prijašnjoj egzistenciji ne naziva bodhisattom $\mathrm{i}$ da svrha tih pripovijesti nije ilustracija postepenoga napredovanja $\mathrm{i}$ usavršavanja bodhisatte. Takve se pripovijesti stoga mogu nazivati đātakama samo uz dozu opreza. ${ }^{699}$

Anālayo je (2012) analizirao pripovijesti iz prošlosti u prve četiri nikāye Suttapiṭake kao i parabole u Vinayapițaki. Ističe da su te pripovijesti imale za svrhu pojašnjavanje pojedine točke nauke ili ukazivanje na ispravan način djelovanja. Usporedio ih je potom s đātakama u Đātakaț̣havaṇnani i istaknuo da su takve pripovijesti postale đātakama u užem smislu tek poistovjećivanjem nekoga od likova s bodhisattom (2012: 89). ${ }^{700}$

Appleton (2010: 51) također naglašava razliku između đātaka u prve četiri nikāye i kasnijih đātaka u Đātakaț̣havaṇṇani:

The idea that jātakas demonstrate the Bodhisatta's gradual path to perfection is not found in such texts, rather the stories show how special the Buddha is, and what impact he has had on the world through his presence and teachings.

Značenje koje đātake imaju u životopisu Buddhe dolazi do izražaja posebno u Nidānakathi gdje životopis Gotame Buddhe započinje njegovim zavjetom i stupanjem na put bodhisatte i završava darivanjem gaja Đetavana kod Sāvatthī (skt. Śrāvastī), u kojem je Gotama, prema buddhističkoj predaji, ispričao većinu pripovijesti o svojim prethodnim rođenjima. Životopis Gotame u njegovoj posljednjoj egzistenciji, iznesen u drugome i trećem dijelu Nidānakathe, vodi dakle do vremena i mjesta u kojem su đātake iznesene osiguravajući im tako kontekst i uvjerljivost.

U prvome dijelu Nidānakathe, u kojem se prepričavaju događaji iz daleke prošlosti, iznesene su okolnosti pod kojima je budući Gotama Buddha izrekao svoj zavjet pred svakim od svoja dvadesetičetiri prethodnika. Slijedi lista prethodnih Gotaminih egzistencija i prethodnih buddha kakva se susreće u prvome dijelu Nidānakathe.

\footnotetext{
${ }^{699}$ Samo Mahāsudassanasutta (DN, sutta br. 17) i Makhādevasutta (MN, sutta br. 83) imaju svoju paralelu u kanonskim đātakama. DN ii. 169 i d. = ĐātA. I. 391 i d. (đātaka br. 95, Mahāsudassanađātaka), MN ii. 74 i d. = ĐātA. I. 137 i d. (br. 9, Makhādevađātaka), ĐātA. VI. 95 i d. (br. 541, Nimiđātaka). Gotama se u svojoj prijašnjoj egzistenciji kao Mahāgovinda spominje u Nidānakathi (ĐātA. I. 45), međutim ta se đātaka ne nalazi u kanonskoj knjizi Đātaka.

${ }^{700}$ Usp. i Cummings (1982: 20): Most Jātakas at the time of Bhārhut were simply used as parables in illustration of the Doctrine, and did not yet carry any specific significance as stories of the Buddha's previous incarnations.
} 


\begin{tabular}{|c|c|}
\hline Bodhisatta & Prijašnji buddha \\
\hline Brahman Sumedha & Dīpaṅkara \\
\hline Sveopći vladar Viđitāvin & Koṇḍañña \\
\hline Brahman Surući & Mangala \\
\hline Kralj nāga Atula & Sumana \\
\hline Brahman Atideva & Revata \\
\hline Brahman Ađita & Sobhita \\
\hline Vrhovni yakkha & Anomadassin \\
\hline Lav & Paduma \\
\hline Trapljenik & Nārada \\
\hline Đațila Mahratta & Padumuttara \\
\hline Brahman Uttara & Sumedha \\
\hline Sveopći vladar & Suđāta \\
\hline Brahman Kassapa & Piyadassin \\
\hline Trapljenik Susima & Atthadassin \\
\hline Kralj nebesnika Sakka & Dhammadassin \\
\hline Trapljenik Mañgala & Siddhattha \\
\hline Ratnik Suđāta & Tissa \\
\hline Ratnik Viđatavin & Phussa \\
\hline Kralj nāga Atula & Vipassin \\
\hline Kralj Arindama & Sikkhin \\
\hline Kralj Sudassana & Vessabhū \\
\hline Kralj Khema & Kakusandha \\
\hline Kralj Pabbata & Koṇagamana \\
\hline Brahman Đotipāla & Kassapa \\
\hline
\end{tabular}

U Nidānakathi se navodi kako je budući Gotama proveo četiri neizmjerna razdoblja i sto tisuća kalpa usavršavajući savršenstva koja će ga u konačnici dovesti do posljednjega rođenja u kojem će postati Probuđeni. ${ }^{701}$ Nidānakatha dalje navodi primjere prijašnjih Gotaminih života u

${ }^{701}$ ĐātA. I. 44: Tattha amhākam Bodhisatto Dīpaṃkarādīnam catuvīsatiyā Buddhānaṃ santike adhikāram karonto kappasatasahassādhikāni cattāri asaṃkheyyāni āgato. 
kojima je uvježbavao svako od deset savršenstava (pāramitā, transcendentnih / odrješujućih krjeposti).

\begin{tabular}{|c|c|}
\hline Savršenstva & Prijašnji životi \\
\hline Darežljivost (dāna) & $\begin{array}{l}\text { Brahman Akkati, brahman Sañkha, kralj Dhanañđaya, } \\
\text { kralj Mahāsudassana, Mahāgovinda, kralj Nimi, } \\
\text { kraljević Ćanda, trgovac Visayha, kralj Sivi, plemeniti } \\
\text { zec, kraljević Vessantara }\end{array}$ \\
\hline Ćudoređe (sīla) & $\begin{array}{l}\text { Kralj nāga Sīlavat, kralj nāga Ćampeyya, kralj nāga } \\
\text { Bhūridatta, kralj nāga Ćhaddanta, kraljević Alīnasattu, } \\
\text { kralj nāga Sañkhapāla }\end{array}$ \\
\hline Samoodreknuće (nekkhama) & $\begin{array}{l}\text { Kraljević Somanassa, kraljević Hatthipāla, mudrac } \\
\text { Ayoghara, kralj Sutasoma }\end{array}$ \\
\hline Mudrost (pañña) & $\begin{array}{l}\text { Mudrac Vidhura, mudrac Mahāgovinda, mudrac } \\
\text { Kuddāla, mudrac Araka, isposnik Bodhi, mudrac } \\
\text { Mahosadha, mudrac Senaka }\end{array}$ \\
\hline Napor/ hrabrost (viriya) & Kralj Mahāđanaka \\
\hline Strpljivost (khanti) & Isposnik Khantivāda \\
\hline Iskrenost/ istinoljubivost (saćća) & Kralj Sutasoma \\
\hline Odlučnost (adhițthāna) & Mūgapakkha \\
\hline Dobrohotnost (mettā) & Kralj Benaresa \\
\hline Ravnodušje (upekhā) & Goli isposnik \\
\hline
\end{tabular}

Taj je pregled samo sažetak, a za puni prikaz Nidānakathā upućuje na Ćariyāpiṭaku, djelo mlađega postanka i uvršteno u Khuddakanikāyu. ${ }^{702}$ Ćariyāpitaka je podijeljena u tri dijela i sadrži ukupno trideset $\mathrm{i}$ pet đātaka u stihu. U prvome se dijelu nalazi deset pripovijesti posvećenih veličanju savršenstva u darežljivosti, u drugome deset pripovijesti posvećenih ćudoređu dok se u trećem dijelu nalazi petnaest pripovijesti posvećenih savršenstvu odricanja od svjetovna (pet pripovijesti), odlučnosti (jedna pripovijest), dobrohotnosti (dvije pripovijesti), iskrenosti (šest pripovijesti) i ravnodušju (jedna pripovijest). U Ćariyāpițaki nema primjera za tri savršenstva (pañ̃̄a , viriya, khanti).

\footnotetext{
702 ĐātA. I. 47.
} 
U Mahāvastuu je prisutna zamisao o četirima stupnjevima u razvoju bodhisattve i o deset boravišta $(\text { bhūmi })^{703}$ kao i lista od šest savršenstava, ${ }^{704}$ a đātake su dominantna književna vrsta. Gotovo svaki događaj iz Buddhina života postaje prilikom da se pokaže kako je Buddha, $\mathrm{u}$ istome događaju i u nekom prethodnom rođenju već sudjelovao. To, moglo bi se reći, nekontrolirano bujanje đātaka, koje često prekidaju izlaganja i od kojih se mnoge prepričavaju po nekoliko puta (a katkad i u izmjenjenu obliku) čini tekst Mahāvastua teško čitljivim, a na pojedinim mjestima čak i nerazumljivim. Budući da su đātake u Mahāvastuu izrazito zastupljene i da naglasak stavljen na prethodne Buddhine egzistencije predstavlja jedan od najizraženijih načina proširivanja njegova životopisa, niže će se dati njihov prikaz te ukazati na paralele s pālijskom knjigom Đātaka. Valja međutim naglasiti da se, kada je riječ o pripovijestima o prethodnim egzistencijama, u Mahāvastuu susreće nekoliko skupina tekstova. ${ }^{705}$ Upravo zato što se na tim skupinama tekstova može naslutiti razvoj književnoga roda đātaka, pojavu širenja Buddhina životopisa na prethodne živote neću oslikati polazeći od pālijske zbirke đātaka u Đātakaț̣havaṇnani nego na primjerima iz Mahāvastua.

1) Bodhisattva u dijelovima teksta u kojima se nabrajaju prethodni buddhe i okolnosti pod kojima je izrekao svoj zavjet

U Mv. i. 1-4 nabrajaju se četiri stupnja u razvoju bodhisattve. To su prakrtićaryā (stupanj u kojem bodhisattva živi “običnim” životom u domaćinstvu), praṇidhānaćaryā (stupanj u kojem bodhisattva izriče zavjet), anulomaćaryā (stupanj u kojem živi u skladu sa zavjetom) i anivartanaćaryā (stupanj u kojem ne postoji mogućnost da bodhisattva odustane od puta i ne dosegne probuđenje). U tome se dijelu Mahāvastua navodi kako je u prvome stupnju bodhisattva bio univerzalni vladar (ćakravartin) za vrijeme buddhe Aparāđitadhvađe. Na drugome je stupnju bodhisattva bio bogati trgovac koji je zavjet dao buddhi Śākyamuniu. Na trećem stupnju, ponovno kao univerzalni vladar, dao je zavjet buddhi Samitāvinu, dok je na četvrtome stupnju kao mladić Megha dao zavjet buddhi Dīpankari. Također, navodi se kako je buddha Sarvābhibhū prorekao redovniku Abhiđitu kako će za sto tisuća kalpa, u rođenju kao Gautama Śākyamuni, postati Probuđeni.

\footnotetext{
${ }^{703}$ Mv. i. 63-157. Kada je riječ o deset boravišta ili polja Jones (1949/2007a: xiii) piše: [I]t would seem that the section on the ten bhūmis was inserted only because it was the policy of the compilers to include in the Mahāvastu every piece of Buddhistic lore that they came across. It is introduced abruptly, and certain inconsistencies in the recital show that it was not really understood.

${ }^{704} \mathrm{~V}$. gore.

${ }^{705}$ Sažetak se đātaka u Mahāvastuu nalazi i u Appleton (2016).
} 
U Sūtri o mnogobrojnim buddhama (Mv. i. 46-54) navodi se kako je budući Gautama pod imenom Puṣpa štovao tri stotine buddha, ali ni jedan od njih nije prorekao njegovo probuđenje. U ovome dijelu Mahāvastua bodhisattva izriče zavjet kao bogati trgovac buddhi Śākyamuniu, kao univerzalni vladar buddhi Samitāvinu, uz poklon od osamdeset palača izgrađenih od sandalovine izriče zavjet buddhi Guruu, kao kralj Arka izriče zavjet buddhi Parvati i, na samome kraju poglavlja, izriče, po peti put, zavjet pred buddhom Ratanendrom.

U poglavlju o posjetu nebesnicima iz skupine Śuddhavāsa (Mv. i. 54-63) Gautama redovniku Mahāmaudgalyāyani nabraja prethodne buddhe koji su mu potvrdili da će u budućnosti postati Probuđeni. Gautama tvrdi da mu je potvrdu dalo tri stotine koția buddha zvanih Śākyamuni, osam stotina buddha zvanih Dīpañkara, osam tisuća buddha zvanih Pradyota, tri koția buddha zvanih Puṣpa, osamnaest tisuća zvanih Māradhvađa, pet stotina zvanih Padmottara, devedest tisuća zvanih Kāśyapa, petnaest tisuća zvanih Pratāpa, dvije tisuće zvanih Kauṇdinya i osamdeset tisuća pratyekabuddha. Spominje se i Gautamino darivanje buddhe Aparāđitadhvađe u životu kada je bio sveopći vladar Drịịgadhanu i darivanje buddhe Ratne (Ratnavan) pred kojim je izrekao zavjet i dobio potvrdu da će postati Probuđeni.

Mv. i. 63-93 sadrži deset poglavlja o boravištima (bhūmi). U prva se dva veličaju vrline bodhisattva, ali se ne iznose njihovi primjeri. U poglavlju o trećem boravištu navodi se osam primjera bodhisattvine darežljivosti u zamjenu za riječ mudrosti (Mv. i. 91-95). U sažetku se navode još četiri dodatna primjera. U poglavlju o četvrtome polju tvrdi se da se sve đātake odvijaju za vrijeme bodhisattvina boravka u osmome boravištu (Mv. i. 105). U poglavlju o petome boravištu (Mv. i. 110-120) nabraja se deset Gautaminih prethodnih egzistencija u kojima je darivao buddhe i izrekao zavjet. U tim je prethodnim egzistencijama Gautama bio trgovac (ondašnji je buddha bio Yaśavrata), sveopći vladar Dharaṇīṃdhara (buddha Sudarśana), sveopći vladar Aparāđita (buddha Nareśvara), ministar Viđaya (buddha Suprabha), sveopći vladar Aćyuta (buddha Ratanaparvata), sveopći vladar Priyadarśana (buddha Kanakaparvata), kralj Durđaya (buddha Puṣpadanta), kralj Ćaturañgabala (buddha Lalitavikrama) i kralj Mṛgapatisvara (buddha Ratanaćūḍa).

U poglavlju o buddhi Mañgali (Mv. i. 248-252) Gautama tvrdi da je u njegovo vrijeme izrekao zavjet kao kralj nāga Atula.

U poglavlju o prijašnjim buddhama u Mv. iii. 224-250 nabrajaju se prethodni buddhe među kojima se usput spominju i buddhe koje je darivao budući Gautama u nekoj od svojih prijašnjih egzistencija. 
2) Pripovijesti o Gautaminim prethodnim rođenjima koja se u Mahāvastuu ne nazivaju đātakama ili nisu đātake u užem smislu

Pripovijesti o Abhiyi (bodhisattva) u Mv. i. 34-45 iznosi nebesnik iz skupine Śuddhavāsa, ali likove iz prošlosti s likovima iz sadašnjosti povezuje Gautama.

U poglavlju o sedmome polju (Mv. i. 127-136) nalazi se pet pripovijesti o Gautaminim prethodnim rođenjima kojima je svrha pokazati kako se bodhisattve uvijek zalažu za nenasilje. Bodhisattva se pojavljuje kao kralj Kuśa, kralj nāga Ugra, lav, predvodnik karavane trgovaca i kralj čija je supruga uhvaćena u preljubu. Pripovijesti iznosi redovnik Mahākatyāyana.

U poglavlju o pošastima u Veśālī (Mv. i. 283-290) nalaze se tri pripovijesti o Gautaminim prijašnjim egzistencijama od kojih se samo zadnja naziva đātakom. ${ }^{706}$ Sve tri za svrhu imaju pokazati kako je Gautama u prošlosti spasio grad od kuge. U prvoj se Gautama poistovjećuje s mudracem Rakṣitom, u drugoj sa slonom, a u posljednjoj s bikom. U prvoj se pripovijesti nalaze stihovi koji svoju paralelu imaju u ĐātA. IV. 72 i d. (br. 453, Mahāmañgalađātaka). ${ }^{707}$

Poglavlje o buddhi Dīpaṅkari (Mv. i. 193-248) obuhvaća pripovijest o Meghi i Meghadatti, u kojoj se opisuju okolnosti pod kojima je Megha (budući Gautama) izrekao svoj zavjet pred buddhom Dīpañkarom. Likove iz prošlosti i sadašnjosti povezuje Gautama, ali nedostaje priča iz sadašnjosti.

U poglavlju o Buddhinu posjetu Veśâlī (Mv. i. 267-270) redovnik Vāgīśa pripovijeda kako je u prošlosti Gautama bio brahman koji je natkrio stūpu prethodnoga buddhe dok je Vāgīśa bio učenik toga brahmana.

Pripovijest o Ghațikāri i Đyotipāli (Mv. i. 317-338) iznosi Gautama, ali na njenu kraju nema povezivanja likova iz prošlosti i sadašnjosti. U Mahāvastuu je okarakterizirana kao vyākaraṇa.

U poglavlju o povijesti Gaja jelena (Mv. i. 355-366) nalazi se pripovijest o kralju jelena Nyagrodhi. Iako ta pripovijest ima svoju paralelu u ĐātA. I. 145 i d. (br. 12, Nigrodhamigađātaka), u Mahāvastuu se ne naziva đātakom. Nyagrodha se ne poistovjećuje s Bodhisattvom.

U pripovijesti o Padumāvatī (Mv. iii. 153-172), koju iznosi Gautama, Bodhisattva je vidjelac Māṇḍavya. Iako ima obilježja đātake, u Mahāvastuu je okrakterizirana kao padumāvatīye parikalpa.

\footnotetext{
706 V. niže.

${ }^{707}$ V. Jones (1949/2007a: 237, bilj. 1).
} 
Pripovijest u Mv. iii. 172-175 u kojoj se objašnjava razlog za Rāhulin ostanak u majčinoj utrobi tijekom šest godina naziva se pürvayoga.

Mahāgovindīyasūtra (Mv. iii. 197-224) svoju paralelu ima u pālijskome kanonu (DN 19), ${ }^{708}$ a Mahāgovinda se spominje i u ĐātA. I. 45-46 i ĐātA. III. 469 i d. (br. 424, Ādittađātaka). Iako ju iznosi Gautama koji se na njezinu kraju poistovjećuje s brahmanom Govindom i unatoč činjenici da se u Mahāvastuu tvrdi da je riječ o prethodnoj egzistenciji Blaženoga, naziva se sūtrom.

U pripovijesti o Sarvaṃdadi (Mv. iii. 250-254) Bodhisattva je (iako se to izričito ne navodi) milostivi i darežljivi kralj Sarvaṃdada pred kojim nebesnik Śakra stvara pakao ispunjen darežljivim i milosrdnim bićima u želji da ga obeshrabri. Pripovijest svoju paralelu ima u đātaki o kralju Viđitāvinu. ${ }^{709}$

Pripovijest o Kṣāntivādinu (Mv. iii. 356-361) svoju paralelu ima u ĐātA. III. 59 i d. (br. 313, Khāntivādiđātaka), međutim u Mahāvastuu se ne zove đātakom. Izostaje poistovjećivanje likova iz prošlosti s onima iz sadašnjosti.

3) Đātake koje se tako zovu, ali u kojima izostaje lik bodhisattve

U Anagaṇađātaki (Mv. ii. 271-276) Gautama objašnjava bogatstvo domaćina Đyotiṣke kao posljedicu zasluga stečenih u ranijoj egzistenciji.

Prvom se đātakom o Āđñāti Kauṇ̣̣inyi (Mv. iii. 347-349) tvrdi da je Āđãāta prvi razumio sadržaj Prve propovijedi budući da je u nekoj od svojih ranijih egzistencija iskazao pomoć pratyekabuddhi.

Yaśodađātaka (Mv. iii. 413-415) pripovijest je o prijašnjoj egzistenciji laika Yaśode u kojoj je, iskazavši poštovanje pratyekabuddhi Bhadriki, zaslužio znanja i moći.

Đātaka o trojici braće Kāśyapa (Āyuṣmantānāṃ uruvilvākāśyapa-nadīkāśyapagayākāśyapānāṃ đātaka) u Mv. iii. 432-434 pripovijeda o trojici braće koji su živjeli za vrijeme buddhe Puṣpe. Braća su štovala buddhu, a nakon njegove su mu smrti podigli stūpu, čime su stekli zasluge.

4) Đātake u užem smislu

Triśakunīyađātaka ili đātaka o tri ptice (Mv. i. 271-283) donosi pripovijest o kralju Brahmadatti kojega savjetuju tri ptice: sova (Ānanda), śārika (Śāriputra) i papiga (bodhisattva). Svoju paralelu ima u ĐātA. V. 109 i d. (br. 521, Tesakuṇađātaka).

\footnotetext{
${ }^{708}$ V. gore.

${ }^{709}$ V. niže.
} 
Ṛṣabhasyađātaka ili đātaka o biku treća je pripovijest u poglavlju o prijašnjim pošastima u Veśālī (Mv. i. 288-290). Gautama se na njezinu kraju poistovjećuje s bikom. Kralj Bimbisāra ondašnji je kralj Añga.

U đātaki o darivanju ogrlice Yaśodhari (Śrīyaśodharāyehārapradānađātaka) u Mv. ii. 67-69, Gautama se poistovjećuje s kraljem koji vrijednom ogrlicom dariva glavnu kraljicu. Đātaka naizgled nema moralnu pouku ni paralelu u pālijskim izvorima.

U priči iz sadašnjosti u đātaki o Yaśodhari kao tigrici (Śrīyaśodharāyevyāghrībhūtāyeđātaka) koja se nalazi u Mv. ii. 68-72, pripovijeda se kako su nakon Gautamina odlaska u isposništvo Yaśodharu zaprosili Devadatta i Sundaranda. U priči iz prošlosti Yaśodhara je tigrica koja odbija slona (Devadatta) i bika (Sundaranda). Za supruga bira lava s kojim se Gautama poistovjećuje. Đātaka nema svoju paralelu u pālijskim izvorima.

Dharmpālađātaka (Mv. ii. 77-83), u kojoj se Gautama poistovjećuje s brahmanom Brahmāyusom koji odbija povjerovati da mu je sin Dharmapāla stradao (Rāhula), nalazi se i u ĐātA. IV. 50 i d. (br. 447, Mahādhammapālađātaka), međutim, tu je Gotama Dhammapāla.

U Śarakṣepađātaki (Mv. ii. 82-83) Gautama se poistovjećuje s kraljem koji je, za vrijeme boravka u gradu Takșaśili, čuo za opsadu svojega grada. Odapeo je strijelu koja je, preletjevši zemlju, pogodila sjedalo osvajačkoga kralja u Benaresu. Djelomična se paralela nalazi u ĐātA. II. 86 i d. (br. 181, Asadisađātaka).

U Amarāđātaki (Mv. ii. 83-89) Bodhisattva je Mahauṣadha koji zagonetkama osvaja srce kovačeve kćeri Amare (Yaśodhara). Mahosadha i Amarā spominju se i u ĐātA. VI. 364 i d. (br. 546, Ummagađātaka), međutim, pripovijest u Mahāvastuu u mnogo većoj mjeri nalikuje na Sūćiđātaku (ĐātA. III. 281 i d., br. 387) u kojoj se kovačeva kći i Bodhisattva ne imenuju.

Śiriđātaka (Mv. ii. 89-94) u kojoj je mladi brahman spreman isušiti more kako bi dobio ruku trgovčeve kćeri Śiri ilustrira vrlinu napora ili truda (vīrya).

Kinnarīđātaka (Mv. ii. 94-115) još je jedna u nizu pripovijesti o Gautaminim prijašnjim osvajanjima Yaśodhare. Tu kraljević Sudhanu (Bodhisattva) osvaja kinnarī imenom Manoharā (Yaśodhara). ${ }^{710}$

Śyāmāđātaka (Mv. ii. 166-176) ispričana je kao obrazloženje Gautamine ravnodušnosti spram Yaśodhare u trenutuku bijega od doma. Bodhisattva je trgovac konjima Vađrasena, a Yaśodharā kurtizana Śyāmā. Slična se pripovijest nalazi u ĐātA. III. 63 i d. (br. 318, Kanaverađātaka).

\footnotetext{
${ }^{710}$ Pripovijest obuhvaća čak dvadeset stranica Jonesova prijevoda.
} 
U Ćampakađātaki se (Mv. ii. 177-188) pripovijeda kako je Yaśodhara i ranije pomagala Gautami. Tu je Bodhisattva kralj nāga Ćampaka kojega iz ruku trgovca zmijama spašava nāgakanyā. Svoju paralelu ima u ĐātA. IV. 454 i d. (br. 506, Ćampeyyađātaka).

Śyāmakađātaka (Mv. ii. 209-231) ispričana je prvo u prozi pa u stihu. Tu je Bodhisattva mladić Śyāmaka kojega otrovnom strijelom pogađa kralj grada Kāśi (Ānanda). Njegovi ga roditelji (Śuddhodana i Māyā) spašavaju od smrti svojim moćima. Đātaka nema svoju paralelu u pālijskim izvorima.

Śiriprabhađātaka (Mv. 231-237) još je jedan primjer odanosti Yaśodhare koja u svojoj prijašnjoj egzistenciji kao košuta odbija napustiti supruga Śiriprabhu (Bodhisattva) zarobljenoga u klopci lovca (Ānanda). Vidjevši košutinu hrabrost i odanost, lovac oslobađa jelena. Đātaka se nalazi u ĐātA. III. 182 i d. (br. 359, Suvaṇṇamigađātaka).

Śakuntakađātaka (Mv. ii. 240-243) susreće se i u ĐātA. I. 434 i d. (br. 118, Vatṭakađātaka). Bodhisattva je mudra ptica (śakunataka) koja bježi iz klopke trgovca (Māra).

Kaććhapađātaka (Mv. ii. 244-245) dijeli neke sličnosti s pripoviješću u Saṃyuttanikāyi (SN iv. 177 i d.). Bodhisattva je mudra kornjača koja nadmudruje lovca (Māra).

U Markatađātaki (Mv. ii. 245-250), s paralelom u ĐātA. II. 158 i d. (br. 208, Suṃsumārađātaka), Bodhisattva je mudri majmun koji nadmudruje krokodila željna njegova srca (Māra).

Pripovijest o mudroj ptici koja izmiče lovcu, odnosno o Bodhisattvi i Māri nalazi se u još jednoj Śakuntakađātaki (Mv. ii. 250-255), a svoju paralelu ima u ĐātA. II. 160 i d. (br. 209, Kakkarađātaka).

Surūpađātaka se (Mv. ii. 255-257) ne nalazi u pālijskim izvorima. Pripovijest o jelenu (Bodhisattva) koji je spreman odreći se života za mudru misao nadovezuje se na spomen Bodhisattvine spremnosti da se žrtvuje za mudrost u Mv. i. 75.

Anangaṇađātaka (Mv. ii. 271-276) donosi pripovijest o Anañgaṇi, bogatom trgovcu koji je ugostio Bodhisattvu i zahvaljući tomu dobročinstvu zaslužio postati redovnik Đyotișka u Gautaminoj redovničkoj zajednici. ${ }^{711}$

U Mahāvastuu postoje dvije Kuśađātake (Mv. ii. 419-496 i Mv. iii. 1-27), od kojih je druga uglavnom metrička i skraćena verzija prve. Također, druga je verzija sličnija Kusađātaki koja se nalazi u ĐātA. V. 278 i d. (br. 531).

Vṛṣabhađātaka (Mv. iii. 28-29) nema svoju pālijsku paralelu. Bodhisattva je bik koji umiče šakalu Giriki (Māra).

\footnotetext{
${ }^{711}$ Jones (1952/2006: 254, bilj. 1) napominje da se pripovijest o Đyotiṣki susreće i u Divyāvadani.
} 
Mv. iii. 29-33 sadrži dvije Vānarađātake. Bodhisattva je kralj majmuna koji u prvoj nadmudruje rākṣasu koji prebiva u vodi (Māra), a u drugoj vodenu zmiju (Māra). Prva se nalazi u ĐātA. I. 170 i d. (br. 20, Nāḷapānađātaka), a druga u ĐātA. I. 278 i d. (br. 57, Vānarindađātaka).

U Punyavantađātaki (Mv. iii. 33-41) Bodhisattva je kraljević Punyavant koji pokazuje četvorici prijatelja da je vrlina (śīla) moćnija od snage (vīrya), umjetničkog stvaralaštva (śilpa), mudrosti (prađ̃̃ā) i ljepote (rūpa).

Đātaka o Viđitāvinu (Mv. iii. 41-47) iznesena je i u prozi i u stihu. Bodhisattva je kralj Mithile Viđitāvin pred kojim nebesnik Śakra stvara pakao ispunjen dobročiniteljima i darežljivima. Paralelu ima u pripovijesti o Sarvaṃdadi. ${ }^{712}$ Viđitāvin se spominje u ĐātA. I. 30.

U đātaki o pet stotina trgovaca (Rākṣasīdvīpakṣiptānāṃ đātaka) u Mv. iii. 67-90, koja je ispričana prvo u prozi a potom u stihu, Bodhisattva je konj (Keśin u prozi i Valāha u stihovima) koji spašava pet stotina trgovaca od morskih demonica (pet stotina sljedbenika Sañđayinih). Djelomičnu paralelu ima u ĐātA. II. 127 i d. (br. 196, Valāhassađātaka)

Kākađātaka (Mv. iii. 129-133) ili đātaka o vrani susreće se i u ĐātA. II. (br. 292, Supattađātaka). Bodhisattva je kralj vrana Supārśva, njegova supruga Supārśvā je Yaśodharā, a ministar vrana redovnik Kālodāyin.

Hastinīđātaka ili đātaka o slonici (Mv. iii. 129-137) ispričana je i u prozi i u stihu. Bodhisattva, sin slijepe slonice u zatočeništvu, uspijeva spasiti svoju majku i povratiti joj vid. Slonica je poistovjećena s Mahāprađāpatī. Đātaka nema svoju paralelu u pālijskim izvorima.

Đātaka o Nalinī u Mv. iii. 141-152 (u prozi i stihu) ima svoju paralelu u ĐātA. V. 193 i d. (br. 526, Nalinikāđātaka). Nalin̄̄ (Yaśodharā) zavodi isposnika Ekaśṛngu (Bodhisattva) mekim tkaninama i raznovrsnim poslasticama.

Đātaka o Upāliu i Gañgapāli (Upāligaṃgapālānāṃ đātaka) (Mv. iii. 182-197). U pripovijesti se o prošlosti pripovijeda kako su dva siromašna dječaka izrekla zavjet pred nekim pratyekabuddhom. Jedan je poželio biti kralj (kralj Brahmadatta, u zaključku kralj Śuddhodāna), a drugi brahman (Upaka, u zaključku Gautama). U kompliciranu se priču upleće i kraljev brijač Gaṅgapāla (budući redovnik Upāli) koji će također, kao i Upaka postati isposnik. Usp. ĐātA. III. 444 i d. (br. 421, Gañgamālađātaka).

Dharmalabdhađātaka (Mv. iii. 286-300) svoj povod ima u znatiželji redovnika koje zanima kako se Gautama uspio oduprijeti Mārinim kćerima. Bodhisattva je trgovac i predvodnik karavane Dharmalabdha koji se uspijeva osloboditi demonice.

${ }^{712}$ V. gore. 
U drugoj đātaki poglavlja o Āđñāti Kauṇḍinyi (Mv. iii. 349-353) nalaze se dvije đātake kojima je svrha objasniti zašto je Āđñāta prvi razumio sadržaj Prve propovijedi. Samo se u drugoj javlja lik Bodhisattve (kralj Kośale). Āđñāta je trgovac s kojim kralj Kośale dijeli svoje bogatstvo.

U đātaki o petorici isposnika (Paṃćakānāṃ bhadravargikānāṃ đātaka) Bodhisattva je trgovac koji je žrtvao svoj život kako bi spasio petoricu suputnika čiji je brod napala morska neman.

U Śarabhañgađātaki (Mv. iii. 361-375) Bodhisattva je isposnik Śarabhañga koji na kraju komplicirane i brojnim detaljima opterećene pripovijesti odgovara na Śakrina pitanja. Usp. ĐātA. V. 125 i d. (br. 522, Sarabhañgađātaka).

Svrha je Asthisenađātake (Mv. iii. 418-420) ukazati na ispravan način prošnje hrane. Usp. ĐātA. III. 351. I d. (br. 403, Atthisenađātaka). Bodhisattva je lutajući isposnik Asthisena.

U đātaki o kralju Arindami (Mv. iii. 449-461) Bodhisattva je isposnik Śroṇaka, prijatelj iz djetinjstva kralja Arindame (kralj Bimbisāra). Iako se razlikuju u detaljima, ta đātaka svoju paralelu ima u ĐātA. V. 247 i d. (br. 529, Sonakađātaka).

\subsection{Zaključna razmatranja}

Pālijski kanon i Mahāvastu obiluju epitetima kojima se veliča lik Gotame Buddhe. Neki od njih, kao što su primjerice bhikkhu (skt. bhikṣu), samaṇa (śramaṇa), isi (rși), muni i arahant (arhant) nalaze se pripisani i drugim pojedincima dok se pojedini koriste isključivo za Gotamu Buddhu. Pripisani epiteti odražuju Buddhinu tjelesnu, duhovnu i intelektualnu izvanrednost, ${ }^{713}$ a tome Griffiths (1989: 503) kaže:

In almost every epithet applied to the Buddha in the early texts, this thrust towards the superlative is very clear: the goal is to predicate every possible good quality of the Buddha and to show that he has it to the greatest possible extent.

U Mahāvastuu se potreba za dugim nabrajanjima i gomilanjem epiteta može tumačiti i kao ukorijenjena u predodžbi o nadnaravnoj ili onosvjetskoj (lokottara) Buddhinoj naravi koja se razvila unutar škole mahāsāṅghika, ${ }^{714}$ iako je bitno naglasiti da se epitet lokottara u tome djelu javlja vrlo rijetko. Da je, kada je riječ o razvoju poimanja Gotame Buddhe i njegova životopisa, bolje govoriti o mijenama nego promjenama, ilustraciju mogu dati epiteti bodhisatta i arahant.

\footnotetext{
${ }^{713}$ V. i Sumañgalavilāsinī III. 873-877.

${ }^{714}$ Usp. Xing (2009: 394) i Xing (2005: 53 i d.).
} 
Buddha se bodhisattom, odnosno bodhisattvom, naziva u svim navedenim izvorima ali se pod bodhisattom može podrazumijevati Gotama u razdoblju od začeća do probuđenja, Gotama u nekoj od svojih prethodnih egzistencija i Gotama kao utjelovljenje ideala bodhisatte. U svim se navedenim izvorima koriste sva značenja toga epiteta, ali se izvori razlikuju po naglasku stavljenom na pojedino značenje. Slično vrijedi i za epitet arahant, odnosno arhant. Ideal arahanta jedan je od najvažnijih pojmova theravādske tradicije i čest predmet rasprava $u$ komentatorskoj i indološkoj literaturi. Tako je I. B. Horner (1934 i 1936) analizirala ideal arahanta u theravādskoj tradiciji i izložila svoje viđenje razvojnoga puta toga ideala. Prema njezinoj pretpostavci (1934: 786), u ranome razdoblju buddhizma pod arahantom se podrazumijevao [...] man growing up to perfection as he ran on and fared on, his thought, word and deed becoming finer and purer in each new rebirth. U kasnijem, monastičkom razdoblju došlo je do značajne promjene pa je arahantom postao [...] man or a women who has won perfection here and now. Bond (1984) predlaže oprečno stajalište kada, govoreći o theravādskoj tradiciji, zaključuje:

With the reference to the textual evidence, the probability seems to rest with the view that the arhantship developed from the early notion of the immediate enlightenment to a later notion of very gradual enlightenment.

Katz (1982) u završnome poglavlju svoje knjige Buddhist Images of Human Perfection zaključuje da se rani mahāyanski tekstovi odnose spram arhanta na dva načina. S jedne se strane arhant prikazuje kao inferioran bodhisattvi dok se s druge izjednačuje s bodhisattvom (1982: 272). Harrison se (2005: 121) ne slaže s pojedinim Katzovim zaključcima i tvrdi da u ranim mahāyānskim tekstovima postoji jasna razlika između arhanta, pratyekabuddha i bodhisattva ali ističe da sljedbenici bodhisattvayāne [..] were not prepared to write off rest of the saingha or sever its own connection with it [..].

Dok je Buddhina izvanrednost u najvećem dijelu pālijskoga kanona prikazana kao rezultat njegova preobražavajućega unutarnjega iskustva, odnosno probuđenja, u Nidānakathi je, kao i u pojedinim kasnijim djelima uvrštenima u Khuddakanikāyu i Mahāvastu, ona u većoj mjeri posljedica zasluga stečenih u mnogobrojnim prijašnjim egzistencijama negoli tjelesnoga i duhovnoga napora upregnutoga u posljednjoj egzistenciji. Duhovno-intelektualna savršenstva Buddhe zajednička svim izvorima jesu posjedovanje triju ili šest viših znanja, deset moći, četiriju iskusnosti, šest ili deset savršenstava i pet vrsta oka ili vida. Pojedina su njegova postignuća ili savršenstva pretočena u epitete kao što su sabbaññ̄ (sarvađña), ćakkhumant (ćakṣuṣmant), teviđđa (traividya) i dasabala (daśabala). 
Čudesne i zadivljujuće pojave koje prate ključne trenutke Gotamina života, kao što su potresi, pojava snažne svjetlosti ili kiše cvijeća, čudesna ozdravljenja i slično, ilustrirane su kanonskim ulomacima u kojima se nabrajaju uzroci za pojavu potresa i ostalih zadivljujućih pojava, a uvođenjem takvih pojava nosioci predaje nastojali su potkrijepiti vjeru da je pojava buddhe u svijetu izniman, rijedak i kolosalan događaj. ${ }^{715}$ U Mahāvastuu se također, usprkos spominjanju stotina i bezbroja buddha, još uvijek naglašuje da je pojava buddhe u svijetu rijedak događaj. ${ }^{716}$ U Nidānakathi i Mahāvastuu je u mnogo većoj mjeri, negoli je to slučaj u pālijskome kanonu, naglašena težnja da se ključni trenutci Buddhina života iskite zadivljujućim elementima. Možda najbolji primjer pribjegavanja opisima čudesnih pojava u kasnijim djelima daju epizode o odlasku u beskućništvo i o probuđenju koje su u Nidānakathi i Mahāvastuu uokvirene mnogobrojnim novim detaljima i opširnim njihovim opisima. I ostale su ključne epizode dodatno urešene, a takve su nadogradnje za cilj nesumnjivo imale istaknuti posebitost Buddhe, prikazati njegov život kao niz zapanjujućih događaja i time poticati oduševljenje spram lika velikoga Učitelja.

Kada je riječ o isticanju Buddhine superiornosti nad nebesnicima, ta se težnja može tumačiti kao jedan od načina uspostavljanja autoriteta i prvenstva Buddhina nauka nad ostalima, suparničkim duhovnim pokretima, a o tom Bapat (1926: 7) kaže:

This illustrates the attempt on the part of the Buddhist writer or writers to make the ignorant people believe that they should join the new school of religious reform, led by the Buddha, in as much as even the chief of the popular gods acknowledges the superiority of the Buddha.

Također, čestim se povezivanjem Gotame s nebesnicima pojačava dojam da je Gotama izvanredno biće koje je po svojim svojstvima bliže nebesnicima nego ljudima. U svim se navedenim izvorima nalaze primjeri u kojima se Buddha opisuje kao nadmoćan nebesnicima. Budući da su, u skladu s postupno razvijanim buddhističkim vjerovanjem, i nebesnici podložni ponovnim rođenjima, i njima je kao i ljudima potrebno Buddhino učenje.

Povećanje broja prethodnih buddha od šest, koliko je pobrojano u Mahāpadānasutti Dīghanikāye, do dvadest i četiri (ili dvadest i sedam, ukoliko se računaju i oni imenovani buddhe čiji životopis nije iznesen) u Buddhavaṃsi i Nidānakathi pokazuje da je zamisao o prethodnim buddhama postupno prihvaćena i dalje razrađivana i unutar theravādske škole. Nakamura (1980/1987: 84) tvrdi da ideja o prethodnim buddhama svoj temelj ima u

\footnotetext{
715 V. npr. AN i. 23.

${ }^{716}$ Mv. i. 233-234, iii. 62.
} 
brahmanističkoj predaji o sedam rșia ili vidjelaca koji se spominju već u Ṛgvedi, dok Gombrich (1980: 63-64) smatra da je na povećanje broja Gotaminih prethodnika izravno utjecala đinistička tradicija prema kojoj je Mahāvira dvadesetičetvrti u nizu tīrthan்kara. Također smatra da je predaja o prethodnim buddhama utemeljena u potrebi da se Gotamina dhamma potvrdi dugom lozom prethodnika koji su ju također otkrivali i propovijedali. Budući da se u suttama koje opisuju njegovo probuđenje jasno ističe da je Gotama do oslobađajućega znanja došao svojim trudom i bez vodstva drugih učitelja, autentifikacija njegova učenja mogla je biti samo mitološka. Neizmjerno dugo razdoblje koje je prethodilo pojavi Gotame Buddhe naselilo se na taj način buddhama koji su ranije otkrivali i propovijedali dhammu i ujedno davali potvrdu budućemu buddhi da je na putu prema probuđenju. ${ }^{717}$ Bivajući neprestano potvrđivani kroz neizmjerno vrijeme, Buddha i njegova dhamma zadobili su "pečat starine", a s druge strane i "zakonitost", i time dodatnu vjerodostojnost.

Povećanje broja prethodnih buddha u uskoj je vezi i s povećanjem broja prethodnih Buddhinih egzistencija iako je teško reći je li povećanje broja prethodnih buddha utjecalo na povećanje broja prethodnih egzistencija Gotame ili je pak povećanje broja prethodnih egzistencija Gotame utjecalo na broj prethodnih buddha.

Povećanje broja prethodnih Buddhinih egzistencija koje se prepričavaju u đātakama jedan je od najizraženijih smjerova u razvoju njegova životopisa. Ranije je rečeno da se đātake rijetko pojavljuju unutar Vinayapițake i prve četiri nikāye Suttapițake. Gotama se tu naziva bodhisattom u kontekstu njegova začeća i rođenja te života prije njegova probuđenja. Tu se ne može govoriti o idealu bodhisatte kao u mahāyānskome buddhizmu, ali se vrlo često ističu Buddhino suosjećanje i mudrost, što su, u kasnijim, tzv. mahāyānskim tekstovima, temeljne odlike bodhisattve. Mahāyanski autori znadu naglašivati razliku svoje nauke prema prethodnoj, koju, umanjujući ju, nazivaju hīnayānom (dosl. manje/ inferiornije vozilo). No zapravo su pripovijesti o primjerima plemenitosti ili mudrosti, koje počinju kao primjeri i parabole u Buddhinim govorima, zatim se počinju interpretirati kao događaji iz njegovih prethodnih života, da bi se naposljetku oblikovali po obrascu đātaka u pripovijesti o prošlim životima od pet sastavnica, služile kao dragocjena građa za propovijedi buddhističkih učitelja i redovnika i širile nove ideje plemenitosti i mudrosti. Te su ideje, koje su se razvile u starijem buddhizmu, morale razviti ideal bodhisattve u kasnijem buddhizmu, preko māhāsaṅghika i lokottaravādina, do mahāyāne. Stoga razlika između starijega buddhizma i mahāyane nije u tome što stariji

\footnotetext{
717 Čini se manje vjerojatnim da je povećanje broja prethodnih buddha utjecalo na povećanje broja prethodnih Gotaminih egzistencija.
} 
buddhizam nije imao takve vrijednosti i ideje, nego što su se one u mlađemu buddhizmu poopćile i oblikovale u zamišljeni ćudoredni ideal bodhisattve. A ideal privlači više sljedbenika nego ideje. Slično tomu što je rečeno, već Samuels (1997), pozivajući se na dijelove pālijskoga kanona, zaključuje da opreka nije utemeljena i da se razlika između dvaju putova ili vozila (yāna) može predstaviti

[...] by referring to Mahāyāna Buddhism as a vehicle in which the bodhisattva ideal is more universally applied, and to Theravāda Buddhism as a vehicle in which the bodhisattva ideal is reserved for and appropriated by certain exceptional people. [...] Hence, it should be stressed that the change introduced by the Mahāyāna traditions is not so much an invention of a new type of saint or new ideology, but rather taking of an exceptional ideal and bringing it into prominence. (Samuels, 1997: 408)

Zapravo se je u palijskome kanonu i theravādskoj tradiciji postupno razvijala definirana predodžba bodhisatte, o čem ponajviše svjedoče djela uvrštena u Khuddakanikāyu, Ćaryāpiṭaka i Buddhavaṃsa. Ideja o postupnom stjecanju vrlina kroz brojne prijašnje egzistencije posebno je izražena u Nidānakathi. Tu je bodhisatta prikazan kao biće u kojem se javlja misao o probuđenju (bodhićitta), koje potom izriče zavjet (abhinīhāra) i dobiva potvrdu (vyākaraṇa) od tadašnjega buddhe Dīpaṃkare da će nakon određenoga vremena zaista postati buddha. U nabrojanim je theravādskim djelima jasno istaknuto da biće, u ovom slučaju Sumedha, stupa na put bodhisatte iz suosjećanja i imajući dobrobit svih bića na umu. Osim toga, tu je već jasno opisano deset savršenstva (pāramī) u kojima se bodhisatta mora usavršiti na svome putu prema probuđenju. Popularnost Nidānakathe koja slijedi Buddhavaṃsu i Ćariyāpițaku i činjenica da predstavlja uvod u komentar uz kanonsku knjigu Đātaka u kojoj je pobrojano čak 547 prethodnih Gotaminih egzistencija svjedoči o razvoju predodžbe o bodhisatti i o njenoj popularnosti i prihvaćenosti unutar theravādske tradicije. Bodhisattama se, štoviše, nazivaju i prijašnji buddhe prije probuđenja, a u pojedinim se suttama naviješta i pojava novoga buddhe Metteye, iz čega proizlazi da je taj put, i unutar pālijskoga kanona, otvoren i drugim bićima, a ne samo Gotami. U mahāyāni se je ta ipak ograničena i ekskluzivna otvorenost samo generalizirala i "demokratizirala", a ne tek prvi put stvorila.

U Mahāvastuu su đātake dominantna književna vrsta, a predodžba je bodhisattve u mnogo većoj mjeri razvijena i definirana te obuhvaća i nauk o četiri stupnja razvoja i deset boravišta $(b h \bar{u} m i)$ koje bodhisattva prelazi usavršavajući se, u ovome slučaju, u šest savršenstava (pāramitāa, transcendentnih krjeposti).Valja još jednom istaknuti da se u tome djelu, na mnogim mjestima, susreću đātake koje po svojoj strukturi još uvijek ne odgovaraju 
razvijenoj definiciji prema kojoj je đātaka pripovijest koju iznosi Buddha o nekoj od svojih prijašnjih egzistencija, a koja se sastoji od priče o sadašnjosti, priče o prošlosti i zaključka u kojem se Buddha poistovjećuje s nekim od likova iz priče iz prošlosti. Pripovijesti o prethodnim rođenjima obuhvaćaju i prethodne živote istaknutih pojedinaca redovničke zajednice kao i članova Buddhine obitelji. Pālijski kanon uključio je i djelo Apadāna koje sadrži dva poglavlja (Therāpadāna i Therī-āpadāna) u kojima se nalazi nešto manje od šest stotina pripovijesti o prethodnim životima istaknutih redovnika i redovnica u kojima su, na neki način, bili od koristi bodhisatti na njegovu putu, ili su iskazali poštovanje buddhi. Komentar uz pālijsku knjigu Đātaka, Đātakaț̣havaṇnana, također pripovijeda i o prethodnim rođenjima redovnika i redovnica. Tako se, primjerice, Ānanda spominje u 147, Sāriputta u 90, Moggallana u 57, a Devadatta u 67 đātaka. ${ }^{718}$ Vimānavatthu i Petavatthu, također pālijska kanonska djela, sadrže pripovijesti o bićima koja obitavaju na nebesima ili ispaštaju u slikovitim paklovima ovisno o karmanskim posljedicama djela izvršenih u prethodnim egzistencijama. One, naravno, služe ćudorednoj pouci. Mnoge su od tih pripovijesti tematski vezane uz epizode Buddhina života.

Vidi se, dakle, da se je predodžba o uzorima plemenitosti, pa o bodhisattvi Gotami prije nego što je postao Buddha kao takvu uzoru tijekom niza svojih prethodnih rođenja, već u pālijskome kanonu, zatim u sanskrtskim životopisima poput Mahāvastua, kao i u pālijskome komentaru uz Đātake, postupno razvijala prema poopćenomu idealu bodhisattve koji su pozvani slijediti mnogi redovnici i svjetovni sljedbenici Buddhina puta, kakav je poslije propovijedala mahāyāna. Ne postoji oprjeka, nego postupan razvoj.

Izdvojene sastavnice životopisa ilustracija su nekih od načina upotrijebljenih za stvaranje idealizirane slike o Gotami Buddhi i njegovu životu. Mijene u poimanju Gotame Buddhe izravno su utjecale na način iznošenja njegova životopisa pa je tako primjerice jačanje ideala bodhisatte nedvojbeno utjecalo na stvaranje novih životopisnih pripovijesti smještenih $\mathrm{u}$ mnogobrojne njegove prethodne živote. Također, jačanje predodžbe o Gotami kao o nadčovjeku ili onosvjetskome biću utjecalo je na povećanje broja njegovih epiteta, stavljanje sve većega naglaska na savršenstva, isticanje njegove ravnopravnosti s nebesnicima, pa čak i njegove nadmoći nad njima, kao i na ukrašavanje epizoda njegova života detaljnim opisima čudesnih i zadivljujućih pojava koje su ih popratile.

\footnotetext{
718 Woodward (1997: 54) u: Schober (1997).
} 
Osvrtom na povećanje broja buddha i prethodnih egzistencija Gotame Buddhe nastojala sam ukazati također i na širenje njegova životopisa u prošlost, odnosno na dugo razdoblje koje je, kako se pripovijeda, proveo kao bodhisatta pripremajući se za konačno rođenje u kojem će postati Probuđeni.

Valja još jednom naglasiti da se sastavnice Gotamina životopisa prikazane u ovome poglavlju mogu naći u svim izvorima, a da je razlika među njima u stupnju, u brojnosti i čestoti. Vjerojatno su duga usmena predaja i pālijskoga kanona i sanskrtskih životopisa Buddhe, koji su također mogli biti i dio kanona drugih škola, te doticaji među različitim buddhističkim sljedbama morali dovesti i do međusobnih utjecaja jednih na druge. Takvi su pak međusobni utjecaji mogli poticati pojavu podudarnih sastavnica, kao i dijelom usporedan smjer nekih mijena i razvoja predočaba, pa tako i poimanja Buddhe i njegova životopisa. Zato možemo u Mahāvastuu možda naći gdjekad i ranije stupnjeve razvoja đātaka nego u Đātakaț̣nhavaṇnani te nam predaje različitih škola mogu pomoći da razvoj svake bolje razumijemo. U kasnijim djelima, Nidānakathi i Mahāvastuu, naizgled se teško dolazi do onoga što bi se moglo nazvati predajom o povijesnom Gotami. Međutim, ta djela nisu odbacila kanonski obrazac i ono što je o Gotami i njegovu životu rečeno ranije već su se, u skladu s razvojem buddhističke predaje i učenja unutar pojedine škole, nadovezala na ranije tekstove te ih prilagodila novim shvaćanjima, proširivala i unosila u njih novine u poimanju Buddhine naravi. 


\section{ZAKLJUČAK}

\subsection{Ukratko o životopisu Gotame Buddhe u korištenim izvorima}

Pālijski kanon, kako je pokazano, ne sadrži cjelovit životopis Gotame Buddhe. Najdulji biografski fragmenti sadržani su u Aććhariyabbhutadhammasutti (MN, sutta br. 123) u kojoj se iznosi pripovijest o njegovu začeću i rođenju, Ariyapariyesanāsutti (MN, br. 26) u kojoj se opisuju događaji od njegova odlaska u beskućništvo do pokretanja kotača nauka, Mahāvaggi Vinayapițake koja sadrži opis događaja od probuđenja do obraćenja Sāriputte i Mahāparinibbānasutti u kojoj se opisuju Gotamino posljednje putovanje, njegova smrt i raspodjela relikvija. Suttanipāta (pogl. 3.11 i. 3.12) također sadrži kraći prikaz Gotamina odlaska u beskućništvo i borbe s Mārom prije probuđenja.

Mahāpadānasutta, četrnaesta sutta Dīghanikāye, sadrži sistematizirane elemente Buddhina životopisa kojima su obuhvaćeni događaji od začeća do pokretanja kotača nauke, međutim opisani su događaji pripisani buddhi Vipassinu, tako da je tu uspostavljen opći legendarni obrazac za životopis svakoga boddhisatte od posljednjega rođenja do postajanja buddhom, koji će se onda primijeniti i na Gotamu. Sažet se životopis Gotame Buddhe nalazi i u Buddhavaṃsi Khuddakanikāye. Iako se na polju buddhističkih studija pālijski kanon u načelu ističe kao primarni izvor za proučavanje života povijesnoga Gotame, u njem se nerijetko paralelno s ulomcima u kojima se Buddha pojavljuje kao čovjek javljaju i ulomci u kojima je naglasak stavljen na čudesne i nadljudske Buddhine osobine. Pālijski je kanon kompilacija tekstova koji se razlikuju po vremenu svoga postanka i svojem odnosu spram Gotame Buddhe. $\mathrm{U}$ istraživanjima ranijega datuma, posebno onima tzv. anglo-germanske škole, polazilo se od pretpostavke da je Gotama Buddha nedvojbeno bio povijesna osoba do čijega se životopisa, $\mathrm{u}$ većoj ili manjoj mjeri, može doći odstranjivanjem mitoloških nadogradnja, a koje su se smatrale posljedicom kvarenja izvornoga ili najranijega buddhizma. Ipak, to ne znači da se ti mlađi dijelovi smiju zanemarivati jer se zanemarivanjem tih dijelova Buddhina životopisa gubi bitna dimenzija predaje budući da ona svjedoči ne samo o razvoju theravādskoga poimanja Gotame Buddhe već i o promjenama koje su zadesile redovničku zajednicu kao i društvo u kojem je ona djelovala.

Nidānakathā, kada je riječ o Gotaminoj posljednjoj egzistenciji i ključnim epizodama njegova života, sadrži gotovo sve elemente predaje sadržane u pālijskome kanonu. Međutim, na ovome su stupnju razvoja dijelovi teksta u kojima se opisuju začeće i rođenje, odlazak u beskućništvo i okolnosti neposredno prije i nakon probuđenja razrađeniji i prošireni novim detaljima, osobito obiljem zadivljujućih pojava. Kako je pokazano, sadržaju samoga probuđenja i prve propovijedi nije posvećena posebna pažnja. Razlog tomu možda leži u 
jednostavnoj činjenici da je Nidānakathā uvod u komentar uz kanonsku knjigu Đātaka. U Nidānakathi je životopis Gotame Buddhe, a koji se proteže od vremena buddhe Dīpañkare do donacije samostana Đetavane u kojem je prema predaji Buddha iznio glavninu đātaka, iznesen kako bi se pružila uvjerljivost pripovijestima o njegovim prijašnjim rođenjima. Time se pokazalo da su sva njegova savršenstva kao i životni put, koji su ovdje popraćeni mnogim zadivljujućim pojavama, u mnogo većoj mjeri posljedica zasluga stečenih u prijašnjim rođenjima negoli spoznaje koju je stekao u noći probuđenja i koju je potom izložio petorici isposnika. Kao djelo koje pripada theravādskoj tradiciji, a koje sadrži relativno razvijenu i definiranu predodžbu o bodhisatti kao biću na putu probuđenja od stupanja na put do probuđenja samoga, Nidānakathā može poslužiti kao kamen kušnje u propitivanju pojednostavljena shvaćanja prema kojem se (iz mahāyanske perspektive) theravādski buddhizam poistovjećuje sa sāvakayānom (skt. śrāvakayāna, put slušatelja), a mahāyānski s bodhisattvayānom (put bodhisattve). Nidānakathā tako, zajedno sa zbirkom Đātaka u koju uvodi, dokumentira ključnu točku razvoja zamisli, u kojoj su se prethodni životi bodhisatte i pojave prethodnih buddha koordinirali, i u kojoj se je pojam bodhisatte definirao kao pojam bića koje u nizu života usavršava transcendentne krjeposti ili savršenstva (pāramī, skt. pāramitāa) koje će ga dovesti do transcendencije ovoga (Mārina) svijeta pri probuđenju u posljednjem životu. Kako ta savršenstva uključuju darežljivost, ćudorednost (u govoru, činima i životu), samoodreknuće, mudrost (proznaju), hrabrost (napor), strpljivost, iskrenost (istinoljubivost), odlučnost, dobrohotnost (prema svima bićima) i ravnodušje (prema žudnjama i odbojnostima) - a kasnije će se u mahāyāni naglasiti suosjećanje (karuṇā) umjesto samoodreknuća (naișkramya) - očito su pripovijesti o prethodnim rođenjima bodhisatte koji je u posljednjem rođenju postao Buddha stvorile sve pretpostavke da se ta još dosta ekskluzivna zamisao bodhisatte pretvori u poopćeni ideal bodhisattve u mahāyāni, koji ne samo da usavršava krjeposti i pomaže nekim bićima, pa i žrtvuje se za njih, nego koji će sebi uzeti u zadatak spašavanje svih bića iz svijeta patnje i prerađanja, i time svima služiti kao uzor.

Mahāvastu sadrži razrađen, iako ne i cjelovit, životopis Gautame Buddhe. Kao što je slučaj i u pālijskome kanonu, ni ovdje životopis nije iznesen sustavno već se sastoji od duljih ili kraćih ulomaka koje je, zbog mnogobrojnih digresija, a i višekratnih ponavljanja, vrlo teško pratiti i povezati u smislenu cjelinu. Slijeđenje tijeka događaja posebno otežava činjenica da se mnoge epizode Buddhina života prepričavaju po nekoliko puta $\mathrm{i}$ to vrlo često s primjetnim modifikacijama. Ipak, može se zaključiti da su ključne epizode Buddhina života kakve ih nalazimo u pālijskome kanonu prisutne i u ovome djelu. Karakteristično lokottaravādinsko tumačenje Buddhine naravi, dovelo je, s jedne strane, do zanemarivanja svega što bi Gotamu 
moglo dovesti u vezu s njegovom ljudskom prirodom i, s druge strane, do nekontroliranoga bujanja epiteta i pretjerivanja u nadodavanju elemenata koji bi se mogli okarakterizirati kao nadnaravni, čudesni i zadivljujući. Međutim, vrlo je bitno naglasiti da je, kada je riječ o ključnim epizodama Buddhina životopisa, kanonski obrazac ispoštovan i da ga Mahāvastu slijedi u najvećoj mjeri. Mahāvastu predstavlja razvijeni tip životopisa u kojem su svoje mjesto pronašli raznovrsni tekstovi iz različitih izvora, sakupljeni kroz razdoblje dugo nekoliko stoljeća. Iako životopis Gautame Buddhe u Mahāvastuu posjeduje neke značajke zbog kojih se smatra prijelazom prema mahāyanskom shvaćanju naravi buddhe, na umu valja imati činjenicu da se u ovome djelu susreću i tekstovi velike starine, kao i brojne paralele $\mathrm{s}$ tekstovima sadržanim u pālijskome kanonu.

\subsection{Tri lica Buddhe i njegova životopisa}

Danas je gotovo općeprihvaćeno da iza legendarnoga lika Gotame Buddhe, urešenoga mnogobrojnim nadnaravnim značajkama i praćena nadnaravnim pojavama, a usto i prikazana po utvrđenome obrascu legende o buddhama, postoji povijesna ličnost i da buddhistički tekstovi vjerojatno sadrže dijelove koji bi se mogli smatrati istinitom predajom vezanom uz njegov život. Ipak, treba naglasiti da se niti jedan od izvora koji nam je na raspolaganju u proučavanju Gotamina životopisa ne može datirati u vrijeme njegova života ili smatrati povijesnim dokumentom u užem smislu. ${ }^{719}$

Nastojanje da se iz buddhističkih tekstova izdvoje povijesni Gotama i njegov život lišen popularnih i mitoloških elemenata bila je do nedavno odlika zapadnih istraživanja. Međutim, odstranjivanjem iz životopisa onih dijelova koji modernomu, racionalistički i pozitivistički nastrojenomu čitatelju izgledaju kao tvorevine mašte osiromašujemo cjelovitost slike i zanemarujemo mogućnost da je za svoje sljedbenike, čak i one najranije, Gotama Buddha bio više od čovjeka, učitelja i osnivača redovničke zajednice. Ne smijemo smetnuti s uma, također, ni činjenicu da među buddhistima i unutar široke buddhističke književnosti nikada nije bilo pokušaja ispisivanja života Gotame Buddhe temeljenoga na povijesnim činjenicama i da buddhistički tekstovi vrlo rijetko pokušavaju dati odgovor na pitanje tko je bio čovjek Gotama a da se, s druge strane, u velikoj mjeri posvećuju nastojanjima da odgovore na pitanje koja svojstva buddhu čine buddhom.

\footnotetext{
${ }^{719}$ Usp. i Schopen (1997: 3): Notice, finally, that no thought is given to the fact that even the most artless formal narrative text has a purpose, and that in "scriptural" texts, especially in India, that purpose is almost never "historical" in our sense of the term.
} 
U posljednjem postmodernome razdoblju taj se pristup mijenja. Gethin tako ističe (1998: 16): $[\ldots]$ as the Buddhist tradition tells it, the story of the life of the Buddha is not history nor meant to be. Važno je napomenuti i da elementi Buddhina životopisa izdvojeni u prethodnome poglavlju, a među kojima su pojedini nerijetko bili zanemarivani ili tumačeni kao odraz "kvarenja" buddhizma uzrokovanoga prodiranjem izvanjskih laičkih utjecaja ili pasivnim podlijeganjem zahtjevima masa, sadrže neke od ključnih pojmova buddhističke misli, doktrine i kozmologije. Također, oni predstavljaju neke od djelotvornih načina kojima je redovnička zajednica održavala Gotamin autoritet na životu nakon njegove smrti. Treba uzeti u obzir da je, što je Gotamin život tonuo dublje u prošlost, trebalo to jače osvijetliti njegov lik da bi sjao do sadašnjosti i budućnosti. Osim toga, redovnička je zajednica time osiguravala i svoj opstanak, širenje i nužnu materijalnu potporu laika pa se uloga svih tih čimbenika ne smije podcijeniti. Iako ne posjedujemo jednostavne kriterije kojima bismo došli do neupitne stratifikacije tekstova i metode sigurnoga razlučivanja povijesti od mita, kroz slojeve tekstova prikazane u ovome radu možemo dobiti približan uvid u otiske povijesne osobe Gotamine u njegovu legendarnome životopisu. No s druge strane, treba u obzir uzimati sve elemente predaje kao punovrijedne sastavnice postupno izgrađivane slike o liku i životu Gotame Buddhe za potrebe njegovih sljedbenika, kao što uopće treba biti svjestan značenja i uloge koju je njegov životopis imao u buddhizmu i za buddhiste.

Promatraju li se izvori u cjelini, u obliku u kojem su nam danas dostupni, može se reći da Gotama Buddha posjeduje "tri lica" ili "tri identiteta" koja je teško u cijelosti odvojiti. ${ }^{720}$ To su 1) Gotama Buddha kao čovjek i učitelj s ljudskim slabostima i ljudskim tijelom podložnim propadanju i bolestima, 2) Buddha kao nad-čovjek koji posjeduje nad-ljudska znanja i moći, kao i trideset i dva znaka tjelesnoga savršenstva i 3) Buddha kao utjelovljenje vječnoga stanja Probuđenosti, pri čem je svaki buddha jedan od mnogih koji su postojali prije njega i onih koji se tek trebaju pojaviti u svijetu, a svi imaju iste osobine i isti životni put kao i svi prije njih. Spomenuta su tri lica podjednako važna u proučavanju njegova životopisa, kako zbog njihove međusobne isprepletenosti, tako i zbog činjenice da se svakomu od tih triju lica mogu pripisati odgovarajući biografski ulomci ili odgovarajuća tumačenja životopisa.

Mnogobrojni su primjeri koji ostavljaju dojam vjerodostojnih uspomena na čovjeka podrijetlom iz naroda Śākya, suvremenika kralja Kosale Pasenadia (skt. Prasenađit) i kraljeva Magadhe Bimbisāre i Ađātasattua (Ađātaśatru), koji je u odlučnome trenutku svojega života napustio dom i obitelj i, nakon godina trapljenja, vlastitom odlučnošću i iznimnim naporom

\footnotetext{
${ }^{720}$ Usp. Xing (2009: 393).
} 
dosegao, vjerojatno za boravka u Bodhgayi, znanje za koje je vjerovao da oslobađa patnje. To je znanje ustrajnošću predanoga učitelja četrdesetipet godina, od propovijedi u Sārnāthu do konačnoga odlaska u Kuśinagari, propovijedao u nizu mjesta, poput Sāvatthī (Śrāvastī), Rāđagahe (Rāđagṛha), Vesālī (Vaiśālī) ili Kosambī (Kauśāmbī), onima koji su i sami bili željni usavršavanja i oslobođenja. ${ }^{721}$ Prikazan je kao lutajući isposnik (samaṇa), mudrac (muni) i neupitni Učitelj (satthar) koji je s osjetljivošću dobra pedagoga prilagođavao svoja učenja svakomu tko ga je slušao. Brojni su i primjeri sutta koje donose opis oduševljenja slušatelja nakon Gotamine pouke: “Tako je govorio Blaženi. Zadovoljni su se redovnici obradovali riječima Blaženoga". ${ }^{722}$

Čini se da pālijski kanon na mnogim mjestima iskreno bilježi i teškoće i neuspjehe s kojima se je Gotama susreo tijekom svoga života. Iako prikazan kao nenadmašan propovjednik i učitelj, postoje i primjeri u kojima nije zadobio odobravanje redovnika i slušatelja, ${ }^{723}$ a pojedini su njegovi sljedbenici napustili red i vratili se svjetovnomu životu ${ }^{724}$. Također, Vinayapițaka obiluje primjerima u kojima je Gotama upleten u sasvim ovosvjetske i ljudske brige, slabosti i razmirice, a imao je i protivnike koji su podrivali njegov autoritet i iskazivali sumnju u njegovo probuđenje i nauk. Uvjerljiva slika posljednjih dana velikoga učitelja i vođe zajednice koji je, bolestan i iscrpljen probavnim smetnjama, umro u dobi od osamdeset godina, okružen vjernim i uplašenim sljedbenicima, iskrsnut će pred čitateljem izdvoje li se odgovarajući dijelovi Mahāparinibbānasutte. Među korištenim izvorima, takva se slika lika i životnoga puta Gotame Buddhe može ekstrahirati iz pālijskoga kanona i, u nešto manjoj mjeri, iz Nidānakathe i Mahāvastua.

\footnotetext{
${ }^{721}$ DN ii. 100 sadrži sljedeće Buddhine riječi upućene Ānandi: Što još, o Ānando, zajednica redovnika očekuje od mene? Poučavao sam, o Ānanda, dhammu, ne čineći razliku između javnoga i skrovitoga. Nije, o Ānanda, u pitanjima dhamme Tathāgata bio učitelj stisnute šake (izvornik dan na str. 183). S druge strane, SN v. 438 donosi ove Buddhine riječi: Upravo tako, o redovnici, postoji mnogo toga što sam spoznao, a nisam vam izložio. A zašto, o redovnici, nisam izložio? Zato što, o redovnici, nije korisno, nije bitno za krjepostan život niti vodi do nestanka privrženosti niti do besstrašća niti obuzdavanja osjetila niti smirenja niti znanja niti probuđenja niti nibbāne. Zato, o redovnici, nisam izložio. (Evam eva kho bhikkhave etad eva bahutaram yam vo mayā abhiññaya anakkhātam. Appamattakam akkhātam. Kasmā cetam bhikkhave mayā anakkhātam. Na hetam bhikkhave atthasamhitam nādibrahmacariyakạ̣ na nibbidāya na virāgāya na nirodhāya na upasamāya na abhiñ̄̃āya na sambodhāya na nibbānāya saṃvattati. Tasmā tam mayā anakkhātam.)

${ }^{722}$ Idam avoca bhagavā. Attamanā te bhikkhū bhagavato bhāsitam abhinandunti.

${ }^{723}$ Tako primjerice Mūlapariyāyasutta (MN i. 6) bilježi da redovnici nisu bili oduševljeni Gotaminom poukom (Idam avoca bhagavā. Na te bhikkhū bhagavato bhāsitam abhinandunti). Isposnik Udāyin ne pristupa Gotaminom redu unutač trudu i vremenu koje Gotama ulaže u poduku (MN, sutte br. 77 i 79).

${ }^{724}$ Mahāvagga (Vin. I. 32, 1) donosi propovijest o redovniku Arițthi koji je napustio red ne želeći se odreći svojih stavova. Gotamino se nezadovoljstvo Arițhom nalazi opisano i u MN i. 130-133. Redovnik Sunakkhatta napustio je red tvrdeći da Gotama ne posjeduje ni posebna znanja ni magične moći ( $\mathrm{MN}$ i. 68).
} 
Pālijski kanonski tekstovi obiluju i primjerima u kojima je Gotama Buddha prikazan kao nad-čovjek i objekt posvemašnjega idealiziranja, štovanja i obožavanja. Valja naglasiti da je, za razliku od biografskih fragmenata u Vinayapițaki i prve četiri nikāye Suttapițake iz kojih se može iščitati da su Gotamin nad-ljudski ugled i savršenstvo u očima sljedbenika bili posljedica intenzivnoga intelektualnoga i tjelesnoga napora uloženoga u njegovoj posljednjoj egzistenciji, u kasnijim djelima uvrštenima u Khuddakanikāyu, kao i u Nidānakathi i Mahāvastuu, naglasak stavljen na mnogobrojne prethodne egzistencije u kojima je Gotama predano usavršavao vrline koje će mu, u njegovoj posljednjoj egzistenciji, podariti status buddhe i sva obilježja koja takvu biću pripadaju. Njegovo tjelesno, duhovno i intelektualno savršenstvo i s tim nenadmašnim savršenstvom usklađen životni put prožet nesvakidašnjim i zadivljujućim pojavama, shvaćeni su kao posljedica zasluga stečenih mnogo prije negoli je rođen u posljednjem rođenju kao sin Māye i Suddhodāne. U Mahāvastuu je njegova nadljudskost dijelom i odraz poimanja buddhe kao bića koje je lokottara (nadnaravno, onosvjetsko) i koje je nemoguće pojmiti u svim njegovim vrlinama i moćima, što je zajedničko obilježje svih sljedaba proisteklih iz škole mahāsanghika, među kojima je i sljedba lokottaravāda. Ipak, treba još jednom naglasiti da se epitet lokottara u Mahāvastuu rijetko koristi i da se Buddhina transcendentna narav opisuje u samo jednom odlomku. $\mathrm{U}$ tome se odlomku tvrdi da svaki buddha, u skladu sa svojom transcendentnom naravi, boravi određeno vrijeme na ovome svijetu, istina u tjelesnoj i materijalnoj pojavi, ali to je tek privid ili usluga učinjena onima koji imaju sreću biti u njegovu prisustvu. ${ }^{725}$ Mahāvastu obiluje primjerima u kojima je svaki bodhisattva i svaki buddha, pa tako i Gotama, obilježen nenadmašnim vrlinama, sposobnostima i obilježjima koja ih u svem razlikuju od ostalih bića i nebesnika. Promatran u cijelosti, Mahāvastu iznosi životopis nad-ljudskoga bića pa se pretjerivanje u nadodavanju epiteta, naglašivanje Gautamine izvanrednosti i detaljni opisi čudesnih i zadivljujućih pojava lako mogu razumjeti. Ipak, ne treba previdjeti da se takva slika može sresti, doduše u nešto manjoj mjeri, i u pālijskome kanonu.

Gotama je Buddha i utjelovljenje vječnoga stanja Probuđenosti, on je jedan od mnogih buddha koji se pojavljuju kako bi iznova otkrili vječnu dhammu pa se, s time u skladu, i njegov životopis može tumačiti kao pojavnica temeljnoga obrasca, odnosno mjesto na kojem se ostvaruje dhammatā. Unutar prve četiri nikāye Suttapițake takvo je shvaćanje životnoga puta Gotame Buddhe oblikovano prema obrascu koji je dan u Mahāpadānasutti koja prikazuje životni put buddhe Vipassina. Buddhavaṃsa, kao i Nidānakathā koja u bitnome slijedi

\footnotetext{
${ }^{725}$ Mv. i. 168.
} 
Buddhavaṃsu i Ćarīyapițaku, sadrži uz Gotamin životopis i “životopise” dvadeset i četiri njegova prethodnika, koji se međusobno razlikuju samo u detaljima. Dok u pālijskoj Mahāpadānasutti životopis buddhe Vipassina služi kao potkrjepa učenja da svi buddhe imaju isti životni put, u Nidānakathi i Mahāvastuu tu ulogu preuzima životopis buddhe Dīpaṅkare. U Mahāvastuu se također naglašuje da je Gotama Buddha samo jedan od nebrojenih buddha koji su se već pojavili i od kojih svaki posjeduje ista svojstva i isti životni put. Na tome tragu, i svaki bodhisattva, pa tako i Gautama, posjeduje ista svojstva i isti put koji mora prijeći kako bi u konačnici postao Probuđeni. Svaki bodhisattva prije rođenja boravi u nebesima Tușita i prije silaska na zemlju razmatra vrijeme, kontinent, mjesto i obitelj u kojima će se roditi. Svi se bodhisattve rađaju u plemenitim obiteljima brahmana ili kṣatriya i sve majke bodhisattva umiru sedam dana nakon poroda. Trenutak začeća događa se u noći punoga Mjeseca, a obilježen je snažnim potresom u kojem bića nikada ne stradavaju i snom u kojem majke budućih buddha sanjaju bijeloga slona koji im ulazi u utrobu. Ni jedan se buddha ne rađa kao rezultat spolnoga čina iako ima oca i majku. Buddhe ne umiru i mogli bi, po želji, živjeti neograničeno vrijeme. Može se zaključiti da su tri lica Gotame Buddhe i njima odgovarajuća tumačenja životopisa međusobno isprepletena iako je u korištenim izvorima stupanj njihove prisutnosti različit: $\mathrm{u}$ onima koji čuvaju najviše starine i najviše prenose riječi Učitelja najprisutnije je prvo lice, u onima koji imaju naglašeniju vjersku predanost Buddhi drugo, a u onima koji imaju najrazvijeniju buddhološku nauku treće lice.

Ako pogledamo na razvoj životopisa samoga u korištenim izvorima, on se može tumačiti kao proces njegova koncentričnoga širenja oko ključnih biografskih epizoda zajedničkih svim izvorima, a pri kojem je došlo do 1. objedinjavanja i sistematiziranja prenošenih podataka, 2. obogaćivanja predaje novim detaljima, pa čak i cijelim novim biografskim epizodama, i 3. stavljanja većega naglaska na dijelove učenja ili predaje koji potkrijepljuju stajališta pojedine škole ili, drugim riječima, zanemarivanja elemenata koji to ne čine.

Kao jedan od najizraženijih smjerova u razvoju životpisa Gotame Buddhe valja istaknuti proširivanje životopisa pripovijestima o Gotaminim prethodnim rođenjima, što je dovelo do razvoja predodžbe o bodhisatti, a na kraju i do stvaranja ideala bodhisatte naspram idealu arahanta, kakvo je bilo već u starijem buddhizmu osobito karakteristično za sljedbu mahāsanghika. U prve četiri nikāye Suttapițake kao i u Vinayapiṭaki predodžba o bodhisatti nije izražena pa se u tim dijelovima kanona pripovijesti o prethodnim Buddhinim rođenjima rijetko susreću. U kasnijim kanonskim djelima u petoj nikāyi Suttapiṭake, kao što su Buddhavaṃsa, Ćariyāpițaka i Đātaka, naglasak je stavljen upravo na prethodne Buddhine 
živote, čime se je njegov životopis protegnuo na nemjerljivo vrijeme koje mu je prethodilo. Vrhunac toga procesa unutar theravādske tradicije jest Nidānakathā, životopis Gotame Buddhe kojemu je svrha, kako se čini, pružiti uvjerljivost pripovijestima o Budhinim prethodnim rođenjima u zbirci Đātaka, a već su u Mahāvastuu đātake u tolikoj mjeri prisutne da su u konačnici te pripovijesti o njegovim prethodnim rođenjima ali i prethodnim rođenjima drugih pojedinaca, zasjenile njegovo posljednje rođenje u kojem je postao buddha.

\subsection{Uloga i značenje životopisa Gotame Buddhe}

Mahāparinibbānasutta bilježi da su Buddhinu smrt prihvatili mirno i pribrano redovnici koji su prije toga dosegli razinu arahanta. Međutim, među prisutnima je bilo i onih koji su [...] "plakali uzdignutih ruku, padali kao presječeni, njihali se naprijed-nazad [naričući]: 'Prebrzo je Blaženi iščezao, prebrzo je Sretni iščezao, prebrzo je nestalo Oko u svijetu!'"'.726

Među sljedbenicima je, kako se može iščitati iz te sutte, bilo onih kojima je odlazak velikoga učitelja i oslonca na duhovnome putu ostavio prazninu, a s kojom se je zajednica morala nositi ukoliko je željela opstati. Iako nije imenovao nasljednika, Buddha je prije smrti svojim učenicima ipak ostavio duhovno naslijeđe koje je, u njegovu odsustvu, trebalo voditi zajednicu:

Tada je Blaženi ovako rekao poštovanom Ānandi: "Moglo bi biti, o Ānanda, da među vama bude ovako: Nestala je riječ Učitelja, nemamo Učitelja. Ali, o Ānanda, ne treba to tako gledati. Nauka i redovnička pravila kojima sam vas poučio i koja sam obznanio bit će vam, nakon mojega odlaska, Učitelj", ${ }^{727}$

Ostavivši učenicima dhammu (nauku) i vinayu (pravila za život u zajednici) i savjetovavši im da sami sebi budu utočište, Buddha je dosegnuo parinibbānu i zauvijek napustio redovničku zajednicu koju je osnovao. Ipak, kako je primjetio Gombrich (1988/2006: 120) proturječje između "budite sebi utočište" i traženja utočišta u tri dragulja (pāli tiratana, skt. triratna) i više je nego očito. Formula koju pristupnik izgovara pri stupanju u red "Utječem se Buddhi, utječem se dhammi, utječem se sanghi" ${ }^{728}$ utoliko je problematična jer je od budućih sljedbenika tražila da se uteknu Buddhi kojega više nema.

Pālijski kanon ne sadrži cjelovit Buddhin životopis i čini se vjerojatnim da izravni Buddhini sljedbenici nisu imali potrebu sastavljati prikaz učiteljeva života budući da su s tim

\footnotetext{
${ }^{726}$ DN ii. 158. Izvornik dan na str. 197-198.

${ }^{727}$ DN ii. 154. Usp. MN iii. 9. Izvornik na str. 192-193.

${ }^{728}$ Buddham saraṇaṃ gacchāmi, Dhammam saraṇam gacchāmi, Sañgham saraṇaṃ gacchāmi.
} 
životom bili dobro upoznati "iz prve ruke" ${ }^{729}$ Međutim, u nešto kasnijem razdoblju, kada je živa uspomena na Buddhu počela blijediti, javila se je, vjerojatno, unutar redovničke zajednice, potreba da se praznina nastala Buddhinim iščeznućem popuni, kao i da se lik i djelo osnivača zajednice približi onima koji ga nisu izravno poznavali. Joachim Wach (1962: 5), vezano uz smrt Učitelja, piše sljedeće:

In the true spirit of their master, those who are left behind - who often possess entirely different personalities - are brought together through the image which is sacred to each of them. [...] The personality of the master lives on as an effective force.

Wachov zaključak da osobnost učitelja ima moć zadržati zajednicu na okupu potkrjepljuje činjenica da je Buddhin životopis služio i nadalje služi kao sredstvo povezivanja različitih buddhističkih škola i redovničkih zajednica, koje su, koliko god udaljene u prostoru, vremenu ili po pojedinim elementima kasnije razvijene nauke, ipak okupljene oko središnjega lika Buddhe i snage njegova autoriteta.

Ne treba, međutim, zaboraviti da Buddhin nauk nije bio namijenjen samo članovima redovničke zajednice već i onima koji su smatrali Buddhu duhovnim autoritetom i prihvaćali njegov nauk a da su se nisu odrekli svjetovnoga života. Naime, opstanak redovničke zajednice uvelike je ovisio o potpori laičkih sljedbenika, tako da se njihov utjecaj na razvoj Gotamina životopisa i općenito buddhizma ne smije podcijeniti. Laici, jednako kao i redovnici, nalaze utočište u Buddhi pa se i njih podjednako tiče pitanje tko je bio, kako je živio i kakvu je poruku ostavio veliki Učitelj. ${ }^{730}$ Prenošenje predaje o životu osnivača zajednice, koja se je s vremenom i dograđivala elementima o kojima je bilo riječi, budućim naraštajima (potencijalnih) redovnika i laičkim sljedbenicima čini se kao logičan odgovor na pitanje komu se utječe redovnik ili laik kada se utječe Buddhi, prvomu dragulju i utočištu svih buddhista. ${ }^{731}$

Životopis Gotame Buddhe imao je znatnu ulogu u uspostavljanju i održavanju buddhizma na novim područjima. Utemeljenje se buddhizma na novim područjima najjasnije očitovalo podizanjem thūpa koje su sadržavale Buddhine relikvije čija je pak svetost potvrđivana ili ulomcima njegova životopisa ili stvaranjem sasvim novih biografskih epizoda.

\footnotetext{
${ }^{729}$ Usp. Endo (2002: 1), Nakamura (2000/2002: 20).

${ }^{730}$ Sīgālovādasutta (DN, sutta br. 31) u cijelosti je posvećena dužnostima i vrlinama laika. Usp. Upālisutta (MN, sutta br. 56) i Gaṇakamoggallānasutta (MN, sutta br. 107).

731 Usp. Reynolds (1976: 56-57): [...] These traditional biographical fragments and the more complete and intergrated accounts of the Buddha's life continue to express and to transmit a sense of ascetic and royal greatness and charisma of the Founder, and to support his continuing role as one of the Three Jewels (the Buddha, the Dhamma, and the Sangha) in which all Buddhist take refuge.
} 
Tako primjerice kasnije theravādske kronike, kao što su Mahāvaṃsa i Dīpavaṃsa, proširuju Gotamin životopis novim epizodama kojima je svrha potvrditi autentičnost i svetost relikvija i potaknuti štovanje pojedinih mjesta na Śri Lanki povezujućih ih s dijelovima Gotamina životopisa. Theravādska je tradicija proizvela i kronike posvećene isključivo relikvijima, kao što su Mahābodhivaṃsa (10. st.), Thūpavaṃsa (12/13. st.) i Dāṭhavaṃsa (13. st.), a koje također sadrže dijelove Gotamina životopisa. Te su kronike dokaz ne samo iznimno važne uloge koju su relikvije imale u širenju buddhizma, već i važnosti Gotamina životopisa u misionarskom aspektu toga duhovnoga pokreta. Buddhine su relikvije služile i još uvijek služe buddhističkim vladarima i političkim vođama buddhističkih zemalja kao sredstvo legitimizacije moći i jačanja osjećaja zajedničkoga (nacionalnoga) identiteta. ${ }^{732}$

Mahāparinibbanasutta sadrži i opis začetka hodočasničkoga aspekta buddhizma. Hodočašća u mjesta povezana s ključnim trenutcima života Gotame Buddhe bila su sastavnim dijelom buddhističke prakse vjerojatno i prije 3. st. pr. n. e, a to nam je to potvrđeno Aśokinim natpisima. Tako je, primjerice, gaj Lumbinī potvrđen kao mjesto Gotamina rođenja i hodočasničko odredište natpisom na jednom od Aśokinih stupova, otkrivenim 1896. godine. Na natpisu otprilike stoji:

Kada je kralj Dēvānāmpriya Priyadarśin bio posvećen za kralja već dvadeset godina, došao je ovdje i odao počast ovomu mjestu zato što je Buddha Śakyamuni tu rođen. Dao je izraditi ploču [...] i podići kameni stup [kako bi pokazao] da je Blaženi bio ovdje rođen. Oslobodio je selo Lummini poreza i naložio da daje samo osminu uroda. ${ }^{733}$

Đātake, pripovijesti o prijašnjim Buddhinim rođenjima, imaju posebnu važnost unutar razvojnoga puta buddhizma i njegove književne tradicije. Proces njihova kanoniziranja započeo je, čini se, rano i usporedo s popularizacijom buddhizma kao novoga vjerskoga pokreta među širokim slojevima ondašnjega indijskoga društva. Đātake su u buddhističku književnost uvele mnogobrojne priče indijske pripovjedačke tradicije, uklopljene u obrazac đātake, u kojem se najčešće glavni junak na kraju poistovjećuje s bodhisattvom, a te su priče potom postale jedan od najpopularnijih načina za širenje buddhističke nauke kao primjeri u propovijedima. Đātake su imale velik utjecaj među sljedbenicima buddhističkoga nauka u Indiji, Kini, Tibetu, Burmi i

\footnotetext{
${ }^{732}$ V. Schober (2000).

${ }^{733}$ Devānapiyena Piyadasina lājina vīsativasābhisitena atana āgācha mahīyite hida Budhe jāte Sakyamunīti silāvigaḍabhīcā kālāpite silāthabecha usapāpite hida Bhagavam jāte ti Lummini gāme ubalike kațe ațabhāgiye ca. Prijevod prema: Hultzsch (1969: xxii, 164).
} 
drugim buddhističkim zemljama, a pojedine su došle i do Perzije, Sirije, arapskih zemalja, pa čak i Europe i opet tu našle svoju književnu, pa i religijsku primjenu.

Buddhin životopis imao je također važnu ulogu kao ishodišna točka novih životopisa unutar buddhističke književne tradicije. Naime, njegov je životopis poslužio kao izvor motiva ili model za kasnije životopise buddhističkih učitelja i svetaca. Njima je pažnju posvetio Reginald Ray (1994/1999: 61) koji zaključuje: [...] at some times more than at others but always undeniably, the Buddhist saints tend to approximate the type and life of their founder.

Buddhin životopis, uključujući i pripovijesti o njegovim prijašnjim rođenjima, poslužio je kao bogat izvor tema i ikonografskih motiva u buddhističkoj umjetnosti te je snažno utjecao i na indijsku umjetnost u cjelini. Kao impresivni primjeri buddhističke arhitekture, reljefnih prikaza i skulpture ističu se stūpe u Sāñćhī i Bhārhutu, kamene ograde u Amaravatī i spilje u Ađanti.

Reynolds (1976: 56) ističe i ulogu životopisa u različitim buddhističkim proslavama i ceremonijama, kao što je primjerice Vesākha-pūđa kojom se istovremeno može obilježavati dan Gotamina rođenja, probuđenja i ulaska u konačnu nibbānu, ili pak obred pristupanja novih članova redovničkoj zajednici prilikom kojega se uprizoruje pripovijest o Buddhinu napuštanju obitelji i odlasku iz Kapilavatthua.

Unutar kanonske buddhističke književnosti biografski su fragmenti imali važnu ulogu kao narativni okvir Buddhinih propovijedi. Taj okvir ne pruža samo kontekst i uvod u pojedine vidove i teme nauke već, štoviše, služi kao način potvrde autentičnosti izlaganja. Životopis Gotame Buddhe ima i iznimno znatnu didaktičku vrijednost budući da je Buddhin život predstavljen kao model koji bi trebao služiti kao primjer idealnoga moralnog djelovanja.

Buddhin se je životopis slagao i razvijao postupno i usporedno sa širenjem buddhizma, razvojem buddhističkih škola i buddhističke misli, a pratio je i promjene društvenih, kulturnih i političkih uvjeta, tako da se u njem nalaze i poveznice s pojmovima proizašlima iz buddhističke misaone tradicije, ali i poveznice sa širim povijesnim i društvenim kontekstom kojemu se je buddhizam nužno prilagođavao i time postupno mijenjao i oblikovao. Sve se te poveznice mogu očitavati i u tekstovima kojima su u ovome radu oslikane mijene i razvoj poimanja Buddhe i Buddhina životopisa u starijem buddhizmu te se za sve o čem je ovdje bila riječ u njima može naći razlog i potkrjepa. A sami se tekstovi pak bez tih poveznica $\mathrm{s}$ koordinatama svojega sadržaja i konteksta ne mogu razumjeti u onoj punini u kojoj ih valja doživjeti i razumijevati. 


\section{POPIS POKRATA}

\begin{tabular}{ll} 
AN & Añguttaranikāya \\
Apd. & Apadāna \\
BHSD & Buddhist Hybrid Sanskrit Dictionary \\
BHSG & Buddhist Hybrid Sanskrit Grammar \\
Bhv. & Buddhavaṃsa \\
Dhmp. & Dhammapāda \\
DN & Dīghanikāya \\
Dpv. & Dīpavaṃsa \\
ĐātA. & Đātakatțhavanṇnana \\
Lv. & Lalitavistara \\
Manu & Manuov zakonik \\
m.c. & metri causa \\
Mhv. & Mahāvaṃsa \\
MN & Mađđhimanikāya \\
MPS & Mahāparinibbānasutta \\
Mv. & Mahāvastu \\
PED & Pāli English Dictionary \\
PTS & Pali Text Society \\
SED & Sanskrit English Dictionary \\
Skt. & sanskrt, sanskrtski \\
Smp. & Samantapāsadikā \\
SN & Samyuttanikāya \\
Sn. & Suttanipāta \\
Thag. & Theragāthā \\
Thīg. & Therīgāthā \\
Ud. & Udāna \\
Vin. & Vinayapițaka \\
Vsm. & Visuddhimagga \\
Vv. & Vimānavatthu \\
\hline
\end{tabular}




\section{POPIS PRIMARNE I SEKUNDARNE LITERATURE}

\section{Pālijski kanonski izvori: izdanja}

\section{Vinayapitaka}

Oldenberg, Hermann (izd.) (1997.), Vinaya Pițakaṃ, sv. 1, The Mahāvagga. PTS, London: Luzac \& Company, Ltd. ([1879.], Williams and Norgate. Pretisak: PTS, 1929, 1964, 1997).

Oldenberg, Hermann (izd.) (1995.), Vinaya Pitakam, sv. 2, The Cullavagga. PTS, London: Luzac \& Company, Ltd. ([1880.], Williams and Norgate. Pretisak: PTS, 1930, 1964, 1977, 1995).

Oldenberg, Hermann (izd.) (1993.), Vinaya Pitakam, sv. 3, The Suttavibhanga (1. dio: Pārāđika, Saṃghādisesa, Aniyata i Nissaggiya). PTS, London: Luzac،\& Company, Ltd. ([1881.], Williams and Norgate. Pretisak: PTS, 1964, 1984, 1993).

Oldenberg, Hermann (izd.) (1993.), Vinaya Pițakam, sv. 4, The Suttavibhanga (2. dio: kraj Mahāvibhange i Bhikkhunīvibhanga). PTS, London: Luzac \& Company, Ltd. ([1882.], Williams and Norgate. Pretisak: PTS, 1964, 1984, 1993).

Oldenberg, Hermann (izd.) (1982.), Vinaya Pițakaṃ, sv. 5, The Parivāra. PTS, London: Luzac, \& Company, Ltd. ([1883.], Williams and Norgate. Pretisak: PTS, 1964, 1982).

\section{Suttapitaka}

Dīghanikāya

Rhys Davids T. W, Carpenter, Estlin J. (izd.) (1966.), Dīgha Nikāya, sv. 2 (Mahāvagga, sutte 14-23). PTS, London: Luzac, \& Company, Ltd. ([1903.]).

Rhys Davids T. W, Carpenter, Estlin J. (izd.) (1967.), Dīgha Nikāya, sv. 1

(Silakkhandavagga, sutte 1-13). PTS, London: Luzac \& Company, Ltd. ([1890.]. Carpenter, Estlin J. (izd.) (1960.), Dīgha Nikāya, sv. 3 (Pāṭikavagga, sutte 24-34). PTS, London: Luzac, \& Company, Ltd. ([1911.]).

\section{Mađđhimanikāya}

Trenckner, V. (izd.) (1888.), Majjhima Nikāya, sv. 1 (sutte 1-76). London: PTS (pretisak: 1948, 1964, 1979).

Chalmers, Robert (izd.) (1896.), Majjhima Nikāya, sv. 2 (sutte 77-106). London: PTS (pretisak: 1951, 1960, 1977).

Chalmers, Robert (izd.) (1899.), Majjhima Nikāya, sv. 3 (sutte 107-152). London: PTS (pretisak:1951, 1977). 
Samyuttanikāya:

Feer, L. (izd.) (1884-1898.), Samyutta Nikāya, sv. 1-5. London: PTS

Añuttaranikāya:

Morris, R. (izd.) (1885.), Anguttara Nikāya of the Sutta Pițaka, sv. 1. London: PTS (drugo izdanje: Warder, A. K. (1961.).

Morris, R. (izd.) (1888.), Anguttara Nikāya of the Sutta Pițaka, sv. 2. London: PTS (pretisak: 1976).

Hardy, E. (izd.) (1897.), Anguttara Nikāya of the Sutta Pițaka, sv. 3. London: PTS (pretisak: 1976).

Hardy, E. (izd.) (1899.), Anguttara Nikāya of the Sutta Pițaka, sv. 4. London: PTS (pretisak: 1958).

Hardy, E. (izd.) (1900.), Anguttara Nikāya of the Sutta Pițaka, sv. 5. London: PTS (pretisak: 1958).

Khuddakanikāya

Andersen, Dines, Smith, Helmer (izd.) (1913.), Sutta-Nipāta. London: PTS (pretisak: 1948, 1965, 1984).

Fausbøll, Viggo (izd.) (1877-1896.), The Jātaka, sv. 1-6. London: PTS.

Hinüber, Oscar von, Norman K. R. (izd.) (1995.) Dhammapāda. London: PTS ([1885.], Fausbøll, Viggo, Copenhagen, pretisak: 1909, London).

Jayawickrama, N. A. (izd.) (1974.), Buddhavaṃsa and Cariyāpițaka. London: PTS ([1882.], Morris, R. London: PTS).

Jayawickrama, N. A. (izd.) (1977.), Vimānavatthu and Petavatthu. London: PTS ([1886.], Gooneratne, E. R. London: PTS).

Lilley, Mary E. (izd.) (1925-1927.), The Apadāna of the Khuddaka Nikāya, sv. 1 i 2. London: PTS.

Oldenberg, Hermann, Pischel, R. (izd.) (1883.), The Thera- and Therī-Gāthāa. London: PTS

Steinthal, Paul (izd.) (1885.), Udāna. London: PTS (pretisak: 1948, 1982).

\section{Pālijski kanonski izvori: korišteni prijevodi}

Horner, I. B. (1971.), The Book of Discipline. Vinaya Pitaka, sv. 4, Mahāvagga. London. Luzac \& Company Ltd ([1951.], pretisak:1961, 1971). 
Rhys Davids, T. W, Oldenberg, Hermann (pr.) (1974.), Vinaya Texts: The Pātimokkha, The Mahāvagga, I-IV. Delhi, Patna, Varanasi: Motilal Banarsidass ([1882.], Oxford University Press. Pretisak: 1965, 1968, 1974, Motilal Banarsidass).

Rhys Davids, T. W, Rhys Davids, C. A. F. (pr.) (2007.), Dialogues of the Buddha, sv. 2. Delhi: Motilal Banarsidass ([1910.]).

\section{Pālijski izvankanonski izvori: izdanja i prijevodi}

Geiger, Wilhelm (pr.) (1912.), The Mahāvamsa or the Great Chronicle of Ceylon. London: za PTS Henry Frowde, Oxford University Press.

Oldenber, Hermann (izd. i pr.) (1879.) The Dïpavamsa. An Ancient Buddhist Historical Record. London: Williams and Norgate.

Rhys Davids, C. A. F. (izd.) (1920-1921.), Buddhaghosa: Visuddhimagga, sv. 1 i 2. London: PTS.

Rhys Davids, T. W., Carpentier, J. (izd.) (1886.), Sumañgala-Vilāsinī. Buddhaghosa's Commentary on the Dīgha Nikāya. London: za PTS Henry Frowde, Oxford University Press Warehouse.

Takakusu J, Nagai, Makoto (izd.) (1924.), Samantapāsādikā. Buddhaghosa's Commentary on the Vinaya Pitaka, sv. 1. London: PTS (pretisak: 1975).

Taylor, Arnold, C. (izd.), Katthāvatthu, sv. 1 i 2. London: PTS (pretisak: 1897, 1997.).

\section{Tekstovi na buddhističkom hibridnom sanskrtu i sanskrtu: izdanja i prijevodi}

Bühler, Georg (pr.) (1969.) The Laws of Manu. SBE, sv. 25. New York: Dover Publications ([1886.], Oxford).

Johnson, E. H. (izd. i prijevod) (2004). The Buddhacarita or Acts of the Buddha. Delhi: Motilal Banarsidass ([1936.], Lahore, pretisak: Delhi, 1972, 1978, prošireno izdanje: Delhi, 1984, pretisak: 1992, 1995, 1998, 2004).

Jones, J. J. (pr.) (2006.), The Mahāvastu, sv. 2. Lancaster: PTS ([1952.], Sacred Books of the Buddhists. London: Luzac \& Co).

Jones, J. J. (pr.) (2007a.), The Mahāvastu, sv. 1. Lancaster: PTS ([1949.], Sacred Books of the Buddhists. London: Luzac \& Co).

Jones, J. J. (pr.) (2007b.), The Mahāvastu, sv. 3. Lancaster: PTS ([1956.], Sacred Books of the Buddhists. London: Luzac \& Co).

The Play in Full: Lalitavistara (2013.). (pr. Dharmachakra Translation Committee). Dostupno na: https://read.84000.co/translation/toh95.html (lipanj, 2021.). 
Senart, Èmile (izd.) (1882.), Mahāvastu-avadānaṃ, sv. 1. Société asiatique Paris: À l' Imprimerie Nationale.

Senart, Èmile (izd.) (1890.), Mahāvastu-avadānam, sv. 2. Société asiatique Paris: À l' Imprimerie Nationale.

Senart, Èmile (izd.) (1897.), Mahāvastu-avadānaṃ, sv. 3. Société asiatique Paris: À l' Imprimerie Nationale.

\section{Rječnici i gramatike}

Edgerton, Franklin (1998.), Buddhist Hybrid Sanskrit. Grammar and Dictionary, sv. 1 i 2. New Delhi: Motilal Banarsidass ([1953.], New Haven: Yale University Press. Pretisak Delhi: 1970, 1972, 1977, 1985, 1993, 1998).

Monier Williams, Monier (1999.), Sanskrit English Dictionary. Delhi: Motilal Banarsidass ([1899.], Oxford University Press. Pretisak: Delhi: 1963, 1964, 1970, 1974, 1976, 1979, 1981, 1984, 1986, 1990, 1993, 1995, 1997, 1999).

Rhys-Davids, T. W., Stede, William (2007.), Pāli English Dictionary. Nataraj Books ([1921.], London: PTS).

\section{Popis sekundarne literature}

Almond, Philip C. (1988.), The British Discovery of Buddhism. Cambridge: Cambridge University Press.

Anālayo, Bhikkhu (2006.), The Buddha and Omniscience. The Indian International Journal of Buddhist Studies 7, str. 1-20. Dostupno na: https://www.buddhismuskunde.unihamburg.de/pdf/5-personen/analayo/buddha-omniscience.pdf (siječanj, 2017.).

Anālayo, Bhikkhu (2012.), Canonical Jātaka Tales in Comparative Perspective. The Evolution of Tales of the Buddha's Past Lives. Fuyan Buddhist Studies, br. 7, str. 75-100, Hsinchu: Fuyan Buddhist Institute.

Appleton, Naomi (2010.), Jātaka Stories in Theravāda Buddhism: Narrating the Bodhisatta Path. London, New York: Routledge.

Appleton, Naomi (2016.), A Summary of the Jātaka Stories in the Mahāvastu. Dostupno na: https://naomiappleton.files.wordpress.com/2016/08/01/the-jatakas-of-the-mahavastu/ (svibanj, 2020.).

Appleton, Naomi (2019.), What Does It Mean To Be a Badly Behaved Animal? An Answer from the Devadatta Stories of the Pāli Jātakas. Religions 10 (4), 288; 
https://doi.org/10.3390/rel10040288. Dostupno na: https://www.mdpi.com/20771444/10/4/288/htm (siječanj, 2017.)

Bailey, Greg (1995.), Problems of the Interpretation of the Data Pertaining to Religious Interaction in Ancient India: The Conversion Stories in the Sutta Nipāta. Indo-British Review 19, br. 1, str. 1-20.

Balasooriya, Somaratna et al. (ur.) (1980.), Buddhist Studies in Honour of Walpola Rahula. London: Gordon Fraser.

Bapat, P. V. (1926.), The Different Strata in the Literary Material of the Dīgha Nikāya. Annals of the Bhandarkar Oriental Research Institute, sv. 8, br. 1, str. 1-16.

Bareau, Andre (1963.), Recherches sur la biographie du Buddha dans les Sūtrapitaka et les Vinayapițaka anciens (I-III). Paris: École française d'Extrême-Orient.

Bareau, Andre (1971.), The Superhuman Personality of Buddha and its Symbolism in the Mahāparinirvāṇasūtra of the Dharmaguptaka. U: Kitagawa, J. M, Long, Charles H. (ur.), str. 9-21.

Baruah, Bibhuti (2000.), Buddhist Sects and Sectarianism. New Delhi: Sarup \& Sons. Basham, Arthur L. (1951). History and Doctrine of the Ajivikas. A vanished Indian Religion. London: Luzac \& Company Ltd.

Bechert, Heinz (1982.), The date of Buddha reconsidered. Indologica Taurinensia 10, str. 2936.

Bechert, Heinz (ur.) (1992.), The Dating of Historical Buddha, sv. 2. Götitngen:

Wandenhoeck \& Ruprecht (Die Datierung des historischen Buddha - Symposien zur Buddhismusforschung, IV, 1.).

Bloss, Lowell W. (1978.), The Taming of Māra: Witnessing to the Buddha's Virtues. History of Religions, sv. 18, br. 2, str. 156-176. Dostupno na: http://www.jstor.org/stable/1062584 (studeni, 2016.).

Bollée, Willem (2005.), Physical Aspects of Some Mahāpuruṣas Descent, Foetality, Birth. Wiener Zeitschrift für die Kunde Südasiens / Vienna Journal of South Asian Studies, sv. 49, str. 5-34. Dostupno na: http://www.jstor.org/stable/24007652 (ožujak, 2019.).

Bond, George (1984.), The Development and Elaboration of the Arahant Ideal in the Theravada Buddhist Tradition. Journal of the American Academy of Religion, sv. 52, br. 2, str. 227-242. URL: http://www.jstor.org/stable/1463997 (srpanj, 2017.).

Boucher, Daniel (1991.), The Pratītyasamutpādagathā and Its Role in the Medieval Cult of the Relics. The Journal of the International Association of Buddhist Studies, sv. 14, br. 1, str. $1-27$. 
Boyd, James W. (1971.), Symbols of Evil in Buddhism. The Journal of Asian Studies, sv. 31, br. 1, str. 63-75. Dostupno na: http://www.jstor.org/stable/2053052 (studeni, 2019.). Bronkhorst, Johannes (2000a.), The Riddle of the Jainas and Ājīvikas in Early Buddhist Literature. Journal of Indian Philosophy, sv. 28, br. 5/6, str. 511-529.

Bronkhorst, Johannes (2000b.), Two Traditions of Meditation in Ancient India. Delhi, Motilal Banasidass [1993.].

Bronkhorst, Johannes (2009.), Hendrik Kern and the Body of Buddha. Asiatische Studien/Etudes Asiatiques, sv. 63 (1), str. 7-27.

Brown, Peter (1981.), The Cult of the Saints: Its Rise and Function in Latin Christianity. The University of Chicago Press.

Brown, Robert L. (1984.), The Śrāvastī Miracles in the Art of India and Dvāravatī. Archives of Asian Art, sv. 37, str. 79-95. URL: http://www.jstor.org/stable/20111145 (kolovoz, 2018.).

Burghart, Richard (1983.), Renunciation in the Religious Traditions of South Asia. Man, New Series, sv. 18, br. 4, str. 635-653. Dostupno na: http://www.jstor.org/stable/2801900 (siječanj, 2018.).

Burnouf, Eugène (2010), Introduction to the History of Indian Buddhism (prijevod: Katia Buffetrille, Donald S. Lopez Jr.). University of Chicago Press ([1844.], Introduction à l'histoire du Buddhisme indien. Paris: Imprimerie Royale).

Burnouf, E., Lassen C. (1826.), Essai sur le Pāli ou langue sacrée de la presqu'île audelà du Gange. Paris: Dondey-Dupreé.

Campbell, Joseph (1973.), The Hero with a Thousand Faces. New Jersey, Princeton University Press ([1949], pretisak: 1968).

Chalmers, Robert (1894.), The Letter from Robert Chalmers. The Journal of the Royal Asiatic Society of Great Britain and Ireland, str. 386-87. Dostupno na:

http://www.jstor.org/stable/25197202 (rujan, 2018.).

Chalmers, Robert (1898.), Tathāgata. The Journal of the Royal Asiatic Society of Great

Britain and Ireland, str. 103-115. Dostupno na:

http://www.jstor.org/stable/25207938?seq=1\#page_scan_tab_contents (srpanj, 2018.)

Charpentier, Jarl (1909.), Das Mārasamyutta im Mahāvastu. Wiener Zeitschrift für die Kunde des Morgenlandes, sv. 23, str. 33-51. Dostupno na:

http://www.jstor.org/stable/23864538 (prosinac, 2018.).

Charpentier, Jarl (1913.), Ajivika. Journal of Asiatic Society of Great Britain and Ireland, str. 669-674. Dostupno na: http://www.jstore.org/stable/25189032 (ožujak, 2018.). 
Charpentier, Jarl (1922.), The History of the Jains. U: Rapson, E. J. (ur.).

Collins, Steven (1992.), Nirvāṇa, Time, and Narrative. History of Religions, sv. 31, br. 3, str. 215-246. Dostupno na: http://www.jstor.org/stable/1062862 (siječanj, 2019.).

Conze, Edward (1976.), Thirty Years of Buddhist Studies. Oxford: Bruno Cassirer Publishers Ltd.

Cousins, Lance, S. (1973.), Buddhist Jhāna. Its nature and Attainment According to the Pāli Sources. Religion, sv. 3, str. 115-131. U: Williams (ur.), sv. 2, str. 34-51.

Cousins, Lance S. (1988/1990.), The 'Five Points' and the Origins of the Buddhist Schools. Buddhist Forum, sv. 2, str. 27-60.

Cousins, Lance S. (2001.), On the Vibhajjavādins, the Mahīsāsaka, Dhammaguttaka, Kassapiya and Tambapaṇiniya branches of the ancient Theriyas. Buddhist Studies Review, sv. 18, br. 2, str. 131-182. Dostupno na: https://journals.equinoxpub.com/index.php/BSR/article/view/8772/6247 (siječanj, 2018.).

Cousins, Lance S. et al. (ur.) (2012.), Buddhist Studies in Honour of I.B. Horner. Dordrecht, Boston: D. Reidel Publishing Company [1974.].

Cowell, Edward B., Eggeling, Julius (1875.), Catalogue of Buddhist Sanskrit manuscripts in the possession of the Royal Asiatic Society (Hodgson collection). Hertford: S. Austin \& sons.

Cummings, Mary (1982.), The Lives of the Buddha in the Art and Literature of Asia. The University of Michigan, Center for South and Southeast Asian studies.

Dayal, Har (1970.), The Bodhisattva Doctrine in Buddhist Sanskrit Literature. Delhi, Patna, Varanasi: Motilal Banarsidas ([1932.] London: Routledge \& Kegan Paul Ltd.).

De Jong, J.W. (1976.), A Brief History of Buddhist Studies in Europe and America. Varanasi: Bharat-Bharati Oriental Publishers and Booksellers ([1974.], The Eastern Buddhist, sv. $8)$.

DeCaroli, Robert (2004.), Haunting the Buddha. Indian Popular Religions and the Formation of Buddhism. Oxford, New York: Oxford University Press.

Deeg, Max (1999.), The Sangha of Devadatta: Fiction and History of a Heresy in the Buddhist Tradition, Journal of the International College for Advanced Buddhist Studies 2, str. $195-230$.

Delehaye, Hippolyte (1907.), The Legends of the saints, an introduction to Hagiography. London: Longmans, Green. 
Derrett, J. Duncan M. (1992.), Homer in India: The Birth of the Buddha. Journal of the Royal Asiatic Society, sv. 2, br. 1, str. 47-57. Dostupno na: http://www.jstor.org/stable/25182448 (prosinac, 2018.).

Dessein, Bart (2009.), The Mahāsāṃghikas and the Origin of Mahayana Buddhism: Evidence Provided in the Abhidharmamahāvibhāṣāsāastra. Eastern Buddhist, sv. 40, br. 1/2, str. $25-61$.

Dutt, Nalinaksha (1930.), Early History of the Spread of Buddhism and the Buddhist Schools. New Delhi, Allahabad: Rajesh Publications.

Dutt, Nalinaksha (1998.), Buddhist Sects in India. Delhi: Motilal Banarsidas ([1970.] Calcutta: Firma K. L. Mukhopadhyay. Drugo izdanje Delhi, 1978, pretisak 1987.).

Dutt, Sukumar (1957.), The Buddha and Five After Centuries. London: Luzac \& Company Ltd.

Endo, Toshiichi (2002.), Buddha in Theravada Buddhism. A Study of the Concept of the Buddha in the Pali Commentaries. Dehiwela, Sri Lanka: Buddhist Cultural Centre [1997.].

Finot, Louis (1932.), The Mahaparinibbana-sutta and Cullavagga, The Indian Historical Quarterly, 8: 2, str. 241-246.

Fiordalis, David V. (2008.), Miracles in Buddhist Literature, doktorska disertacija. University of Michigan. Dostupno na:

https://deepblue.lib.umich.edu/bitstream/handle/2027.42/61721/dvf_1.pdf (svibanj, 2018.).

Fiordalis, David V. (2010.), Miracles in Indian Buddhist narratives and doctrine. Journal of the International Association of Buddhist Studies, sv. 33, br. 1-2, str. 381-401.

Fleet, Jonathan F. (1906.), The Tradition about the Corporeal Relics of Buddha. The Journal of the Royal Asiatic Society of Great Britain and Ireland, str. 655-671. Dostupno na: http://www.jstor.org/stable/25210299 (svibanj, 2018.).

Fleet, Jonathan. F. (1909.), The Day on Which Buddha Died. Journal of the Royal Asiatic Society of Great Britain and Ireland, str. 1-34. Dostupno na: http://www.jstor.org/stable/25210706 (svibanj, 2018.).

Fogelin, Lars (2003.), Ritual and Presentation in Early Buddhist Religious Architecture. Asian Perspectives, sv. 42, br. 1, str. 129-154. University of Hawaii Press. Dostupno na: http://www.jstor.org/stable/42929208 (siječanj, 2018.).

Foucher, Alfred (2003.), The Life of Buddha According to the Ancient Texts and Monuments of India (prijevod: Simone Brangier Boas). New Delhi, Munshiram Manoharlal 
Publishers Pvt. Ltd. ( [1949.], La vie du Bouddha d'après les textes et les monuments de l'Inde. Paris: Payot).

Franke, Otto (1908.), The Buddhist Councils at Rājagaha and Vesālī as Alleged in Cullavagga XI., XII. Journal of the Pali Text Society, sv. 6 str. 1-80.

Franke, Otto (1909.), Die Suttanipāta-Gāthās mit ihren Parallelen. Teil II: SN. III (Mahāvagga). Zeitschrift der Deutschen Morgenländischen Gesellschaft, sv. 63, br. 3, str. 551-586.

Franklin, Jeffrey J. (2005.), The Life of the Buddha in Victorian England. ELH, sv. 72, br. 4, str. 941-974. Dostupno na: http://www.jstore.org/stable/30029996 (srpanj, 2018.).

Frauwallner, Erich (1956.), The Earliest Vinaya and the Beginnings of Buddhist Literature, Series Orientale Roma VIII, Rim, IsMeo.

Garbe, Richard (1914.), Buddhist influence in the Gospels. The Monist, sv. 24, br. 4, str. 481492.

Geiger, Wilhelm (1996.), Pāli Literature and Language (prijevod: Batakrishna Ghosh). New Delhi: Munshiram Manoharlal Publishers Pvt. Ltd. ([1943.], Calcutta: Calcutta University).

Gethin, Rupert (1997.), Cosmology and Meditation: From the Aggañña-Sutta to the Mahāyāna. History of Religions, sv. 36, br. 3, str. 183-217. Dostupno na: http://www.jstor.org/stable/3176457 (siječanj, 2018.).

Gethin, Rupert (1998.), The Foundations of Buddhism. Oxford, New York: Oxford University Press.

Gokhale, Balakrishna G. (1965.), The Theravāda-Buddhist View of History. Journal of the American Oriental Society, sv. 85, br. 3, str. 354-360. Dostupno na: http://www.jstor.org/stable/597819, (siječanj, 2018.).

Gombrich, Richard F. (1980.), The Significance of Former Buddhas in Theravādin Tradition. U: Balasooriya et al. 8ur.), str. 62-72.

Gombrich, Richard F. (1989), recenzija članka: Die Lebenszeit des Buddha - das älteste feststehende Datum der indischen Geschichte? by Heinz Bechert. The Journal of the Royal Asiatic Society of Great Britain and Ireland, br. 2, str. 348-350. Dostupno na: http://www.jstor.org/stable/25212520 (rujan, 2018).

Gombrich, Richard F. (1992.), Dating Historical Buddha. A Red Herring Revealed. U: Bechert (ur.) (1992.), str. 237-259.

Gombrich, Richard F. (2005.), Kindness and Compassion as a Means to Nirvāṇa. U: Williams, Paul (ur.), sv. 2, str. 136-153. 
Gombrich, Richard F. (2006). Theravada Buddhism: A Social History from Ancient Benares to Modern Colombo. London, New York: Routledge ([1988.], Routledge, Kegan \& Paul Ltd.).

Grabovac, Višnja (2013.), Književnost na buddhističkome hibridnome sanskrtu. Mahāvastu: četiri Bodhisattvina viđenja. Književna smotra, br. 167 (1), str. 95-105.

Grabovac, Višnja (2020.), Savršenstvo u mudrosti, mudrost u poučavanju. Izbor iz pripovijesti o prijašnjim egzistencijama Gautame Buddhe u Mahāvastuu. Književna smotra, sv. 52, br. 196 (2), str. 91-97.

Griffiths, Paul J. (1989.), Buddha and God: A Contrastive Study in Ideas about Maximal Greatness. The Journal of Religion, sv. 69, br. 4, str. 502-529. Dostupno na: http://www.jstor.org/stable/1204033 (siječanj, 2018.).

Griffiths, Paul J. (1994.), On Being Buddha: The Classical Doctrine of Buddhahood. Albany: SUNY Press.

Gubernatis, Angelo de (1872.), Zoological mythology or The legends of animals. London, Trübner \& co.

Hallisey, Charles (1995.), Roads Taken and not taken in the Study of Theravāda Buddhism u: Lopez, ur. (1995.), str. 31-61.

Harrison, Paul (2005.), Who gets to ride in the Great Vehicle? Self-image and identity among the followers of early Mahāyāna u: Williams (ur.) (2005, sv. 3), str. 108-125.

Hartmann, Jens-Uwe (1991.), Research on the Date of the Buddha: South Asian Studies Published in Western Languages u: Bechert (ur.), str. 27-45.

Harvey, Peter (2013.), An Introduction to Buddhism. Teachings, History and Practices. Cambridge University Press ([1990.])

Hinüber, Oscar von (1996.), A Handbook of Pāli Literature. Berlin, New York: Walter de Gruyter.

Hinüber, Oscar von (2008.), Hoary past and hazy memory. On the history of early Buddhist texts (Presidential address at the XVth Conference of the International Association of Buddhist Studies, Emory University, Atlanta, Georgia, June 23-28, 2008). Journal of the International Association of Buddhist Studies, sv. 29, br. 2, 2006 (2008), str. 193210.

Hirakawa, Akira (1990.), A History of Indian Buddhism from Śākyamuni to Early Mahāyāna (prijevod: Paul Groner). University of Hawaii Press. 
Hirakawa, Akira (2005.), The Rise of Mahāyāna Buddhism and Its Relationship to the Worship of Stūpas. u: Williams (ur.), sv. 2, str. 181-226 ([1963.], Memoirs of the Research Department of the Toyo Bunko 22, str. 57-106).

Hofinger, M. (1964.), Étude sur le concile de Vaiśālī. Louvain: Bureaux du Muséon.

Hopkins, Washburn E. (1911.), Buddha as Tathāgata. The American Journal of Philology, sv. 32, br. 2, str. 205-209.

Horner, I.B. (1934.), The Four Ways and Four Fruits in Pāli Buddhism. Indian Historical Quarterly, sv. 10, str. 785-796.

Horner, I.B. (1936.), The Early Buddhist Theory of Man Perfected. A Study of the Arahan Concept and the Implications of the Aim to Perfection in Religious Life. London: Routledge \& Kegan Paul Ltd.

Hultzsch, Eugen (1912.), Jātakas at Bharhut. Journal of the Royal Asiatic Society, str. 399410.

Hultzsch, Eugen (1969.), Inscriptions of Asoka. Delhi, Varanasi, Indological Book House. Hume, David (1757.), Four Dissertations. London: A. Millar in the Strand. Dostupno na: https://quod.lib.umich.edu/cgi/t/text/text-idx?c=ecco;idno=004806396.0001.000 (siječanj, 2018.)

Jayatilleke, K. N. (1980.), Early Buddhist Theory of Knowledge. London: George Allen \& Unwin Ltd. [1963.].

Ježić, Mislav (1983.), Buddhistička držanja koja ne valja napustiti. Književna smotra, god. XV, br. 50, str. $73-85$.

Karetzky, Patricia Eichenbaum (1995.), The First Seromon. East and West, sv. 45, br. 1/4, str. 127-147. Dostupno na: http://www.jstor.org/stable/29757209. (ožujak, 2018.).

Katičić, Radoslav (1973.), Stara indijska književnost. Zagreb: Nakladni zavod Matice hrvatske.

Katz, Nathan (1979.), The Concept of the Arahant in the Sutta Pitka, With Reference to the Bodhisattva and the Mahāsiddha (doktorska disertacija). Temple University.

Katz, Nathan (1982.), Buddhist Images of Human Perfection. Delhi: Motilal Banarsidass.

Keown Damien, Charles S. Prebish (ur.) (2013.), Encyclopedia of Buddhism. Routledge ([2007.], pretisak: 2008, 2009).

Kern, Hendrik (1896.), Manual of Indian Buddhism. Grundriss der indo-arischen Philologie und Altertumskunde (prijevod: Bühler, G.). Strassburg: Verlag von Karl J. Trübner. Kitagawa, Joseph M, Long, Chlarles H. (1971.), Myths and Symbols. Studies in Honor of Mircea Eliade. Chicago, London: The University of Chicago Press [1969.]. 
Lamotte, Étienne (1988.), History of Indian Buddhism: From the Origins to the Śaka Era (prijevod: Sara Wobb-Boin). Louvain la Neuve, Institut Orientaliste ([1958.], Histoire du Bouddhisme Indien, des origines à l'ère Śaka, Louvain, Bibliothèque du Muséon).

Lopez, Donald S. Jr. (ur.) (1995.), The Curators of the Buddha: The Study of Buddhism under Colonialism. Chicago: University of Chicago Press.

Lopez, Donald S. Jr. (ur.) (2005.), Critical Terms for the Study of Buddhism. Chicago, London: Chicago University Press.

Lopez, Donald S. Jr. (2005.), Buddha. U: Lopez (ur.) (2005.), str. 13-36.

Lüders, Heinrich (1940.), Philologica Indica. Göttingen: Vandenhoeck \& Ruprecht.

Malandra, Geri Hockfield (1981.), Māra’s Army. Text and Image in Early Indian Art. East and West, sv. 31, br. 1/4, str. 121-130. Dostupno na:

http://www.jstor.org/stable/29756586 (prosinac, 2016.).

Masefield, Peter (1986.), The Divine Revelation in Pali Buddhism. Columbo: The Sri Lanka Institution of Traditional Studies.

Masuda, Jiryo (1925.), Origin and Doctrines of Early Buddhist Schools. A Translation of Hsüang-Chwang Version of Vasumitra's Treatise. Asia Minor 2, str. 1-78.

Miller, Barbara Stoler (1979.), On Cultivating the Immeasurable Change of Heart: The Buddhist Brahmavihāra formula. Journal of Indian Philosophy, sv. 7, br. 2, str. 209221. Dostupno na: http://www.jstor.org/stable/23440381 (ožujak, 2018.).

Minoru, Hara (2009.), Divine Procreation. Indo-Iranian Journal, sv. 52, br. 2/3, str. 217-249. Dostupno na: http://www.jstor.org/stable/24664700 (siječanj, 2018.).

Nakamura, Hajime (1987.), Indian Buddhism. Survey With Bibliographical Notes. Delhi, Varanasi, Patna, Madras: Motilal Banarsidass [1980.].

Nakamura, Hajime (2002.), Gotama Buddha. A Biography Based on the Most Reliable Texts (I) (prijevod: Gaynor Sekimori). Tokyo, Kosei Publishing Co [2000.].

Nakamura, Hajime (2005.), Gotama Buddha. A Biography Based on the Most Reliable Texts (II) (prijevod: Gaynor Sekimori). Tokyo, Kosei Publishing Co [2000.].

Nitta, Tomomichi (2008.), On the "Deification" of the Historical Buddha in the Studies of the Buddha's Life Story. Hōrin 15. Dostupno na: https://www.academia.edu/20319019/On_the_Deification_of_the_Historical_Buddha_i n_the_Studies_of the_Buddha_s_Life_Story (srpanj, 2017.).

Norman, Keith R. (1983.), Pāli Literature Including Canonical Literature in Prakrit and Sanskrit. (A History of Indian Literature (ur. Jan Gonda), sv. 7, fasc. 2). Wiesbaden: Otto Harrassowitz. 
Norman, Keith R. (1997.), A Philological Approach to Buddhism. The Bukkyb Dendo Kybkai Lectures 1994. London: School of Oriental and African Studies.

Oberlies, Thomas (2001.), Pāli. A Grammar of the Theravāda Tipițaka. Berlin, New York: Walter de Gruyter.

Obermiller (1931.), History of Buddhism (Chos-hbyung) by Bu ston. The Jewelry of Scripture. Heidelberg: O. Harassowitz, Leipzig.

Oldenberg, Hermann (1912.), Studien zum Mahāvastu. Nachrichten der Akademie der Wissenschaften in Göttingen, str. 123-154 (pretisak u: [1967.], Kleine Schriften, sv. 2, str. 1037-1068).

Oldenberg, Hermann (2007.), Buddha. Njegov život, njegovo učenje, njegova zajednica. (prijevod: Boris Mikulić). Demetra, Zagreb (Buddha Sein Leben, seine Lehre, seine Gemeinde, Berlin-Stuttgart: Cotta [1881], 7. izd. 1920. Na temelju 7. izd., novo izdanje s pogovorom i registrom priredio Helmuth von Glasenapp, Stuttgart, 1961. pretisak Stuttgart: Magnus Verlag).

Pachow, W. (1965.), A Study of the Dotted Record. Journal of the American Oriental Society, sv. 85, br. 3, str. 342-349. Dostupno na: http://www.jstor.org/stable/597817 (rujan, 2018.).

Pande, Govind C. (1957.), Studies in the Origins of Buddhism. Allahabad: The University of Allahabad.

Penner, Hans H. (2009.), Rediscovering the Buddha. The Legends and Their Interpretations. Oxford, New York: Oxford University Press.

Prebish, Charles S. (1974.), A Review of Scholarship on the Buddhist Councils. The Journal of Asian Studies, sv. 33, br. 2, str. 239-254. Dostupno na: http://www.jstor.org/stable/2052186 (lipanj, 2018.).

Prebish, Charles S., Nattier, Janice J. (1977.), Mahāsāṃghika Origins. The Beginnings of Buddhist Sectarianism. History of Religions, sv. 16, br. 3, str. 237-272. Dostupno na: http://www.jstor.org/stable/1062592 (siječanj, 2018.).

Prebish, Charles S. (1994.), Survey of Vinaya Literature. Taipei: Jin Luen Publishing House.

Rahula, Walpola (1974.), Wrong Notions of Dhammatā (Dharmatā) u: Cousins et al. (ur.) str. $181-191$.

Rapson, E. J. (ur.) (1922.), Cambridge History of India, sv. 1. Cambridge: Cambridge University Press.

Ray, Reginald (1993.), Death of Buddha. Buddhist-Christian Studies, sv. 13, str. 168-179. Dostupno na: http://www.jstor.org/stable/1389884 (svibanj, 2017.). 
Ray, Reginald (1999.), Buddhist Saints in India. New York, Oxford: Oxford University Press [1994.].

Regamey, Constantin (1951.), Buddhistiche Philosophie. Bern: A. Francke.

Reynolds, Frank (1976.), The Many Lives of Buddha. A study of Sacred Biography and

Theravāda Tradition u: Frank E. Reynolds, Donald Capps (ur.), str. 37-61.

Reynolds, Frank (1997.), Rebirth Traditions and the Lineages of Gotama. A Study in

Theravāda Buddhology. U: Schober (ur.), str. 19-39.

Reynolds, Frank E, Carbine, Jason A, (ur.) (2000.), The Life of Buddhism. Berkeley, Los Angeles, London: University of California Press.

Rhys Davids, T. W. (1907.) Buddhism. Its History And Literature. New York: G. P Putnam's Sons [1896.].

Rhys Davids, T. W. (1911.), Buddhist India. New York: G. P Putnam's Sons [1903.].

Rhys Davids, T. W. (1912.), Buddhism being a sketch of the life and teachings of Gautama, the Buddha. London: Society for Promoting Christian Knowledge [1877.].

Rhys Davids, T. W. (1908.), Early Buddhism. London, Archibald Constable \& Co Ltd.

Rockhill, Woodville W. (pr.) (1882.), The Life of the Buddha and Early History of his Order.

London: Kegan Paul Trench Trubner And Company Limited- Dostupno na:

https://archive.org/details/lifeofthebuddha029842mbp/page/n7/mode/2up (svibanj, 2017.)

Samuels, Jeffrey (1997.), The Bodhisattva Ideal in Theravāda Buddhist Theory and Practise:

A Reevaluation of the Bodhisattva- Śāvaka Opposition. Philosophy East and West, sv. 47 (3), str. 399-415. Dostupno na: http://www.jstor.org/stable/1399912 (siječanj, 2018.).

Sastri, Hirananda (ur.) (1983.), Epigraphia Indica (sv. 20). New Delhi: The Director-General Archeological survey of India. ([1929-1930.] Dostupno na mrežnim stranicama National Digital Library of India (siječanj, 2018.)).

Schmitthausen, Lambert (1981.), On Some Aspects of Descriptions of Theories of Liberating Insight and Enlightenment in Early Buddhism. Studien zum Jainismus und Buddhismus: Gedenkschrift Ludwig Alsdorf (ur. Klaus Bruhn, Albrecht Wezler), Wiesbaden: Franz Steiner Verlag.

Schmithausen, Lambert (1992.), An Attempt to Estimate the Distance in Time between Aśoka and the Buddha in Terms of Doctrinal History. U: Bechert, Hans (ur.) (1992.), str. 110147. 
Schober, Juliane (1997.), The Biographical Genre in Local Buddhist Cults and Practise. U: Schober (ur.), str. 257-288.

Schober, Juliane (1997.), Trajectories in Buddhist Sacred Biography. U: Schober (ur.), str.115.

Schober, Juliane (ur.) (1997.), Sacred Biography in the Buddhist Traditions of South and Southeast Asia. University of Hawaii Press.

Schober, Juliane (2000.), A Tooth Relic and the Legitimation of Power u: Reynolds, Frank E, Carbine, Jason A, (ur.), str. 46-59.

Schopen, Gregory (1985.), Two Problems in the History of Indian Buddhism: The Layman/Monk Distinction and the Doctrines of the Transference of Merit. Studien zur Indologie und Iranistik 10, str. 9-47.

Schopen, Gregory (1988.), On the Buddha and His Bones: The Conception of a Relic in the Inscriptions of Nāgarjunikoṇda. Journal of the American Oriental Society, sv. 108, br. 4, str. 527-537. Dostupno na: http://www.jstor.org/stable/603142 (studeni, 2018.).

Schopen, Gregory (1991.), Archaeology and Protestant Presuppositions in the Study of Indian Buddhism. History of Religions, sv. 31, br. 1, str. 1-23. Dostupno na: http://www.jstor.org/stable/1062872 (siječanj, 2018.).

Schopen, Gregory (1997.), Bones, Stones and Buddhist Monks: collected papers on the archaeology, epigraphy, and texts of monastic Buddhism in India. University of Hawaii Press.

Senart, Émile (1882.), Essai sur la légende du Buddha, son caractère et ses origines. Paris, Imprimerie Nationale ([1873-1875.] Journal asiatique).

Sharf, Robert H. (1999.), On the Allure of Buddhist Relics. Representations, br. 66, str. 7599. Dostupno na: http://www.jstor.org/stable/2902880 (srpanj, 2018.).

Silk, Jonathan (2002.), What, if Anything, is Mahāyāna Buddhism: Problems of Definitions and Classifications. Numen, sv. 49, str. 355-405. Dostupno na: www.brill.nl (prosinac, 2017.).

Silk, Jonathan (2003.), The Fruits of Paradox. On the Religious Architecture of the Buddha's Life Story. Journal of the American Academy of Religion, sv. 71, br. 4, str. 863-881. Skilling, Peter (1982.), Uddaka Rāmaputta and Rāma. Pāli Buddhist Rewiev 6.2. (19811982.), str. 99-105.

Snellgrove, David L. (1973.), Sākyamuni’s Final nirvāṇa. Bulletin of the School of Oriental and African Studies, University of London, sv. 36, br. 2, In Honour of Walter Simon (1973,), str. 399-411. Dostupno na: http://www.jstor.org/stable/613517 (srpanj, 2018.). 
Spagnoli, Maria (2005.), Searching for the Origin of the "bhūmisparśa-mudrā". East and West, sv. 55, br. 1/4, str. 329-344. Dostupno na: http://www.jstor.org/stable/29757652 (prosinac, 2018.).

Stoesz, Willis (1978.), Buddha as a Teacher. Journal of the American Academy of Religion, sv. 46, br. 2, str. 139-158. Dostupno na: http://www.jstor.org/stable/1462218 (siječanj, 2017.).

Strong, John S. (1997.), A Family Quest: The Buddha, Yaśodharā, and Rāhula in the Mūlasarvāstivāda Vinaya. U: Schober, J. (ur.), str. 113-128.

Strong, John S. (2004.), Relics of the Buddha. Princeton, Oxford: Princeton University Press. Talim, Meena (2002/2003.), Buddha and Miracles. Bulletin of the Deccan College Research Institute, sv. 62/63, Proffesor Ashok R. Kelkar Felicitation Volume, str. 249-263. Dostupno na: http://www.jstor.org/stable/42930622 (studeni, 2018.).

Timm, Jeffrey R. (1997.), recenzija knjige: Curators of the Buddha: The Study of Buddhism Under Colonialism. Philosophy East and West, sv. 47, br. 4, str. 588-595. Dostupno na: http://buddhism.lib.ntu.edu.tw/FULLTEXT/JR-PHIL/jeffrey.htm (srpanj, 2017.).

Thomas, Edward J. (2000.), The Life of Buddha as Legend and History. New York: Dover Publications, Inc ([1949.] London: Routledge \& Kegan Paul Ltd (prvo izdanje 1927.)). Tournier, Vincent (2012.), The Mahāvastu and the Vinayapitaka of the MahāsānghikaLokottaravādin. ARIRIAB XV, str. 87-104.

Tournier, Vincent (2017.), La formation du Mahāvastu et la mise en place des conceptions relatives à la carrière du bodhisattva. Paris: École française d' Extrême-Orient.

Trainor, Kevin (2013.), Kapilavastu, u: Keown, Prebish (ur.), str. 436-43.

Vetter, Tilmann (1988.), The Ideas and Meditative Practices of Early Buddhism. Leiden, New York, København, Köln: E.J. Brill.

Xing, Guang (2005.), The Concept of the Buddha. Its Evolution from Early Buddhism to the trikāya theory. London, New York: Routledge.

Xing, Guang (2009.), The Development of the Concept of the Buddha. Buddhist and Pali Studies in Honour of The Venerable Professor Kakkapalliye Anuraddha. Centre of Buddhist Studies, University of Hong Kong.

Wach, Joachim (1962.), Master and Disciple. Two Religio-Sociological Studies. The Journal of Religion, sv. 42, br. 1-21.

Waldschmidt, Ernest (1950-1951.), Das Mahāparinirvāṇasūtra, I-III. Abhandlungen der Deutschen Akademie der Wissenschaft zu Berlin, Klasse für Sprachen, Literatur und Kunst. Berlin, Akademie-Verlag. 
Walland, L. A. (1914.), The So-Called Mahapadana Suttanta and the Date of the Pali Canon. The Journal of the Royal Asiatic Society of Great Britain and Ireland, str. 661-680. Dostupno na: http://www.jstor.org/stable/25189204 (siječanj, 2018.).

Walters, Jonathan S. (1997.), Stūpa, Story, and Empire. Construction of the Buddha biography in Early Post-Aśokan India. U: Schober (ur.), str. 160-192.

Walters, Jonathan S. (1999.), Suttas as History. Four Approaches to the Sermon on the Noble Quest (Ariyapariyesanasutta). History of Religions, sv. 38, br. 3, str. 247-284. Dostupno na: http://www.jstor.org/stable/3176354 (rujan, 2018.).

Wasson, Gordon R, O'Flaherty, Wendy D. (1982.), The Last Meal of the Buddha. Journal of the American Oriental Society, sv. 102, br. 4, str. 591-603. Dostupno na: http://www.jstor.org/stable/601968 (svibanj, 2018.).

Watters, Thomas (1904.), On Yuang Chwang's Travels in India 629-645 A.D. London: Royal Asiatic Society.

Wayman, Alex (1997/1998.), Some Theories of Buddhist Dates. Indologica Taurinensia. Official Organ of the International Association of Sanskrit Studies, sv. 23/24, str. 205216.

Welbon, Richard Guy (1968.), The Buddhist Nirvana and Its Western Interpreters. Chicago: The University of Chicago Press.

Williams, Paul (2009.), Mahāyāna Buddhism. The Doctrinal Foundations. London, New York: Routledge [1989.].

Williams, Paul (ur.) (2005.), Buddhism. Critical Concepts in Religious Studies (sv. I-III). Oxon, New York: Routledge.

Williams, Raymond B. (1970.), Historical Criticism of a Buddhist Scripture: „The Mahāparinibbāna Sutta“. Journal of the American Academy of Religion, sv. 38, br. 2 , str. 156-167.

Windisch, Ernest (1895.), Māra und Buddha. Des XXV. Bandes der Abhandlung der Philologisch-Historischen Klasse der Königl. Sächsischen Gesellschaft der Wissenscahften, Leipzig: Bei S. Hirzel.

Windisch, Ernest (1908.), Buddhas Geburt und Lehre von der Seelenwanderung. Des XXVI. Bandes der Abhandlung der Philologisch-Historischen Klasse der Königl. Sächsischen Gesellschaft der Wissenscahften, II, Leipzig: B.G. Teubner.

Windisch, Ernest (1909.), Die Komposition des Mahāvastu. Abhandlungen der PhilologischHistorischen Klasse der Könglich Sächsischen Gesellschaft der Wissenschaften, 27, 14. 
Abhandlungen der Könglich Sächsischen Gesellschaft der Wissenschaften, 57, 14.

Leibzig: B. G. Teubner.

Winternitz, Maurice (1999.), History of Indian Literature. Buddhist and Jaina Literature (sv.

2). Delhi: Motilal Banarsidass ([1983.], Delhi. Pretisak: Delhi, 1988, 1993).

Wogihara, U (1902.), The Term Sahampati. The Journal of the Royal Asiatic Society of Great

Britain and Ireland, str. 423-424. Dostupno na: http://www.jstor.org/stable/25208416 (studeni, 2018.).

Woodward, Mark R. (1997.), The Biographical Imperative in Theravāda Buddhism. U:

Schober (ur.) (1997.), str. 40-63.

Wynne, Alexandar (2005.), The Historical Authencity of Early Buddhist Literature. A Critical Evaluation. Wiener Zeitschrift für die Kunde Südasiens/Vienna Journal of South Asian Studies, sv. XLIX, str. 35-70.

Wynne, Alexander (2007.), The Origin of Buddhist Meditation. London, New York, Routledge.

Yuyama, Akira (2001.), The Mahāvastu-Avadāna in Old Palm-Leaf and Paper Manuscripts. Tokyo: The Centre for East Asian Cultural Studies for UNESCO, the Tokyo Bunko. 


\section{Životopis}

Višnja Grabovac rođena je 1981. godine u Ljubljani. Osnovnu školu i opću gimnaziju završila je u Slavonskome Brodu, a 2008. godine studij indologije i filozofije na Filozofskome fakultetu Sveučilišta u Zagrebu. Od 2008. do 2014. godine radila je kao stalni suradnik časopisa Meridijani i kao restauratorica-konzervatorica na poslovima obnove hrvatske kulturne baštine. Od akademske godine 2010./ 2011. do 2014. radila je kao vanjski suradnik Odsjeka za indologiju i dalekoistočne studije Filozofskoga fakulteta u Zagrebu te držala nastavu iz predmeta Hindske jezične vježbe. Godine 2014. zaposlena je na mjestu lektora na Katedri za indologiju Odsjeka za indologiju i dalekoistočne studije Filozofskoga fakulteta Sveučilišta u Zagrebu. Na preddiplomskoj razini drži nastavu iz predmeta Hindske jezične vježbe I-VIII, Hindski seminar, Buddhistički hibridni sanskrt i Indijska književnost, a na diplomskoj razini nastavu iz predmeta Buddhizam I. Sudjelovala je na domaćim i inozemnim znanstvenim i stručnim skupovima te objavljivala radove u domaćim i inozemnim publikacijama.

Popis objavljenih radova

Grabovac, Višnja (2012.), Utjecaj buddhističkih đātaka na nastanak legende o svetome Eustahiju. (Prijevod s pālija:) Nigrodhamigađātaka. Književna smotra broj 166 (4), str. 91-104.

Grabovac, Višnja (2013.), Književnost na buddhističkome hibridnome sanskrtu. (Prijevod s buddhističkoga sanskrta:) Mahāvastu: Četiri Bodhisattvina viđenja. Književna smotra, broj 167 (1), str. 95-105.

Grabovac, Višnja (2013.), Ivan Andrijanić: Filozofija vedānte (recenzija knjige). Filozofska istraživanja 129, sv. 33, travanj 2013., broj 1, str. 190-193.

Grabovac, Višnja i Beljak, Valentina (2019.), Kroeśiyā me Bhārat Vidyā. Vikās, Svarūp evam Dṛști. Vishwa Hindi Patrika, str. 24-29. ISSN: 1694-2477

Grabovac, Višnja (2019.), Previous Existences - Present Bonds: Jātakas of the Members of Buddha’s Family in Mahāvastu. Manas, sv. 5, br. 2. ISSN: 2367-6256

Grabovac, Višnja (2020.), Hindski frazemi sa sastavnicom roțil/ kruh i njihovi prijevodni ekvivalenti u hrvatskome jeziku. Strani jezici, 49 (1). ISSN: 0351-0840, DOI:

10.22210/strjez/49-1/5, str. 113-129.

Grabovac, Višnja (2020). Dvije đātake o gušteru (prijevod s pālija i buddhističkoga hibridnoga sanskrta). SIC 10 (3). ISSN1847-7755, DOI:10.15291/sic/3.10.1t.4 
Grabovac, Višnja (2020.), Savršenstvo u mudrosti - mudrost u poučavanju. Izbor iz pripovijesti o prijašnjim egzistencijama Gautame Buddhe u Mahāvastuu. Književna smotra, sv. 52, br. 196 (2). ISSN: 0455-0463, str. 91-97.

Grabovac, Višnja (2020.), Buddha u prvom i trećem pripovjednom licu. Umjetnost riječi, sv. 64, br. 1-2, str. 115-134, https://doi.org/10.22210/ur.2020.064.1_2/05. 